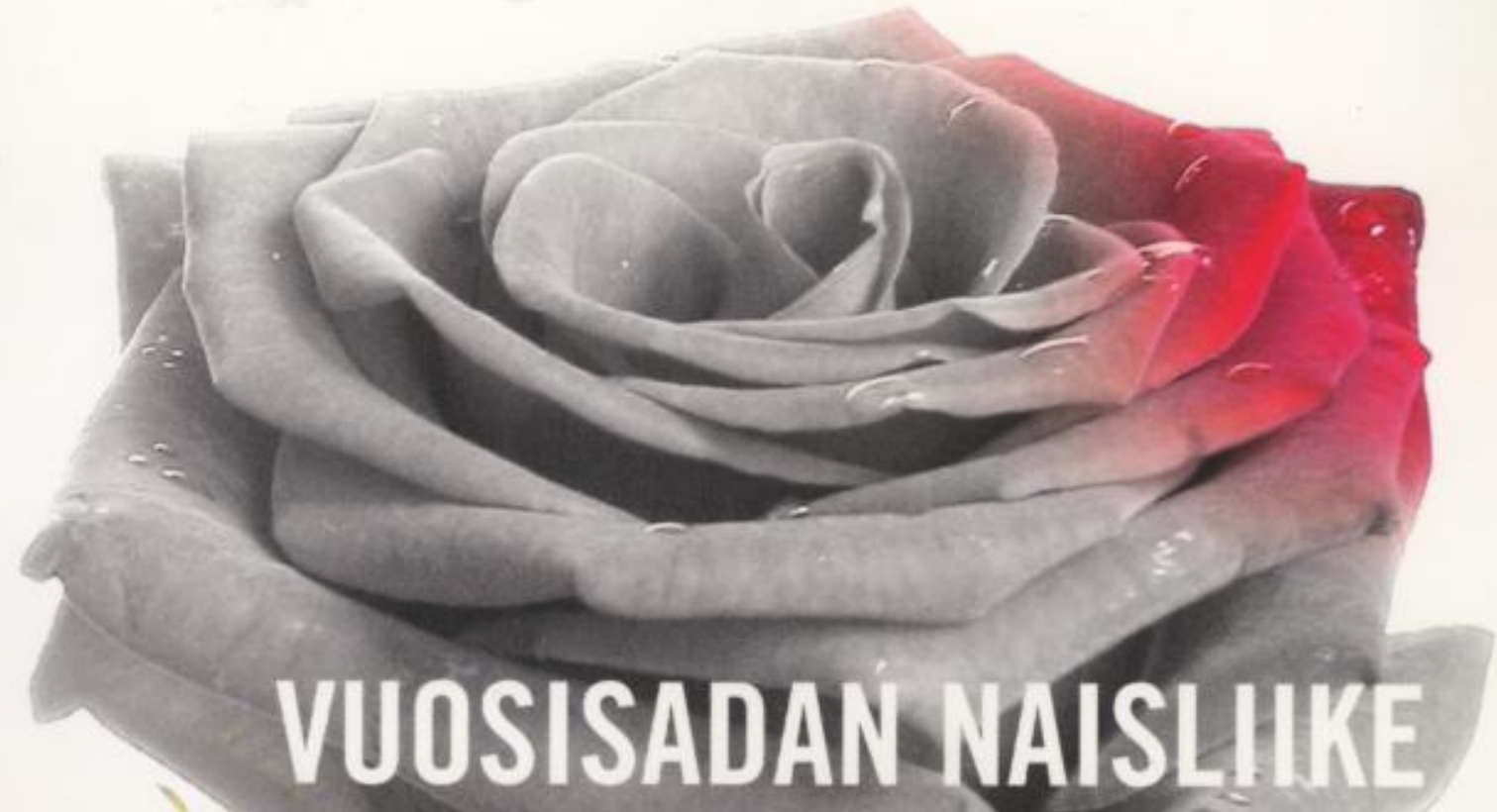

NAISET JA SOSIALIDEMOKRATAA

I 900 -LUVUN SUOMESSA

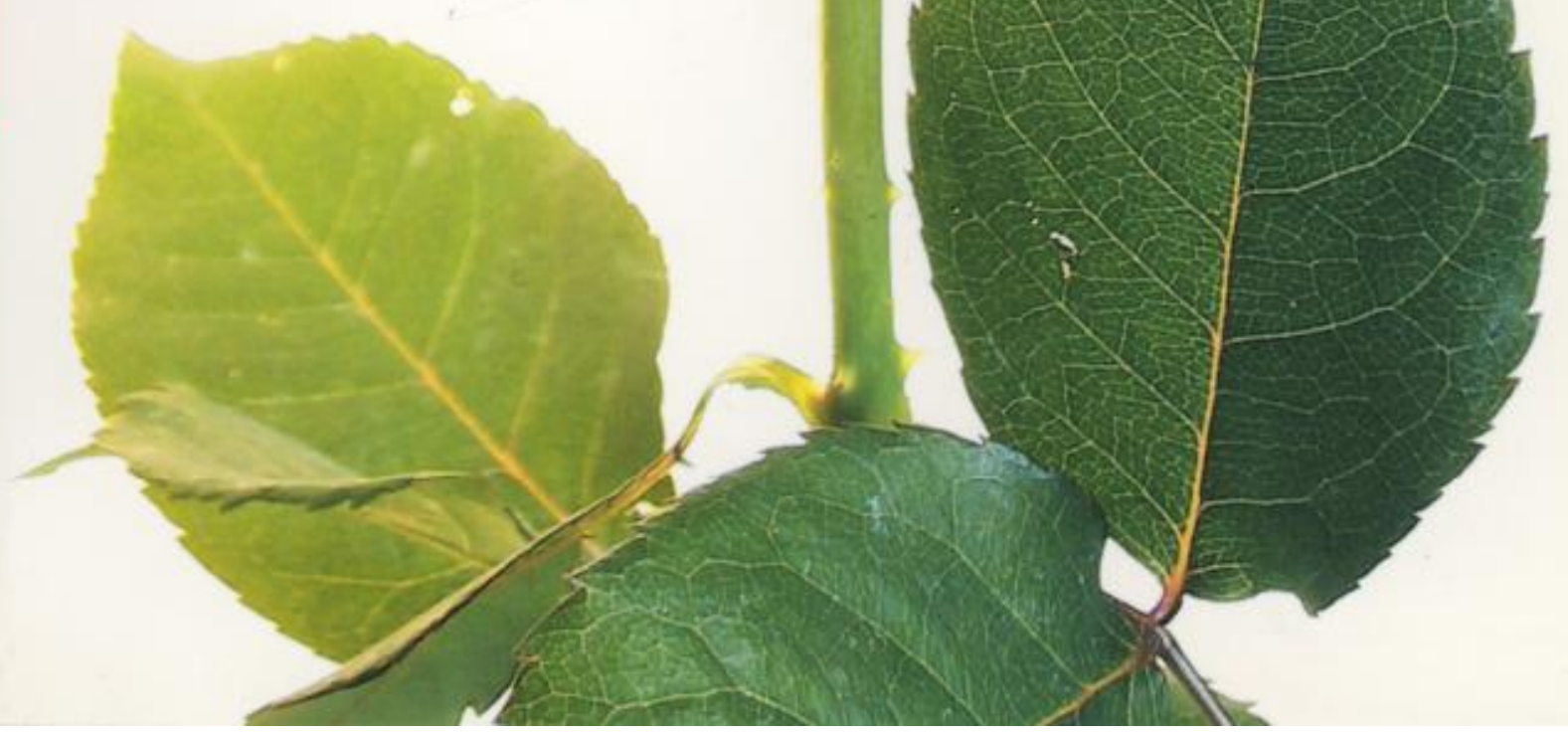


Vuosisadan naisliike 

Maria Lähteenmäki

\section{Vuosisadan naisliike}

Naiset ja sosialidemokratia 1900-luvun Suomessa

Sosialidemokraattiset Naiset -

Socialdemokratiska Kvinnor 
(C) Maria Lähteenmäki

Kansi: Pekka Piippo

Kuvatoimitus: Maria Lähteenmäki

ISBN 952-91-2315-9

\section{Hakapaino Oy}

Helsinki 2000 


\section{Sisällys}

1900-LUKUA...

JOHDATUS AIHEESEEN 15

$\begin{array}{ll}\text { Suuren vallankumouksen varjo } & 15\end{array}$

$\begin{array}{ll}\text { Vallattomat ja oikeudettomat naiset } & 18\end{array}$

$\begin{array}{ll}\text { Kansanterveyden sanansaattajat } & 19\end{array}$

I. FENNOMAANINEN TYÖLÄISNAISLIIKE 25

1. Ompelijoiden ja palvelijoiden esiinmarssi 25

*Työläislasten alkuopetus $\quad 27$

*Päiväkoti 1800-luvulta 31

2. Taistelevat siskot 45

*Suomen Työväenpuolueen ohjelma 49

*Suomen kansanedustajat 1907-17 57

3. Sosiaalisen toiminnan suuntaviivat 58

*"Älä pelota mustalla miehellä" - kasvatusneuvoja vuodelta 1908

4. Kansainvälistyvä naisliike $\quad 62$

*Vapun vietto 67

*Kansainvälinen naistenpäivä 70

II. KAPINA JA KAPINALLISET T 73

1. Vuosien 1917-18 tapahtumat 73

*Naisten marssi $\quad 83$

2. Puheenjohtaja Aalle-Teljon sota $\quad 84$

*Naistoverin puolustuspuhe $\quad 88$

3. "Punikkiämmä" Hjulgrenin teloitus 89

*Valtiorikosoikeuksissa syytetyt ja tuomitut naiset 191893

4. Ministeri Pärssisen pako 94

*Uusi kotimaa 98 
1. Naisliiton uusi suunta $\quad 99$ *Punaorvot $\quad 120$

2. Sosiaalidemokraattinen kotivalistus 118 * Äitienpäivä 124

3. Espanjan lasten avustaminen $\quad 130$

*Joulumerkkikoteja työläisperheiden lapsille $\quad 134$

IV. KRIISIAJAN YHTEISVASTUU 135

1. Ensikoti-toiminta eriytyy 135

*Lastenneuvolat ja äitiyspakkaukset $\quad 140$

2. Sota-ajan huoltotyö 139

*"Emme ole elävää naista nähneet viikkokausiin..." 147

3. Työvelvollisuusnaiset Saksassa 146

*Sosiaalidemokraatit lottina? 152

4. Naisliiton sisäiset jännitteet 154

*Naiset sotatarviketehtaissa, pelloilla ja talkoissa $\quad 158$

5. Vaimoista palkkatyöläisiksi $\quad 160$

*Morsiuskurssit 164

V. JÄLLEENRAKENNUKSESTA HAJAANNUKSEEN 168

1. Kurssien kulta-aika $\quad 168$

*Perheenäitien talvipäivät $\quad 172$

2. Martta ja Tyyne - Tannerin kamarineitsyet 173

*Naisedustajat Suomen eduskunnassa 1919-2000 194

3. Lomatoiminta, vanhustyö ja kotitalousvalistus eriytyvät 193

*Vaatepaketteja rajaseutujen lapsille $\quad 199$

4. Naisliiton toinen hajaannus 197

*Puhujakurssi vuodelta 1959 
1. Kohti uutta maailmankuvaa 206 *Herraksi tulemisen pelko... 212

2. Rauhaa ja solidaarisuutta 214 *"Vallankumous leimahti Pariisissa" 218

3. 1960-luvun suuri roolitutkimus 220 *E-pilleri 224

4. Perhepolitiikan vuosikymmen 222 *Tane 229

VII. NAISYHTEISÖ PUOLUEESSA 230

1. Puolueen naiset 230

*Naisinternationaali 242

2. Mannen liitto 243

*Köyhyys hyvinvointivaltiossa 254

3. Naisten Eurooppa 253

*Eurooppalaista tasa-arvoa 260

VIII. MINNE MENET SOSIALIDEMOKRAATTINEN NAISLIIKE? 261

*Tasa-arvon, kansanvallan ja yhteisvastuun puolesta $\quad 274$

YHTEENVETO:

HILJAISEN VALLANKUMOUKSEN TIE 276

Lähteet 285

Liiteosa 301

Sammandrag $\quad 321$

Summary $\quad 329$

Henkilöhakemisto 336 


\section{Liiteosa}

Liite 1. Sosialidemokraattisen naisliiton puheenjohtajat ja sihteerit

Liite 2. Sosialidemokraattisen naisliiton jäsenmääriä

Liite 3. Sosiaalidemokraattisten naisten lehdet

Liite 4. Sosiaalidemokraattisten naisten järjestöjen eriytyminen

Liite 5. Sosiaalidemokraattisten naisten kansainvälisiä ja pohjoismaisia kokouksia

Liite 6. Naisten asemaa koskevia lakeja ja asetuksia 314

Liite 7. Tapahtumakalenteri 


\section{0-lukua...}

voidaan yleisessä mielessä nimittää naisliikkeen, tasa-arvon ja sosialidemokratian vuosisadaksi - ainakin jos asiaa tarkastellaan pohjoismaisesta näkökulmasta. Suomessa sukupuolten väliselle tasaarvokehitykselle loivat edellytykset naisten holhouksenalaisuuden purkaminen ja poliittisten oikeuksien salliminen. Tärkein demokratisoitumisen moottoreista 1900-luvulla oli kuitenkin naisten, erityisesti naimisissa olevien naisten, palkkatyöläistyminen ja siihen kytketyt sosiaalipoliittiset uudistukset. ${ }^{1}$ Yhdenvertaisuutta näyttävät siis edistäneen toimet, jotka vahvistivat naisten oikeudellista ja taloudellista itsenäisyyttä. Sanoihan valistusajattelija Mary Wollstonecraft jo muinoin, että “...on turhaa odottaa hyveellisyyttä naisilta ennen kuin he ovat tiettyyn mittaan saakka miehistä riippumattomia... ". ${ }^{2}$ Sittemmin kirjailija Virginia Woolf kuvasi naisten itsenäisyyden kaipuuta oma huone -metaforalla.

Mistä tuo vuosisatainen riippumattomuuden kaipuu sitten nousi? Ranskalainen Simone de Beauvoir toteaa lakonisesti naisten epäitsenäisyydestä, että "Naisten toiminta on aina ollut vain vertauskuvallista liikehdintää, he ovat saavuttaneet vain sen mitä miehet ovat suvainneet sallia. "3 Näin ankara tulkinta saa nykynaiset epävarmoiksi: onko naisten toiminta todellakin ollut vain näennäispuuhastelua.

On kyllä totta, että tasa-arvokehityksen kärjessä kulkeneen pohjoismaisen naisliikkeen toiminta ei näyttäydy yksinomaan myönteisenä kehityskertomuksena, vaan rosoisena, edistyksen ja taantumuksen vuoro-astuntana, naisten työteliäänä ja loputtomalta tuntuvana kamppailuna. On myös totta, ettei pohjoisissa mallimaissakaan sukupuolten väliseen yhdenvertaisuuteen päästy sadan

1 Naimisissa olevien naisten siirtyminen kodin ulkopuoliseen palkkatyöhön alkoi kasvaa hitaasti 1910-luvulta lähtien, ks. Tunkelo 1933 ja Lähteenmáki 1995, s. 29-34.

2 Mary Wollstonecraft teoksessaan Vindication of the Rights of Women (1972), ks. KoivistoMäki-Uusitupa 1995, s. 142.

3 de Beauvoir 1981, s. 14. 
vuoden työskentelyn jälkeen. Naisten palkat ovat edelleen selvästi alhaisemmat kuin miesten, naisten ammatillinen urakehitys on työläämpää kuin miesten sekä kodin ja palkkatyön yhdistäminen eli naisten kaksoistaakka tuottaa yhä suuria ongelmia äideille. Ei myöskään liene aivan sattuma, että samaan aikaan kun Suomi sai ensimmäisen naisen presidentiksi helmikuussa 2000, maalle annettiin uusi perustuslaki. Siinä presidentin valtaa kavennettiin merkittävästi.

Sosiaalidemokraattiselle aatteelle 1900-luku oli yleisessä mielessä yhtä onnekas kuin naisliikkeellekin. Vuosisata oli sosiaalidemokraattien keskeisimpien poliittisten tavoitteiden toteuttamisen aikaa. Sosiaalidemokraatit saivat monessa yhteiskuntapoliittisessa kysymyksessä tahtonsa läpi ja muokkasivat kiistatta suomalaista yhteiskuntaa itsensä näköiseksi.

Arkisen elämän näkökulmasta 1900-lukua voidaan nimittää myös pimeäksi leirien vuosisadaksi. Se oli lukuisten veristen ja tuhoisten sotien ja vallankumousten sekä siviiliuhrien aikakausi. Näiltä osin 1900-luvun historia on saanut jo ensimmäiset analyysinä. Eräs näistä on brittihistorioitsija Eric Hobsbawmin teos "Ä̈rimmäisyyksien aika" (1999). Tutkimuksessaan Hobsbawm toteaa, että viime vuosisata on vaikea tutkimuskohde siksi, että se on tutkijoiden ja lukijoiden itsensä kokemaa aikaa, omien muistojen kautta. Hän otaksuu, että tämän vuosisadan ihmisinä me olemme selvemmin sidoksissa ajan arvoihin ja normeihin kuin jos tutkisimme varhaisempia aikakausia. ${ }^{4}$ Niin tai näin, historiantutkimuksen kysymykset nousevat joka tapauksessa aina tutkijan omasta ajasta - oli varsinainen tutkimuskohde sitten historiallisesti lähellä tai kaukana.

Niin on asia myös tässä tapauksessa. Tasa-arvo on ollut viime vuosina uudelleenarvioinnin kohteena muun muassa naiskiintiöistä ja työpaikkademokratiasta käytyjen keskustelujen vuoksi, mutta myös laajemmassa mielessä. Siirtolaisuus ja pakolaisuus ovat asettaneet monen keskiverto-eurooppalaisen suvaitsevaisuuden ja tasaarvo -käsityksen koetteille. Samalla ne ovat pakottaneet miettimään "meidän" ja "ulkopuolisten" välistä suhdetta. 
Mielenkiintoista niin sanotussa myöhäismodernissa eli 1900luvun lopun maailmassa on etenkin sukupuoleen, luokkaan, etnisyyteen ja kansallisuuteen liittyvien minäkuvien eli identiteettien uudelleenjäsentyminen. Kulttuurintutkija Stuart Hall on todennut, että 1900-luvun lopulla oli kyse meille sosiaalisina yksilöinä vankkoja asemia antaneiden kategorioiden, kuten sukupuolen, luokan tai kansallisuuden, kulttuuristen maisemien pirstoutumisesta. Hall kirjoittaa Anthony Giddensiä lainaten, että modernit yhteiskunnat ovat jatkuvien, nopeiden ja pysyvien muutosten yhteiskuntia, mikä on heijastunut ihmisten tapaan hahmottaa itsensä ja suhteensa muihin.

Globalisaatiosta johtuen moderniteettiä määrittää hyvin refleksinen elämänmuoto: Kun maapallon eri alueiden kanssakäyminen nopeutui ja aktivoitui, huuhtoivat sosiaaliset muutokset koko maapalloa. Näin suuret muutokset laittoivat myös henkilökohtaiset identiteetit liikkeelle. Uusia identiteettejä ei kuitenkaan voinut uusissa, nopeasti muuttuvissa oloissa enää rakentaa niin vakaiksi kuin aiemmin, koska ihmiset uudistivat sosiaalisia käytäntöjä alati uuden tiedon mukaisiksi. Samalla he irtautuivat aikaisemmin vahvoista siteistä perinteeseen. ${ }^{5}$ Jotta tietäisimme, mistä olemme irtautumassa ja mitä jälkitraditionaalisessa järjestyksessä eläminen tarkoittaa, on meidän Giddensin mukaan määriteltävä perinteisen yhteiskunnan ominaispiirteet. ${ }^{6}$ Historiantutkimus tarjoaa tähän oivan mahdollisuuden.

Nämä 1900-luvun aikana tapahtuneet perustavaa laatua olevat muutokset ihmisten identiteetin rakentumisessa ja suhteessa perinteeseen tarjoavat mielenkiintoisen teoreettisen viitekehyksen työväenliikkeen tutkimukseen. Ne saavat pohtimaan sitä, miten yhtäältä luokkaidentiteettejä ja toisaalta sukupuoli-identiteettejä on rakennettu työväenliikkeessä, miten niitä on uusinnettu ja millä tavalla muutokset näkyivät 1900-luvun lopun modernisaatiokehityksessä ja näkyvät tänä päivänä. Sosiologi Ulrich Beck on esittänyt kiinnostavan analyysin nykyisestä murroskaudesta. Hänen mukaansa uusi aikakausi ei murru läpi vallankumouksen tai katkerien kokemusten kautta, kuten aiemmat uudet aikakaudet, vaan vähin äänin, suunnittelematta ja epäpoliittisesti sivuuttaen demokraattisen itseymmärryksemme. Beckin mukaan huippunopea teol-

\footnotetext{
Hobsbawm 1999, s. 9-11.

Hall 1999, s. 23-25.

Giddens 1996, s. 90-91.
} 
linen dynamismi vie meidät uuteen yhteiskuntaan ikään kuin varkain. ${ }^{7}$ Poliittisille toimijoille tämä visio on uhka ja haaste.

Tässä tutkimuksessa tarkastelun kohteena ei ole koko työväenliike, vaan tehtävä rajautuu työläisnaisliikkeen historiaan. 1900luvun historia esitetään Suomen vanhimman poliittisen naisliiton, ${ }^{8}$ kesällä 2000 sata vuotta täyttävän Sosialidemokraattisen naisliiton eli nykyisen Sosialidemokraattiset Naiset -järjestön historian kautta. Tutkimuksessa selvitetään yhtäältä sitä, miten yksittäinen poliittinen naisjärjestö luotsasi, mukautti ja sovitti toimintaansa vuosisadan yhteiskunnallisissa ja poliittisissa muutoksissa ja kriiseissä. Toisaalta tarkastellaan sitä, mikä oli naisten rooli miehisessä puolueessa ja millaiseksi 1900-luvun naisten poliittinen kulttuuri rakentui. Lopuksi esitellään poliittisten naisten omat arviot uuden, jälkiteolliseksi nimetyn aikakauden haasteista.

Länsimaista työläisnaisten ja työläisnaisliikkeiden historiaa on tutkittu 1960-luvulta lähtien ahkerasti. Aluksi tutkimuksissa keskityttiin tarkastelemaan teollistumisen vaikutuksia naisten asemaan. Erääksi ongelmaksi nousi se, heikensivätkö vai paransivatko elinkeinorakenteen muutokset naisten asemaa. Vallitsevaksi tulkinnaksi 1970-80-luvulla nousi käsitys, jonka mukaan teollistuminen ja sen tuottamat taloudellis-poliittiset tekijät kohensivat pääosin maaseudun kurjistuvista oloista muuttaneiden nuorten naisten asemaa. ${ }^{9}$

Naistutkimuksen painopiste siirtyi 1970-luvulla kurjuus- ja työtutkimuksesta naisten toiminta-alueiden eli sfäärien arviointiin suhteessa miesten toimintapiireihin. Esitettiin, että kaupungistumisen ja elintason kohoamisen myötä yhteiskunnallinen elämä sukupuolittui aikaisempaa jyrkemmin, mikä heijastui naisten asemaan ja toimintaan sekä kotona että kodin ulkopuolella. Tästä asetelmasta nousi sukupuolten sfäärien erkaantumista korostavan ideologian tutkiminen. On esitetty, että juuri nouseva naisliike ja työ-

7 Beck 1996, s. 11-14.

8 Poliittisella naisjärjestöllä tarkoitetaan tässä puolueisiin selkeästi sitoutuneita naisjärjestöjä Omalla tavallaan myös vanhemmat naisasialiitot olivat poliittisia. Poliittisista naisjärjestöistä 1902 perustettiin Nuorsuomalainen naisklubi, 1906 Suomalaisen puolueen naisvaliokunta, RKP:n Svenska Kvinnoförbundet ja Suomalainen naisliitto perustettiin 1907, Kokoomuksen Naisten Liitto ry 1919, Suomen Keskustanaiset ry 1941 ja Suomen Naisten Demokraattinen Liitto 1944.

9 Mm. Shorter 1975; Scott-Tilly 1978; Suomessa Haapala 1986. 
väenliike olivat kärjekkäimmin ottamassa kantaa 1800-luvun lopun naisten aseman uudelleen määrittelyyn. Keskeisimmiksi ongelmiksi tutkimuksissa nousivat muun muassa kysymykset, millä perusteella naisten paikka määriteltiin kotiin ja mitkä olivat naisten toimintaa ohjaavat ihanteet ja aatteelliset vaikutteet. ${ }^{10}$

Taloudellisesti hyvinä 1980-luvun vuosina naistutkimus laajeni sfääritutkimuksesta sekä temaattisesti että teoreettisesti. Yksittäisten naisten sankaritarinat ja naisten historian tekeminen näkyväksi saivat rinnalleen monipuolisempia lähestymistapoja: naisten, lasten, ikääntyneiden, miesten ja erilaisten alakulttuurien historiat nähtiin kompleksisempana ja kerroksellisempana kuin aikaisemmin. ${ }^{11} 1990$-luvun naistutkimukset edustavat siinä määrin postmodernia aikaa, ettei voida esittää yhtä tai kahta vallitsevaa tutkimussuuntausta.

Eräs ero aiempaan tutkimukseen on kuitenkin nähtävissä: tasaarvon sijasta tutkitaan enemmän sukupuolieron perustaa ja sitä, miten naiset ovat itse vaikuttaneet nykyisiin vallitseviin arvoihin ja muokanneet niitä. Erään näkymän viimeaikaiseen naishistorian tutkimukseen antavat Bergenin yliopiston historian professori Ida Blomille omistetun juhlakirjan "Women Politics and Women in Politics" artikkelit. Niissä käsitellään muun muassa pohjoismaiden "vahvoja naisia", islantilaista identiteettiä, naisten julkista toimintaa kaupunkiyhteisössä, lapsikuolleisuutta, naistoimintaa ennen äänioikeuskamppailua, modernismia, naiskansalaisuutta ja eurooppalaista feminismiä. ${ }^{12}$

Suomessa naishistorian tutkimus painottui 1980-90-luvulla taloushistoriaan ja poliittiseen historiaan. Työelämäntutkimus on ollut tärkeällä sijalla, ovathan suomalaiset naiset olleet palkkatyöläisyyden kärkijoukkoa. ${ }^{13}$ Toinen vahva tutkimusalue on ollut naisten järjestäytyminen ja poliittinen toiminta. ${ }^{14}$ Sen sijaan naisten kulttuurin ja sosiaalihistorian tutkimus odottaa vielä lisää perustutkimusta.

10 Mm. Degler 1980; Lerner 1969; Suomessa mm. Sulkunen 1987 ja Ollila 1993

$11 \mathrm{Mm}$. Hirdman 1988; Hartmann 1981; Walby 1986.

12 Teos julkaistaan elokuussa 2000 Oslossa.

13 Mm. Vattula 1981; Pohls 1994; Lehto-Sutela 1999; Hentilä 1999

14 Mm. Ramsay 1993; Kuusipalo 1989; Katainen 1994; Yksi kamari-kaksi sukupuolta 1997 
Työläisnaisliikkeen historia on tullut minulle tutuksi arkisen työn eli pölyisten pahvilaatikoitten kautta. Kun 1980-luvun puolivälissä järjestelin Työväen Arkistossa Sosialidemokraattisen naisliiton hajanaista ja tuolloin vielä lähes käyttämätöntä arkistoa, miellyin siihen siinä määrin, että hyödynsin aineistoa ensin lisensiaattityössäni "Naisia liikkeessä" (1991) ja väitöskirjassani "Mahdollisuuksien aika. Työläisnaiset ja yhteiskunnan muutos 1910-30-luvun Suomessa” (1995) yhtenä lähdemateriaalina. Voisi sanoa, että käsillä oleva teos on tämän trilogian viimeinen osa.

Tutkimus ei koskaan synny yksin, vaan vuoropuheluna eri toimintayhteisöjen kanssa. Niinpä myös tämän kirjan valmistumiseen ovat vaikuttaneet useat tahot. Kiitän lämpimästi Kansan Sivistysrahastoa ja sen alaista Työväen Kukkasrahastoa, jotka ovat tukeneet hanketta taloudellisesti. Käsikirjoituksen kommentoinnista kiitän VTK Marja Rantalaa, VTK Elina Kataista ja VTT Marjaliisa Hentilää.

Haluan osoittaa kiitokseni hyvästä yhteistyöstä myös Sosialidemokraattisille Naisille, etenkin puheenjohtajille Liisa Jaakonsaarelle ja Tarja Filatoville, pääsihteereille Tuula Haataiselle ja Marja-Liisa Kiljuselle sekä Irma Tuomistolle, Sinikka Luja-Penttilälle, Pirkko Arolle, Meeri Kalavaiselle, Marja-Liisa Kunnakselle, Ulla Laaksolle, Merja-Hannele Vuohelaiselle ja Päivi Lipposelle sekä lukuisille muille haastatelluille ja muutoin hanketta tukeneille henkilöille. Tutkimuksen tarkoitus on olla toisaalta yleisesitys 1900luvun naisten poliittisesta kansalaistoiminnasta, toisaalta käsikirja.

Rakenteeltaan teos ei ole perinteinen järjestöhistoria, vaan se koostuu kolmesta osasta: perustekstistä, tietoiskuista ja tilasto-osasta. Jälkimmäisestä käy ilmi muun muassa Sosialidemokraattisen naisliiton luottamushenkilöt ja jäsenmäärien ja kansainvälisten suhteiden kehitys. Lisäksi lopussa on naisten asemaan vaikuttaneiden lakien ja asetusten luettelo sekä kronologinen tapahtumakalenteri. Tilasto-osan kokoamisesta kiitän FM Hannes Toivasta ja kirjan taittamisesta FT Ilkka Teerijokea. Kiitän myös Työväen Arkiston henkilökuntaa, erityisesti Petri Tanskasta, oivallisesta yhteistyöstä.

Helsingissä 1.5.2000

Maria Lähteenmäki 


\title{
Johdatus aiheeseen
}

\author{
Suuren vallankumouksen varjo
}

Tutkittaessa suomalaisen tai minkä tahansa muun eurooppalaisen maan naisliikkeen ja työväenliikkeen historiaa, ei kertomusta voida aloittaa mainitsematta Ranskan suurta vallankumousta. Kun taloudelliseen ja poliittiseen ahdinkoon sysätyt ranskalaiset ryntäsivät kaduille vaatimaan vapautta, veljeyttä ja tasa-arvoa tricolorelippuja heilutellen, käynnistivät he samalla kehityksen, joka leimasi koko 1800-luvun Eurooppaa. Paitsi että vallankumous johti eri maat sisäisiin selkkauksiin ja liittosotiin, sysäsi se liikkeelle yhteiskunnallisen tasa-arvon vaatimuksen.

Myös naisille Ranskan suuri vallankumous antoi toimintamalleja: lokakuussa 1789 noin 6000 työläisnaista marssi 30 kilometrin matkan Pariisista Versaillesin palatsiin sotahuutonaan "leipää ja viljaa!" Palatsissa olleen kuninkaan oli taivuttava ja naiset palasivat menestyksellisen marssinsa jälkeen kaupunkiin mukanaan jauho- ja jyväkuormastoja. Turvanaan heillä oli kansalliskaartin sotilaita, joilla oli leipää pistimissään. Ranskattarien viesti oli selkeä: Naiset eivät enää suostu odottamaan mitä heille annettaisiin, vaan siirtyvät suoraan toimintaan. Pariisittaret olivat nälkämellakoiden lisäksi mukana myös aseellisissa kahakoissa. ${ }^{1}$ Vastaavanlaisia naisten mielenosoituksia, kahakoita ja osallistumista nälkälevottomuuksiin tunnetaan myös Englannista 1700-luvun lopulta. ${ }^{2}$

Suomessa naiset eivät vielä tuolloin yhtyneet ranskalaisten sisartensa marssiin, mutta vähitellen myös Suomessa vapaammat tuulet alkoivat herätellä ensin sivistyneistöä ja sitten kansaa. Tilaa uusille aatteille antoivat maltilliset Venäjän tsaarit, ensin Aleksanteri I ja sitten liberaali Aleksanteri II. Hänen astumisensa Venäjän valtaistuimelle (1855) tuli merkitsemään paljon sekä Suomen si-

1 Ranskalaisten naisten osallistumisesta vallankumoustapahtumiin vuosina 1789, 1830, 1848 ja 1871 ks. mm. Hufton 1971; Women, state and revolution 1986; Edwards 1971.

2 Valistusajan naiskysymyksestä ks. Haikala 1985, s. 113-124; Thompson 1996, s. 133-135 


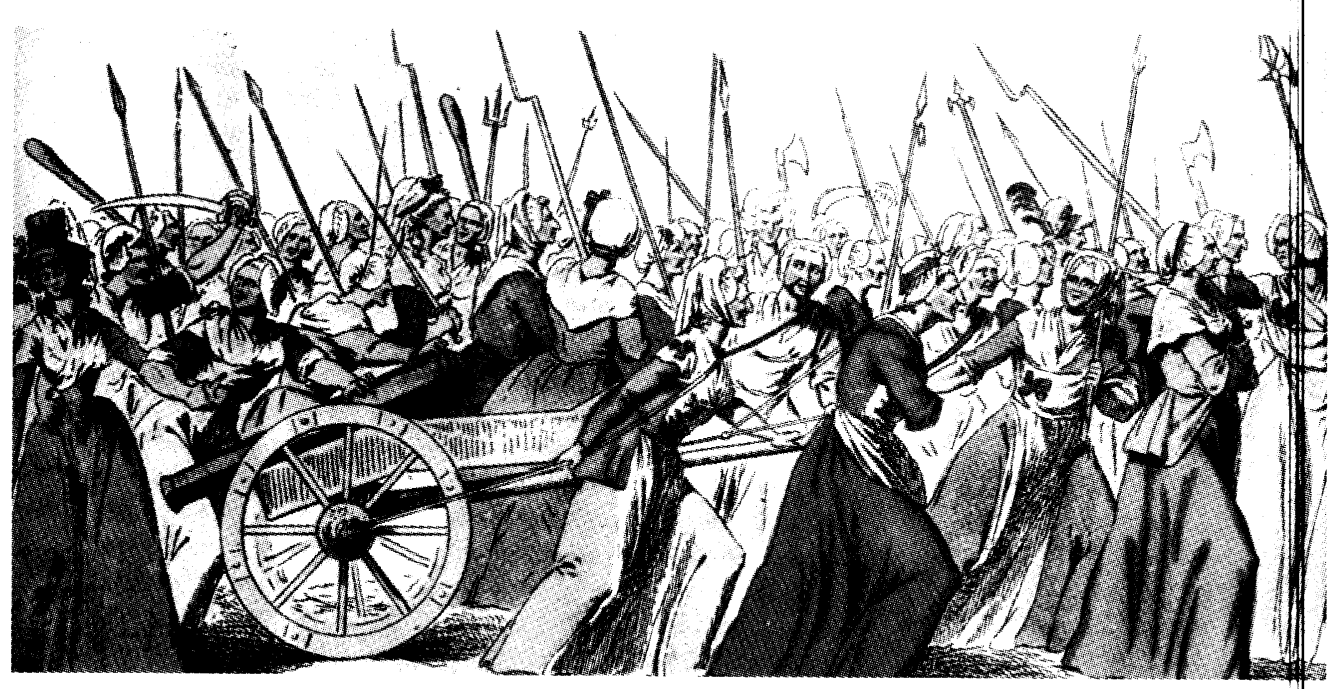

Leipää vaativia ranskattaria matkalla Versaillesiin 5.10.1789. Kuva: Työvalen Arkisto.

säiselle että ulkoiselle kehitykselle. Liberalismi merkitsi yhteiskunnan kaikkien rakenteiden - niin taloudellisten, sosiaalisten, kulttuuristen kuin poliittistenkin - kyseenalaistamista ja uudelleenrakentamista.

Tavallisen kansan elämän rakentumiseen vaikuttivat mullistavasti katovuodet. Paitsi nälän ja kuoleman kokemuksina, suuret nälkävuodet (1865-68) vaikuttivat siihen, mistä rahvas tuli saamaan leipänsä jatkossa. Kriisin vuodet pakottivat päättäjät laajentamaan maan elinkeinopohjaa. Vuosisadan alkupuoliskolla hitaasti tilaa saanut teollisuuden suosiminen vahvistui vuosisadan lopulla. Liberalistinen talouspolitiikka konkretisoitui vuonna 1879 uusittuihin elinkeino- ja muuttovapaussäädöksiin: työ ja työväki vapautettiin liikkumaan. Samalla alkoivat liikkua myös vapaamielisemmät aatteet.

Ennen näitä mullistavia säädöksiä suomalainen yhteiskunta oli hierarkkinen ja suhteellisen staattinen. Muutamista herrassuvuista koostunut kapea eliitti johti virkapaikoiltaan maata. Rahvaan elämä kulki toista rataa. Säätykierto oli vähäistä ja yhteiskunnallinen kuilu säätyläisten ja kansan välillä syvä. Harvaanasutussa Suomessa asui vuonna 1860 noin 1,7 miljoonaa henkeä, joista valtaosa sai elantonsa maa- ja metsätaloudesta. Itse asiassa ei ollut olemassa yhtä Suomea, vaan sivistyneistön ja rahvaan Suomet, rannikkoalueiden ja sisämaan Suomet. ${ }^{3}$ 
Paitsi liberalismi, Suomea alkoi ravistella muun Euroopan tapaan vuosisadan toinen suuri aate, nationalismi. Kansallisten liikkeiden historia on jaettu kolmeen kehitysvaiheeseen. Ensimmäinen vaihe on puhtaasti kulttuurinen, kirjallinen ja folkloristinen. Toisessa vaiheessa nousevat esille yksittäiset edelläkävijät, nationalismin kansalliset esitaistelijat. Tässä vaiheessa ilmaantuvat myös ensimmäiset poliittisen kampanjan alkumerkit. Kolmannessa vaiheessa kansalliset ohjelmat saavuttavat joukkokannatuksen ja politisoituvat. $^{4}$

Tätä mallia voi soveltaa myös Suomen oloihin. Kansallisen herätyksen viriämisestä kielivät vuonna 1821 ilmestynyt Åbo Morgonbladet ja vuonna 1831 perustettu Suomalaisen Kirjallisuuden Seura. Toisessa vaiheessa rahvas, josta suurin osa ei kuulunut mihinkään viralliseen neljään säätyyn eikä näin ollen omannut kansalaisoikeuksiakaan, nousi kansallisten johtomiesten keskusteluissa keskeiselle sijalle. Sitä aikaisemmin "kansa" oli ollut sivistyneistön filantrooppisten harrastusten kohteena, nyt siitä tuli suomalaisuusliikkeen elinehto ja voimavara. Kolmannessa vaiheessa 1800luvun lopun kansanliikkeet - raittiusliike, työväenliike ja naisliike - ilmensivät jo suomalaisuusliikkeen joukkokannatuksen laajenevaa pohjaa.

Kansanliikkeitä yhdistävä tekijä oli kansansivistys. Se rakentui 1800-luvun alun fennomanian eli suomen kieltä ja kulttuuria korostavan aatesuunnan ja 1800-luvun lopun sosiaaliliberalismin ${ }^{5}$ humaaneille periaatteille. Eteläisen Suomen taajamissa elävä työväki pääsi jo aikaisessa vaiheessa osalliseksi näistä uusista tuulista, mutta yllättävän varhain myös maan reuna-alueilla alettiin ottaa kantaa yhteiskunnallisiin kysymyksiin: kansan tietoisuus itsestään, omista tarpeistaan ja oikeuksistaan alkoi kirkastua. ${ }^{6}$ Kansanliikkeet alkoivat joukolla rakentaa Suomeksi nimettyä aluekokonaisuutta yhdeksi kokonaiseksi kansakunnaksi. Olisi kuitenkin jälkiviisautta väittää, että liikkeessä mukana olleilla olisi tuolloin ollut selkeä käsitys tulevaisuudesta tai että jo tuolloin mielikuvissa kangasteli siniristilippu ja leijonavaakuna. Toimijoiden intressit olivat varsin erilaisia ja yhteiskunnallinen tilanne herkkä

4 Miroslav Hrochin malli, ks. Hobsbawm 1994, s. 21.

5 Sosiaaliliberalismi tarkoittaa liberalismin suuntausta, jossa sosiaalipoliittiset asiat ovat keskeisellä sijalla.

6 Kansanliikkeistă ja kansan ja sivistyneistön suhteista ks. mm. Alapuro-Liikanen-Smeds 1987; Liikanen 1995. 
muutoksille. Työväenliike ja naisliike olivat tässä murrosvaiheessa omine intresseineen näyttävästi mukana.

\section{Vallattomat ja oikeudettomat naiset}

Naisliikkeen ja työväenliikkeen vallankumouksellinen tasa-arvon vaatimus nousi naisten ja työväestön oikeudettomista oloista. Toiset naiset olivat kuitenkin oikeudettomampia kuin toiset. Naiset eivät muodostaneet yhtenäistä ryhmää eikä naisten asema ollut aina yksiselitteisen heikko. Laeissa ja asetuksissa naisen aseman määrittely oli sidoksissa hänen siviilisäätyynsä ja varallisuuteensa. Muun muassa vuoden 1734 laki antoi naisista leskivaimoille erikoisaseman. He saivat hallita itseään ja omaisuuttaan. Naimattomat naiset puolestaan olivat joko isiensä tai työnantajiensa holhouksen alaisina. Naimisissa olevat naiset puolestaan olivat vajaavaltaisia ja miestensä edusmiehisyyden alaisia.

Naimattomat naiset vapautettiin ensimmäiseksi vuoden 1864 asetuksella. Lyhyesti sanottuna heidät vapautettiin palkkatyöhön kasvavan teollistumisen ja virkamiehistymisen myötä. Uudistus toi naimattomille naisille myös muita vapauksia. He saivat oikeuden valita puolisonsa ja hallita ansaitsemiaan palkkatuloja. Naimisissa olevien naisten aseman kohentaminen sen sijaan vei pidemmän aikaa. Muutamia pienempiä uudistuksia heidän oikeudelliseen asemaansa tehtiin 1800-luvun loppupuoliskolla, mutta vaimon holhouksenalaisuus purettiin vasta vuonna 1929 laaditulla ja vuonna 1930 voimaan tulleella avioliittolailla.

Naisten palkkatyöläistymisen kannalta vuoden 1864 asetuksen lisäksi muita tärkeitä uudistuksia olivat vuoden 1879 elinkeinoasetuksen tuoma oikeus hallita omia palkkatuloja, naisten oikeus toimia postilaitoksessa (1864 ja 1916) sekä naisten oikeus virkoihin (1926).

Tavallisen kansannaisen elämän ehdot 1800-luvulla olivat riippuvaisia siviilisäädyn lisäksi hänen sukutaustastaan, sosiaaliluokastaan ja suhteestaan maahan. Myös sillä, millä puolella Suomea hän sattui asumaan, oli merkitystä hänen elämänsä rakentumiseen. Se, oliko hän talontytär, torpparin vai palkollisen lapsi tai orpo asetti hänet yhteiskunnallisessa katsannossa kastiin, josta hänen oli vaikea irrottautua. Vuosisadan loppua ajatellen ei myöskään ollut merkityksetöntä, oliko rahvaannainen syntynyt sisä-Suo- 
men kaskimailla, eteläisellä sahojen merkitsemällä rannikkoseudulla vai Lapin jokivarsilla.

Naisten määritteleminen yhdeksi "luokaksi", jolla olisi yhdenmukaisia tarpeita ja vaatimuksia, ei siis ollut mitenkään itsestäänselvä asia. Tämä olikin ensimmäinen suuri haaste ja naisliikkeen toiminnan ja kannatuspohjan laajentamisen elinehto. 1800-1900luvun vaihteen uudistuva lainsäädäntö palveli tässä suhteessa naisliikkeen päämääriä. Paitsi että naisia koskeva lainsäädäntö tasaarvoisti naisia keskenään, se mahdollisti tien myös sukupuolten väliselle tasa-arvokehitykselle.

Naisten virallisen aseman määrittäminen lainsäädännön kautta ajoittui Suomen historian yhteen tärkeimpään murroskauteen. Ajanjaksoa 1864-1930 voidaankin syystä kutsua suomalaisten naisten laillisten oikeuksien toteutumisen kaudeksi. Käytännössä naisten vapautuminen tarkoitti tasa-arvoistumista lain edessä. Ennen kuin tasa-arvoistavaan lainsäädäntöön päästiin, oli naisten yhteiskunnallinen asema jo muutoksen kourissa niin palkkatyöhön siirtymisen ja ydinperheistymisen osalta kuin niistä johtuvien uusien kodinhoito- ja lastenhoitojärjestelyjen vuoksi.

$\mathrm{Se}$, että naisilla ei ollut agraarisessa yhteiskunnassa ${ }^{7}$ oikeudellisia tai poliittisia oikeuksia, ei tarkoittanut sitä, etteikö heillä olisi ollut valtaa sosiaalisissa yhteisöissään. Tunnemme hyvin mielikuvat talonemännistä, joiden leveillä lanteilla killuivat isot avainniput vallan symboleina. Pientiloilla emännät puolestaan jakoivat työt miestensä kanssa ja vastuun taloudenpidosta. Naisten oikeudettomuus ja vallattomuus ilmeni 1800-luvulla karkeana eriarvoisuutena nimenomaan julkisessa, kodin ulkopuolisessa elämässä.

\section{Kansanterveyden sanansaattajat}

Naisten elämänhallintaa 1800-luvun loppupuolella rajoittivat oikeudellisen ja poliittisen vajaavaltaisuuden lisäksi kansanterveydelliset epäkohdat. Vaikka yksittäisiä naisia yhteiskunnallinen vallattomuus kosketti hyvin eri tavalla, voidaan osoittaa kuitenkin suhteellisen yhtenäinen naisten ikäluokka, joka joutui tai sai koh-

7 Suomalaisten naisten asemasta 1600-1700-luvulla ks. Pylkkänen 1990; Sirén 1999; Waris 1999. 
data yhteiskunnan muutokset kriiseineen kovin omakohtaisesti, nimittäin 1860-luvun nälkävuosien aikana ja heti sen jälkeen syntyneet suuret ikäluokat. Nämä naiset kokivat kaksi venäläistämiskautta, ensimmäisen ja toisen maailmansodan, kansalaissodan ja 1930-luvun alun oikeistoradikalismin. Heidän elämänhallintaansa heikensivät lisäksi selvemmin kuin esimerkiksi heidän itsenäisyyden alussa syntyneiden lastenlastensa eloa tappavat taudit: kolera, influenssat, hinkuyskä, lavantauti, tuberkuloosi ja espanjantauti.

Lukijasta saattaa tuntua oudolta, että poliittista naisjärjestöä esittelevän tutkimuksen yhtenä lähtökohtana on kansanterveydellinen näkökulma. Sitä voidaan perustella kuitenkin sillä, että enemmän kuin mikään muu seikka, terveys ja sen menettäminen hallitsivat työläisnaisten ja heidän perheidensä elämän rakentumista ja vaikuttivat heidän elämänhallintaansa. Näin ollen myös työläisnaisten etujärjestö, Sosialidemokraattinen naisliitto, asetti ohjelmissaan ja käytännön toimissaan kansanterveysasian keskeiselle sijalle. Tästä näkökulmasta katsottuna työläisnaisliike nousi hyvin konkreettisista arkipäivän epäkohdista.

\section{Ihmistapojen opetusta}

Tavallisen kansan siisteys- ja puhtauskäsitykset olivat 1800-1900luvun vaihteessa tämän päivän tapoihin verrattuna varsin alkeelliset ja niiden muuttaminen oli työlästä. Naisjärjestöjen lisäksi myös etenkin maaseudulla kansakoulut levittivät uusia elämäntapoja, kuten seuraavasta muistelmasta käy ilmi: ${ }^{8}$

Siisteys oli alkukantainen. Niinpä miehet sylkivät lattialle räkä- ja tupakkasylkensä. Samainen lattia oli myös lasten käymälä. Kun kansakouluja alkoi tulla useampia kuntiin, oli niillä suuri merkitys ihmistapojen opetuksessa. Niinpä koulua käyvät lapset jo vaikuttivat vanhemmille, että tapoja on korjattava, kun opettajat kouluissa selittävät lapsille, kuinka kulkutaudit leviävät bakteerien vaikutuksesta. Monet vanhat pistivät leikiksi, ettäs mikäs se semmonen "patteri on, kun se ei näy". Mutta paljon oli myös vanhempaa väkeä, jotka ottivat huomioon koululaisten varoitukset. 
Kaupungeissa siisteysolot eivät olleet sen paremmat. Suuri maaltamuuttoliike 1800-luvun lopulla aiheutti asuntopulan suurimmissa kaupungeissa ja niinpä kaupunkeihin muuttaneet nuoret tytöt joutuivat asumaan ahtaasti sukulaistensa nurkissa hellahuoneissa, palveluspaikkojensa keittiöissä sekä leipomojen ja ruokaloiden takahuoneissa, joissa he altistuivat paitsi taudeille, myös seksuaaliselle hyväksikäytölle. Etenkin ravintoloissa töissä olleet naiset leimautuivat usein ns. huonoiksi naisiksi. Eräitä helsinkiläisiä yrityksiä arvioitiin näin: "Leskirouva Engbergin liikkeessä on erittäin oppilaitten huone pieni ja huonolla ilmalla pilattu vesijohdon tähden, tässä huoneessa makaa 5 oppilasta kahdessa kerrossängyssä..." Sama surkea asumistaso oli myös nuorten miesten kohtalona: "Fischerin liikkeessä työntekijöiden asuinhuoneet ovat erittäin ahtaat ja epäkuntoiset, kahdessa vähäisessä huoneessa asuu 10 miestä, vuoteita 7...Myös Andstenin liikkeessä asunto on niin ahdas, että osan täytyy maata työhuoneessa, 6 miehellä käytettävänä 3 sänkyä". ${ }^{9}$ Sänkyjen vähäisyydestä johtuen nukuttiin samoissa vuoteissa ja petivaatteissa vuorotellen, jolloin taudit pääsivät hyvin leviämään. Nouseville ammattiosastoille ja työväenyhdistyksille asuntojen ja työpaikkojen terveysolojen kohentamisesta tulikin monikymmenvuotinen valistusprojekti.

Työläisnaisliikkeessä terveysvalistus oli osa työväestön kokonaisvaltaista sivistämistä ja kokonaisen uuden asenteen ja elämäntavan ja vastuun opettamista, kuten seuraavasta, työläisnaisaktiivi ja kansakoulunopettaja Hilja Pärssisen kirjoituksesta vuodelta 1908 ilmenee: ${ }^{10}$

Sivistynyt työläisnuoriso on perillä terveydenhoidosta, se käsittää, mitä ruuan, ollakseen ravitsevaa, tulee sisältää, että huoneessa tulee olla valoa, ilmaa, lämpöä, tilaa ja puhtautta, se tietää miten sivistystarpeet kysyvät kustannuksia ja kuinka kaikki nuo ovat suuremmat kun perustetaan koti, tullaan perheen elättäjiksi.

Hyvinvointia tutkittaessa kiinnitetään huomiota yleensä kuolleisuudessa tapahtuneisiin muutoksiin. Onkin osuvasti sanottu, että olipa hyvinvointi mitä tahansa, se ei ole sairautta ja ennenaikaista

9 Helsingin työväenyhdistyksen leipuri- ja kondiittori-ammattiosaston pöytäkirja 8.11.1897 TA; Marjatta Nokan (s. 1924) haastattelu. Työväen Muistitietotoimikunnan kokoelmat 1346/ 2.

10 Porvarit työläisten avioliiton ja perheen vihollisina, kirj. Hilja Pärssinen, 1908, s. 3 
kuolemaa. 1800-1900-luvun vaihteen suomalaiset eivät eläneet hyvinvointivaltiossa. Jos he selvisivät korkean imeväisyyskuolleisuuden uhasta, he kärsivät tappavista tartuntataudeista ja elivät lyhyemmän elämän kuin vuoden 2000 suomalaiset. Vuonna 1900 syntyneen tytön elinaika oli noin 47 vuotta, vuonna 1990 syntyneelle se on noin 80 vuotta. ${ }^{11} 1900$-luvun muutos tässä suhteessa on ollut raju.

Tartuntataudit olivat vuosisadan vaihteen ihmisten yksi suurimmista vitsauksista. Vielä vuonna 1936 ne kattoivat yli puolet alle 35-vuotiaiden kuolemista. Erityisesti tuberkuloosi eli keuhkotauti oli pahimpia kansanterveysongelmia. Tuberkuloosi poikkesi muista tartuntataudeista siinä, että se oli leimallisesti perhetauti: yhden perheenjäsenen sairastuttua oli todennäköistä, että muutkin perheenjäsenet saivat ahtaissa oloissa asuttaessa tartunnan. Kansan uskomusten mukaan keuhkotaudin sai kylmästä. Kansa lääkitsi itseään juomalla virtsaa, tervaa, maitoa ja veteen liuotettuna katajaa ja suopursua.

Vuosisadan vaihteessa alettiin valtiovallan taholta järjestelmällisemmin tukea erityisiä hoitolaitoksia keuhkotautisille. Ensimmäinen lapsille tarkoitettu parantola perustettiin vuonna 1901 ja aikuisille vuonna 1903. Varsinainen kansanparantolajärjestelmä suurine sairaaloineen ja avarine terasseineen toteutettiin vuodesta 1925 lähtien. Suomessa toimi 1930-luvun lopulle tultaessa 44 keuhkotautiparantolaa. Niissä potilaille opetettiin itsehoidon merkitystä, hygieniaa ja ylipäätään uutta asennoitumista asumiseen ja puhtauteen. Tuberkuloosin vastustamistyöllä oli tätä kautta suuri merkitys kansan siisteys- ja puhtauskäsitysten muokkauksessa. Tässä työssä naisjärjestöjen rooli oli keskeinen aina 1950-luvulle saakka, jolloin kulkutauteihin keksittiin tehokkaita lääkkeitä. Samoihin aikoihin kansan terveydentila elintason nousun myötä nousi yleisemmässäkin mielessä. ${ }^{12}$ Tämä heijastui myös naisjärjestöjen työhön.

11 Koskinen-Martelin 1994, 's. 150-225.

12 Ks. mm. Backman-Savonen 1934; Nenola 1986; Kuusi 1995; Lähteenmäki 2000, s. 147162 . 


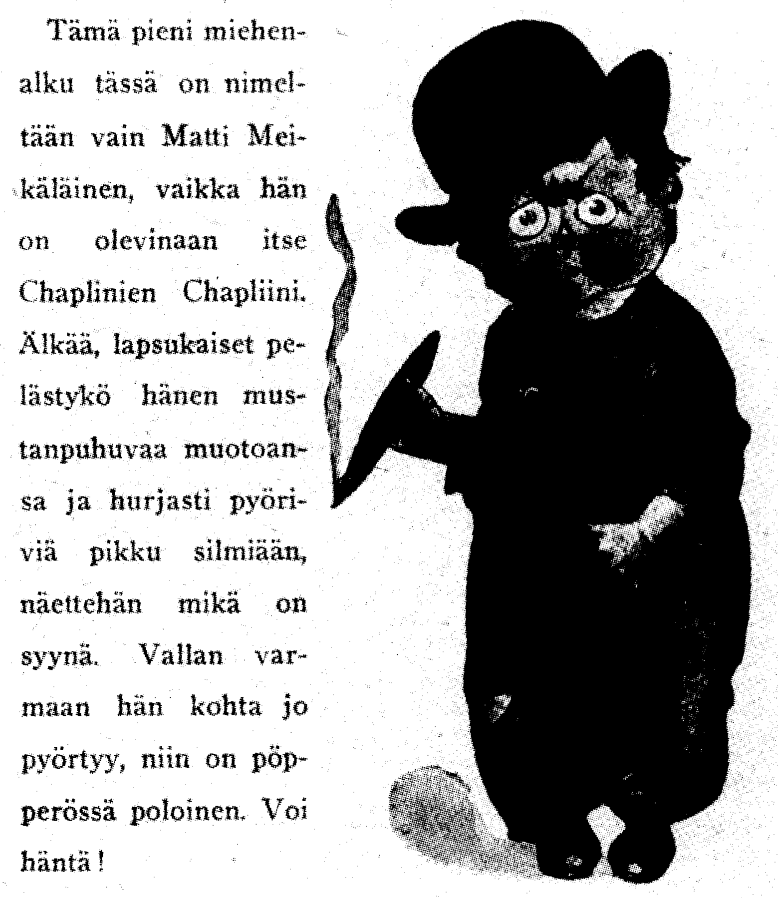

Sosialidemokraattisen naisliiton äänenkannattajassa julkaistiin terveysvalistusta ja tapakasvatusta koskevia artikkeleita. Kuvan varoitus julkaistiin Toverittaressa nro 1/1924. Kuva: Työväen Arkisto.

Työläisnaisliikkeen yleisenä kasvualustana voidaan sanoa olleen uusien aatteiden - liberalismin ja nationalismin - tasa-arvon sano$\mathrm{ma}$, kaupungistumisen ja teollistumisen aiheuttamat muuttuneet elinolot ja naisten oikeudeton asema. Järjestäytymistä kiihdytti oletettavasti myös yhteyksien höltyminen agraariseen elintapaan sekä sosiaalisen kanssakäymisen ja verkostojen puuttuminen uusissa oloissa. ${ }^{13}$ Nuoret kaupunkilaiset etsivät uusia yhteisöllisyyden muotoja kansanliikkeistä. Sen sijaan vanha selitys siitä, että kurjuus olisi ajanut työväestöä järjestäytymään, ei ole riittävä eikä uskottava peruste. 1800-luvun lopullahan päinvastoin olot alkoivat kohentua ja epäkohtiin alettiin kiinnittää aikaisempaa enemmän huomiota.

13 Ks. Hobsbawm 1994, s. 56. 
Kurjuusperuste kaatuu siihen yleiseen havaintoon, että muutoksenhakuisuus tai kapina vallitsevia oloja vastaan ei lähde liikkeelle kaikkein surkeimmissa oloissa elävien joukosta, vaan jo hieman parempaan asemaan päässeiden ja yhteiskunnalliselta tietoisuudeltaan tietyn tason saavuttaneiden joukosta. Lähteäkseen esittämään yhteiskunnallisia vaatimuksia ihmisillä täytyy olla jokin käsitys siitä, että heidän kärsimyksensä eivät ole väistämättömiä, maailman menoon kuuluvia asioita, vaan johtuvat yhteiskunnallisista oloista ja ovat muutettavissa. Heillä täytyy siis olla jonkinlainen ideologia, vaikka yksinkertainenkin. ${ }^{14}$ Näin oli asianlaita myös työläisnaisliikkeessä.

Kaavio 1. Sosialidemokraattisen naisliiton nimenmuutokset

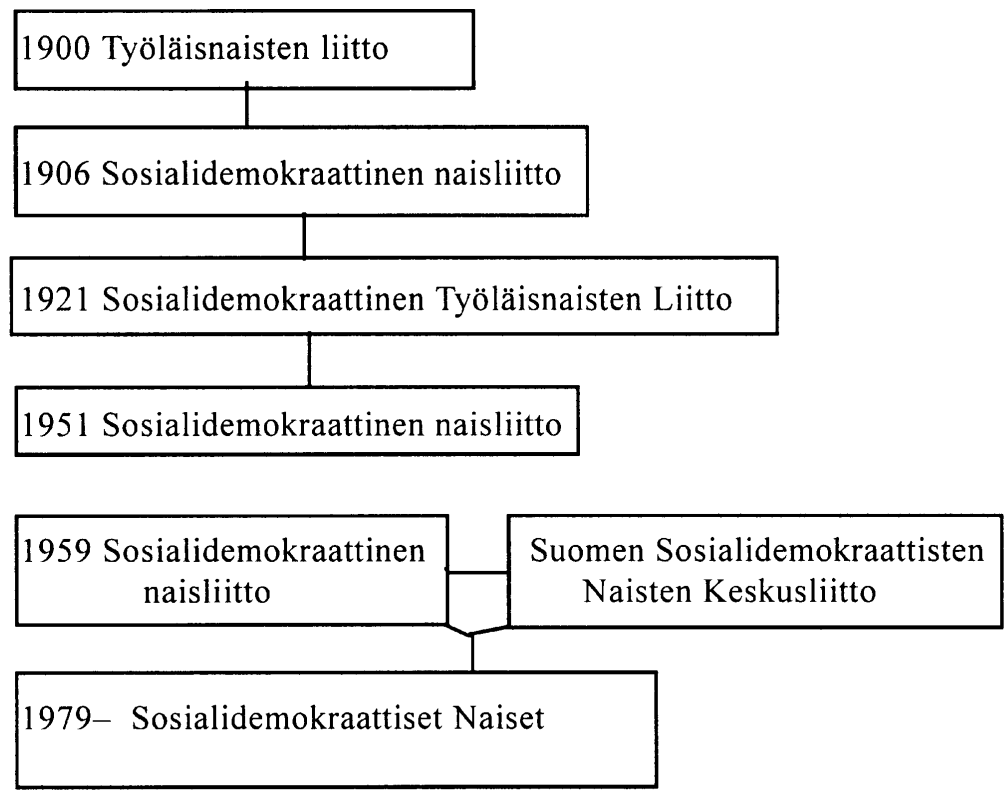

14 Ks. mm. Soikkanen 1987, s. 105-113; Kaukamaa 1939, s. 480-492; Alapuro 1990, s. 238; Ks. myös Thompson 1996, s. 126-150. 


\section{Fennomaaninen työläisnaisliike}

\section{Ompelijoiden ja palvelijoiden esiinmarssi}

Suomalaisen työläisnaisliikkeen primus motoreita olivat naisvaltaisten alojen naiset, nimittäin ompelijat ja palvelijattaret. Siitä, miksi juuri nämä ryhmät järjestäytyivät ensin, voidaan esittää moniakin arveluita. Vaikka ammattien sosiaalinen status oli kovin erilainen - ompelijat olivat tuolloisen käsityksen mukaan lähes keskiluokkaisia ja palvelijat selkeästi piikatyttöjä - niitä yhdisti kaksi tekijää, jotka selittävät järjestäytymisen aikaisuutta. Nimittäin kaupunkilainen elämäntapa ja läheinen kytkeytyminen porvarilliseen elämänmenoon ja -tapoihin.

Ompelijoiden asiakaskunta oli keskiluokkaista, palvelijoiden isäntäväki samoin. Työläisnaisliikkeen pioneereilla oli arkielämän kautta saatu kosketus ja kokemus siitä, millaista elämä oli vähemmän niukassa taloudessa. Porvarilliseen elämäntapaan liittyvä sanomalehtien ja kirjallisuuden lukeminen sai aikaan vastakaikua ja tiedonjanoa myös palveluskunnassa. Nämä kuulivat ja seurasivat isäntäväen keskusteluja ja väittelyitä ajankohtaisista yhteiskunnallisista kysymyksistä, kuten kansanvalistuksesta, suomalaisuusliikkeestä eli fennomaniasta ja raittiusliikkeestä. Ompelijattarien statusta nostatti puolestaan käsityöläisten vanha kunniakas perinne ja he pitivätkin itseään monta kertaa mieluummin herrasväkeen kuuluvina kuin palkkatyöläisinä. Näitä ammattiryhmiä yhdisti myös aivan toisenlainen liikkumavapaus kuin tehdastyöläisiä. 1800-luvun lopun nopeasti kasvavissa kaupungeissa palvelijattarien ja ompelijattarien kysyntä oli jatkuvaa, ja nämä saattoivat valita parhaita paikkoja ja vaihtaa paikkaa halunsa mukaan.

Ompelijoilla ja palvelijattarilla oli toimintamalli, esikuva ja tavoite joka päivä edessään. He olivat tässä mielessä oivallisen sopivia kansanvalistajia: toinen jalka kansanelämässä, toinen herraspiireissä. Ammatin mukana tulevan kokemuksen kautta he vertasivat ja arvottivat omaa, usein torppariperheen taustaansa ja vanhempiensa elämää palveluspaikan isäntäväen elämään. Vastakohtai- 
suuden tunnistaminen synnytti epäoikeudenmukaisuuden kokemuksen ja loi kannatuspohjaa nouseville tasa-arvovaatimuksille. Työläisnaisten ensimmäisinä järjestöinä perustettiin vuonna 1890 ompelijatar-osasto Helsinkiin ja vuonna 1892 palvelijatar-osasto Viipuriin.

Sosiaalidemokraattisen naisliikkeen 100-vuotisen historian kannalta on symbolista, että liikkeen esiäidit tekivät töitä käsillään ja palvelivat muita.

Kaiken kaikkiaan varhaisimmat työläisnaisten yhteenliittymät olivat perusluonteeltaan kansallisuusaatteen elähdyttämiä ammatillisia etujärjestöjä ja sosiaalisia yhteisöjä: "Ammattiosastojen toiminta keskittyi alkuaikoina enemmän huvipuoleen". ${ }^{1}$ Suomalaista työväenliikettä voidaan kutsua ensimmäisistä työväenyhdistysten perustamisista (1883) aina 1890-luvun puoliväliin saakka liikkeen porvarilliseksi kaudeksi. Näin siksi, että toimintaa johtivat Viktor Julius von Wrightin kaltaiset tehtailijat ja maltilliset liberaalit. ${ }^{2}$ Työläisnaisten valtakunnallinen järjestö syntyi kuitenkin vasta liikkeen siirryttyä liberaalilta sivistyneistöltä radikaalien työläisten käsiin. Näin ollen Työläisnaisten liitto oli lähtökohtaisesti luokkasidonnainen järjestö.

\section{Erillinen naisliitto}

Euroopan työväenliikkeen historiassa on erikoista, että työväenpuolueen yhteyteen perustettiin erillinen valtakunnallinen naisliitto. Näin kuitenkin kävi Suomessa heinäkuussa 1900. Se, ettei erillisiä työläisnaisorganisaatioita suosittu sosialistisessa liikkeessä, juontui työväen asian sukupuolettomuuden periaatteesta: työväenliikkeessä ei katsottu olevan erillistä naiskysymystä vaan yhteinen työväenkysymys. Toisekseen naistoiminnan eriytymättömyys kertoo naisten poliittisten oikeuksien puutteesta. Esimerkiksi Saksassa naisten kuuluminen poliittisiin järjestöihin oli vuoteen 1908 saakka kielletty. Tämä ei kuitenkaan tarkoittanut sitä, etteivätkö myös siellä naiset olisi järjestäytyneet. He kuuluivat moninaisiin kulttuuri- ja hyväntekeväisyysjärjestöihin sekä virkistys- ja ääni-

1 Ulapalla 1910 , s. 16

2 Ns. wrightiläisestä eli porvarillisesta työväenliikkeen kaudesta mm. Tuomisto 1984; Soikkanen 1961; Koskinen 1952. 
*Työläislasten alkuopetus

Teollisuusyhteisöissä työväestön tyttäret ja pojat saivat ensimmäiset oppinsa tehtaankouluissa. Suomen ensimmäisiä tehtaankouluja perustettiin 1600-luvun alussa heti sen jälkeen, kun yleinen asetus lastenkouluista oli annettu. Maalaisrahvaan lapset puolestaan saivat oppinsa niin ikään 1600-luvulta lähtien perustetuissa pitäjänkouluissa. Alkeisopetusta annettiin myös rippikouluissa, pyhäkouluissa ja yksityisissä "köyhäinkouluissa" sekä käsityöläisten oppipoikia ja kisällejä varten perustetuissa sunnuntaikouluissa.

Ruotsin valtakunnan ensimmäiset tehtaankoulut perustettiin rautaruukkien yhteyteen ja ne oli aluksi suunniteltu ulkomailta tulleiden mestareiden lapsille. Koulujen opetussuunnitelmissa oli laskentoa, kirjoitusta, taloudenpitoa sekä ennen muuta uskontoa. Työväestön lapsille tarkoitetuissa tehtaankouluissa opetettiin pääosin lukemista, laskentoa ja kristinoppia. Valtakunnan itäosaan, Suomeen, ensimmäinen tehtaankoulu perustettiin Kemiöön vuonna 1649 pappien myötävaikutuksella. Siihen valittiin paikkakunnan lahjakkaita lapsia oman työväen lasten lisäksi. Pyrkimys oli selkeä: kouluttamalla paikkakunnan väkeä pyrittiin pysyttämään heidät oman tehtaan palveluksessa.

Koulua käytiin vuodessa noin viiden kuukauden ajan, kaksi kuukautta syksyllä ja kolme keväällä. Koulut olivat tasoltaan kovin erilaisia ja opetettavat lapset oli jaettu niissä kahteen ryhmään: köyhimpien lapsille opetettiiin pääasiassa uskontoa, muille useampia oppiaineita. Myös sukupuolella oli merkitystä: tytöille opetettiin pääasiassa vain uskontoa ja sisälukua, pojille myös kirjoitusta ja laskentoa.

Uudenaikainen kansakoululaitos syrjäytti pitäjäkoulut ja tehtaankoulut vuonna 1866 annetun ensimmäisen kansakouluasetuksen seurauksena. Ensimmäinen tytöille ja pojille yhteinen yhteiskoulu perustettiin vuonna 1883. Yhteiskoululla sanotaan olleen suuri merkitys tyttöjen integroimiseksi yhteiskunnalliseen toimintaan.

Lähde: Aurola Eelis, Suomen tehtaankoulut 1636-1881. Suomen Historiallinen Seura. Helsinki 1961; Tyttöjen koulunkäynnin alkuvaiheesta ks. Wilkama Sisko, Naissivistyksen periaatteiden kehitys Suomessa 1840-1880-luvulla. Historiallisia tutkimuksia XXIII. Suomen Historiallinen Seura. Helsinki 1938. 
oikeusseuroihin. Saksalaiset naiset eivät kuitenkaan lainmuutoksen jälkeenkään luoneet omaa liittoa. Tätä on selitetty sillä, että naisilla oli muutenkin suhteellisen vahva asema Saksan sosialidemokraattisessa puolueessa eikä liiton perustaminen esimerkiksi puoluekokous- ja puolueneuvostoedustajien nimeämisen vuoksi ollut tarpeellista. ${ }^{3}$

Suomessahan tilanne oli toinen. Työläisnaisten liitto sai naisten etujärjestönä edustajan puolue-elimiin. Yksittäisellä yhdistyksellä tai naisjärjestöjen ulkopuolisilla naisilla tähän ei ollut mahdollisuutta.

Myöskään Ruotsissa erillistä valtakunnallista naisliittoa ei katsottu tarpeelliseksi perustaa ennen kuin vuonna 1920 Ruotsin sosialidemokraattinen naisliitto -nimisenä. Sitä ennen siellä toimi poliittisena naisorganisaationa vuodesta 1892 lähtien Tukholman yleinen naisklubi ja ammatillisena organisaationa vuonna 1902 perustettu Naisten Ammattiliitto, joka julkaisi Morgonbris (Aamunkoitto)-lehteä. ${ }^{4}$ Kaiken kaikkiaan ammatillinen järjestäytyminen oli vahvempaa muissa pohjoismaissa, mikä johtui osittain Suomen teollistumisen myöhäisyydestä.

Suomalaisten työläisnaisten järjestäytymisen ensivaiheessa ammatillinen kytkentä oli kuitenkin vahvempi kuin poliittinen. Uskottiin, että konkreettiset palkkavaatimukset ja kurjat työolot olisivat ne tekijät, jotka saisivat naiset laajemminkin liikkeelle. Työväenpuolueen perustavassa kokouksessa (1899) käytiin laaja keskustelu naisten "herättämisestä". Helsingin työväenyhdistyksen naisosasto esitti suoraan, että tärkeintä on se, onko työläisnaisilla leipää ja vasta sitten "kun kaikkien taloudellinen hyvinvointi on taattu, voimme miettiä herrasnaisten kanssa yhteisiä kysymyksiä. Silloin on myöskin helpompi pääsy sivistyksen suurelle vainiolle ja sen tuottamille henkisille eduille, joka nyt näyttää melkeimpä mahdottomalta." Vaatimalla ensisijaisesti leipää suomalaiset työläisnaiset kuuluivat samaan toimintaperinteeseen kuin Keski-

3 Saksan sosialistisesta naisliikkeestä ks. Niggemann 1981, s. 38-61, 224-225; Evans 1980, s. 356-370; Lumme 1986, s. 295-349

4 Ruotsin työläisnaisliikkeen järjestäytymisestä mm. Flood 1939; Hirdman 1983; Carlsson 1986.

5 Miten työläis-naiset saataisiin liittymään työväenasian mukaiseen yhteistoimintaan taloudellisen sekä yhteiskunnallisen asemansa parantamiseksi, kirj. Helsingin työväenyhdistyksen naisosasto. Kolmannen yleisen Suomen työväenyhdistyksen edustajain kokouksen pöytäkirja Turussa 17.-20.7.1899, alustuksia, s. 53. 
Euroopan nälkämellakoihin osallistuneet ranskalaiset ja englantilaiset työläisnaiset.

Toinen naisosastolaisten vaatimus oli tuottaa naisille sopivaa valistusmateriaalia. Heidän mukaansa oli vedottava tunteisiin ja saatava "valaisevaa" kaunokirjallisuutta. Taavi Tainio kuitenkin käänsi ammatillisesti suuntautuneiden naisten päitä leipäkysymyksistä suurempiin tehtäviin: "Paras keino parantaa asemaansa on se, että naiset ryhtyvät innolla ajamaan äänioikeusasiaa... Minulla on naisista parempi ajatus kuin naisilla itsellään. Minä luulen, että he voivat innostua muuhunkin kuin sellaiseen, mikä tyydyttää heidän tunteitaan". ${ }^{6}$ Näin jo Työväenpuolueen perustavassa kokouksessa naisille valittiin poliittisen työväenliikkeen tie.

Se, että työläisnaisten erillistoiminta sai kannatusta juuri miespuolisten työväenjohtajien keskuudessa, kertoo maan erikoisesta poliittisesta tilanteesta. Suomalaiset miehet eivät siis välttämättä olleet sen ennakkoluulottomampia tai tasa-arvoisempia kuin eurooppalaiset aateveljensä, mutta tuonhetkiset käytännön seikat puhuivat erillisen ja tehokkaan naisvalistuksen puolesta. Suomihan oli epäitsenäinen maa, jota emämaa pyrki juuri tuolloin järjestelmällisesti venäläistämään. Ulkoisen uhan alla työväenjohtajat näkivät mahdollisuuden puolueen vaikutusvallan kasvattamiseen. Tässä monitasoisessa murrosvaiheessa työläisnaisista tuli yksi tärkeä tukijoukko nuorille puoluemiehille. Jotta naiset olisivat tehtävästään tietoisia, perustettiin erillinen liitto heitä valistamaan.

Sitoutuminen tiiviimmin puolueeseen muutti naisliiton toimintaprofiilia. Kun naisliiton ensimmäisessä kokouksessa oli naisammattiosastoja edustettuna 14 ja työväenyhdistysten naisosastoja vain kuusi, oli tilanne vuoden 1909 edustajakokouksessa muuttunut täysin toiseksi. Mukana oli vain kaksi ammattiosastoa ja 38 naisosastoa. Jäsenten siirtymään olivat syynä erillisten ompelija- ja palvelija-ammattiliittojen perustamiset vuonna $1906 .^{7}$ Naisliitto luopui myös "Työläisnaisten liitto" -nimestään vuonna 1906. Siitä tuli Sosialidemokraattinen naisliitto ja samalla sinetöityi puoluepoliittinen suuntaus naisliiton toiminnassa. Naisten ammattiyhdistysvalistus pyrittiin siirtämään vuonna 1907 riitaisesti perustetulle Suomen Ammattijärjestölle, mutta koska se ei ollut vielä

6 Kolmannen yleisen Suomen työväenyhdistysten edustajain kokouksen pöytäkirja Turussa 17.-20.7.1899, s. 83 .

7 Ulapalla 1910 , s. $15-17$. 
valmis järjestelmälliselle naisasiatyölle ${ }^{8}$ järjesti naisliitto edelleen ammatillisia kokouksia. Muun muassa vuonna 1911 se organisoi 46 ammatillista kokousta. ${ }^{9}$

\section{Naisasialiike ja työläisnaiset}

Työväen tietokirja selitti naisliikkeen syntyä seuraavasti: ${ }^{10}$

Naisliike sai ensimäiset asianajajansa yläluokasta. Jo 15-1600-luvuilla alkoi ilmestyä naisen asemaa käsitteleviä kirjateoksia. Nämät olivat enemmältään miesten, nim. etevien ajattelijain ja kirjailijain työtä. Niissä ihannoitiin naista ja asetettiin hyveissä miehen edelle. Taistelu naisen yhteiskunnallisista oikeuksista, naisliike uudemman aikaisessa merkityksessä, syntyi Amerikassa. Vapaussodan aikana 1776 alkoivat siellä muutamat johtavien miesten rouvat, kuten Adams ja Warren, esittää naisen valtiollisia oikeuksia koskevia vaatimuksia. Englanti seurasi jäljessä. John Stuart Mill jätti parlamentille asiaa koskevan anomuksen v. 1866 ja kolme vuotta myöhemmin hän perusti naisten äänioikeusyhdistyksen...

Suomalaiselle naisasialiikkeelle valmistivat tietä porvarilliset rouvasväenyhdistykset, joista ensimmäinen perustettiin Viipuriin vuonna 1835 saksankielisenä ja Frauenverein-nimisenä. 1840-luvulla perustettiin kymmenkunta rouvasväenyhdistystä eri puolille Suomea. Rouvasväenyhdistykset olivat kuitenkin puhtaasti hyväntekeväisyysyhdistyksiä ja niissä toimivien naisten aviomiehet sekä muut kansallisen herätyksen johtomiehet Topeliuksesta Snellmaniin olivat niissä aktiivisesti mukana. Näin ollen rouvasväenyhdistyksistä ei voida vetää suoraa linjaa varsinaisiin naisasiajärjestöihin, joskin osa naisasialiikkeessä toimineista naisista oli toiminut myös

8 Käytännössä naisten ammatillinen toiminta jäi vuosikausiksi hoitamatta, mikä näkyi naisten ammatillisen järjestäytymisen hitautena. Vuonna 1906 ammatillisesti järjestäytyneitä naisia oli $12 \%$ kaikista järjestäytyneistä. Vuosina 1923-29. vasemmistososialistien ja kommunistien johtoon siirtyneessä SAJ:ssa toimi naisjaosto. Sosiaalidemokraatit perustivat puolestaan vuonna 1938 SAK:n yhteyteen naisjaoston, joka toimii edelleen. Valkonen-Ala-Kapee 1980; Lähteenmäki 1995, s. 149-165; SAJ:n perustamisesta ks. Ala-Kapee-Valkonen 1982, s. $111-127$.

9 Pöytäkirja Sosialidemokraattisen Naisliiton VIsta edustajakokouksesta Helsingissă 1-3. p. syyskuuta 1911, s. 45-46.

10 Työväen tietokirja 1922, s. 190-191; Tietokirjahankkeessa oli naisista mukana Miina Sillanpää ja Hulda Salmi. 


\section{*Päiväkoti 1800-luvulta}

Helsingin Punavuoressa aloitti vuonna 1847 toimintansa Marian turvakoti, joka oli perustettu varattomien työtätekevien luokkien lapsille. Kaksitoista vuotta myöhemmin se sai rinnalleen Semigradskyn pientenlasten koulun Kruununhaan kaupunginosaan. Kotien perustamista ajaneet rouvat olivat saaneet kimmokkeen turvakodin perustamiseksi kruununprinssi Aleksanterin vuonna 1842 tekemän Suomen vierailun yhteydessä. Toimintamuotoa oli jo testattu, olihan kaupungissa toiminut vuosina 1840-46 lasten "päivähoitolaitos". Toimintavaransa päiväkodit saivat yksityisistä testamenttilahjoituksista, mutta kaupunki valvoi hallinnollisesti niiden toimintaa ainoastaan säätyläismiehistä koostuneen johtokunnan avulla.

Koteihin otettiin pääasiassa 3-8 -vuotiaita lapsia, jotka vanhemmat toivat hoitoon aamuisin ja hakivat iltaisin. Lapset saivat kodissa lämpimän aterian, joka oli yleensä puuroa tai velliä. Varattomat saivat sen ilmaiseksi. Opettajan lisäksi kotien henkilökuntaan kuuluivat pari apuopettajaa, keittäjä ja vahtimestari. Opettajan työ oli aluksi lähinnä lapsista huolehtimista, mutta 1860-luvulla eräs opettajista teki opintomatkan Keski-Eurooppaan ja tutustui Pestalozzin ja Friedrich Fröbelin ajatuksiin ja kasvatusmenetelmiin. Tämän jälkeen tuolloinen päiväkotitoiminta alkoi vähitellen muuttaa muotoaan: Marian turvakotiin hankittiin muun muassa urkuharmooni sekä tauluja seinille. Leikin ja kristinopin määrä kasvoi opetuksessa. Lapsilla oli käytössään alusta lähtien pienet lukuaapiset ja liitutaulut, mutta ei leluja. Semigradskyn koulussa oli toimintatilana yksi iso sali, jonka toinen pää oli varattu "rinkileikkeihin" ja toinen lukemiseen. Pihalle oli rakennettu puutarha liikuntaa varten, olihan luonnon ymmärtäminen yksi opetettavista aiheista. Fröbeliläisittäin pyrittiin lapsimäärä pitämään alle kolmenakymmenenä. Suurin osa lapsista oli työväestön lapsia, mutta mukana oli myös uusista opetuskokeiluista kiinnostuneiden säätyläisten lapsia.

1800-luvun lopussa avattiin uusia lastentarhoja Helsingin väkimäärän kasvaessa voimakkaasti. Samalla puhtaasti hyväntekeväisyyslaitokset alkoivat vähentyä kuntien ja kaupungin otettua enemmän vastuuta pienten lasten hoidosta.

Lähde: Toivanen Hannes, Lastenhoitotyö ja varhaisopetuksen kehitys ja kehittäjät Marian turvakodissa ja Semigradskyn pientenlastenkoulussa 1840-1910. Suomen historian proseminaariesitelmä. Helsingin yliopisto 1996. 
rouvasväenyhdistyksissä. Se, että myös vuosisadan lopulla toimineiden naisasianaisten kaksi tärkeää keskusteluteemaa olivat hyväntekeväisyys ja koulutuskysymykset, yhdistivät seuroja.

Rouvasväenyhdistyksissä käytiin 1840-50-luvulla kiihkeää keskustelua kansanopetuksen tarpeellisuudesta ja siitä, tulisiko kansanopetus olla vain kirkon tehtävä. Näin etenkin kun vuoden 1850 sensuuriasetus salli vain uskonnollisen ja käytännöllisen kansankielisen kirjallisuuden levittämisen. Kirkkohan oli 1800-luvulla yhteiskunnan johtavin henkinen voima ja kulttuurielämän perusta. Tuonaikaista kansanopetusvaatimusta johti J.V. Snellman Saimalehtensä välityksellä. Ensimmäiset säätyläisnaisten hyväntekeväisyyteen perustuvat köyhäinkoulut perustettiin Kokkolaan ja Raaheen vuonna 1840. Seuraavalla vuosikymmenellä niitä oli jo lähes kaikissa kaupungeissa. Suurimpiin kaupunkeihin ilmestyivät myös ensimmäiset rouvasväenyhdistysten ylläpitämät lastenkodit turvattomille tytöille. On kuvaavaa, että köyhille tytöille tarkoitetuissa ensimmäisissä kouluissa opeteltiin paitsi luku- ja kirjoitustaitoa, myös talous- ja käsityötaitoja.

Naisasialiikkeen käytännön toiminta nousi siten kolmesta keskeisestä aiheesta: tyttöjen ja naisten koulutuskysymyksestä, sosiaalisesta vastuusta vähävaraisia kohtaan ja naisten keskeisestä asemasta perheen moraalin ja kasvatuksen ylläpitäjinä.

Emansipatorisen naisliikkeen voidaan sanoa alkaneen Suomessa vuonna 1869, jolloin säätyläisneitokainen Adeleine Ehrnrooth kirjoitti Helsingfors Dagbladetiin esittelyn englantilaisen liberalistin John Stuart Millin teoksesta Subjection of Women, joka suomennettiin Naisen asema-nimisenä vuonna 1910. Teoksesta tuli naisten äänioikeuskamppailun käsikirja eri maiden radikalisoituvissa naisasiapiireissä. Kirjassaan Mill vaatii naisille kaikkia niitä oikeuksia, mitä miehilläkin oli: äänioikeutta, oikeutta hallita omaisuuttaan, oikeutta toimia eri ammateissa...eli kaikkia niitä oikeuksia, joita naisille ei tuolloin suotu.

Jo ennen Ehrnroothin kirja-esittelyä oli kansalliskirjailijaksi nostetun Johan Ludvig Runebergin vaimo Fredrika tiivistänyt naisen aseman heikot kohdat 1850-60-luvun kirjoituksissaan: omistusoikeuden rajoitukset, ammattiopetuksen puuttuminen, vaikeus yltää korkeampaan sivistykseen ja työvalinnassa ilmenevät hankaluudet. Fredrika Runebergiä on luonnehdittu pohjoismaisen nais- 
liikkeen esitaistelijoiden, kuten 1830-luvulta lähtien vaikuttaneen suomalaissyntyisen Fredrika Bremerin, ensimmäiseksi suomalaiseksi seuraajaksi. ${ }^{11}$

Suomalaisten työläisnaisjohtajien esikuvina ja alkuajan ohjaajina toimivat porvarilliset naisasiajärjestöt, vuonna 1884 perustettu Suomen Naisyhdistys ja etenkin vuonna 1892 siitä erkaantunut Naisasialiitto Unioni. Työläisnaiset julistivat kuitenkin olevansa toisenlaisia valistajia kuin porvarilliset kollegansa: ${ }^{12}$

Siispä tahdomme säälimättä paljastaa sen kurjuuden, jossa nykyinen yhteiskunta pitää suuren osan jäsenistään, työväestön himmentämällä työläisten itsetunnon ja selittämällä heille kaikki epäkohdat luonnollisina Jumalan lähettäminä viittauksina, joihin on paras tyytyväisyydellä alistua. Kuulemme alinomaa, kuinka eräät parempiosaiset muka haluten "valistaa" kansaa lähestyvät tätä puheilla, joiden tarkoitus on nukuttaa työväestöä, että rikkaat voisivat heistä yhä eteenkinpäin hyötyä.

Järjestäytyvän työläisnaisliikkeen suhde porvarillisiin naisjärjestöihin muovautui aluksi myönteiseksi. Kun työläisnaisten liitto piti ensimmäisiä kokouksiaan, näyttivät porvarilliset naiset kädestä pitäen mallia, miten tilaisuudet oli järjestettävä ja mitkä teemat olisivat keskeisiä naisjärjestöjen työssä. Esimerkiksi Helsingin työväenyhdistyksen naisosaston perustavassa kokouksessa toukokuussa 1898 puhetta johti Naisasialiitto Unionin Lucina Hagman. Työläisnaisten suhde porvarillisiin naisiin kuitenkin viileni ja muuttui kriittiseksi 1900-luvun alussa sitä mukaa, mitä tiukemmin työläisnaiset sitoutuivat työväenpuolueeseen ja omaksuivat radikaalimmat vaatimukset.

Selvä taitekohta torjuvampaan suuntaan ajoittui naisten äänioikeuskamppailun alkuaikoihin. Vielä työläisnaisten toisessa edustajakokouksessa vuonna 1902 oli mukana Naisasialiitto Unionin edustaja tohtori Maikki Friberg. Ilmapiiri oli kuitenkin jo viilennyt naisten keskinäiselle yhteistyölle, vaikka Friberg kehuikin työläisnaisten "löytäneen itsensä". Ennen tätä tunnustusta naisliiton Maria Laine piti palopuheen työläisnaisten oman lehden perustamisesta. Kokousta seurannut lehtimies Anton Huotari kuvaa tilan-

11 Wilkama 1938, s. 97-98; Rouvasväenyhdistyksistä ja porvarillisesta naisliikkeestä ks. myös Ramsay 1993; Jallinoja 1983; von Alfthan 1966.

12 Sananen työväenasiasta. Lentokirjasia työvăestőlle II. 1903, s. 3. 
netta näin: "Mutta kun Laineen Maija oli musertavasti todistanut, kuinka puoluelehtienkin toimituksissa irvistellään naisten kirjoituksille ja repäisevällä tavalla huudahtanut "mitä nainen tahtoo, sitä tahtoo jumalakin!" niin kohta tahtoi jumala, että kokouksen enemmistö oli oltava lehtihankkeen takana". Huotari pilkkaa avoimesti kiittelevää Fribergiä pitäen tämän puhetyyliä niin äitelänä, että "minua vieläkin se ällöttää". ${ }^{13}$

Työläisnaisaktiivi Hilja Pärssinen totesi vuonna 1903: "Porvarilliset ohjaajat ovat riveistämme pois karisseet ja järjestömme toiminta on puhtaan sosialidemokratian kannalla". ${ }^{14}$ Tätä eroa kuvaa hyvin se, että "rouvien ystävä", Palvelijatar-yhdistyksen puheenjohtaja Miina Sillanpääkin alkoi vuonna 1904 tunnustaa julkisesti väriä eli liittyi sosialidemokraattiseen puolueeseen. Naispiirejä erottavana tekijänä olivat paitsi ideologiset syyt, myös porvarisnaisten nihkeä suhtautuminen työläisnaisten oikeuksien laajentamiseen, erityisesti äänioikeuteen. Työläisnais- ja porvarisnaisaktiivit löysivät kuitenkin toisensa hetkellisesti äänioikeuskokouksessa marraskuussa 1904, kuten tuonnempana kerrotaan. ${ }^{15}$

Työläisnaisaktivistien henkinen irtiotto porvarillisesta "holhouksesta" tapahtui viimeistään suurlakon (1905) jälkeen. Seuraavana vuonna työläisnaisten edustajakokouksessa kiellettiin porvarillisten lehtien kirjeenvaihtajien läsnäolo, samoin kiellettiin puolueeseen kuulumattomilta osallistuminen kokoukseen. ${ }^{16}$ Naisliiton ovet suljettiin ulkopuolisilta.

Tämä ovien konkreettinen sulkeminen voidaan nähdä symbolisena merkkinä siitä, että työläisnaisliitto oli kypsynyt määrittämään toimintansa suhteessa työväenliikkeeseen, mutta ennen kaikkea suhteessa naisliikkeeseen. Järjestäytyneiden naisten työläisidentiteetti rakentui näin porvarilliseen naisliikkeeseen liittyvän eron merkitsemisen ja poissulkemisen kautta. Työväenpuolueen piirissä 1900-luvun vaihteessa nousseen yhtenäisen identiteetin rakentamisen tarve liittyi työväenpuolueen samanaikaisiin valtapyrkimyksiin. Naisista tuli oiva väline saavuttaa sellaisia kannattajia,

13 Naisten yleistä kokousta seuraamassa, kirj. Anton Huotari 5.6.1910. Ulapalla 1910, s. 4344.

14 Eteenpäin. Kalenteri kansalle 1903, s. 43.

15 Aalle-Teljo ja muut työläisnaisaktivistit, kuten Maria Laine, Sandra Reinholdsson, Mimmi Kanervo ja Alma Jokinen toimivat ns. kutsuntalakkojen (1902-04) aikana yhteistyössä kagaalin naisten kanssa, ks. Uranuurtajan tie 1953; Lähteenmäki 1997, s. 71-74, 111-113; Kujala 1995, s.184-268: Katainen-Oittinen 1997, s. 86-90.

16 Työläisnaisten ylimääräisen edustajakokouksen pöytăkirja Viipurissa 8.-10.10.1906, s. 8. 

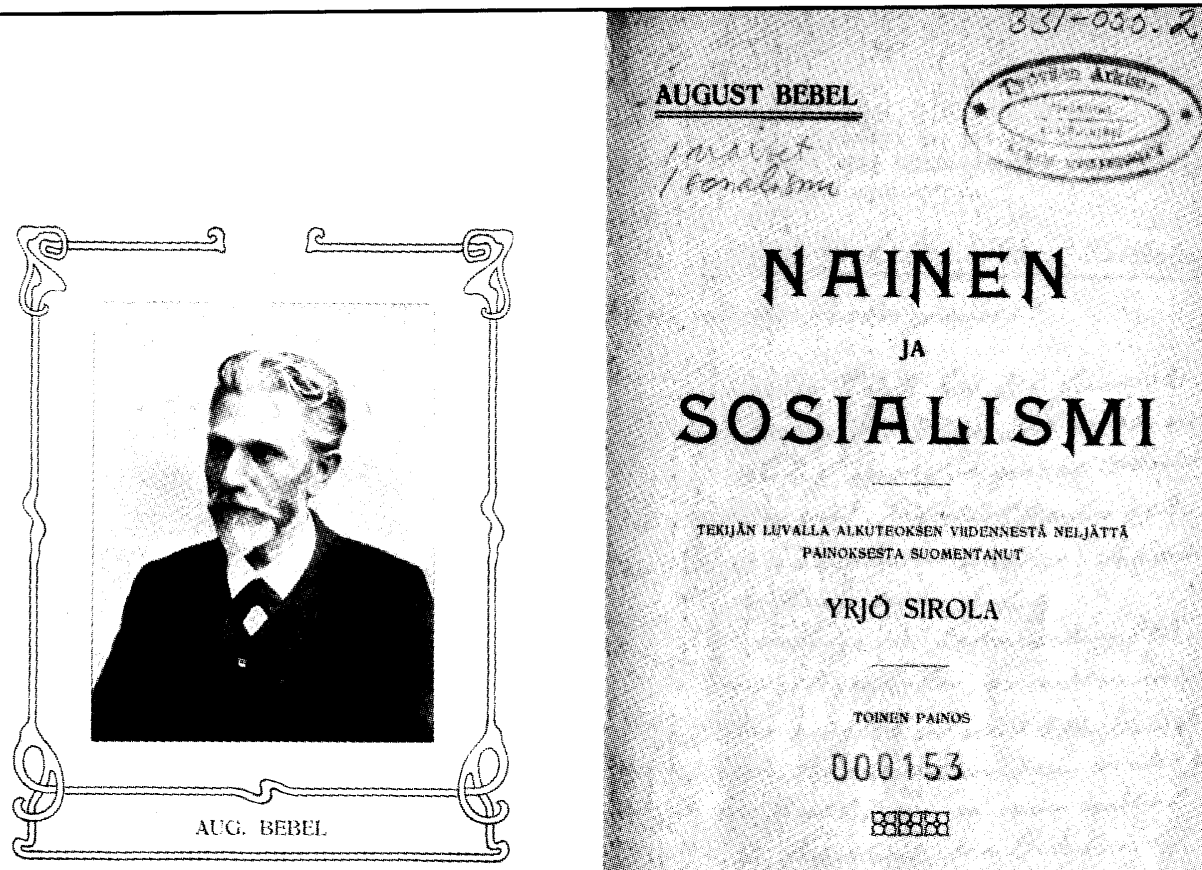

\section{NAINEN}

JA

\section{SOSIALISMI}

TEKHKN LUVALLA ALKUTEOKSEN VIDENEESTA NELAATTA PANOKSESTA SUOMENTANUT

\section{YRJO SIROLA}

TOWEK PANOS

\section{3}

898888

Trovis swuk

whis7o

hothass hen

WHALAW SON T WOAE SANOMALET: in GiNJPAND-OSULSKUNTA $\mathrm{r}$. .

Saksalaisen August Bebelin (1857-1933) laajalti levinneen ja paljon luetun teoksen suomenkielinen nimilehti vuodelta 1907. Kuva: Työväen Arkisto.

joita muutoin olisi ollut vaikea tavoittaa. Rakennettua työläisidentiteettiä vahvistettiin yhteisillä tunnuksilla ja symboleilla, lipuilla, rintamerkeillä, väreillä ja vallankumousretoriikalla. Stuart Hallia lainaten voisi sanoa, että identiteetit nousevat esiin erityisten vallan muotojen leikeissä, minkä vuoksi ne ovat pikemminkin eron ja poissulkemisen tuotteita kuin identtisten, luonnostaan muodostuneiden yksikköjen merkkejä. ${ }^{17}$ Näin työväenliikkeenkin minäkuvaa rakennettiin suhteessa tuolloiseen porvarilliseen ja sivistyneistön liikkeeseen. 
Mistä nousevat työläisnaisjohtajat saivat sitten ainekset identiteettinsä peruspilareiksi ja tietonsa sosialismin teoriasta? Se olikin vaikeaa, kuten Ida Aalle-Teljo on muistellut. Pääosa naisista oli vajaan kansakoulun tai kiertokoulun käyneitä eikä vierailla kielillä lukeminen tai puhuminen onnistunut, olkoonkin että osa ruotsinkielisissä palveluspaikoissa olleista naisliittolaisista oli oppinut puhumaan ja ymmärtämään arkipäivän ruotsia.

Ulkolaista sosialistista kirjallisuutta ei oltu vielä 1800-luvun lopulla käännetty suomeksi paljoakaan. Esimerkiksi August Bebelin vuonna 1879 ilmestynyt Die Frau und der Sozialismus käännettiin vuonna 1904 suomeksi Nainen ja yhteiskunnallinen kysymys -nimisenä ja Yrjö Sirolan kääntämänä. Karl Kautskyn Erfurtin ohjelma käännettiin vuonna 1899 ja Sosialismin historia vuonna 1900. Karl Marxin ja Friedrich Engelsin Kommunistinen manifesti ilmestyi suomeksi vuonna 1906. Paljon käytettyjä käsikirjoja olivat vuosisadan vaihteessa N.R. af Ursinin Työväenkysymyksiä I-II (18971899), jotka esittelivät sosialismin peruskysymyksiä. 1900-luvun puolella käännökset yleistyivät.

Tilanteen ollessa tämä työläisnaisaktiivien oli koottava tietonsa sieltä sun täältä. Tietoa uudesta aatteesta saatiin ensisijassa perustettujen työväenyhdistysten puhuja- ja keskusteluseuroista, joiden kokoukset varsinkin 1890-luvulla saattoivat muodostua kiivaiksikin väittelytilaisuuksiksi. Esimerkiksi Helsinkiin perustettiin puhujaja keskusteluseura vuonna 1888. Siihen aikaan naiset eivät tosin vielä osallistuneet sen kokouksiin. Sosialismin tuulahduksen ja ilmapiirin radikalisoitumisen myötä 1890 -luvulla seuran toiminta virisi uudestaan entistä aktiivisempana ja mukaan toimintaan tuli myös naisia. Helsinkiläiset työväenyhdistysmiehet valittivat, että naiset pitivät siellä hirveää mekkalaa iänikuisesta sorretusta asemastaan. ${ }^{18}$

Puhujaseuroilla oli tärkeä merkitys naisten luokkatietoisuuden avaajina sekä kokous- ja väittelytaitojen kehittäjinä. Sosialidemokraattisen puolueen 64 yhdistyksestä 17:1lä oli puhujaseura vuonna 1900. Niihin kuului sekä miehiä että naisia. ${ }^{19}$

18 Tiuppa 1910 , s. $86,88-89$

19 Suomen sosialidemokraattisen puolueen tilastoa 1903. TA. 
Eräissä yhdistyksissä naiset perustivat lisäksi omia puhuja- ja muita "kehitysrenkaita" pohtiakseen erityisesti naisia koskettavia kysymyksiä. Esimerkiksi Vaasan työväenyhdistyksen naisosastossa luettiin "Osia Pebelin Naisesta". Lisäksi luettiin Kommunistista manifestia sekä sosiaalihuoltoon ja äänioikeuteen liittyviä kirjasia. Naisliiton tehtäväksi tuli lähettää valistuneempia sisaria maakuntiin selvittämään sosialismin vaikeaa käsitteistöä. ${ }^{20}$

Suurimpien työväenyhdistysten naisosastot lähettivät myös omia naispuhujiaan maaseudulle. Esimerkiksi vuonna 1903 Helsingin yhdistyksen naisosasto lähetti kolme puhujaa palvelijattarien vapaaviikolla puhumaan järjestäytymisen välttämättömyydestä. Sama naisosasto vaati jo vuonna 1899 puoluehallinnolta "erityistä naispuhujaa". Tähän ei suostuttu varojen puutteessa, mitä naisosastolaiset paheksuivat syvästi. ${ }^{21}$ Naiset perustivat myös omia ja työväenyhdistysten tarpeita silmällä pitäen ompeluseuroja, joista monista kehkeytyi varsinaisia naisosastoja. Ompeluseurojen perustaminen oli sikäli luontevaa naisaktiiveille, että suurin osa toimijoista oli ammatiltaan ompelijoita. Sitä paitsi käsityötaidon katsottiin kuuluvan "luonnostaan" joka naisen hallitsemaan työsarkaan.

Kansainvälisistä tapahtumista ja etenkin naisasialiikkeen riennoista ja keskusteluteemoista työläisnaiset saivat aluksi tietoja etenkin porvarillisista naistenlehdistä. Suomen Naisyhdistyksen äänenkannattaja Koti ja Yhteiskunta alkoi ilmestyä vuonna 1889 ja Naisasialiitto Unionin Nutid vuonna 1895. Niissä käsiteltiin varsin paljon köyhälistön naisten asemaa kodin ja palkkatyön kurimuksessa.

Työläisnaisten liiton oman Yhteistyöhön -nimisen lehden näytenumero ilmestyi vuonna 1902, mutta ensimmäinen venäläistämisvaihe tyrehdytti yrityksen: painoasiain ylihallitukselta ei saatu lupaa lehden julkaisemiseen. Kaksi vuotta myöhemmin yritys uusittiin ja Kevätesikoisen näytenumero näki päivänvalon. Kuvaavaa on, että sen ensimmäinen artikkeli oli nimeltään "Köyhälistön naiset ja Kaarlo Marx", toinen oli ruotsalaisen Ellen Keyn esittelyä "Perhe ja yhteiskuntakysymys" ja kolmas ranskalaisen Flora

20 Vaasan työväenyhdistyksen naisosaston pöytäkirja 28.1.1900. TA; Vaasan työväenyhdistyksen naisosaston kehitysrenkaan pöytäkirjat 1913. TA; Helsingin työväenyhdistyksen naisosaston pöytäkirja 7.10.1904. TA; Alustuksia ja ehdotuksia sos.dem. naisliittotoimikunnalle Helsingissä 4.-6.10.1917, s. 12.

21 Helsingin työväenyhdistyksen naisosaston kertomus 1899. TA. 
Tristanin romaanin esittelyä naisten sorretusta asemasta. ${ }^{22}$ Yrjö Sirola käänsi artikkelit ja oli muutenkin naisliittolaisten tukena alussa. Kevätesikoisenkin julkaiseminen kiellettiin ja vuonna 1906 naiset perustivat uuden lehden, Kansan naisen. Sen ensimmäinen artikkeli käsitteli Venäjän sosialistis-vallankumouksellisen puolueen periaatteita. Vuosina 1905-06 ilmestyi myös Palvelijatar-yhdistyksen julkaisema Palvelijatar-lehti, jonka nimi vaihdettiin vuonna 1906 Työläisnaiseksi. ${ }^{23}$ Kuten näistä esimerkeistä nähdään, suomalaisten työläisnaisten äänenkannattajat olivat alusta lähtien suuntautuneet kansainvälisyyteen. Toinen ensimmäisistä lehdistä välittyvä kuva on aiheiden laaja-alaisuus, vaikka toki naisiin liittyviä artikkeleita olikin eniten.

Mielenkiintoista on Ellen Keyn ajattelun laajahko esittely työläisnaisten lehdissä. Keyhän oli julkaissut useita naisten roolia ja seksuaalimoraalia käsitteleviä kirjoituksia vuosisadan vaihteessa ja pääteoksensa Lapsen vuosisata vuonna 1900 ja Elämänlinjoja vuonna 1903. Key oli kiistelty hahmo ja hänen kirjoituksensa olivat moniselitteisiä: Toisaalta häntä arvosteltiin vapaan rakkauden papittarena, naisen sukupuolisuuden ylikorostajana ja kirkollisen vihkimisen vastustajana (Keyhän kannatti siviilivihkimistä), toisaalta vanhakantaisena ja naisia äitiyteen ja erotiikkaan kahlitsevana. Keyn mukaan sukupuolirakkaus oli naisen elämän perusarvo. Se teki mahdolliseksi tyydyttää hänen yhtä voimakkaan äitiyden tarpeensa, mutta sen tuli säilyä hänen elämässään positiivisena voimana aina vanhuuteen saakka. Keyn sanomaan liittyi siis kaksi vahvaa elementtiä, ja häntä oli siten helppo tulkita täysin päinvastaisista suunnista. Hänen esityksensä, että äidin piti kasvattaa lapsiaan eikä käydä töissä kodin ulkopuolella, ärsytti naisasianaisia. Esimerkiksi kirjailija Minna Canth väitti Keyn äitiyttä korostavia käsityksiä taantumuksellisiksi. Naisen leimaaminen ensisijaisesti sukupuoliolennoksi sai myös Alexandra Gripenbergin tuomion: hän sanoi suorastaan "tuntevansa suurta tuskaa" tällaisia kirjoituksia lukiessaan.

Eniten myönteistä palautetta Key sai aviovaimojen laillisia oikeuksia käsittelevistä kirjoituksistaan. Key oli kirjoittanut jo vuonna 1884 Suomen Naisyhdistyksen julkaisuun "Naidun naisen omistus-

22 Kevätesikoinen 26.4.1904.

23 Kansan nainen nro 1, 1.5.1906. 
oikeudesta ja täysivaltaisuudesta" ja vuonna 1888 hän kävi esitelmämatkalla Naisyhdistyksen tilaisuudessa ja myöhemmin myös Naisasialiitto Unionin luennoitsijana. ${ }^{24}$

Kun naisasianaiset pohtivat sivistyneistökotien tyttärien uramahdollisuuksia ja yhteiskunnallista äitiyttä, työläisnaiset halusivat kotiin raskaista palkkatöistä. Se, miksi Key sai vastakaikua ja paljon myös ihailijoita, liittyi 1800 -luvun porvarillisen romantiikan käsitykseen, jonka mukaan naisten paikka oli kotona. Keyn artikkeleiden ilmestyminen ensimmäisiin työläisnaisten lehtiin kertoo työläisnaisaktiivien halusta osallistua ajankohtaiseen, naisten asemaa käsittelevään julkiseen keskusteluun.

Ellen Keyn artikkeleiden rinnalla työläisnaisten ensimmäisissä lehdissä oli myös kiivaita taistelu- ja vallankumousartikkeleita, mikä aiheutti ongelmia painolupa-asioissa ja johti ensimmäisten lehtien lakkautuspäätöksiin. Työläisnaisten lehdet hakivat 1900luvun alkuvuosina vielä omaa suuntaansa ja artikkelit olivatkin enemmän esitteleviä kuin julistavia. Monet kirjoitukset olivat suoria käännöksiä ruotsalaisista, saksalaisista ja englantilaisista työläisnaislehdistä.

\section{Naisten muuttuvat roolit}

Ei ole sattuma, että naisasiajärjestöt ja työläisnaisliike syntyivät aikana, jolloin perheen rooli oli muuttumassa. Niin porvaris- kuin työläisnaisaktiiveille tuli tarve määritellä uudelleen perhe ja naisten roolit siinä missä puhtaan ja oikean elämän rajat muutenkin. Perheet pienenivät ydinperheiksi (isä, äiti ja lapset), äidit lähtivät töihin ja kaupungistuminen kyseenalaisti perinteisiä kirkkovihkimiseen, aviolliseen uskollisuuteen ja suurperheeseen (äiti, isä, lapset, osa sukulaisista ja palvelijat) perustuvia perhemalleja. Uudelleenmäärittely lähti yksilöityvän naisen kykyjen ja tarpeiden hyödyntämisestä perheen ja yhteiskunnan onneksi.

Määrittelyn pohjana olivat 1840-luvulta lähtien julkaistut kaunokirjalliset teokset, kuten Henrik Ibsenin "Nukkekoti". Se esitettiin Suomalaisessa teatterissa helmikuussa 1880 . Ibsen vaati ajan hengen mukaisesti, että naisten tuli olla kokonaisia, todellisia ih-

24 Rajainen 1973, s. 58-65; Ellen Keyn vaikutuksesta Clara Zetkiniin ks. Hentilă 1989(b), s. $115-122$. 
misiä eikä tahdottomia nukkeja. Juhani Ahon mukaan Ibsenin teokset olivat suomalaisille todellisia uusien aatteiden juhlia. John Stuart Millin teosta lehdissä esitellyt Adeleine Ehrnrooth oli myös Ibsenin ihailija ja esittelijä. ${ }^{25}$ Myös Venäjällä vapaan ja militantin "uuden naisen" malli levisi yläluokkaisen nuorison ja nihilistien keskuudessa ja ajan henki ilmeni muun muassa Ivan Turgenevin romaaneissa. ${ }^{26}$

Kaunokirjallisuuden ja siitä virinneen kiivaan keskustelun lisäksi naiset muovasivat käsityksiään naiseudestaan ja rooleistaan 1880-luvulta lähtien julkaistujen erityisesti naisille suunnattujen seksuaalivalistus- ja terveysoppaiden avulla. Päinvastoin kuin useimmissa "uuden aallon" kaunokirjoissa, joissa korostui naisten yksilöllisyys ja toimintavapaus kodin ulkopuolella, oppaiden lääkärit määrittelivät naiset kahlitsevasti suvunjatkajiksi, äideiksi ja kasvattajiksi. Niissä korostettiin, ettei naisten terveydentila ollut äitiydestä johtuen heidän yksityisasiansa, vaan sillä oli merkitystä yhteiskunnalle ja koko ihmiskunnalle. Joissakin oppaissa oli rodunjalostuksellisia piirteitä: varoittavia sanoja suunnattiin erityisesti keskiluokkaisille naisille ja naisten vartalolle annettiin ihanteelliset mitat leveine lantioineen ja pyöreine rintoineen. Näin tulevat raskaudet, synnytykset ja itse lapset olisivat mahdollisimman onnistuneita. ${ }^{27}$

Sääty-yhteiskunnassa kun elettiin, oli naisten roolien määritteleminen luokkasidonnaista. Avainkysymyksiksi nousivat toisaalta naimattoman säätyläisnaisen paikka, toisaalta työläisvaimon osa. Naimattomat säätyläisnaiset olivat jääneet ikään kuin tyhjän päälle, ilman roolia, suvun merkityksen vähetessä ydinperhemallin myötä. Tässä hajaantumisprosessissa naisliikkeestä tuli heille uusi henkinen koti ja toimintapiiri. Koulutusmahdollisuuksien vaatimisen ja säätyläisnaisten poliittisten oikeuksien lisäämisen taustavaikuttimina olivat siten hyvin konkreettiset ja kipeät taloudelliset ja sosiaaliset syyt.

Toinen julkisuudessa keskusteltu kysymys oli työläisvaimon muuttuva osa sekä sen johdannainen eli lasten päivähoidon järjestäminen ja kasvatus. Suurin osa työläisperheistä tarvitsi kohtuullisen elintason saavuttamiseen kumpaisenkin puolison palkkatulon,

25 Wilkama 1938, s. 264.

26 Wilkama 1938, s. 261-263.

27 Mm. Räisänen 1995, s. 166-188. 
mutta lastenhoidon järjestämiseksi ei oltu tehty yksittäisiä päiväkotikokeiluja lukuunottamatta juuri mitään.

Työläisnaisjohtajat lähtivät 1800-1900-luvun vaihteen kirjoituksissaan siitä, että naimisissa olevat pienten lasten äidit olisi vapautettava kodin ulkopuolisesta palkkatyöstä hoitamaan kotejaan ja lapsiaan, kuten seuraavassa vaaliviestissä vuodelta 1903 oivallisesti kuvataan:

Kyllä yhteiskunnan parempiosaiset eli yläluokka osaavat, nähdessään likaisuutta ja kurjuutta työläiskodeissa, moittia työmiesten vaimoja laiskuudesta ja huolimattomuudesta. Eivät he ota huomioon, että noissa olosuhteissa on mahdotonta hoitaa kotia ja kasvattaa lapsia. Sillä kodin hoito ja lasten kasvatus ovat asioita, jotka vaativat aikansa. Surulla täytyy työläisnaisen jättää nämä tehtävät, nähdä lapsensa hoidon ja kasvatuksen puutteessa usein paheiden tielle sortuvan. Siinä on sitten se kehuttu vapaus. ${ }^{28}$

Viisi vuotta myöhemmin, vuoden 1908 eduskuntavaalien kynnyksellä, Hilja Pärssinen hyökkäsi kirjasessaan "Porvarit työläisten avioliiton ja perheen vihollisena" voimakkaasti sitä porvallisten piirien levittämää käsitystä vastaan, että sosialistien pyrkimyksenä olisi tuhota avioliitto ja perhe. Tämä ei pitänyt hänen mielestään paikkaansa.

Työläisnaisjohtajat tukeutuivat käsityksissään naisen paikasta myös sosialismin klassikoihin. Historiallinen katsaus perhejärjestelmän muovautumisesta historian aamunkoitosta teollistuvan yhteiskunnan perhemalliin saatiin Friedrich Engelsin vuonna 1884 julkaistusta teoksesta Perheen, yksityisomaisuuden ja valtion alkuperä. Tarkemmat määrittelyt 1800-1900-luvun vaihteen naisten asemaan lainattiin etenkin jo aiemmin mainitun August Bebelin sekä Lily Braunin ja Clara Zetkinin suomeksi käännetyistä kirjoituksista. Naisliitossa Hilja Pärssinen välitti teoreetikkojen sanoman jäsenistölle, kuten seuraavasta katkelmasta käy ilmi: "Vaadittaessa suojeluslakeja lausuvat mm. tässä Saksan naissosialistit rvat Braun ja Zetkin, että naisen toiminnan ja merkityksen vuoksi perheessä tulee vaatia suojeluslakeja pääoman-omistajien kurjistusta vastaan". 29

28 Sananen työväenasiasta. Lentokirjasia työväestölle II. 1903, s. 4-5

29 Pärssinen 1907, s. 29, 44-45. 
Clara Zetkin (1857-1933) oli kansainvälisen työväenliikkeen yksi vaikutusvaltaisimmista naisista. Kuva: Työväen Arkisto.

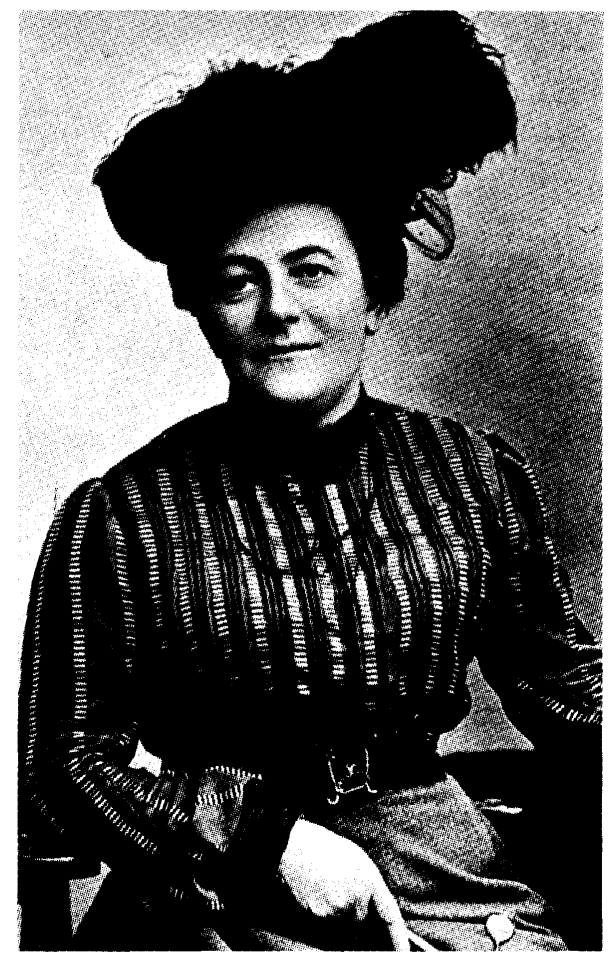

Lily Braunin Naiskysymys ja sosialidemokratia ilmestyi suomeksi 1906 ja Zetkinin Nainen ja hänen taloudellinen asemansa vuonna 1907. Molemmissa kirjasissa käsitellään naisten aseman muutosta perheessä ja yhteiskunnassa kapitalistisen talousjärjestelmän vallitessa. Zetkin kirjoittaa: "Nykyiset aineelliset olosuhteet ovat riistäneet lasten kasvatuksen äidin käsistä. Kasvatus lakkasi useammissa tapauksissa olemasta perheeseen kuuluvien henkilöitten velvollisuutena ja tehtävänä; nyt se on siirtynyt vieraille, perheen ulkopuolella oleville henkilöille". ${ }^{30}$

Näitä kirjoituksia leimaa voimakas vastakkainasettelu. August Bebel oli alkanut ottaa kantaa naisten asemaan 1860-luvulta lähtien. Pääteoksensa (Nainen ja sosialismi) lisäksi Bebeliltä käännettiin suomeksi Naisen asema porvarillisessa ja sosialistisessa yhteiskunnassa -niminen kirjanen vuonna 1908. Siinä Bebel esittää, että porvarillisen avioliiton siveetön kaksinaismoraali ja naisten aseman heikkous perustuvat siihen, että "porvarillisen" avioliiton solmimisen taustalla olivat taloudelliset motiivit. Koska mies oli hallitseva osapuoli taloudellisesti ja yhteiskunnallisen asemansa

30 Zetkin 1907 , s. 22. 
vuoksi, oli nainen porvarillisessa avioliitossa tuomittu sorronalaisuuteen. Miehen tyrannius oli verrattavissa Bebelin mukaan siihen tyranniuteen, jota porvaristo harjoitti köyhälistöä kohtaan, joskin joskus jopa vieläkin pahempaa: nainen oli sidottu mieheensä elinajakseen. Tätä vaimon elinkautista vartioi Bebelin mukaan kirkko vanhakantaisine oppeineen. Sen sijaan "ainoastaan sosialismissa pääsee nainen, samoin kuin jokainen sorronalainen, nauttimaan täysiä ihmisoikeusia...Ainoastaan sosialismissa voi ihmisen jaloin vietti, rakkaus, täysin ja kokonaan kehittyä...Sosialistisessa yhteiskunnassa on avioliitto mitä puhtain, ainoastaan molemminpuolisesta taipumuksesta solmittu suhde. "31

Kuten edellisistä esimerkeistä nähdään, keskustelu ja kirjoittelu naisten uusista rooleista 1800-luvun lopulla velloi laidasta laitaan, se kiihdytti ja suututti. Eikä suotta, sillä näin valtavan suurta muutosta perheen ja äidin rooleissa voidaan hyvällä syyllä luonnehtia vallankumoukselliseksi. Se voidaan nähdä lähtölaukauksena kaikelle naisten poliittiselle ja yhteiskunnalliselle toiminnalle. Naisten paikan määritteleminen ja siitä käyty keskustelu pohjustivat tietä asennemuutokselle, joka vapautti naiset julkiseen yhteiskunnalliseen työhön. Prosessi oli hidas ja kivulias, mutta naisjärjestöaktiivit tekivät hartiavoimin töitä tehdäkseen oman toimintansa uskottavaksi ja vetivät oman esimerkin voimalla naisia ulos kodin piiristä.

\section{Idan ja Marian liitto}

Suomen Työväenpuolueen ensimmäinen näkyvä naisjohtaja ja Työläisnaisten liiton ensimmäinen puheenjohtaja ei ollut palvelija eikä ompelija, vaan hieman yllättäenkin yksityisyrittäjä Ida Ahlstedt. Tuolloisessa katsannossa häntä olisi voitu kutsua myös kauppiaaksi tai pikkuporvariksi. Lähempi tarkastelu auttaa ymmärtämään Idan nostamisen työläisnaisliikkeen esikuvaksi. Hänessä nimittäin henkilöityivät juuri ne ominaisuudet, joita nousujohtoinen nuori työväenpuolue katsoi tarvitsevansa: rohkeus, edustavuus, sanavalmius ja aktiivisuus.

Vasta 9-vuotias Ida oli muuttanut monen muun torpparin tyttären tavoin kasvavaan pääkaupunkiin Nurmijärveltä 1880-luvulla. 
Tukenaan hänellä oli kolme vanhempaa sisarta ja sukulaisverkosto, joka kasvatti ja koulutti hänet sokerileipuriksi. Osakkaaksi leipomoliikkeeseen hän pääsi täytettyään 18 vuotta vuonna 1893. Työväen riennoista Ida kiinnostui liikkeen radikalisoitumisen myötä 1890luvulla. Hänen ensimmäinen virallinen edustustehtävänsä oli vuonna 1897, jolloin hän edusti raittiusyhdistys Koittoa Tampereen juomalakkokokouksessa. Kimmokkeen työväenyhdistystoimintaan hän oli saanut ollessaan Kansanvalistusseuran kursseilla, missä työväenliikkeen nuoret miehet Eetu Salinin ja Taavi Tainion johdattamina kävivät värväämässä nuoria naisia työväenyhdistyksen kokouksiin. Puheet tuottivatkin tuloksia ja keväällä 1898 Ida liittyi sisarensa Mandin ja ystävänsä Olga Johanssonin (sittemmin rouva Tainio) Helsingin työväenyhdistyksen jäseneksi. Idan kyvyt löydettiin nopeasti ja hän oli jo seuraavana vuonna edustamassa Helsingin työväenyhdistystä Suomen Työväenpuolueen perustavassa kokouksessa Turussa.

Nopea nousu näkyi neiti Ahlstedtin olemuksessa. Vuosisadan alun valokuvissa uhmakkaan naisellisena röyhelöpuseroissaan ja koruissaan poseeraava itsevarman oloinen Ida edusti työväestön eliittiä siinä määrin, että tavallisempi rahvas piti häntä suorastaan herraskaisena. Tässä herraskaisuudessaan Ida oli ihannemalli siitä, miten työväenpuolueen tavoite kouluttaa ja johtaa jäsenensä taloudellisesti ja henkisesti korkeammalle tasolle oli onnistunut. Lähtökohtaisesti puolue saattoi olla Idaan ja Ida puolueseen varsin tyytyväinen. Ida Ahlstedt oli puolueen miesten mielestä niin reipas, että sai kutsumanimen "veli Ida". Hänen menestyksensä salaisuus piili paitsi esiintymistaidoissa ja sosiaalisissa kyvyissä, myös hänen ammatistaan tulevassa uskottavuudessa. Hänen kansanomainen puhetaitonsa sai kuulijat vakuuttuneiksi hänen sanomastaan: "Iita sanoi niinkuin asiat oli ja kaikki ymmärsi". Kuulijat löysivät hänestä yhteisten kokemustensa ja tunteidensa tulkin, joka näytti muutosta janoaville tien jota kulkea. Ida oli samalla kertaa sekä läheinen kohtalotoveri että asiallinen työväenjohtaja. ${ }^{32}$ Ensimmäisten työväenjohtajien retorinen kyvykkyys oli tärkeää erityisesti siksi, etteivät kuulijakunnan kyvyt riittäneet aina seuraamaan kirjoitettua kieltä.

32 Uranuurtajan tie 1955, passim; Lähteenmäki 1997, s. 63-80. 
Ida Ahlstedtin työtoveriksi, naisliiton ensimmäiseksi sihteeriksi, palkattiin aivan toisentyyppinen nainen, muurarin vaimo ja ompelija Maria Laine. Hän ei ollut lainkaan niin sovinnollinen ja sopuisa kuin Ida, mutta intohimoinen, ahkera ja aatteellinen. Yhdessä tomerat naiset alkoivat luotsata uutta naisliittoa puolueen viitoittamaa tietä.

Maria Laine oli liiton johtajista pohjoisen naisia, kotoisin Iistä monilapsisesta torppari-kippari-perheestä. Marian äidin kuoltua yhdeksänteen synnytykseensä vuonna 1883 tyttö muutti tätinsä luo Helsinkiin 14-vuotiaana ja elätti itsensä ajan tavan mukaan ensin palvelijana. Sittemmin hän hankkiutui ompelukurssille ja teki ompelutöitä kotonaan. Idan tavoin myös Maria liittyi Helsingissä raittiusyhdistys Koittoon ja hän pysyikin useimpien naisliittolaisten tapaan kiihkeänä raittiusasian ajajana koko elämänsä. Maria liittyi myös ompelija-ammattiosastoon ja työväenyhdistykseen. Pääsiäisenä 1898 hän oli perustamassa Helsingin työväenyhdistyksen naisosastoa ja tuli valituksi sihteeriksi hyvän kirjoitustaitonsa ja aktiivisuutensa vuoksi. Kun Ida Ahlstedt sai miehiltä tunnustusta, johtui se osittain siitä, että Ida oli poliittiselta profiililtaan yleispoliitikko. Maria Laine oli sen sijaan kiihkeä naisasianainen, eivätkä miestoverit nostaneet häntä kuten Idaa. Tästä huolimatta Maria Laine oli 1910-luvulle saakka keskeinen naisliittolaisvaikuttaja. Hänen työkentäkseen tuli naisasian ja raittiustyön ohella varhaisnuorisotyö. ${ }^{33}$

\section{Taistelevat siskot}

\section{Ä̈nioikeustaistelu}

Työläisnaisliikkeen järjestäytyminen nivoutuu kiinteästi paitsi naisten taloudellisen paikan uudelleenmäärittelyyn ja fennomaaniseen kansanvalistukseen, myös naisten äänioikeuskysymykseen. Tarjosihan käyty äänioikeustaisto työläisnaisille mahdollisuuden profiloida porvarillisen naisliikkeen ja työläisnaisliikkeen välistä eroa.

33 Lähteenmäki 1997, s. 106-121. 
Saksan sosialisteja on pidetty naisten äänioikeusvaatimuksen esiinnostajina työväenliikkeessä. August Bebel teki Saksan sosialidemokraattisen puolueen kokouksessa vuonna 1875 esityksen naisten äänioikeusvaatimuksen ottamisesta puolueohjelmaan. Aika ei kuitenkaan ollut vielä kypsynyt näin radikaaliin muutokseen edes työväenliikkeessä. Kesti 16 vuotta ennen kuin asiaan palattiin: vuonna 1891 Saksan sosialistien Erfurtin kokouksessa se otettiin ohjelmaan. Kaksi vuotta myöhemmin naisten äänioikeusvaatimus hyväksyttiin myös toisen internationaalin ohjelmaan ja vuonna 1899 Suomen Työväenpuolueen ensimmäiseen ohjelmaan. ${ }^{34}$

Vaikka työväenpuolue olikin Suomessa ensimmäinen puolue, joka vaati yleistä ja yhtäläistä äänioikeutta sukupuoleen katsomatta, oli naisten äänioikeuskeskustelu virinnyt jo aiemmin myös täällä. Yleisempään keskusteluun se nousi vuonna 1884, jolloin kirjailija Minna Canth ja toimintaansa aloitteleva Suomen Naisyhdistys alkoivat vaatia äänioikeuden ulottamista ainakin osaan naisia. 1890luvulla useammat piirit yhtyivät vaatimukseen, kuten Naisasialiitto Unioni ja vuoden 1897 valtiopäivillä joukko Suomen Naisyhdistyksen evästämiä edustajia. Nämä esittivät äänioikeuden myöntämistä naisille sekä porvaris- että talonpoikaissäädyssä siten, että äänioikeutettuja naisia olisivat olleet naimattomat varakkaat naiset. Mihinkään konkreettisiin toimenpiteisiin esitys ei kuitenkaan tuossa vaiheessa johtanut.

Olojen muutoksesta kertoo se, että kun asia viimein vuosien 1904-05 valtiopäivillä otettiin seuraavan kerran esiin, oli valtiopäivämiesten käsiteltävissä neljä erillistä anomusta naisten äänioikeudesta. Vain talonpoikaissääty puolsi naisten äänioikeutta, pappissääty vastusti koko äänioikeusuudistusta. Puolueista vain Suomalainen puolue kannatti yleistä ja yhtäläistä äänioikeutta, sen sijaan Perustuslaillinen puolue vaati ensisijaisesti ääni- ja vaalioikeuden myöntämistä kaikille miehille, jonka jälkeen tulisi vasta naisten vuoro. Kun säätyvaltiopäivät pitivät kokoustaan Säätytalossa maaliskuussa 1905 ja siirsivät äänioikeuskeskustelun seuraaville valtiopäiville, leimasi paikalle kokoontunut suuri joukko kokouksen säätyjen häpeäpäiväksi. ${ }^{35}$

34 Naisten äänioikeus toteutui ennen Suomea 1890-luvulla eräissä amerikkalaisissa osavaltioissa, Wyomingissa 1890, Coloradossa 1893, Utahissa 1896 ja Idahossa 1896 sekä Uudessa Seelannissa 1893 ja Australiassa 1902.

35 Ks. mm. Koskinen 1997, s. 26-40. 


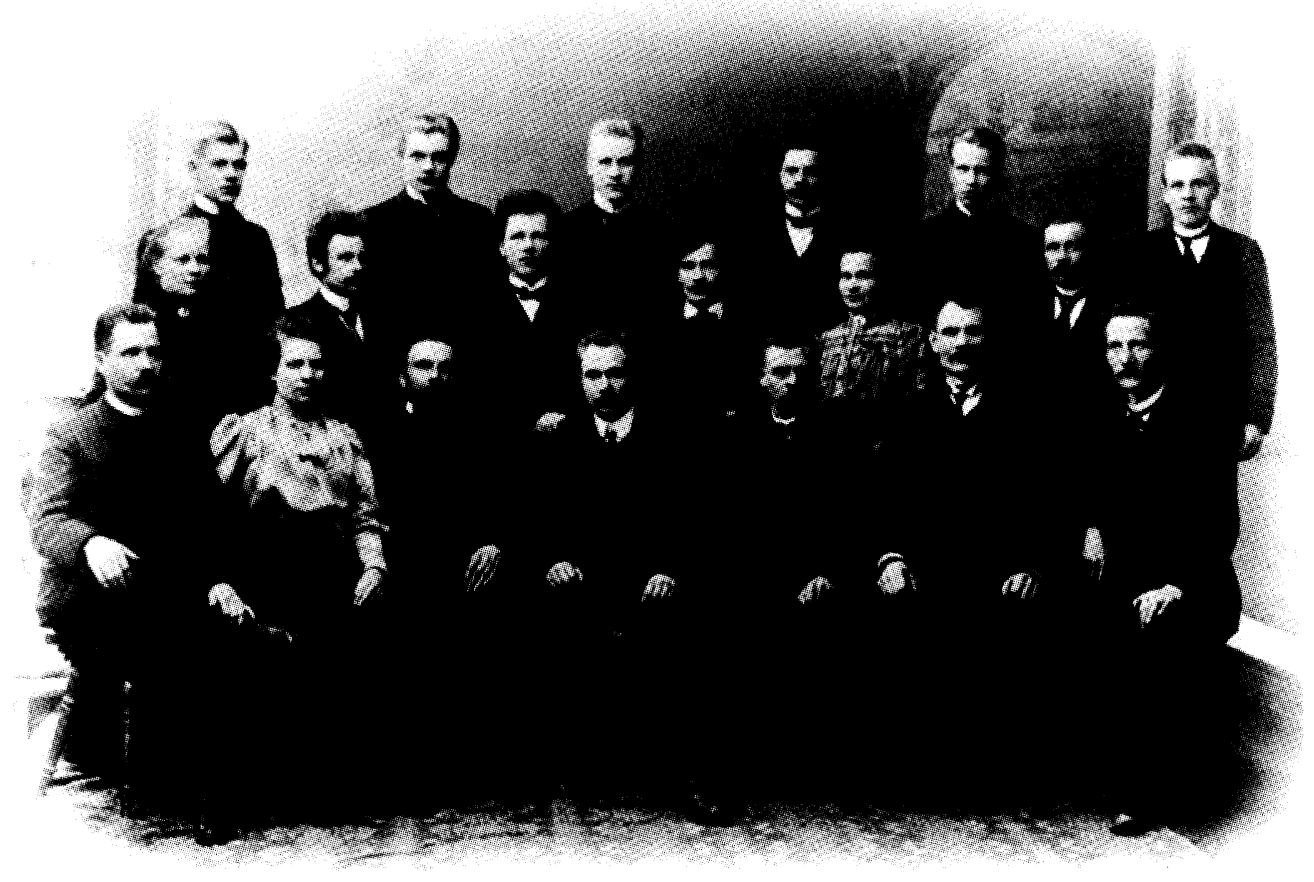

Sosiaalidemokraattisia agitaattoreita Tampereen torpparikokouksessa huhtikuussa 1906. Alarivissä vasemmalta Vilho Lehokas, Ida Aalle, A. Käcklund, Yrjö Sirola, J. Kivikoski, Heikki Jalonen ja V. Aro. Keskirivissä vasemmalta Aura Kiiskinen, O. Jalava, F. Malinen, E. Malmberg, Sandra Reinholdsson ja J. A. Helenius. Ylärivissä vasemmalta A. Markkanen, I. K. Lehtinen, J. Kirjarinta, A. Riipinen, T. Hyrskymurto ja K. H. Jokinen. Kaikki kolme naista olivat Sosialidemokraattisen naisliiton johtonaisia. Kuva: Työväen Arkisto.

Porvarillisten naisten ja työläisnaisten tiet äänioikeustaiston varhaisvaiheessa kulkivat eri polkuja. Porvarilliset naisjärjestöt taistelivat omaa miehistä edustusjärjestelmää vastaan melko yksin ja vaativat äänioikeutta pääsääntöisesti vain oman säätynsä naisille. Työväenliikkeen naiset puolestaan saivat heti rinnalleen oman puolueensa tuen ja vaativat kokonaisvaltaisempaa uudistusta: ääni- ja vaalioikeutta kaikille naisille ja työmiehille varallisuuteen katsomatta.

Työläisnaisten liitto pyrki myös oma-aloitteisesti edistämään itselleen tärkeää uudistusta. Se julkaisi muun muassa vuonna 1903 lentolehtisen Äänioikeus-asia työläisnaisten kannalta, jossa korostettiin naisten äänioikeuden tärkeyttä työväestön olojen kohentamisessa. Naisliiton monistuskoneet pyörittivät tuhansittain aihetta käsitteleviä lentolehtisiä. 
Työläisnaiset ja porvarilliset naiset pyrkivät sovittamaan kantojaan äänioikeusasiassa vuosisadan ensimmäisinä vuosina useampaan otteeseen, mutta vasta marraskuussa 1904 Naisasialiitto Unionin Lucina Hagman saattoi avata naisten yhteisen äänioikeuskokouksen Seurahuoneella Helsingissä. Hagman oli juuri palannut Berliinistä kansainvälisestä naisten äänioikeuskokouksesta. Työläisnaisten Ida Ahlstedt valittiin kokouksen toiseksi puheenjohtajaksi ja hän piti myös avauspuheen, mikä kertoi työläisnaisten keskeisestä roolista äänioikeusasiassa. Sali oli ääriään myöten täynnä ja tunnelma kiihkeä: työläisnaiset huomasivat pian, etteivät saaneet puheenvuoroja lainkaan ja Mimmi Kanervo alkoi järjestää eri puolille salia huutosakkeja. Työläisnaiset alkoivat häiritä porvarillisia puhujia huutamalla heitä alas. Meluisa kokous päättyi loppujen lopuksi työläisnaisten voittoon: naisten tavoitteena olisi yleinen ja yhtäläinen äänioikeus. Konservatiivinen Suomen Naisyhdistys ei ollut suostunut lainkaan tulemaan mukaan kokoukseen.

Työläisnaisliiton naiset alkoivat tämän jälkeen järjestelmällisemmin agitoida äänioikeuden puolesta. Heinäkuussa 1905 pidetyssä Tampereen edustajakokouksessa kehoitettiin suurimpia naisosastoja perustamaan äänioikeuspiiritoimikuntia. Toimikuntia perustettiinkin 11 paikkakunnalle, lähinnä suurimpiin kaupunkeihin. Marraskuun ensimmäisenä päivänä suunniteltiin pidettäväksi naisten äänioikeuden agitatsioonipäiviä, mutta ne jouduttiin siirtämään suurlakon vuoksi. ${ }^{36}$

\section{Suurlakko yhdessä porvareitten kanssa}

Suomen suurlakko (30.10.-7.11.1905) oli osa Venäjän vuoden 1905 vallankumouksellista liikehdintää. Venäjällä lakko oli alkanut jo viittä päivää aikaisemmin. Onkin sanottu, että lakon samanaikaisuus sekä Venäjällä että Suomessa sai aikaan sen, että Suomen suurlakko oli niin menestyksellinen: tsaarilla ei ollut varaa lähettää joukkoja hillitsemään tilannetta Suomessa. Suurlakko on monessa suhteessa mielenkiintoinen tapahtuma. Ensinnäkin se paljasti varhaisten työväenjärjestöjen kyvyn organisoida joukkotapahtumia. Toi-

36 Työläisnaisten kolmannen edustajakokouksen pöytäkirja Tampereella 17.-19.7.1905, s. 6476; Kilpi 1953, s. 64-76. 


\section{*Suomen Työväenpuolueen ohjelma 1899}

Kansainvälisen työväenliikkeen vaatimukset nousivat Ranskan suuren vallankumouksen sanomasta "Vapaus, veljeys, tasa-arvo". Suomessa työväestö järjestäytyi valtakunnallisesti Turussa kesällä 1899, jolloin työväenyhdistysten kolmannessa edustajakokouksessa perustettiin Suomen Työväenpuolue. Ensimmäisissä, vuosien 1893 ja 1896 työväenjärjestöjen kokouksissa, ei ollut mukana yhtään naisedustajaa, sen sijaan Turun kokouksessa oli neljä naista: rouva Matilda Tuominen ja neiti Aino Roine Turun työväenyhdistyksestä, Ida Ahlstedt (Aalle-Teljo) Helsingin työväenyhdistyksestä ja neiti Anna Ryynänen Viipurin työväenyhdistyksestä. Uusi puolue oli naisten äänioikeusasiassa radikaali: se asettui varauksettomasti tukemaan yleistä ja yhtäläistä vaali- ja äänioikeutta sukupuoleen katsomatta. Mallinsa se oli ottanut Saksan sosialistien Erfurtin ohjelmasta (1891). Työväenpuolueen ohjelma sisälsi muitakin radikaaleja vaatimuksia, kuten seuraavasta ohjelmasta nähdään.

"Suomen Työväenpuolue, joka perustuu yleisen työväenliikkeen periaatteisiin yhteiskuntakehityksen suhteen, pyrkii kaikissa suhteissa Suomen työväen taloudelliseen ja yhteiskunnalliseen vapauttamiseen. Huomauttaen, että perusedyllytyksinä siihen on Suomen kansallisen itsenäisyyden säilyttäminen ja suojeleminen, on puolue lähimpäin pyrintöjensä päämääräksi hyväksynyt seuraavan ohjelman:

1) Yleinen, yhtäläinen ja välitön vaali- ja äänioikeus kaikille 21 vuoden ikäisille Suomen kansalaisille sukupuoleen katsomatta kaikissa vaaleissa ja äänestyksissä.

2) Lainsäädäntö- ja itseverottamisoikeus kansalle eduskunnan kautta.

3) Täydellinen yhdistymis-, kokoontumis-, lausunto- ja painovapaus.

4) Työaika on saatava 8 tuntiseksi. Pisin työaika ja alin tuntipalkka valtion ja kuntien töissä heti pantava käyttöön.

5) Yleinen koulupakko. Maksuton opetus kaikissa oppilaitoksissa. Kansakoulu järjestettävä kaikkien ylempien oppilaitosten pohjakouluksi.

6) Sotilastaakka suuresti vähennettävä ja rauhanaatetta kehitettävä ja käytännössä toteutettava.

7) Naisen ja miehen täydellinen yhdenvertaisuus.

8) Yleinen kieltolaki väkijuomien valmistuksen ja kaupan suhteen aikaansaatava.

9) Työväensuojelulainsäädäntöä kehitettävä.

10) Asteittain nouseva tulo- ja perintövero.

11) Työväen vakuutus on otettava valtion huostaan.

12) Maksuton oikeudenkäynti ja maksuton lääkärin apu.

13) Irtaimen väestön, maanvuokraajain ja pikkutilallisten asemaa parannettava. 
saalta se osoitti sen, kuinka keskeisessä asemassa ensimmäiset työläisnaisjohtajat olivat työväenliikkeen sisällä. Kolmanneksi se panee pohtimaan sitä, miten niin laaja joukkoesiintyminen agraarisessa yhteiskunnassa oli ylipäätään mahdollinen. Neljäs merkittävä seikka olivat suurlakon seuraamukset: Suomessa toteutettiin yksikamarinen eduskuntajärjestelmä ja yleinen ja yhtäläinen äänija vaalioikeus. Vuosi 1905 on näistä syistä johtuen eräs tärkeimmistä käännekohdista Suomen 1900-luvun historiassa.

Mistä lakossa sitten oli kysymys? Kuten sanottu, lakon taustalla oli tsaarinvastainen liikehdintä sekä Venäjällä että Suomessa. Työväenliikkeellä oli kuitenkin toinenkin päämäärä, johon lakon avulla pyrittiin, nimittäin työväestöltä uupuvat poliittiset oikeudet alkaen äänioikeudesta. Ensimmäinen venäläistämiskausi eli yleisvaltakunnallisen lainsäädännön ulottaminen Suomeen oli alkanut helmikuun manifestilla vuodelta 1899. Siinä tsaari Nikolai II pyrki järjestelmällisesti kiinnittämään "irti päässeen" nationalismin hapattaman Suomen tiukemmin emämaahan venäläistämällä Suomen lakeja, koululaitosta, virkakuntaa ja keskushallintoa.

Suomea venäläistämään tsaari lähetti uskottunsa Nikolai Bobrikovin, joka närkästyneenä totesi tulleensa Suomeen kuin ulkomaille - niin erilaista maassa oli verrattuna Venäjään. Laajasta autonomiasta nauttineet suomalaisjohtajat eivät kuitenkaan alistuneet venäläistämispyrkimyksiin mukisematta ja Suomessa syntyi erilaisia toimintaryhmiä laajan autonomian palauttamiseksi. Työväenjärjestöjen väki naiset mukaanlukien ryhmittyi osin passiivisen, osin aktiivisen vastarinnan taakse. ${ }^{37}$

Työläisnaisjohtajien rooli on tässä mielenkiintoinen: monet Työläisnaisten liiton johtonaisista toimivat hyvin keskeisesti aktiivisen vastarinnan riveissä yhdessä suomen- ja ruotsinkielisten liberaalien perustuslaillisten kanssa. Näitä radikaaleja naisia olivat muun muassa naisliiton puheenjohtaja Ida Ahlstedt (Aalle-Teljo), liiton sihteeri Maria Laine sekä puhujat Sandra Reinholdsson (myöhemmin Lehtinen) ja Mimmi Kanervo.

Venäläistämisen ensimmäinen ja suurta kohua aiheuttanut tapahtuma oli tsaarin antama uusi asevelvollisuuslaki vuonna 1901. Sen mukaan suomalaiset nuorukaiset voitiin siirtää minne tahansa laajaa Venäjää suorittamaan asevelvollisuuttaan. Kutsuntalakot oli-

37 Ks. Soikkanen 1975 , s. 78-119. 
vat suomalaisten yhteinen voimannäyte venäläistämistä vastaan. Niitä järjestettiin vuosina 1902-04. Työläisnaisjohtajat olivat järjestämässä lakkoja, puhumassa lakkoon liittymisen puolesta, välittämässä, salakuljettamassa ja levittämässä kutsuntaikäisille lentolehtisiä ja muuta tietoa lakon merkityksestä. Kutsuntalakot onnistuivat niiden järjestäjien kannalta hyvin. Samalla kokonaisia ikäpolvia koulittiin vastarintaan tsaarin laittomiksi katsottuja toimia vastaan.

Työläisnaisliiton toimisto kuhisi elämää noina dramaattisina vuosina: Ida Ahlstedt muutti Kotkaan hoitamaan täysihoitolaa, jonne maan alla piileksiviä aktivisteja ja kiellettyä kirjallisuutta voitiin piilottaa. Apunaan Idalla oli sisarensa Tilda. Suurlakon kynnyksellä Idan oli paettava Ruotsiin pidätysuhkauksen vuoksi. Maria Laine puolestaan kiersi puhumassa niin tiuhaan tahtiin, että koti ja lapset saivat jäädä täysin miehen hoitoon. Maria kävi yksistään vuonna 1905 pitämässä 18 puhetta kutsuntalakoista ja äänioikeudesta. Hän joutui useaan eri otteeseen kuulusteluihin toimiensa vuoksi. ${ }^{38}$ Myös Sandra Lehtinen ja Mimmi Kanervo kiersivät eri puolilla maata agiteeraamassa lakkojen ja työväestön oikeuksien puolesta. Myös he joutuivat tekemisiin venäläisten santarmien kanssa.

Naiset olivat näyttäviä ja mieliinpainuvia agitaattoreita jo yksistään sen vuoksi, ettei heitä oltu totuttu näkemään poliittisissa tilaisuuksissa. Silminnäkijä on kertonut esimerkiksi suurlakon aikaisesta näkemästään Kuopion piirissä näin: “...mukana oli myös eräs naisihminen, jolla oli suuri, loistava tulipunainen nauha yli rinnan, neiti Sandra Reinholdsson, jonka Helsingin sosialistiseura oli lähettänyt kääntämään Kuopion syviä rivejä sosialidemokraattiseen oppiin". ${ }^{39}$

Maria Laine sai puolestaan kuulla jatkuvasti huomautuksia ja ilkkumista värikkäästä pukeutumisestaan ja hiustensa kähertämisestä. Poliittisen naisen oli todella vaikea olla uskottava, jos samalla halusi näyttää naiselta. ${ }^{40}$ Sinänsä järjestäytyneiden työläisnaisten pilkkaaminen ei ollut uutta. Aina siitä lähtien, kun naiset alkoivat pitää julkisia puheita, heitä oli ilkuttu ja heistä oli levitet-

38 Uranuurtajan tie 1955 , s. 39-40; Lähteenmäki 1997 , s. 63-80 ja 106-121.

39 Katainen-Oittinen 1997, s. 93.

40 Lăhteenmäki 1997, s. 114-116. 


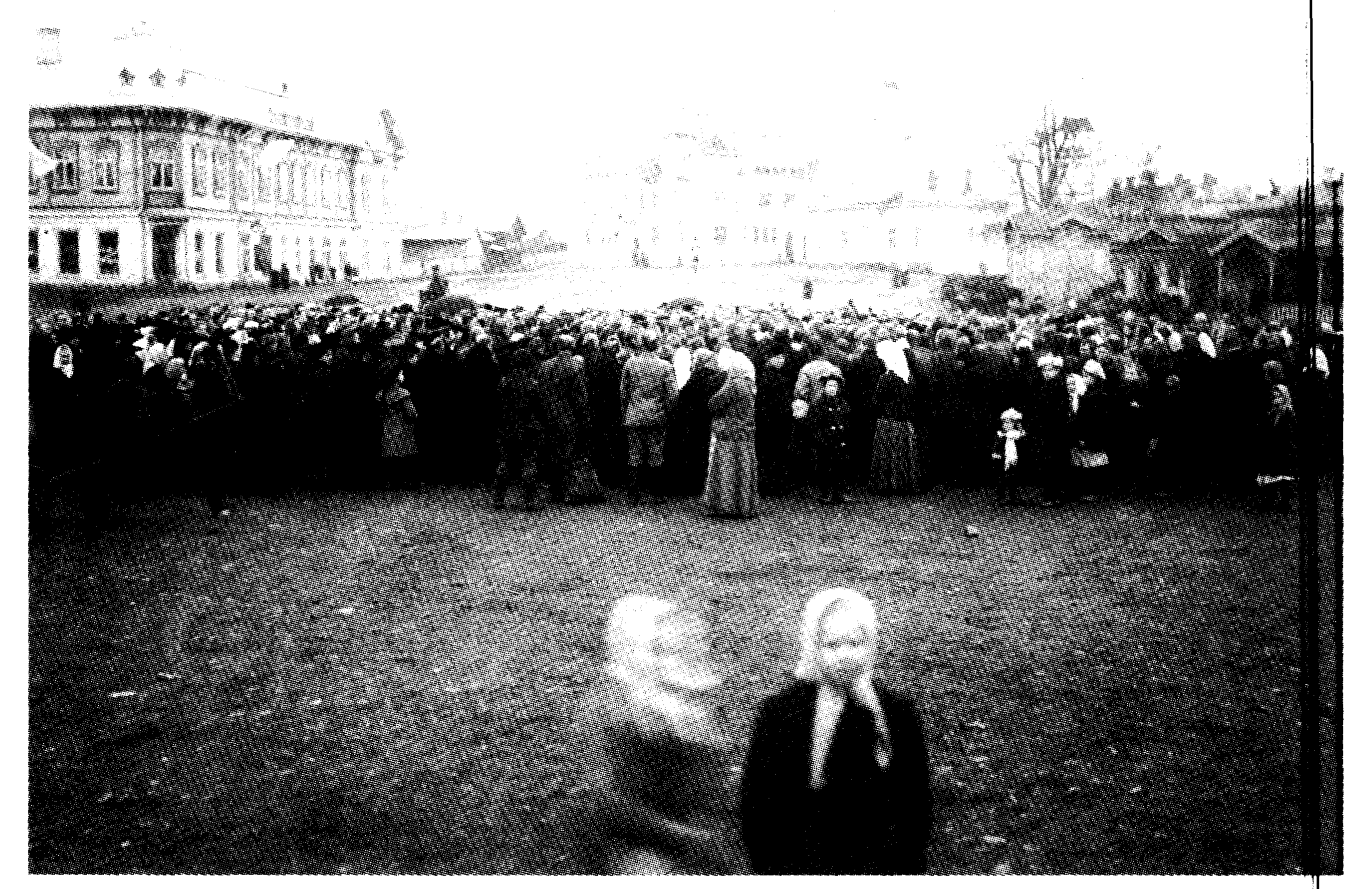

Suurlakon julistusta luetaan Sortavalan torilla vuonna 1905. Kuva: Työväen Arkisto.

ty ilkeitä juoruja. Niiden mukaan muun muassa Miina Sillanpää oli alkujaan ollut "Vaasasta tullut entinen huora". ${ }^{41}$

\section{Lakon huipennus}

Suurlakon johto siirtyi lakon alettua Tampereelle, jossa Yrjö Mäkelin laati punertavalle paperille radikaalin julistuksen, jota alettiin kutsua punaiseksi julistukseksi. Siinä vaadittiin avoimesti laajempaa itsenäisyyttä Suomelle, jopa irtaantumista kokonaan Venäjästä. Julistus kuljetettiin Helsinkiin, jossa se 3.11.1905 suuren innostuksen vallassa luettiin kaikelle kansalle Rautatientorilla pidetyssä kansalaiskokouksessa. Seuraavana päivänä valittiin ns. väliaikainen hallitus. Pietarista tuli samana päivänä tsaarin perääntymisestä kertova manifesti: laittomina pidetyt asevelvollisuuskut- 
sunnat peruutettiin. Työväenjohtajat eivät kuitenkaan olleet tyytyväisiä, sillä keisari kutsui koolle vanhat säätyvaltiopäivät. Neljän säädyn ulkopuolellehan jäi suurin osa tavallisesta rahvaasta. Työväenliikkeellä ei kuitenkaan ollut tuossa vaiheessa keinoja muuttaa asetelmaa toiseksi ja lakko päätettiin 7. päivänä marraskuuta 1905.

Keisarin manifesti palautti joka tapauksessa "lailliset olot" maahan. Suurin voitto oli se, että Suomessa voitiin toteuttaa eduskuntauudistus, jonka lähtökohtana oli yleinen ja yhtäläinen äänioikeus. Maahan asetettiin eduskuntauudistuskomitea ja säädyt kokoontuivat käsittelemään asiaa 20.12.1905. Käydyissä keskusteluissa naisen asema nousi esille paitsi ääni- ja vaalioikeuden myöntämisen kautta, myös naimisissa olevien naisten aseman kautta: oliko myös miehensä holhouksenalaisuudessa elävien vaimojen saatava äänija vaalioikeus? Vaikka tsaari näytti vihreää valoa kokonaisvaltaiselle uudistukselle, monet porvarilliset ryhmät suhtautuivat naisten äänioikeuteen edelleen kielteisesti ja hangoittelivat vastaan vielä viime metreillä. ${ }^{42}$ Naisasialiikkeen naisista muun muassa Alexandra Gripenberg arvosteli avoimesti työläisnaisille suunniteltuja kansalaisoikeuksia. ${ }^{43}$

\section{Naisten viimeinen ponnistus}

Heti suurlakon jälkeen työläisnaiset pitivät strategiakokouksen ja varoittelivat porvarisnaisten yhteistyöstä: "He ovat ruvenneet kalastelemaan työläisnaisten kannatusta yleisen äänioikeuden nimissä". Naisliitto organisoi 17.12.1905 naisten äänioikeuspäivän, jolloin 63 paikkakunnalla järjestettiin kulkueita ja kokouksia. Tunnelma oli huikea: osanottajia näissä kokouksissa oli peräti noin 22000. Naispiirien omien puhujien lisäksi maata kiersi naisliiton kuusi puhujaa. Liiton kiertokirjeissä kehotettiin levittämään tietoa ja aktivoimaan erityisesti naisia.

Näin vilkastuneen toiminnan myötä perustettiin uusia naisosastoja ja entisten osastojen jäsenmäärät kasvoivat: "Äänioikeusagitatsiooni sai uneliaimmatkin liikkeelle”. Liittohallinnolle alkoi tulla kyselyjä naisten punakaartien perustamisesta: "Miten nais- 
ten punakaartien on toimittava?"ja "Onko naiskaartien yleismerkkiä saatavissa?". Työläisnaisten liitto kehoitti naisia luopumaan "punakaartihommasta" ja perustamaan sen sijaan naisten suurlakkojärjestöjä ja toimimaan muutoin äänioikeusasian edistämiseksi.

Liitto varautui myös mahdolliseen tappioon ja kysyi jäsenistöltä: "Mihin toimiin ryhdytään, jos säätyeduskunta kieltää naisilta äänioikeuden?" Vastauksia lähetti 91 osastoa, joista 82 kannatti suurlakkoon ryhtymistä. Kentän kanta oli siis hyvin yksimielineen eli taistelua oli jatkettava: "Kun meiltä kielletään äänioikeus, poljetaan meidät häpeälliseen holhoustilaan”. Naisten ei kuitenkaan tarvinnut ryhtyä lakkoon, sillä heinäkuussa 1906 vahvistettiin Suomen uusi valtiopäiväjärjestys, joka perustui yleiseen ja yhtäläiseen äänioikeuteen ja yksikamariseen eduskuntaan. Työväki ja naiset olivat voittaneet taistelunsa.

Työläisnaiset alkoivat uudistuksen jälkeen järjestää uutterasti vaalityötä ja keskittyivät aluksi vaalilain lukemiseen. Liitto astui uusille urille vaihtamalla nimeään: Työläisnaisten liitosta tuli Sosialidemokraattinen naisliitto. ${ }^{44}$ Vaalityö oli kiihkeimmillään vuoden 1907 alussa. Liiton tuolloinen sihteeri kirjoitti Viipurista kannustavia kirjeitä: "Nyt ei kelpaa nolo nurina, vaan luja yksimielinen työ! ". 45

\section{Naiskansanedustajat ryhmäkuvassa}

Ensimmäiset yksikamarisen eduskunnan vaalit toimitettiin 15.16.3.1907. Äänioikeutettuja oli 1,2 miljoonaa ja noin 70 prosenttia heistä käytti äänioikeuttaan. Valituista 200 edustajasta 19 oli naisia. Sosialidemokraattinen puolue menestyi erinomaisesti; työväenedustajia istui upouudessa parlamentissa 80 , joista yhdeksän oli naisia - kaikki Sosialidemokraattisen naisliiton johtajia.

\footnotetext{
44 Toisen yleisen Suomen Työläisnaisten edustajain kokouksen Pöytäkirja 17.-19.7.1902 liitteineen; Työläisnaisten kolmannen edustajakokouksen pöytäkirja 17-19.7.1905 liitteineen; Työläisnaisten ylimääräisen edustajakokouksen pöytäkirja 8.-10.10.1906 liitteineen.

45 Sos.dem. naisliiton kiertokirjeitä 1907. TA.
} 


\section{SUOMEN KANSAN EDUSKUNNAN SOSIALIDEMOKRATISET NAISEDUSTAJAT}

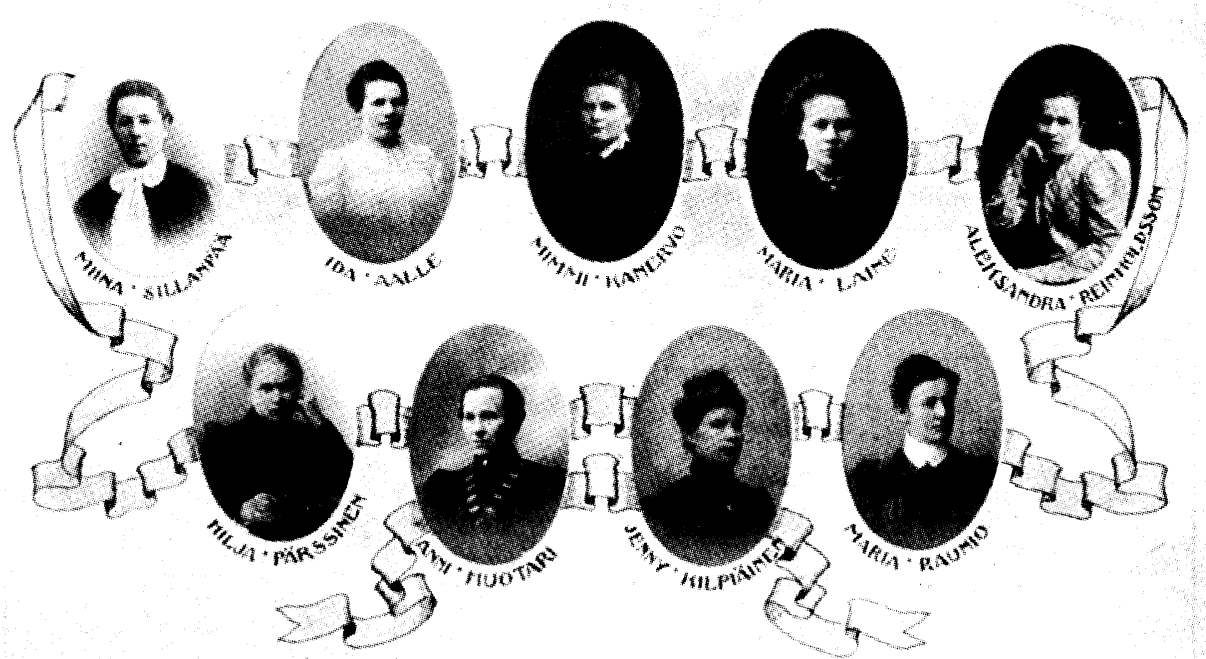

Ensimmäisissä eduskuntavaaleissa maaliskuussa 1907 valittiin parlamenttiin 19 naista, joista yhdeksän oli sosiaalidemokraattia. Puolue teetti historiallisen tapahtuman muistoksi naisista postikortin. Kuva: Työväen Arkisto.

\section{Ompelijoita ja palvelijoita}

Kun nämä työväen virallisiksikin edustajiksi valitut yhdeksän naista muiden mukana astelivat toukokuun 25. päivänä 1907 valtiopäivien juhlallisiin avajaisiin, oli kansaa kerääntynyt Senaatintorille ja katujen reunoille suurin joukoin seuraamaan mustiin pukeutuneen arvokkaan juhlakulkueen menoa. Historiallisen tapauksen kunniaksi sosialidemokraattinen puolue painatti yhdeksästä naisestaan postikortin: ylärivissä olivat Miina Sillanpää, Ida Aalle, Mimmi Kanervo, Maria Laine ja Sandra Reinholdson (Lehtinen). Alarivissä olivat Hilja Pärssinen, Anni Huotari, Jenny Kilpiäinen ja Maria Raunio.

Naisten sijoittelu valokuvassa kertoo heidän tuonaikaisesta hierarkiastaan: Palvelija Miina Sillanpää oli noussut kuuluisuuteen "piikakenraalina" ja oli jo hivuttautunut puolueen ykkösnaisen, leipomoyrittäjä Ida Aalteen rinnalle (Ahlstedt suomensi nimensä Aalteeksi suuressa sukunimien suomalaistamisvillityksessä suurlakon aikana). Aalteen parivaljakko ompelija Maria Laine puolestaan jäi kuvassa keskeisimmälle paikalle sijoitetun Mimmi Kanervon oikealle puolelle. Sandra Lehtinen ja Miina Sillanpää näyttäi- 
sivät tässä asetelmassa olevan tasavahvoja. Alarivin naisista Hilja Pärssisen suuri rooli naisliiton kansainvälistyttäjänä odotti tulemistaan. Ompelija-ammattiosastoaktiivi, Tampereella asuva viipurilainen Anni Huotari sekä niin ikään viipurilaissyntyinen ja Kuopion vaalipiiristä valittu kutoja Jenny Kilpiäinen ja keuruulainen ompelija Maria Raunio olivat hierarkian hännillä.

Mimmi Kanervon keskeistä paikkaa valokuvassa ei sovi ihmetellä sikäli, että hän oli ollut yhdessä Ida Aalteen kanssa näkyvästi mukana suurlakkokomiteassa vuonna 1905. Kanervo oli esiintynyt vaaliesitteissä tynnyrintekijän vaimona ja saanut Satakunnasta vaalipiirinsä sosiaalidemokraateista suurimman äänimäärän. Hän oli syntynyt Urjalassa vuonna 1870 ja toiminut palvelijana. Hänen esittelynsä Punaset-kirjasessa ei ole pitkä: "Ollut edustajana puoluekokouksissa ja monissa muissa luottamustoimissa". ${ }^{+6}$

Miina Sillanpää nousi eduskuntaan Palvelijatar-yhdistyksen paikanvälitystoimiston johtajan paikalta. Hänen läpimenoaan varmisti se, että hänet oli edellisenä vuonna valittu Ida Aalteen sijalle puoluetoimikuntaan. Aalle puolestaan oli muuttanut yrittäjäksi Kotkaan. Myös se, että Sillanpää oli vanhin työläisnaisedustajista ja ammattiyhdistysaktiivi, loivat häneen uskottavuutta. Sillanpää täytti 41 vuotta kesäkuussa 1907. Toiseksi vanhin naisista oli 39vuotias Maria Laine. Nuorin oli 25-vuotias Jenny Kilpiäinen. Suurin osa eli kuusi yhdeksästä edustajasta olivat 1870-luvun alussa syntyneitä kolmikymppisiä, kuten seuraavasta asetelmasta nähdään:

Sosialidemokraattisen puolueen naiskansanedustajat 1907:

$\begin{array}{llllc}\text { Nimi } & \text { Ammatti } & \text { Ikä } & \begin{array}{l}\text { Siviili- } \\ \text { sääty }\end{array} & \begin{array}{c}\text { Lapsia } \\ 1907\end{array} \\ \text { Aalle Ida } & \text { leipuri } & 32 & \text { naimaton } & - \\ \text { Huotari Anni } & \text { ompelija } & 33 & \text { aviossa } & 3 \\ \text { Kanervo Mimmi } & \text { palvelija } & 37 & \text { aviossa } & - \\ \text { Kilpiänen Jenny } & \text { kutoja } & 25 & \text { naimaton } & - \\ \text { Laine Maria } & \text { ompelija } & 39 & \text { aviossa } & 3 \\ \text { Pärssinen Hilja } & \text { opettaja } & 31 & \text { aviossa } & - \\ \text { Raunio Maria } & \text { ompelija } & 35 & \text { leski } & 5 \\ \text { Reinholdsson Sandra } & \text { ompelija } & 34 & \text { naimaton } & - \\ \text { Sillanpää Miina } & \text { palvelija } & 41 & \text { naimaton } & -\end{array}$


*Suomen kansanedustajat 1907-17

Suomen eduskunnan edustajapaikat 1907-17

Sdp Sp Nsp Rkp Ml Ktvl Kp äänestys-

$\begin{array}{lllllllll}1907 & 80 & 59 & 26 & 24 & 9 & 2 & - & 71 \\ 1908 & 83 & 55 & 26 & 24 & 10 & 2 & - & 64 \\ 1909 & 84 & 48 & 29 & 25 & 13 & 1 & - & 65 \\ 1910 & 86 & 42 & 28 & 26 & 17 & 1 & - & 60 \\ 1911 & 86 & 43 & 28 & 26 & 16 & 1 & - & 60 \\ 1913 & 90 & 38 & 29 & 25 & 18 & - & - & 51 \\ 1916 & 103 & 33 & 23 & 21 & 19 & 1 & - & 56 \\ 1917 & 92 & 32 & 24 & 21 & 26 & - & 5 & 69\end{array}$

Naisedustajat Suomen eduskunnassa 1907-17

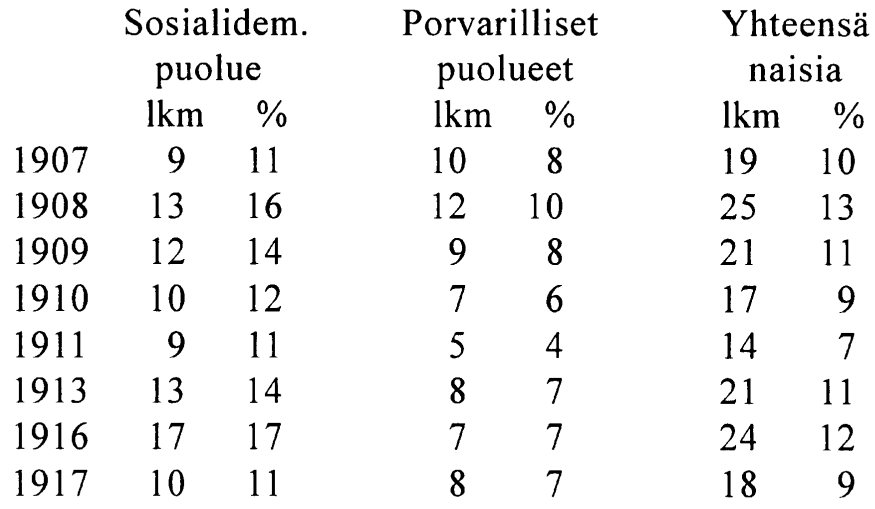

Lyhenteet

$\mathrm{Sdp}=$ Sosialidemokraattinen puolue

$\mathrm{Sp}=\quad$ Suomalainen puolue

$\mathrm{Nsp}=$ Nuorsuomalainen puolue

$\mathrm{Rkp}=$ Ruotsalainen kansanpuolue

$\mathrm{Ml}=$ Maalaisliitto

$\mathrm{Ktvl}=$ Kristillinen työväenliitto

$\mathrm{Kp}=\quad$ Kansanpuolue

Lähteet:

Suomen Eduskunnan kalenterit 1907-17. 
Listan naisista Kilpiäinen ja Reinholdsson avioituivat vuoden 1907 aikana. Naisten yhteistyö eduskunnassa yli puoluerajojen ei ollut kovinkaan aktiivista eikä kitkatonta. Se ei alkanut rohkaisevissa merkeissä: Wienissä 1907 pitämässään puhessaan Alexandra Gripenberg sanoi suoraan, että hänen mielestään Suomen eduskunnassa ei ollut ainoastaan sivistyneitä naisia, vaan "kamalaa sanoa, myös palvelijatar, pesijätär ja muita plebeijinaisia”. Kansainvälisessä sosialistinaisten äänenkannattajassa Gleichheitissa Clara Zetkin arvosteli Gripenbergin kannanottoja jyrkästi. Hänen mielestään tämä edusti tyypillistä vanhoillista naisliikettä. ${ }^{47}$

\section{Sosiaalisen toiminnan suuntaviivat}

Työläisnaisten liitto otti heti toimintansa varhaisvaiheessa voimakkaasti kantaa työläisnaisten arkisen elämän epäkohtiin. Järjestön kansanvalistuksen idea ei siis lähtenyt yksinomaan ylhäältä alaspäin suunnattuna valistuksena, vaan hyvinkin konkreettisina toimina ruohonjuuritasolla.

\section{Äitien ja lasten kesäsiirtolat}

Kesäsiirtola-ajatus nousi 1880-90-luvulla työväenyhdistysten ja naisasiajärjestöjen keskusteluaiheeksi. ${ }^{48}$

Helsingin työväenyhdistyksen kertomus vuodelta 1890 paljastaa, että "Kaikkiaan kuuluu 94 kivulloista ja heikkoa lasta anniskeluyhtiön antamilla varoilla toimitetun maalle kesälomaansa viettämään". +9

Työläisnaisten liitto otti Turun kokouksessaan (1902) kantaa siirtolakysymykseen. Osastoja kehotettiin mahdollisuuksien mukaan perustamaan kesäsiirtoloita, joissa jäsenistölle tarjottaisiin sekä asunto että ruoka. Tätä ennen olivat viipurilaiset ompelijattaret perustaneet oman kesäsiirtolan vuokraamaansa huvilaan vuonna

47 Gleichheit 22.6.1907 ja 7.12.1908, ks. Hentilä 1989(a), s. 174-175.

48 Lasten "siirtäminen" tunkkaisesta kaupungista "puhtaalle" maaseudulle kesäajoiksi kertoo teollistumisen ja kaupungistumisen aiheuttamista sosiaalisista ongelmista, mutta siihen sisältyy myös kulttuurisen murroksen taitekohta: urbaaniin elämäntapaan ei oltu vielä totuttu. Lastenhuollon järjestymisen yleisistä lähtökohdista 1800-luvun lopulla ks. Pulma 1987, s. 64-96.

49 Helsingin Työväenyhdistyksen kertomus 1890 , s. 14-15. 


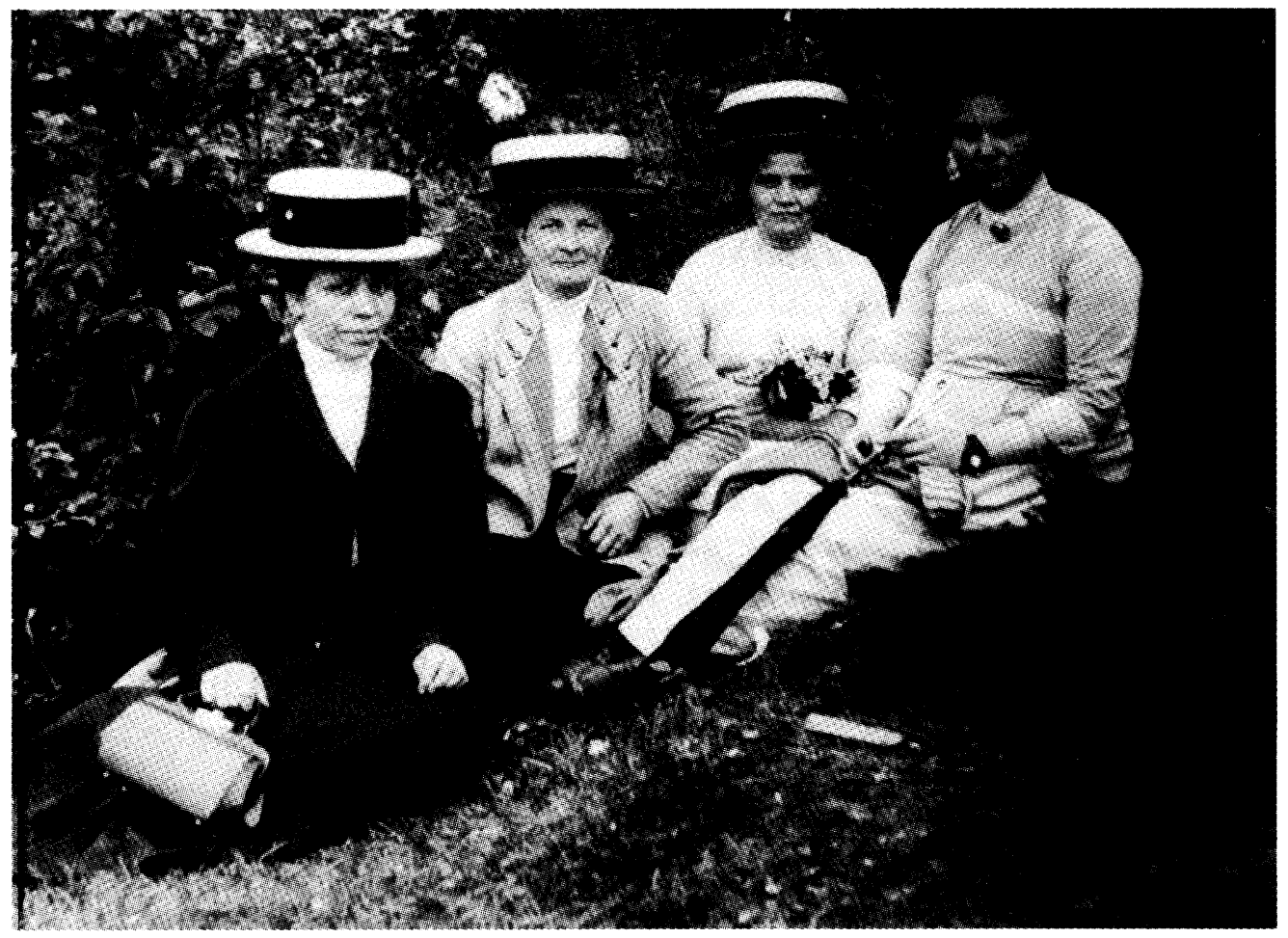

Tampereen Sosialidemokraattisen Naisyhdistyksen kesäsiirtola-retkikunta Nokialla 23.6.1912. Kuva: Työväen Keskusmuseo.

1901. Työläisnaisten loma-ajatus oli niin radikaali, että rouvasväki lähetti poliisin selvittämään nuorten naisten touhuja. Myös Helsingissä ja Turussa ompelijattaret olivat aloitteentekijöitä. Helsinkiläiset perustivat vuonna 1905 siirtolarahaston sekä siirtolan kaksi vuotta myöhemmin. Samaan aikaan Turun neulojattaret perustivat oman siirtolansa ja Turun työväenyhdistyksen naisosasto vuonna 1906 lastensiirtolarahaston ja neljä vuotta myöhemmin siirtolan. Myös Tampereelle, Jyväskylään, Poriin, Vaasaan, Lahteen, Hämeenlinnaan, Raumalle ja Uuteenkaupunkiin perustettiin työläisnaisten omia siirtoloita 1910-luvun alussa.

Siirtoloiden perustaminen kertoo uusista tuulista kansanterveyden alalla. Raitis ilma, puhtaus ja lepo nousivat kansanterveyttä ylläpitäviksi taikasanoiksi. Työväki oli saatava terveelliselle maaseudulle kaupunkien ahtaista asunnoista: ahtauden ja tunkkaisuuden nähtiin edesauttavan etenkin tuberkuloosin levinneisyyttä. Työväen Kalenteri kirjoitti vuonna 1895 keuhkotaudin olevan työväen keskuudessa yksi tappavimmista taudeista, jota vastaan oli ryhdyttävä taistelemaan muun muassa järjestämällä lomia. 
Siirtola-asia oli vuonna 1909 eduskunnan käsittelyssä ja koululaisten kesäsiirtolatoimintaan alettiin myöntää valtionapua. Se oli ensimmäinen askel työväestön lomatoiminnan yhteiskunnalliselle tuelle. Ensimmäinen valtionapu sosiaalidemokraattisten naisten kesäkodeille saatiin vuonna 1928.

Työläisnaisosastot vaurastuivat 1920-luvulla ja alkoivat ostaa omiksi siirtolahuviloitaan. Vuonna 1926 toimi jo seitsemän lomakotia omassa kiinteistössä, mikä vakiinnutti toimintaa. Varoja kesäkotien ylläpitämiseen naiset hankkivat ompeluseuratoiminnalla ja arpajaisilla. Myös kunnat jakoivat apurahoja toimintaan. "Arpajaisia toisinaan pidettiin tuhkatiheään ja voitot etupäässä kerjättiin. Meillä oli tätä varten oikein kerjuukomppania. Voittoina saattoi olla mm. 2-3 metriä rimoja ja jopa lehmä". Tärkeää oli myös työväenyhdistysten talkootuki.

Kesäkotien taloudellinen tilanne parani, kun vuonna 1938 valtion talousarvioon saatiin 50000 markkaa vähävaraisten äitien ja lasten lomatoiminnan tukemiseen. Lomatoimintaa normittivat vuosien 1922 ja 1938 vuosilomalait, jotka takasivat jokaiselle toisen työssä olevalle määräpituisen palkallisen loman - ainakin periaatteessa. Sen ulkopuolelle jäivät kuitenkin kotiäidit ja yksityisyrittäjät. Äitien virkistystoiminta sai uutta potkua, kun vuonna 1948 myös äitien lomia järjestävät yhteisöt alkoivat saada mahdollisuuden valtionapuun. ${ }^{50}$

\section{Varhaisnuoriso- ja raittiustyö}

Helsingin työväenyhdistyksen naisosasto teki vuonna 1902 aloitteen varhaisnuoriso-osaston perustamiseksi. Se suunniteltiin uskonnollisten pyhäkoulujen rinnakkaisjärjestöksi ja nimettiin Ihanneliitoksi. Aatteellisen opetuksen lisäksi lasten kanssa laulettiin, kerrottiin satuja ja tarinoita, tehtiin käsinkirjoitettuja lehtiä, opeteltiin keskustelemaan sekä leikittiin. Pari kertaa vuodessa järjestettiin juhlat, joissa lapset esiintyivät. Ihanneliiton tunnukseksi tuli Tie valoon ja vapauteen. Lapsille jaettiin jäsenkortit, joihin oli painettu runot äidille ja isälle. Martta Salmela-Järvinen on muistellut kaiholla tätä jaksoa elämässään: "Ainakin meille, pääkau- 


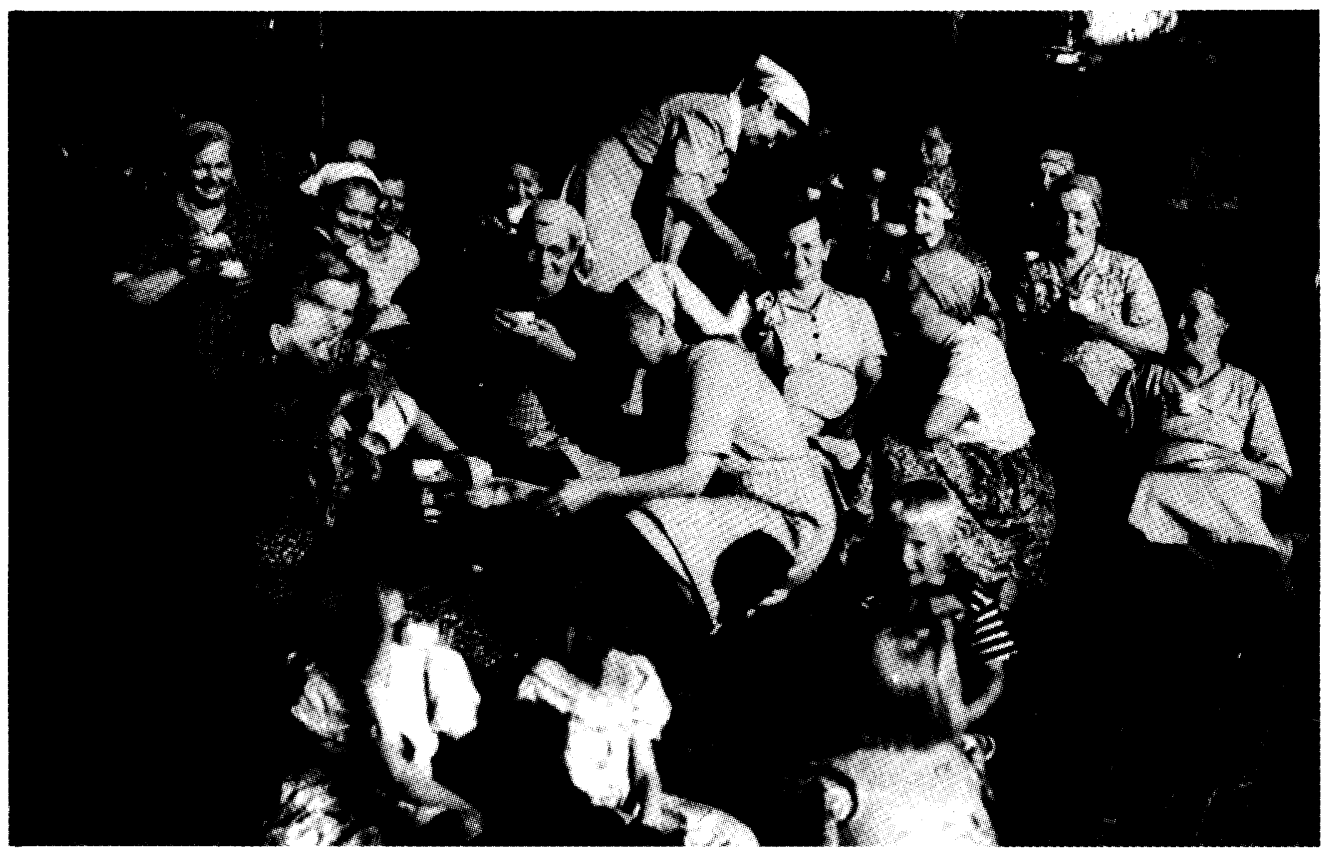

Jyväskylän Sosialidemokraattinen naisyhdistys perustettiin vuonna 1906. Heti alkuunsa jäsenistöä kiinnosti kesäsiirtolan hankkiminen. Jo seuraavana vuonna yhdistys perusti siirtolatoimikunnan ja päätti, ettei miehiä huolita siihen niinkuin ei koko yhdistykseenkään. Vielä samana vuonna hankittiin maapaikka, pidettiin arpajaiset ja kaupungilta haettiin väkijuomayhtiön varoista avustusta. Nimeksi siirtolalle annettiin Akkala. Varojen kokoaminen kesti useita vuosia ja tontille nousi tupa, näyttämö ja sauna vähin erin jäsenistön virkistykseksi. Kuva Akkalan pihalta. Kuva: Työväen Arkisto.

pungin laitaosien, takapihojen lapsille, ovat Ihanneliitto-muistot parhaimpia ja kauneimpia lapsuusmuistoja, ne antoivat sisältöä lapsuutemme yksitoikkoisten harmaiden päivien elämään. " 51

Pian eri paikkakunnille alettiin perustaa Ihanneliittoja ja vuoden 1906 puoluekokouksessa sosialidemokraattinen puolue otti varhaisnuorisotyön suojelukseensa. Yhdyssiteeksi naisliitto perusti Ihanne -nimisen lehden, joka ilmestyi vuosina 1908-14. Opettajia varten toimitettiin Ihanneliiton opas. Jäseniä Ihanneliittoihin liittyi useita tuhansia. Yksistään Helsingin osastossa oli parhaimmillaan noin 600 lasta.

Ihanneliittojen elinaika ei kuitenkaan jäänyt pitkäksi. Toinen venäläistämiskausi painoi päälle ja liittojen toiminta katsottiin sen

51 Salmela 1925 , s. 101-103. 
harjoittaman kasvatustoiminnan takia yhteiskunnallisesti vaaralliseksi. Paitsi santarmisto, myöskään suomalainen opettajisto ei katsonut hyvällä Ihanneliittotyötä. Sanottiin, että "kaikki mikä lähtee työväentalolta on jumalankieltäjien oppia”. Opettajat jopa kielsivät koululaisia menemästä Ihanneliittoon koulusta erottamisen uhalla.

Ihanneliitot jäivät historiaan, mutta ei sosiaalidemokraattinen varhaisnuorisotyö - se jatkui toisen nimisenä. Olojen vapauduttua Venäjän maaliskuun 1917 vallankumouksen ansiosta voitiin virallisesti perustaa uusi nuorisojärjestö, tällä kertaa Järjestönuorten liitto -nimisenä. Kansalaissodan jälkeen Järjestönuorten liitto liittyi Työväen Raittiusliittoon. Se siirtyi työväenliikkeen suuntariidoissa vasemmistosiiven hallintaan. Sosiaalidemokraatit perustivat oman raittiusliittonsa vuonna 1924. Se julkaisi lastenlehteä Sarastus. ${ }^{52}$

\section{Kansainvälistyvä naisliike}

Suomalaisten työläisnaisliittolaisten minäkuvan rakentumisessa yhteyksillä kansainvälisiin aatesisariin tuli olemaan suuri merkitys. Ensimmäiset yhteydenotot ulkomaisiin sisarjärjestöihin otettiin 1900-luvun ensimmäisinä vuosina, mutta vakiintuneemmat yhteistyösuhteet luotiin suurlakon jälkeen. Naisliitto rakensi yhteydet ensin Ruotsiin, sitten Saksaan ja lopuksi Englantiin. Kanssakäymistä hidastivat rahapula ja kielivaikeudet.

Työväenliikkeen yhteydet muihin pohjoismaihin oli aloitettu jo 1800-luvun lopulla. Naisliittolaisten ensimmäinen varsinainen edustusmatka tuli ajankohtaiseksi vuonna 1905. Tuolloin Ida Aalle, Miina Sillanpää ja Hilja Pärssinen matkustivat Ruotsiin ja Tanskaan. He pitivät siellä esitelmät suomalaisten naisten järjestäytymisestä ja äänioikeustaistelusta. Ruotsalaisten työläisnaisten olot olivat suomalaisille jo tutumpia: Hilja Pärssinen oli kääntänyt sekä Ellen Keyn sukupuolisiveellisyyttä, naistarkastajien työtä että naisten työvoiman väärinkäyttöä käsitteleviä artikkeleita. Myös Kata Dahlströmin työläisnaisten järjestäytymistä ja Anna Johanssonin tehdasnaisten oloja käsitteleviä kirjoituksia luettiin. 


\section{* “Älä pelota mustalla miehellä” - kasvatusneuvoja vuodelta 1908}

Sosialistipiirit alkoivat suunnata vuosisadan vaihteessa työläisäideille "lyhyitä, yksinkertaisia ja helposti ymmärrettäviä" oppaita kasvatuskysymyksistä. Eräs näistä kirjasista oli saksalaisen Heinrich Schulzin kirjoittama ja Väinö Jokisen suomentama Äiti kasvattajana - Käytännöllisiä kasvatusneuvoja köyhälistön äideille (1908). Ohjeisto oli tarkoitettu vastapainoksi työläiskotien aatemaailman vastaiselle ajattelutavalle, jota katsottiin "nykyisen luokkavaltion kansakoulussa" harjoitettavan.

Monet oppaan ohjeet ovat yllättävänkin moderneja: äitejä kehotettiin antamaan tilaa isille kasvattajina, olemaan torumatta nukeilla leikkivää pikkupoikaa, kohtelemaan lapsia tasapuolisesti sukupuoleen katsomatta ja selittämään sukupuoliasiat sellaisina kuin ne ovat. Lasten tuloa ei siis saanut selittää siten, että vauva löytyi saunan lattian alta. Tämän päivän äideistä tuntuvat myös tutuilta oppaan neuvot kunnioittaa kasveja ja suojella eläimiä: "Opeta lastasi kunnioittamaan hiljaista, turvatonta kasvia, joka on kestänyt pitkän ja vaikean elämäntaistelun, ennenkuin se voi avata hennon kukkansa auringolle. Opeta lapsesi myöskin inhoamaan raakaa, tunteetonta eläinrääkkäystä. " Myös ohjeet leikkiä lasten kanssa, lukea heille, olla heidän ystävänsä ja vastata heidän kysymyksiinsä kuulostavan tutuilta.

Osa oppaan neuvoista on sidoksissa vuosisadan alun oloihin. Kansainvälisen työväenliikkeen raamiin ei sopinut äärinationalismi. Äitejä kiellettiinkin kasvattamasta lapsistaan "eläköön-isänmaallisia". Pojalle ei siis sopinut antaa lahjaksi kirjavaa sotilastakkia tai kannustaa häntä sotaleikkeihin. Myös lasten koulun historiantunneilta saamat yltiöisänmaalliset tarinat oli vanhempien oikaistava. Lapsia ei myöskään saanut pelotella pimeillä huoneilla, mustilla miehillä eikä poliiseilla: "Meidän lapsemme eivät saa oppia tuota perinnäistä poroporvarillista pelontuntoa poliisia kohtaan: heidän tulee oppia olemaan vallan näkemättä poliisia".

Oppaassa korostuu myös vuosisadan alun hengen mukaisesti uudet hygieniavaatimukset: äitejä kehotettiin siisteyteen, puhtauteen ja järjestykseen, heitä vaadittiin hoitamaan omaa terveyttään velvollisuudesta lapsiaan kohtaan. Ohjekirjasen lopuksi kehotettiin äitejä työskentelemään alituisesti itsensä valistamiseksi ja kehittämiseksi: "Se on tarpeellista ei vain sinun itsesi vuoksi, kapitalismin kaksinkerroin riistämä palkkaorja kun olet, se on tarpeellista myöskin voidaksesi täyttää tärkeän tehtäväsi äitinä, lastesi kasvattajana". Voidakseen kasvattaa lapsista tulevia taistelijoita oli äitien luettava työväenlehtiä, puhuttava miehensä kanssa valtiollisista kysymyksistä ja käytävä kuuntelemassa esitelmiä. Silloin avautuisi köyhälistön äidillekin mahdollisuus olla hyvä äiti.

Lähde: H. Schulz, Äiti kasvattajana. Käytännöllisiä kasvatusneuvoja köyhälistön äideille. Helsinki 1908. 
Kuten aiemmin on kerrottu, Suomessa seurattiin myös ruotsalaisten sosiaalidemokraattisten naisten Morgonbris-lehteä ja tanskalaisten Kvinden-lehteä. Kun suomalaisista naisista tuli ääni- ja vaalioikeuden saavuttamisen myötä kansainvälisiä "julkkiksia", lisääntyivät yhteydet myös muihin pohjoismaihin. Esimerkiksi Miina Sillanpää vieraili vuonna 1907 Tukholmassa pidetyssä naisten ammattikongressissa. Samana vuonna puhuja Maria Laine vieraili esitelmämatkalla Tanskassa. ${ }^{53}$

Kööpenhaminassa kesällä 1910 pidetty sosialistinaisten kansainvälinen konferenssi oli pohjoismaalaisittain suurtapaus, saapuivathan sinne kaikki kansainvälisen sosialistiliikkeen johtajat. Suomesta kokoukseen osallistui Ida Aalle, joka oli varsinainen edustaja, mutta myös kansanedustajat Miina Sillanpää, Hilda Herrala, Aura Kiiskinen ja Hilja Pärssinen. Tässä kokouksessa päätettiin muun muassa kansainvälisen naistenpäivän vietosta. ${ }^{54}$

Saksalainen ja kansainvälinen sosialistinen naisliike tuli suomalaisille tutuksi paitsi Die Gleichheit-(Yhdenvertaisuus) lehdestä käännettyjen artikkeleiden, myös matkojen välityksellä. Ensimmäinen merkittävä ja suomalaisten naisten itsetuntoa hivellyt kansainvälinen esiintyminen oli Stuttgartissa elokuussa 1907 pidetyssä ensimmäisessä kansainvälisessä sosialistinaisten kokouksessa. Suomi sai naisten äänioikeuden mallimaana jopa oman edustajansa kokouksen sihteeristöön: Hilja Pärssinen toimi kokouksen toisena sihteerinä. Kaikkiaan kokoukseen osallistui 58 naista. Stuttgartin kokouksen tärkein saavutus oli naisten äänioikeutta käsittelevä päätöslauselma.

Pärssinen tapasi kokouksessa kaikki merkittävät naissosialistijohtajat. Etenkin saksalainen Clara Zetkin teki häneen suuren vaikutuksen ja tämä pysyikin Pärssisen esikuvana pitkään. Zetkin puolestaan nimitti Gleichheitin Suomen kirjeenvaihtaja Pärssistä "rakkaaksi tulleeksi avustajaksi". Pärssinenhän julkaisi parikymmentä Suomen oloja käsittelevää artikkelia kyseisessä lehdessä. ${ }^{55}$ Hauska ja suomalais-saksalaisia suhteita kuvaava yksityiskohta on, että sosialistinaisten kokoukseen 1912 Baseliin suomalaiset valtuut-

53 Työläisnainen 25.-26.2.1907

54 Työläisnainen 8.9.1910; Sos.dem. naisliiton liittotoimikunnan pöytäkirjat 3.2.1910 ja 21.6.1910. TA.

55 Hentilä 1989(a), s. 175-179. 


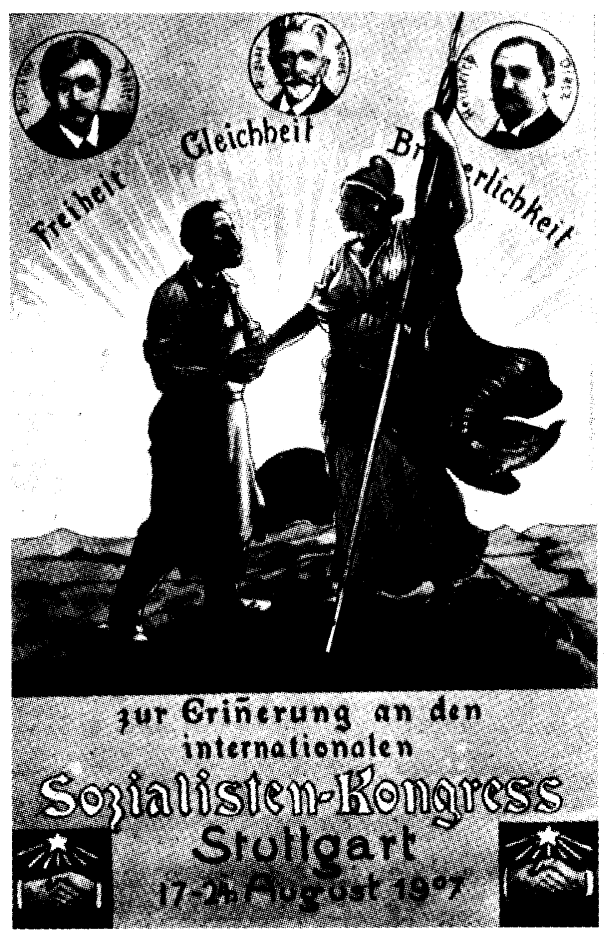

Saksalainen vappukortti mainostaa tulevaa sosialistikonferenssia vuonna 1907. Kuva: Työväen Arkisto.

tivat Zetkinin edustamaan myös itseään. ${ }^{56}$ Kun Zetkin vangittiin kesällä 1916, lähettivät suomalaiset aatesiskot paheksuvan sähkeen Saksan hallitukselle. Seuraavana vuonna Clara Zetkinin täytettyä 60 vuotta, naisliitto lähetti hänelle onnittelusähkeen ja vakuutti "köyhälistönaisten yhteenkuuluvaisuutta sotatilasta huolimatta". ${ }^{57}$

Koska työläisnaisten kielitaito oli vähäinen, oli Hilja Pärssisen rooli keskeinen luotsattaessa naisliittoa kohti kansainvälistä toimintapiiriä. Pärssinen "vei" Suomen työläisnaisten asian myös Englantiin. Hän teki vuonna 1913 laajan opintomatkan saarivaltakuntaan ja ihastui näkemäänsä siinä määrin, että alkoi opiskella tarmokkaasti maan kieltä ja kotiin päästyään kalusti yhden huoneen kodistaan englantilaiseksi siniseksi huoneeksi.

Englantilaisissa lehdissä esiteltiin suomalaisen naiskansanedustajan näkemyksiä Suomen naisten asemasta ja työstä eduskunnassa, suomalaisten työläisnaisten järjestäytymistä, sosialidemokraattisen naisliiton toimintaa ja naisliikkeen nopeaa kasvua.

56 Alustuksia ja esityksiä sos.dem.naisliittokokoukselle Tampereella 23.-25.10.1913, s. 11

57 Suomen Sosialidemokratisen Naisliiton kahdeksannen edustajakokouksen pöytäkirja 4.6.10.1917 pöytäkirja, liiteosa, s. 11 . 
Uteliaille lehtimiehille Pärssinen selitti suomalaisen työläisnaisliikkeen nopean kasvun olevan yhteiskoulun ansiota. Jo lapsista lähtien tytöt ja pojat kasvoivat ja kävivät koulua rinta rinnan. Tämä yhdenvertaisuuteen kasvaminen jatkui sitten aikuisuudessa. Pärssisen mukaan myös sosialidemokraattinen puolue tuki yhdenvertaisuuskasvatusta, eivätkä naisetkaan olleet jääneet tässä asiassa passiivisiksi. Pärssinen korosti suomalaisten työläisnaisten halua toimia yhdessä miesten kanssa, naispuoluetta Suomeen ei oltu perustamassa. Kaiken kaikkiaan hän ei suositellut raskasta eduskuntatyötä pienten lasten äideille ja kehui työläisnaisedustajien aktiivisuutta eduskunnassa. ${ }^{58}$ Äitien parlamenttityön suhteen Pärssisen näkemys oli muuttunut sitten vuoden 1907 . Vastavalittuna kansanedustajana hän ei kokenut parlamenttityötä raskaaksi edes äideille. Muun muassa August Bebel käytti tätä Pärssisen aikaisempaa lausuntoa osoituksena siitä, että raskaudet eivät häiritsisi naisten työskentelyä politiikassa eikä odottava äiti olisi parlamentissa "ruma ilmestys". ${ }^{9}$

Ollessaan paluumatkalla Englannista Pärssinen kävi myös Saksassa ja hänen artikkelinsa aviottomista lapsista julkaistiin Documente des Fortschritts International Revue:ssä.

Suomalaisten työläisnaisten yhteydet emämaahan Venäjälle vilkastuivat hieman ennen suurlakkoa 1905 . Venäjän naisliike jakaantui noihin aikoihin kahtia porvarilliseen ja työläisten muodostamaan siipeen. Venäläiset perustivat keväällä 1906 Pietarin työläisklubin yhteyteen naisosaston ja seuraavana vuonna työläisnaisklubin. Tärkeän sysäyksen Venäjän naisliikkeelle antoi joulukuussa 1908 pidetty laaja yleisvenäläinen naiskongressi. Kongressi oli porvarisnaisten järjestämä eikä siellä hyväksytty esimerkiksi yleisen ja yhtäläisen äänioikeuden vaatimusta. Kuten Suomessa, myös Venäjällä ero porvarillisista naisista suuntasi työläisnaisten toimintaa kansainvälisen sosialistisen naisliikkeen piiriin. Venäläisen naisliikkeen kiistaton johtohahmo oli Aleksandra Kollontai, joka aktiivisesti piti yllä suhteita kansainväliseen naisliikkeeseen. Hän osallistui muun muassa Stuttgartin (1907) ja Kööpenhaminan (1910) kokouksiin.

58 The Christian Science Monitor 26.12.1913, The Daily Herald 27.11.1913 ja The Christian Commonwealth 3.12.1913. Hilja Pärssisen arkisto. TA; Työläisnaisten Englannin kirjeenvaihtajana toimi aina 1920-luvulle saakka suomalainen kirjailija Aino Malmberg. Toveritarlehden avustajaluettelo 1921-22. TA.

59 Hentilä 1989(a), s. 177. 


\section{*Vapun vietto}

Vapun päivän vietto ei ole alunperin työväenliikkeen juhla. Kansanperinteessä toukokuun ensimmäistä on juhlittu kevään tulon ja satokauden onnistumiseksi. Ylioppilaat puolestaan ovat viettäneet vappua jo 1800-luvun alkupuolelta.

Nouseva työväenliike teki vapusta kansainvälisen mielenosoituspäivän vuonna 1889 toisen internationaalin kokouksessa Pariisissa. Ensimmäisiä vappumielenosoituksia oli vietetty kolme vuotta aiemmin (1886) Yhdysvalloissa. Heti alussa vapun mielenosoitusten päävaatimus oli kahdeksan tunnin työpäivä.

Ensimmäinen Suomessa vietetty työväestön vappujuhla lienee ollut Helsingin Kirjaltajayhdistyksen vuonna 1890 järjestämä huviretki Erottajalta Korkeasaareen. Laivarannassa miesten seurueeseen liittyi perheenjäseniä ja joukko naisia. Soitannan, laulun ja maljannoston lomassa juhlan pääsanoma oli selkeä: kahdeksan tunnin työpäivän vaatimus. Tämän jälkeen eri työväenjärjestöjen vappukävelyt ja iltamat yleistyivät. Vappua valtakunnallisena yleisenä työväen juhlana vietettiin vuonna 1907. Suuria ja näyttäviä vappujuhlia pidettiin poliittisesti levottomina vuosina 1905 ja 1917 sekä myöhemmin vuosina 1944-47, jolloin vasemmisto marssi yhtessä, ja 1970-luvun alussa. Vuonna 2000 vasemmisto marssi jälleen yhdessä, mutta sellaista mahtipontisuutta ei marssissa enää ollut kuin aiemmin.

Vappupuheiden teemat ovat vaihdelleet kulloistenkin ajankohtaisten aiheiden mukaan. Sosialidemokraattinen naisliitto kehotti vuonna 1906 jäsenistöään vapunviettoon seuraavasti:

“Äänioikeustoimikunnille. Kehoitamme viettämään vapun päivää seisauttamalla kaikki pyörät sekä toimeenpanemalla kokouksia ja kulkueita! Samalla kehoitamme hommaamaan jonkinlaisia rusetteja juhlamerkiksi, joita sopisi myydä äänioikeusrahastojen kartuttamiseksi."

Vappujuhlaan työväki sonnustautui jo varhaisessa vaiheessa punaisin nauhoin ja yhdistysten lipuin. Ensimmäiset vappumerkit ilmestyivät rintapieliin vuonna 1907. Myös vappukukat ja -lehdet ilmestyivät vappujuhliin. Niillä kerättiin rahaa järjestötoimintaan. Yleiseksi vapaapäiväksi vappu hyväksyttiin Suomessa vuonna 1944. 1900-luvun loppupuolella vapusta tuli aikaisempaa epäpoliittisempi juhlapäivä, jota juhlivat ylioppilaiden lisäksi poliittiset puolueet laidasta laitaan.

Lähde: Sos.dem. naisliiton kiertokirjeet ja kertomukset 1900-1917. TA; Vappu, ikivanha paremman huomisen juhla, kirj. Tutta Runeberg. Me 5/1986, s. 47. 
Suomalaisten työläisnaisten ensikontaktit Venäjälle luotiin 1900luvun vaihteessa ensimmäisen venäläistämiskauden aikana. Johtavat työläisnaiset osallistuivat tsaarinvastaiseen toimintaan jakamalla ja piilottelemalla kiellettyä kirjallisuutta, toimimalla kuriireina ja järjestämällä kokouksia. Venäläistämisuhan poistuttua suurlakon 1905 myötä alkoivat maiden naisjärjestöjen virallisetkin tapaamiset. Venäläisiä naisia kävi muun muassa 1906 ja 1907 seuraamassa suomalaisnaisten kokouksia. Toisen venäläistämiskauden aikana suhteita pidettiin edelleen yllä. Eräs yhteydenpitäjä oli Hilja Pärssinen, joka opiskeli Englannissa samaan aikaan Alexandra Kollontain kanssa. ${ }^{60}$ Kollontai lähetti Lontoosta Suomeen vuoden 1913 naisliiton edustajakokoukseen seuraavanlaisen viestin: ${ }^{61}$

Tummat pilvet kattavat Suomen valtiollista ja yhteiskunnallista taivasta. Synkkä, tukahdutettu on mieliala maassa... Raaka taantumuksen haamu kohoaa muuttaakseen Suomen mykäksi ja tahdottomaksi venäläiseksi maakunnaksi.

Mutta arvoisat ja rakkaat toverit siitä maasta, johon minäkin haluan lukeutua, sillä olen ylpeä suomalaisesta verestä, jonka olen äidiltäni perinyt, älkää kadottako rohkeutta ja toivoa voitosta... Me venäläiset toverit ihailemme Suomen köyhälistön urheutta, kestävyyttä ja tarmoa, erittäin Suomen naistoverien intoa...

Paitsi Kollontai, ylläpitivät naisliiton Venäjä-suhteita Ostroumoffin sisarukset. He olivat mukana sekä sosialidemokraattisen puolueen että naisliiton toiminnassa ja kielitaitoisina hoitivat yhteyksiä erityisesti Venäjän tsaarinvastaisiin piireihin toisen venäläistämiskauden alkaessa 1908. Vanhin sisaruksista, Vera, oli toiminut senaatin kielenkääntäjänä ja työväenlehtien toimittajana, Ljuba oli käynyt Sortavalan opettajaseminaarin ja oli niin ikään ahkera kirjoittaja. Nuorin Maria oli Helsingin yliopistosta valmistunut maisteri ja opettaja. Kirjoittelunsa vuoksi kaksi vanhinta sisarta sai syytteen majesteettirikoksesta ja passitettiin Siperiaan. Nuorin pakeni ensin Ruotsiin ja sieltä Yhdysvaltoihin. Toiset sisarukset vapautuivat Siperiasta vuonna 1917 ja Vera oli vuonna 1918 auttamassa

60 Kollontai valmisteli Englannissa kirjojansa "Työssäkäyvä nainen" (1914) ja "Yhteiskunta ja äitiys" (1916). Ks. Hentilä 1989(a), s.182 ja alaviite 41.

61 Suomen Sosialidemokratisen Naisliiton seitsemännen edustajakokouksen pöytäkirja 23.25.10 .1913 , s. 6-7. 
Moskovassa suomalaisia punapakolaisia. ${ }^{62}$ Sosialidemokraattinen naisliitto avusti venäläisiä aatetovereitaan keräämällä varoja nälkäänäkevien avustamiseksi vuonna $1917 .^{63}$

Maltillisen suunnan edustajien yhteydet Neuvosto-Venäjälle katkesivat naisliikkeen kahtiajaon jälkeen ja yhteyksiä pitivät yllä kommunistit ja vasemmistososialistit. ${ }^{64}$ Vielä lokakuussa 1917 naisliitto lähetti tervehdyksen vangitulle Alexandra Kollontaille. ${ }^{65}$

\section{Kultakausi tradition lähteenä}

Työläisnaisliikkeen historiassa vanhan työväenliikkeen kautta eli aikaa ennen kansalaissotaa on usein mystifioitu ja se on nähty kollektiivisen toiminnan kultakautena. Luonnehdintaan onkin hyvät perustelut. Ajoittuuhan tuohon kauteen joukkojärjestöjen perustaminen, suurlakko, äänioikeustaisto, tsaarinvastainen kamppailu, vuoden 1916 voitokkaat eduskuntavaalit ja jäsenkunnan moninkertaistuminen vuonna 1917: työväenliikkeen voittokulku ennen suurta romahdusta.

Vanhan työväenliikkeen kautta on sanottu myös lukuisissa työväenjärjestöjen historiikeissa yhtenäisyyden ajaksi, josta sekä sosiaalidemokraattisen että vasemmistolaisen liikkeen traditio on ammettu. Romanttinen kuva aatteellisesti puhtaan, alkuperäisen, ensimmäisenä järjestäytyneen ja itsevarman työväen marssista kohti parempaa tulevaisuutta on kovin tuttu mistä tahansa työväenliikkeen historiasta. Luotu luokkaidentiteetin kuva on tietenkin fantasiaa, mutta sellaisena se on ollut tärkeä koossapitävä voima etenkin kriisien ja hajaannusten vuosina.

Giddensiä soveltaen voisi sanoa, että traditionaalisissa yhteisöissä menneisyyttä kunnioitetaan ja symboleja arvostetaan, koska ne sisältävät ja säilövät sukupolvien kokemusta. ${ }^{66}$

62 Lähteenmăki 1989 , s. 152-153.

63 Suomen Sosialidemokratisen Naisliiton kahdeksannen edustajakokouksen pöytäkirja 4.6.10.1917, s. 19.

64 Kommunistien yhteyksistä Neuvosto-Venäjälle ks. Saarela 1996.

65 Suomen Sosialidemokratisen Naisliiton seitsemännen edustajakokouksen pöytäkirja 4.6.10.1917, s. 13.

66 Ks. Hall 1999, s. 24. 


\title{
*Kansainvälinen naistenpäivä
}

Vielä tänäkin päivänä vietettävän Kansainvälisen naistenpäivän historia liittyy kiinteästi naisten äänioikeuskamppailuun ja työläisnaisliikkeeseen. Ajatus eri maissa samanaikaisesti vietettävästä naistenpäivästä syntyi samoihin aikoihin Euroopassa ja Amerikassa. Asia oli esillä jo vuoden 1907 Stuttgartin sosialistikongressa, mutta se ei johtanut konkreettisiin toimenpiteisiin. Yhdysvalloissa ryhdyttiin sanoista tekoihin: työläisnaiset viettivät helmikuussa 1909 maanlaajuista naisten äänioikeuspäivää. Virallisesti päätös kansainvälisen naistenpäivän vietosta tehtiin Kööpenhaminassa elokuussa 1910 seuraavin sanoin:

\begin{abstract}
Kansainvälinen naistenpäivä
27.8.1910 esitys Kansainväliselle Sosialistiselle Naiskongressille Kööpenhaminassa: Kaikkien maiden sosialistiset naiset järjestävät joka vuosi yksissä neuvoin proletaaristen luokkatietoisten poliittisten ja ammatillisten organisaatioiden kanssa naistenpäivän, jonka tarkoitus on ensisijassa agitoida naisten äänioikeuden puolesta. Vaatimusta on valaistava koko naiskysymyksen yhteydessä ja sen on vastattava sosialidemokraattista käsitystä. Naistenpäivällä on oltava kansainvälinen luonne ja se on valmisteltava huolella.
\end{abstract}

Clara Zetkin, Käthe Duncker ja toverittaret.

Ensimmäisiä kansainvälisiä naistenpäiviä vietettiin 19.3.1911, Suomessa 8.3.1914. Ennen kansainvälistymistään naistenpäiviä oli toki vietetty kansallisesti niin porvarillisten kuin työläisnaistenkin piireissä. Porvarilliset naiset kokoontuivat keskustelemaan naiskysymyksistä jo 1890luvulla epävirallisille äänioikeupäivilleen. Myös työläisnaisilla oli omia naistenpäiviään. Suomessa Työläisnaisten liitto kehoitti vuonna 1902 naisosastojaan järjestämään naistenpäiviä työläisnaisten "herätystyön" ja valistuksen merkeissä. Päivien ohjelmaan kuului työväenasiaa, kasvatusta, siveyttä ja terveydenhoitoa käsitteleviä luentoja. Liitto järjesti myös 17.12.1905 naistenpäivän äänioikeusvaatimusten vauhdittamiseksi: se onnistuikin yli odotusten. Peräti 22000 henkeä arveltiin olleen mukana päivän tapahtumissa. Vuonna 1906 naisliitto päätti vakiinnuttaa päivän vieton vuosittaiseksi tapahtumaksi. Valtiollisen äänioikeuden saavuttamisen jälkeen Suomessa otettiin päivien teemaksi kunnallisen äänioikeuden vaatimus ja eduskunnan oikeuksien laajentaminen.

Miksi sitten päivää vietetään 8.3.? Se että päivää vietettäisiin joka maassa aina samaan aikaan, ei alussa saanut kaikkien kannatusta. Muun muassa asiaa ajanut Clara Zetkin katsoi, että järjestäjille oli jätettävä liikkumavaraa, riitti että päivä ajoittuisi suurinpiirtein maaliskuulle. Amerikkalaiset ja suomalaiset esittivät kuitenkin päivän vakinaistamista. Käytännössä vuosina 1911-20 vietetyt naistenpäivät vaihtelivat kui- 
tenkin maaliskuusta toukokuuhun, joskin useana vuonna päivä sijoitettiin maaliskuun 8.-9. päiville. Vasta työväenliikkeen hajaannuksen jälkeen vuonna 1921 kommunistinen naisliike teki virallisestikin päätöksen naistenpäivän vietosta juuri 8. maaliskuuta.

Maaliskuun kahdeksannen päivän valinnalle on haettu monia selityksiä. Amerikkalaiset ovat perustelleet päivän valintaa 8.3.1908 New Yorkissa pidetyllä naisten lakolla ja naisten ammattiliiton perustamispäivällä. Päivän merkitys on kytketty eri yhteyksissä historian vallankumouksiin, kuten Ranskan suuren vallankumouksen aikaisiin naisten nälkämellakoihin vuodelta 1789 , vuoden 1848 vallankumoukseen ja siihen liittyneisiin maaliskuun juhliin ja Pariisin kommuunin perustamiseen. Yhtä selitystä 8.3. traditioon ei siis ole löydettävissä.

1920-luvulta aina 1960-luvulle saakka kansainvälisen naistenpäivän vietto oli leimallisesti itä-blokin maiden naisten hanke. Toki myös Euroopan sosiaalidemokraatit viettivät sitä vaihtelevasti. Uusi käänne päivän vietossa tapahtui 1970-luvulla, jolloin siitä alkoi tulla yleisemmin naisten juhlapäivä. Tänä päivänä kansainvälisen naistenpäivän poliittinen luonne on rapistunut ja se on kaikkien naisten yhteinen juhlapäivä.

Lähde: Hentilä Marjaliisa-Lähteenmäki Maria, Kansainvälinen naistenpäivä 1910-1990. Työväen Arkiston julkaisuja 2. Helsinki 1990.

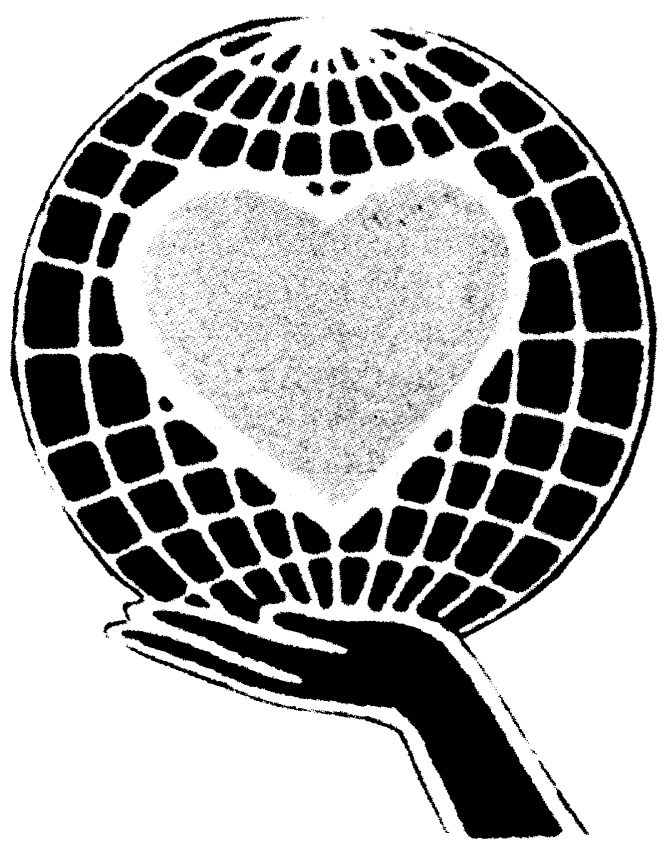

Kansainvälinen sosialistinaisten kokous päätti Kööpenhaminassa vuonna 1910 kansainvälisen naistenpäivän vietosta. Päivää vietettiin ensimmäisen kerran Suomessa 8.3.1914. Kuvan merkki on 1950-luvulta. Kuva: Työväen Keskusmuseo. 
Sosiaalidemokraattinen naisliitto esitti muun muassa vuonna 1916 osastoilleen lukurenkaiden perustamista. Tähän tarkoitukseen suositeltiin seuraavaa kirjalistaa:

Marx-Engels: Kommunistinen manifesti

Kautsky: Erfurtin ohjelma

Kautsky: Siveysoppi ja materialistinen historiankäsitys

Kautsky: Yhteiskunnallinen vallankumous

Danneberg: Sosialidemokratinen ohjelma

Kautsky: Ranskan vallankumousajan luokkavastakohdat

Bebel: Nainen ja sosialismi

Ursin: Tulevaisuutta kohti

Lisäksi esitettiin sopiviksi romaaneiksi seuraavia:

Aakjer: Vihan lapset

Zola: Ansa

Minna Canth: Köyhää kansaa

Erään työläisnaisen nuoruus 


\section{Kapina ja kapinalliset}

\section{Vuosien 1917-18 tapahtumat}

Vanhassa valokuvassa nuorehko raskaana oleva nainen makaa kuolleena kadulla, huivi päässä, kädet ojossa. Häntä lähellä makaa kyljittäin kuollut hevonen. Kadun toisella puolella on ohikäveleviä kivääreillä varustettuja miehiä valkoiset nauhat käsivarsissaan. Järkyttävän rauhallisen ilmapiirin välittämää kuvaa katsellessa tulee mieleen, että nainen on ollut väärässä paikassa väärään aikaan: Helsingin Pitkänsillan kupeessa huhtikuun lopulla 1918. Vai oliko hän sittenkään paikalla sattumalta, oliko hän uhri vai kanssasyyllinen?

Kuva ei kerro, kuka nainen oli tai oliko nainen punainen vai valkoinen. Kuvan viesti on niin vahva sodan raadollisuudesta, että ehkäpä ei olekaan olennaista tietää naisen poliittista vakaumusta.

\section{Sisällissodan harmaa vyöhyke}

75 vuotta myöhemmin, vuonna 1993, joukko yliopistotutkijoita muisteli kansallista murhenäytelmää pohtimalla sitä, mitä nimitystä käydystä sodasta tulisi käyttää. Ehdotuksia oli monta: kansalaissota, kapina, luokkasota, sisällissota, vallankumous vai vapaussota. Jokaiseen nimitykseen löydettiin perustelunsa riippuen siitä, katsottiinko asiaa punaisten vai valkoisten näkökulmasta, taloudellisia tai ideologisia seikkoja painottaen. ${ }^{1}$

Tätä asetelmaa ja samoin koko tähänastista suomalaista kansalaissotatutkimusta leimaa kaksijakoisuus ikään kuin sodassa olisi ollut vain kaksi osapuolta ja ikään kuin koko kansa olisi todella osannut sanoa, olivatko he punaisia vai valkoisia. Tämä kaksijakoisuus juontuu siitä, että tutkijoita on kiinnostanut etupäässä

1 Historiallinen Aikakauskirja 2/1993. 


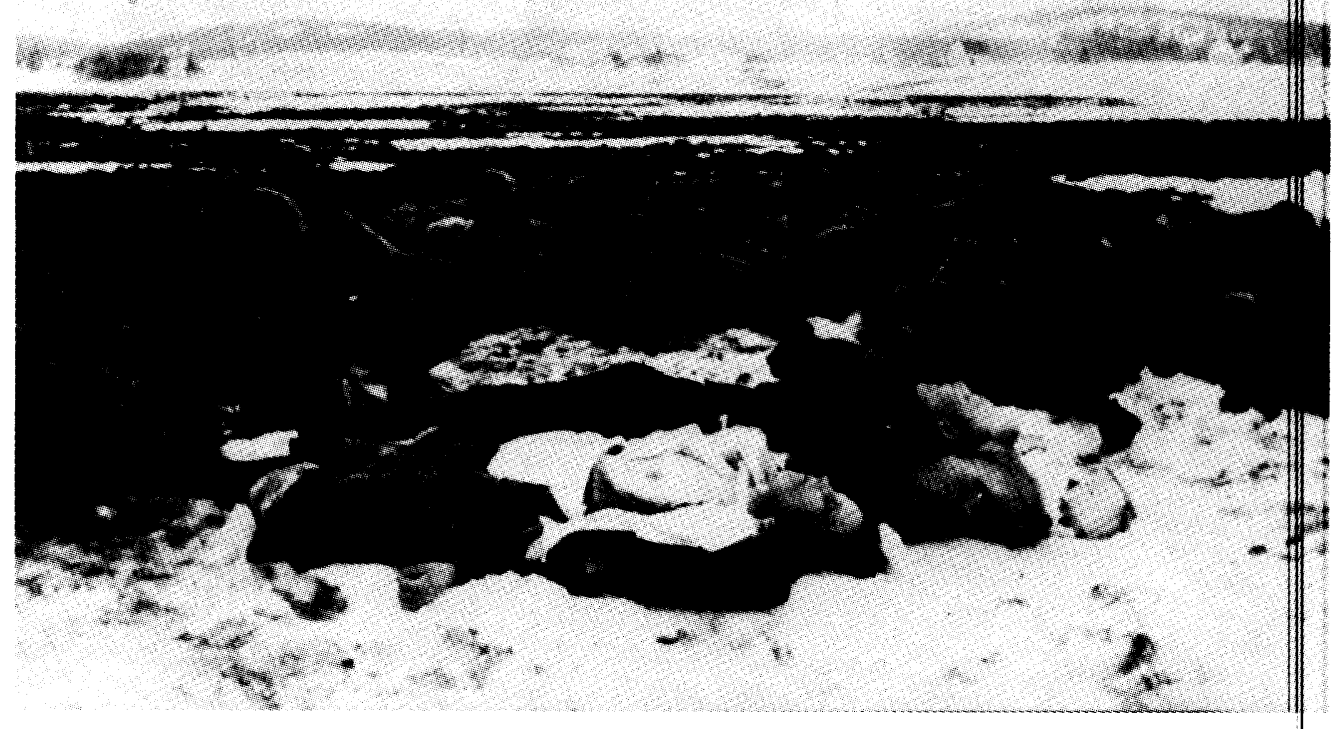

Tampereen taisteluissa kaatuneita maaliskuussa 1918. Kuva: Kansan Arkisto.

sodan sotilaallisen ja poliittisen johdon teot ja toimet. Poliittisen historian vastapainoksi on syytä tuoda tähän kaksijakoiseen ajatteluun uusi, sodan harmaa vyöhyke: epäilijöiden, tietämättömien ja kantaansa määrittelemättömien valtaisa joukko.

Oletan, että suuri osa näistä harmaan vyöhykkeen ihmisistä oli naisia, joista toiset kamppailivat perheineen laman, nälän ja turvattomuuden arkisessa noidankehässä. Toiset puolestaan asuivat niin etäällä poliittisesti tulenaroista keskuksista, että sota ei koskettanut heitä omakohtaisesti. Eri puolilla Suomea sota kosketti naisia ja perheitä eri tavalla. Erään muistelijan tavoin: "Meillä, jotka asuimme kaukana keskuksista, olisi pitänyt olla taito lukea rivien välistä. Emme olleet läheskään tietoisia siitä, mitä keskuksissa tapahtui, ja tuskimpa meidän mielipiteemme olisi paljoakaan ratkaissut". ${ }^{2}$ Kriittisemmäksi alueeksi muodostui kansalaissodan rintamalinjojen rajamaat sekä työläisjoukkojen valtaama ns. punainen Suomi eli rajalinjan Viipuri-Pori etelänpuoleinen osa.

2 Aatteet ja vaatteet 1964 , s. 250 
Sosiaalidemokraattisen naisliikkeen johtonaiset muutamia lukuunottamatta liittyivät velvollisuudesta mukaan punaisen hallinnon toimintaan. Kaksi heistä toimi ministerinäkin - Suomen ensimmäisinä naispuolisina ministereinä - Hilja Pärssinen ja Hanna Karhinen. ${ }^{3}$ Naisliiton kanta aseelliseen yhteenottoon oli kielteinen: se sopi huonosti sosiaalipoliittisia uudistuksia ja kansanvallan laajentamista korostavaan ohjelmaan. Työläisnaisille sota merkitsi katastrofia, miesten, sulhasten ja poikien menettämistä, kasvavaa niukkuutta, epävarmuutta tulevaisuudesta, pelkoa ja huolta. Ensimmäisen maailmansodan alettua kansainvälisen sosialistisen naisliikkeen kannanotot olivat vahvasti sodanvastaisia: murskasihan sota sosialistisen ajatusmallin työväenliikkeen kansanvälisestä yhteydestä, eri maiden työläisistä tulikin vihollisia.

Levottomuuksien lisääntyessä syksyllä 1917 työläisnaisjärjestöt ottivat aktiivisen roolin rauhanomaisten olojen palauttamiseksi. Sosialidemokraattinen naisliitto järjesti useita rauhanmielenosoituksia ja julkaisi Työläisnaisessa rauhaa korostavia kannanottoja. Muun muassa naisten militarisointia Venäjällä paheksuttiin syvästi. Olojen kiristyessä vuodenvaihdetta kohti eräät naiset jäivät toiminnasta kokonaan pois. Syrjäänvetäytyneiden joukossa oli 51vuotias Miina Sillanpää, joka ei enää osallistunut naisliiton lokakuiseen edustajakokoukseen $1917 .{ }^{4}$ Hilja Pärssinen kertoi ajan tunnelmista näin: ${ }^{5}$

Musta, musta on taivas. Lankeavat tummat varjot yli kylien ja kaupunkien. Tukahduttava aavistus puhkeaa uhkaavaksi todellisuudeksi. Ja tummaa taivaanrannan taustaa vastaan kuvastuvat sorron ja nälän luurankohaamut. Kaamea on tuntea, miten päivä pakenee ja yö yllättää. Kaamea on vastavallankumouksen uhka ja nälkävuoden syksy...

Naisliitto julkaisi marraskuun yleislakon aikana 9.11.1917 kiertokirjeen, jossa se ensimmäisen kerran kehotti "köyhälistönaisia olemaan valveilla ja tietoisia luokkansa vapaustaistelusta suurina vallankumouksellisina hetkinä". Bolsevikkien valtaantulo Venä-

3 Ks. Piilonen 1988, s. 39-48.

4 Sos.dem. naisliiton liittotoimikunnan pöytäkirjat 1.9.-30.12.1917. TA.

5 Hilja Liinamaa-Pärssinen, Vallankumouskuvia Työväenjuhlaan Helsingissä 26.8.1917. 
jällä innoitti työväenjärjestöjä palauttamaan asemansa eduskunnan hajotuksen jälkeen: sosiaalidemokraatit olivat menettäneet etulyöntiasemansa Venäjän väliaikaisen hallituksen määrättyä uudet vaalit kesällä 1917.

Naisliittolaisten kiertokirjeen pääsisältö käsitteli kuitenkin uusien kunnallislakien suomaa mahdollisuutta osallistua seuraaviin kunnallisvaaleihin. Työläisnaisia kehotettiin asettamaan naisten kunnalliskomiteoita, joiden tehtävä olisi hoitaa kunnallisasiain valmistelu naisten näkökulmasta. Mielenkiintoista kiertokirjeessä on se, että tarvittaessa voitaisiin perustaa naisten järjestysjoukkioita, jotka toimisivat mainittujen työläisnaisten kunnalliskomiteoiden johdolla ja yhteistyössä miesten järjestysjoukkojen kanssa. Naisten järjestysjoukoilla olisi erikoistoimenaan sairaanhoitoavun antaminen. Viittaus ensiapuun ja kirjeen loppu ennakoivat selvästi aseellista yhteenottoa ja siihen valmistautumista: "Osatoverit! Hetket ovat kalliit. Porvariston häikäilemättömyys ja sokea, heidän luokkaetujaon turvaama politiikka on nyt kohonnut huippuunsa. Emme enää siedä sitä! Maamme valtiollinen vapaus on luotava. On särjettävä sulut kansanvaltaisten uudistusten tieltäl! "6 Kirjeessä on selkeästi Hilja Pärssisen kädenjälkiä. Kuten edellisestä viittauksesta käy ilmi, naisliittolaisten tavoitteet ovat vuosisadan alun tapaan kaksijakoiset: valtiollinen itsenäisyys ja vapautus porvariston ikeestä.

Vielä epävarmuudessa olevia työläisnaisia kiirehdittiin valitsemaan puolensa, kuten nimimerkki H.V.:n lokakuussa 1917 Metsämaan Korvenkylän työläisnaisille osoitetusta kiertokirjeestä nähdään: ${ }^{7}$

Suuri osa osastonne jäsenistä rimpuilevat vielä mukana porvarillisten koplien "kotiopisto"hommissa. Ei sovi, että palvelette kahta herraa. Sanoutukaa jo kerrankin lopullisesti irti porvareista ja perustakaa keskuuteenne työväen rientoja edistävä opintoseura. Siten saatte parempaa ajanvietettä kuin iänkaiken kulkemalla porvareitten talutusnuorassa...

Epävarmuutta suunnan valinnasta oli myös naisliiton johdolla: “...on meidän kunkin itse kohdastamme koetettava saada tarkka

6 Sos.dem. naisliiton kiertokirje 9.11.1917. TA.

7 Metsämaan Korvenkylän työläisnaisille lokak. 1917. Kirjeitä 1917. Sos.dem. naisliiton arkisto. TA. 


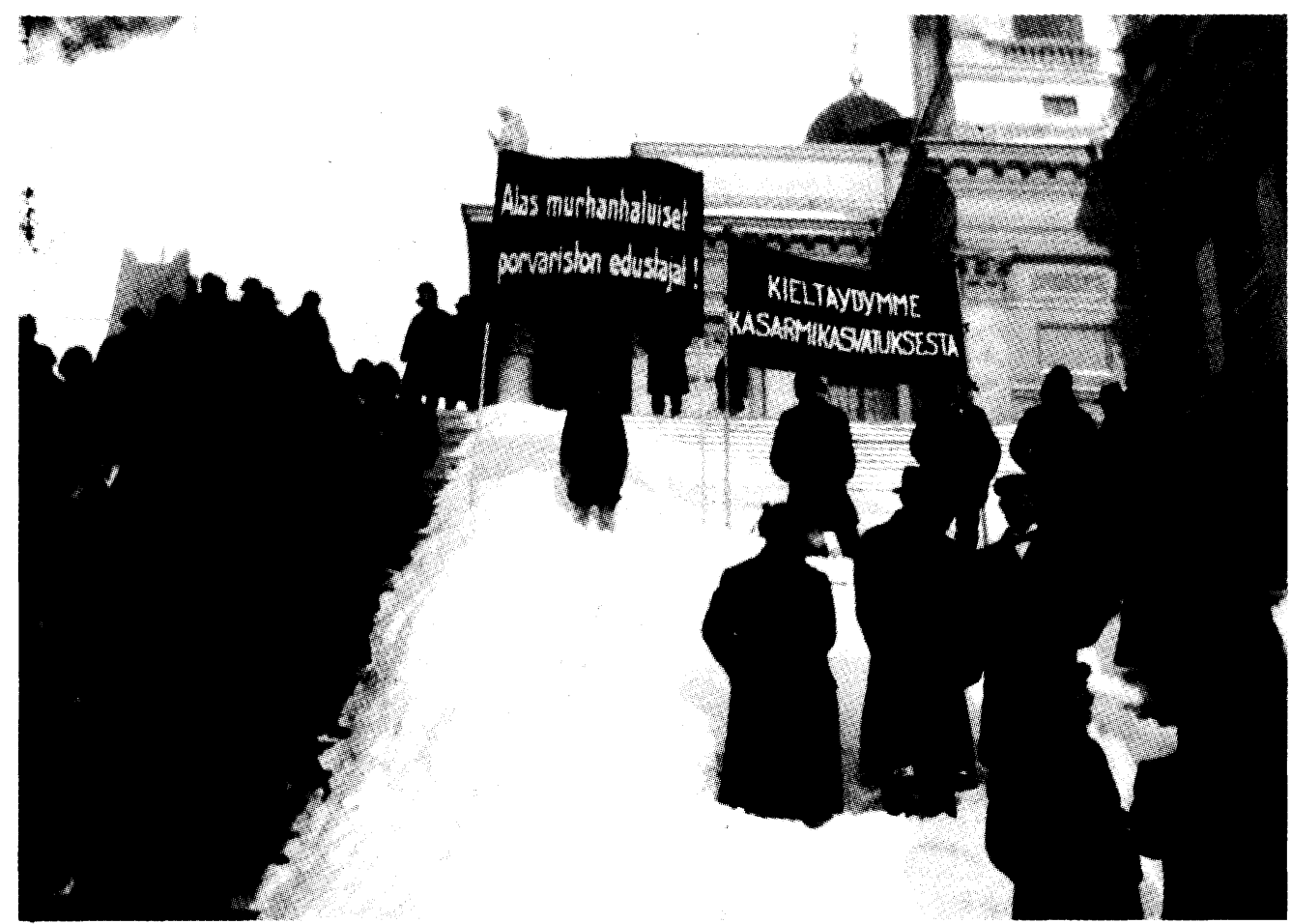

Mielenosoittajia Nikolainkirkon (Suurkirkon) portailla Helsingissä vuonna 1917. Kuva: Työväen Arkisto.

selvyys siitä, mihin pyrimme ja mitä menettelytapaa toiminnassamme käytämme..." Asian selvittämiseksi naisliitto pyysi kiinnittämään erityistä huomiota valistukseen ja perustamaan kirjallisuusja agitaatiotoimikuntia. ${ }^{8}$

Marraskuinen kiertokirje jäi naisliiton ainoaksi kehotukseksi osallistua "vapaustaisteluun". Liitto toimi Sosialidemokraattisen puolueen esimerkin mukaisesti eikä ottanut suoraan kantaa punakaartien toimintaan. ${ }^{9}$ Naisliitto ei kuitenkaan missään vaiheessa vaatinut naisia osallistumaan aseelliseen taisteluun - sen ei yksinkertaisesti katsottu sopivan naisten tehtäviin. Tämä ei kuitenkaan tarkoittanut sitä, että naisliittolaisia olisi kehotettu pysymään asian ulkopuolella. Päinvastoin. Kaikissa myöhemmin julkaistuissa artikkeleissa ja kirjeissä naisia pyydettiin olemaan miestensä tukena. Naisten tehtäviksi määriteltiin sairaanhoito, huoltotyö ja en-

8 Naisliiton kiertokirje osastoille 16.10.1917. Sos.dem. naisliiton arkisto. TA.

9 Salkola 1985 , s. 192. 
nen kaikkea henkinen tuki ja moraalin ylläpitäminen. Myös valkoisten puolella naisten aseistamista pidettiin sopimattomana: ylipäällikkö Mannerheim korosti, että sotainen kamppailu rintamalla oli miesten yksinoikeus ja velvollisuus. Sen sijaan "kodin ja konnun" hoitaminen kuului naisille ja niin myös mahdollisille naispataljoonille. ${ }^{10}$

Ensimmäisen maailmansodan puhjettua kansainvälinen sosialistinen naisliike otti tiukan kannan "imperialistista" sotaa vastaan. Clara Zetkinin vetoomus kansainvälisen työväenliikkeen yhtenäisyyden puolesta Kaikkien maiden sosialistinaisille! julkaistiin Työläisnaisessa 20.10.1917. Kymmenen päivää myöhemmin riihimäkeläinen Anni Joki kirjoitti samasta aiheesta: ${ }^{11}$

Satoihin nousevat ne vastalauseet, joilla maamme sosialidemokraattinen työväestö on tuominnut sodan, häikäilemättömän ja raa'an teurastuksen, jonka alkusyyt ovat kapitaalimaailman tekaisemat, saadakseen sota-ajan riiston kautta perinpohjin toteuttaa imperialistiset saalistussuunnitelmansa...Sallitteko ilman vastarintaa ryöstää poikanne ja miehenne kasarmeihin, järjestelmällisesti oppimaan ihmisteurastusta sen sijaan, että he työllään hyödyttäisivät yhteiskuntaa? Ette voi! Ette saa! Meistä proletaarinaisista täytyy löytyä sen verran inhimillisyyttä, ettemme voi vastalauseitta sivuuttaa porvariston julkeata sotalaitossuunnitelmaa. Pienen kansan ainoa, paras turva on aseettomuus. Työläisnainen: lastesi, nuortesi tulevaisuuden tähden tee jotain!

Paitsi yleinen maailmanrauha, työläisjärjestöjä huolettivat kaavailut suojeluskuntien julistamisesta hallituksen joukoiksi.

Joulukuun puolivälissä 1917 naisliiton julistuksissa oli selkeä sanoma: "Sotalaitosta vastaan Työläisnaiset puhukaa! Tuo kaikin puolin turmiollinen yritys tulisi tukemaan porvarillista luokkavaltaa ja lujittaisi osaltaan kaikissa maissa rehoittavaa, kapitalismin kannattamaa militarismia. Kehoitetaan työläisnaisten järjestöjä toimeenpanemaan joulupäivänä suuria työläisnaisten mielenosoituskokouksia..."12 Naisliitto kääntyi ulkomaisten sosiaalidemokraattisten naisjärjestöjen puoleen ja kehotti näitäkin toimeenpanemaan rauhanmielenosoituksia.

10 Soikkanen 1969, s. 205

11 Köyhälistöäidit! Riihimäellä 30.10.1917. Sos.dem. naisliiton kirjeet 1917. TA.

12 Sos.dem. naisliiton kiertokirje 14.12.1917. TA. 
Hilja Pärssinen laati mallialustuksen joulupäivän rauhankokouksille ja varoitti, ettei "pistinvallalla ja sisäisellä sotavoimalla" voida alhaalta tulevaa sodanvastaisuutta poistaa, vaan sillä päinvastoin lietsotaan lisää levottomuuksia, jotka johtavat "veriseen kansalaissotaan". Vaihtoehto aseistukselle olisi hänen mukaansa yhteiskunnalliset uudistukset ja "pohjakerrosten" taloudellisen tilan korjaaminen. ${ }^{13}$ Rauhankokouksia järjestettiin myös joulun jälkeisellä viikolla. Esimerkiksi Kymintehtaan ja Kouvolan työväenyhdistysten naisosastot järjestivät suuren kansalaiskokouksen sotaa ja sotalaitosta vastaan 30.12.1917. ${ }^{14}$ Myös Turussa järjestettiin suomalaisten ja venäläisten yhteinen kulkue ja rauhankokous. ${ }^{15}$

Eduskunnassa käytiin myös kiivaita puheenvuoroja sotalaitosta vastaan ja puolesta. Anni Huotari piti naisliiton nimissä 11.12.1917 puheen, jossa hän vastusti jyrkästi sotalaitoksen perustamista Suomeen. Hän ihmetteli, että "juuri nyt, kun maailman sotakauhut ovat silmiemme edessä, puuhataan Suomeen sellaista". Hän korosti, että naiset kaikissa maissa ovat nousseet sotalaitosta vastaan, sillä juuri naiset saavat siitä eniten kärsiä, erityisesti siitä kärsisivät työläisnaiset. Samassa eduskuntapuheessaan Huotari julkisti naisliiton ponnet, joiden mukaan sotalaitosta oli vastustettava ensinnäkin siksi, että sota yleensä ja sen perustana oleva sotaväki soti sosialistista maailmankatsomusta ja veljeyden aatetta vastaan. Toiseksi ponsissa tähdennettiin, että kaikissa maissa sotajoukkoja käytetään työväenluokkaa vastaan ja naisten mukaan oli syytä olettaa, että näin kävisi myös Suomessa. Suomen vähäinen sotaväki olisi siksikin naisten mukaan turha, ettei se voinut asettua suurvaltoja vastaan. Lisäksi miehiä tarvittiin työssä maan hyväksi eikä lorvailemaan siveellisesti turmeleviin kasarmeihin. ${ }^{16}$

Seuraavana päivänä eduskunta sosiaalidemokraattien suureksi pettymykseksi hyväksyi 97 äänellä 85 vastaan lain suojeluskuntien nimittämisestä Suomen sotalaitokseksi. Työmies-lehden kirjeenvaihtaja kuvasi työväestön edustajien järkytystä ja kirjasi tulistuneen Hilja Pärssisen huudahduksen: "Minä katsoin porvariston

13 “Sotalaitos Suomeen?" 18.12.1917 Sos.dem. Naisliiton puolesta H. Părssinen. Sos.dem. naisliiton kirjeet 1917. TA.

14 Työmies 10.1.1918, s. 4.

15 Työmies 3.1.1918, s. 4.

16 Anni Huotarin eduskuntapuheenvuoro 11.12.1917. Sota sotaa vastaan 1973, s. 113-115; Anni Huotarista ks. myös Markkola 1997, s. 145-162. 
iloista naurua päätöksen johdosta. Mutta minä sanon, te jotka nyt nauratte, te kohta itkette." 17

Vielä 25.1.1918 naisliitto lähetti osastoilleen kiertokirjeen, jossa se kannusti järjestämään kansainvälisiä naistenpäiviä, teemana sosiaalidemokraattinen naisliike ja taistelu militarismia vastaan. ${ }^{18}$ Turhaan. Kolme päivää myöhemmin aseet alkoivat puhua.

\section{Naissotilaat}

Naisten rooli Suomen kansalaissodan taisteluoperaatioissa ja hallinnollisessa johdossa oli marginaalinen. Tästä huolimatta naisten osallistuminen etenkin punakaartien toimintaan aseellisina joukkoina on kiehtonut monia erikoisuutensa takia. Sodan aikana ja sen jälkeen aseistautuneet punikkinaiset olivat valkoisille oiva propaganda-ase. Heissä nähtiin ruumiillistuvan punakapinan moraalittomuus ja julkeus. Viime aikoina historiantutkimus on niin ikään naisista puhuttaessa kiinnostunut juuri tästä miehisestä toimintamuodosta.

Naisten aseistaminen ei ollut ensimmäistä kertaa esillä: vuosisadan alussa vastarintaliikkeen aikana ja erityisesti vuosina 190506 asiaa oli pohdittu. Kuten aiemmin on kerrottu, naisliitolle tuli runsaasti tiedusteluja naiskaartien perustamisesta, harjoituksista sekä mahdollisesta kaartien rintamerkeistä. Naisliitto otti naiskaartien perustamiseen kielteisen kannan. Naisliiton johto vastusti ensinnäkin kaarti-nimen käyttöä ja korosti, että "naisten ei ole tarpeellista esiintyä ulkosalla harjoituksissa miehiä matkien" perustamalla punakaarteja. Niiden sijaan kehoitettiin aidossa valistushengessä perustamaan naisten suurlakkokomiteoita ja lukurenkaita. ${ }^{19}$

Mallia naisten aseistamisesta saatiin myös Venäjältä, missä naiset olivat jo 1800-luvulta lähtien osallistuneet miesten rinnalla ja aseet käsissä katumellakoihin. Myös ensimmäisen maailmansodan aikana venäläisissä osastoissa rintamalla oli mukana naisia. Naispataljoonia perustettiin vapaaehtoisuuteen perustuen etenkin lokakuun vallankumouksen 1917 jälkeen. Monien naisten kapinoinnin

17 Työmies 21.1.1918, s. 4.

18 Naisliiton kirjelmä 25.1.1918 piiritoimikunnille. Sos.dem. naisliiton arkisto. TA.

19 Sos.dem. naisliiton kiertokirjeet v. 1905-06. TA. 


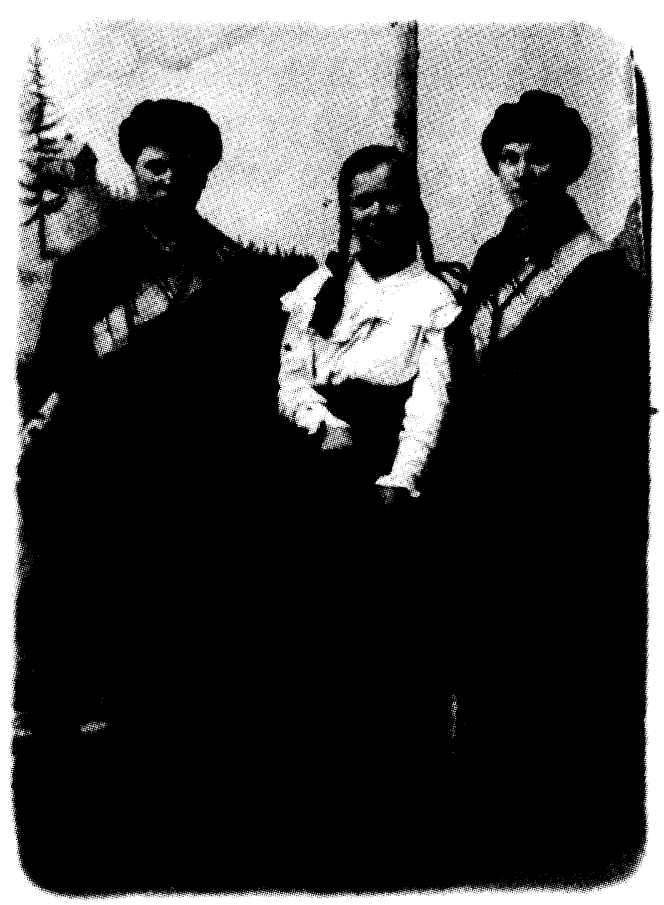

Naispunakaartilaisia Viipurista keväällä 1918. Keskellä Saimi Sorvali ja oikealla Hanna Sorvali. Kuva: Työväen Keskusmuseo.

pontimena oli yhä heikentyvä elintarviketilanne. Suomen kansalaissodan sytyttyä oli vapaaehtoisten, punakaarteihin liittyneiden venäläisten joukossa myös yksittäisiä naisia ainakin Tampereella ja Karjalan rintamalla, mikä lienee ollut esimerkkinä suomalaisille naisille. ${ }^{20}$

Kaiken kaikkiaan Suomen punakaarteihin kuului noin 2000 naista eli noin kolme prosenttia punakaartin kokonaisvahvuudesta. On kuvaavaa, että nuo pari tuhatta naista eivät värväytyneet sosialidemokraattisesta naisliitosta, vaan pääosin sosialidemokraattisesta nuorisoliitosta. Olivathan naissotilaat nuoria naimattomia naisia, enimmäkseen ompelijoita, palvelijoita ja teollisuustyöläisiä. He pyrkivät pukeutumaan yhdenmukaisesti housuasuihin ja otattivat valokuvia muistoksi vallankumouspäivistä. Naiskaarteja perustettiin helmi-maaliskuussa 1918 ensin Helsinkiin ja Viipuriin, sitten myös Mäntsälään, Kotkaan, Orivedelle, Loviisaan, Maariaan, Uuraalle, Tampereelle, Kangasalalle ja Juupajoelle. ${ }^{21}$

20 Ks. Stites 1987, s. 246-255; Piiroinen-Honkanen 1995, s. 12-16; Myös McDermid 1999; Wood 1997; Porter 1988.

21 Klemettilä 1976, s. 88 sekä liite 1. 
Eri yhteyksissä naisten keskeisimmiksi liittymismotiiveiksi on arveltu aatteellinen innostus ja taloudelliset syyt. Myös ystävien esimerkki, seikkailunhalu, nuoruudesta johtuva toiminnanhalu sekä elintarvikepulasta johtuvat taloudelliset seikat vaikuttivat liittymiseen. Taloudellinen motiivi oli etenkin nuorille, tehtaista työttömäksi jääneille naisille tärkeä. Kaartilaisille maksettiin palkkaa, jonka lisäksi he saivat muonan ja vaatetusta. Tämän takia myös monet taloudellisessa ahdingossa olevat vaimot pyrkivät kaarteihin. Heitä ei kuitenkaan niihin mielellään otettu. ${ }^{22}$ Martta Salmela oli eräs niistä naimisissa olevista ja perheellisistä naisista, joilta evättiin pääsy kaartiin. Silloin hän oli ulosajosta "sydänjuuriaan myöden loukkaantunut”, myöhemmin kun hänen miehensä vietiin leiriin, hän kiitti mielessään ettei häntä oltu huolittu. ${ }^{23}$ On kuitenkin liioiteltua sanoa, että naiset liittyivät punakaarteihin pelkästään leivän tähden: taustalla oli lähes aina jonkin asteinen aatteellinen sitoutuminen - tai suoranainen yhteisön tai johtajien taloudellinen ja sosiaalinen painostus.

Punakaarteissa jouduttiin nimittäin sodan jatkuessa turvautumaan yhä enemmän pakotteisiin. Aluksi korostettiin, että liittyminen kaartiin oli työväenluokkaan kuuluvan velvollisuus. Myöhemmin tähdennettiin, että punakaartiin liittymästä kieltäytyvä oli petturi. Maaliskuun alussa 1918 kansanvaltuuskunta päätti, että elintarvikekorttien saanti riippui kuulumisesta punakaartiin tai työskentelemisestä "yleishyödyllisissä töissä". Paikallisesti saatettiin käyttää voimakkaampiakin pakotteita. Sodan aikana kirjoitetuista kirjeistä nähdään, että etenkin vanhemman ja keskipolven työväenliikkeen aktiivit kokivat väkivallanteot hyvin raskaina ja punaisten asiaa vaikeuttavana. Esimerkiksi äidit kirjoittivat rintamalla oleville pojilleen pyytäen näitä muistamaan jumalan ja äidin uskon. Kotijoukoille sodan päämäärät jäivät monta kertaa epäselviksi ja tapahtumat olivat kaoottisia. Läheisten menettämisen pelon lisäksi työläisäitejä huolestuttivat heikko elintarviketilanne ja muut käytännölliset arkipäivän asiat. ${ }^{24}$

Nuoret naiset, jotka liittyivät punakaarteihin, kohtasivat paljon ennakkoluuloja myös omiensa puolelta. Muuan mäkitupalainen arvosteli ankarasti naisten tuloa mukaan. Hänen mielestään puna- 


\section{*Naisten marssi}

Silloin Kertun äiti pyyhälsi juosten portista ja huusi: "Tulkaa katsomaan, naiset marssivat rintamalle!" Syöksyttiin kadunkulmaan, 4. linjan ja Porthaninkadun kulmaan. Ja tosiaan. Pitkä rivi naisia marssi pitkälle sillalle päin. Heillä oli kivääri olalla, ei kaikilla, josta joku tiesikin, että ne on sairaanhoitajia. Jokseenkin jokaisella oli esiliina, josta joku arveli että kai taskujen tähden. Liina oli sidottuna tiukasti niskaan, josta taas joku sanoi "ettei nuttura hajoaisi".

Itkeviä lapsia koetti pysytellä rivistön mukana, pitäen kiinni äitinsä hameesta tai kädestä. Naiset marssivat vakavin kasvoin, pystypäin, suoraselkäisinä, uljaina. He lauloivat ja marssivat sen tahdissa. Katu kaikui heidän laulustaan. He lauloivat sitä samaa laulua, jonka koko kulmakunnan lapsetkin olivat oppineet, sen jälkeen kun venäläinen sotaväki jätti koulun ja punakaartilaiset ottivat sen haltuunsa. Se oli ollut myös lasten marssilaulu sotaleikeissä: "Pieni Suomen kansa, katkoo kahleitansa... Äiti itki ihan huutamalla: tämä ei voi olla oikein! Ei voi!"

Juuri äitien osallistuminen sotatoimiin aiheutti tunnekuohua paitsi työväestön itsensä keskuudessa, myös porvarillisissa piireissä. Mannerheimin päiväkäskyn mukaan valkoisten naisten paikka oli kriisin hetkelläkin kotona: "Sotaista kamppailua pidän miehen yksinoikeutena ja velvollisuutena". Näin Mannerheim vastasi Lapuan naisliiton ja Suomalaisen Naisliiton Helsingin osaston aikomuksiin perustaa naispataljoonia. Naispataljoonat eivät siis olleet yksinomaan punaisten hankkeita, tosin vain he saivat esikunnaltaan luvan niiden perustamiseen.

Lähde: Kansalaissodan aikana 9-vuotiaan Esteri Mikolan (s. 1909) muistelma 1930-luvulta. SATA 11680-11738. SKS; Soikkanen Hannu, Kansalaissota dokumentteina 2. Valkoista ja punaista sanankäyttöä 1917-18. Helsinki 1969, s. 205.

kaartilaiset olivat remusakkia, joka kaiket yöt tanssi ja melusi. Hänen mukaansa naisia ei olisi pitänyt kuljettaa rintamalle, sillä "ne pilasivat koko sakin". ${ }^{25}$ Kansalaissodan rintamanaisia voidaan verrata toisen maailmansodan aikaisiin nuoriin rintamalottiin, joskaan Suomessa lotat eivät olleet aseistettuja. 


\section{Puheenjohtaja Aalle-Teljon sota}

Tammikuun lopussa 1918 Ida Aalle-Teljo käveli Helsingin keskustassa mieli kuohuksissa. Hän oli juuri lukenut tolppaan kiinnitetystä julistuksesta, että vallankumous oli alkanut. Ida oleili kotona jännittyneenä pari seuraavaa päivää, kunnes hän 30.1. sai kirjeen Eero Haapalaiselta. Hänen oli välittömästi saavuttava Kansanvaltuuskunnan huoneistoon Senaatintorille. Ida sai tehtäväkseen matkustaa lääkäri Castrenin kanssa Malmille, jossa oli odotettavissa verinen yhteenotto. Tappelua ei tullut, mutta Ida joutui seurueineen punakaartilaisten epäluulon kohteeksi ja hän pääsi pois Malmilta vasta seuraavana päivänä.

Helmikuun 6. päivänä Aalle-Teljo määrättiin Työväen Pääneuvoston jäseneksi naisliiton ehdotuksesta. Ida oli tuohon aikaan naisliiton puheenjohtaja ja kauan harkittuaan hän suostui tehtävään "velvollisuudesta puoluetta kohtaan". Hänen tehtäväkseen annettiin mielten rauhoittaminen ja moraalin ylläpitäminen. Hän kiersi niin rintamalla kuin toreillakin pitämässä puheita. Hän sai toimestaan palkkaa kahdelta kuukaudelta 1200 markkaa. ${ }^{26}$

Lisäksi hän oli yhdessä Miina Sillanpään ja Hedvig Gebhardin kanssa Helsingin kaupungin hätäapukomitean alaisessa keittolakomiteassa, joka oli perustettu edellisenä vuonna. ${ }^{27}$

Työmiehessä esiteltiin 4.2.1918 Työväen Pääneuvostoon valitut jäsenet ja varajäsenet. Naisista oli valittu neuvostoon Hanna Kohonen Viipurin itäisestä piiristä, Anni Savolainen Mikkelin piiristä ja naisliitosta Ida Aalle-Teljo. Varajäseninä toimivat Turun pohjoisesta piiristä Aino Forstén, Oulusta Hilda Herrala ja naisliitosta Olga Manner. Muista naisliiton johtohenkilöistä Hilja Pärssinen oli valmistelevan valiokunnan jäsen ja kansanvaltuutettu eli ministeri, Anni Huotari oli oikeudellisen jaoston lainvalmistelukunnan jäsen, Alma Jokinen Tampereelta oli oikeudellisen jaoston ylioikeuden jäsen ja Hanna Karhinen Pääneuvoston tulkki, sihteeri ja Pärssisen ohella toinen naispuolinen kansanvaltuutettu. Aura Kiiskinen oli Pääneuvoston Elintarvikeosaston ja Työasiainosaston toimitsija ja kassanhoitaja. Hanna Malm oli Työväen Pääneuvoston

26 Suomen Pääneuvoston jäsenten palkkalistat 14.2.-15.3.1918. Ida Aalle-Teljoa koskevan Valtiorikosoikeuden pöytäkirjan 28.5.1919 liite. KA.

27 Keittolakomitean pöytäkirjan 9.3 .1918 ote. Ida Aalle-Teljoa koskevan Valtiorikosoikeuden pöytäkirjan 28.5.1919 liite. KA. 
Sisäasiainosaston sihteeri, Hulda Salmi kouluneuvoston jäsen ja Elviira Vihersalo oikeudellisen jaoston "ekspeditööri". Kaiken kaikkiaan naisia oli Suomen vallankumouksen keskushallinnossa virkailijoina 61, joista edellä nimeltä mainitut 11 olivat johtavissa tehtävissä ja loput 50 olivat varajäseniä, konekirjoittajia, lähettejä ja muuta toimistohenkilökuntaa. Hallinnossa toimi kaikkiaan 500 henkilöä, joten naisten osuus oli noin 12 prosenttia.

Naiset osallistuivat sisällissodan aikana töihin, joita heille osoitettiin. Valtaosa mukana olleista naisista toimi elintarvike-, huolto-, järjestyksenpito- ja ensiaputoiminnassa. Taistelujen käännyttyä työväelle epäedullisiksi maaliskuussa, alettiin asepalvelukseen ottaa myös naisia. Pääasiassa he joutuivat vartiointitehtäviin, mikä saattoi olla taisteluhaluisille tytöille pettymyskin: "Meitä oli joukko tehtaan tyttöjä, jotka olimme päättäneet liittyä punakaartiin...komennettiin ruoanlaittajiksi tai sairaanhoitajiksi. Lahden naiskomppaniaan otettiin naisia, meitä lähti kolme tyttöä...toivoimme pääsevämme rintamalle. Jouduimme radan vartiointiin. ${ }^{28}$

Kuukauden vaihduttua huhtikuuksi alkoivat punaisten tappiot kasvaa. Tampereen antautuminen valkoisille 6.4. merkitsi punaisten häviötä. Punaiset johtohenkilöt alkoivat siirtyä kohti itää. Huhtikuun lopussa 1918 Ida Aalle-Teljo siirtyi miehensä kanssa viimeisten punaisten joukossa Helsingistä Kotkaan, jossa hän osallistui ainoana naisena rauhanneuvotteluihin paikallisen valkoisen kaartin kanssa. Hän otti osaa myös muonitusosaston työhön ${ }^{29}$ ja piti vappuna sovittelevan puheen Kotkan työväestölle. Toukokuun kolmantena päivänä hän siirtyi kaupungista Tiutisten saarelle sisarensa luo. Siellä hän tapasi vanhan ystävänsä Maria Paaso Laineen, joka oli paennut sotaa poikansa luo. Kun huhuttiin, että kiinni saadut punaiset tapettiin heti, lähtivät Aalle-Teljotkin pakoon saarille. Idalle oli järjestetty laivamatka Venäjälle, mutta hän ei halunnut lähteä ilman miestään.

Aalle-Teljon pariskunta pakoili saarelta toiselle puolitoista kuukautta. Kesäkuun puolivälissä he uskaltautuivat Viron maaseudulle ja syksyllä 1918 Tallinnaan, missä Kyösti Teljo sai paikan orkes-

28 Mandi Nirosen muistelus 1918 tapahtumista. Ka.

29 Luettelo huoltoasiain osaston henkilökunnasta Kotkassa 16.4.1918 ja Lentolehtinen Kymenlaakson työvăelle 1.5.1918. Ida Aalle-Teljoa koskevan Valtiorikosoikeuden pöytăkirjan 28.5.1919 liitteet. KA. 


\section{Rakas Aune!}

(Samoin muut lapseni).

Jos nykyisessä taistelussa sattuisi käymään niin onnettomasti, että äitisi ja minä joko joutuisimme vangiksi tai kuolemaan, niin jätän minä siskosi ja veljesi sinun hoitoosi. Koeta olla heille hyvä sisko, kun olet meidän sijaisenamme. Kasvata heitä kunnon ihmisiksi ja kunnioittamaan vanhempainsa muistoa, vanhempain, jotka ovat tehneet kaikkensa teidän hyväksenne ja uhranneet kalleimpansa köyhälistön asian eteen. Huolimatta erinäisistä ennakkoepäilyistä nykyisen aseellisen taistelun suhteen olemme katsoneet olevamme velkaa liikkeellemme kaiken työkykymme, kun kerran valtataisteluun on päätetty lähteä. Olemme kasvaneet sosialidemokratisen liikkeen mukana, ja velvollisuutemme kutsuu meitä.

Tämän kirjeen alta löydät Pellavatehtaan Työväen Osuuskaupan antaman säästökirjan, jossa on säästöä 1500 markkaa sekä korot. Niillä pääsette alkuun. Rahat on nyt nostettava Osuusliike Voimalta. Sitten kun hätä tulee, muutettakoon myös talo-osakkeet rahaksi. Ne ovat $\mathbf{8 0 0}$ markan panttina Hämeen Työväen Säästöpankissa. Ei pidä myydä niitä alle 5000 markan. Tarpeettomampaa irtaimistoa, kuten salin kalusto, suuri kirjoituspöytä y.m. voidaan sitten rahaksi muuttaa. Kaikessa sopii käyttää esim. Arvi Ahosta apuna. Henkivakuutuksistani on varmasti voimassa vain 2000 markan vakuutus "Suomessa", mutta pitää kuitenkin koettaa saada "Suomen" 3000 mkan ja Kalevan 2000 mkan vakuutus.

Koettakaa kukin käydä koulua niin pitkälle kuin varoja riittää. Poikain ainakin toivoisin jatkavan yliopistoon asti. Ellei sovi, niin sitten on antauduttava mille tahansa kunnialliselle alalle.

Pitäkää, jokainen lapsikultani, elämäntiellänne kunniallisuutta ja rehellisyyttä ohjeenanne! Älkää myöskään unohtako sitä asiaa, jonka puolesta vanhempanne ovat työskennelleet ja kärsineet.

Hyvästi rakkaat lapseni Aune, Aili, Aino, Tauno, Terttu ja Tapio!

Onnea elämänne tielle!

Isänne

Anton Huotari

Tampereella $18 / 21918$

\section{J.K. Aunelle}

Niin pian kuin kykenet kirjalliseen työhön, etsi kokoon tärkeimmät kirjoitelmani. Niitä on eri julkaisuissa kaunokirjallisia sekä asiallisia ja Kansan Lehdessä runsas märä asiallisia artikkeleita monilta aloilta. Voisit julkaista niistä toisen kaunokirjallisen ja toisen artikkelikokoelman. Se olisi muistoni.

Isäsi

Anton Huotarin liikuttava jäähyväiskirje lapsilleen helmikuussa 1918. Ero lapsista ei ollut lopullinen. Huotarit keskeyttivät pakomatkansa ja palasivat kotiin. Heidät tuomittiin vankilaan, josta Anni Huotari vapautui kesäkuussa 1919 ja Anon Huotari tammikuussa 1922. Lähde: Anton Huotarin arkisto. Työväen Arkisto. 
terista. Maaliskuussa 1919 pariskunta pidätettiin ilmiannon perusteella ja passitettiin vangittuna Suomeen. Helsingin satamassa Väinämöisen tuloa oli vastassa suuri joukko Idan ystäviä, muun muassa Mimmi Kanervo. He tervehtivät eloonjääneitä huudahduksin, kukkasin ja paketein. ${ }^{30}$

Ida Aalle-Teljo tuomittiin valtiorikosoikeudessa vankeuteen huhtikuussa 1919: 12 vuotta kuritushuonetta ja 15 vuotta ilman kansalaisluottamusta. Kuultuaan tuomionsa Aalle-Teljo oli järkyttynyt ja kirjoitti armonanomuksensa pianistin rouvan ja entisen kansanedustajan statuksella. "Kun en parhaalla tahdollanikaan voi käsittää että moista ankaraa rangaistusta olisin ansainnut... " Hän paheksui syvästi sitä, että raskauttavana seikkana hänelle oli luettu osallistuminen työväenjärjestöjen toimintaan. Kuulumistaan pääneuvostoon hän selitti sillä, että katsoi maltillisten henkilöiden olleen velvollisia rauhoittamaan tilannetta: hän ei ollut liittynyt kapinallisten hallintoon suinpäin, vaan tarkan harkinnan jälkeen ja sosiaalidemokraattisten naisten pyynnöstä ja naisten edustajana - hänhän oli naisliiton puheenjohtaja. Naisliitto suhtautui hänen mukaansa koko ajan kielteisesti kapinaan. Ansiokseen Aalle-Teljo sanoi, että hän ajoi pääneuvostossa naisten aseistamista vastustavaa kantaa. Punakaarti päätti kuitenkin vastoin hänen tahtoaan toisin.

Aalle-Teljon puolustuspuhe valottaa hänen ja muidenkin naisten asemaa Sosialidemokraattisessa puolueessa: “...viaksi on luettu myös se, että olen puolueessa johtavassa asemassa. Tällainen imarteleva lausunto ei nyt kumminkaan vastaa todellisuutta. Johtoon ei voinut vaikuttaa syystä, että puolueen enemmistö kannatti vasemmistopolitiikkaa, kun taas minä revisionistina lukeuduin puolueen oikeistoon. Puolueen naisten keskuudessa minulla oli jonkun verran luottamusta, tämä johtui siitä, että koko työni ja toimeni tarkoitti työläisnaisten aseman parantamista ja tätä tarkoitusperää varten uhrasin kaiken aikani ja kykyni... "31 Viroon hän pakeni pelastaakseen yksinkertaisesti henkensä tilanteessa, jolloin tutkimatta ja tuomitsematta ampuminen alkoi. Aalle-Teljon tuomio lieveni sittemmin siten, että hän vapautui vankilasta tammikuussa 1922 eli hänen vankeutensa kesti lähes kolme vuotta.

30 Ida Aalle-Teljon muistelmat 1941. Y.K. Laineen kokoelma, kansiot 4 ja 10. TA.

31 Ida Aalle-Teljon kuulusteluasiakirjat. Valtiorikosoikeuden pöytăkirja 28.5.1919 liitteineen. KA. 
Eräänä toukokuun päivänä 1919 asteli Helsingin lääninvankilaan kaksi naista. Toinen heistä oli tunnettu kansanedustaja Miina Sillanpää, toinen Aino Artukka. Naiset ilmoittautuvat Valtiorikosoikeuden avustajalle ja pyysivät että heitä kuulusteltaisiin vangitun Ida Aalle-Teljon asiassa. Oikeus suostui naisten pyyntöön ja kuulusteli Sillanpäätä valallisesti ja Artukkaa ilman valaa. Sillanpää kertoi, että hänen käsityksensä mukaan vangittu ei hyväksynyt aseellista toimenpidettä ennen kapinaa eikä myöskään kapinan aikana. Aalle-Teljo oli hänen mukaansa paheksunut punakaartin toimia useasti. Vangittu oli ajanut Sillanpään mukaan naisasiaa pääneuvostossa.

Sillanpää jatkoi lisäksi, että kun suurlakon 1905 aikana suunniteltiin naisten liittämistä punakaartiin ja naispunakaartien perustamista, vastusti Ida Aalle-Teljo jyrkästi aikeita. Kuulusteltavat antoivat oikeudelle myös otteen vuonna 1917 perustetun Helsingin kaupungin keittolakomitean pöytäkirjasta, josta ilmeni ettei komitea ollut punakaartin alainen, vaan kunnallinen: siihen kuuluminen ei siis voinut olla rikos. Komitea lähetti ruokaa myös valkoisille vangeille. Se joutui kuitenkin toimittamaan ruokaa myös punakaartille: kaarti ei toimittanut sille elintarvikkeita ilman tätä. Keittolakomiteaan kuuluivat sosiaalidemokraattien lisäksi Suomalaista puoluetta edustanut ensimmäisen eduskunnan kansanedustaja Hedvig Gebhard ja kuulusteltava Aino Artukka.

Myös muita porvarisnaisia pyrki toimimaan sodan aiheuttamien seuraamusten lieventämiseksi. Nuorsuomalainen kansanedustaja Lucina Hagman oli sodan sytyttyä pyrkinyt jopa sovittelemaan rauhaa ja käynyt esittämässä neuvotteluja 1.2.1918 Kansanvaltuuskunnassa.

Miina Sillanpään rooli ja ratkaisut naisliiton yhtenä johtohenkilönä olivat kriisin hetkellä toiset kuin Aalle-Teljolla. Siinä missä Aalle-Teljo pasifistisesta kannastaan huolimatta päätti tehdä mitä tehtävissä oli, Sillanpää luopui syyskuussa 1917 naisliiton liittotoimikunnan jäsenyydestä eikä halunnut osallistua toimintaan "levottomien olojen takia". Tämä ei kuitenkaan tarkoittanut sitä, että hän ei tehnyt mitään. Hän toimi aktiivisesti em. keittolakomiteassa, avusti tuttaviaan, kuten Aura Kiiskistä, Hulda Tihlää ja Edvard Gyllingiä, näiden pakomatkalle hankkien passeja ja yövyttäen heitä kotonaan.

Sillanpään poliittisen uran näkökulmasta siirtyminen sivuun kapinan hetkellä avasi hänelle kuningastien sodan jälkeen.

Lähde: Ida Aalle-Teljon mappi. Valtiorikosoikeuden pöytäkirjat liitteineen 12.5.1919. Ida Aalle-Teljon kirje Valtiorikosoikeudelle 13.5.1919, nro 25856. KA; Aura Kiiskisen kirje Miina Sillanpäälle 20.4.1918. Miina Sillanpään arkisto. TA; Mäkikossa Oma, Yhteiskunnalle omistettu elämä. Helsinki 1947, s. 222-224; Soikkanen Hannu, Valkoista ja punaista sanankäyttöä. Kansalaissota dokumentteina 2. Helsinki 1969, s. 155. 


\section{3. "Punikkiämmä" Hjulgrenin teloitus}

Kansanedustajina toimineista sosiaalidemokraattisista naisista teloitettiin sodan loppuselvittelyissä yksi, joutsenolainen Sofia eli Sohvi Hjulgren (os. Lundström). Sosso, joksi häntä ystävät kutsuivat, syntyi vuonna 1875 Kullaalla. Hän oli ammatiltaan kutoja ja naimisissa Ulvilasta kotoisin olevan sahatyöläinen Antton Hjulgrenin kanssa ja heillä oli yksi lapsi. Perhe eli taloudellisesti suhteellisen hyvin, sillä mies oli Joutsenon kunnan töissä työnjohtajana. Eduskunnassa Sofia Hjulgren oli vuosina 1914-16.

Sofia Hjulgren ammuttiin 43-vuotiaana 5.5.1918 Viipurissa koirien hautuumaalla punaisten joukkoteloituksessa. Toisen tiedon mukaan ampuminen olisi tapahtunut 21. toukokuuta. Ennen kuolemantuomion langettamista Sofia piti sorakuopan reunalla puheen, josta on jäänyt tietoja ns. luokkasotakirjallisuuteen. Eräs tarina kertoo, että odotellessaan ampumistaan Hjulgren olisi noussut pienelle mättäälle, paljastanut rintansa ja puhunut. Puheen sisältö vaihtelee vähän, mutta eräiden muistelujen mukaan Sofia Hjulgren julisti, "ettei tämä vapaudelle vuodatettu veriuhri hukkaan vuoda, vaan jokainen pienikin ruohonkorsi, joka tästä viattomalla verellämme punatusta maasta nousee, huutaa kostoa ja vienoinkin tuulenhenkäys tämän jälkeen itkee syyttömästi murhattujen puolesta, eikä lakkaa ennenkuin viattomasti vuodatettu veripisara on kalliisti maksettu". ${ }^{32}$ Hjulgrenin puhe oli kertomuksen mukaan katkennut useiden kiväärien ja upseerien mauser-pistoolien laukauksiin. Seuraavana aamuna vankileiriltä oli viety 60 miestä hautaamaan teloitettujen ruumiita. Niitä oli ollut 130 , Sofia Hjulgrenin ruumis oli ollut hiukan sivussa, rinta yhä paljaana ja monen luodin lävistämänä. Hänen kasvonsa olivat olleet tyynet ja hymyilevät. ${ }^{33}$

Teloittajat puolestaan kirjasivat arvion Hjulgrenista näin:

“...tämä kiihkeä punikkiämmä Joutsenosta, sos.dem. jäsen, kiihkeä kansankiihoittaja, saatiin kiinni, tuomittiin ensimmäisten joukossa, ammuttiin itsensä Ripatin ja muun esikunnan kanssa päävartion seinää vasten 5. toukokuuta".

32 Kilpi 1953, s. 158-159; Paavolaisen kokoelma vuoden 1918 teloitetuista, Hjulgren Sofia. KA.

33 Kuolemaan tuomitut, kirj. Hertta Kuusinen, Kuusinen 1960, s. 149-150. 
Joutsenolainen Sofia Hjulgren (1875-1918) oli ainoa naiskansanedustaja, joka teloitettiin kansalaissodan puhdistuksissa. Kuva: Työväen Arkisto.

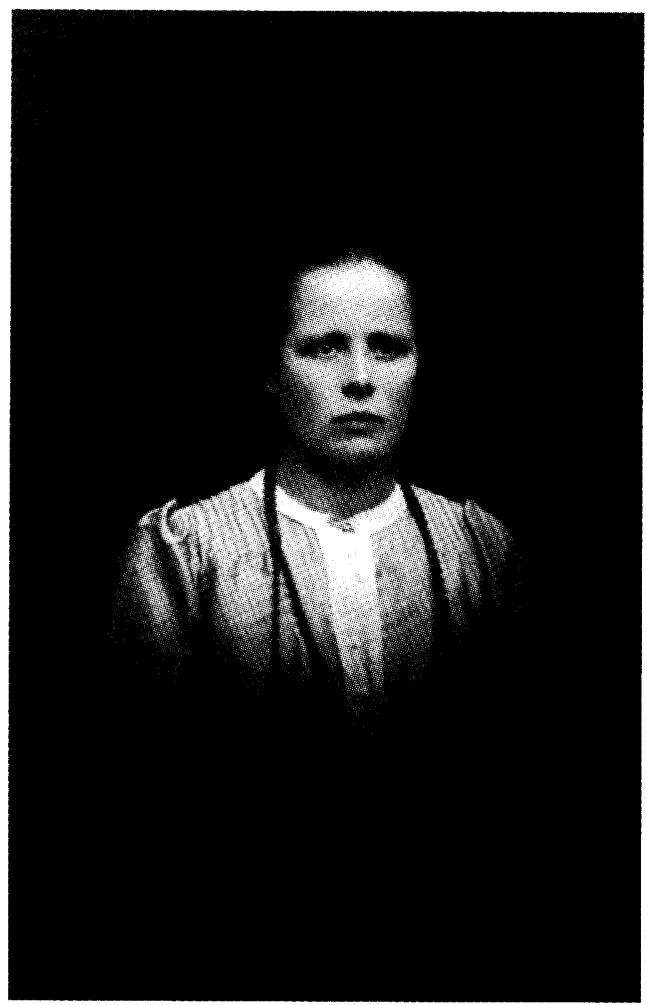

Kuten näistä kovin erilaisista arvioista nähdään, työväestö nosti Sofia Hjulgrenin pyhimyksen ja hyväntekijän asemaan, valkoiset puolestaan murhanhimoiseksi kriminaaliksi. ${ }^{34}$

Näihin tarinoihin liittyy valtavasti symboliikkaa, kuten paljas naisen rinta, josta lapsi imee elinvoimansa tai ruumiiden silpominen häpäisyn merkkinä. Sillä, että väkivallan kohteena oli nainen, oli tärkeä tunteita herättävä merkitys ja sitä käytettiin puolin ja toisin propaganda-aseena. Luokkasotakirjallisuudessa valkoisella kostolla ei nähty olevan mitään rajoja, koska se häpäisi "köyhän työläisäidin" hengen ja ruumiin. Vapaussotakirjallisuudessa puolestaan "punikkiämmien" raadollisuus kuvasti yleisemminkin punaisten ääretöntä ja halveksittavaa moraalittomuutta. Vain nainen saattoi olla sisällissodan pyörteissä yhtä aikaa raaka murhaaja ja pelastava enkeli.

Sofia Hjulgren oli aktiivinen työväenliikkeen toimija ja siitä syystä hänet myös teloitettiin. Hän oli Honkalahden kylän työvä-

34 Luokkasodan muisto 1947, 184; Paavolainen 1967, 117; Tikka-Arponen 1999, 161-163, 189, 197-200, 245, 296. 
enyhdistyksen johtokunnan jäsen ja traagisina vuosina 1917-18 yhdistyksen puheenjohtaja, mikä oli todella poikkeuksellista naiselle. Ehkäpä juuri hänen kansanedustajuutensa ja muutoinkin aktiviinen toimintansa nostivat hänet tähän asemaan. Sofia oli myös naisosaston puheenjohtaja ja kunnallistoimikunnan jäsen, hän toimi myös piirijärjestössä ja osuustoimintaliikkeessä. Hän oli sekä Joutsenon että Lappeenrannan punakaartin esikuntien jäsen, mikä oli naiselle myös hyvin harvinaista.

Muisteluiden mukaan Sofia oli tunnettu ja pidetty henkilö, lahjakas puhuja ja hän esiintyi päättäväisesti kuntakokouksissa ja luottamustehtävissä. Naisliittolaisaktiivi Aura Kiiskinen, joka pakeni Neuvosto-Venäjälle sodan loppupuolella, on muistellut Hjulgrenia näin: "Sofialla oli aina asiaa työläisasuntoihin ja kaikkialla hänet otettiin vastaan kuin hyvän uutissanomain tuoja. Hänellä oli aina kirjapaketti kainalossaan, sanomalehtitilauskirja taskussa ja usein leipäpala tai jokin pikkutuominen toisessa kaikkein köyhimpiä lapsia varten, sillä Joutsenon tehtaan työläiset elivät tavattoman kurjissa oloissa..." 35

Itse sotatapahtumiin Sofia Hjulgren ei aluksi liittynyt, vaan naisliittolaisten tapaan vastusti aseellista yhteenottoa. Sodan pitkittyessä ja käännyttyä punaisille epäedulliseksi ilmeisen temperamenttisen Sosson on kerrottu polkeneen jalkaa "...jumalauta, jos muuten ei pärjätä, opetetaan naisetkin tappelemaan". Hänen sovinnollisuuttaan kuitenkin kuvaa se, että hän punaisten vallan aikana pelasti valkoisia vankeja varmalta kuolemalta. Valkoisten saavuttua paikkakunnalle esitti Hjulgren hyväuskoisesti rauhanneuvottelua valkoisten kanssa. Valkoisten lähestyessä Hjulgrenin pariskunta hakeutui punakaartilaisten suojiin Lappeenrantaan ja jatkoivat sieltä pakomatkaansa kohti Viipuria. He joutuivat 29.4. 1918 vangiksi Viipurin lähellä olevalla Tienhaaran pysäkillä. Viimeisimpiä muistikuvia Sofiasta oli kun hän laittoi ruokaa punakaartilaisille. Viipurista Sofia Hjulgren vietiin Aleksanterin vankileirille. ${ }^{36}$

Sofian mies, Antton Hjulgren pääsi pakenemaan oltuaan jo haudan reunalla ammuttavien joukossa Viipurin leirillä. Erään tiedon mukaan hän hakeutui kotiseudulleen ja piileskeli metsissä vangitsemiseensa saakka. Joka tapauksessa hän oli jo 3.7. 1918 Tammi-

35 Kuusinen 1960, s. 151

36 Tikka-Arponen 1999, 161-163, 189, 296 
saaren vankilassa kuulusteltavana. Antton oli liittynyt aktiivisena työväenliikkeen ihmisenä aluksi järjestyskaartiin marraskuussa 1917 ja punakaartiin tammikuun lopulla 1918. Liittymisensä syyksi hän sanoi piiritoimikunnan kehotuksen. Hänellä oli kivääri ja hän oli jonkin aikaa ollut rintamalla Lappeenrannan, Joutsenon, Korvenkylän ja Honkalahden maisemissa.

Joutsenon Suojeluskunta antoi Anttonista kaksi arviota. Ensimmäisessä häntä luonnehdittiin elämäntavoiltaan säännölliseksi ja työteliääksi, mutta kiihoittajaksi. Jälkimmäisessä hänen elämäntapansa olivat "säännölliset ei läheskään” ja lisäksi hän oli laiska työmies. Hjulgren oli vaimonsa kanssa Joutsenon punaisten kärkinimiä ja Suojeluskunta vaati häntä rangaistavaksi: "Hän on henkilöitä, joita olisi rangastava ankarasti, sillä hän on niitä pahempia Joutsenon kiihottajia, hän oli yleensä luottoa nauttiva henkilö punasten keskuudessa ja hän olisi järkevänä henkilönä voinu vaikuttaa niin että Joutsenon tehtas alueelta ei olisi menny ketään". Antton Hjulgren todettiin syypääksi valtiopetokseen ja ryöstelyihin ja tuomittiin seitsemäksi vuodeksi kuritushuoneeseen ja menettämään kymmeneksi vuodeksi kansalaisluottamuksensa. ${ }^{37}$

Kaiken kaikkiaan kansalaissodan aikana kuoli tai katosi 28088 punaista, heistä oli naisia 755 eli 2,6\% kaikista kuolleista. Valkoisten naisten osalta vastaava luku oli $47(0,8 \%)$. Punaisista naisista kuoli eniten teloituksissa eli 428 naista eli 55,2 \% kuolleista. Toukokuun lopulla vankileireille oli koottu noin 74000 punaista, joista naisia oli noin 4 300. Vankileireillä tai heti vapautumisensa jälkeen kuolleita naisia oli 110, naisista kaatui tai kuoli haavoihinsa 74, kuoli muihin syihin 94 ja katosi 49. Miehiä teloitettiin siten suhteellisesti ottaen vähemmän kuin naisia. Suurin osa miehistä kuoli leireillä $(45,5 \%) .{ }^{38}$ Sotatoimissa mukana olleet naiset koettiin niin hirveiksi ja pahasuisiksi, naisten olemusta ja kutsumusta pilkkaaviksi olennoiksi, ettei heitä säästetty. Muun muassa Ilmari Kianto kirjoitti, että on hulluutta säästää ja olla ampumatta naisia. Hän kutsui punaisia naisia naarassusiksi, jotka olivat vielä pahempia kuin miehensä. ${ }^{39}$

Monia naisliittolaisaktiiveja kuoli kansalaissodan tapahtumien yhteydessä: muun muassa forssalainen, vuonna 1868 syntynyt Maria

37 Valtiorikosoikeuden pöytäkirjat 1918, VRYO 14996, Hjulgren Antton. KA

38 Eerola-Eerola 1998, s. 159-160, loppuviite 252, s. 173.

39 Lehtileikkeitä 1918. Kansio 61. Vuoden 1918 kokoelma. TA. 
*Valtiorikosoikeuksissa syytetyt ja tuomitut naiset 1918

\begin{tabular}{|c|c|c|c|}
\hline \multirow[t]{2}{*}{$\begin{array}{l}\text { Käsittely- } \\
\text { paikka }\end{array}$} & \multirow{2}{*}{$\begin{array}{l}\text { Naisia } \\
\text { syytetty } \\
1 \mathrm{~km}\end{array}$} & \multicolumn{2}{|c|}{$\begin{array}{l}\text { Naisia } \\
\text { tuomittu }\end{array}$} \\
\hline & & $\mathrm{lkm}$ & $\%$ \\
\hline Helsinki & 970 & 675 & 70 \\
\hline Tampere & 920 & 605 & 66 \\
\hline Lahti & 576 & 391 & 70 \\
\hline Riihimäki & 336 & 280 & 83 \\
\hline Hämeenlinna & 1273 & 1026 & 81 \\
\hline Viipuri & 387 & 292 & 77 \\
\hline Tammisaari & 96 & 84 & 88 \\
\hline Turku & 263 & 194 & 74 \\
\hline Pori & 412 & 229 & 56 \\
\hline Kuopio & 19 & 4 & 21 \\
\hline Lappeenranta & 84 & 58 & 69 \\
\hline Kotka & 153 & 136 & 89 \\
\hline Oulu & 4 & 4 & 100 \\
\hline Mikkeli & 27 & 20 & 74 \\
\hline Vaasa & 5 & 3 & 60 \\
\hline Sortavala & 8 & 2 & 25 \\
\hline Yhteensä & 5533 & 4003 & 72 \\
\hline$\%$ kaikista & 7 & 6 & \\
\hline
\end{tabular}

Syytetyistä naisista $72 \%$ sai myös tuomion. Miesten vastaava osuus oli $91 \%$. Naisten rangaistukset myötäilivät miesten saamia rangaistuksia: 2/3 kaikista tuomituista sai 1-3 vuoden kuritushuonetuomion. Kuolemaan valtiorikosoikeuksissa tuomittiin yksi nainen ja 554 miestä. Elinikäisen kuritushuonerangaistuksen sai neljä naista ja 882 miestä. Suurin osa naisista, 3 447, sai kuritushuonetta 1-3 vuotta, joten heidät armahdettiin. 4-12 vuotta kuritushuonetta sai 347 naista. Lisäksi sai 46 naista vankeutta ja viisi naista sakkoja.

Punakaartiin osallistuneista noin 2000 naisesta kuoli taisteluissa ja pidätyksen jälkeen teloitettiin noin $10 \%$ eli 200 naista.

Lähde: SVT XXIII Oikeustilasto 32. Tilastollinen tutkimus 1918. 1923, s. 1516. 
Tähti ammuttiin 21.5.1918, Otalammen työväenyhdistyksen aktiivi Sanni Ståhlberg 19.5. ja keravalainen Ida Savolainen 31.1. ollessaan sitomassa haavoittunutta. Niin ikään keravalainen Tekla Eklöf ammuttiin Lahdessa toukokuussa 1918 ja tamperelainen 18vuotias Saima Rantanen kahden nuoren veljensä kanssa heti Tampereen valtauksen jälkeen Palokunnantalon pihaan. Lappeelainen Elisabeth Starck puolestaan vangittiin miehensä ja poikiensa kanssa: hän itse säästyi, mutta mies ja vanhempi poika ammuttiin, nuorempi kuoli nälkään leirillä. Forssalainen naisliittolaisaktiivi Alina Aaltonen sai kuolemantuomion, mutta se vaihdettiin myöhemmin vapauttavaksi: todettiin, että palvelijatarosaston perustaminen ei liene ollut perusteltu syy kuolemantuomion langettamiseen. ${ }^{40}$ Suurin osa teloituksista tehtiin sodan loppuselvittelyissä Uudellamaalla, Hämeessä ja Viipurissa.

\section{Ministeri Pärssisen pako}

Naisliittolaisaktiivi Hilja Pärssinen valittiin punaisen hallituksen eli Kansanvaltuuskunnan ministeriksi maaliskuun alussa 1918. Hänen ministeriaikansa jäi kuitenkin lyhyeksi, sillä jo 25.3.1918 Hilja varustautui yhdessä miehensä Jaakko Pärssisen kanssa jättämään levottomaksi käyneen Helsingin. Hilja ompeli toisen naisministerin, Hanna Karhisen, kanssa rahanippuja vaatteisiinsa, hameiden helmoihin ja valetaskuihin. Pärssiset olivat realisoineet maallisen omaisuutensa myymällä Laivurinkadulla olevan asuntonsa sekä huvilansa Pieksämäeltä. Pakosuunnitelmakin oli selvä: ensin Siperiaan ja sieltä Sveitsiin asumaan. Pakoepäilysten hälventämiseksi Pärssiset jättivät kotinsa erillään toisistaan ja saapuivat rautatieasemalle eri aikaan. Junassa he etsiytyivät jälleen yhteen ja pakomatka itään saattoi alkaa.

Matkan ensimmäinen pysäkki oli Terijoki, josta Jaakko Pärssinen jatkoi matkaansa suoraan Pietariin. Vaimon oli sen sijaan palattava takaisin Helsinkiin kuultuaan Työväen Pääneuvostosta ankaran vaatimuksen paikoillaan pysymisestä: lähtö ei ollutkaan onnistunut ilman silminnäkijöitä. Vastahakoisesti Hilja palasi pääkaupunkiin ja kävi ilmoittamassa naisliiton toimistolla lähdöstään. Saman tein hän matkusti miehensä perään Pietariin.

40 Työläisnaisen Joululehti XII, 1919, s. 2-3. 


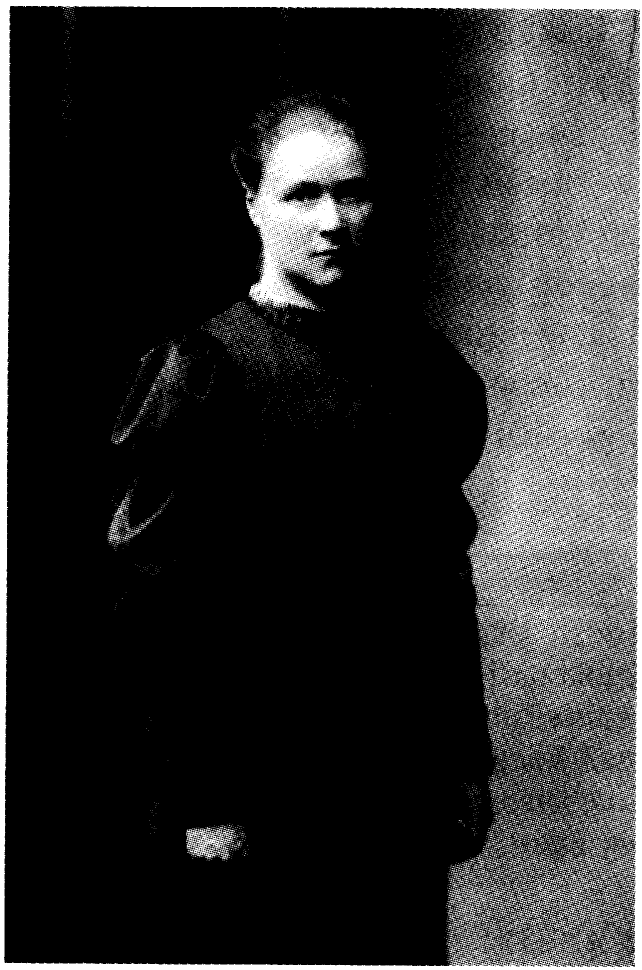

Kansakoulunopettaja Hilja Pärssinen (1876-1935) oli Sosialidemokraattisen naisliiton teoreetikkoja liiton toiminnan kansainvälistäjä. Kuva: Työväen Arkisto.

Pietarissa Pärssiset yrittivät useaan otteeseen hankkia passia ulkomaille matkustamista varten, mutta turhaan: Jaakko Pärssisen mukaan kapinalliset eivät halunneet hajauttaa suomalaisia pakolaisia. Vihdoin he lähtivät omin päin toukokuussa 1918 kohti Siperiaa. Eteneminen pysähtyi kuitenkin valkoisten joukkojen asemapaikoille lähelle Jekaterinburgin isoa kauppakaupunkia. Paria kuukautta myöhemmin bolsevikit surmasivat tsaarin perheen samalla alueella. Pärssisten etenemisen pysäyttivät valkoisten joukot, joten heillä ei ollut muuta mahdollisuutta kuin palata takaisin Pietariin, missä he toimivat muun muassa suomalaisen yhteiskoulun opettajina.

Pärssisten matkustelu ja passinhankintayritykset levottomalla Neuvosto-Venäjällä kestivät runsaat puolitoista vuotta. Marraskuun alussa 1919 Viron viranomaiset toimittivat heidät vangittuina Suomeen. ${ }^{41}$

Hilja Pärssinen tuomittiin valtiopetoksesta ja siihen yllyttämisestä elinkautiseen vankeuteen ja menettämään kansalaisluotta-

41 Hilja Pärssinen: Valtiorikosoikeuden pöytăkirja 27.1.1920 liitteineen. KA: Jaakko Pärssisen henkilömappi. EK-Valpon arkisto. KA. 
muksensa "loppuelämäkseen". Jaakko Pärssinen sai tuomion avunannosta valtiopetokseen. Hilja piti tuomiota "kohtuuttoman ankarana" ja anoi armoa. Asianajajanaan hänellä oli Väinö Hakkila. Alunperin syyttäjä vaati Hilja Pärssiselle kuolemanrangaistusta. Hakkila hyväksyi maanpetoksen, mutta lisäsi samalla, että "syytetyn sukupuoli on otettava huomioon rangaistusta määriteltäessä". Loppujen lopuksi Hilja istui Hämeenlinnan naisvankilassa kolme vuotta ja kaksi kuukautta. Hän vapautui vankilasta 22.1.1923 ollessaan 46-vuotias. Aviomies oli päässyt ehdonalaiseen vapauteen jo kesäkuussa 1921.

Jaakko Pärssinen toimi kansalaissodan aikana Suomen kouluneuvostossa. 20.3.1918 hän lähetti Sosialidemokraattiselle naisliitolle seuraavan sisältöisen kirjeen: "Saamme täten kohteliaimmin tiedustaa haluatteko tulla edustetuksi uudessa koulukomiteassa? Komitean tehtävänä tulee olemaan eri koulumuotojen yhtenäistyttäminen, uuden opetussuunnitelman laatiminen sekä uusien oppikirjojen aikaan saaminen. Edustajastanne ilmoittanette meille ensi tilassa."

Lähde: Vuoden 1918 kokoelma. Työväen Arkisto.

Venäjältä palaavien asema ei ollut helppo myöskään omien keskuudessa: sosiaalidemokraatit suhtautuivat heihin viileästi ja kommunistit leimasivat heidät pettureiksi: "jos et ollut kommunisti olit porvari”. Ei siis ihme, että myös Hilja Pärssisellä oli tarve puhdistaa maineensa sosiaalidemokraattien edessä. Hän kirjoitti Työmieheen artikkelin kokemuksistaan Neuvosto-Venäjällä korostaen maan sekasortoisuutta. Kommunistit ilkkuivat häntä: "Hilja Liinamaa-Pärssinen on nykyisin hieno rouva... Oikeastaan hän ei ole koskaan tehnyt tehtaissa työtä, ei maalla, ei kyökissä. Tästä johtuu, että hän näkee työväessä "lauman", joka likaisena vuona marrii sinne tänne, pieksätyttää itseään, nuolee ruoskaa...". ${ }^{42}$

42 Amerikansuomalainen Työmies 1920-luvulta. Lehtileikekokoelma. Hilja Pärssisen arkisto. TA. 
Kapinallisten paluu arkeen ei ollut helppo. Myös Pärssisen pariskunta joutui sen kokemaan. Opettajan tointa oli "punikkivaimon" ja kapinallisen mahdotonta saada. Syksyllä 1924 Hilja koetti saada edes miehelleen työpaikan Vaasan Työväen Sanomalehti Oy:stä:43

H. Toverit. Mieheni on joutunut kuten tunnettua kapinassa paikatta. En tarvinne hänen opinnoistaan kertoa mm. on kansantalous ja yhteiskuntaoppi pääaineitaan. Tuskimpa pidätte oppineisuutta esteenä, sillä onhan hän sen vastapainoksi ollut työväenliikkeen kanssa ikänsä kosketuksissa ja käynyt Tammisaaren yliopistossa 1,5 vuotta. Tohtorinarvon ja diploomin sai hän keväällä Jenan yliopistossa. Kaarlo Saarelta voitte soveliaisuutta tiedustella. Ilmoittakaa pian, voitteko toimeen kutsua, työttömänä olo käy mahdottomaksi, kuten ymmärrätte. Kun hän vielä aikoo palata koulualalle, toivoisimme, että paikkanne, jos hän siihen tulee, hiljaisuudessa täytettäisiin. Minä jäisin edelleen Terijoelle talvihuvilaamme.

Toveritar tervehdyksin Hilja Pärssinen

Pärssinen oli niitä harvoja kapinassa mukana olleita naisia, jotka valittiin vielä eduskuntaan. Hän oli edustajana vuosina 1929-35. Hilja Pärssisen viimeiset vuodet olivat tummasävyisiä. Hänen miehensä erosi ja otti heidän toisen kasvattityttärensä vaimokseen. Hilja itse sairastui rintasyöpään ja kuoli syyskuussa 1935.44 


\section{*Uusi kotimaa}

Huhtikuussa 1918 punaisten tappioiden myötä alkoi työväenjohtajien pako itään. Venäjälle paenneiden naisten kohtalot olivat monta kertaa tummasävyisiä. Työläisnaisaktiiveista lähtivät Aura Kiiskinen, Aino Forstén, Hanna Malm, Sandra Lehtinen, Alma Jokinen, Elvira Vihersalo ja Hanna Karhinen Hilja Pärssisen ja Ida Aalle-Teljon lisäksi. Anni Huotari lähti myös miehensä Antonin kanssa, mutta keskeytti pakomatkansa Viipuriin: hän ei voinut jättää kuutta lastaan ja palasi kotiin. Hänet tuomittiin viideksi vuodeksi ja neljäksi kuukaudeksi kuritushuoneeseen. Elvira Vihersalo menehtyi pilkkukuumeeseen ja lastensa menettämisestä aiheutuneeseen suruun, kuten naisliittolaiset sittemmin, huhtikuussa 1919, muistelivat. Alma Jokinen menetti miehensä Väinön Kuusisen klubin murhissa Pietarissa elokuussa 1919, itse hän sairastui tuberkuloosiin ja kuoli ennen talvisodan puhkeamista. Hanna Malmin kohtalona oli joutua Stalinin puhdistusten uhriksi 1930-luvulla. Aino Forstén erotettiin toimistaan ja vangittiin niin ikään vuoden 1937 puhdistuksissa. Hän kuoli Petroskoissa vuonna 1947.

Hilja Pärssisen ministeritoverina Suomen Kansanvaltuuskunnassa ollut Johanna Sofia eli Hanna Karhinen pakeni muiden johtonaisten mukana, mutta ei itään vaan länteen. Alkujaan viipurilaisen Andelinin suutariperheen tytär oli avioitunut poliisin kanssa 21-vuotiaana ja teki toimittajan töitä. Kansanedustajana hän oli vuosien 1914 ja 1917 valtiopäivillä. Kansalaissodan aikaan hän oli 40-vuotias. Suomen Kansanvaltuuskunnan sisäasiainosastolla hän oli toiminut tulkkina ja sihteerinä sekä majoitusjaoston valvojana ja huoltoasiainosaston valtuutettuna eli ministerinä. Sodan käännyttyä tappiolliseksi hän pakeni Ruotsiin, missä hän oli kaksi vuotta välittäen sitä kautta poliittista kirjallisuutta. Sieltä hän siirtyi Yhdysvaltoihin toimien puhujana ja toimittajana. Vuonna 1926 Karhinen siirtyi Neuvostoliittoon. Hän asettui Petroskoihin. Puhdistusten aikaan hänet erotettiin Suomen kommunistisesta puolueesta ja hän lienee menehtynyt leirillä.

Naisliittolaisista Aura Kiiskinen säästyi vainoilta ja eli pitkän elämän uudessa kotimaassaan. Hän kuoli Petroskoissa vuonna 1968. Myös Sandra Lehtinen pelastui puhdistuksilta. Pakonsa jälkeen hän palasi Neuvostoliitosta vuonna 1921, mutta meni sinne takaisin ja asui Petroskoissa ja Moskovassa vuodet 1933-45. Tässä välissä hän ehti olla Suomessa vankilassa poliittisista syistä vuodet 1929-32. Sandra Lehtisen tytär Inkeri oli kuulun Kuusisen hallituksen opetusministeri vuonna 1939. Lehtinen palasi Suomeen lopullisesti vuonna 1945 ja kuoli Helsingissä 1954.

Lähteet: Suomen eduskunnan matrikkeli; Kilpi Sylvi-Kyllikki, Sörnäisten tytön vaellusvuodet. Helsinki 1965, s. 99-105; Työläisnaisen Joululehti XII, 1919, s. 2-3. 


\section{Piirun verran oikealle}

\section{Naisliiton uusi suunta}

\section{Lainarahoilla uuteen alkuun}

Sosialidemokraattisen naisliiton toiminnassa oli lähes 11 kuukauden tauko helmikuusta 1918 joulukuuhun 1918 kansalaissodan ja sen jälkiselvittelyjen takia. Marraskuun 26. päivänä 1918 julistettiin yleinen armahdus, jonka jälkeen vankiloihin jäivät punaisten johtotehtävissä olleet. Jäljellä olevat naisliittolaiset kokoontuivat ensimmäiseen sodanjälkeiseen kokoukseensa 14.12.1918, jolloin todettiin, että vain kaksi vakinaista liittotoimikunnan jäsentä, Elin Fagerholm ja Hilda Öberg olivat vapaina. Elannon työntekijöinä kumpikin heistä osallistui vain välillisesti punaisten toimintaan tai kuten Sylvi-Kyllikki Kilpi asian ilmaisi, kumpikaan heistä "ei joutunut punaisten puuhiin".

Naisliiton varat oli siirretty turvaan sodan jaloista kolmen liittotoimikunnan jäsenen huostaan ja ne olivat teillä tietymättömillä. Fagerholmin myötävaikutuksella Sörnäisten työväenyhdistyksen naisosasto lainasi liitolle 200 markkaa, jonka turvin toiminta pystyttiin jälleen käynnistämään. Ensimmäisessä kokouksessa valittiin uusi liittotoimikunta, johon tuli puheenjohtajaksi Elin Fagerholm Sörnäisten osastosta, sihteeriksi ja rahastonhoitajaksi Suomen Sosialidemokraatin toimittaja Lyyli Eronen (hän avioitui myöhemmin osuuskauppamies Uuno Takin kanssa) ja muiksi jäseniksi Hilda Öberg, Mimmi Kanervo, Olga Leinonen, Fiina Pietikäinen ja Anni Kärki. ${ }^{1}$

Naisliittotoimikunta antoi ensi töikseen osastoilleen kehotuksen käynnistää toiminta ja liiton kiertokirjeet alkoivat ilmestyä jälleen kesäkuusta 1919 lähtien. Tuolloin toiminnan todettiin olevan vielä heikolla pohjalla ja osastoja kannustettiin valmistautumaan

1 Kertomus Sos.dem. Naisliiton toiminnasta 14.12.1918-30.9.1919. Alustuksia ja ehdotuksia Suomen Sos.dem. Naisliiton IX edustajakokoukselle 5.-7.12.1919, 6-9. 


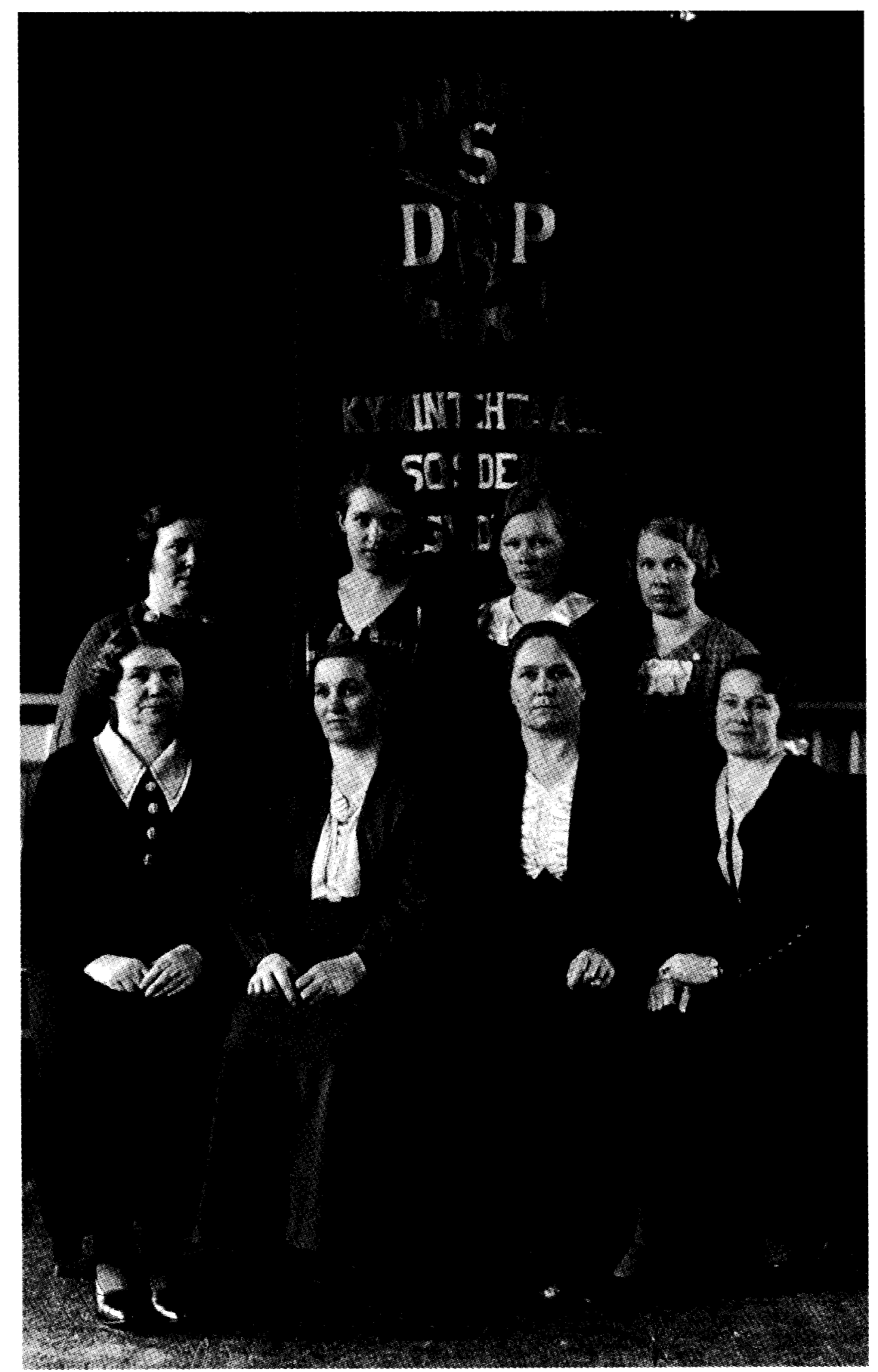

Kymintehtaan Sosialidemokraattisen Naisosaston johtokunta 1930luvulla. Kuva: Työväen Arkisto. 
tulevaa edustajakokousta varten. Ensimmäisen suunnitelman mukaan sen piti olla lokakuussa 1919, mutta kokous siirrettiin pidettäväksi saman vuoden joulukuuhun viikkoa ennen puoluekokousta. $^{2}$

Naisosastot, kuten muutkin työväenjärjestöt, kokosivat rivinsä olosuhteisiin nähden nopeasti. Naisliitolle lähetti vuoden 1919 kertomuksensa jo 65 osastoa. Kaiken kaikkiaan naisosastoja oli 81 vuoden 1919 lopussa. Ensimmäisenä koottiin ompeluseurat varojen keräämiseksi. Hyvä esimerkki aktiivisesta osastosta oli Pietarsaaren naisosasto, joka perustettiin uudelleen 13.3.1919. Siihen liittyi 183 jäsentä. Osasto piti vuoden aikana 14 kokousta. Keskustelu- ja lukuiltoja osasto piti kaksi kertaa kuukaudessa. Käsityöseuraa ylläpidettiin kesäsiirtolaa varten. Osastossa oli kerätty tietoja vuoden aikana työttömistä naisista ja pyydetty heille työpaikkoja kaupunginvaltuustolta. Yleisiä ohjelmallisia naisten kokouksia oli järjestetty kaksikin kertaa kuukaudessa. Kokouksissa oli keskusteltu työttömyyden lisäksi turvattomien lasten asemasta, kieltolakirikkomuksista, asuntopulasta, naisten järjestäytymisestä ja itsekasvatuksesta. Avustuksia osasto jakoi vuoden 1919 aikana 450 markan arvosta. ${ }^{3}$

Työväenjärjestöjen elpymiseen vaikutti osaltaan Sosialidemokraattisen puolueen puheenjohtajan Väinö Tannerin vierailu elokuussa 1918 Ruotsissa ja Tanskassa, mikä oli omiaan kiinnittämään ulkomaiden huomiota Suomeen ja sitä kautta painostamaan poliittisten toimintavapauksien myöntämistä sosiaalidemokraateille: vankileirien järkyttävät kuvaukset eivät olleet eduksi Suomen ulkopoliittisten suhteiden luomisessa. Myös kunnallisen demokratian mahdollistaminen asetti paineita yhteiskuntaelämän normalisoimiselle. Työväenjärjestöjen nopeaan rivien kokoamiseen vaikutti osaltaan myös "vallankumouksellinen henki", joka leimasi vuotta 1919 niin Suomessa kuin muuallakin Euroopassa. ${ }^{4}$

Pietarsaaren työväenyhdistyksen naisosasto oli hyvä esimerkki ripeästi toimintansa käynnistäneestä osastosta, jonka kaikki entiset toimintamuodot otettiin käyttöön jo vuoden 1919 alussa. Myös heikoimmin toimintansa aloittaneet osastot - kuten Talikkalan naisosasto - aktivoituivat vuoden 1919 lopulla puoluekokouksen

2 Sos.dem. naisliiton kiertokirje 12.6.1919. TA.

3 Pietarsaaren naisosaston toimintakertomus 1919. Sos.dem. Naisliiton arkisto D 4. TA; Vuoden 1919 rahasumma $450 \mathrm{mk}$ vastaa vuoden 1995 rahana $811,35 \mathrm{mk}$

4 Ks. Soikkanen 1975, s. 309-337; Ahti 1987, s. 28. 
ja naisliiton edustajakokouksen lähetessä: "Toiminnan aloittaminen pitkän ja pakollisen seisautuksen jälkeen on ollut enempi laimeaa kun kärsittiin niin kova isku...niin ripeys on keskuudestamme pois. Nyt on toimintamme vilkastunut, olemme saaneet varojakin ja yleinen mielipide on päässyt vilkastumaan". ${ }^{5}$

Naisliiton järjestötoiminta palautui jouluun 1919 mennessä kansalaissotaa edeltäviin uomiinsa. Liitto palkkasi kiertäväksi luennoitsijakseen Mimmi Kanervon ja päätti kansainvälisen naistenpäivän vietosta maaliskuun ensimmäisenä sunnuntaina. ${ }^{6}$ Jäseniä liitolla oli vuoden 1919 lopussa 3253 eli noin puolet vuoden 1917 huippuluvuista (jäsenmäärien kehityksestä ks. liite 2).

\section{Hajaannuksen merkit 1919}

Selvät merkit sosialidemokraattisen naisliiton suuntariidoista olivat nähtävissä liiton yhdeksännessä edustajakokouksessa joulukuun alussa 1919. Kokouksessa nousi esille neljä keskeistä teemaa, jotka jakoivat naisedustajien mielipiteitä. Vuoden 1919 vallankumouksellinen henki oli saanut valtoihinsa osan naisistakin. Käytetyistä puheenvuoroista näkyy, että kannat olivat muotoutuneet jo aiemmin, syksyn 1917 ja kansalaissodan jälkiselvittelyn pohjalta. Kiivainta sananvaihtoa saivat aikaan keskustelu sodan oikeutuksesta, päiväkotikysymys, suhde Sosialidemokraattiseen puolueeseen ja naisten erillisen piiritoiminnan virittäminen.

\section{Oikeutettu sota?}

Ei ollut sattuma, että kysymys sodasta nostatti naisten tunteita. Ensimmäisen maailmansodan ja kapinan kokemusten lisäksi ItäKarjalan heimosodat saivat monet kavahtamaan aseellisia yhteenottoja ja korostamaan naisliikkeen toiminnassa perinteistä rauhanliikettä. Kokouksen enemmistö tuomitsikin periaatteessa sodan mielettömyyden ja aseistautumisen. Varsinaiseksi kiistakysymykseksi nousi kuitenkin se, oliko tuomittava kaikki sodat vaiko vain niin sanotut imperialistiset sodat. Oululainen Ellen Mäkelin, Yrjö

5 Talikkalan naisosaston toimintakertomus 1919. Sos.dem. Naisliiton arkisto D 4. TA.
6 Sos.dem. Naisliiton kiertokirje 21.12.1919. TA. 


\section{$(1)=$ huolehti sita, etta mie- hensä on henkivakuutettu \\ KANSA-yhtiössä.}

KANSAN maksut ovat halvimmet. KANSAN thdot ovat edullisinmat. Tapoturmaisen kuolemen sattuessa. suorit ta a henkivekutussumman kaksinkertaisena ainostaan KANSA yht:ö.
Kansa-yhtiön vakuutusmainos Sosialidemokraattisen naisliiton lehdessä Toverittaressa nro 9/1926. Kuva: Työväen Arkisto.

Mäkelinin vaimo, nousi jyrkimmän linjan johtohenkilöksi. Hänen mukaansa naisliitolla oli aiheeseen vain yksi kanta ja sen mukaan oltiin periaatteessa sotia vastaan, mutta "emme voi tehdä päätöstä, että vastustamme sotaa sen kaikissa muodoissa, sillä jos porvaristo hyökkää meitä vastaan, emme voi vastustamatta ottaa lyöntejä vastaan".

Sotaa kaikissa sen muodoissa vastustivat helsinkiläiset Miina Sillanpää ja Taavi Tainion vaimo Olga sekä turkulainen Aino Lehtokoski ja kahdeksan muuta edustajaa. Heitä voidaan pitää vanhan naisliiton pasifistisen politiikan jatkajina. Imperialistiset sodat tuomitsevia oli enemmistö, kaikkiaan 35 edustajaa 46:sta hyväksyi puolustussodan. Vähemmistöön jäivät sellaiset kannanotot kuin vuoksenniskalaisen Lovisa Tiaisen puheenvuoro: "Parlamentaristinen toiminta on meidän kiväärimme. Punainen jäsenkirja, järjestäytyminen ja yhteenliittyminen ovat meidän parhaat aseemme ja niillä me voitamme”. Olga Tainio ja Aino Lehtokoski jättivät kokouksen päätöslauselmaan kirjallisen vastalauseensa, jossa he ilmoittivat vastustavansa kaikkia sotia. ${ }^{7}$ 
Toinen rintamalinjoja jakanut kysymys oli suhtautuminen lasten päiväkoteihin ja yhteiskunnan huolenpitoon äideistä ja lapsista. Keskustelun pohjana oli helsinkiläisen Martta Salmelan alustus. Salmela loi katsauksen kansalaissodan jälkeiseen tilanteeseen, jossa äidit joutuvat jättämään lapsensa päiväkausiksi ilman hoitoa ja ilman säännöllistä ruokailua. Tätä ilmeistä epäkohtaa oli lievennettävä Salmelan mukaan perustamalla lastentarhoja, seimiä ja päiväkoteja, joita ylläpitäisivät valtio ja kunnat hyväntekeväisyysjärjestöjen sijasta. Yksityiset päiväkodit istuttivat lapsiin heidän "omaa luokkaansa vierovia aatteita". Päiväkotikysymys oli Salmelalle sekä taloudellinen että ideologinen kysymys.

Käydyissä keskusteluissa nousi jälleen vastakkain Ellen Mäkelinin sekä Miina Sillanpään ja Hilda Seppälän kannat. Mäkelin vastusti päiväkotien perustamista: "Siinä meillä on periaatteellinen ristiriita. Sellaisten pikkuparannusten kautta emme saavuta päämääräämme, vaan tulee yhteiskuntaolojen muodostua sellaiseksi, että jokaisella äidillä on tilaisuus itse kasvattaa ja hoitaa lapsensa”. Sillanpää puolestaan puolusti päiväkoteja pitäen niitä erityisen tarpeellisina sodan jälkeisessä vaikeassa tilanteessa: "Paikkaustyötä on tehtävä silloin kun hetken tarve sitä vaatii ja tällä kertaa sillä voidaan jonkun verran lieventää ympärillämme olevia kärsimyksiä”.

Vanhan naisliiton kanta päiväkotikysymykseen oli ollut selkeä: jo vuonna 1905 liitossa oli pohdittu kysymystä ja päädytty puoltamaan päiväkotitoimintaa. Vuoden 1919 kokouksessa Hilda Seppälä hyökkäsikin kipakasti jyrkempää linjaa vastaan sen omin argumentein: "Sillä aikaa kun odotamme nykyisen yhteiskunnan romahtavan ennättää moni kuolla nälkään ja kurjuuteen”. Kokouksessa käytettyjen puheenvuorojen sävy oli kuitenkin sovitteleva: vastustettiin päiväkoteja periaatteessa, mutta pidettiin niitä kuitenkin tarpeellisina: "Äideille on annettava niin suuri avustus, että he voivat itse hoitaa ja kasvattaa lapsensa". Jyrkempään siipeen lukeutunut Mimmi Kanervo piti päiväkoteja sosialidemokratian irvikuvina eikä suinkaan naisten periaatteiden mukaisina. Ellen Mäkelin ja Fiina Pietikäinen puolestaan korostivat, että yhteiskuntaan tuli saada sellainen tilanne, ettei äitien tarvitsisi käydä töissä ko- 
din ulkopuolella. Tämähän oli naisliiton vahva periaate jo vuosisadan alusta. ${ }^{8}$

Kielteinen suhtautuminen äitien osallistumiseen palkkatyöhön ja ylipäätään naisten roolin määrittäminen oli kuitenkin alkanut saada rinnalleen uudenlaisen näkemyksen. Naisliiton teoreetikko Hilja Pärssinen näki naisten palkkatyöläisyyden koko naisliikkeen peruskysymyksenä. Hän toi asian esiin muun muassa vuonna 1917. Pärssisen mukaan sosiaalidemokraattisen naisliikkeen ei pitäisi sitoa naista kotiin, vaan antaa hänelle mahdollisuus käydä töissä kodin ulkopuolella. Koska liike ei voinut antaa tai ottaa työpaikkoja, kyse oli periaatteellisesta asennoitumisesta naisten vapauksien ja toimintavaihtoehtojen lisäämiseen.

Kuten vuoden 1919 kokous osoitti, naisliiton kansalaissodan jälkeinen enemmistö oli konservatiivisempi tässä suhteessa: naisten paikka oli kotona. Naisten valinnanvapautta korostanut Pärssinen itse istui vuoden 1919 aikana telkien takana Hämeenlinnan naisvankilassa. Paitsi valinnanvapautta, Pärssinen oli edellisessä edustajakokouksessa esittänyt myös konkreettisia toimia naisten vapauttamiseksi palkkatyöhön. Pääpaino oli laitettava juuri lastenhoidon järjestämiseen ja naisten palkkauksen parantamiseen miesten palkkauksen tasolle. ${ }^{9}$ Naisten vapauttaminen palkkatyöhön jäi kuitenkin itämään nuorempien naisten mieliin ja asia nousi esille 1930luvun keskusteluissa, kuten tuonnempana näemme.

\section{Köyhien puolue vai ei?}

Kolmas dramaattista 1919 edustajakokousta jakanut aihe oli työväenjärjestöjen suuntariidat ja suhtautuminen sosialidemokraattiseen puolueeseen. Asiasta syntyi kiivas sananvaihto jo siitäkin syystä, että Pietarsaaren naisosaston tekemä alustus oli jätetty pois käsiteltävien asioiden listalta. Maltillisiin kuulunut liiton sihteeri Hilda Seppälä luki sen edustajille ääneen. Alustus sisälsi voimakkaan kritiikin puolueen sanomalehdistöä ja eduskuntaryhmää vastaan. Nämä tahot olivat himmentäneet alustuksen mukaan luokka-

8 Sos.dem. Naisliiton IX edustajakokouksen 5.-7.12.1919 pöytäkirja, s. 20-24 ja liiteosa s. 41-43.

9 Suomen Sosialidemokratisen Naisliiton kahdeksannen edustajakokouksen 4.-6.10.1917 pöytäkirja, s. 22. 
käsitteitä siinä määrin, että "luokkatietoinen ryysyköyhälistö sen on tuntenut loukkaukseksi itseään kohtaan sekä niitä tovereita kohtaan solvaukseksi, jotka kaikkensa olivat uhranneet köyhälistön ja tulevan sukupolven hyväksi". Tämän onnettoman tilanteen vuoksi työläisnaisten tehtävä oli valvoa, että sosialidemokraattinen puolue pysyi köyhien omana "puhtaana" puolueena.

Tuohtuneet pietarsaarelaiset syyttivät liittotoimikunnan jäseniä pelkuruudesta, minkä nämä yksimielisesti kiistivät. Sihteeri Hilda Seppälä totesi alustuksen olleen liian suppean niinkin laajakantoiselle kysymykselle. Radikaalimpi Elin Fagerholm puolestaan kielsi pelkuruuden, mutta muutoin yhtyi kritiikkiin. Edustaja Agda Vatanen puolestaan esitti suoraan, että mikäli puolue liittyisi maltilliseen toiseen internationaaliin, olisi naisten liityttävä kolmanteen. Tässä Vatanen osui kiistakysymyksen ytimeen.

Internationaalikiista oli kansainvälistäkin työväenliikettä jakanut keskeinen aihe. Maltilliset kannattivat sosiaalidemokraattien pysymistä toisessa internationaalissa, sen sijaan vasemmistosiipi ja kommunistit vaativat liittymistä kolmanteen eli kommunistiseen internationaaliin. Naisliiton 1919 kokouksessa molemmat näkemykset saivat kannatusta. Hilda Seppälä palautti kiihtyneitä kokousedustajia maan pinnalle toteamalla, ettei naisten päätöksellä ollut mitään vaikutusta tulevassa puoluekokouksessa, missä asia päätettäisiin. Naisten edustaja ei ollut edes äänioikeutettu tulevassa puoluekokouksessa.

Miina Sillanpää puolestaan esitti, että asia jätettäisiin puoluekokouksen päätettäväksi. Ajan hengestä kertoo kuitenkin se, että radikaali kanta sai hienoisen enemmistön: naisliiton oli vaadittava puoluetta pysymään jyrkän marxilaisen luokkataistelun kannalla, kuitenkin niin, että naisliitto säilytti suhteensa sosialidemokraattiseen puolueeseen ennallaan. ${ }^{10}$

\section{Erilliset naispiirit?}

Neljäs kiistaa aiheuttanut kysymys oli naisten piiritoimikuntien uudelleen käynnistäminen. Nyt ideologinen maltillinen ja radikaali vastakkainasettelu ei enää toiminutkaan kuten aiemmissa kiista- 
kysymyksissä, vaan kuvaan tulivat muut perustelut. Piiritoimikuntia vastustivat muun muassa pienet osastot korotettavien jäsenmaksujen ja vähäisten voimien jakamisen pelossa.

Asian taustalla oli myös periaatteellinen ero suhtautumisessa naisten erillistoimintaan paikallistasolla. Esimerkiksi helsinkiläinen Olga Tainio esitti naisten siirtymistä yhteisiin piiritoimikuntiin miesten kanssa. Hänen mukaansa naisten eristäminen omiin piireihin ei tuottanut hyvää lopputulosta. Tähän vastattiin että, “...tunnettuahan on, että yhteisissä kokouksissa miehet syrjäyttävät naiset ja tunnettuahan on myös se, että naiset puhujina voivat vaikuttaa enemmän naisiin kuin miehiin". Piiritoimikuntia puoltaneet suuret naisosastot voittivat kiistan ja naispiiritoimikunnat, jotka oli lakkautettu vuonna 1909 päätettiin jälleen käynnistää.

Naispiirikiistelyn taustalla oli kysymys vallankäytöstä naisliiton sisällä: oliko kaikki valta keskusjohdolla Helsingissä vai hajautettiinko valtaa naispiireille. Vuoden 1919 kiihkeä poliittinen tilanne johti siihen, että naispiirit nähtiin taas tarpeellisiksi. Alueellista ristivetoa oli toki ollut jo aiemminkin liiton sisällä. Esimerkiksi oululainen Ellen Mäkelin oli jo vuoden 1917 kokouksessa vaatinut päätösvallan siirtämistä enemmän osastoille. "Paikallisten toimikuntien ja osastojen tehtäväksi on jätettävä puhetilaisuuksien järjestely ja lopullinen määrääminen”. Keskustelusta näkyi läpi myös naisten huoli omista vaikutusmahdollisuuksistaan suhteessa miehiin: naisilla ei ollut tarpeeksi valtaa miehisissä piiritoimikunnissa, joten he valitsivat toisen tien. ${ }^{11}$

\section{Radikaalit ja maltilliset puoluekokouksessa 1919}

Naisliiton vuoden 1919 edustajakokous pidettiin kaiken kaikkiaan poliittisesti jännittyneessä ilmapiirissä. Helsinkiin oli saapunut jo varsinaisia puoluekokousedustajiakin ja keskustelut kävivät vilkkaina kahviloissa ja kokouksissa. Jos naisliiton kokouksessa radikaalimpi siipi sai hienoisen enemmistön puheenvuoroissa, oli naisliiton uudessa liittotoimikunnassa kuitenkin maltillisten enemmistö (neljä maltillista, kolme radikaalia) toisin kuin useimmissa historiikeissa on esitetty.

11 Sos.dem. Naisliiton IX edustajakokouksen 5.-7.12.1919 pöytäkirja, s. 45-49; Suomen Sosialidemokraattisen Naisliiton kahdeksannen edustajakokouksen 4.-6.10.1917 pöytăkirja, s. 10 . 


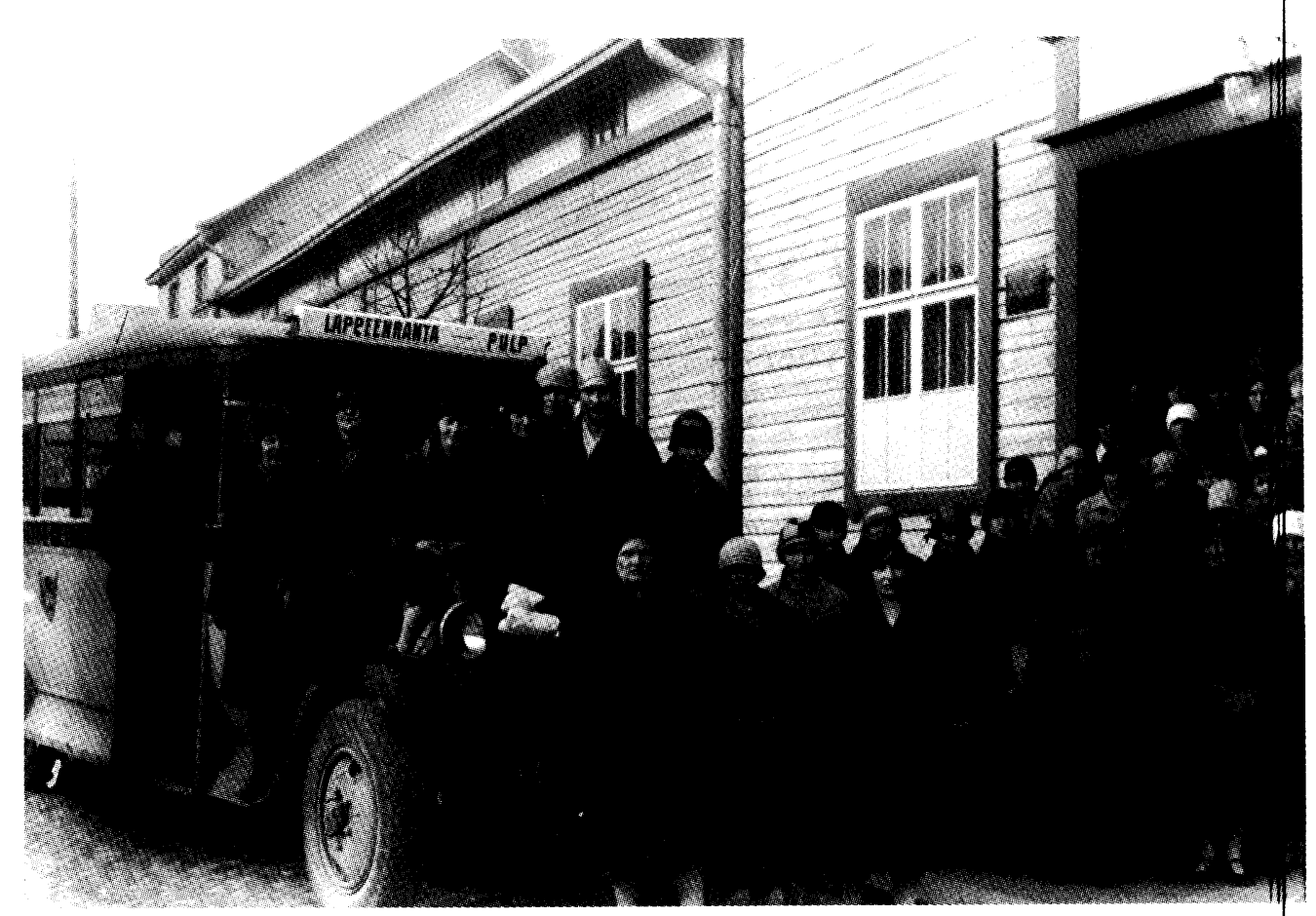

Lappeenrannan Sosialidemokraattisen Naisyhdistyksen väki huviretkellä vuonna 1927. Kuva: Työväen Arkisto.

Maltillisuus näkyi myös samaan aikaan naisten edustajakokouksen kanssa pidetyssä puoluekokouksessa. Kaikkiaan sosialidemokraattisen puolueen vuoden 1919 kokouksessa oli edustajina 25 naista (15\%), joista $17(68 \%)$ edusti maltillista siipeä.

Naisliiton varsinainen edustaja puoluekokouksessa oli radikaaleihin lukeutunut Mimmi Kanervo, joka ei kuitenkaan käyttänyt yhtään puheenvuoroa. Liput liehuen kokouksessa esiintyi muun muassa helsinkiläinen Ida Kantanen, joka julistautui "rehelliseksi luokkataistelijaksi ja kommunistiksi". Kaiken kaikkiaan puoluekokouksessa maltillisten ja radikaalien voimasuhteet jäivät $2 / 3$ maltillisten hyväksi. Tämä näkyi myös henkilövalinnoissa. Puheenjohtajaksi valittiin edelleen Väinö Tanner ja sihteeriksi Taavi Tainio. Naisten asemaan puolueen johdossa kokous ei vaikuttanut: johtoryhmään ei valittu yhtään naista. Ainoastaan maltillinen Hilda Seppälä tuli valituksi varajäseneksi. ${ }^{12}$

12 Sos.dem. puolueen 12. edustajakokouksen pöytäkirja 8.-16.12.1919, s. 235-236: Soikkanen 1975 , s. $365-371$. 
Naisliittolaisten linjanvalintoihin vuoden 1919 suuntakiistoissa vaikuttivat monet tekijät: keskeisimpiä selittäjiä lienevät kiinnittyminen ammattiyhdistys- ja osuustoimintaliikkeeseen sekä alueelliset tekijät. Itäisistä ja pohjoisista piireistä tulleet sekä tehdaspaikkakunnilta saapuneet ja ammattiyhdistystoiminnassa mukana olleet naisedustajat olivat suhteellisesti ottaen radikaalimpia kuin muut. Muun muassa radikaalin siiven valinneet Aura Kiiskinen, Sandra Lehtinen, Mimmi Kanervo, Fiina Pietikäinen, Paula Saari ja Ida Kantanen olivat toimineet nimenomaan ammattiosastoissa. Sen sijaan maltillisemman suunnan edustajat olivat aktiivisia poliittisissa puoluejärjestöissä.

Toiminta osuuskauppaliikkeessä näyttää selittävän jakoa. Maltilliset Hilda Seppälä, Anni Huotari, Lyyli Eronen ja Miina Sillanpää olivat osuustoiminta-aktiiveja. Niin ikään maltillisen suunnan valinneet naisliittolaiset Ida Aalle-Teljo, Ida Wihuri ja Fanny Ahlfors olivat osuustoimintanaisia. Osuustoimintatyössä naiset saattoivat olla paljonkin tekemisissä porvarillisten naisten kanssa. Näin muun muassa Miina Sillanpää, jolla oli lämpimät välit Hedvig Gebhardin kanssa. ${ }^{13}$

Sen sijaan puoluekokouksessa mukana olleiden naisten ikä ei selitä suuntautumista: sekä maltillisten että radikaalien keski-ikä oli 38 vuotta ja enemmistö naisista oli naimisissa: aviopuolison poliittisella suuntautumisella näyttää olleenkin vaikutusta suunnan valinnassa. Esimerkiksi Yrjö Mäkelinin, Anton Huotarin ja Tahvo Pietikäisen vaimot olivat samoilla linjoilla kuin he itse. Toimiminen työväenjärjestöissä ei sekään paljasta radikalisoitumista: molemmissa ryhmittymissä oli mukana sekä vanhoja "konkareita" että vähän aikaa mukana olleita. Naisedustajien ammattijakauma oli niinikään homogeeninen: entisiä ompelijoita ja palvelijoita, puolueen puhujia ja järjestäjiä. Ainoa ylioppilas 25:n naisen joukossa oli maltillisten Lyyli Eronen.

Puoluekokouksessa mukana olleiden naisten kansalaissodan aikainen kokemustausta oli myös samansuuntainen: lyhytaikainen vankeus tai passiivisuus sodan aikana. Radikaali Ellen Mäkelin ja maltillinen Anni Huotari olivat istuneet vankilassa, missä heidän puolisonsa edelleen istuivat. ${ }^{14}$

13 Lähteenmäki 1990, s. 35-41; Hedvig Gebhardista ks. Kaartinen 1997, s. 177-192.

14 Ks. tarkemmin Lähteenmäki 1990, s. 35-41. 
Naisliitossa edustajakokouksen ja puoluekokouksen jälkeinen tilanne oli jännittynyt. Kumpikin ryhmittymä pyrki varmistamaan asemiaan jo selkeästi näkyvän hajaannuksen edessä. Valtataistelua käytiin liiton johdossa vielä koko vuoden 1920 ajan. Huhtikuussa naisliitto lähetti osastoilleen poliittista tilannetta valaisseen kirjeen. Koska puoluekokouksessa vähemmistöön joutuneet vasemmistolaiset olivat alkaneet aktivoitua oman puolueen perustamiseksi, katsoi naisliiton johto aiheelliseksi tiedottaa asiasta maakuntiin.

Yhdistyksille tehtiin tiettäväksi, että myös naisliiton johdossa oli vasemmistosiiven edustajia (Mimmi Kanervo, Fiina Pietikäinen ja Elin Fagerholm), jotka halusivat tietää, oliko liitto edelleen sosiaalidemokraattinen vai ei. Mikäli oli, eivät uuden suunnan edustajat halunneet enää olla mukana sen toiminnassa. Tämän takia esitettiin pidettäväksi jäsenäänestys ja mikäli enemmistö olisi uuden suunnan kannalla, olisi sosiaalidemokraattien (Hilda Seppälä, Olga Tainio, Olga Leinonen ja Hilda Öberg) poistuttava liiton hallinnosta.

Pidetyn liittoäänestyksen tulos oli pettymys uuden suunnan edustajille. Asiaa käsitteli kaikkiaan 66 naisyhdistystä, joista 36 äänesti sosiaalidemokraatteja, 19 vasemmistosiipeä ja 11 ei päätösvallattomina tai muista syistä antanut selkeää vastausta. ${ }^{15}$ Kenttä oli selvästi maltillisen etenemisen linjoilla.

Kun liittoäänestyksen tulos hyväksyttiin naisliiton 12.7.1920 kokouksessa, eivät vasemmistosiiven edustajat jättäneetkään lupauksesta huolimatta paikkojaan, vaan he alkoivat voittaa aikaa. He esittivät liiton toiminnan säilyttämistä ennallaan. Myöhemmin he selittivät tappiollista äänestystulosta sillä, että äänestys pidettiin epäsuotuisaan aikaan: "Osastot eivät olleet vielä kypsyneet kylliksi asiaa ratkaisemaan”. Syntipukiksi nostettiin naisliiton pitkäaikainen sihteeri Hilda Seppälä, jota syytettiin sosialidemokratian agiteeraamisesta. Hilda Seppälän mustamaalaamiseen sosiaalidemokraatit vastasivat, että liiton ainoa kiertävä puhuja oli vasemmistosiiven Mimmi Kanervo. ${ }^{16}$

15 Sos.dem. Naisliiton kiertokirje 17.7.1920. TA.

16 Sos.dem. Naisliiton kiertokirje syyskuussa 1920. TA; Suomen Sosialidemokraatti 4.1.1921, s. 6. 
Koska vasemmistosiiven toimet naisliiton valtaamiseksi eivät olleet onnistuneet, puuttui vasemmistolainen lehdistö asiaan: Suomen Työmiehen palstoilla naisliiton vasemmistolaisia syytettiin toimettomuudesta ja yhteistyöstä sosiaalidemokraattien kanssa: "...sosialististen naisosastojen on erottava sosialidemokraattisesta naisliitosta". Tämän kirjoituksen jälkeen erosivat virallisestikin naisliitosta Hyvinkään (Lydia Kallio), Sörnäisten (Elin Fagerholm), Kuopion (Emmi Mäkelin) ja Oulun (Ellen Mäkelin) naisyhdistykset: liitto oli niiden mukaan hylättävä, koska se oli sosiaalidemokraattinen.

Vanhan naisliiton repeäminen kahtia tapahtui tosiasiallisesti 21.12.1920. Vasemmistosiiven pelaaminen ajalla onnistui sikäli, että tässä kriittisessä tilanteessa maltillinen Olga Leinonen jätti yllättäen paikkansa, jolloin vasemmistosiipi sai enemmistön. Radikaalit peruivat omat eronsa ja sen sijaan erottivat loputkin sosiaalidemokraatit liittohallinnosta. Vaikka miehet olivat kehottaneet vasemmistosiiven naisia eroamaan liitostaan, nämä eivät tähän taipuneet, vaan pysyivät loppuun asti kannassaan: "Me emme jätä liittoa sosialidemokraateille, vaan muutamme sen sosialistiseksi". ${ }^{17}$

Helsinkiläinen Edla Peltola paljastaa kuvaavasti vasemmistosiiven taktiikan: "Eroaminen veisi vain turhaan kallista aikaa - valmiissa järjestössä toiminta saatettaisiin nopeammin käyntiin... Emmehän me Helsingin sosialidemokraattisessa naisosastossakaan lähteneet pois, vaan valtasimme sen, muutimme mielemme ja noskeraukat saivat ruveta rimpuilemaan oman sakin yhdistämiseksi. Se on johdonmukaista taktiikkaa". ${ }^{18}$

Vasemmistosiiven naiset eivät kuitenkaan saaneet pitää liittoaan: marraskuussa 1920 Suomen Sosialistisen Työväenpuolueen (SSTP:n) puolueneuvosto sinetöi vanhan naisliiton kohtalon: "Erikoisen sosialistisen naisliiton muodostaminen ei ole tarpeen, vaan se voi olla jopa vahingollistakin. Sitä vastoin perustetaan puoluetoimikunnan yhteyteen heti työläisnaisten valistusjaosto, jonka jäsenet valitsee puolueneuvosto. Lähimmät ohjeet jaosto saa puoluetoimikunnalta". ${ }^{19}$

Sosiaalidemokraattiset naiset puolestaan alkoivat nopeasti rakentaa omaa keskusjärjestöään uudelleen.

17 Suomen Sosialidemokraatti 4.1.1921, s. 6; Suomen Työmies 20.1.1921, s. 4.

18 Suomen Työmies 12.1.1921, s. 5.

19 SSTP:n puolueneuvoston pöytäkirja 27-28.12.1920. TA. 


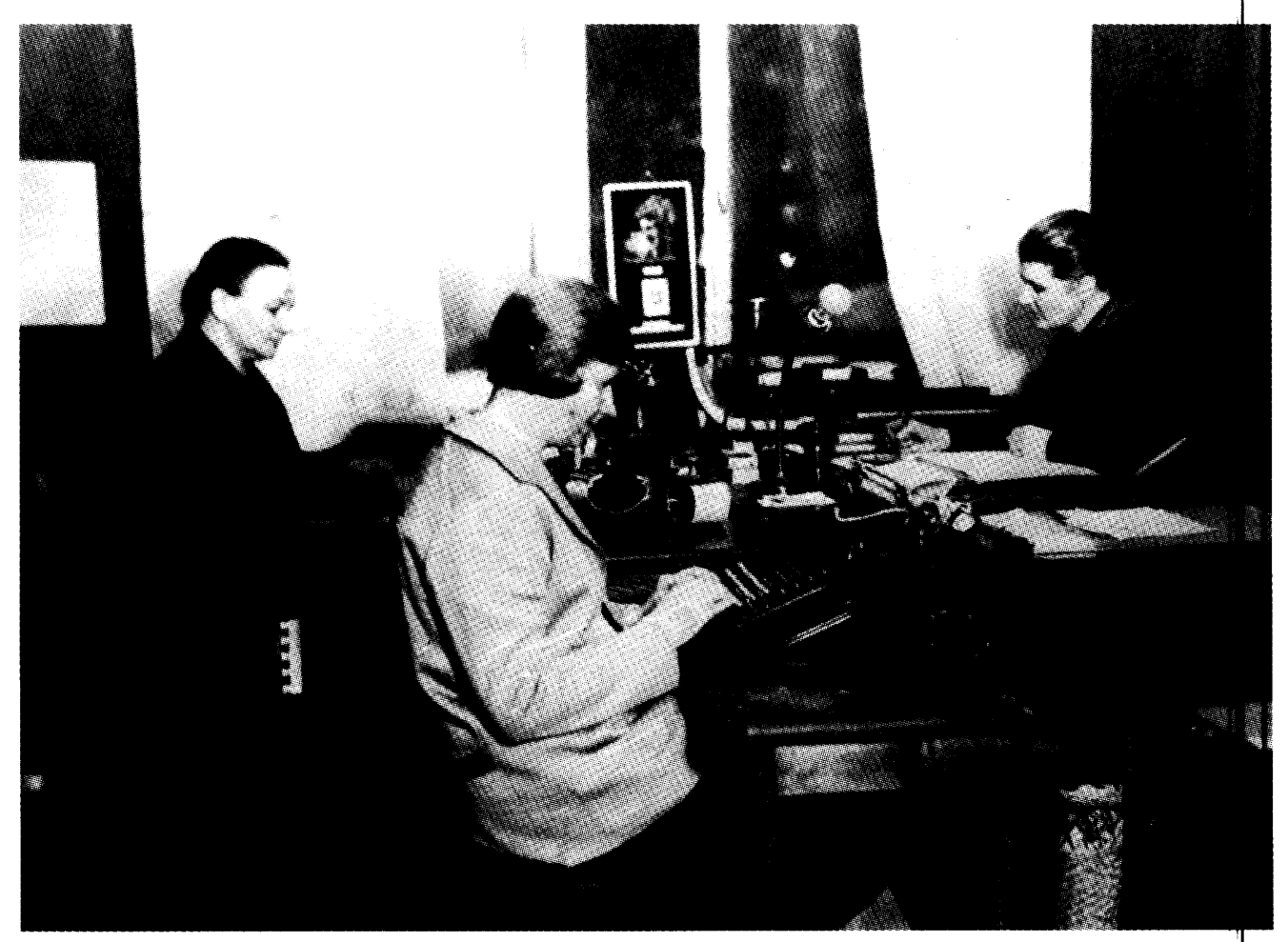

Sosialidemokraattisen naisliiton toimiston henkilökunta 1920-luvun lopussa. Wasemmalta Hilda Seppälä, Tyyne Salmela ja Elsa Metsäranta. Kuva: Työväen Arkisto.

\section{Hildan ja Miinan liitto}

Sosialidemokraattista naisliittoa ryhtyi luotsaamaan kaksi tarmokasta naista, joista Miina Sillanpää oli näkyvämpi. Toinen, aikaisen kuolemansa ja vaatimattoman luonteensa vuoksi varjoon jäänyt johtonainen ja Sillanpään tukihenkilö oli Hilda Seppälä, jonka järjestelmällinen ote näkyy selattaessa naisliiton 1920-luvun aineistoa.

Kansalaissodan päättyessä 39-vuotiasta Hilda Seppälää voisi taustansa puolesta sanoa tyypilliseksi sotienvälisen kauden työläisnaisvaikuttajaksi. Hän oli kotoisin varattomista oloista, keskisuomalaisen kyläräätälin yhdeksänhenkisestä perheestä. Vanhimpana lapsena Hilda joutui 11-vuotiaana lähtemään isänsä mukana kiertämään talosta taloon työn perässä. Näillä kiertomatkoilla Hilda oppi ompelijan ammatin, mutta samalla katkerasti kokemaan sosiaalisen eriarvoisuuden. Osattomuuden kokemus sai hänet liittymään mukaan työväen järjestötoimintaan. 
Kuten monet muutkin työläisnaisaktiivit, myös Hilda elätti itsensä muutettuaan Helsinkiin vuonna 1899 palvelijattarena ja ompelijana. Seuraavana vuonna hän liittyi Helsingin ompelijatarosastoon. Vuonna 1904 Hilda avioitui työväentalolla tapaamansa suutari Hannes Seppälän kanssa ja perheeseen syntyi kaksi tytärtä. Kansalaissodan aikana Hilda menetti nuoremman lapsensa ja sisarensa, itse hän joutui olemaan vankileirillä neljä kuukautta, vaikkei osallistunutkaan sotatoimiin tai punaisten hallintoon.

Kansalaissodan jälkeen Hilda Seppälä tuli aktiivisemmin mukaan naisliiton toimistoon, sitä aiemmin hän oli ollut leimallisesti yhdistystason aktiivi. Hänestä tulikin oivallinen työntekijä. Hänellä oli työläistausta, yhdistystoiminnan rutiinit ja pieni perhe, joten hän saattoi omistautua järjestötyöhön. Lisäksi hän oli vakavarainen ja edusti puolueen oikeaa siipeä. Seppälän luonteenpiirteet herättivät myös luottamusta, häntä on nimitetty "hyödylliseksi kansalaiseksi" viitaten juuri hänen velvollisuudentuntoonsa, tarmokkuuteensa ja pikkutarkkuuteensa. Hildasta tulikin näillä ominaisuuksilla Miina Sillanpään vahva taustatuki.

Seppälän rooli naisliiton sihteerinä ja organisaattorina korostui etenkin 1920-luvun lopulla, jolloin naisliitossa lähdettiin luotsaamaan kotitalouspoliittista suuntausta kentälle ja parlamenttiin. Itse asiassa juuri Hilda Seppälä teki kotitalousohjelman läpiviennin kannalta merkittävän aloitteen vuonna 1924 eduskunnassa eli valiokunta-aloitteen kodinhoitokursseja varten. Seppälä esitti myös muita tärkeitä ja kauaskantoisia aloitteita, kuten valtionapuhakemukset pienten lasten hoidon järjestämiseksi (1923) ja työläisnaisten kesäsiirtolatyön tukemiseksi (1926).

Myös aikalaiset näkivät naisliiton toimintojen keskittämisen Seppälän käsiin: "Hän ja liitto ovat ovat yksi, yksi sydän ja yksi sielu”, kuten hänen 50-vuotisonnittelussaan vuodelta 1929 kirjoitettiin. Hilda Seppälä oli myös puolueensa luottonainen. Hän oli Sosialidemokraattisen puolueen puoluetoimikunnan jäsen vuosina 1920 ja 1930-32. Seppälä osallistui naisliiton edustajana myös Helsingin kunnallispolitiikkaan ja oli kaupunginvaltuuston jäsen vuosina 1919-22. Muiden naisliiton johtonaisten tapaan hän kuului myös Kulutusosuuskauppojen Keskusliiton johtokuntaan ja Elannon edustajistoon. Eduskuntatyössään Hilda Seppälä osoitti jatkuvuutta. Ei edes lamakausi, jolloin naisten edustus parlamentissa väheni, uhannut hänen valintaansa. Eduskunnassa hän kuului talous- ja valtiovarainvaltiokuntaan. 
Hilda Seppälän äkillinen kuolema maaliskuussa 1932 influenssan jälkitautiin ja siitä aiheutuneeseen verenmyrkytykseen otettiin naisliitossa järkytyksellä vastaan. ${ }^{20}$ Hänen poismenonsa horjutti Miina Sillanpään asemaa. Sillanpää toimi vuodet 1921-32 liiton puheenjohtajana. Nyt hän sai taistella siitä, että tuli valituksi liiton sihteeriksi. Tyyne Leivo (-Larsson) arvosteli suoraan niin iäkkään - Sillanpää oli 66-vuotias - henkilön valitsemista sihteeriksi. Myös Martta Salmela-Järvinen arvosteli valintaa viitaten tulevaisuuteen: "Eihän Sillanpään ikä ja kyky ole rajaton". ${ }^{21}$ Sillanpää luopui sihteerin toimestaan vuonna 1936 Martta Salmela-Järvisen hyväksi.

\section{Ministeri Sillanpää ja viiden Väinön hallitus}

Huolimatta 1930-luvulla saamastaan ankarastakin kritiikistä Miina Sillanpää oli ja on edelleenkin yksi sosiaalidemokraattisen naisliikkeen näkyvimmistä lipunkantajista. Hänen nousunsa torpparin tyttärestä, tehtaalaisesta ja piiasta vuoden 1926 hallituksen toiseksi sosiaaliministeriksi on tehnyt hänestä sosiaalisen nousun ruumiillistuman ja mallinaisen, jonka perässä muilla on nähty olleen helpompaa taivaltaa kohti tasa-arvoisempaa yhteiskuntaa.

Vuoden istunutta Väinö Tannerin vähemmistöhallitusta - johon kuului viisi Väinöä22 - ei yleisesti pidetty kovin tuloksellisena edes omien keskuudessa. Sosialidemokraattisen puolueen puoluehallitus arvosteli hallitusta helmikuussa 1927 siitä, että "hallitus ei ole saanut mitään aikaan" ${ }^{23}$ Naisten kannalta sen toimintaan sisältyi kuitenkin tärkeä aikaansaannos: uuden avioliittolain vauhdittaminen. Lakihan tuli voimaan vuonna 1930. Hallituksen aikana hyväksyttiin myös amnestialaki. Sillanpään ministeriys sisälsi 1920luvun poliittisesti kahtiajakautuneessa ja erittäin herkässä ilmapii-

20 Tiedot Hilda Seppälästä on koottu hyvin pienistä fragmenteista, mikä kertoo hänen vaatimattomuudestaan ja jäämisestään jälkikirjoituksissa varjoon. Lähteitä on käytetty: Hilda Seppälän pieni arkisto Työväen Arkistossa, lehtileikkeitä, eri työväenyhdistysten kertomuksia, Toveritar-lehti 1920-luvulta, E-liikkeen uranuurtajia 1967, Eduskunnan matrikkeli, Sosialidemokraattiset Naiset -matrikkeli 1996.

21 Suomen Sosialidemokraattisen Työläisnaisliiton XIII edustajakokouksen pöytäkirja 28.31.10.1932, s. 26-29.

22 Väinö Tanner pääministerinä, Väinö Voionmaa ulkoministerinä, Wäinö Wuolijoki yleisten töiden ministerinä, Väinö Hupli kauppa- ja teollisuusministerinä sekä Väinö Hakkila oikeusministerinä.

23 Tanner 1966, s. 100. 


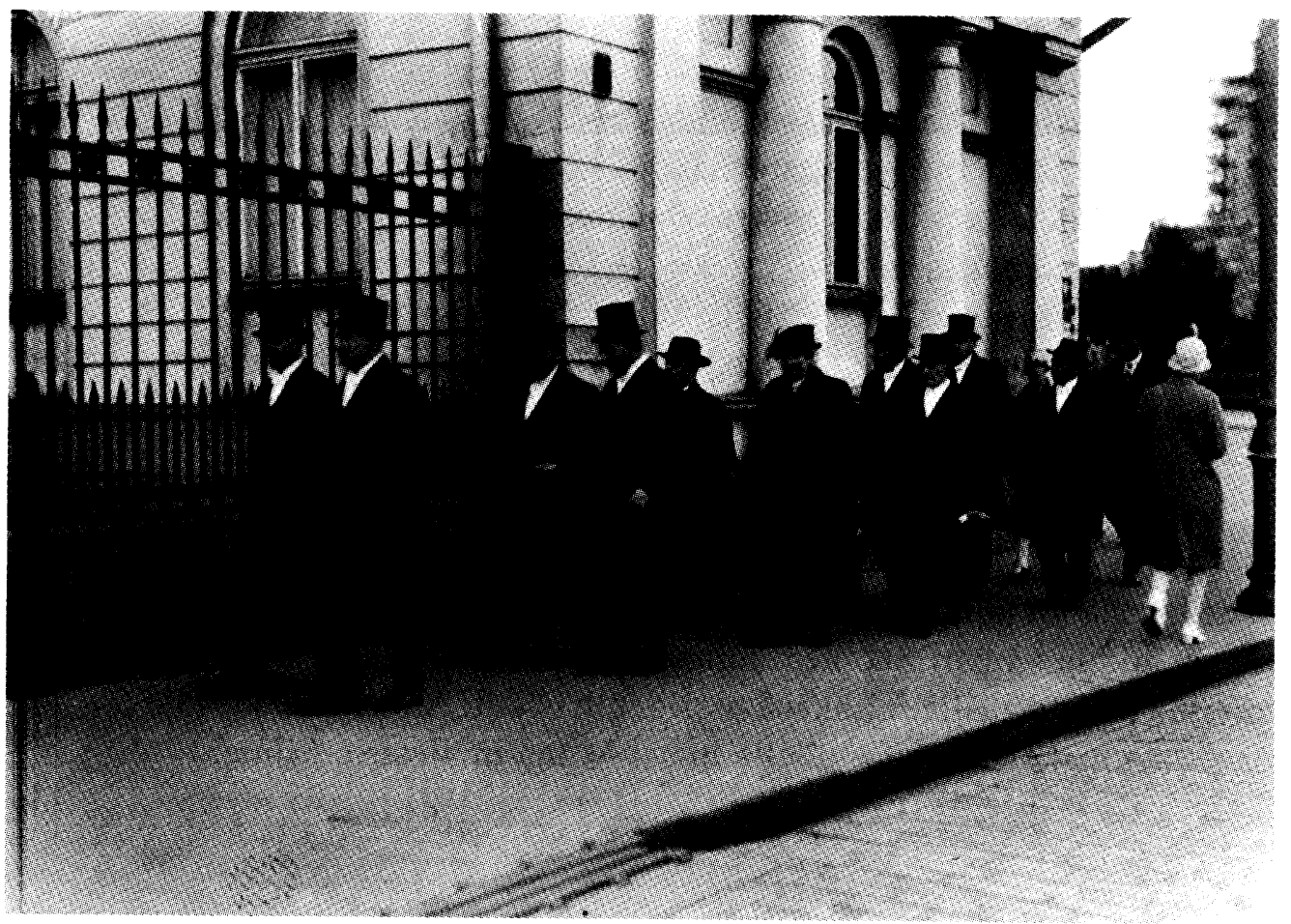

Väinö Tannerin vähemmistöhallitus matkalla presidentti Lauri Kristian Relanderin luo loppuvuodesta 1926. Toinen sosiaaliministeri Miina Sillanpää seurueen keskellä. Kuva: Työväen Arkisto.

rissä lisäksi tärkeän symbolisen kädenojennuksen paitsi sosiaalidemokraateille, myös naisille. 60-vuotiaan "vapaan tyttösen" Miina Sillanpään istuttaminen ministerinpallille oli Väinö Tannerin vaimon Lindan tahto. ${ }^{24}$

Sosialidemokraattiselle naisliitolle tapaus oli vertaansa vailla: olihan Sillanpää liiton puheenjohtaja ja naisten lehden Toverittaren päätoimittaja. Kun tuore ministeri astui eduskuntaan, nousivat kansanedustajatoverit kunnioituksesta seisomaan - paitsi kommunistit. Tapausta voidaan verrata erikoisuudessaan vuoden 1907 ensimmäisen eduskunnan juhlakulkueeseen tai vuoden 2000 ensimmäisen naispuolisen presidentin Tarja Halosen eli kuten saksalaislehdet häntä nimittivät "punaisen Tarjan" valintaan.

Sillanpään nimitys sai aikaan laajan kirjoittelun sekä kotimaisissa että ulkomaisissa lehdissä. Pääosin se oli myönteistä. Sillan- 
pää osoittautui maltilliseksi ja yhteistoimintahaluiseksi, joskin hänen roolinsa hallituksessa oli vähäinen. Pääministeri Tanner kokosi hallitukseen kolme sosiaaliministeriä. Hänen mukaansa hallituksen yksi tärkeimmistä tehtävistä oli sairausvakuutuslain valmistelu, jossa "Johan Helo teki suurimman työn. Sillanpäästä oli tietysti paljon apua siinä". 25

Sitten nuoruusvuosien Sillanpää oli rauhoittunut, nuorempien aatesiskojen mielestä jopa liikaa, kuten 1930-luvun polemiikki naisliiton sisällä osoitti. Sillanpään sovinnollisuus muokkasi kuvaa myös koko sosiaalidemokraattisesta naisliikkeestä "tätiliikkeenä" ja loi pohjaa tulevalle yhteistoiminnalle oikeiston naisten kanssa 1930-luvun lopulla ja sota-aikana.

Sillanpää loi uutta poliittista ministerikulttuuria: hän teki maakuntamatkoja ympäri Suomea, tutustui köyhäintaloihin ja lastenkoteihin paikan päällä. ${ }^{26}$ Ehkäpä presidentti Martti Ahtisaaren idea makuntamatkoista 1990-luvulla nousi Miina-ministerin esimerkistä.

\section{Jälkikuvat}

Miina Sillanpäästä on tehty kolme elämäkertaa ja lukematon määrä artikkeleita. Sillanpään kanonisointi ja jälkikuvan luominen alkoivat hänen vielä eläessään 1940-luvulla. Varhaisin elämäkerta on vuonna 1947 ilmestynyt Oma Mäkikossan Yhteiskunnalle omistettu elämä. Miina Sillanpään elämän ja työn vaiheita. Vuonna 1973 ilmestyi Martta Salmela-Järvisen Miina Sillanpää - Legenda jo eläessään ja vuonna 1989 Irma Sulkusen Naisen kutsumus Miina Sillanpää ja sukupuolten maailmojen erkaantuminen.

Vertaamalla Sillanpään poliittisen huippukauden eli 1920-luvun aineistoja hänestä myöhemmin rakennettuihin jälkikuviin voidaan sekä Mäkikossan jälleenrakennuksen ja kommunisminvastaisen taistelun 1940-luvun ja Sulkusen hyvinvointiyhteiskunnan 1980luvun tutkimuksissa nähdä painotus, joka kertoo ehkä enemmän tutkimusten tekoajasta kuin Sillanpään toiminta-ajasta: kumpaisessakin teoksessa Sillanpää on epäpolitisoitu ja nähty korosteisen yksilönä, liikkeestä irrallisena.

25 Tanner 1966, s. 86.

26 Sillanpään elämänvaiheista ks. Salmela-Järvinen 1973; Mäkikossa 1947; Sulkunen 1989. 
Sen sijaan Salmela-Järvisen poliittisella 1970-luvulla tehdyssä kirjassa Sillanpää hahmottuu osana joukkoa. Salmela-Järvisen joukkoliike-painotukseen on vaikuttanut se, että hän oli myös itse silminnäkijä ja kokija. Salmela-Järvinen näkee Sillanpään kuvaa katsellessaan myös ympäröivät joukot, järjestönaisten verkoston, puolueen miesten varjot, punaliput ja kollektiivisen kokemuksen, jotka puuttuivat lähes tyystin Mäkikossan yksilöä korostavasta teoksesta. Ei ole siis erikoista, että Mäkikossan kirjan ilmestyminen oli suuri pettymys Salmela-Järviselle. Päiväkirjassaan hän vuodattaa: "Kirja on täysi fiasko. Kirjoittaja ei ole halunnut saada ensikäden tietoja asioista, asiantuntijoina ovat olleet pari kolme porvarillista henkilöä. Naisliiton osuus kuitataan muutamilla sivuilla ja nekin sisältävät vääriä tietoja... Miinan itsensä takia en haluaisi kirjaa moittia, mutta vaikea on kehuakaan huonoa työtä". ${ }^{27}$

Miina Sillanpää sai vanhuudenpäivinään tunnustusta suomalaiselta sivistyneistöltä. Vuonna 1949, Sillanpään ollessa 83-vuotias, palkitsi Suomen Kulttuurirahasto hänet 500000 markan palkinnolla tunnustuksena hänen työstään naisten aseman ja yhteiskunnallisten olojen kohentamisessa. Sillanpää liikuttui palkinnosta niin, että itki “...enkä minä ole itkenyt kuin kaksi kertaa elämässäni...". Hän jakoi suuren osan palkinnostaan apurahoina sosiaalidemokraattisille järjestöille. ${ }^{28}$ Vuonna 1945 Sillanpäästä maalautettiin muotokuva taidemaalari Helny Tigerstedtillä. Sosialidemokraattinen naisliitto puolestaan teetti vuonna 1950 Sillanpäästä ja Ida AalleTeljosta reliefit. Jokioisten kotiseutukerho pystytti vuonna 1951 Sillanpään torpan paikalle kiven: "Tällä paikalla olleessa torpassa syntyi 4.6.1866 talousneuvos Miina Sillanpää”.

Myös naisliiton 1950-luvun lopun hajaannuksen jälkeen Sosialidemokraattisten Naisten Keskusliitto nosti Sillanpään johtohahmokseen ja valmistutti hänestä niin ikään reliefin. Sillanpäästä nousi vuonna 1968 Helsingin Hakaniemeen taiteilija Aimo Tukiaisen veistämä "Soihtu" -veistos. Myös valokuvat kerovat henkilökultin luomisesta: suuressa osassa kuvista Miina Sillanpää poseeraa kirjahyllyn tai kirjoituspöydän edessä tai työhönsä liittyvässä ympäristössä. Ryhmäkuvissa hän on lähes aina joukon keskellä.

27 Martta Salmela-Jărvisen päivăkirja 30.9.1947. TA.

28 Salmela-Järvinen 1973, s. 114-115. 
Tuhkimotarina, jossa köyhän torpan tytön nousu valtakunnan vaikuttajaksi ei jättänyt ketään kylmäksi: Sillanpää oli tehnyt mahdottoman mahdolliseksi. Henkilöpalvonta sai toisinaan jopa hurmoksen luonnetta. Kotiliesi kuvasi vuonna 1941 Sillanpään puhujamatkaa näin: "Katselin silmät pystyssä, kuinka eräs räätälinrouva...kavahti itkien tulevan ministerin (Miina Sillanpään) kaulaan hänen laskeutuessaan puhujan lavalta...Eikä aikaakaan, niin riippui joku toinenkin nainen puhujan kaulassa, itki ja niiskutti... "29

Jos Ida Aalle-Teljo ja Hilja Pärssinen olivat vanhan työväenliikkeen johtavia suunnannäyttäjiä, ruumiillistui Miina Sillanpäässä työväenliikkeen ensimmäisen (1918) ja toisen (1957) hajaannuksen välisen ajan minäkuva. Mitä tuo identiteetti piti sisällään ja miten se muovautui, siitä seuraavissa luvuissa tarkemmin.

\section{Sosiaalidemokraattinen kotivalistus}

Kansalaissodan jälkeinen sosiaalidemokraattinen naisliike oli monella tapaa erilainen kuin ennen sotaa, vaikkakin toiminnan peruslinjat pysyivät ulkoisesti samantyyppisinä. Silmiinpistävin eroavuus oli liikkeen poliittisen maltillisuuden korostaminen, kun radikaalein aines siirtyi vasemmistososialistien ja kommunistien leiriin. Naisliikkeen "puhdistuminen" miesten kanssa yhteistoimintaa korostaneista äärilinjalaisista johti sosiaalidemokraattisen naistoiminnan aikaisempaa selkeämmin perheiden ja kotien liikkeeksi. Siitä tuli aktiivinen osa sitä laajempaa suomalaisten koteja keskiluokkaistavaa valistusprojektia, jossa ahersi jo Marttaliike. 1920-luvulla tähän samaan rintamaan liittyivät myös kokoomusnaiset Hedvig Gebhardin johdattamana.

Lähtökohtana sosiaalidemokraattisessa kotivalistuksessa oli ideologinen kamppailu: sodan jälkeen elettiin voimakkaan oikeistolaisessa hengessä ja naiset näkivät äärimmäisen tärkeäksi lyödä poliittista kiilaa tiivistyvään ja itsevarmaan oikeistorintamaan. Sosiaalidemokraatit ottivat oppia Martoista ja lähtivät hakemaan uudelle kotivalistustyölleen valtionapua. Liittolaisikseen he kelpuuttivat Gebhardin kokoomusnaiset ja Marttojen yksinoikeutta valistaa koteja lähdettiin yhdessä tuumin murtamaan eduskunnan kaut-

29 Ks. Mäkikossa 1947, s. 162. 


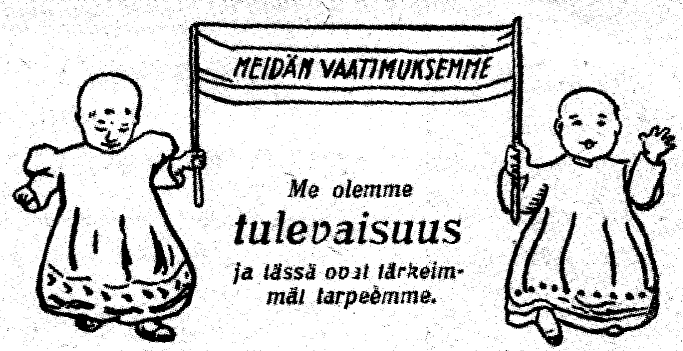

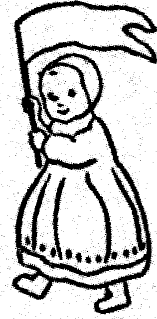

Hyvãă maitoa!

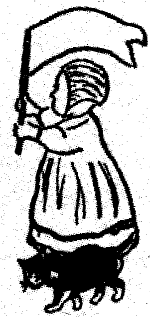

Raikasta ilmaa!

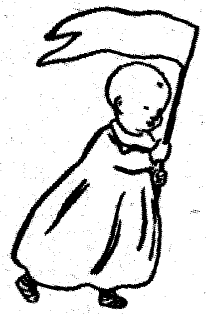

Puhdasta ravintoa!

Kuin kukka puhkeavi ummustaan ja pyytä vettă, päiväă, ravintoa, niin kasvamme me. Onko paikallaan, jos joutuncmme vaille hoitelua?

Kas lintuemo vaali pienoistaan; ei siivet hennot uuvu lentajâtä, mut moni meistả kuihtux kehdossaan, työmyllyn kita ăidin rístäă tältă.

Myös mehilätset kerää kennohin hunajan makean vuoks' pienoisitten. Mut tulos ihmistyóstá useinkin valahtaa taskuihin vain rikkahitten.

Vain pivo pieni jauhovakkaseen keräảntyy rahavallan määrätessä, ken tuottaa tuottehet ja markkoineen saa nistä maksaa, meidän nääntyessä.

Ei lastenseimeä, ei sitrtolaa, ei kelpo ravintoa meille kerry, siks' lihaksemme hervota ne saa, ei pieni poski terveheksi verry.

Mut yhteenlitttyessä toisin kảy, kun äidit, isät itse hallitsevat, e i y h de n voitto yläpuolla näy, pois noidat kehdoiltamme pakenevat.

Me pienokaiset, ajan vastaisen, jotk' oomme vartiot ja uusi voima, me teihin katsomme nyt vedoten vuoks' aattehen, mi ammoin kunnioima työn raatajien oli ahkerain. Te osuustoiminnassa täyttäkăătte min voitte. Tuosta oloin parempain myös lapsillenne koituvan te näătte.

Hilja Linomad-Pärssinen.

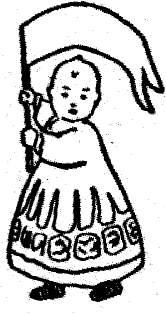

Alkää suudelko meitä huulille |

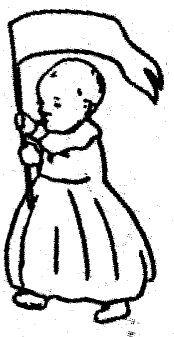

Stojelkaa meita vahingoilta!

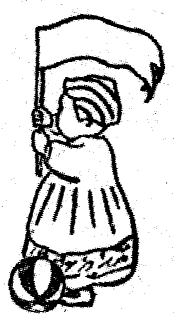

Antakaa meille vaarattomia ja hyödyllisiá leikkikaluja!

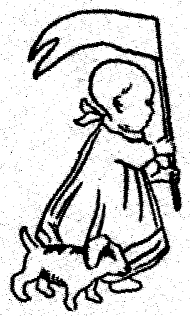

Alkää antako kärpăsten kiùsata meitä!

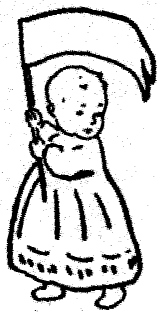

Alkää hyssytelkö meitầ liikaa!

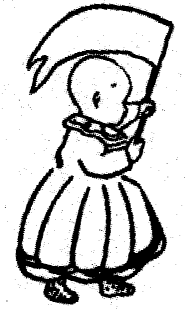

Älkää hemmoitelko meitä liioilla vaatteilla!

Hilja Pärssisen lastenhoitovalistusta Toverittaressa nro 8-9/1924. Kuva: Työväen Arkisto. 


\section{*Punaorvot}

Elokuussa 1918 perustivat 12 vankileireiltä pelastunutta helsinkiläistä sosiaalidemokraattia ensimmäisen avustusjärjestön, Suomen työläisten avustuskomitean, korjaamaan valkoisen terrorin jälkiä. Komitea listasi 29011 apuatarvitsevaa lasta. Kaikkiaan avun piiriin tuli 43066 henkilöä 12900 perheestä. Varansa komitea keräsi iltamilla sekä lahjoituksilla niin koti- kuin ulkomailtakin. Tämä toimikunta lopetti työnsä helmikuussa 1920 ja toiminta siirtyi uudelleenperustetuille työväenjärjestöille. Näin perustettiin toinen toimikunta, Työväenjärjestöjen avustustoimikunta huhtikuussa 1920 . Siihen liittyi 21 keskusjärjestöä. $2 / 3$ jaetuista varoista saatiin ulkomailta.

Työläisnaisia loukkasi syvästi se, että osa oikeistopiireistä kuulutti, että "sotaorvoissa on valtava määrä sellaisia, joiden äidit ovat pidettävät siveellisesti ala-arvoisina, joiden käsiin yhteiskunta ei voi uskoa niin kallista omaisuutta kuin heidän omat lapsensa". Vieraisiin perheisiin sijoitettuja punaorpoja oli vuoden 1920 lopulla vajaat 2000 . Lisäksi lastenkoteihin siirrettyjä lapsia oli runsaat 3000 . Heistä noin 600 oli siirretty vieraisiin kuntiin sijaiskoteihin. Karkeasti ottaen noin puolet punaorvoista (vajaat 6000 lasta) sai jäädä kotiinsa. Naisliittolaisten huoli koski nimenomaan "valkoiselle" Pohjanmaalle lähetettyjen lasten ja lastenkotilasten ideologista kasvatusta.

Sosiaalidemokraattiset naiset vaativatkin, että eduskunta kiireellisesti muuttaisi helmikuussa 1919 annettua lakia, jonka mukaan kansalaissotaan osallistuneiden soturien perheille annettu eläke koskisi myös punaisten riveissä kaatuneiden omaisia. Epäoikeudenmukaisen eläkejärjestelyn lisäksi naiset pitivät kohtuuttomana, että lapsia vietiin kodeistaan vastoin äitien tahtoa. Viedäkseen asiaansa eteenpäin naiset alkoivat julkaista erityistä punaorpomerkkiä ja lehteä sekä järjestää turvattomien päivää, joilla saadut varat luovutettiin punaorpotyöhön. Naisliiton punaorpotyö jatkui 1920-luvun puoliväliin saakka, jolloin se annettiin paikallisosastojen toimeksi ja viime kädessä kuntien ja valtion vastuulle.

Lähteet: Työväenjärjestöjen avustustoiminta kansalaissodassa turvattomaksi jääneiden hyväksi, kirj. Hilda Seppälä. Turvattomien päivä. Sos.dem. naisliiton syysjulkaisu 1921, s. 7; Suomen sos.dem. työläisnaisliiton X edustajakokouksen pöytäkirja 20.-22.5.1921, 21-26. 
ta. Yhteistoiminta tuotti tulosta ja vuonna 1929 myös muut naisjärjestöt kuin Martat saivat valtionapua kotitalouskurssien järjestämiseksi. Sinänsä valtionavun saaminen ei ollut uusi asia. Jo 1800luvun lopulla valtio oli tukenut työväenyhdistysten toimintaa. Itsenäistymisen myötä valtionapujärjestelmä kuitenkin muuttui järjestelmällisemmäksi ja jaettavien avustusten ja tuettavien kansalaisjärjestöjen määrä kasvoi.

Sosiaalidemokraattiset naiset saivat ensimmäisen kerran valtionapua vuonna 1924 pienten lasten hoitokursseja varten ja vuonna 1928 raittiuskasvatukseen. Näihin kolmeen painopisteeseen keskittyikin aikaisempaa tiukemmin sosiaalidemokraattisen naisliikkeen toiminta 1920-luvulta aina 1950-luvun lopulle saakka: lasten ja naisten elinolojen kohentamiseen, terveysvalistukseen ja raittiuskasvatukseen.

\section{Kuluttajavalistuksen puolesta}

Mitä naiset sitten tekivät kursseillaan? Ohjelma koostui lyhyestä poliittisesta selostuksesta tai agiteerauksesta ja aiheista, joiden uskottiin ja haluttiin kiinnostavan työläisnaisia eli käytännön ruokaohjeiden ja kodin kunnossapitoon liityvien vihjeiden jakamisesta. Kentän ääni oli vankkumaton: mitä enemmän käytännönläheistä toimintaa, sitä suuremman tuen kentän naiset antoivat naisliiton politiikalle. Naisliiton tehtävä oli tämän mukaan ennen kaikkea naisten elämän helpottaminen eikä yleinen puoluepolitikointi.

Kuvaavan esimerkin naisliittolaisten kiinnostuksesta antavat Helsingin sosialidemokraattisen naisyhdistyksen vaalikokouksessa pidetyt esitelmät vuodelta 1924: Kuulijat saivat tietoa asuntokurjuudesta, lasten huoltolaitoksista ja päiväkodeista, lasten kouluruokinnasta ja pikkulasten hoidon opetuksen kehittämisestä. Lisäksi pidettiin esitelmä 1920-luvulla muotiin tulleista kesäsiirtoloista, joita Helsingin kaupunki alkoi järjestää. Vaalikokouksen lopuksi ilmoitettiin käsityöseuran kokoontuvan joka maanantai-ilta. Kokouksen jälkeen vietiin kuulijat katsomaan omaa mallikotinäyttelyä.

Jäsenistön kiinnostus käytännönläheisiin aiheisiin näkyi myös Toveritar-lehden kiertokyselyssä vuodelta 1925. Lukijat pitivät lehden poliittista uutisointia liian raskaana ja toivoivat lehteen enemmän kevyempää luettavaa, kaunokirjallisuutta, talousohjeita ja 
lastenhoitoa käsitteleviä artikkeleita. Utralainen Anni Romppainen tilitti tuntojaan näin: "Moni emäntä ja neitonen tilaa mieluummin Nyyrikin tai Vipusen sen kevyen ja vaihtelevan lukemisen takia... Lisäksi moni pelkää sosialisti-sanaa...Apinoimishalu ja välinpitämättömyys on yksi meidän vähemmän kauniita ominaisuuksiamme. Onhan jotain kuulua tuohon kermakerrokseen, vaikkapa ei todellisuudessa kuulutakkaan...". Monissa keski-eurooppalaisissa sosialidemokraattisissa naisjärjestöissä lehtiongelma ratkaistiin perustamalla kaksi erillistä lehteä. Toisessa pohdittiin ideologisia ja puoluepoliittisia kysymyksiä, toisessa tarjottiin ajanvietettä.

Kotitalouskurssit saivat suuren suosion. Vuonna 1929 naisliiton järjestämillä kursseilla oli osallistujia kaikkiaan 8 500. Samanaikaisesti naisliitossa oli maksavia jäseniä 1800 ja koko puolueessa 8700 naisjäsentä. Seuraavana vuonna kuulijoiden määrä oli jo yli 20000 ja vuonna 1931 noin 50 000. Näin siitä huolimatta, että elettiin tiukentuvan oikeistosuuntauksen aikaa eikä toimintaa naisliiton kertomusten mukaan voitu järjestää täysipainoisesti. Kurssitoiminnasta tulikin naisliitolle neljäksi vuosikymmeneksi oikea "kultakaivos". Muun muassa vuoden 1929 budjetista naisliitto sai 70 prosenttia valtiolta. Paitsi rahallista turvaa kurssit toivat myös poliittista painoarvoa eli kentän myötämielisyyttä ja kannatusta. ${ }^{30}$

Se, että jäsenistö niinkin yksimielisesti otti vastaan uuden toimintamuodon, johtui osittain siitä, että puoluehajaannuksen jälkeen Sosialidemokraattisen puolueen jäsenistö maalaistui ${ }^{31}$ ja tämä näkyi myös naisten ammateissa: naisliiton jäsenistössä oli aikaisempaa enemmän perheenäitejä, jotka ainakin osittain olivat kotona lapsiaan hoitamassa. ${ }^{32}$ Jäsenistön sosiaalisen rakenteen muutoksen naisliiton johto otti huomioon suunnitellessaan uusia toimintalinjoja. Miina Sillanpää ilmaisi asian näin: "Kotitalousneuvontatyö ei kylläkään varsinaisesti kuulu ohjelmaamme puoluejärjestönä, mutta tämän kautta voimme hankkia puolueeseen uusia jäseniä, kannattajia ja äänestäjiä, ja siten tehdä valistustyötä puolueemme hyväksi". ${ }^{33}$

30 Ks. Lähteenmäki 1990, s. 70-84; Lähteenmäki 1995, s. 201-218.

31 Kettunen 1986, s. 216-220.

32 Toveritar $1 / 1926$, s. 5.

33 Miina Sillanpää avatessaan Sos.dem. naisliiton edustajakokouksen 1929. Suomen Sosialidemokraattisen Työläisnaisliiton XII edustajakokouksen pöytäkirja 28.-31.5.1929, s. 4. 


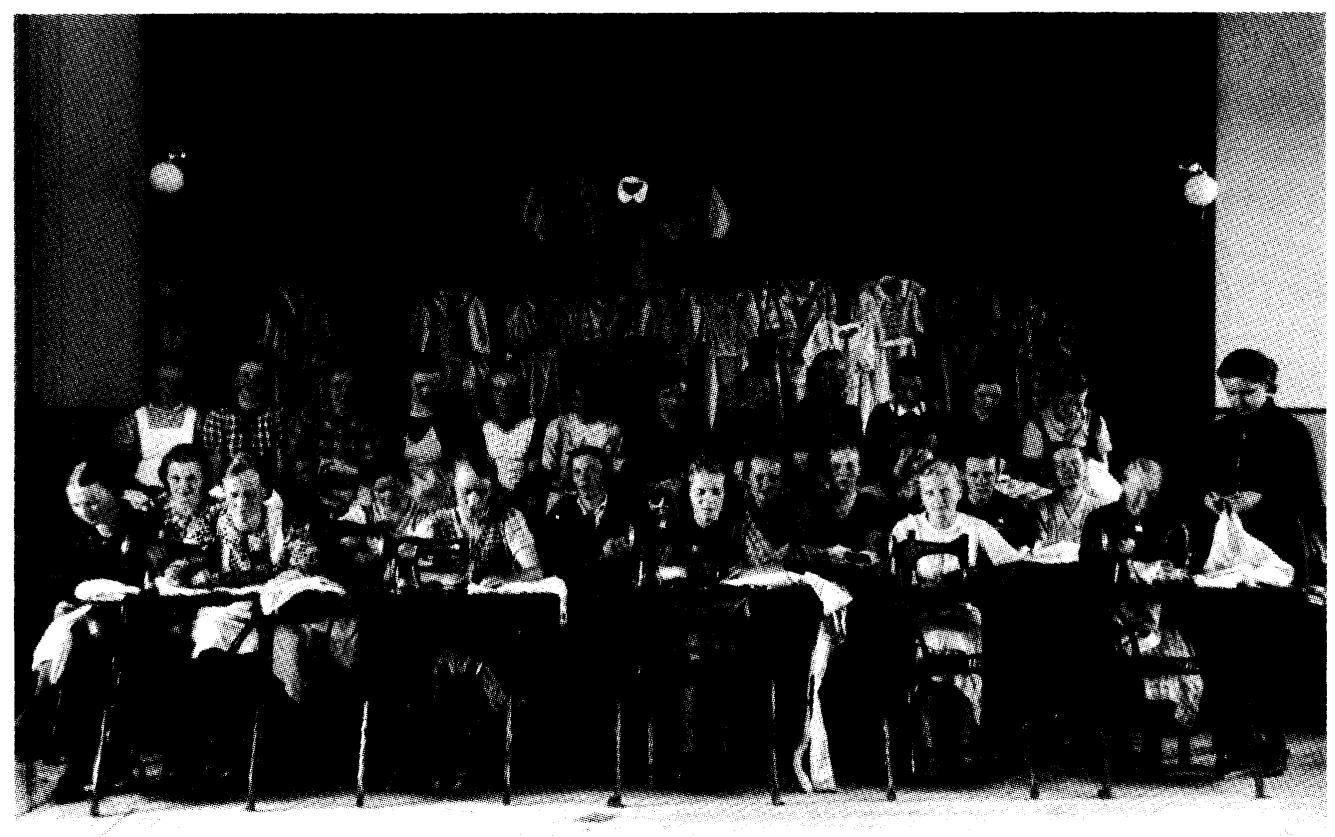

Oulun sosialidemokraattisen naispiirin vanhasta uutta -kurssit 1920-luvun lopulla. Kuva: Työväen Arkisto.

Paitsi ideologinen työ ja puhdas "jäsenkalastus", oli naisliiton toiminnan suuntautumisella kotivalistukseen myös laajemmat yhteiskunnalliset ulottuvuutensa. Kuten jo vuosisadan vaihteessa, naisliittolaisten valistustyöllä oli kansanterveydellinen ulottuvuutensa. Vielä 1920-40-luvullakin pelättyjen tartuntatautien keskeisimmäksi syyksi propagoitiin epäsiisteyttä ja köyhyyttä. ${ }^{34}$ Näitä paheita vastaan myös keskiluokkaistuva sosiaalidemokraattinen työväenliike tahtoi taistella. Naisliikkeestä tuli kotitalous- ja lastenhoitokurssien kautta yksi kansanterveyden sanansaattajista muiden naisjärjestöjen ohella. Myös taloudelliset kriisiajat, kuten vuosien 1917-18 pula, vuosien 1929-32 lama ja toinen maailmansota nostattivat naisten kurssi- ja ohjaustoimintaa. Talouslaman aikana muun muassa Toveritar julkaisi "Käytännöllisiä neuvoja" -palstaa, jossa esiteltiin säästäväisen emännän ruokaohjeita, vaatteiden kunnostusta ja lastenhoitoa. Samantyyppisiä ohjeita julkaistiin lehdessä myös kansalaissodan jälkeisessä vaikeassa taloudellisessa tilanteessa. $^{35}$

$35 \mathrm{Mm}$. "Maukkaita ja hal poja ruokia tähteiksi jääneistä leipäpalasista ja -kannikoista", Toveritar 2/1930, s. 24; "Porkkanaruokia, kakkuja", Toveritar 19/1928, s. 302. 


\section{*Äitienpäivä}

Ensimmäiset äitienpäivät vietettiin Suomessa vuonna 1918. Alun perin Yhdysvalloista alkunsa saanut tapa levisi nopeasti ensin Kanadaan ja Australiaan. Euroopassa päivän vietto aloitettiin ensin Belgiassa vuonna 1913, josta se levisi muihin maihin. Suomeen äitienpäivän vieton toi Kotikasvatusyhdistys, joka oli perustettu vuonna 1907 vahvistamaan kotien ja äitien asemaa. Järjestön sihteeri teki kolme vuotta myöhemmin opintomatkan Yhdysvaltoihin, jossa päivän vietto oli saanut innostuneen vastaanoton. Suomessa otollinen tilaisuus tuli kansalaissodan jälkeen ja on kuvaavaa, että ensimmäisten äitienpäiväjuhlien kunniavieraita olivat juuri voittaneiden valkoisten äidit. Ensimmäiset äitienpäivät olivatkin Suomessa leimallisesti valkoisen Suomen juhlamuoto. Sellaiseksi ne työväenliike myös mielsi.

Ei siis ollut yllättävää, että ensimmäiset äitienpäivät eivät saaneet työläisnaisjärjestöissä vastakaikua. Sen sijaan vappumarssit ja maaliskuinen kansainvälinen naistenpäivä kokosi työläisnaisia työväentaloille ja kulkueisiin. Etenkin kansainvälisen naistenpäivän juhlissa korostettiin äitien työn merkitystä ja vaadittiin yhteiskunnalta arvostuksen osoittamista myös punaisille naisille teoin eikä juhlapuhein. Sisällissodan jälkeen se olikin vaikeaa: punaisia naisia leimattiin kelvottomiksi lastenkasvattajiksi ja punaorpoja siirrettiin valkoiselle Pohjanmaalle kasvattilapsiksi.

Työläisnaisjärjestöjen suhtautuminen äitienpäivään muuttui 1920luvun lopulla. Läpimurto tapahtui, kun Sosialidemokraattinen Työläisnaisten liitto teki marraskuussa 1929 päätöksen äitienpäivän viettämisestä. Asiaa oli pohdittu jo edellisinä vuosina niin liiton toimistossa kuin osastoissakin. Eräät maaseutuyhdistykset olivat ennättäneet järjestää juhlia menestyksellisesti. Näin naisliitto tavallaan legitimoi jo tapahtuneen muutoksen. Vuonna 1930 naisliitto lähetti kymmeniä puhujia ympäri maata äitienpäiväjuhlille.

Tärkeä tekijä naisliiton kannanmuutokselle olivat jäsenistöltä tulleet pyynnöt juhlien järjestämiseksi. Toisaalta naisliitto ei katsonut hyvällä, kuinka työläisnaiset riensivät porvarillisten järjestöjen organisoimiin juhliin rukoushuoneille ja seuraintaloille. Järjestämällä omia äitienpäiväjuhlia väki saatiin omalle työväentalolle ja niinpä työläisnaisosastoja kehotettiin järjestämään juhlia, joissa hyvän ja "työväenluokan taisteluhenkeen sopivan ohjelman muodossa muistetaan kovia kokeneita, unohdettuja työläisäitejä ja tarjotaan heille virkistystä ja valistusta". Koska äitienpäivä oli aluksi niin leimallisesti valkoisten juhla, esitettiin nimen uusimista "vanhempain päiväksi", mutta se ei saanut kannatusta. 
Juhlamuodot omaksuttiin osin porvarillisten naisten juhlista, osaksi omasta juhlatraditiosta. Äideille ojennettiin valkovuokkoja ja tarjottiin kahvia, omenoita ja karamelleja. Ohjelmasta vastasivat pääasiassa lapset: oli lausuntaa, kuorolaulua, puheita, näytelmiä, kertomuksia ja torvisoittoa. Työläislapsille juhlaohjelmaan osallistuminen merkitsi astumista uudenlaisen julkisen työväenkulttuurin piiriin. Juhlamuotoihin vaikutti myös se, missä määrin juhlajärjestelyissä oli oltu yhteistyössä paikkakunnan muiden järjestöjen kanssa.

Lähde: Sosialidemokraattisen naisliiton kertomukset ja pöytäkirjat 1920-30luvulta. TA.

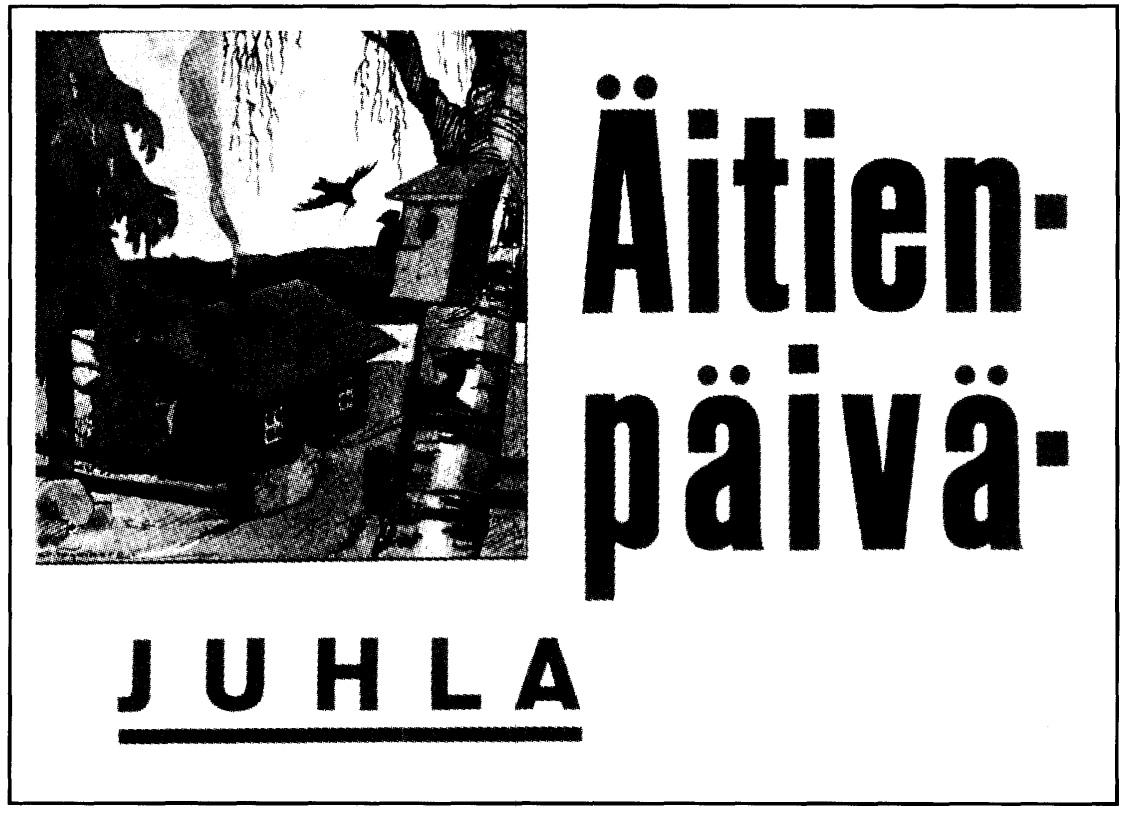

Äitienpäivän juhlamainos vuodelta

1939. Kuva: Työväen Arkisto. 


\section{Naiset Mukaan -toimikunnat}

Osuustoimintaliikkeen painoarvo vahvistui 1920-luvulla. Tämä kertoo viime kädessä elintason noususta. Sosiaalidemokraattisten naisten toiminta osuuskauppaliikkeessä oli aktiivista jo vuosisadan alkupuolella. Osuuskauppaliikehän jakaantui vuonna 1916 aatteellisesti kahtia: yhtäältä työväestön niin sanottuun edistysmieliseen Kulutusosuuskauppojen Keskusliittoon (KK:hon) ja toisaalta tuottajien hallitsemaan Suomen Osuuskauppojen Keskuskuntaan (SOK:hon). Naisten osuus KK:laisten osuusliikkeiden jäsenistöstä nousi 1920-luvun aikana: vuonna 1926 naisten osuus oli noin 24 prosenttia, kolmea vuotta myöhemmin lähes 30 prosenttia. $^{36}$

Ei siis ollut ihme, että sosiaalidemokraattiset naiset näkivät osuustoimintaliikkeen kautta avautuvat mahdollisuudet tavoittaa kotiäidit myös poliittiseen toimintaan. Osuustoiminta nähtiin työläisnaisliikkeen kasvukumppaniksi, erottamattomaksi osaksi: "Isoveli osuuskauppaliike ja terhakka siskotyttö työläisnaisliike”, kuten Lyyli Takki asian osuvasti ilmaisi. Käytännössä tämä sisaruus hoidettiin perustamalla vuodesta 1928 lähtien osuuskauppoihin naistoimikuntia, jotka saivat nimekseen "Naiset Mukaan -toimikunnat". Niiden tehtävänä oli naisten valistaminen periaatteella "Hallitse kauppaa ja tuotantoa".

Ajatusten tulkiksi perustettiin Koti-niminen vuosikirja perheenemännille. Kirjan viesti oli selkeä: "Kodin sielu on nainen. Nykyajan perheenemännän pitäisi kyetä hoitamaan taloutensa niin, että myöskin nykyajan sivistykselliset ja kauneudelliset vaatimukset voidaan kodissa tyydyttää". Koti-vuosikirja edusti puhtaasti pikkuporvarillista koti-ideologiaa ja siihen kirjoittivat pääasiassa eri alojen asiantuntijat, eivät poliitikot. Sosiaalidemokraattisten naisten ja muiden naisjärjestöjen kotitalouskurssit loivat pohjan, johon Koti-vuosikirja rakensi oman ohjelmansa. Naiset nähtiin tärkeinä kuluttajina ja perheiden ostosten tekijöinä, siksi heitä oli koulittava vastaanottamaan kaupallistuvan yhteiskunnan haasteet. Heidän tuli olla paitsi hinta- ja laatutietoisia, myös yritystietoisia: piti osata ostaa oikeat ostokset oikeista kaupoista.

36 Suonoja 1966, s. 72-78, 86; Kuluttamisen lisääntymisestä ks. Hentilä 1999 


\section{Kritiikki}

Vaikka sosiaalidemokraattisten naisten valtaosa hyväksyi liiton toiminnan suuntaamisen kotivalistukseen kurssitoiminnan muodossa, se ei saanut aivan kaikkien myötämielisyyttä osakseen etenkään 1930-luvulla. Varsinkin nuoren polven aktivoituvat naiset näkivät kurssitoiminnassa myös riskejä. Tähän liittyi laajempi keskustelu Toverittaren linjasta ja liiton sihteerin paikasta pitkään naisliitossa toimineen Hilda Seppälän kuoleman (1932) jälkeen.

Nuorempaa, kriittisempää ja poliittisella urallaan eteenpäin haluavaa naispolvea edustivat Martta Salmela-Järvinen, Tyyne LeivoLarsson ja Sylvi-Kyllikki Kilpi. Näiden Helsingin sosialidemokraattisen keskusteluseuran naisjaoston johtonaisten mukaan toiminnan liiallinen eriyttäminen miesten toiminnasta ei ollut hyväksi. Naiset olisi saatava opintokerhoihin käsityökerhoista: "Käsityökerho, jossa kokoonnutaan vain ompelemaan ja jutustelemaan toisarvoisista asioista on rikos järjestötoimintaa kohtaan yhtä paljon kuin miestovereitten tuntikautiset oleskelut biljardihuoneissa ja työväentalon juttutuvissa".

Näin jyrkin sanoin tuomitsi Sylvi-Kyllikki Kilpi liiton linjan. Hän varmisti viestin perillemenemisen vertaamalla naisliiton ohjelmaa "fascistiseen" ohjelmaan. Sekin kun vaati naisia ajettavaksi takaisin keittiöön. Puheensa tueksi Kilpi esitti lukuja kerhojen määrästä: varsinaisia opintokerhoja osastoissa oli 14, mutta ompelukerhoja peräti 61. Vanhan kaartin edustajat puolustivat linjaansa vedoten kentän tukeen. Pitäytyminen pelkästään poliittisella linjalla ei ollut onnistunut ja naiset olivat pakotettuja uudistamaan linjaansa. ${ }^{37}$

Sosiaalidemokraattien käymä keskustelu kuvaa hyvin eurooppalaisessa naisliikkeessä tapahtunutta yleistä muutosta 1930-luvun alussa. Saksassa kansallissosialistit julistivat kolmen k:n politiikkaansa (Kirche, Küche, Kinder) ja jopa Neuvostoliitossa, missä 1920-luvulla yritettiin vapauttaa nainen keittiön kahleista, palattiin vanhaan perhekeskeiseen malliin. Taloudellinen lama oli yksi tärkeä tekijä, minkä vuoksi naisia pyrittiin vetämään pois työmarkkinoilta kotitöihin. ${ }^{38}$

37 Suomen Sosialidemokraattisen työläisnaisliiton XV edustajakokouksen 27.-29.10.1935 pöytäkirja, s.17, alustusvihko, s. 18, 46-47.

38 Neuvostonaisen mallista ks. Liljeström 1995; Saksan mallista mm. Bock 1991. 


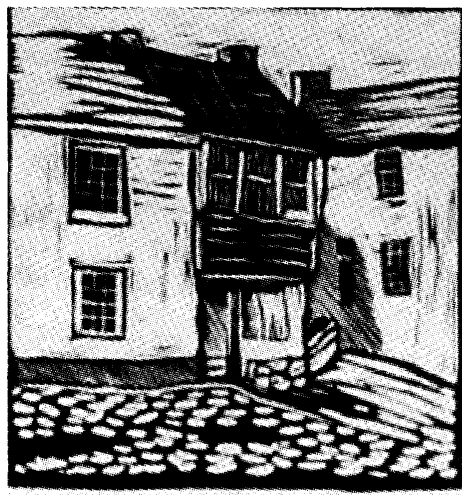

Arvostelu:

Suurisuuntalnen,

Onnistunut,

AJankohtalnen.

MITEN ASUMME?

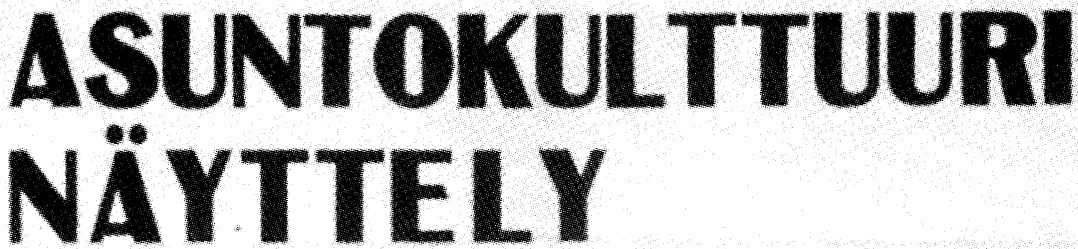

Työvăentalon E-salissa. Järjes-

MITEN MEIDÄN PITÄISI ASUA? tånyt Sos.-dem. Työläisnaisliltto

Näyttely avoinna arkipativisin klo $11-16$ ja 17-21 sunnuntaisin $+10-21$

Patasy $2 \mathrm{mk}$.

Kāykāā tutustumassa!

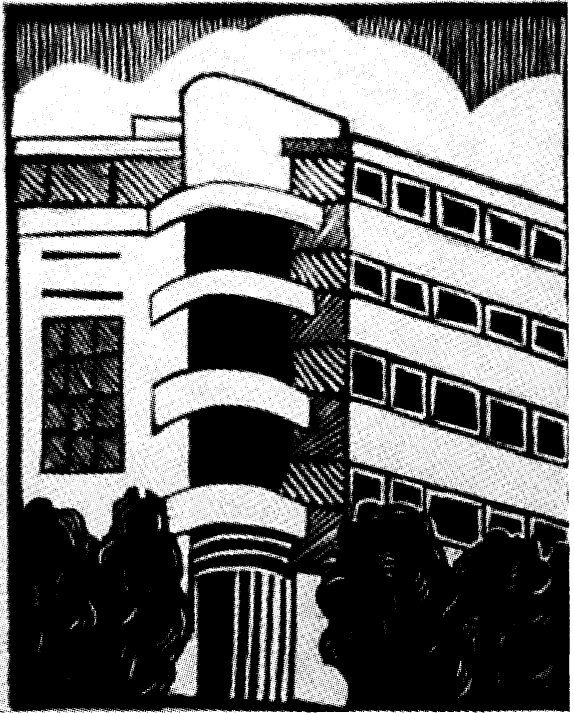

Mainos kutsuu asuntokulttuurinäyttelyyn vuonna 1935. Kuva: Työväen Arkisto. 
Sosiaalidemokraattiset naiset elivät tiiviisti ajan hermolla 1930luvun muuttuvassa ja uusia vaatimuksia esittävässä maailmassa. He järjestivät vuonna 1935 jopa oman asuntokulttuurinäyttelynsä. Sinänsä ajatus ei ollut naisliitolle uusi. Työväestön asumisvaikeudet olivat olleet keskeisiä kysymyksiä jo vuosisadan vaihteen naisliitolle. Liiton lehdessä julkaistiin lukuisia artikkeleita asunto-ongelmista. Muun muassa vuonna 1912 Työväen Kalenterissa julkaistiin artikkeli "Työväen huonekaluista". Naisliitto oli mukana myös Asuntoreformiyhdistyksen vuonna 1921 järjestämillä Naisten Asuntopäivillä. 1930-luvulla naisliitto oli nostamassa työväestön asuntoasiaa yleisemmän kiinnostuksen kohteeksi.

Naisliittolaisten mielestä asuntokysymys oli osa lajempaa kulttuurikysymystä, sillä "sitä mukaa kun sivistystaso kohoaa, sitä mukaa vaaditaan ja saadaan parempia asuntoja”. Asuminen ei ollut naisliittolaisten mukaan yksityisasia, vaan siinä oli otettava huomioon myös yleiset terveydelliset, siveelliset ja sivistykselliset tekijät, joiden merkitystä valitettavan harvat työläiset ymmärsivät. Tämä ymmärtämättömyys puolestaan johtui siitä, etteivät työläiset olleet vielä oppineet arvioimaan sitä, mitä asunto ihmiselle oikeastaan merkitsi. Työnsä pontimena naisliitolla oli siis vanha vahva kansanvalistusajattelu. Hellahuoneet saivat naisten tuomion: "On kauheata ajatella yhden huoneen asuntoja. Muutaman neliömetrin alalla synnytetään, sairastetaan ja kuollaan, syödään, työskennellään, maataan, eletään avioelämää lasten todistajina ollessa loppumattomiin. Ihme ettei ihmisistä tule mielipuolia vieläkin suuremmassa määrässä sellaisissa oloissa." Turmiollisin asuntomuoto oli naisliiton mielestä kuitenkin asukkijärjestelmä, jossa nuoret saattoivat joutua suorastaan hyväksikäytetyiksi.

Uutta asuntokulttuuria naisliitto lähti propagoimaan esitelmillä, lehtikirjoittelulla ja näyttelyillä. Alvar Aalto kävi pitämässä esitelmän lokakuussa 1935 työläisnaisten luentopäivillä ja Toverittaressa julkaistiin teemanumero asuntokulttuurista. Naisliiton asunto-ohjelmaan kuului muun muassa neuvoja siitä, miten tottumaton osaisi asua avarammissa asunnoissa. Muuankin työläisperhe, joka oli saanut tehtaalta kahden huoneen asunnon kahdella sisäänkäynnillä, oli ymmärtämättömyyttään asunut keittiössä ahtaasti ja kamari oli ollut kylmillään "vierashuoneena". Naisliiton vuoden 1935 edustajakokous velvoitti liittotoimikuntaa pitämään asunto- 
kysymystä vireillä voimiensa mukaan muun muassa vaatimalla arkkitehdeiltä enemmän pientalopiirustuksia. Kunnallista asuntopolitiikkaa oli naisliiton mukaan myös kehitettävä, jotta vähävaraisten asumiskustannukset olisivat kohtuulliset.

Asuntokulttuurinäyttelyn idea syntyi, kun kesäretkeily- ja opintopäivien yhteydessä olleet pienimuotoiset asuntouudistusnäyttelyt saivat suurta huomiota osakseen. Nämä naisten "kotimessut" pidettiin Helsingissä työväentalolla maaliskuussa 1935. Piirustukset näyttelyyn rakensi arkkitehti Elna Kiljander ja näytteillepanijoita oli useita, kuten Elanto, Enso Gutzeit oy, Asko, Merivaaran Rautasänkyliike (hetekathan olivat suurta muotia 1930-luvulla!) ja Uuniliike Kastor. Näytteillä oli "tyypillisiä työläiskoteja". Näyttely sai suuren suosion. Kahden näyttelyviikon aikana sitä kävi katsomassa noin 5000 henkilöä. Sanomalehdissä annettiin naisliitolle julkinen tunnustus siitä, että se oli rohkeasti käynyt käsiksi polttavaan asuntokysymykseen. ${ }^{39}$

\section{Espanjan lasten avustaminen}

Sosiaalidemokraattisten naisten yksi keskeisimmistä toimintamuodoista oli lastenhuoltoon liittyvä avustus- ja tukitoiminta. Naisliiton mittavin hanke 1930-luvulla oli Espanjan sisällissodan jaloissa olevien tasavaltalaisten lasten auttaminen. Keräys suoritettiin kolmessa erässä, ensimmäinen oli vuosien 1936-37 vaihteessa, toinen vuoden 1937 lopulla ja kolmas vuosien 1938-39 vaihteessa. Kaksi ensimmäistä keräystä naisliitto toimitti yksin, viimeisessä oli mukana myös muita työväen- ja rauhanjärjestöjä. Sen sijaan poliittinen oikeisto ei asialle lämmennyt.

Sylvi-Kyllikki Kilpi, joka oli aktiivisesti mukana keräyshankkeessa, kirjoitti päiväkirjaansa: "Olen yrittänyt houkutella maalaisliittolaisia antamaan roponsa Espanjan lasten hyväksi. Ainoakaan ei ole sitä tehnyt". Kansanedustaja ja oikeistolaisuudestaan tunnettu Hilja Riipinen suorastaan syytti naisliittoa "aselähetyksistä”. Kilven mukaan myös jyrkimmät vasemmistolaiset suhtautuivat keruuseen nihkeästi, koska naisliittolaiset eivät antaneet "kir-

39 Suomen Sosialidemokraattisen Työläisnaisliiton XIV edustajakokouksen pöytäkirja 27.29.10.1935, s. 30, liiteosa 15, s. 32-36. 


\section{L'ACTION"MILITARRE"DES REBELLES}

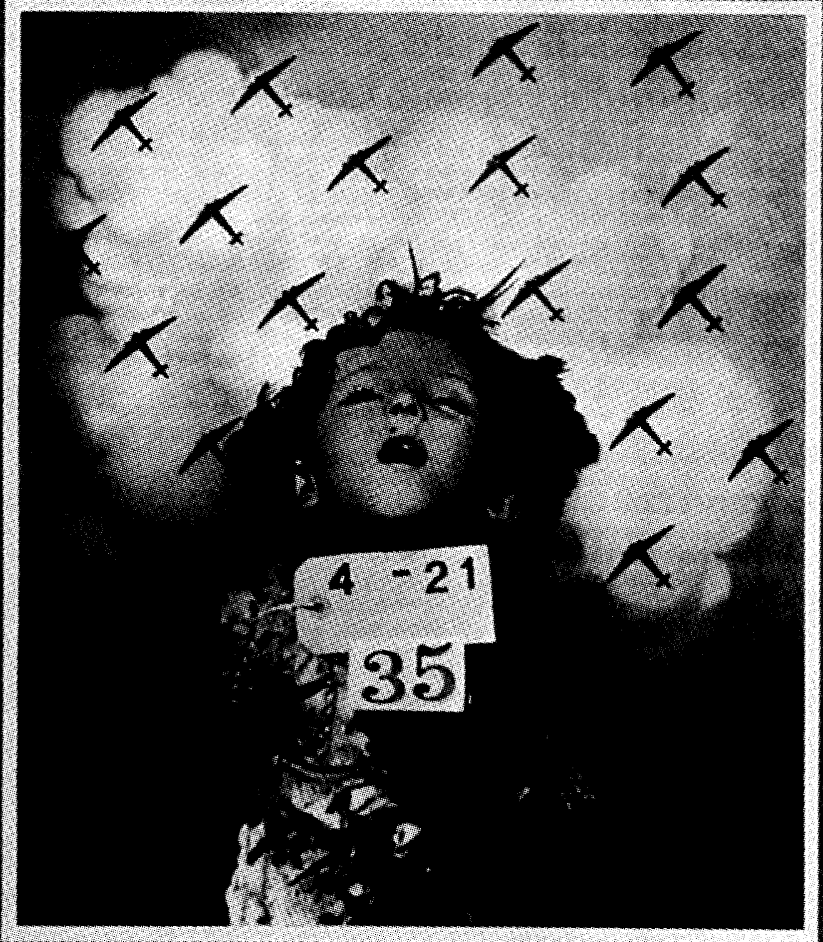

\section{CE QUE L'EUROPE TOLĖREOU PROTĖGE CEQUE VOS ENFANTS PEUVENTATTENDRE}

Sosialidemokraattinen naisliitto järjesti kolme keruuta Espanjan sisällissodan (1936-39) siviiliuhreille. Kampanjassa käytettiin sekä espanjankielisiä että suomennettuja julisteita. Kuva: Työväen Arkisto. 
peitä poliittisia julistuksia" eivätkä paljastaneet fasismin kaikkia toimintamuotoja". ${ }^{40}$

Naisliitto sai keräysajatuksensa Ruotsista ja kansainväliseltä sosialistinaisten kongressilta, jossa kehotettiin toimeenpanemaan kansallisia keräyksiä. Muun muassa Ruotsissa ja Norjassa Espanja-keräykset olivat kuitenkin paljon laajemman organisaation harteilla. Suomessa Sosialidemokraattinen puolue ja SAK lähettivät toki varoja espanjalaisille, mutta jättivät varsinaisen keräystyön naisten harteille. Voi olla, että siirto tehtiin tietoisesti ajatellen lupavaikeuksia. Toisaalta lastenhuolto ja muu avustustoiminta olivat jo vakiintuneet naisliiton tehtäviksi, joten tämäkin hanke oli helppo siirtää naisille. Naisliitto sai ensimmäisen keräyksen aikana vieraakseen Espanjan Ruotsin ja Suomen yhteisen lähettilään Isabel de Palencian. Tämä oli yllättynyt siitä, että Suomen keräys ei ollut saanut taakseen sivistyneistöä, taiteilijoita tai tieteen edustajia, kuten muissa maissa. ${ }^{41}$

Sosiaalidemokraattisten naisten avustusprojekti oli tästäkin näkökulmasta merkittävä ja rohkea. Maan oikeistoa ja poliittista keskiryhmää edustaneet suhtautuivat kriittisesti tasavaltalaisten tukemiseen ja mieluummin antoivat kannatuksensa Francon kumouksellisille. Suomesta lähti vapaaehtoisina Espanjan sisällissotaan noin 120 tasavaltalaisten ja parikymmentä Francon joukkoihin.

Muitakin avustusmuotoja naisliitolla oli sotienvälisellä kaudella, kuten punaorpojen, Neuvosto-Karjalan ja Saksan nälkäänäkevien avustaminen sekä juutalaisten ja Abessinian pakolaisten avustaminen.

Kerätyillä varoilla, kaikkiaan huikeat $900000 \mathrm{mk}$, ostettiin kondensoitua maitoa, lihasäilykkeitä ja maitopulveria. Ei ole tiedossa, miten maitopulverin kävi, sillä ainakin Eino Kilpi piti sitä hengenvaarallisena aineena maistettuaan sitä vahingossa. Ainakin suomalainen munapulveri ja petsamolainen kalanmaksaöljy otettiin tyytyväisenä vastaan. Lisäksi lähetettiin vaatetavaraa, jota naiset olivat valmistaneet ompelukerhoissa ja keränneet tuttaviltaan. ${ }^{42}$ Suomalaiset tukivat myös viittä espanjalaista kummilasta. ${ }^{43}$ Lahjoittajat olivat pääosin työväestöä, jolle keräys oli suunnattukin.

\footnotetext{
40 Kilpi 1960, s. 132-142.

41 Toveritar 24/1937; Kilpi 1960, s. 140-143.

42 Kilpi 1960, s. 138.

43 Laitinen 1998, s. 1-3, 29, 34
} 


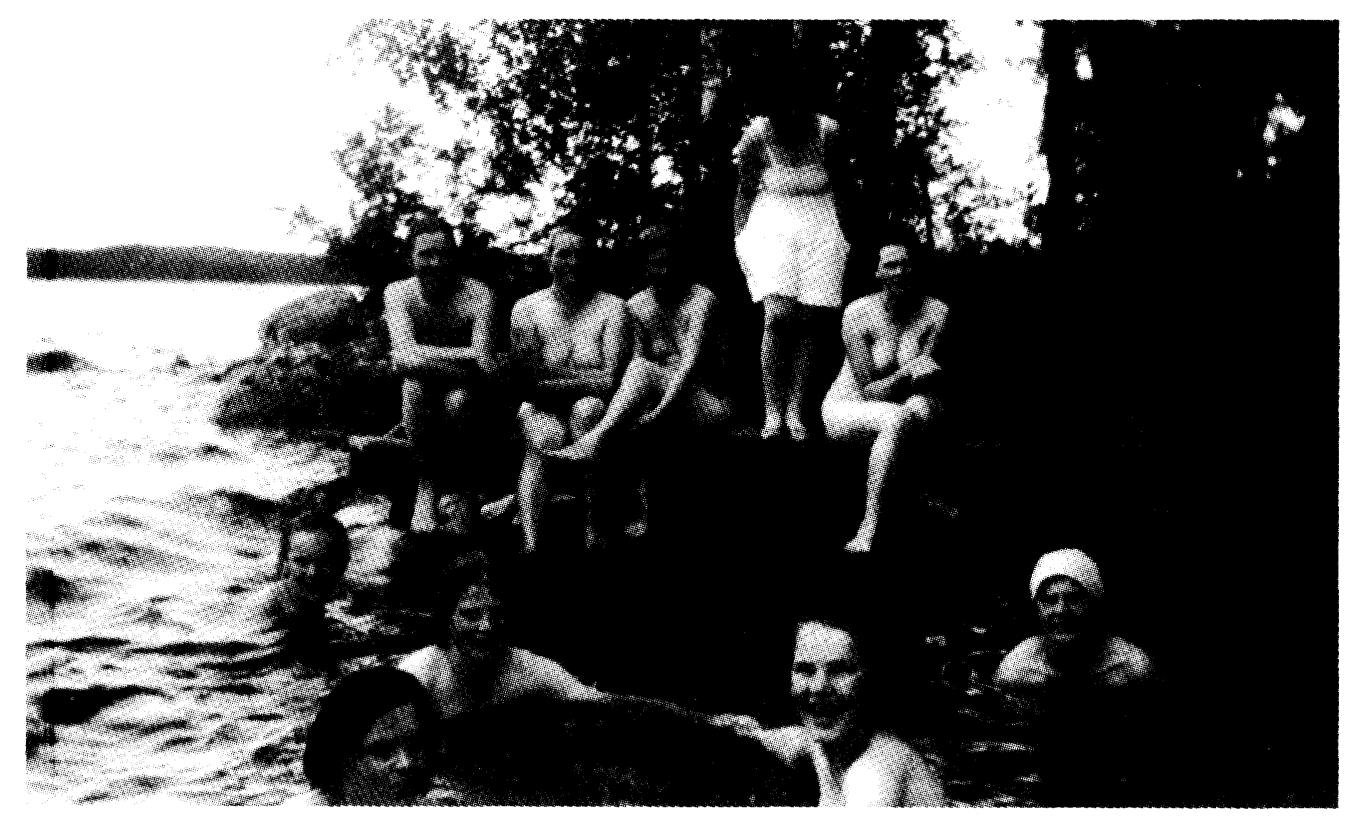

"Lahden Sosialidemokraattisen Naisosaston likkoja ja akkoja mielityössään" 1930-luvulla. Kuva: Työväen Arkisto.

Rahakeräyksen toimeenpaneminen ei ollut aivan yksinkertainen asia 1930-luvun oikeistovoittoisessa ilmapiirissä. Luvat keräykseen kuitenkin saatiin, koska kysymys oli "puhtaasti" humanitäärisistä syistä. Listoja työpaikoillaan kierrättäneille keruu saattoi koitua kuitenkin kohtalokkaaksi. Eräskin Huhtamäki-Hellaksen naistyöntekijä sai lopputilin kerättyään rahaa Espanjan lapsille. Vaikka naisliitto ja Elintarviketyöläisten liitto ottivat asiassa yhteyttä tehtaan johtoon, ei irtisanomista peruttu. ${ }^{44}$

Liiton Espanja-keräys oli selvä osoitus sosialidemokraattisen naisliiton palaamisesta kansainvälisemmille toimintakentille solidaarisuustyössä sitten puoluehajaannuksen. 
*Joulumerkkikoteja työläisperheiden lapsille

Yksi osoitus yhteiskunnan painoarvon ja vastuun kasvamisesta 1930luvun sosiaalisessa työssä olivat ns. Joulumerkkikodit. Ne olivat tuberkuloottisista perheistä eristetyille vastasyntyneille lapsille tarkoitettuja turvakoteja. Ensimmäinen niistä perustettiin tehdaskaupunki Tampereelle vuonna 1936, sen alaosasto aloitti toimintansa Pälkäneellä vuonna 1939. Pohjoiseen Ouluun perustettiin oma Joulumerkkikotinsa vuonna 1945. Kuopiossa Joulumerkkikoti toimi vuosina 1954-64. Nimensä kodit saivat joulumerkeistä, joita myytiin Tuberkuloosin Vastustamisyhdistyksen toimesta. Varhaisimmat keuhkotautisten hyväksi myydyt merkit olivat jo vuodelta 1908 ja merkkejä on myyty näihin päiviin saakka. Idea merkeillä kerättävistä varoista saatiin ulkomailta, Amerikasta ja muista pohjoismaista. Ajatuksen isänä pidetään tanskalaista Einar Holbollia, jonka toimesta Tanskassa julkaistiin ensimmäinen joulumerkki vuonna 1904.

Lasten eristäminen keuhkotautisista vanhemmista oli raju päätös ja kertoo siitä vakavuudesta, millä yhteiskunta pyrki ehkäisemään taudin leviämistä. Vauvat olivat kodeissa syntymästään noin kuuden - kahdeksan kuukauden ikäisiksi. Lapset tulivat pääosin työläisperheistä. Esimerkiksi Oulun kodin asukeista $45 \%$ oli työntekijöiden lapsia, $21 \%$ maanviljelijöiden ja $18 \%$ ammattityöntekijöiden lapsia. Omaisille lapsen eristäminen oli kova pala. He saivat käydä katsomassa pienokaisiaan lasin läpi. Mikäli vauvan vanhemmat menehtyivät tuberkuloosiin eivätkä sukulaiset voineet ottaa lasta huostaansa, hänet adoptoitiin tai siirrettiin tavalliseen lastenkotiin. Tuberkuloosikuolleisuuden laskiessa 1950-luvun alusta lähtien tehokkaan rokotuksen ja antibioottien keksimisen ansiosta, loppui vähitellen myös Joulumerkkikotien toiminta 1970luvulla.

Lähde: Joulumerkkikodit 1936-1973. Suomen Tuberkuloosin Vastustamisyhdistys ry. Helsinki 1982. 


\section{Kriisiajan yhteisvastuu}

\section{Ensikoti-toiminta eriytyy}

Kun arvioidaan sosialidemokraattisen naisliiton toimintaa 1900luvun vaihteesta talvisodan syttymiseen, on yllättävää, kuinka paljon poliittinen naisjärjestö teki sosiaalista hyväntekeväisyystyötä lasten hyväksi. Sota-aikana tämä laajaksi käynyt tehtäväsarka kuitenkin eriytettiin erillisorganisaatiokseen. Tärkeä motiivi eriyttämiselle oli valtionavun lisääntyminen lapsityöhön uuden järjestön myötä: parempien resurssien tuella työtä voitiin tehdä järjestelmallisemmin ja asiantuntevammin.

Lastensuojelu ja äitien huolto oli lähellä naisliiton sydäntä toiminnan alkuajoista lähtien. Vuosisadan alussa huoli maalta kaupunkeihin muuttaneiden piikatyttöjen sijoittumisesta johti paikanvälitystoimistojen perustamiseen. Naisliitto vaati vuonna 1905 kunnallisten äiti-lapsi -kotien perustamista epäinhimilliseksi koetun kunnalliskoteihin sijoittamisen sijasta. Päästyään vaikuttamaan eduskuntatyöhön oli työläisnaisedustajien ensimmäisiä aloitteita aviottomien lasten aseman kohentaminen.

Hilja Pärssinen esitti kesäkuussa 1907 pidetyssä istunnossa "että ryhdyttäisiin perustamaan naimattomia äitejä ja heidän lapsiaan varten koteja, joissa vastuunalaisuus-tunne herätetään ja syvennetään ja äitejä kehitetään itseapuun, sekä, joissa orvot ja turvattomat lapset saisivat kunnollisen hoidon ja kasvatuksen". Ehdotus oli aikanaan ennakkoluuloton ja rohkea. Ei siis ihme, että se herätti laajan väittelyn eduskunnassa, asiasta käytettiin peräti 29 puheenvuoroa. Mielenkiintoisella tavalla eduskunnan naisrintama jakaantui kahtia, vaikka porvarilliset naiset olivat esittäneet myös avioliiton ulkopuolella syntyneiden lasten aseman kohentamista. Suomalaisen puolueen tiukkalinjaiset edustajat hyökkäsivät opettajatar Hilda Käkikosken johdolla avoimesti Pärssistä vastaan. Käkikoski suorastaan ilkkui: "Mikä on se hyvä työ, josta näitä puheena olevia naisia on palkittava?!” Äitien avustamisen sijasta oikeistonaiset vaativat isien etsimistä ja asettamista vas- 
tuuseen. Eräät edustajat vertasivat työläisnaisten vaatimia turvakoteja porttoloiksi, jotka "sikisivät siveettömyyden mätähaavasta" ja leimasivat aviottomat äidit langenneiksi huonoiksi naisiksi.

Pärssinen ja muut työlaisnaisedustajat esittivät, että aviottomien äitien ja lasten surkea asema oli yhteiskunnallisten olojen syytä ja siksi yhteiskunnan tuli järjestää heille inhimillisemmät olot. Pärssisen mukaan "tällainen äiti on tavallisesti kotoisin alaluokasta, köyhälistön kerroksista...Hän on saanut nähdä sekä hengen että ruumiin nälkää... Kun tällainen köyhä tyttö 9-10 vuotiaana lähetetään palvelukseen, niin muuttuu hänen asemansa vielä surkeammaksi. Sinä aikana, jolloin hän olisi oikeutettu saamaan kasvatusta ja kouluopetusta, hänen täytyy mennä vieraan luokse orjana raatamaan..." Tällainen turvaton tyttö joutui usein viettelijän uhriksi, sillä tämä usein aviossa oleva mies ei lähestynyt Pärssisen mukaan varakkaiden kansanluokan tyttäriä. Näin siksi, että näillä oli perheen ja suvun suoja turvanaan. Pärssinen kuittasi Käkikosken ynnä muiden siveettömyys-syytökset julistamalla, että avioliitoissa oli yhtä paljon siveettömyyttä kuin niiden ulkopuolella. Työläisnaisten ehdotusta kannattivat vain nuorsuomalaiset naiset, opettajattaret ja ystävykset Lucina Hagman ja Alli Nissinen. ${ }^{1}$

Aviottoman äidin ja hänen lastensa asian eteneminen vei pitkän ajan, siksi syvällä ennakkoluulot olivat päättäjien mielissä. Kansanedustajien kiihkeän tuomitsevat kannanotot kielivät tiukentuvasta moraalikoodistosta, jota istutettiin kaupunkimaiseen elämänmenoon. Vielä 1800-luvulla maaseutuyhteisöissä hyväksyttiin esiaviolliset suhteet, kunhan ne johtivat avioliittoon. Saattoipa raskaana oleva morsian olla työvoimavaltaisessa yhteisössä toivottukin: suvunjatkamiskyky kun tuli näin todistetuksi.

Avioliiton ulkopuolella syntyneen lapsen asema määriteltiin vuoden 1922 laissa. Lakia uudistettiin vuonna 1927 siten, että äidillä oli mahdollisuus hakea elatusmaksua lapsen isältä. Käytännössä tämä oli kuitenkin vaikeaa ja saatu avustus pieni. Monta kertaa synnyttävä naimaton nainen menetti asuntonsa ja työpaikkansa "syntinsä palkaksi". Ei ollut harvinaista, että abortteja tehtiin laittomasti ja laillisesti. Sanomalehdistä saatiin lukea myös ilmoituksia, joissa tulevat äidit tarjosivat vastasyntyneitä kasvateiksi.

1 Valtiopäivät 1907, pöytäkirja II, s. 470-511; Käkikoskesta ks. Ahtisaari 1997, s. 213-241. 
Lastenhuollossa saavutettiin kuitenkin yksi tärkeä edistysaskel, kun kuntiin määrättiin erityiset lastenvalvojat hoitamaan "ruokkomaksujen" perintää. Tehostettu elatusmaksatus määriteltiin vuoden 1949 laissa.

Kun eduskuntatyö ei lukuisista yrityksistä huolimatta näyttänyt tuottavan tarpeeksi nopeasti tuloksia tai tulokset koettiin riittämättömiksi, ryhtyivät sosiaalidemokraattiset naiset puheista tekoihin. Naisliitto teki päätöksen aviottomien äitien ja heidän lastensa tueksi rakennettavista turvakodeista vuonna 1929. Jo vuosisadan alussa kehitetyn idean herätti henkiin liiton sihteeri Hilda Seppälä: "Olen tullut tätä asiaa ajatelleeksi nähdessäni, miten valtio avustaa kaikkia porvarien perustamia, jos minkä nimisiä koteja ja hoitoloita. Miksi emme mekin voisi perustaa ja hoitaa tällaisia laitoksia meille mieluisessa hengessä?" Hilja Pärssinen tuki Seppälää, mutta "veli Ida", Ida Aalle-Teljo ja Miina Sillanpää epäilivät hankkeen menestymistä. Sillanpää arveli, että oli parasta tyytyä siihen, mitä valtio ja kunnat tällä alalla saisivat aikaan. Asia ei ollutkaan aivan yksinkertainen, olihan yksityisen turvakodin rakentaminen ristiriidassa naisliiton vanhan, hyväntekeväisyyttä vierastavan periaatteen kanssa. Liiton mukaan kuntien tuli hoitaa äidit ja lapset, ei yksityisten armonantajien. ${ }^{2}$

Epäilyistä huolimatta Hilda Seppälä uskoi asiaansa ja esitti erillisen Työväen Kukkasrahaston perustamista turvakotien rahoituksen varmistamiseksi. Traagisella tavalla Seppälän oma kuolema (1932) sinetöi päätöksen hankkeelle edulliseksi: Kun jäsenyhdistykset halusivat muistaa pidettyä sihteeriään, kehotti naisliitto kukkien asemasta merkitsemään summan Hilda Seppälän nimeä kantavaan rahastoon, joka tulisi jakamaan varoja turvattomille äideille ja lastenkodeille. ${ }^{3}$ Varoja tulikin ja näin ensikotitoiminta sai sosialidemokraattisessa naisliitossa alkunsa.

Erillinen Työläisäitien ja Lasten Kotiyhdistys perustettiin vuonna 1936. Ensimmäisenä järjestäytyivät hankkeen taakse helsinkiläiset naiset. Tässä vaiheessa myös Miina Sillanpää lämpeni asialle. Varoja yhdistys sai aluksi raha-automaattiyhdistykseltä. Vuonna 1940 voitiin aloittaa ensimmäisen ensikodin rakentaminen. Helsingin kaupunki antoi tontin vuokratta käyttöön ja talo valmistui

2 Suomen Sosialidemokraattisen Työläisnaisliiton XII edustajakokouksen pöytäkirja 28.31.5.1929, s. 35-37.

3 Suomen Sosialidemokraattisen Työläisnaisliiton XIII edustajakokouksen pöytäkirja 28.31.10 .1932 , s. 50-51. 


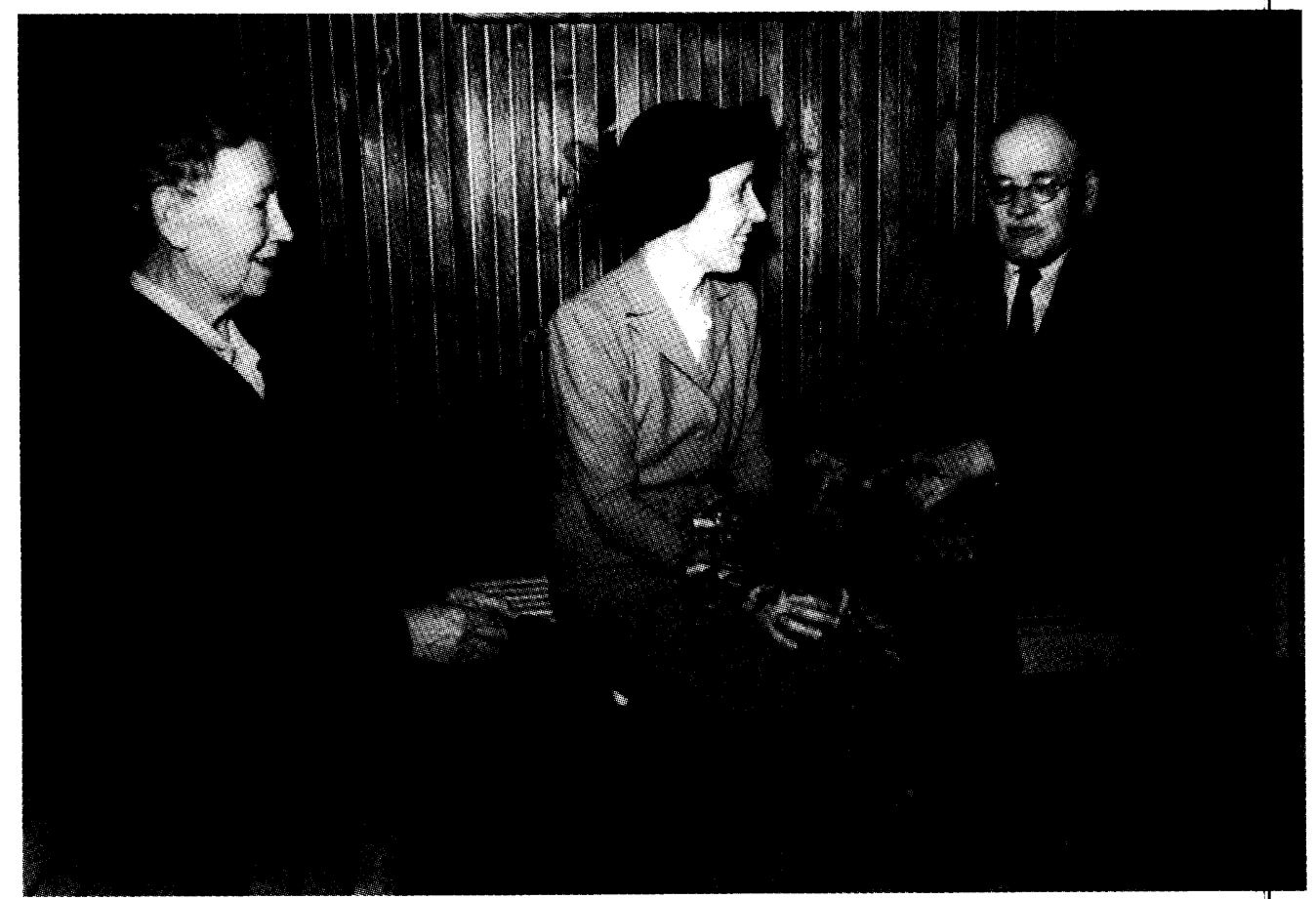

Helsingin Ensi Kodin talon katselmus 2.6.1942. Vasemmalla Miina Sillanpdä, keskellä Gerda Ryti ja oikealla Väinö Hakkila. Seurue istuu saunan lauteilla. Kuva: Työväen Arkisto.

kesäkuussa 1942. Eri paikkakunnille nousseiden ensikotien kattojärjestöksi perustettiin vuonna 1945 Ensi Kotien Liitto. Nopeasti kohosi yhä uusia ensikoteja: vuosina 1948-61 perustettiin seitsemän kotia. Niiden toimintaperiaate oli yhdenmukainen: äidit tulivat kotiin noin kuukautta ennen synnyttämistä ja olivat puoli vuotta synnytyksen jälkeen "turvassa". Äideille opetettiin lastenhoitoa, lasten ulkoiluttamista ja vaatteiden valmistamista. Äidit osallistuivat kodeissa myös ruoanlaittoon ja siivoukseen, osa kävi töissa kodin ulkopuolella.

Naisliittolaiset arvelivat, että ensikotien myötä pilkka ja häpeä, joka liitettiin naimattomiin äiteihin, hälvenisi. ${ }^{4}$ Naisliiton saama palaute ensikotitoiminnasta oli hyvin myönteistä. Osa ensikodeissa olleista äideista alkoi sittemmin toimia myös itse kotien tukemiseksi, kuten seuraavan kirjeen kirjoittaja kertoo: "Koko tämän pitkän taipaleen Ensi kodista lähtöni jälkeen, on Ensi koti ja sen toi- 
minta ollut hyvin lähellä sydäntäni...tässä työssä varmaankin voisin olla mukana. Jos voin jotain tehdä teen ilomielin, kiitokseksi siitä hyvästä mitä Ensi koti tarjosi minulle siellä ollessani... ” Kirjoittaja oli pakotettu nuorempana tekemään abortti miehen vaatimuksesta. Vuosikaudet oli teko kalvanut kirjoittajan mieltä, syyllistänyt ja ahdistanut. Kun hänen taloudellinen tilanteensa sittemmin hieman kohentui, uskaltautui hän hankkimaan naimattomana toisen lapsen "saadakseni tunnolleni rauhan ja äidilliset vaistoni tyydytetyksi". 5

Ensikoti-toiminnan eriyttämisen myötä sosialidemokraattinen naisliitto jatkoi äitien ja lasten tukitoimintaa osallistumalla aktiivisesti lainsäädäntötyöhön eduskunnassa. Alalla saavutettiinkin merkittäviä uudistuksia jo ennen sotia: vuoden 1936 lastensuojelulaki ja vuoden 1937 äitiysavustuslaki olivat niistä tärkeimpiä. Näin sota-aikana ja sen jälkeen tehdyn sosiaalisen lainsäädäntötyön perusta luotiin jo 1930-luvulla. ${ }^{6}$

\section{Sota-ajan huoltotyö}

Naisliiton käytännöllinen huoltotoiminta syrjäytti poliittisen työn syksyn 1939 kertausharjoitusten ja talvisodan puhkeamisen (30.11. 1939) vuoksi. Isien lähdettyä kotoaan tarvitsivat monet perheet ulkopuolista apua. Talvisotaan rientävien miesten asusteet olivat lisäksi kehnot ja lämmintä vaatetta tarvittiin valtavat määrät. Myös rajaseudun siirtoväki kaipasi tukea. Tämä kaikki johti siihen, että erilaiset kansalaisjärjestöt lähtivät joukolla vapaaehtoistyöhön mukaan.

Sosialidemokraattinen naisliitto lähetti osastoilleen 18.10.1939 kiertokirjeen, jossa se kehotti naisyhdistyksiä ja jaostoja perustamaan ompeluseuroja valmistamaan lämpimiä vaatteita reservissä oleville miehille ja heidän perheilleen. Lähes 200 naisosastoa sai liiton toimiston kautta lahjoituksina kankaita ja lankoja, joista ne kuuluisat naisten näppärät kädet valmistivat vaatteita niitä tarvitseville. Marraskuussa 1939 alettiin koko valtakunnan tasolla organisoida huoltotoimintaa. Sen keskukseksi tuli Sosiaaliministeriön alainen Vapaan Huollon keskustoimikunta ja alaisuuteen lääni- 


\section{*Lastenneuvolat ja äitiyspakkaukset}

Lasten neuvolatoiminta on ennaltaehkäisevää terveydenhoitoa. Neuvoloiden syntyhistoria voidaan ajoittaa vuosisadan alkuun, jolloin Maitopisarayhdistys aloitti toimintansa Helsingissä (1904). Toimintamuotonsa yhdistys otti suoraan Ruotsista, minne se oli omaksuttu Ranskasta. Helsingin jälkeen neuvonta-asemia perustettiin Viipuriin, Tampereelle, Mikkeliin ja 17 muulle paikkakunnalle. Aluksi yhdistysten tehtävänä oli maidon ja maitoseosten jakelu, mutta toiminta laajeni pian yleisemmäksi lasten terveyttä ja terveydenhoitoa koskevaksi neuvonnaksi. Alkuaikojen työmuotoihin kuuluivat myös hoitajien kotikäynnit, jolloin varattomat äidit saivat lainata vaatteita vauvoilleen sekä käytännön neuvoja. Neuvolatoimintaa kehitti edelleen Mannerheimin Lastensuojeluliitto, joka vuonna 1922 avasi oman pienten lasten huoltolan. Lakisääteistä lastenneuvolatyötä on Suomessa tehty vuodesta 1944, jolloin kuntia velvoitettiin pitämään yllä ja perustamaan äitiys- ja lastenneuvoloita. Vuodesta 1945 lähtien lastenneuvolajärjestelmään on kuulunut suurin osa syntyneistä ikäluokista.

Ensimmäiset järjestelmälliset suunnitelmat valtion äitiysavustusten jakamisesta laadittiin vuonna 1935. Laki äitiysavustuksesta annettiin syyskuussa 1937 ja se tuli voimaan seuraavan vuoden alusta. Lakia uusittiin vuosina 1941 ja 1949. Ensimmäisessä laissa avustuksen saannin ehto oli vähävaraisuus, joka myöhemmissä uudistuksissa poistettiin. Jälkimmäiseen lakiin lisättiin kuitenkin avustuksen saannin ehdoksi se, että odottavan äidin oli käytävä lääkärin tai terveydenhoitajan tarkastuksessa raskauden aikana:

"Äitiysavustuslaki pyrkii tarjoamaan äideille - noille pienoisvaltioitten, kotien - haltijattarille jatkuvaa terveyttä ja nuoruutta niin, että ne aikaisemmin esiintyneet surulliset kuvat, jolloin jo 30-vuotias nuori äiti muutaman synnytyksen jälkeen saattoi näyttää mummolta, häviäisivät näköpiiristämme. '"

Äitiysavustuspakkausten saajien määrä oli ensimmäisinä jakovuosina 1938-39 noin 50 000, vuoteen 1950 mennessä määrä oli kaksinkertaistunut. Avustusten arvo oli 450 markkaa ja siihen kuului rahan lisäksi

kohtaiset huoltotoimikunnat. Sosiaalidemokraattisia naisia osallistui runsain joukoin näiden toimikuntien työhön. Naisliittoa edustivat Vapaan Huollon keskustoimikunnassa Martta Salmela-Järvinen ja Sylvi-Kyllikki Kilpi.

Talvisodan sytyttyä keskustoimikunnan nimi vaihtui Suomen Huolloksi. Naisliitto oli aktiivisesti mukana tässä organisaatiossa, mutta myös monissa muissa sota-ajan huolto- ja järjestelytöissä, 


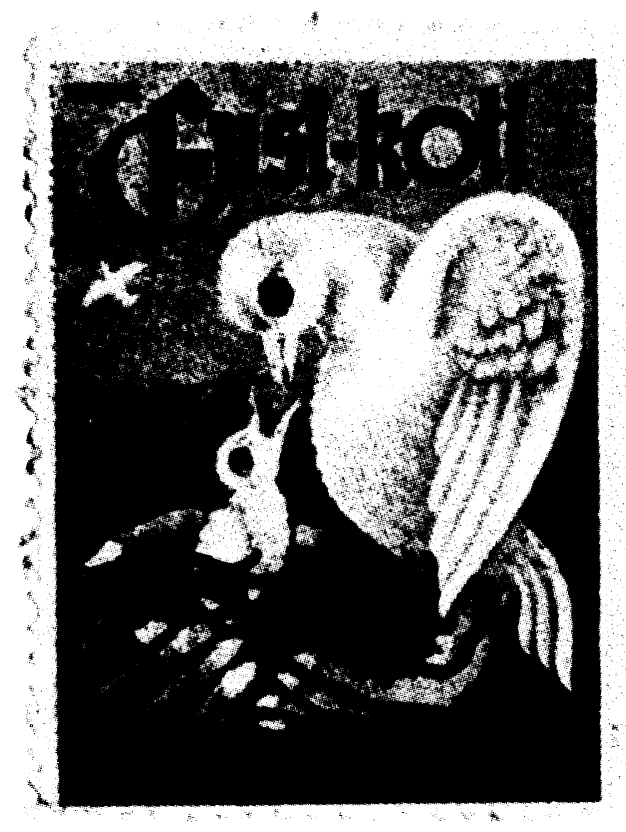

Turun Ensi Kodin toiminnan tukemiseksi myyty kirjemerkki. Koti perustettiin vuonna 1951. Kuva: Työväen Keskusтияеo.

tekstiilejä sekä äidille että lapselle. Vuoden 1938 äitiyspakkauksessa äideille annettiin lakanoita, sideharsoa ja vanua, lapselle napavöitä, paitoja, kapaloita ja pesulappuja. Vuoden 1941 pakkauksen uutuutena oli nykyisinkin vielä käytössä oleva pahvilaatikko lapsen ensisängyksi. Erillistä vauvansänkyä perusteltiin tautien tartuntavaaran ehkäisyllä. Seuraavana vuonna mukana oli lisäksi Ohjekirja tulevalle äidille ja lahjoituksena saatua saippuaa. Vuonna 1947 pakkauksessa oli lisäksi vauvalle ylellinen röyhelökaulus.

Lähde: Helsingin Maitopisarayhdistyksen johtokunnan vuosikertomukset 19051940. Helsingin Kaupunginarkisto; Valtion lahja Suomen äideille. Äitiysavustustoiminta 10-vuotias. Helsinki 1948. Sosiaaliministeriön arkisto. KA.

kultaesineitä keränneessä Kultakeräystoimikunnassa (Anni Huotari ja Elli Nurminen), lapsia Ruotsiin lähettävässä Pohjoismaisen avun keskuksessa (Tyyne Leivo-Larsson ja Martta Salmela-Järvinen), rautaromun ynnä muiden jätteiden keruuta järjestävässä Maan Romu -järjestössä (Helmi Toivonen) ja invalidien huoltojärjestelyissä. Liitto osallistui lisäksi Naisten Työvalmiusliiton perustamisvalmisteluihin ja toimintaan (Tyyne Leivo-Larsson ja Selma 
Hiisivaara). Naisliitto oli mukana myös Työvalmiusliiton organisoimassa Rajan Apu -toimikunnassa (puheenjohtajana Martta Salmela-Järvinen). Jälkimmäisen tehtävänä oli sotatoimialueiksi joutuneiden rajaseutujen ihmisten avustaminen. Toimikunnan ehkä merkittävin hanke oli lastensairaalan perustaminen Suomussalmelle. Naisliiton toiminta sodan poikkeusaikana oli erityisen vilkasta ja laaja-alaista, kuten muun muassa ensikotihanke osoittaa. ${ }^{7}$

\section{Kummilapset}

Sosialidemokraattinen naisliitto oli myös mukana järjestämässä kummilapsitoimintaa. Liitto sai kesällä 1940 Sveitsin Työläisten avustusjärjestöltä 12000 Sveitsin frangia, jotka se jakoi avustuksina 110 suomalaiselle kummilapselle. Lapsista otettiin valokuvat henkilötietoineen Sveitsin kummeille. Kummirahaa maksettiin työläisjärjestöihin kuuluvien sotaleskien lapsille. Kun Sveitsin raha loppui, jatkoi naisliitto kummitoimintaansa. Varoja se keräsi omilta osastoiltaan, eri ammattiliitoilta sekä muilta työväenjärjestöiltä. Myös naisliiton oma, vuonna 1932 perustettu Kukkasrahasto antoi varoja kummitoimintaan. Lisäksi valtakunnalliselta Suomen Huollolta saatiin varoja aina vuoteen 1949. Sen jälkeen naisliitto jatkoi vielä kummiavustuksiaan vuoteen 1962 saakka. ${ }^{8}$ Viimeinen kummilapsi oli Isma Veikkalainen. Hänen täytettyään 16 vuotta päättyi naisliiton kummityö.

Valtaosa kummilapsista oli puoliorpoja: isä oli kaatunut sodassa ja äiti hoiti lapsia yksin. Eräs kummilapsista oli porilainen, 2vuotias Terttu, joka otettiin kummilapseksi heinäkuussa 1942. Hänen kummiavustuksensa oli 200 markkaa kuukaudessa ja sen maksattamisesta huolehti tehtävään valittu "isännöitsijän rouva". Tertun äiti oli ravintola-apulainen ja työmies-isä oli kuollut haavoituttuaan sodassa. Äiti sai pienen palkkansa lisäksi sotakuukausipalkkaa. Terttu oli perheen ainoa lapsi. Avustuksen antamista ehdotti Porin sosialidemokraattinen naisyhdistys, jonka nimetty jäsen kävi Tertun kotona useamman kerran kotikäynneillä: "30.12. 1943 Terttu on aikaisemmin sairastanut tuhkarokon sekä jälkitautina pitkäaikaista yskää, nyk. terve. Harrastaa ulkoilua...". Toi-

7 Sos.dem. naisliiton huoltotoiminta 1939-40. Sos.dem. naisliiton arkisto. TA.

8 Sos.dem. naisliiton kertomukset 1939-62. TA. 


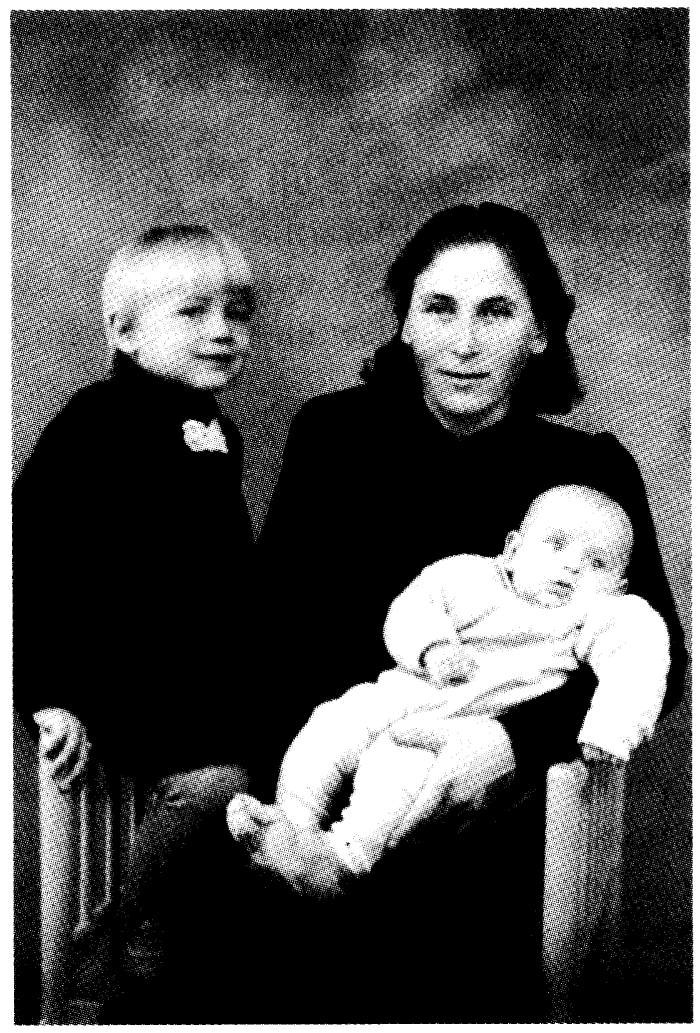

Eräs Sosialidemokraattisen naisliiton kummilapsista oli kemiläinen Toivo Koivusaari. Kuvassa Toivo poseeraa äitinsä ja pikkusisarensa/veljensä kanssa vuonna 1942. Perheen isä kaatui talvisodan taisteluissa Kuhmossa. Kuva: Työväen Arkisto.

sen kotikäynnin jälkeen "tarkastaja" selosti: "Äiti on Tampereen talouskoulussa 4,5 kk. Terttu on hoidettavana sotalesken X luona. Rahaa tarvittaisiin toistaiseksi vaatteiden ostoa varten...". Myös äiti kirjoitti tyttären voinnista naisliittoon: "7.6.1944 Terttu on sairastanut keskikorvan tulehduksen, mutta parantunut. Menee maalle kesäksi...". Kaiken kaikkiaan pikku-Tertulle maksettiin kuukausittain kolmena vuotena noin 8000 markkaa. ${ }^{9}$

Toinen esimerkkilapsi oli 8-vuotias iisalmelainen Ulla. Perheeseen kuului kolme lasta. Heidän isänsä oli kadonnut rintamalla talvisodan aikana. Ennen naisliiton kummiutta Ullalla oli ollut vuoden ajan yksityinen henkilö kummina. Äiti asui lastensa kanssa anoppinsa luona maksaen kiinteistömenot puoleksi tämän kanssa. Valtiolta äiti sai miehestään eläkettä. Kummisuhdetta ehdotti Iisalmen tyoväenyhdistyksen naisjaosto. Sen johto ilmoitti Ullan olevan etevän ja ahkeran koulussa: seitsemän oli alin numero todistuksessa. Myös tytön äiti kirjoitti säännöllisesti naisliittoon: "10.8.1944 Aseveljien hankkima oma koti on valmistumaisillaan.

9 Sotakummikortisto. Sos.dem. naisliiton arkisto. TA. 
Hirret on hakattu Rukajärvellä... "Ulla oli naisliiton kummilapsena viisi vuotta eli vuoteen 1949. Hänen kuukausittainen avustuksensa vaihteli 250-350 markan välillä. ${ }^{10}$

Kaiken kaikkiaan naisliiton kummilapsia oli useita satoja. Kummisuhde lopetettiin lapsen täytettyä 16 vuotta tai sitten kun äidit avioituivat uudelleen. Kuten edellä esitetyistä esimerkkitapauksista nähdään, kummilasten valitsemisen ja seurannan hoitivat paikalliset naisosastot. ${ }^{11}$

\section{Naisliiton työtuvat}

Naisten työpanos ompelu- ja muissa tuvissa oli poikkeusaikana hyvin tärkeä. Työtupatoiminta olikin yksi mittavimmista sota-ajan vapaaehtoistöistä talkoiden rinnalla. Työtupatoiminnalla on oma historiansa hätäaputöiden yhtenä muotona jo vuosisadan alusta. Muun muassa Helsingissä toiminta aloitettiin vuonna 1913. Toimintaa jatkettiin aina talvisodan puhkeamiseen saakka, jolloin se organisoitiin uudelleen. Myös yksityiset järjestöt perustivat naisten työtupia: muun muassa vuosina 1914-15 perustivat porvarilliset naisjärjestöt naisten työkodit Helsinkiin ja Viipuriin "pelastaakseen" maalta tulleita tyttöjä moraaliselta rappiolta. ${ }^{12}$

Sosialidemokraattisen naisliiton sodanaikaisissa tuvissa tehty työ ei ollut kaikilta osin vapaaehtoisuuteen perustuvaa, vaan työstä maksettiin 28 markkaa päivältä. Naisliiton ensimmäinen työtupa nousi Helsinkiin Vallilan työväentalolle vuoden 1940 alussa. Pian sen jälkeen järjestettiin neljä työtupaa eri puolille kaupunkia. Tuvissa valmistettiin lumipukuja, alusvaatteita, paperipatjoja, tallukoita, villapaitoja, lapasia ja sukkia. Töitä ohjasivat vapaaehtoiset käsityönopettajat. Työtuvat lopettivat toimintansa olojen tasaannuttua kesällä 1940. Syksyllä työttömyys kasvoi ja naisliitto perusti uuden työtuvan. Naisia tuvissa oli yli sata. Helsingin kaupunki, Sosiaaliministeriö ja Suomen Huolto tukivat taloudellisesti työtupien toimintaa. ${ }^{13}$

10 Sotakummikortisto. Sos.dem. naisliiton arkisto. TA.

11 Kummitoimintaa koskevat asiapaperit. Sos.dem. naisliiton arkisto. TA.

12 Naisten työkodit. Työväen Kalenteri 1934, s. 73-79; Kertomus Helsingin kaupungin kunnallishallinnosta 1938 , s. 265

13 Suomen sos.dem. työläisnaisliiton avustus- ja kurssitoiminta v. 1939-40. Sos.dem. naisliiton arkisto. TA. 


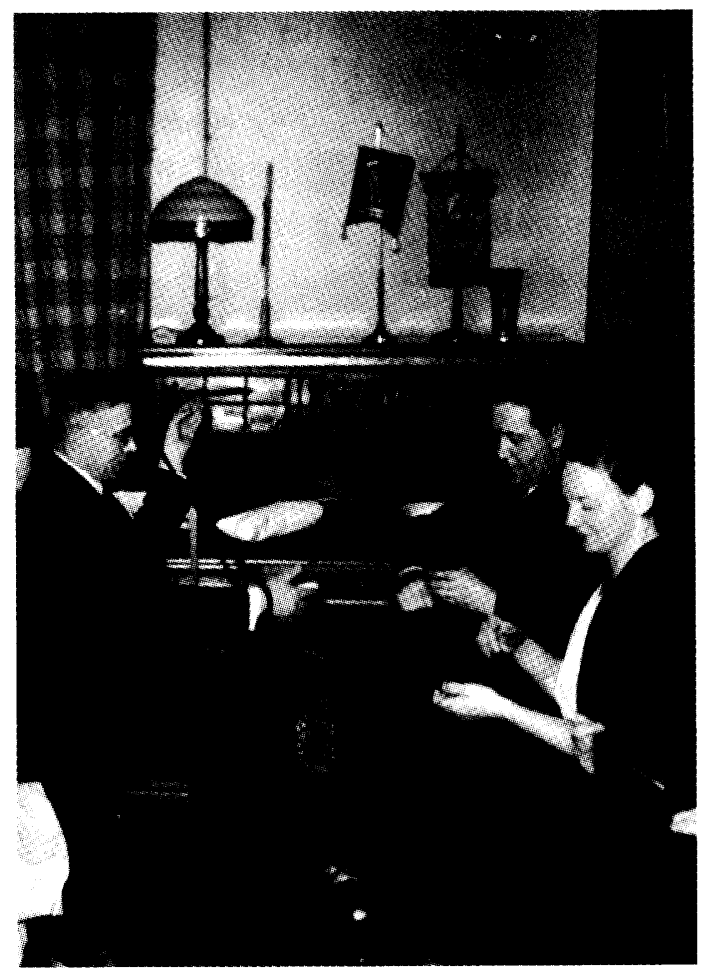

Pakettien kokoamisessa tuntemattomille sotilaille auttoivat myös miehet, mikäli osasivat. Kuvassa Rafael Paasio (oikealla) ystävineen koettaa saada lankavyyhtiä oikenemaan Sosialidemokraattisen naisliiton toimistossa. Kuva: Työväen Arkisto.

Työtupien lisäksi toimivat sota-aikana vilkkaasti naisliiton suuren suosion saaneet kotitalouskurssit, kuten seuraavasta taulukosta nähdään:

Sosialidemokraattisen naisliiton kotitalouskurssit vuonna 1940:

Piiri Kurssi- Osanotta- Luentoja Kuulijoita paikkakuntia jia

$\begin{array}{lrrrr}\text { Oulu } & 20 & 580 & 74 & 3290 \\ \text { Turku ja Pori } & 37 & 622 & 143 & 5783 \\ \text { Mikkeli } & 11 & 196 & 54 & 4480 \\ \text { Häme } & 43 & 1176 & 107 & 5735 \\ \text { Uusimaa } & 12 & 429 & 57 & 1310 \\ \text { Kuopio } & 21 & 492 & 156 & 7135 \\ \text { Vaasa } & 12 & 261 & 58 & 3339 \\ \text { Viipuri } & 11 & 510 & 28 & 2492 \\ \text { Lappi } & 13 & 423 & 67 & 3132 \\ \text { Yhteensä } & 180 & 4626 & 744 & 36696\end{array}$


Organisoidun ja järjestöjen kautta tapahtuvan avustustoiminnan lisäksi naisliitto sai pyyntöjä myös suoraan yksittäisiltä perheenäideiltä. Talvisodan aikana muun muassa rovaniemeläinen "seitsenhenkisen perheen köyhä äiti" ja rintamalla ollut mies pyysivät ja saivatkin apua naisliitosta: "Jos voisitte lähettää vaimolleni lahjakortin, että hän saisi ostaa ruokaa itselleen ja pikku Lassellemme tai lämmintä vaatetta. Perheeni on joutunut puutteeseen ja vaimoni on vielä sairas. Joka hetki heitä muistan. Mutta minun on täytynyt jättää ansiotyöni ja sotilaana täyttää tehtäväni viimeiseen asti...". ${ }^{14}$

\section{Työvelvollisuusnaiset Saksassa}

Sosiaalidemokraattiset naiset olivat 37:n muun järjeston kanssa perustamassa vuosina 1939-40 Naisten Työvalmiusliittoa, jonka tehtävänä oli organisoida vapaaehtoisuuteen perustuvaa naisten työpalvelua poikkeusoloissa. Mallia naisten työpalvelun organisoimiseksi haettiin Saksasta. ${ }^{15}$ Työvalmiusliiton hallituksen puheenjohtajana toimi sosiaalidemokraatti Tyyne Leivo-Larsson, joka teki toukokuussa 1941 opintomatkan Saksaan yhdessä työvalmiusliiton hallituksen jäsenten, poliittista oikeistoa edustaneiden Armi Hellsten-Kallian, Margit Borgin ja Ebba Östensonin kanssa. Naiset olivat saaneet kutsun Saksan hallitukselta Suomen ulkoministeriön kautta. Kulku- ja yleisten töiden ministeriö maksoi heidän matkakustannuksensa.

\section{Työpalvelua kansallissosialismin puolesta}

Koska suhde kansallissosialistiseen Saksaan on ollut Suomessa pitkään sodan jälkeen arka asia, on syytä tarkastella lähemmin naisten matkaa. Millä mielellä he sinne lähtivät ja mitä vaikutteita he sieltä saivat?

Suomalaisnaisten matka kesti viisi päivää tarkoin ennakolta suunnitellun ohjelman mukaisesti. Tutustuttaminen järjestelmään aloitettiin perinpohjaisesti. Heti aluksi suomalaiset vietiin tutustu-

14 Sos.dem. naisliitolle saapuneita kirjeitä 1940. TA.

15 Sinänsä mallin hakeminen Saksasta ei ollut uusi idea. Akateemisten Naisten Karjalaseura oli jo ennen talvisotaa käynyt tutustumassa Saksassa naisten työpalveluun. Ks. Heikinheimo 1942 , s. $42-57$. 
*“Emme ole elävää naista nähneet viikkokausiin..."

Sosiaalidemokraattisten naisten sota-ajan kirjeet ja paketit saivat lämpimän vastaanoton rintamamiehiltä. Seuraavassa näyte naisliittoon saapuneista kiitoskirjeistä:

-2.2.1940 Helsingin työväenyhdistyksen Neidot. Terveiset täältä kaukaa jostakin. Täällä annamme ryssää selkään että raikuu. Kuinka siellä kotirintamalla jaksetaan, onko "Molotofin" rauhankyyhkyt käyneet hävitysretkellä, onko kodit pysyneet pystyssä. Oletteko olleet terveitä. Täällä kyllä jaksamme hyvin ja on reipas mieli kaikilla ja hyvä taisteluinto. Eläkää vain toivossa, kyllä kohta saadaan ryssä ajetuksi uraliin, että ei se ikinä pääse meitä häiritsemään. Lähettäkää tänne jokunen kirjelappu, sillä täällä on hauskaa kun saa jonkun kirjeen lukeakseen... Hyvää vointia toivottaen teille Neitoset...Tkm S. Laitinen.

-Talvisen hämärän laskeutuessa rintaman ylle, konekiväärien rätinän ja tykkien kaukaisen jyskeen kantautuessa vielä korviimme saapui teidän pakettinne joukkueemme kämpälle. Jännityksellä ja riemulla se avattiin ja kovin tervetullutta sen sisältö oli. Yleisellä huutoäänestyksellä ratkaistiin kuka mitäkin lahjaa eniten tarvitsi ja sen oli saapa. Niin jaettiin paketista löytyneet 2 paria ihania villasukkia, yksi loistopaita ja "mammankultu" kaulanlämmittäjä. Kaikki tavarat joutuivat oikeille miehille. Kiitos, sydämellinen kiitos teille kauniista lahjastanne...Pieninkin naistemme osoittama ystävällisyys on ihmeen ihana asia, varsinkin kun täällä emme ole elävää naista nähneet enää viikkokausiin... $3 \mathrm{KKK} / 11 \mathrm{JR}: n$ pojat

-Osaatteko Te kuvitella, miten hauskalta yllätykseltä tuntuu saada lämpöiset ja pehmoiset jalkarätit väsyneisiin jalkoihin, kun on toista vuorokautta vaeltanut vihollisen alueella räntäkelillä ja edessä on nouseva, kipakka pakkanen? Entä osaatteko Te kuvitella, miten suuresti tuntemattoman lahja lämmittää tuntemattoman sotilaan sydäntä etenkin sen vuoksi, että se tulee aina iloisena yllätyksenä ja että se tuo mukanaan meille tänne etulinjoille voimakkaan tunteen siitä, että meillä on takanamme ja tukenamme Suomen kansan koko suuri yhtenäinen perhe. Viiden jalkarättiparin saajien puolesta kiitän siis Teitä, Arvoisat, Uskolliset ja Uutterat Työläisnaiset, yhtenä onnellisena vastaanottajana. St V.V. Vankkoja

-Lähetän teille parhaimpien tervehdyksieni ohella pienen pyynnön, koska tiedän, että sikäli kuin mahdollisuuksia on, te kykenette sen täyttämään. Täällä meillä on muutamalla pojalla puutetta villaisista alushousuista, tarkemmin sanoen viidestä parista sekä yhdestä villapaidasta... Muuten on meillä täällä (olemme kaikki H:gin poikia) kaikin puolin hyvät olot...Tänne näyttää siltä, etta rintaman se lohko, jonka työskentelyyn tekin menestyksellä olette osallistuneet on yhtä vahva ja muuttumaton kuin kaikilla muillakin tahoilla...Tervehtien Olavi Lindblom, Res. alikersantti

Lähde: Sos.dem. Naisliitolle saapuneita kirjeita 1939-40. TA. 
maan tyttöjen leiriin, sitten vähitellen työpalveluorganisaation huipulle asti eli seuraamaan ylimpien johtajien koulutusta. Vieraiden mielestä johtajakoulu oli "luonteeltaan kasvatuksellista syvämuokkausta", jonka tarkoituksena oli paitsi työopetus, myös "oikean hengen luominen johtajistoon". Politiikan tunneilla johtajakokelaat lauloivat ja tekivät "puhdetöitä". Joka-aamuinen lipputervehdys oli osa ideologista kasvatusta: naisten työpalvelun tärkein tehtävä oli Saksan kansan palveleminen sekä yksilöllisen ja joukkokurin ylläpitäminen.

Suomalaisnaiset havaitsivat heti, että Saksassa naisten työpalvelu oli paljon enemmän kuin kotitalousavun tai muun työpalvelun tarjoamista tai työttömyyden lieventämistä, kuten Suomessa. Työpalvelu oli Saksassa pakollista toisin kuin Suomessa. Sinne koottiin kutsuntojen kautta tietyn ikäluokan nuoret naiset. Ennen vuotta 1936 Saksassakin naisten työpalvelu oli ollut vapaaehtoista, mutta sen jälkeen se otettiin osaksi kansallissosialistien määrätietoista työpalvelusuunnitelmaa. Pakollisuus näkyi nopeasti työtyttöjen määrän kasvuna.

Saksalaisen järjestelmän tehokkuudesta kertoo se, että koko maa oli jaettu 26 naisten palvelupiiriin, joiden johtajat saivat käskyt keskitetysti suoraan valtakunnan johdolta. Kussakin piirissä toimi useampia leirejä. Nämä puolestaan oli jaettu ryhmiin, joissa oli kymmenkunta tyttöä tai naista ja ryhmäjohtaja. Koulutus kesti puoli vuotta, jonka jälkeen työtytöt ja -naiset lähtivat töihin pääosin monilapsisiin perheisiin kaitsemaan lapsia ja tekemään sisä- ja ulkoaskareita sekä maataloustöitä. Samoja töitä teetettiin työtytöillä ja -naisilla myös Suomessa.

Tytöt koulutettiin leireillä nimenomaan kotitaloustöihin. Olihan heidän tulevat tehtävänsä jatkossakin "saada vähäisin keinoin koti käytännölliseksi, iloiseksi ja viihtyisäksi”. Myös lastenhoidon opettelun nähtiin palvelevan naiseksi kasvamista: taito käsitellä lapsia ja kiintymys heihin oli parasta valmennusta omaa kotia varten. Tällainen koti-ideologia ei ollut yksin kansallissosialistien keksintö, kuten olemme nähneet työläisnaisjärjestöjen 1920-30luvulla harjoittamasta kotitalousvalistuksesta.

Suomalaiset retkeläiset arvioivat, että Saksan työpalvelussa korostettiin "uuden työn eetoksen" luomista, käden taitojen asettamista kunniaan ja sen tunnustamista siunaukseksi. Lasten työpalvelu nähtiin osana oppivelvollisuutta, jonka tavoitteena oli opettaa "yksittäisten ihmisten alisteisuutta kokonaisuutta kohtaan ja 


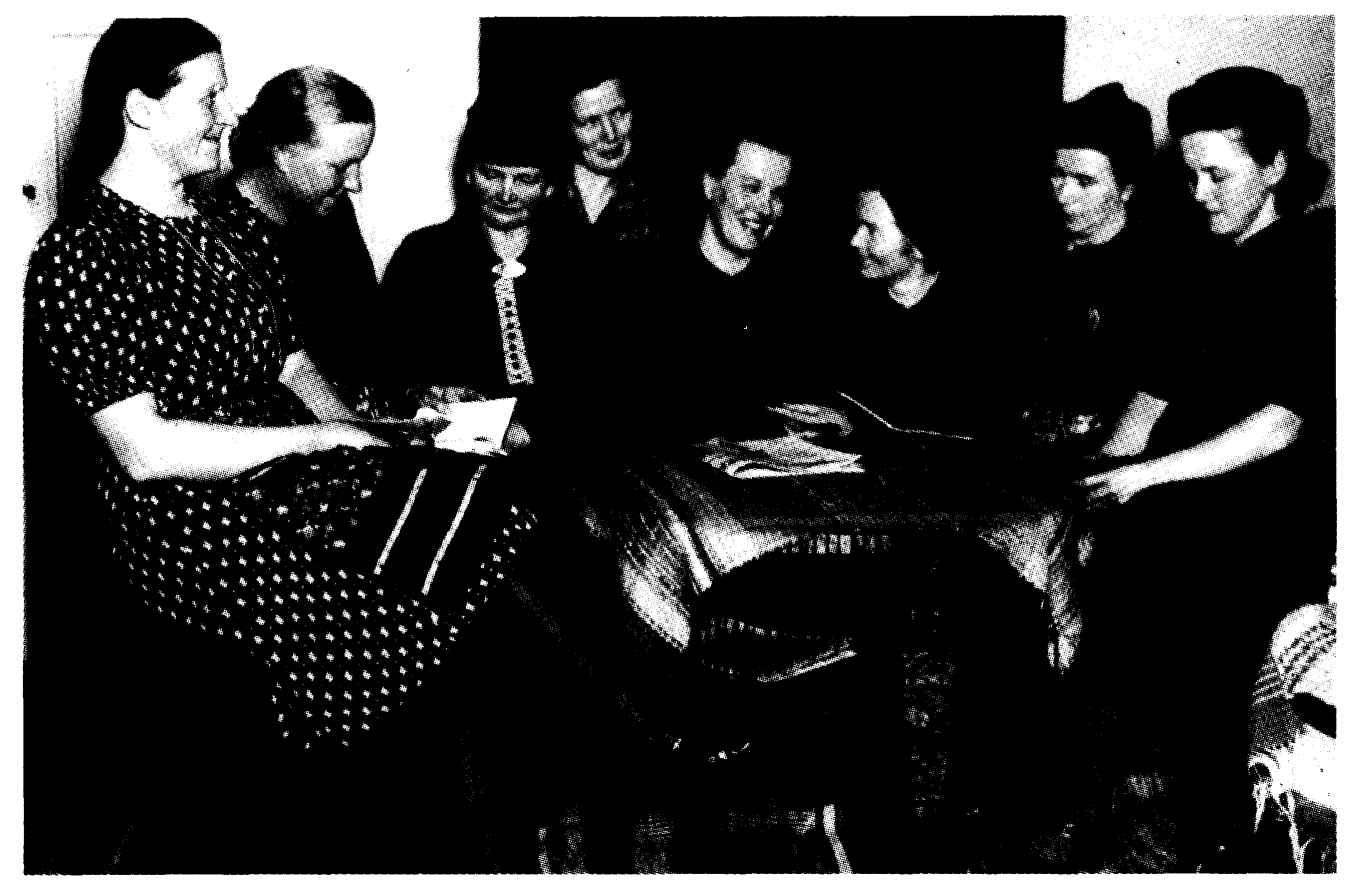

Jämsän Työväenyhdistyksen Naisjaoston opintokerho kokoontui myös sota-aikana. Kuva on vuodelta 1943. Päivän aiheena oli "Hurskas kurjuus". Kuva: Työväen Arkisto.

vuorenvarmaa uskoa johtajaan". Saksalaisessa työpalveluopetuksessa pantiin painoa myös sen opettamiseen, miten lapset ja nuoret käyttivät vapaa-aikaansa. Tällainen vapaa-ajan valtiojohtoisuus oli vuosilomalakien myötä omaksuttu Suomessakin 1920-30-luvulla. Muun muassa vuonna 1938 sosiaaliministeriö asetti erityisen lomankäyttökomitean pohtimaan vapaa-ajan käyttöä ja demokratisoimista. ${ }^{16}$

Eniten suomalaiset naiset vieroksuivat saksalaisessa mallissa Hitlerin ympärille rakennettua henkilökulttia. ${ }^{17}$ Leivo-Larsson ja kumppanit arvioivat, että Suomen oloihin niin henkilökeskeinen orientaatio ei sopisi, mutta sen sijaan Suomessa voitaisiin ottaa lähtökohdaksi jokin historiallinen aikakausi, joka on merkinnyt uuden ajan alkamista. Tällaiseksi historian tirkistysaukoksi ja kansakunnan yhteenliittäjäksi naiset esittivät talvisodan puhkeamista, joka "kerää kuin polttopisteeseen kansallisen herätyksen ja yhteiskunnallisten uudistusponnistusten luoman ja syvällisistä risti-

16 Ks. Lähteenmäki 1995, s. 140-148.

17 Naisten asemasta kansallissosialistisessa Saksassa ks. Bock-Thane 1991; Koonz 1986. 
riidoista kirkastuneen kansankokonaisuuden". Kuten otteesta huomataan, suomalaiset naiset omaksuivat nopeasti saksalaisen retoriikan. He näkivät myös, että poliittinen opetus meni parhaiten läpi, jos opettajalla oli selkeä maailmankatsomus ja yksinkertainen esitystapa.

Suomalaiset kiinnittivät matkallaan huomiota myös ruumiin kulttuuriin, jota saksalaisessa työpalvelussa korostettiin. Naisten mukaan siinä mentiin hieman liiallisuuksiin. "Ikärasistisesti" johtajilta edellytettiin ei enempää eikä vähempää kuin ikuista nuoruutta ja "naisellisen oman olemuksen hallintaa". Uusi niin sanottu arkikauneuden käsite ulotettiin myös työpalvelussa fyysisestä näyttävyydestä esineisiin ja elinympäristöön.

Kaiken kaikkiaan suomalaiset vierailijat arvelivat työpalvelua tehokkaaksi työmuodoksi, koska siihen sisältyi myös yhteisökasvatus. Toisaalta he epäilivät pakollisuuden vaikutusta työmoraaliin ja suosittivat vain asteittaista pakollisuutta, jos siihen ylipäätään päädyttäisiin. Muutenkin opintoretkeläiset olivat sitä mieltä, että saksalaista mallia ei voitaisi suoraan soveltaa Suomeen. He olivat iloisia siitä, että saksalaiset kutsuivat suomalaisia työpalvelun leirijohtajia ja niiksi koulutettavia opintomatkalle Saksaan. Näin sittemmin kävikin: keväällä 1942 Saksassa oli opintomatkalla 20 suomalaista työpalvelujohtajaa. ${ }^{18}$

Työpalvelunaisten Saksan matka oli siis antoisa, eivätkä retkeläiset missään kertomuksensa vaiheessa esittäneet kriittisiä arvioita Saksan oloista. Ajan henki oli Saksa-myönteinen ja aseveljeys hallituksen linja. Eri yhteiskuntaluokista ja ammattiryhmistä kävi useita vierailijoita Saksassa: muun muassa Työväen urheiluliiton urheilijanuorukaiset kävivät Väinö Leskisen johdolla siellä vuonna 1941 Hitler-Spartakiadeissa, syksyllä 1942 Saksaan matkusti Aseveliliiton valtuuskunta mukanaan Penna Tervo ja Väinö Leskinen. Väinö Tanner puolestaan kävi Saksassa samana vuonna Suomen hallituksen kanssa. ${ }^{19}$

18 Kulkulaitosten ja yleisten töiden ministerille. Kertomus Saksan matkasta 18.-22.5.1941 Armi Hellsten-Kallia, Margit Borg, Tyyne Leivo-Larsson ja Ebba Österson. Naisten Työvalmiusliiton arkisto. KA.

19 Keskinen 1978, s. 31; Hentilä 1982, s. 503-505, 524-525. 


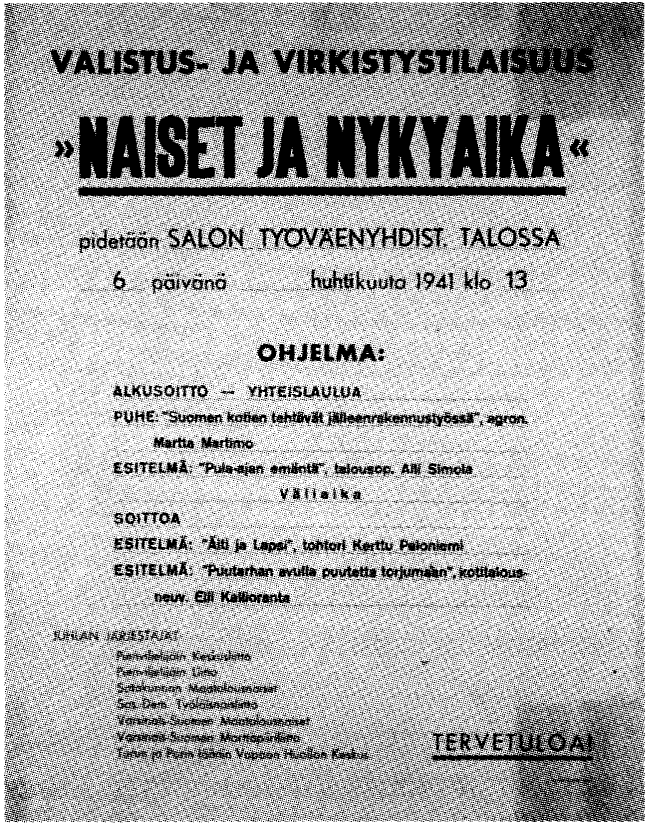

Työläisnaisia kutsutaan virkistys-ja valistustilaisuuteen vuonna 1941. Kuva: Työväen Arkisto.

Suomen malli "naisten asevelvollisuudesta"

Marraskuussa 1939 perustettu Naisten Tyopalveluskeskus organisoitiin uudestaan Naisten Työpalveluliitoksi 29.5.1940 eli noin viikko sen jälkeen, kun Tyyne Leivo-Larsson kumppaneineen oli käynyt Saksassa. Suomessa naisten työpalvelun muodoksi valittiin vapaaehtoisuus. Sosiaalidemokraatit vastustivat etenkin Akateemisten Naisten Karjalaseuran tukemaa saksalaista pakko-mallia. ${ }^{20}$

Ensi töikseen Työvalmiusliitto alkoi koota kortistoa yhteiskunnallisia asioita harrastavista naisista, jotka varsinaisen arkityönsä ohella olisivat valmiita ottamaan vastaan esimerkiksi sosiaalisessa toiminnassa ilmaantuneita tehtäviä. Liiton yksi tärkeä työmuoto oli nuorille naisille (16-25-vuotiaille) tarkoitetut, puoli vuotta kestäneet työleirit. Työtyttöjen tehtävänä oli auttaa, kuten Saksassakin, monilapsisia perheitä maaseudulla. Kaikkiaan työpalvelun suoritti Suomessa sota-aikana 1450 tyttöä. Toimintavaransa tyovalmiusliitto sai pääosin valtiolta. Aikuisten naisten osalta työ-

20 Toveritar 10/1941, s. 139; Salmela-Järvinen 1968, s. 53 
Kansallisen yhtenäisyyden pyrkimys kriisiaikana näkyi eri naisjärjestöjen yhteistyönä paitsi työpalvelussa ja huoltotoiminnassa, myös yksittäisten järjestöjen lähentymisenä. Sosialidemokraattinen naisliitto teki maaliskuun 6. päivänä 1940 päätöksen, että naisliiton jäsenet saivat liittyä lottiin ja antaa tarvittaessa tukeaan paikallisille lottajärjestöille. Vastaavasti lottien sallittiin liittyvän sosiaalidemokraattisiin yhdistyksiin: "Aktiivisiin maanpuolustustehtäviin haluavat sosialidemokraattiset naiset voivat ryhtyä Lotiksi... " Päätöstään naisliittotoimikunta perusteli sillä, että se noudatti Sosialidemokraattisen puolueen neuvoa: talvisodan riehuessa helmikuussa 1940 puoluetoimikunta ja SAK:n toimikunta antoivat nimittäin yhteisen julistuksen, jossa kehotettiin työväkeä suhtautumaan ennakkoluulottomasti suojeluskuntiin ja haluttaessa myös liittymään niihin jäseniksi.

Vaikka elettiin voimakkaassa poliittisen yhtenäistämisen paineessa, oli monille naisliittolaisille vaikeaa suhtautumisen muuttaminen lottajärjestöihin: ne oli nähty kansalaissodan raadollisten suojeluskuntien sisarjärjestönä. Asenteita oli vaikea muuttaa yhtäkkiä. Vaikka suositus yhteistyöstä annettiin epätietoiselle kenttäväelle, jäi epäilys itämään sodan päätyttyä.

Välirauhan aikana, toukokuussa 1941 pidetyssä edustajakokouksessa asia otettiin uudelleen esiin. Vanhemman puolueväen kerrottiin vieroksuvan yhteistyötä ja "routaa" järjestöjen välillä oli sopimuksesta huolimatta. Osa kokousedustajista vastusti sopimusta suoraan. Miina Sillanpää puolusti ratkaisua sillä, että puoluetoimikunnalla ei ollut "muuta mahdollisuutta" ja samoin teki naisliitto. Tarkoitus ei ollut kehottaa naisia liittymään lottiin, mutta liittyminen sallittiin virallisesti. Kyse oli suuresta sisäpoliittisesta asiasta: kriisitilanteessa oli saatava vanhat erimielisyydet pois päiväjärjestyksestä. Helpottuneina työläisnaiset panivat kuitenkin merkille, ettei joukkosiirtymää lottiin ollut tapahtunut, mitä oli hieman pelätty.

Vielä kesäkuun 1944 kokouksessaan naisliittolaiset olivat epäileväisiä yhteistyöstä muiden järjestöjen kanssa. Esimerkiksi otettiin Aseveliliitto, jonka toiminta oli joiltakin osin naisliiton periaatteiden vastainen. Paikallisissa asevelinaisissa toimi aktiivisesti myös näkyviä sosiaalidemokraattisia naisia, kuten Sylvi Siltanen Turussa. Myös Tyyne Leivo-Larssonin oloa Naisten Työvalmiusliitossa arvosteltiin. Kokous päätyi kuitenkin siihen, että yhteistoimintaa jatkettaisiin poikkeusolojen takia, vaikka siinä ilmenikin ongelmia. 
Naisliiton sodanaikaisella puheenjohtajalla Sylvi-Kyllikki Kilvellä olisi puoluetoimikunnan jäsenenä ollut mahdollisuus vastustaa suojeluskuntien ja puoluejärjestöjen yhteistoimintaa, mutta sitä hän ei tehnyt. Sylvi-Kyllikin puoliso Eino Kilpi istui niin ikään puoluetoimikunnassa toukokuussa 1940. Hänen mukaansa "kun on kyse lottatoiminnasta, niin en ole tavannut yhtään meikäläistä rintamalta palannutta sotilasta, joka ei olisi antanut tunnustusta rintamalla toimineille lotille". Puoluetoimikunnan jäsenistä ainoastaan K.H. Wiik vastusti alusta lähtien yhteistyötä suojeluskuntajärjestöjen kanssa. Osa ehdotti, että suojeluskunta-nimi muutettaisiin yhteistyön myötä "kotijoukoiksi". Suojeluskunnat eivät tähän kuitenkaan suostuneet.

Sodan päätyttyä suojeluskuntajärjestöt lottajärjestö mukaanlukien lakkautettiin.

Lähde: Sos.dem. naisliiton liittotoimikunnan pöytäkirjat 1939-44; Sos.dem. naisliiton XVI edustajakokouksen pöytäkirja 22.-24.5.1941, s. 17-18, alustukset s. 22-23; Sos.dem. naisliiton edustajakokouksen pöytäkirja 11.-12.6. 1944, s. 19-20 ja toimintakertomus 1942; sos.dem. puolueen puoluetoimikunnan pöytäkirjat 1940-44.TA.

JULKILAUSUMA

"Sos.dem. Puoluetoimikunnan julkilausuma.

Suomen Sosialidemokraattinen Puoluetoimikunta, jonka vuoden 1939 puoluekokous velvoitti neuvottelemaan suojeluskuntain johdon kanssa takeiden saamiseksi siitä, että suojeluskunnissa erinäisissä tapauksissa ilmennyt sosiaalidemokraatteja vieroksuva mieliala ja henki saataisiin ennen sosiaalidemokraattisten työläisten niihin liittymistä poistetuksi, selittää, neuvoteltuaan asiasta myöskin Suomen Ammattiyhdistysten Keskusliiton työvaliokunnan kanssa, että Suojeluskuntain päällikön ylläesitetyn kehoituksen jälkeen puoluetoimikunta ei katso enää olevan olemassa esteitä sosiaalidemokraattisesti ajattelevan työväen suojeluskuntiin liittymiselle."

Lähde: Sos.dem. puolueen puoluetoimikunnan pöytäkirjan 16.2.1940 liite 2 . Sdp:n arkisto. TA. 
palvelu muodostui naistyöttömyyden tasaustoiminnaksi, joskin sillä oli myös kasvatuksellisia tavoitteita - ainakin alussa. ${ }^{21}$

Muistellessaan myöhemmin Saksan matkaansa Tyyne LeivoLarsson on todennut, etta idea Saksan työpalveluun tutustumisesta tuli IKL:läiseksi luonnehtimaltaan Armi Hallsten-Kallialta. Muut seurueen jäsenet olivat suhtautuneet asiaan epäillen ja suostuneet lähtemaan ehdolla, ettei heidän matkaansa käytetä propagandassa "natsi-Saksan" hyväksi. Alun perin naiset päättivät keskenään, etteivät he tule antamaan haastatteluja sen enempää Saksassa kuin Suomessakaan - ja näin tapahtuikin: matkatiedot löytyvät vain Työvalmiusliiton arkistomateriaalin joukosta.

Myös Martta Salmela-Järvinen, joka oli Rajan Apu-organisaation puheenjohtaja ja siten mukana naisten työpalvelutoiminnassa, suhtautui varovaisesti oikeistonaisten "Kraft durch Freude"innostukseen. Monet muutkin naisjärjestöt olivat varauksellisia, mikä näkyi Helsingissä keväällä 1941 pidetyssä suuressa naiskokouksessa, jossa käsiteltiin "naisten asevelvollisuutta" eli kysymystä siitä, tulisiko naisten työpalvelu olla pakollinen myös Suomessa. $^{22}$

\section{Naisliiton sisäiset jännitteet}

Sota-aika oli sosialidemokraattiselle naisliitolle käytännön huoltotyön aikaa. Poliittiset intohimot nousivat kuitenkin sodan loppupuolella kärjekkäinä esiin. Myös naisliitto tempautui niihin mukaan etenkin puheenjohtajansa Sylvi-Kyllikki Kilven kautta. Kilpi oli ollut koko 1930-luvun naisliitossa äänekkäästi mukana, milloin järjestämässä Espanjan lasten avustuksia, milloin kritisoimassa kotitalouskursseja ja vaatimassa lisää aatteellista valistusta ja rauhantyötä. Sota-aikana hän oli esillä pakolaisten avustajana. Toisaalta sotatapahtumien yleinen käänne ja toisaalta oman perhepiirin sisäiset kriisit saivat hänet vuonna 1943 arvioimaan myös omaa poliittista kantaansa uudelleen. Hänen kaksi sisartaan, Aira ja Elvi, olivat kommunisteina turvasäilössä, poika Kalevi rintamalla Syvärillä ja toinen poika Yrjö rannikkotykistössä ja "itse olen kummallisesti ahdistunut". ${ }^{23}$

21 Saraste 1983, s. 146; Työtytöistä ks. Sysiharju 1997

22 Leivo-Larsson 1970, s. 33-36; Salmela-Järvinen 1968, s. 52-55.

23 Sylvi-Kyllikki Kilven päiväkirja 22.11.1943, ks. Kalemaa 1992, s. 199. 


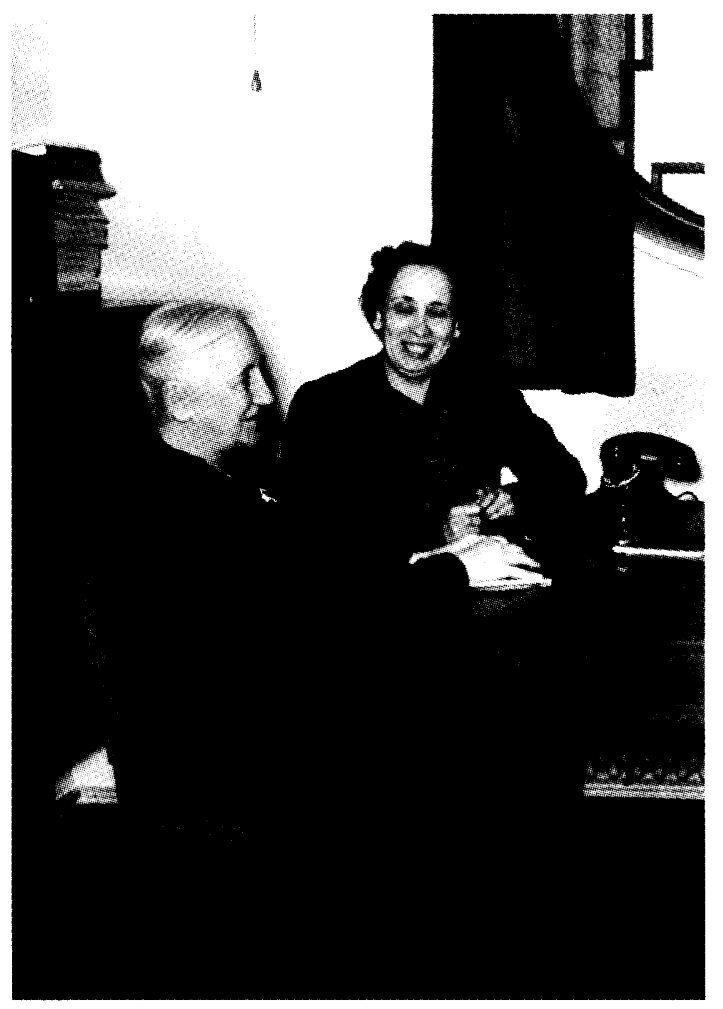

Kansanedustajia Anni Huotaria (1874-1943) ja Sylvi-Kyllikki Kilpeä (1899-1987) naurattaa eduskunnassa vuonna 1939. Kuva: Työväen Arkisto.

Kilpi alkoi osallistua aktiivisemmin ns. rauhanopposition toimintaan. Siinä oli mukana väkeä Urho Kekkosesta Ruotsalaisen Kansanpuolueen poliitikkoihin. Kilven suhtautuminen Kekkoseen oli myönteinen. Esimerkiksi puoluetoimikunnan kokouksessa 19.6.1944 Sylvi-Kyllikki esitti uudeksi pääministeriksi Kekkosta: "Hän ei ole ollut virallisesti oppositiossa, mutta hän ei ole vanhoillinen ja hän voisi ajaa rauhan asiaa ehkä suuremmalla harrastuksella kuin Ramsay...". ${ }^{24}$ Sosiaalidemokraateista rauhanoppositioon kuuluivat nimekkäimpinä Atos Wirtanen, Yrjö Kallinen ja Niilo Wälläri.

Ilmassa leijui pelko saksalaisten Suomen miehityksestä ja sotaväsymys painoi päälle. Tästä ilmapiiristä syntyi eri puolueista koottu Ryhmä 33:n kirjelmä presidentti Rytille. Sosiaalidemokraatteja allekirjoittaneiden joukossa oli 14, Sylvi-Kyllikki oli ainoa nainen. Muut naisliittolaiset olivat lojaaleja puoluejohdolle. Kirjelmässä kiirehdittiin erillisrauhan solmimista ja suhteiden solmimista Yhdysvaltoihin. Sosiaalidemokraattien keskuudessa kirje herätti

24 Sdp:n puoluetoimikunnan pöytäkirja 19.6.1944. Sdp:n arkisto. TA. 
ristiriitaisia tunteita: osa ajatteli, että allekirjoittaneet olivat rikkoneet törkeästi puolueen menettelytapoja. Kiistaa jatkettiin puolueneuvoston kokouksissa. Aluksi Sylvi-Kyllikki Kilpi pyrki luovimaan tannerilaisten riveissä, mutta marraskuussa 1943 hän kirjoitti päiväkirjaansa olevansa Tannerin vastaisen opposition edustaja. ${ }^{25}$ Eroprosessi sosiaalidemokraateista oli alkanut.

Sodan kriittisinä hetkinä, kesäkuun 11.-12. päivinä 1944 kokoontunut naisliiton edustajakokous alkoi synkeissä merkeissä. Kilpi piti liiton puheenjohtajana alustuksen poliittisesta tilanteesta ja vaati nopeaa irrottautumista sodasta ja "ennen kaikkea irrottautumista Saksan aseveljeydestä". Hän totesi lopuksi, että on turha kuvitella, että joku suurvalta kävisi taisteluaan Suomen puolesta. Selostus kuitattiin hiljaisuudella. ${ }^{26}$ Puoluetoimikunnan kokouksessa Kilpi puolestaan totesi heinäkuun alussa 1944: "Meikäläiset ministerit eivät voi enää kauan aikaa jäädä hallitukseen, elleivät halua natsistua..."27

Rauhanoloihin siirtyminen laukaisi lopulta sisäiset jännitteet avoimeksi konfliktiksi. Marraskuussa 1944 pidetyssä puoluekokouksessa Sylvi-Kyllikki Kilpi ei enää tullut valituksi puoluetoimikuntaan, vaan hänen paikkansa sai Martta Salmela-Järvinen. Hieman ennen puoluekokousta Kilpi tuki J.V. Ketoa, joka esitti puolueesta sodan aikana erotettujen ottamista takaisin. Erottaminen oli Kilven mukaan ollut "ikävä ja valitettava erehdys". ${ }^{28}$

Myös naisliitossa kuohui. Naisliittolaiset kävivät kiivaasti johtajataistoaan syyskuussa 1945 pidetyssä liittoneuvoston kokouksessa. Kilpi piti jälleen alustuksen poliittisesta tilanteesta. Se sai aikaan vastalauseiden myrskyn. Kyse oli sotasyylliseksi nimettyjen rankaisemisesta. Pidettiin epäoikeudenmukaisena, että osaa rangaistaisiin ja osaa ei. Kilpi jäi alustuksineen yksin. Kilven poliittinen kilvoittelu kesti kolmisen vuotta: kesäkuussa 1946 pidetyssä liittoneuvoston kokouksessa hän ilmoitti eroavansa heti naisliiton puheenjohtajan tehtävästä ja poistui salista.

Lähtiessään Kilpi jätti selostuksen eronsa syistä. Hän kirjoitti: "Liityin sos.dem. puolueen oppositioon sodan viimeisenä vuonna, mutta puoluekokouksen jälkeen jäin siihen ryhmään, joka ei voinut erota omasta puolueestaan vaikka sen johtoon pääsi sosiali-

25 Sylvi-Kyllikki Kilven päiväkirja 7.11.1943, ks. Kalemaa 1992, s. 205

26 Suomen Sosialidemokraattisen Työläisnaisliiton edustajakokouksen pöytäkirja 11.-12.6.1944, s. $16-17$.

27 Sdp:n puoluetoimikunnan pöytäkirja 1.7.1944. Sdp:n arkisto. TA

28 Sdp:n puoluetoimikunnan pöytäkirja 22.11.1944. Sdp:n arkisto. TA 
demokraattiselle ajattelulle vähemmän vieraita, etupäässä asevelitoiminnassa ja sotapropagandassa kunnostautuneita kapteeneita ja muita sotapolitiikassa aktiivisesti mukana olleita... " Liitto oli Kilven mukaan kokonaan ns. sotapolitiikan hyväksyneiden käsissä ja alistunut " $n s$. aseveliklikin suunnitelmien nöyriksi palvelijoiksi". Kilpi hyökkäsi ennen muuta liiton sihteeriä, Martta Salmela-Järvistä, vastaan. Kilpi valitti, että liiton sihteeri ja muut liittoimikunnan jäsenet yhtä lukuunottamatta (Lilli Pesonen) olivat tietoisesti vähentäneet hänen toimintamahdollisuuksiaan liitossa ja suorastaan syrjäyttäneet hänet edustustehtävistä, jotka olisivat kuuluneet puheenjohtajalle. Kilpi moitti myös Salmela-Järvisen tapaa hoitaa talousasioita.

Kilven piikittely oli välillä kovinkin henkilökohtaista: "Hosuminen monissa tehtävissä onnistuu 30 ja 40 vuotiaalta, ei enää onnistu sellaiselta, joka on sivuuttanut puolivuosisataa! ${ }^{29}$ Salmela-Järvinen oli tuolloin 54-vuotias, Kilpi 47-vuotias ja Leivo-Larsson 44-vuotias. Kilpi vaatikin suoraan luottamushenkilöiden nuorentamista, samoin aktiivisempaa panosta nuorten naisten vetämiseksi mukaan toimintaan.

Sinänsä ei ollut ihme, että Kilpi ja Salmela-Järvinen eivät enää mahtuneet samaan liittoon: Martan painoarvo liitossa oli noussut selkeästi kriisiajan ja Sylvi-Kyllikin poliittisen epävarmuuden kasvamisen myötä, samoin kuin Tyyne Leivo-Larssonin. Tässä vahvojen naisten kamppailussa Kilven oli väistyttävä. Asia ratkesi viimeistään silloin, kun Kilpi otti vastaan Suomi-NeuvostoliittoSeuran puheenjohtajuuden. Vaikka Sylvi-Kyllikki lähti liitosta ovet paukkuen, arvioi hän naisliitossa oloaikaansa ja vuosien 1941-46 puheenjohtajuuttaan myönteisesti: “... ne vuodet ovat merkinneet itselleni monella tapaa kehitysrikkaita ja erikoisesti naiskysymystä selventäviä vuosia...". Sosialidemokraattisen puolueen kansanedustajana hän ehti toimia 12 vuotta (1934-46).

Toukokuun 1947 kokoukseen mennessä pahimmat jännitteet olivat naisliitossa purkautuneet. Kiihkeän kommunisminvastaisuuden aikana naisliiton kokoukseen puolueen tervehdystä tuova puheenjohtaja Emil Skog totesikin: "Puolueemme sisällä ilmenneet ristiriidat ovat hävinneet olemattomiin ja ryhdikäs, taisteleva sosialidemokratia on tullut tilalle". ${ }^{30}$

29 Liitekirjelmä sos.dem. naisliiton liittoneuvoston pöytäkirjaan 14.6.1946. TA.

30 Sos.dem. naisliiton edustajakokouksen pöytăkirja 16.-17.5.1947, s. 9-19. 
*Naiset sotatarviketehtaissa, pelloilla ja talkoissa

Kun Suomen miehet taistelivat itärajalla maan itsenäisyyden puolesta, muodostivat naiset laajan huolto-organisaation eturintaman takana: sotaa ei olisi voitettu ilman naisten työtä. Perinteisissä sotahistorian tutkimuksissa keskitytään yleensä tarkastelemaan vain varsinaisia aseellisia yhteenottoja ja käskytyssuhteita, mutta unohdetaan se, etteivät miehet olisi voineet suorittaa tehtäväänsä ilman ammuksia, vaatteita, muonaa eikä ilman henkistä ja fyysistä huoltoa.

Porilainen Elvi Litonpalo oli eräs sotatarviketehtaan työläisistä. Hän työskenteli Porin Tulitikkutehtaalla eli Tikkulassa. Erityisesti hänelle on jäänyt mieleen Molotovin coctailien valmistus. Ne tehtiin käsityönä ja koska materiaali oli niin tulenarkaa, oli kaikkien samassa huoneessa työskentelevien oltava erityisen tarkkaavaisia. Jos valmistettavat sytytystikut vähänkään pääsivät hankaamaan toisiaan vasten, ne syttyivät räjähdysmäisesti. Onnettomuuksia sattuikin useita. Pahin onnettomuus sattui joulukuussa 1939. Eräs huolimaton työntekijä heitti rikkoutuneen tikun sytytysmassan joukkoon tuhoisin seurauksin. Eräs nainen paloi soihtuna kuoliaaksi ja useita muita naisia loukkaantui. Eniten tulitikkutehtaalaiset pelkäsivät pommituksia, joita Poriin tehtiinkin useita. Vihollinen yritti tuhota tehtaita ja lentokenttiä. Turvallisuussyistä naiset joutuivatkin työskentelemaan öisin. Kun Elvi teki sytytystikkuja, oli hänen miehensä rintamalla autonkuljettajana. Sota-ajan työstä sotatarviketehtaassa jäi Elville loppuikäinen ikävä muisto: hän sai tehtaassa käytetyistä kemikaaleista astman.

Kaiken kaikkiaan sotien aikana työskenteli sotatarviketeollisuudessa noin 70000 naista. Naiset tekivät muun muassa käsikranaatteja, tykinammuksia ja muita aseita. Varsinaisten ase- ja ammustehtaiden lisäksi lukuisten elintarvike-, säilyke-, jalkine- ja kutomatehtaiden tuotanto suunnattiin palvelemaan armeijan kysyntää. Naisten osuus teollisuustöissä oli korkeimmillaan vuonna 1943 (51\% työväestä).

Naisten siirtäminen miesten aloille, kuten metalliteollisuuteen, ei ollut yksinkertaista. Suurimmaksi ongelmaksi nähtiin naisten ammattitaidottomuus. Se pyrittiin ratkaisemaan rationalisoimalla, keventämällä ja yksinkertaistamalla työprosesseja. Sota-aika kiihdytti siten siirtymistä liukuhihnatöihin. Kaikkia töitä ei kuitenkaan pystytty keventämään ja niinpä esimerkiksi raskaissa ammussorvaamoissa naiset suorittivat lähes kaikkia työvaiheita. Työhön opastus oli vähäistä, yleensä vaihetta aikaisemmin hoitanut mies näytti mallia muutaman kerran ja naiset jatkoivat siitä. Ei siis ollut ihme, että työtapaturmia sattui tuon tuosta. 


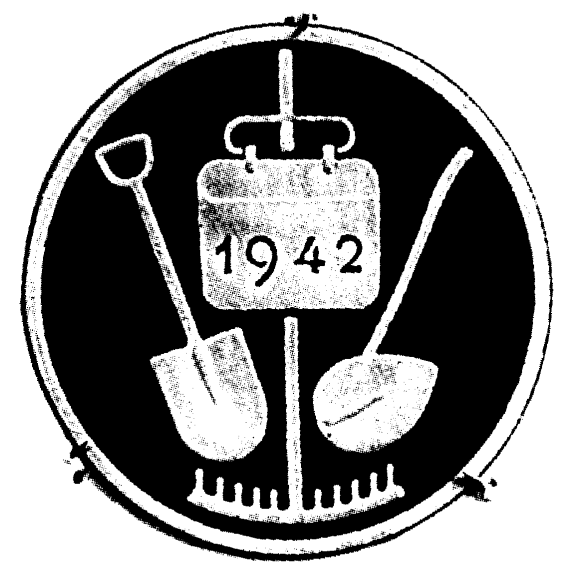

Sota-aika oli talkoiden kulta-aikaa. Kuvassa kirjeensulkijamerkki vuodelta 1942. Kuva: Työväen Keskusmuseo.

Paitsi sotatarviketeollisuuteen, naisia tarvittiin myös pientilavaltaisessa maassa maatalouden pyörittämiseen. Naisia määrättiin kevätkylvöihin, heinätöihin, puintiin ja perunannostoon. Koska elintarvikkeiden omavaraisuus oli sota-oloissa niin siviileille kuin sotilaillekin elintärkeä, vetosi maan hallitus muun muassa kuntatyönantajiin ja yksityisiin liiketyönantajiin, jotta nämä olisivat vapauttaneet kesiksi työntekijänsä maataloustöihin. Esimerkiksi vuonna 1943 määrättiin maataloustöihin lähes 150000 naista ja metsä- ja polttoturvetöihin noin 9 000 naista. Metsätöissä naiset tekivät ns. kevyempiä töitä, kuten keräsivat käpyjä, pihkaa ja parkkia, hakkasivat halkoja, purkivat lasteja ja istuttivat metsää.

Hyvin suosittu työ etenkin nuorten naisten keskuudessa oli puolustusvoimien tarjoama työ. Yli 200000 lottaa toimi hyvin monenlaisissa tehtävissä, kuten konttoristeina, ilmansuojelutehtävissä, muonittajina, sairaanhoitajina sekä kanttiinien ylläpitäjinä vihreiden sisarien eli sotilaskotisisarten ohella.

Yksi laaja toiminta-alue naisille oli vapaaehtoinen talkootoiminta. Muun muassa kampanjan "Miten viettää lomansa Suomen nainen kesällä 1942" avulla värvättiin asutuskeskusten naisia maataloustöihin. Talkoiden pääjärjestäjä, Suomen Talkoot/Suurtalkoot, organisoi lisäksi talkootyön naisvaliokunnan ja naisleiriosaston järjestämään naisten talkootoimintaa. Naisjärjestöjen panos tässa työssä oli mittava.

Lähde: Elvi Litonpalon haastattelu 16.1.1991. Nide nro 256/1221/4. Työväen Muistitietotoimikunta; Sotatarviketeollisuudesta mm. Saraste 1983; Nainen sodassa, kotona ja rintamalla 1939-1945 Suomen vapauden puolesta. Valitut Palat. Helsinki 1995. 


\section{Vaimoista palkkatyöläisiksi}

Työläisnaisten historian näkökulmasta sota-ajan poikkeusolot vaikuttivat monella tavalla heidän arkiseen elämäänsä. Ehkä vaikuttavin muutos perhe-elämään isien poissaolon lisäksi oli se, että myös äidit enenevässä määrin olivat töissä kodin ulkopuolella. Naimisissa olevien naisten osuus palkkatyöläisnaisista kaksinkertaistui sotavuosina. Esimerkiksi naisvaltaisessa vaatetusteollisuudessa oli vuonna 1929 ansioäitien osuus 14 prosenttia, vuonna 1946 heitä oli 32 prosenttia naistyöläisistä. Myös muilla naisia työllistäneillä aloilla, kuten liike-alan ammateissa, muutos oli samansuuntainen: vuonna 1935 liiketyöntekijöistä oli naimisissa 18 prosenttia, vuonna 1946 noin 39 prosenttia. Ansioäitien osuuden kasvu koski pääasiassa kaupunkilaisia työpaikkoja.

Vaikka naimisissa olevien naisten osuus oli kasvanut hiljalleen jo 1910-luvulta, sota-ajan murros näkyy selvänä piikkinä. Naisten siirtymistä työmarkkinoille lisäsi poikkeusajan lainsäädäntö: vuonna 1938 annettiin laki yleisestä työvelvollisuudesta sodan aikana ja vuonna 1942 työvelvollisuuslaki. Naisten osuuden kasvu työpaikoilla pakotti miettimään uudelleen naisen paikkaa suomalaisessa yhteiskunnassa. Muutos oli siksi merkittävä, että se jätti selvät jälkensä koko jälleenrakennuksen aikaan.

\section{Työvoiman ylitarjonnasta työvoimapulaan}

Suomen kokonaistappiot talvi- ja jatkosossa olivat 280000 miestä. Työmarkkinoiden näkökulmasta luku oli huolestuttavan suuri: jälleenrakennus tarvitsi rakennusmiehiä, sotakorvauksien maksaminen teollisuuden välitöntä laajentamista, karjalaiset rintamamiehet oli asutettava ja tuhottu Lappi piti rakentaa kokonaan uudelleen. Lisäksi pyrkimys päästä eroon säännöstelytaloudesta edellytti tuotannon kasvattamista kaikilla sektoreilla. Kaikki nämä vaativat lisää työvoimaa. Katseet kääntyivät naisiin, jotka sodan aikana olivat olleet tukipylväinä niin sotatarviketeollisuudessa ja maataloudesa kuin kotirintaman huollossakin.

Rauhan aikaan palaaminen synnytti kuitenkin ristiriitaisia vaatimuksia naisten tehtävistä. Toisaalla työnantajat vaativat työvoimaa, toisaalla valtio antoi vuosina 1944 ja 1945 edullisia kodinperustamislainoja ohjatakseen naisia kotiin ja toisia kursseille teh- 


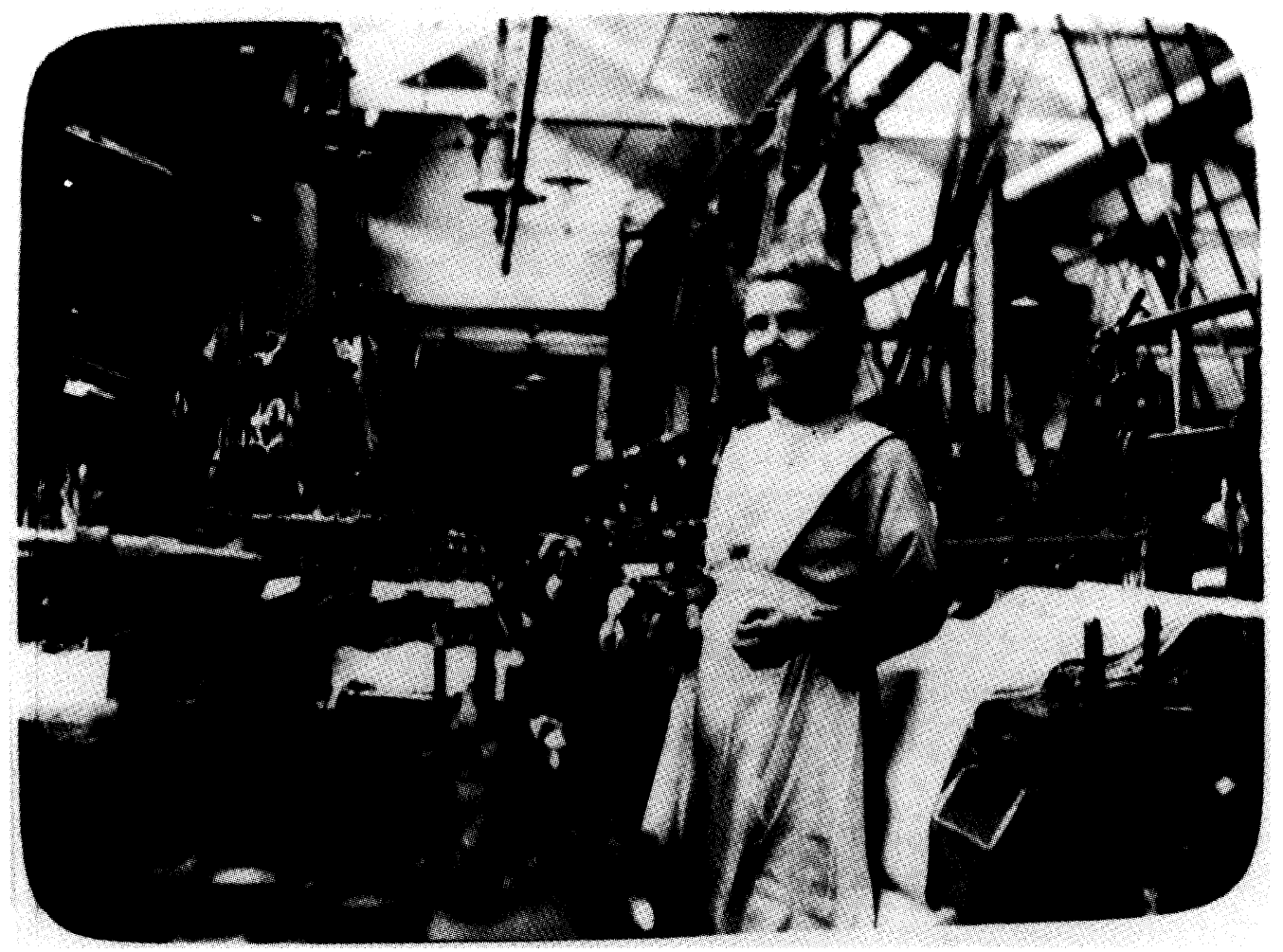

Naimisissa olevien naisten ja vanhempien naisten osuus palkkatyöläisnaisista alkoi nousta 1910-luvulta lähtien. Sota-aikana nousu kiihtyi. Kuvassa tamperelainen Ida Ojaniemi ahtaassa työpisteessään Lapinniemen puuvillatehtaalla 1910luvulla. Kuva: Työväen Keskusmuseo.

däkseen tilaa rintamalta tuleville miehille. Sodan takia olivat monet siirtäneet avioitumista. Liittojen määrä nousikin huikeasti heti sodan jälkeen ja pian kasvoi myös lapsiluku. Lehtiin alkoi ilmestyä kirjoituksia, joissa pohdittiin, kuinka naiset ehtivät olla kotiäiteinä ja palkkatyöläisinä samanaikaisesti. Työvoimapoliittiset ja väestöpoliittiset intressit iskivät rajusti yhteen. ${ }^{31}$

Osa naisista palasi poikkeusolojen jälkeen ilomielin kotilieden ääreen: vuonna 1944 naisten osuus työvoimasta supistuikin 50 prosentista 38 prosenttiin. ${ }^{32}$ Tästä huolimatta oli paljon naisia, jotka halusivat tai joiden oli pakko pysyttäytyä palkkatyössä. Naisjär-

31 Mm. Väestökomitean mietintö 1945:4, s. 11; Perheellisyyden vaikutus naisten työsuhteeseen, Sosiaalinen Aikakauskirja 1946, s. 376-386.

32 Ks. Saraste 1984, s. 95-118. 
jestöt olivat erityisen huolestuneita naistyöttömyydestä heti rauhan solmimisen jälkeen. Niiden synkeät ennusteet siirtyivät kuitenkin muutamalla vuodella: Vasta vuonna 1948, jolloin säännöstely helpottui, maahan alkoi tulla halpoja elintarvikkeita ulkomailta ja sotakorvauksista alkoi olla suuri osa maksettuna, alkoi naisten kotiinajo.

Sodanjälkeinen kolmivuotiskausi oli naimisissa oleville naisille verraton: kysyntää oli niin työmarkkinoille kuin kotitöihinkin. Asenteet ansioäitien työssäkäynnille olivat suotuisat toisin kuin esimerkiksi vuosien 1930-32 laman aikana. Tuolloinhan aloitettiin koko Euroopassa järjestelmällinen naiset kotiin -propaganda, jonka kärjessa kulkivat Saksa ja Hollanti. Isossa-Britanniassa vaimojen työssäkäyntiä rajoittavia säännöksiä oli ollut jo aiemmin, Pohjoismaissa ja Yhdysvalloissa vaimojen työkieltoja ei suoranaisesti kirjattu normeiksi, mutta käytännössä niitä kuitenkin sovellettiin: työpaikat oli varattu ensisijaisesti miehille ja naimattomille naisille.

Joissakin maissa naisen oli erottava työpaikastaan, jos miehen tulotaso ylitti tietyn rajan, toisissa määrättiin, etteivät mies ja vaimo voineet olla samaan aikaan valtion virassa. 1920-30-luvulla oli yleinen käytäntö, että nainen erotettiin työpaikastaan avioitumisen tai viimeistään raskaaksitulon jälkeen. Sota-aika merkitsi asenteiden muutosta, vaikka samalla korostettiin, etta vaimojen palkkatyön tuli olla luonteeltaan tilapäistä. Myönteinen asennoituminen ansioäiteihin oli suhdanne- ja alasidonnainen. ${ }^{33}$

Sosiaalidemokraattiset naiset pyrkivät eduskunnan kautta ja yhteistyössä muiden naisjärjestöjen kanssa vaikuttamaan siihen, että ansioäitien ristiriitainen asema eli kaksoistaakka saataisiin jotenkin jäsenneltyä ja epäkohdat korjattua. Vuonna 1945 asetettiinkin komitea tutkimaan naimisissa olevien naisten asemaa. Yksi hankkeen vaatijoista oli Sosialidemokraattinen naisliitto äänitorvenaan liiton sihteeri ja puhuja Martta Salmela-Järvinen. Komitea-aloitteen takana olivat myös SAK:n naisjaosto, Suomen Naisten Demokraattinen Liitto, TUL:n naistoimikunta sekä Suomen Kansallisliiton Ammattikomitea ja Väestöliitto. 
Komitean työskentelyn lähtökohta oli sota-ajan pinnalle nostattama vaimojen ristiriitainen asema kodin ja palkkatyön ristipaineessa: Oliko naimisissa olevilla naisilla ylipäätään oikeutta tehdä palkkatyötä?

Ansioäitejä arvioitiin olevan Suomessa vuonna 1940 noin 800 000: valtaosa heistä oli maatalouden piirissä ja noin 100000 teollisuudessa. Ongelman ydin ei kuitenkaan ollut määrässä, vaan äitien palkkatyöhon liittyi suuria periaatteellisia, naisen paikkaa määrittäviä yleisiä kulttuurisia ja ideologisia tekijöitä.

Komitea teki työtä käskettyä. Se kartoitti naimisissa olevien naisten asemaa ennen sotaa ja huomasi, että jo 1910-luvulta lähtien naimisissa olevien naisten osuus palkkatyössä oli kasvanut. Se näki myös lamakausien ajaneen vaimoja kotiin, samoin 1930-luvun oikeistosuuntauksen. Sotatarviketeollisuuden kasvu puolestaan oli sallinut myös vaimot aseidentekijöiksi.

Puhuminen naimisissa olevien naisten palkkatyöstä ei ollut siis uusi asia. Se ei ollut uusi myöskään sosialidemokraattiselle naisliitolle. Liitto oli lähtenyt 1900-luvun alun linjanvedoissaan siitä, että vaimot piti vapauttaa palkkatyöstä hoitamaan kotejaan, kuten aiemmin on kerrottu. Naisliittolaisten kanta oli kuitenkin alkanut muuttua vähitellen ja varsinkin 1930-luvulla, jolloin Martta Salmela-Järvinen - itsekin äiti ja palkkatyöläinen - vaati naisille oikeutta käydä töissä. ${ }^{34}$ Sota-aika kypsytti 1930-luvulla nousseita ajatuksia, mutta asenteellisella tasolla muutos oli paljon hitaampi. Vasta 1960-luvulla alkoi yleinen ilmapiiri muuntua äitien palkkatyölle myönteisemmäksi.

\section{Perhepalkkakeskustelu}

Työväenjärjestöjen kanta perhepalkkaan eli järjestelmään, jossa miehelle "perheenelättäjinä" maksettaisiin niin suurta palkkaa, ettei vaimon tarvitsisi käydä töissä kodin ulkopuolella, oli ristiriitainen. 1900-luvun vaihteessa työväenjohtajat kannattivat ajatusta, jonka mukaan naiset oli vapautettava kotiin ja miesten palkkoja

34 Naisen oikeus työhön, Toveritar 20/1934, s. 286; Itsensă elättävät naiset, Toveritar 7-8/ 1934, s. 98-99; Lähteenmäki 1995, s. 247-251. 


\section{*Morsiuskurssit}

Morsiuskurssit olivat vuosina 1944-46 pidettyjä, suuren suosion saaneita kursseja. Avioliittojahan solmittiin tuolloin ennätyksellisen paljon ja kysyntää käytännön neuvoista riitti. Kursseilla opastettiin morsiamille kodinhoitoa ja pidettiin luentoja kodin perustamiskysymyksistä. Malli kurssien pitämiselle ei ollut uusi, jo ensimmäisen maailmansodan jälkeen järjestettiin Saksassa ns. morsiustutkintoja: kuka tahansa ei päässyt naimisiin, vaan tulevan vaimon tuli osata kokata ja hoitaa kotia ainakin kohtalaisesti.

Toisen maailmansodan päättyessä sosialidemokraattisen naisliiton organisoimia kursseja järjestettiin 15 paikkakunnalla. Esimerkiksi Turun eteläisen piirin naisjaosto järjesti kaksi viikkoa kestäneen morsiuskurssin vuoden 1945 alussa. Kurssit sisälsivät luentoja yhteiskunnallisista aiheista ja sairaanhoidosta. Varsinaista talousopetusta antoi ammattimainen kotitalousopettaja. Näyteruoat tehtiin vuokralle saadun koulun keittiössä. Kurssi kokoontui seitsemänä iltana viikossa, joista kahtena harjoiteltiin keittiössä. Raaka-aineiden, kuten kortilla olevien sokerin, maidon, voin, lihan ja nisujauhojen ostoluvat haettiin kaupungin kansanhuoltolautakunnalta. Kurssi aloitettiin juhlalla Turun Työväenyhdistyksen talolla esitelmin ja korviketarjoiluin. Kurssimaksu oli 100 markkaa, paitsi kursseja tukeneen Huhtamäki-Yhtymän työntekijöille, joille se oli ilmainen.

Lähteet: Turun et.sos.dem. piirin naisjaoston morsiuskursseja järjestävän toimikunnan pöytäkirjat 9.11.1944-29.1.1945. TA; Sos.dem. naisliiton kertomukset 1944-46. TA.

korotettava: "Miehille annetaan sen verran palkkaa, että perheillä on riittävä toimeentulo niin ei vaimotkaan itseänsa kauppaa, ei ainakaan kaikki". ${ }^{35}$ Heti toisen maailmansodan jälkeen samanlaiset perustelut nousivat jälleen esille. Toisaalla työväenjärjestöissä korostettiin ristiriitaisesti kuitenkin sitä, että naisille ja miehille oli maksettava sama palkka samasta työstä. Perhepalkka-ajatus ei tähän sopinut.

Ei ole sattuma, että perhepalkkaa kutsuttiin myös tarvepalkaksi tai sosiaalipalkaksi. Perhepalkka tarkoitti nimittäin paitsi miesten korkeampaa rahapalkkaa, myös yhteiskunnan erilaisia tukijärjestelmiä perheille, kuten lapsilisiä ja perheellisiä suosivia vero-

35 Forssan värjäri-ammattiosaston pöytäkirja 8.8.1906, ks. Lähteenmäki 1995, s. 264. 


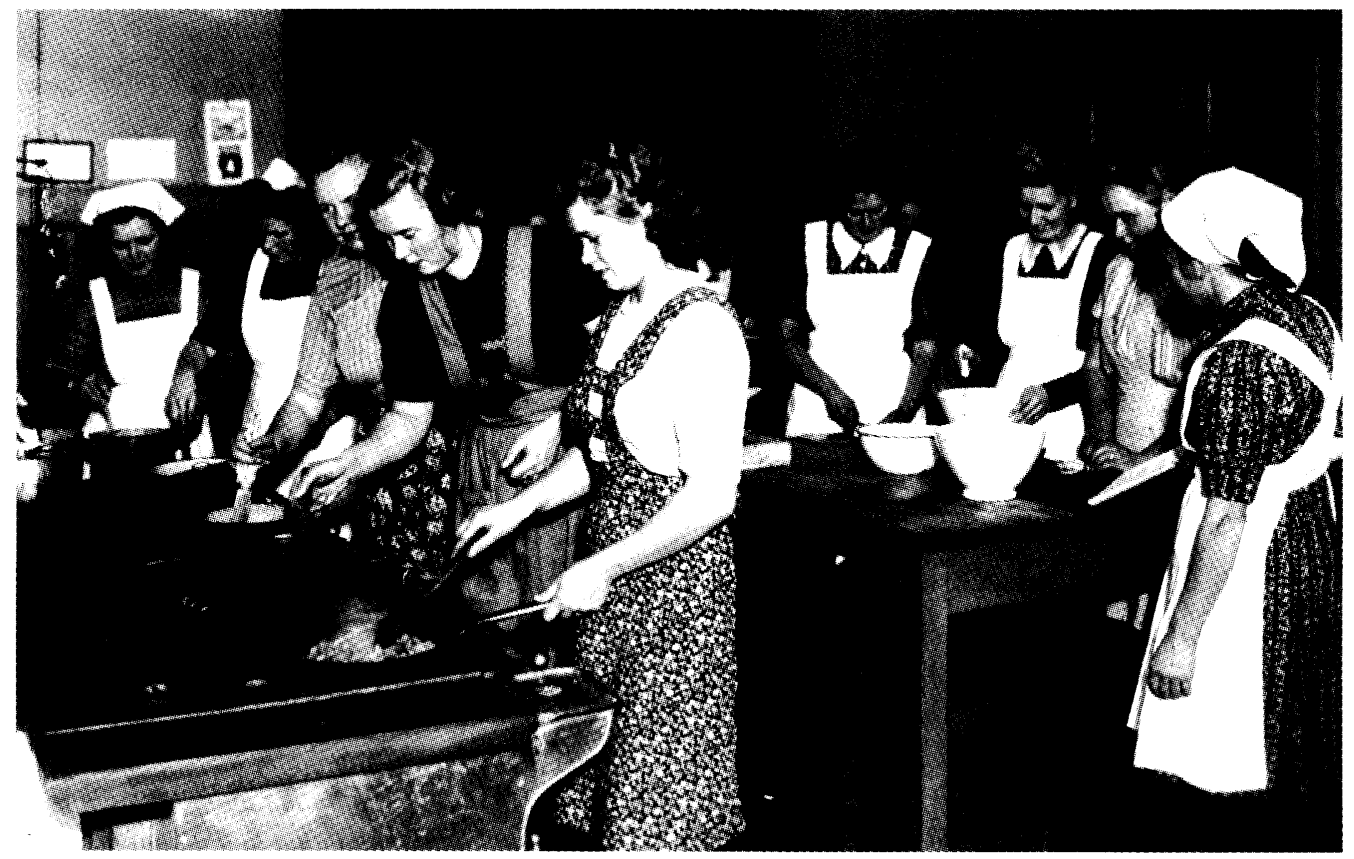

Morsiuskurssilaisia Kotkassa joulukuussa 1944. Kuva: Työväen Arkisto.

ratkaisuja. Sosiaalipalkan suuruuden määräsi toisaalta korvaus työsuorituksesta, toisaalta lasten lukumäärä. Perhepalkkaperiaate sisälsi siten kokonaisvaltaisemman näkemyksen perheiden toimeentulon rakentumisesta kuin samapalkka-periaate. Palkkatyöläisnaisten näkökulmasta perhepalkka-periaate ontui kuitenkin pahasti. Oli kyseenalaista, missä olosuhteissa naiset määriteltäisiin "ensisijaisiksi perheenelättäjiksi" ja siten korkeamman palkan saajiksi. Heti sodan jälkeen mietintönsä luovuttanut perhepalkkakomitea täsmensi tätä ongelmaa ja Työnantajien Keskusliittokin päätyi ehdotukseen, että leski tai eronnut nainen olisi myös oikeutettu saamaan perhepalkkaa. ${ }^{36}$

Käytännössä perhepalkkaa toteutettiin ainoastaan poikkeusoloissa sotien tai taloudellisten kriisien aikana kalliinajan lisien ja perheavustusten muodossa. Euroopan eri maissa ensimmäisen ja toisen maailmansodan aikana sitä toteutettiin juuri mainituissa muodoissa. Palkankorotusten sijasta maksettiin tarveharkintaisia lapsiluvusta riippuvaisia perhelisiä. Ne tulivat halvemmaksi työnantajille ja yhteiskunnalle kuin yleiset palkankorotukset.

36 Perhepalkkakomitean mietintö 1947:8; Työnantajien Keskusliiton kiertokirje 1.7.1947, ks. Lähteenmäki 1995, s. 263. 
1900-luvun alkupuoliskon perhepalkkakeskusteluilla oli tärkeä merkitys ensinnäkin sen takia, että niistä nähdään eri yhteiskuntapiirien asennoituminen naisen yhteiskunnalliseen asemaan. Keskustelut olivat myös sikäli tärkeitä, että ne johtivat sittemmin lapsilisien maksattamiseen. Nimittäin toisen maailmansodan aikana tukilisät määrättiin maksettaviksi ensin erillisinä perhelisinä vuodesta 1943 lähtien ja kaikille lapsille tarkoitettujen lapsilisien maksatus alkoi vuonna 1948. Nämä tukimuodot helpottivat merkittävästi sodasta toipuvien perheiden toimeentuloa ja taloudellista selviytymistä. Perhepalkka-periaatteeseen sisältyneen perhelisän eriyttäminen oli naisten palkkatyöläisyyden kannalta merkittävä tekijä. Ainakaan perhepalkkajärjestelmä ei ollut esteenä naisten siirtymiselle kodin ulkopuoliseen ansiotyöhön. 

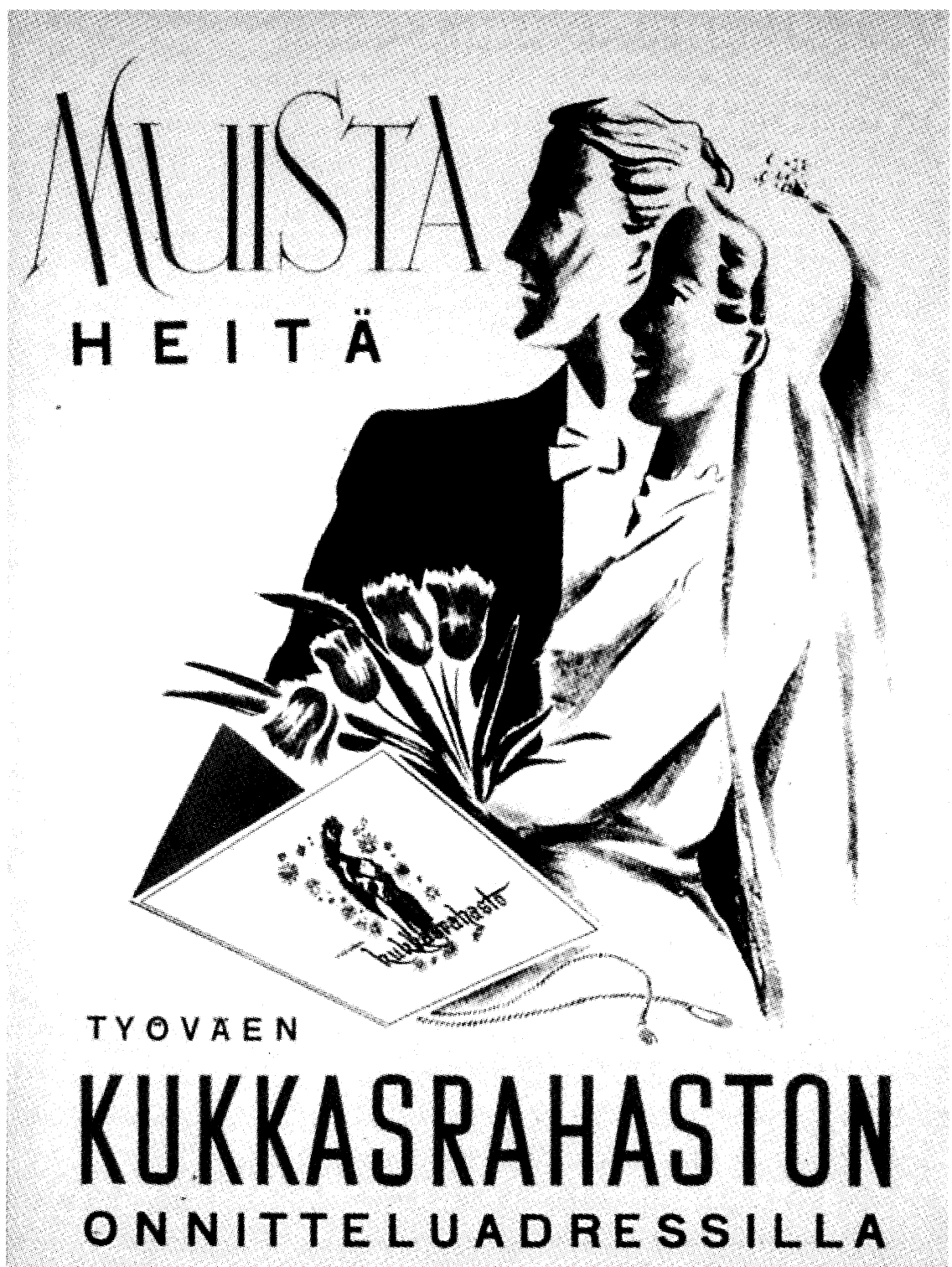

Asiamies

Osoite

M yös SUR UADR ESSE JA s a t a va na

Sosialidemokraattisen naisliiton perustaman Kukkasrahaston juliste vuodelta 1947. Kuva: Työväen Arkisto. 


\section{Jälleenrakennuksesta hajaannukseen}

\section{Kurssien kulta-aika}

Sosialidemokraattisen naisliiton historiassa sodanjälkeisiä vuosia aina vuoteen 1957 voi hyvällä syyllä sanoa kurssien kulta-ajaksi, siksi keskeisessä asemassa liiton toiminnassa oli käytännöllinen kurssi- ja valistustoiminta. Kun toiminta oli keskittynyt niinkin vahvasti naisten omille alueille, herää kysymys, mikä oli naisten edustuksellinen asema sosialidemokraattisessa puolueessa 1920 50-luvulla suhteessa aiempaan ja myöhäisempään aikaan?

\section{Naiset ja puolue}

Miehisen puolueen ja naisliiton suhde kurssien kulta-aikana oli "siistin asiallinen". Työnjako oli eriytetty siten, että naiset hoitivat pääasiassa naisten ja lasten asemaan liittyvät sosiaalipoliittiset kysymykset, miehet muut yleispoliittiset aihepiirit. Kumpikin ryhmittymä hyväksyi tehtäväjaon kutakuinkin yksimielisesti 1920 1930-luvulla, mutta sodan jälkeen tilanne muuttui.

Naisten asemaa puolueen edustusjärjestelmässä voidaan mitata monella tavalla. Eräs tapa on katsoa, miten naiset ovat olleet edustettuina puoluekokouksissa, eduskuntaryhmässä ja puolueen ministerilistoilla. Naisten osuus on vaihdellut viimeisen sadan vuoden aikana seuraavasti sosialidemokraattisen puolueen puoluekokouksissa: 
Taulukko: Äänioikeutettujen naisedustajien keskimääräinen osuus Suomen Sosialidemokraattisen puolueen puoluekokousedustajista vuosina 1899-19991

$\begin{array}{lc}\text { Kokousvuodet } & \text { Naisia \% } \\ 1899-1919 & 9 \\ 1922-1939 & 2 \\ 1944-1957 & 5 \\ 1960-1978 & 10 \\ 1981-1999 & 28\end{array}$

Puolueen perustamisvuonna 1899 naisten osuus puolueen jäsenistä oli 11 prosenttia. Heidän osuutensa puoluekokouksessa oli samaan aikaan kuusi prosenttia. Naistoiminnan eriytyminen ja työnjaon syveneminen johti siihen, että kurssien kulta-ajalla 1920-50luvulla naisedustus laski selvästi: puolueen jäsenistöstä oli keskimäärin noin $25 \%$ naisia, puoluekokouksessa naisten edustusosuus oli vajaat $4 \%$. Erityisesti 1930-luvun lama näkyi naisedustuksen selvänä alenemisena. Ero on huikea, jos verrataan sitä 1980-90luvun edustukseen. Vuonna 1999 puolueen jäsenistä naisia oli noin 40 prosenttia ja puoluekokousedustajista 33 prosenttia.

Naisten osuus sosialidemokraattisen puolueen kansanedustajista pysyi pitkään runsaan kymmenen prosentin tienoilla.

Taulukko: Naisten keskimääräinen osuus Suomen Sosialidemokraattisen puolueen kansanedustajista vuosina 1907-1999²

$\begin{array}{lc}\text { Vaalivuodet } & \text { Naisia \% } \\ 1907-1919 & 13 \\ 1922-1939 & 14 \\ 1945-1958 & 16 \\ 1962-1979 & 22 \\ 1983-1999 & 37\end{array}$

Tästäkin luettelosta nähdään 1920-50-luvulla pysähtyneisyyttä. Verrattaessa tilannetta muihin pohjoismaihin näyttää se kuitenkin

\footnotetext{
1 Suomen Työväenpuolueen/Sosialidemokraattisen puolueen puoluekokouspöytäkirjat 18991999.

2 Suomen Eduskunnan kalenterit 1907-1999.
} 
valoisammalta: tilanne oli niissä 1920-luvulla heikompi. Sosiaalidemokraattisia naisedustajia oli muiden pohjoismaiden parlamenteissa keskimäärin 2 prosenttia, Suomessa vastaava osuus oli $9 \%$. Tilanne tasaantui 1950-luvulla: Suomen eduskunnassa oli sosiaalidemokraattisia naisia 15 prosenttia edustajista, Ruotsissa 13, Tanskassa 9 ja Norjassa 6 prosenttia. 1980-luvulla tilanne kaikissa pohjoismaissa tasoittui edelleen niin, että naisten osuus sosialidemokraattisten puolueiden kansanedustajista oli kivunnut 30 prosenttiin. ${ }^{3}$

Sosialidemokraattisen puolueen ministerilistoilla samoin kuin puoluetoimikunnassa naiset oli aina 1970-luvulle saakka valittu yhden naisen edustus-periaatteella. Verrattaessa muihin puolueisiin sosiaalidemokraatit johtivat kuitenkin naisministerilistaa pitkään. Vuonna 1918 kapinahallituksessa oli kaksi sosiaalidemokraattista naista (Hilja Pärssinen ja Hanna Karhinen), vuoden 1926-27 hallituksessa Miina Sillanpää, vuosien 1948-50, 1954, 1954-56 ja 1958 hallituksissa oli Tyyne Leivo-Larsson. Sen sijaan ensimmäinen porvarillinen naisministeri valittiin vasta vuoden 1953 hallitukseen (maalaisliiton Vieno Simonen) ja ensimmäinen kokoomuslainen naisministeri vuonna 1962 (Kyllikki Pohjala). Naisministerien paikka oli alkuaikoina sosiaaliministeriössä. Ensimmäisen kerran nainen valittiin muuhun kuin sosiaaliministerin toimeen vuonna 1954 (maalaisliiton Kerttu Saalasti opetusministeriksi). ${ }^{4}$

\section{Perhe-edustus}

Se, miksi työläisnaisaktiivit, puhumattakaan ns. tavallisista rivijäsenistä, hyväksyivät 1950-60-luvulle saakka miesten yksiselitteisen johtoaseman puolueessa, palautui kulttuuristen ja uskonnollisten tekijöiden lisäksi naisten asemaa määrittävään lainsäädäntöön. Kuten aiemmin on jo esitetty, Suomessa niin kuin monissa muissakin Euroopan maissa, aviovaimo oli miehensä edusmiehisyyden alainen ja siten vajaavaltainen edustamaan itseään ja perhettään aina 1920-1930-luvulle saakka. Niinpä oli luontevaa, että aviomies edusti perhettään myös työväenpuolueessa niin kuin kaikessa muussakin julkisessa elämässä. Tähän edustusjärjestelmään

3 Sundberg 1995, s. 345.

4 Ks. Kuusipalo 1989, liite 4. 


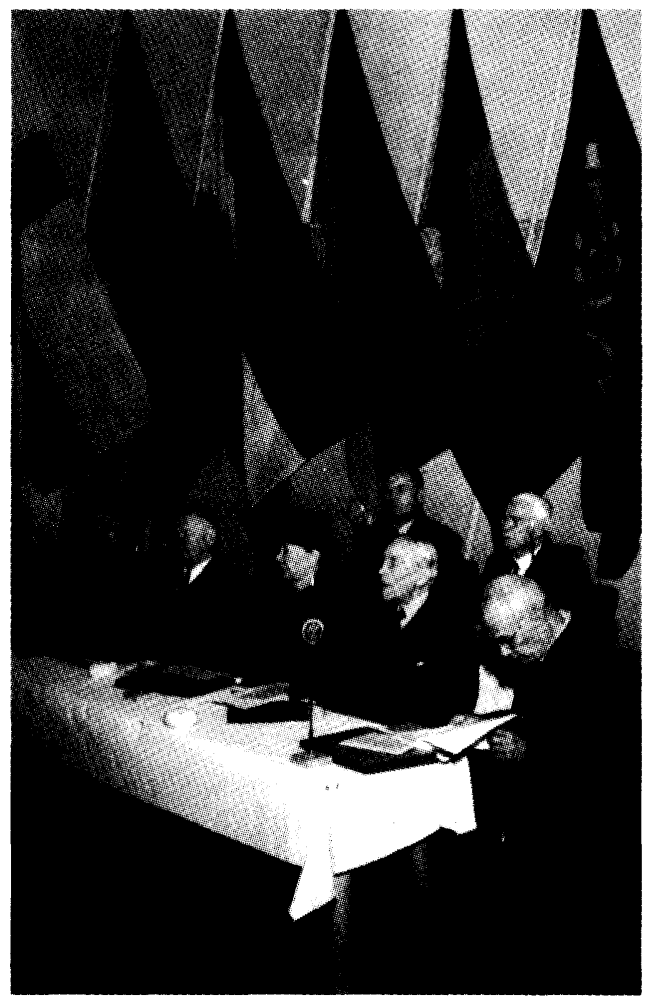

Sosialidemokraattisen puolueen kunniajäsenet puoluekokouksessa vuonna 1949. Vasemmalta Ida Aalle-Teljo, Oskari Tokoi, Miina Sillanpää, J.E. Lillnix, Matti Vuolukka, Otto Toivonen ja Santeri Saarikivi. Kuva: Työväen Arkisto.

liittyi myös työläisperheen rahankäyttö ja puoluejäsenyys. Mies edusti perhettään ja niukassa taloudessa vain hänen "puolueveronsa" maksettiin. Tästä perhekollektiivin näkökulmasta vuosisadan alun jäsenlukuihin voi suhtautua varauksellisesti. Naisten esiinmarssi 1960-luvulla voidaan nähdä tästä näkökulmasta tietynlaisen perhe-edustuksen kulttuurin päättymisenä ja individualismin nousuna: kukin edusti itseään eikä enää välttämättä koko perhettään.

Eri puolueiden naisedustuksen heikkous 1920-50-luvulla voidaan palauttaa ensisijaisesti Euroopassa nousseeseen perhekeskeiseen ajattelutapaan, familismiin, jonka perusajatuksena oli pysyttää ja/tai palauttaa äidit koteihin ja jättää julkinen elämä miesten tehtäväksi. ${ }^{5}$ Myös suomalaiset poliittiset naisjärjestöt ammensivat ideansa näistä "uusista" tuulista, mikä näkyi keskittymisenä kotitalousvalistukseen ja sosiaalipoliittisiin kysymyksiin.

5 Hyvän katsauksen naisten asemaan 1920-30-luvun Euroopassa ja työväenpuolueiden rooleihin antaa Helmut Gruberin ja Pamela Gravesin toimittama teos "Women and Socialism/ Socialism and Women" vuodelta 1998. 


\section{*Perheenemäntien talvipäivät}

Sosiaalidemokraattiset naiset alkoivat järjestää kesävirkistystoiminnan rinnalla myös talvivirkistyspäiviä. Piirikunnalliset talvijuhlat ja opintopäivät saivat nimekseen perheenemäntien talvipäivät. Niiden tarkoituksena oli tarjota osanottajilleen hyötyä, huvia ja iloa, mutta samalla hankkia piiritoimikunnille varoja: päivien aikana järjestettiin kotityön rationalisointiin opastavia näyttelyitä, myyjäisiä ja arpajaisia. Ensimmäiset talvipäivät järjestettiin Kokkolassa, Oulussa ja Mikkelissa vuonna 1948. Seuraavana vuonna kaksipäiväisiä tapahtumia vietettiin jo kaikissa piireissä. Liitto toimitti valistusmateriaalia, näyttelytarvikkeita ja puhujia. Liikkeet ja teollisuusyritykset lähtivät hankkeeseen mukaan ja niinpä toisilla talvipäivillä olivat "sponsoreina" ja näytteillepanijoina OTK, Enso-Gutzeit oy, Huhtamäki-yhtymä ja paikalliset osuusliikkeet. Osanottajia päivillä oli lähes 33000 . Päivistä saadut tulot naisliitto käytti valistustoimintaan.

1950-luvun alussa pidetyillä talvipäivillä oli mukana jo mannekiiniesityksiä, rainoja ja elokuvaesityksiä, kotitaloudellisia työkilpailuja, pyykinpesunäytöksiä ja havaintoesityksiä painekattilalla. Muun muassa vuoden 1952 päiville toimitti Wärtsilä-yhtymä näytteille uutuutensa, sähkökäyttöisen Peko-koneen ja Tepsis-pesuaineen, T:mi Veljekset Saari toimitti Liisa-harjanvarren ja puhdistussienen. Huhtamäki-yhtymä tarjosi puolestaan maistiaisia ja Nuoret Kotkat kokosivat päiville askartelutyönäyttelyn. Jokaiselle emännälle näytti olevan tarjolla jotakin!

Päivien yhteydessä naisliitto järjesti kaksipäiväisiä huoltoemäntä- ja toimitsijakursseja. Toinen päivä omistettiin sosiaalisille kysymyksille, kuten perhelisäperheiden valistamiseen. Huoltoemäntätyö eli naapuriapu oli aloitettu jo sotavuosina ja se tarkoitti vapaaehtoista työtä vaikeuksiin joutuneille perheille, kuten perunan nostoa, pyykinpesua, matonkuteitten leikkaamista, villojen kehruuta, ompelutyötä ja vanhusten ja sairaiden hoitoa sekä käytännön ohjeiden antamista suurperheille. Naisliiton piirissä toimi yli tuhat huoltoemäntää ja huollettavia koteja oli useita tuhansia. Talkootyö jatkui siis pitkälle vielä sodan jälkeenkin: aatteelliset kysymykset kulkivat jossakin mukana, mutta punaiset liput liehuen naiset eivät päivilleen menneet. Talvipäiviä vietettiin 1950-luvun lopulle, jolloin kotitalousvalistustyö siirrettiin naisliitosta eriytyneelle omalle organisaatiolle, Kuluttajaliitolle.

Lähde: Sos.dem. naisliiton toimintakertomukset 1948-59. TA. 


\section{Martta ja Tyyne - Tannerin kamarineitsyet}

Sodan jälkeen sosiaalidemokraatit olivat vasemmalta tulevan paineen kohteena. "Puolue on ajautunut kahden tulen väliin ja kahden rintaman sotaan", kuten puoluesihteeri Leskinen asian ilmaisi. ${ }^{6}$ Jo sodan aikana puolueen näkyvä läsnäolo sotapolitiikassa, K.H. Wiikin johtamien kuutosten toiminta Tanneria vastaan ja puheet erillisrauhasta saivat monet tavalliset rivikannattajatkin mietteliäiksi. Eräässä viialalaisessa perheessä jälkipolvi kertoo sotaaikaan liittyvää juttua Tyyne-mummosta ja hänen poliittisesta käännöksestään: mummo oli lukenut Kansan lehdestä Tannerin sanoneen välirauhasta, ettei "väärä rauha kestä kauan". Mummo oli tästä kimpaantunut, ottanut sakset ja puhkaissut Tannerin kuvasta silmät ja tokaisuut: "Kuinka rauha voi koskaan olla väärä!'”. Kansan Lehti lakkasi tämän jälkeen tulemasta perheeseen. ${ }^{7}$

Myös Tanneria tukeneet naisliittolaisaktiivit saivat ryöpytyksestä osansa heti sodan jälkeen. Alunperin Wiikin kuutosten perustama Vapaa Sana moitti naisliiton sihteeriä Martta Salmela-Järvistä "sodan jumalattareksi" ja Marttaa ja Tyyne Leivo-Larssonia yhdessä "Tannerin kamarineitsyeiksi". Marttaa myös syytettiin siitä, että hän olisi yllyttänyt sosiaalidemokraattisia naisia liittymään lottiin. Huhujen mukaan hän oli saanut myös mitalin palveltuaan fasismia. Salmela-Järvinen itse ei nähnyt toimintaansa Rajan apu-järjestössä fasismina.

Jos yhteistyö lottien kanssa tulkittiin fasismiksi, "syypäitä" olivat koko liittotoimikunnan jäsenet ja erityisesti naisliiton sodanaikainen puheenjohtaja Sylvi-Kyllikki Kilpi, joka "loikkasi" SKDL:ään sodan jälkeen. Salmela-Järvisellä oli myös antipatiansa kommunisteja kohtaan: marraskuussa 1944 hän oli sitä mieltä, ettei kommunisteja eikä kuutosia tulisi päästää hallitukseen. Hän näki heidät uhkana sosiaalidemokraateille. Toukokuussa 1945 pidettyyn suureen rauhanjuhlaan Martta ei päässyt puhumaan, hän oli kuulemma ollut liian innokas sotapolitiikan kannattaja. ${ }^{8}$

Oman puolueen mies, rauhanoppositiossa ollut professori Väinö Voionmaa puolestaan nimitti Salmela-Järvistä "tuoksi sotatammaksi" ja "aivan silmittömän tannerilaiseksi". 9

6 Mm. Sdp:n puoluetoimikunnan pöytäkirja 11.11.1947. TA.

7 Toimittaja Riitta Lehtimäen kertomaa 17.11.1999 Maria Lähteenmäelle.

8 Salmela-Järvinen 1968, s. 97-102; Martta Salmela-Järvisen päiväkirja 8.5.1945. TA; Voionmaa 1971 , s. 398.

9 Voionmaa 1971, s. 401, 412. 
Sosiaalidemokraattien keskeistä roolia sodanaikaisessa politiikassa ei unohdettu valvontakomission (1944-47) aikaisessa Suomessa. Voimansa tunnossa oleva kansandemokraattinen liike käytti sitä valtataistelussaan, kuten Vapaan Sanan kirjoituksista näkyy. Myös oman puolueen "rauhanmiehet ja -naiset" ryöpyttivät Tanneria ja tämän tukijoita laidan täydeltä. Naisliitossahan tämä näkyi Sylvi-Kyllikki Kilven erona vuonna 1946. Sosialidemokraattinen puolue ei kuitenkaan kritiikistä lannistunut, vaan aloitti ankaran taistelun kommunisteja vastaan.

Taistelua lähtivät johtamaan sodassa olleet nuoret miehet, jotka olivat merkittävillä paikoilla puoluehallinnossa. He olivat myös aktiivisesti mukana elokuussa 1940 perustetussa Suomen Aseveljien Liitossa ja läheisessä yhteydessä etenkin kokoomus-poliitikkoihin. Näihin asevelisosialisteihin kuuluivat etujoukkona olympiauimari, ässäluutnantti ja hurmuri Väinö Leskinen, jota on luonnehdittu myös "30-luvun pop-pojaksi" ja "sörkan gibaksi". ${ }^{10}$ Leskinen oli sosialidemokraattisen puolueen puoluesihteeri vuosina 1946-57. Hänen lisäkseen aseveljiin kuului vuosina 1944-46 puoluesihteerinä toiminut ja puoluetoimikunnan jäsenenä aina kuolemaansa (1955) saakka ollut Unto "Pitkä roisto" Varjonen. Niin ikään puoluetoimikunnassa istuivat vanhempi ja jäyhempi Penna Tervo sekä Jorma Tuominen ja toimittaja ja Työväen Akatemian johtaja Yrjö "Jahvetti" Kilpeläinen. Asevelipiiriin lukeutuivat myös muun muassa sittemmin puoluetoimikuntaan valitut Veikko Helle ja Aarre Simonen sekä Kalle Lehmus. Jälkimmäinen oli ollut sodan aikana päämajan tiedotuspäällikkö. Ammattiyhdistysliikettä edustivat Eero A. Wuori ja Olavi Lindblom, jotka olivat niin ikään puoluetoimikunnassa, Wuori vuosina 1944-45 ja Lindblom 1955-72, josta suurimman osan aikaa puoluetoimikunnan puheenjohtajana. ${ }^{11}$

Leskisen, Tervon ja Varjosen yhteishenki oli tiivistä: Presidentti Kekkonen on muistellut, että eräässä tilaisuudessa Kalastajatorpalla nämä kolme miestä menivät yhdessä vessaan ja lauloivat siellä “... silimien välliin, silimien välliin, silimien välliin ryssää juu...”. Laulun jälkeen miehet olivat palanneet pöytäänsä. ${ }^{12}$ Nämä aseveljet luotsasivat sodanjälkeistä sosiaalidemokraattista liikettä "pysähtyneisyyttä" ja kommunismia vastaan. Sosiaalidemokraattisten

10 Tiainen 1968, s. 244-245; Sorsa 1995, s. 88

11 Sosiaalidemokraattien sodanaikaisista toiminnasta ks. lähemmin Soikkanen 1987, s. 397460 .

12 Keskinen 1978, s. 78. 


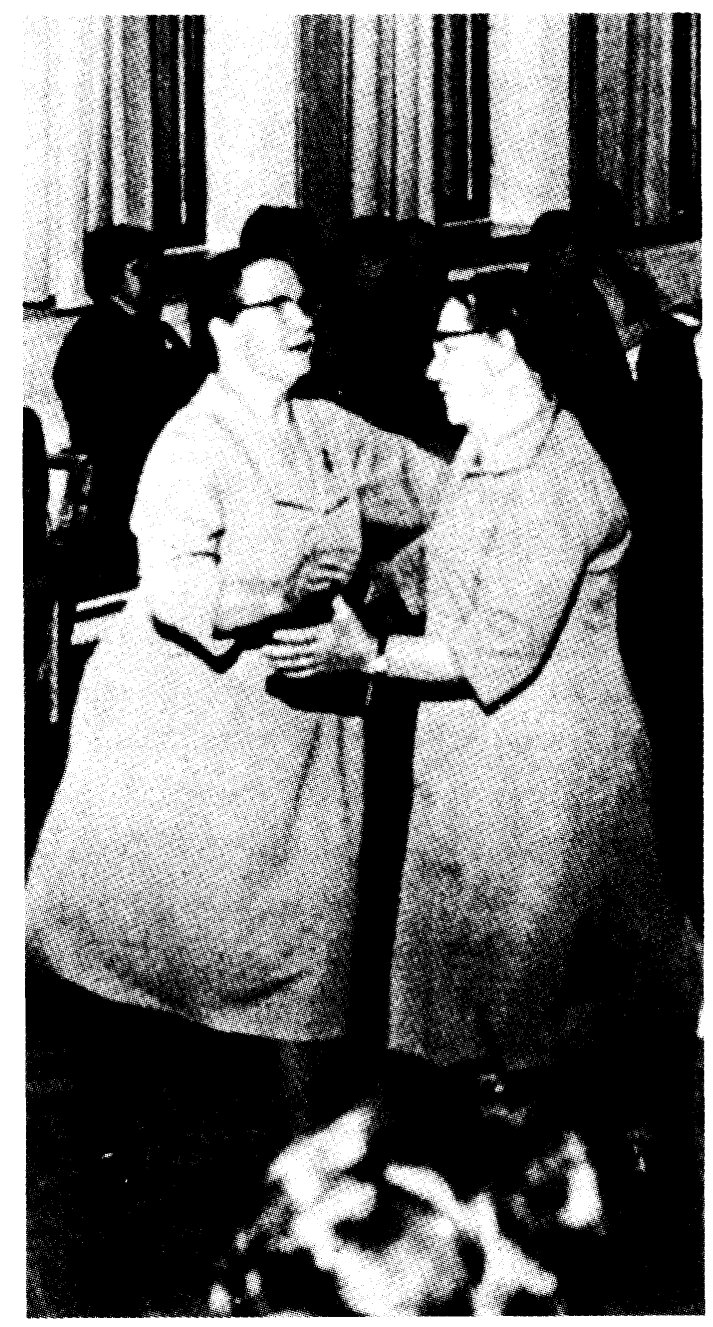

Toisen maailmansodan jälkeen naisliittolaiset havaitsivat tanssivansa eri tahdissa ja jopa eri työväentaloilla kuin Sosialidemokraattisen puolueen miesjohto. Kuvan "tyttöpari" tanssii naisliiton retkeilypäivillä. Kuva: Työväen Arkisto.

naisjohtajien joukossa uusi, aikaisempaa dynaamisempi politiikka ei saanut varauksetonta kannatusta, ei ainakaan vanhempien järjestönaisten keskuudessa.

Martan synkkä yksinpuhelu

Martta Salmela-Järvinen kuului niihin vanhoihin järjestöihmisiin, joille uusi linja ei ottanut istuakseen. Sodan aikaista politiikkaa ja linjauksia hän ei kuitenkaan katunut. Salmela-Järvinen kirjoitti päiväkirjaansa 9.2.1945: "Ei olisi voitu kulkea toista tietä, kun on kuljettu. Se olisi ollut mahdotonta niin kauan kuin Saksaa pidettiin voittajana. Silloin oltiin humalassa sen voitoista". ${ }^{13}$ Sodan

13 Martta Salmela-Järvisen păivăkirja 9.2.1945. TA. 
jälkeisinä vuosina Martta joutui arvioimaan poliitikon rooliaan uudelleen: "En sittenkään oikein mielestäni sovi politiikkaan. Olin mielelläni vapaa ja riippumaton. Nyt kaikki hajoaa kuin tuuleen. Minulla ei ole ketään ystävää, jolle voisin uskoutua. Aina vain täytyy näytellä". ${ }^{14}$

Salmela-Järvisen itsetutkiskelu johtui osin menneestä hävitystä sodasta ja sosiaalidemokraattien panoksesta sotapolitiikassa, mutta myös omasta paikastaan muuttuvassa liikkeessä. Puolueen johtomiesten suhtautuminen häneen oli nihkeää. Eräänkin kerran kun Salmela-Järvinen oli Oslossa kokouksessa Emil Skogin ja Väinö Leskisen kanssa, eivät nämä huolineet häntä mukaan elokuviin, vaan kehuivat menevänsä kapakkaan, jonne Martta ei voinut lähteä. Tästä tuntui, että miehet olivat kiusautuneita hänen mukana olostaan: "Miesten on kai mahdotonta esiintyä toverillisesti naisia kohtaan. Kun tämä ei enää naisena heitä kiinnosta, eivät he ylipäänsä näe hänessä mitään". ${ }^{15}$ Myös toisessa tilanteessa Salmela-Järvisen kyyniseksi käynyt suhtautuminen puolueen miehiin näkyi. Kun Helsingin kaupungin sosiaalijohtajan virkaa täytettiin vuoden 1948 alussa, oli Martta ehdokkaana Tyyne Leivo-Larssonin esityksestä. Jussi Railo sai kuitenkin sosiaalidemokraattien ryhmässä kolme ääntä enemmän ja tuli valituksi: "En ollut uskaltanut koko jutun onnistumiseen luottaa, sillä ymmärrän että tarvitaan paljon ansioita ennenkuin voi kilpailla miehisen asiantuntemuksen kanssa." 16

"Järjestöjyrän" arki oli työntäyteinen. Salmela-Järvinen oli aktiivisesti mukana vuonna 1950 perustetussa Lasten Päivän Säätiössä, joka pyöritti huvipuisto Linnanmäkeä, ja Ensi Kotien liitossa. Vanhainkotihanke eteni Salmela-Järvisen ja Ida Aalle-Teljon aktiivisen työn tuloksena ja Käpyrinteen vanhainkodin harjannostajaisia juhlittiin lokakuussa 1950 ja avajaisia maaliskuussa 1952. Samaan aikaan Salmela-Järvinen kirjoitti koko ajan näytelmäkäsikirjoituksia.

Järjestöaktiivisuus ja terveysongelmat veivät kuitenkin voimia. Hän näki uusien tuulien kääntyvän itseään vastaan myös naisliitossa. Vuoden 1950 naisliiton edustajakokouksen jälkeen Martta Salmela-Järvinen kirjoitti päiväkirjaansa, että "tuntui siltä, että

\footnotetext{
14 Martta Salmela-Järvisen päiväkirja 26.12.1946. TA.

15 Martta Salmela-Järvisen päiväkirja 6.1.1947. TA.

16 Martta Salmela-Järvisen päiväkirja 7.1.1948. TA
} 


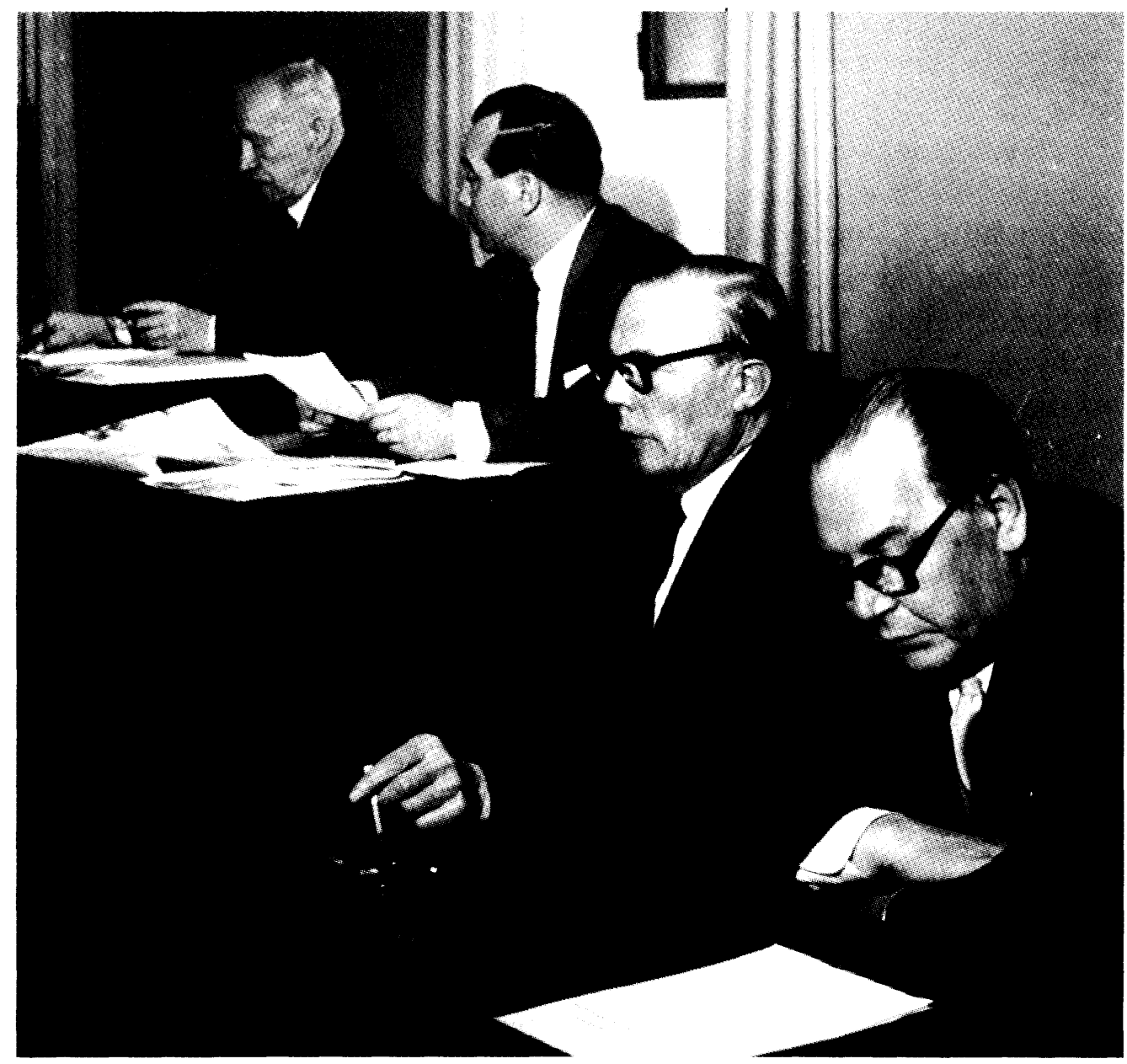

Sosialidemokraattisen puolueen johtomiehet 1950-luvun alkupuolella. Vasemmalta Väinö Tanner, Väinö Leskinen, Penna Tervo ja K.A. Fagerholm. Kuva: Työväen Arkisto.

olisin saanut armon jääd̈a." ${ }^{17}$ Marttaa painoi myös se, että "Tyyne haukuskeli koko ajan ja kehoitteli jättämään muut tehtävät ja antautumaan enemmän liiton asioihin". Salmela-Järvinen päätti odottaa vielä seuraavat vaalit, "mutta niiden jälkeen lähden". Naisten välisistä yhteenotoista näki, että Tyynen ja Martan tiet alkoivat kulkea liian lähellä toisiaan. Naisliiton kokouksissa naiset kalvoivat alituisesti toisiaan. Marraskuussa 1950 Salmela-Järvinen kirjoitti: "Surullista mutta taas tietämättäni jollain lailla olin Tyynen tiellä". Kyse oli Oslon kokouksesta, jossa käsiteltiin samapalkkaisuut-

17 Martta Salmela-Järvisen päiväkirja 9.11.1950. TA. 
ta. ${ }^{18}$ Leivo-Larssonhan oli toisena sosiaaliministerinä vuosina 1948-50 ja siten itseoikeutettu edustamaan naisliittoa ulkomaanmatkoilla.

Sosiaalidemokraatit pitivät maaliskuussa 1951 ennen vaaleja puolueäänestyksen, jossa ensimmäisen kerran naisten keskinäinen arvo mitattiin. Salmela-Järvinen tuli viidenneksi K. A. Fagerholmin, Tannerin, Leskisen - ja Leivo-Larssonin jälkeen, joka hiuksen hienosti ohitti Martan. Hän ymmärsi tilanteen dramaattisuuden hyvin: "No niin, minun vuoroni on tullut ja nyt kai aletaan laskeutua alamäkeä". Laskuaan Salmela-Järvinen selitti kuulonsa heikentymisellä. Hän oli tuolloin 59-vuotias. Varsinaisissa vaaleissa sosiaalidemokraatit menettivät hiukan ääniä. Martta tuli kolmanneksi, joskin menetti paljon ääniä. Hänen mukaansa osa äänistä meni Tannerille, osa Leivo-Larssonille. Vaalin tulos ahdisti Salmela-Järvistä entistä enemmän. Elli Nurmisen erottua naisliiton liittotoimikunnasta kesällä 1951 mietti Martta: "Tuntuu aika kovalta ajatella lähtöä, mutta kai minunkin on se tehtävä". SalmelaJärvinen koki voimakkaasti, että hän joutui vetämään vain muiden vankkureita eikä saanut ansaitsemaansa kiitosta. Uusissa hallitusneuvotteluissa asia tuli jälleen kylmänä suihkuna Salmela-Järvisen niskaan. Hallitukseen kaavailtiin naisministeriä ja naisliiton piiristä ehdotettiin Aino Malkamäkeä ja Tyyne Leivo-Larssonia: "Ei kukaan voi kiistää heidän ansioitaan, mutta sittenkin mieleeni jämähtää ajatus: minun vuoroni ei tule koskaan." histä Leskisellä oli selvä kanta näiden naisten paremmuudesta. Myöhemmissä hallitusneuvotteluissa hän vastusti voimakkaasti Leivo-Larssonin nostamista ja esitti Aino Malkamäkeä. Fagerholm piti kuitenkin Leivo-Larssonin puolta. ${ }^{20}$

Myöskään kirjallisella saralla Salmela-Järvinen ei menestynyt. Näytelmäkäsikirjoitukset eivät tuottaneet toivottua vastaanottoa: "Itselläni on taas täydellisen epäonnistunut tunne". Riitaiset kotiolot pahensivat tilannetta. ${ }^{21}$

Martta Salmela-Järvinen koki naisliitossa jälleen takaiskun kesäkuussa 1952. Leivo-Larssonin valta alkoi näkyä yhä selvemmin: naiset esittivät puoluetoimikuntaan naisten ehdokkaaksi Tyyneä. Martta ohitti hänet vain siksi, että "ukot nyt eivät kertakaikkiaan

18 Martta Salmela-Järvisen päiväkirja 9.11.1950 ja 30.11.1950. TA.

19 Martta Salmela-Järvisen päiväkirja 17.7.1951. TA.

20 Kyse oli vuoden 1956 ministeripohdinnoista. Tiainen 1968, s. 54-56.

21 Martta Salmela-Järvisen päiväkirja 1.11.1951. TA. 
sulata Tyyneä". Syyskuun kokouksessa "Tyyne tyrkytti itseään liittotoimikunnassa niin, että oli pakko valita Milanoon kansainväliseen sosialistikonferenssiin. Minunkin teki mieleni, mutta en toki kehdannut sentään itseä tuolla tavalla kaupitella!" Jälleen lokakuussa 1952 Salmela-Järvinen uhkasi lähteä naisliitosta "heti ensi keväänä". Marraskuussa puolue asetti yksimielisesti LeivoLarssonin ministeri-ehdokkaaksi. Salmela-Järvinen esitti häntä myös naisliiton edustajana. Kukaan ei esittänyt Marttaa. Seuraavana päivänä valintoja jo peruttiin ja Salmela-Järvinen sai aiheen kirjoittaa päiväkirjaansa: "Nainen oli kertaalleen jälleen punnittu ja köykäiseksi havaittu”. ${ }^{22}$

Naisliitolle valittiin syksyllä 1953 uusi sihteeri. Valituksi tuli Anu Karvinen. Salmela-Järvisen mukaan valinnassa oli "paljon kieroutta". Paikka pantiin avoimeen hakuun ja sitä hakivat Aune Seme ja Martan tytär Irja. Näitä kumpaakaan ei kuitenkaan valittu, vaan otettiin "puoliväkisin" henkilö, joka ei edes hakenut. " $J a$ kotonakin on kaikki päin helvettiä”. Myös Käpyrinteen vanhainkodin talous oli sekaisin: johtajatar oli sanottava irti rahasekaannusten takia. Hän oli muun muassa lainannut Ida Aalle-Teljolta varoja henkilökohtaisiin kuluihinsa eikä pystynyt niitä maksamaan. Ei niin pahaa ettei hyvääkin. Naisten eteneminen eduskuntavaaleissa maaliskuussa 1954 ilahdutti Salmela-Järvistä: "Naiset alkavat olla hereillä ja antaa ukoille palttua".

Uusi pettymys oli kuitenkin vuoden 1954 hallituksen muodostus. Leivo-Larssonista tuli toistamiseen sosiaaliministeri: "Lujille nyt otti, lujemmalle kuin koskaan aikaisemmin. Mutta saimme kuin saimmekin naisen ajetuksi lävitse, mikä merkitsi, että myöskin Maalaisliitto otti naisen. Miesten kummallista logiikkaa. Toinen toisen kiusalla. Ensimmäisen kerran hallituksessa 2 naista". ${ }^{23}$ Toinen naisista oli maalaisliiton Vieno Simonen.

Myös kotiolot painoivat Salmela-Järvisen mielen matalaksi. Hänen aviomiehensä halvaantui vuoden 1954 alussa ja toimitettiin sairaalahoitoon. Martan äiti kuoli puolestaan vuoden 1954 lopussa. Salmela-Järvisen järkytykseksi aviomies siirrettiin yksityiseltä osastolta kroonikko-osastolle: "Muutos onkin jyrkkä ja kauhea. Os. VII puurakennukseen: ei jälkeäkään mukavuudesta. Potilaita on 15 samassa huoneessa ja hirvittävä löyhkä löi ovelta vastaan..."

22 Martta Salmela-Järvisen päiväkirja 4.6., 9.9., 17.10. ja 1.12.1952. TA.

23 Martta Salmela-Järvisen päiväkirja 1.9.1953, 5.5.1954, 10.3.1954 ja 14.12.1954. TA. 
Vanhusten hoito oli vielä 1950-luvulla varsin vaatimatonta. Vaikka puutteellinen hoito sairaalassa huolestuttikin Salmela-Järvistä, helpottuivat hänen kotiolonsa huomattavasti. ${ }^{24}$

Salmela-Järvinen alkoi ottaa myös etäisyyttä politiikkaan. Maaliskuussa 1955 hän kirjoitti päiväkirjaansa: "Puoluekokous lähestyy. Paineita. Tällä kertaa minun on pyrittävä vapautumaan puoluetoimikunnasta. Olen jo tehnyt urakkani, yli 10 vuotta".

Näin tapahtuikin ja vahdinvaihto Salmela-Järvisen ja LeivoLarssonin välillä oli nyt entistä selvempi. Jälkimmäinen valittiin puoluetoimikuntaan naisliiton edustajana. Fagerholm asetettiin samassa kokouksessa puolueen presidenttiehdokkaaksi, SalmelaJärvinen tosin epäili tämän menestymistä: "En usko, että F:n kanssa onnistutaan. Hän on kuitenkin äidinkieleltään ruotsalainen ja sitten hänen hoipertelunsa 10 vuotta takaperin..." 25

Kotioloissa Salmela-Järvistä kohtasi suuri onnettomuus, kun hänen tyttärensä kaksi pientä poikaa hukkuivat toukokuussa 1955 perheen kesäpaikalla olevaan suvantoon: "Pepe ja Timuli...Pepe ja Timuli...voi!" voihki Martta suurta suruaan. ${ }^{26}$ Kuukauden päästä kuoli Salmela-Järvisen hyvä ystävä ja naisliiton suuri nainen Ida Aalle-Teljo.

Kun Leivo-Larsson valittiin toistamiseen ministeriksi vuonna 1954, oli Salmela-Järvisen alistuttava rooliinsa. Heinäkuussa 1955 naiset olivat yhdessä matkalla Lontoossa. Martan mukaan matka oli hauska ja mielenkiintoinen. "T. L-L. ei ollut lainkaan hassumpi matkaseura, paitsi että jouduin tavan takaa toteamaan, kuinka tavattoman itsekeskeinen hän on". Salmela-Järvinen vertasi LeivoLarssonia Englannin naisliiton puheenjohtajaan. Hänen mukaansa britti oli kylmä ja määrätyllä tavalla keimaileva. Kotiintulo kuitenkin nostatti jälleen Salmela-Järvisen kiukkua. Hän oli keskeisessä asemassa ensikoti-toiminnassa, mutta " $L$-L. pitäisi täälläkin päästä jotenkin esille. Naurettavaa!'"27

Syksyn 1955 puolueäänestyksessä Martta Salmela-Järvinen oli pudonnut naisista kolmanneksi Tyyne Paasivuoren ja Leivo-Larssonin jälkeen. "No mitäpä siitä, kerran se tulee vuoro siirtyä sivuun ja antaa tilaa nuoremmille (mutta kirvelee silti)." 28

24 Martta Salmela-Järvisen päiväkirja 30.3. ja 7.4.1954. TA.

25 Martta Salmela-Järvisen päiväkirja 23.3. ja 6.6.1955. TA.

26 Martta Salmela-Järvisen päiväkirja 31.5. ja 6.6.1955. TA.

27 Martta Salmela-Järvisen päiväkirja 31.7. ja 3.9.1955. TA.

28 Martta Salmela-Järvisen päiväkirja 29.9.1955. TA. 


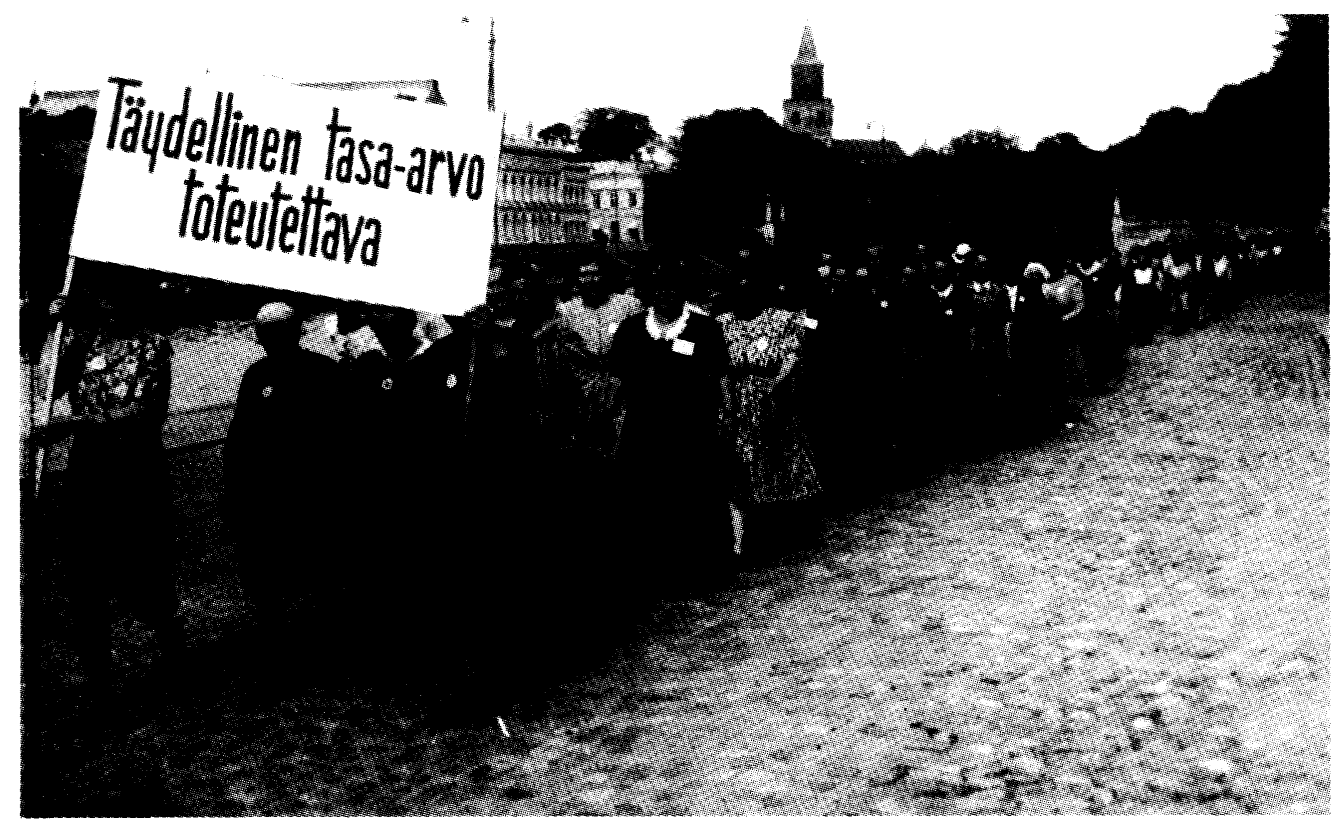

Turun Sosialidemokraattisen Kunnallisjärjestön Naisjaosto marssii vuonna 1946. Sanoma ei jääne epäselväksi. Kuva: Työväen Arkisto.

\section{Yhden naisen kiintiö}

Eläkeläisenä Martta Salmela-Järvinen arvioi omaa paikkaansa sosialidemokraattisessa puolueessa. Hänhän oli vuosina 1944-53 puoluetoimikunnan jäsen: “...minä en koskaan kuulunut niihin sisärenkaisiin...Minä tiesin ja vaistosin, että semmoisia on olemassa, mutta minua ei semmosiin salaisuuksiin vihitty, mikä oli erinomaisen hyvä asia, sillä siitä mistä ei tiedä, siitä ei ole vastuus$s a . . . "$ Sodan jälkeen sisäpiiriä oli yksimielinen asevelijuntta. Salmela-Järvisen mukaan juntta katsoi, että se oli niin voimakkaasti ajanut isänmaan ja itsenäisyyden asiaa, että se tuli palkita sodan jälkeen. Salmela-Järvisen mielestä tässä omien ryhmäetujen ajamisessa oli se vika, että sellainen vanha järjestöihminen kuin Martta ei voinut hyväksyä nuorten ryhmäpäätöksistä lipeämistä ja päätösten ohittamista. Salmela-Järvinen muisteli, kuinka ikävä oli mennä puoluetoimikunnan kokouksiin, koska kaikki asiat oli jo etukäteen sovittu. Naisedustajan annettiin kyllä puhua, ehdottaa ja ottaa kantaa ja toiset kuuntelivat sulavasti, mutta mitään seuraamuksia 
keskusteluista ei ollut. Salmela-Järvinen turhautui nopeiden nuorten miesten menoa katsellessa. ${ }^{29}$

Uudella puoluejohdolla oli myös selkeä kanta naisliiton erillistoimintaan. Heti sodan jälkeen Salmela-Järvinen naisliiton edustajana pyysi puoluetoimikunnalta avustusta naisliiton valistustyöhön. Hän perusteli hakemusta sillä, että aina vuoteen 1939 saakka puolue oli säännöllisesti tukenut naisliittoa taloudellisesti eikä sodan jälkeen kentällä toiminut yhtään naispuhujaa. Vastaus oli musertava. Puoluetoimikunta tuli siihen tulokseen, että liiton olisi pyydettävä toimintaansa varoja valtiolta, "koska sen toimintaan sisältyy myös paljon sellaista käytännöllistä neuvontatyötä, jonka tukeminen on katsottava valtion asiaksi" ${ }^{30}$ Naiset jäivät itse kaivamaansa kuoppaan.

\section{Puolueelle tarpeellinen väkkärä}

Sosialidemokraattisen puolueen vuoden 1949 puoluekokouksessa Tyyne Leivo-Larsson, Martta Salmela-Järvinen, Miina Sillanpää sekä muut naisaktiivit esittivät ankaraa kritiikkiä puoluesihteeriä kohtaan. Tuohuksissaan he kysyivät, tarvitsiko puolue naisia ylipäätään. Joitakin maakunnista tulleita naisia oli loukannut, ettei kyseisessä puolueen 50-vuotisjuhlakokouksessa oltu annettu edes pienen pientä vaatimatonta puheenvuoroa naisliitolle. Kokouksen yleinen ilmapiiri oli itsenäisen naisliiton vastainen ja useat miespuoliset edustajat esittivät naisliiton integroimista tiiviimmin puolueeseen: sitä kautta naiset tulisi valistettua miesten mukana.

Naisliiton toiminta nähtiin liian yksipuoliseksi. Leskinen nauratti rehvakkaasti yleisöä aloittamalla, että naiset ovat turhaan tuohuksissaan, sillä juuri hän oli pyytänyt naisliitolta esitystä naisten asemasta puolueessa. Eräiden muidenkin miesten asenteet olivat samansuuntaisia: "Normaalisti kehittyneen miehen ei olisi aihetta puhua naiskysymyksestä, sillä siinä saattaa joutua vihoihin naisten kanssa". Naiset olivat kiihdyksissään ja loukkaantuneita. LeivoLarssonin aloitettua puheenvuoronsa huudahti Fagerholm väliin "Älä ole vihainen!".

29 Martta Salmela-Järvisen haastattelu. TMTTK:n kokoelmat, sidos 256, s. 29-31

30 Sdp:n puoluetoimikunnan pöytäkirja 1.12.1945. TA. 
Leivo-Larsson paheksui syvästi sitä, että naisliiton esitystä, jossa puoluetta pyydettiin maksamaan naisliitolle vuosittainen korvaus eli $50 \%$ puolueen naisjäsenten jäsenmaksuista, oli muokattu: "Minusta tässä asiassa on harjoitettu eräällä tavalla... (Leskisen välihuuto: diktatuuria!)...jollei nyt diktatuuria, niin on haluttu johtaa asiat määrättyyn pisteeseen, ettei se näyttäisi niin pahalta kuin se tosiasiassa on". Salmela-Järvinen puolestaan sanoi ottavansa jatkopuheenvuoronsa aluksi iloisemman ilmeen, ettei Leskinen pelkäisi, mikä aiheutti hilpeyttä salissa. Leskinen vastasi naisten vaatimuksiin, että "on heikko lähtökohta, jos pyydetään vain rahaa". Rahallinen avustus ei naisasiaa hänen mukaansa ratkaissut.

Vaikka naiset yrittivät selittää, että ennen sotaa puolue oli avustanut naisliittoa säännöllisesti ja että muissa pohjoismaissa, Saksassa ja Englannissa sosialidemokraattiset puolueet tukivat säännöllisesti naisjärjestöjään, oli puolueen miesten kanta tyly. Naisten mukaan heillä oli "sellainen erikoislaatuinen kunnia omata naisliike, jolla ei ole puolueen tukea". Miehet puolustautuivat ymmärtävänsä naisten merkityksen: "Nainen on sellainen väkkärä yhteiskunnassa, että jos se on pitkän päälle poissa meidän kokouksistamme eikä meidän asioitamme puolusta, niin siitä ei seuraa hyvää, sen vuoksi, että naiset kasvattavat lapsia. Me miehetkin niitä kasvatamme, mutta nainen se on, joka antaa lapsille ajatustavan, se on tosiasia. Missä äidit eivät sitä tee, niin eivät lapset myöskään sosialisteja ole... ", kuten eräs puolueen kunniajäseneksi valittu edustaja asian ilmaisi.

Naisliiton esityksistä hyväksyttiin naisvastaavien nimeäminen puolueosastoihin, osastojen velvollisuus levittää naisten lehteä Tulevaisuutta ja puolueosastoja kehotettiin lisäksi perustamaan naisjaostoja. Puolue lupasi myös mahdollisuuksien mukaan tukea naisliittoa taloudellisesti. ${ }^{31}$ Sittemmin Salmela-Järvinen on muistellut Leskisen sanoneen hänelle, että "minä en lepää ennen kuin olen saanut naisliiton toiminnan lakkaamaan". ${ }^{32}$ Naisliittolaisten ja puoluesihteerin välit olivat ymmärrettävistä syistä jännitteiset.

31 Pöytäkirja I ja II. Suomen Sosialidemokraattisen Puolueen XXI Puoluekokouksesta Helsingissä 30.10.-3.11.1949, s. 37-38, 71-99, 263; Naisliiton esitys nro 9, s. 96-103; Puoluetoimikunnan lausunto, s. 103.

32 Keskinen 1978, s. 67. 


\section{Kosteat kokoukset}

Toinenkin uusi järjestökulttuurin piirre sodanjälkeisessä työväenliikkeessä oli: ravintolakokoukset. Tämä ärsytti vanhoja raittiusliikkeeseen sitoutuneita järjestöaktiiveja. Salmela-Järvisen mukaan ennen kokouksia istuttiin kapakassa ja sovittiin päätettävät asiat ja sen jälkeen mentiin kokoukseen lyömään ne pöytään. Salmela-Järvinen ei ollut yhtään kiinnostunut tämäntyyppisestä järjestötyöstä, vaikka samanlaista käytäntöä oli muissa pohjoismaissa, etenkin Tanskassa. Komiteoihin ja edustustehtäviin tuli näin valittua "kapakkakokouksissa koulunsa käyneitä" ja Salmela-Järvisen tapaiset maallikot jäivät kuin lukutaidottomina seuraamaan vierestä.

Työväen järjestökulttuuri eli uutta aikaa ja vanhat tavat alkoivat jäädä syrjään uusien toimijoiden myötä. Leskisen tyyli, jolla hän ilmaisi "hoitavansa asian" tympäisi Martta Salmela-Järvistä, joka piti sitä epädemokraattisena. Yhteisillä matkoilla muissa pohjoismaissa Salmela-Järvinen sai kuulla Leskisen ihanteen: "Tanskan järjestelmä - pöytä puoluetoimistossa ja Nina Andersen". ${ }^{33}$ Vaalea Nina Andersen oli Tanskan sosiaalidemokraattien johtavia naisia. Hän toimi ahkerasti kansainvälisissä ja pohjoismaisissa yhteistyöjärjestöissä.

Naiset yrittivät oikoa miesten uusia järjestötapoja ja palauttaa heidät työväenliikkeen raittiuslinjalle. Esimerkiksi kun Leskinen vapautui rattijuopumusrangaistuksestaan, ${ }^{34}$ ottivat Helsingin sosialidemokraattisen naispiirin naiset hänet nuhdeltavaksi. Leskinen meni närkästyneen naisjoukon eteen ja alkoi kyynelsilmin katua tekojaan. Kerrotaan, että naiset liikuttuivat puheesta niin, että jotkut jopa puhkesivat itkuun. Liikuttavan puheensa lopuksi Leskinen syleili nyyhkyttävää puheenjohtajaa: tuhlaajapoika oli saanut kaiken anteeksi. ${ }^{35}$

Puolue- ja ammattiyhdistysmiehiä lienee kovastikin huvittanut naisten epätoivoinen yritys. Sodanjälkeisen ajan miehen mallia miehet itse kuvasivat näin: "Me emme tarvitse miehiä, jotka eivät

33 Salmela-Järvinen 1968 , s. 176

34 Puoluesihteeri Leskinen ja satakuntalainen kansanedustaja Valter Kuusela ajoivat huhtikuussa 1948 humalassa poikajoukon päälle sillä seurauksella, että yksi pojista kuoli ja toinen loukkaantui vakavasti. Leskinen sai 5 kk vankeutta ja Kuusela, joka oli ollut tapahtuman hetkellä ajovuorossa, sai $1 \mathrm{v}$ ja 6 kk vankeutta. Keskinen 1978, s. 61-62.

35 Sorsa 1995 , s. 90 


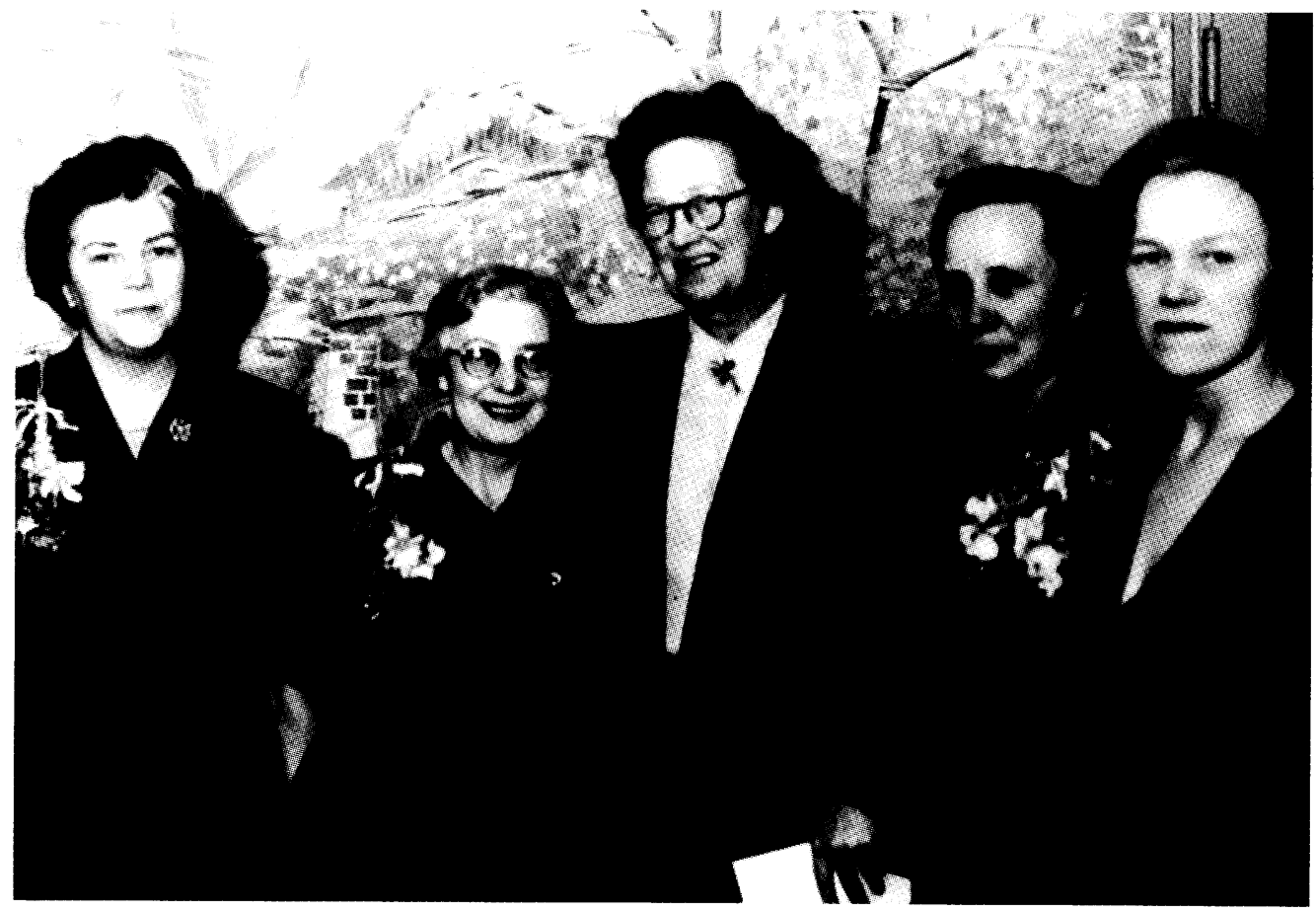

Pohjoismaista yhteistyötä Lundissa 27.3.1947. Vasemmalta Disa Västberg, Nina Andersen, Ebon Anderson, Martta Salmela-Järvinen ja Anse Liones. Kuva: Työväen Arkisto.

osaa ryypätä, vaan miehiä, jotka ovat selväpäisiä vielä kaksinkertaisen tuplagrogin jälkeenkin!" 36

Kaiken kaikkiaan Martta Salmela-Järvisen ristiriitainen olo sodan jälkeen selittyy paitsi henkilökohtaisilla tragedioilla ja menetyksillä, myös vanhan ja uuden järjestökulttuurin kohtaamisella. Salmela-Järvinen eli konkreettisesti kulttuurista murroskautta. Se vanha naisliiton perinne, jonka lippua oli kantanut suurena ja tyynenä Miina Sillanpää, oli siirtymässä syrjään. Sillanpää kuoli vuonna 1952. Toinen vanhan naisliiton perintöä ja kokemusta siirtänyt johtonainen, Ida Aalle-Teljo, kuoli vuonna 1955. Kolmas, niin työväenpuolueen kuin naisliitonkin perustamiskokouksissa mukana ollut viimeinen perinteenvartija Olga Tainio kuoli vuonna 1961. Vastuu liikkeen traditiosta siirtyi Salmela-Järvisen tapaisille 1920luvulla toimintaan mukaan tulleille naisille. Voisi sanoa, että Salmela-Järvisen ikäluokka koki työväenliikkeen kulttuurisen diskurssin muutoksen niin suurena, että ahdistui. Sitä lisäsi alkava avoin kamppailu järjestöistä ja puolueen hajaannus. 


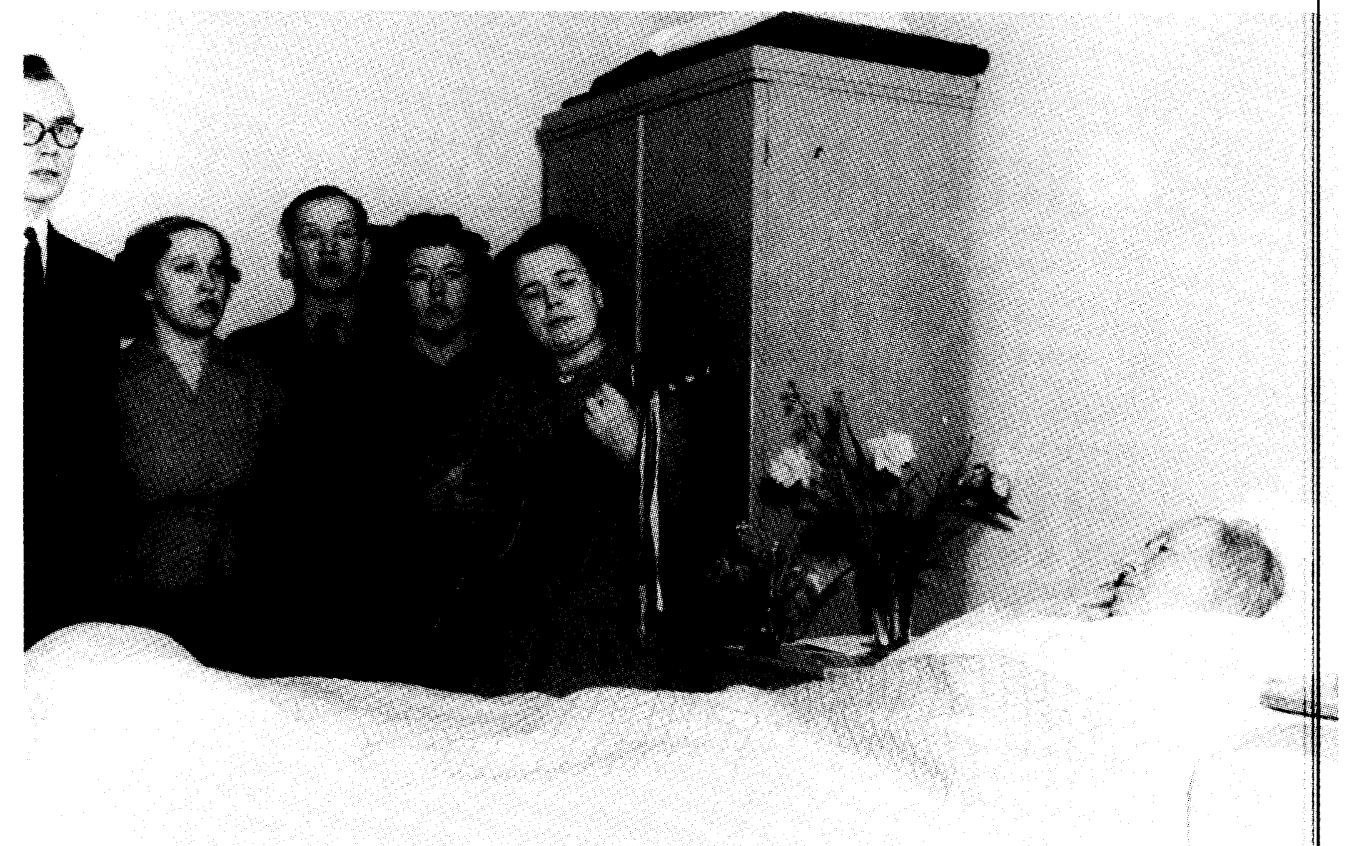

Ystävät tervehtivät kuolevaa Miina Sillanpäätä vuonna 1952. Kuva: Työväqn Arkisto.

\section{Rivit alkavat rakoilla}

Asevelijuntan tiivein kausi kesti kymmenisen vuotta. Sen johtomiehet, Väinö Leskinen ja Penna Tervo, alkoivat vetää eri suuntiin Työväen Urheiluliiton riidoissa vuosina 1953-55. TUL:n tapahtumia on pidetty Sdp:n hajaannuksen ensivaiheena. ${ }^{37}$ Vuoden 1953 puoluekokouksesta lähtien johtavien sosiaalidemokraattien keskinäiset ristiriidat alkoivat kasaantua ja ne kärjistyivät vuoden 1957 ylimääräisessä puoluekokouksessa. Salmela-Järvisen mukaan puoluekokouksen ensimmäinen suuri riidanaihe oli se tapa, jolla kokous kutsuttiin koolle. Olihan edellisestä puoluekokouksesta kulunut vain runsas vuosi. Kokouksen näin pikaiseen koollekutsumiseen oli syynä voimakas arvostelu istuvaa puoluetoimikuntaa kohtaan: sitä pidettiin kykenemättömänä ja taitamattomana. Sii-

37 TUL:n riidoista ks. Hentilä 1984, s. 365-452. 
hen kuuluivat puheenjohtaja Emil Skog, puoluesihteeri Väinö Leskinen ja jäseninä sellaisia tunnettuja nimiä kuin Eero Antikainen, Tyyne Leivo-Larsson, Matti Lepistö, K.A. Fagerholm, Väinö Tanner ja Aarre Simonen.

Uusi puoluetoimikunta valittiin Salmela-Järvisen mukaan "sellaisilla poppakonsteilla", ettei siitä saanut kukaan jälkikäteen selvää. Martta ihmetteli, miten muka Helsingissä oli yhtäkkiä tuhat jäsentä enemmän kuin aikaisemmin. Kerrottiin vitsinä, että kaikki kokoomuksen nuoretkin kävivät äänestämässä sosialidemokraattisen puolueen jäsenkirjalla. Valittu puoluetoimikunta oli SalmelaJärvisen mukaan leskisläinen ja "täydellisen puhdas" oppositiohenkisistä edustajista. ${ }^{38}$

Uuteen puoluetoimikuntaan tulivat naisista valituiksi puolueen miesten luottamusta nauttineet Meeri Kalavainen ja Sylvi Siltanen. Kansalaissodan aikana syntynyt Kalavainen oli valittu kansanedustajaksi vuonna 1948 Kotkasta. Turun läänin eteläisestä piiristä kansanedustajaksi vuonna 1958 valittu Siltanen puolestaan tuli valituksi tannerilaisen siiven luottonaisena vielä vuosien 1960 , 1963 ja 1969 puoluekokouksissa puoluetoimikuntaan. Vuonna 1972 Turun ja Porin läänin maaherraksi valittu Siltanen oli Suomen ja samalla pohjoismaiden ensimmäinen naispuolinen maaherra. Puoluetoimikunnassa Siltasen paikan perivät sittemmin Satakunnan piiristä Margit Eskman ja Pirkko Työläjärvi, joihin palataan vielä tuonnempana. ${ }^{39}$

\section{Irti puolueesta}

Puoluehajaannuksen dramaattisin vaihe oli opposition edustajien ulosmarssi puoluekokouksesta huhtikuussa 1957. Saman vuoden syyskuussa alettiin huhuta V.J. Sukselaisen kolmannesta hallituksesta, johon olisi menossa myös sosiaalidemokraatteja. Sosialidemokraattinen puoluetoimikunta ei ollut tästä suunnitelmasta selvillä ja Tanner varoitteli joukkoja epäparlamentaarisen hallituksen muodostamisesta: "siitä ei kunnian kukko laula". Viisi oppositiossa ollutta sosiaalidemokraattia, muun muassa naisliittolainen Aino Malkamäki, ${ }^{40}$ menivät kuitenkin puolueen kannasta riippu-

38 Martta Salmela-Järvisen haastattelu. TMTTK:n kokoelmat, sidos 256, s. 34-37.

39 Sosialidemokraattiset Naiset. Matrikkeli 1996.

40 Muut olivat Matti Lepistő, Valdemar Liljeström, Aarre Simonen ja Olli Uoti. 


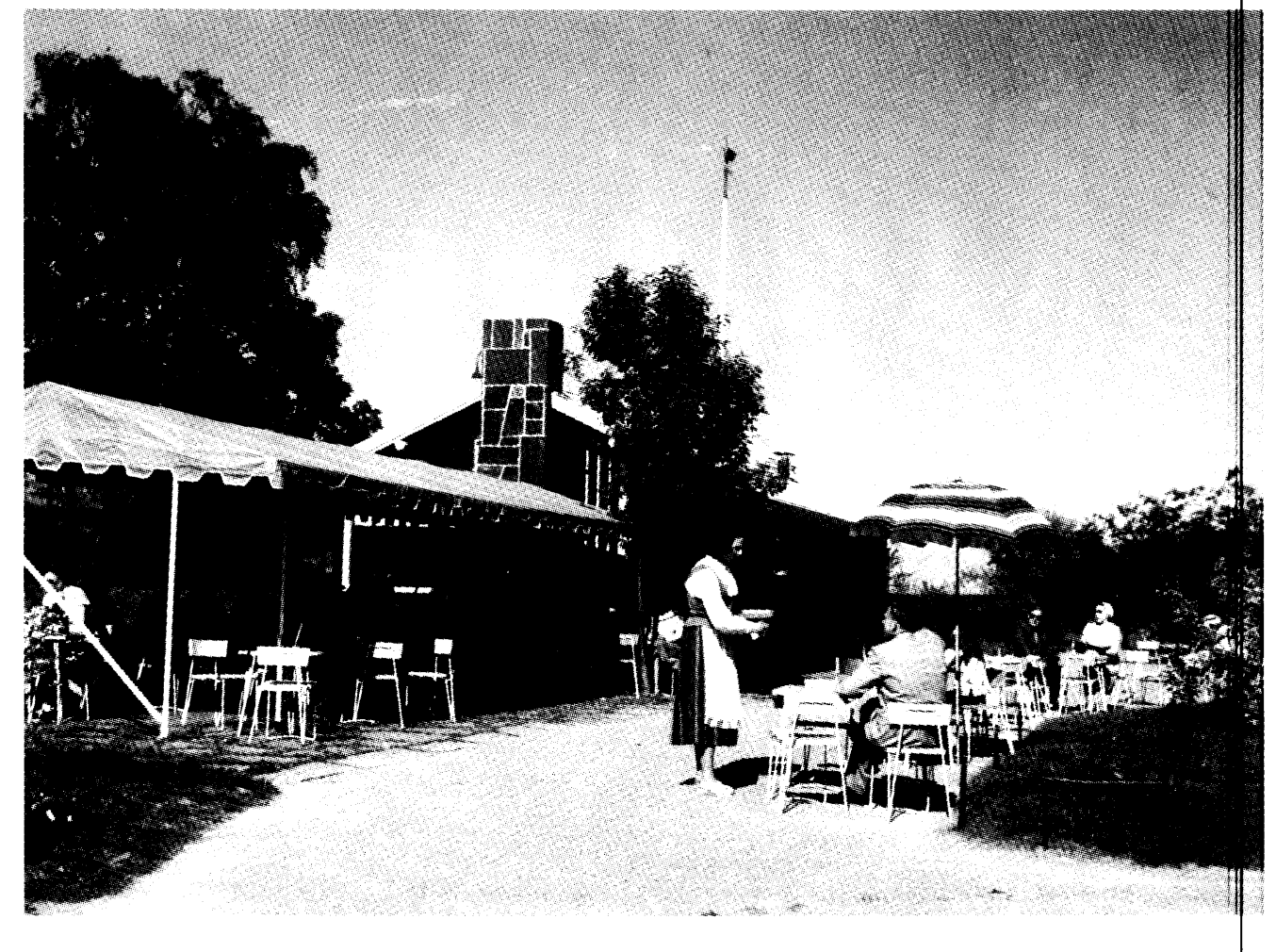

Sosialidemokraattinen naisliitto perusti vuonna 1951 Ursula Oy:n tukemaan vanhainkoti Käpyrinteen sekä Kallioniemen ja Kotorannan kesäkotien toimintaa. Yhtiö avasi vuonna 1952 ulkoilmakahvila Ursulan Helsingin Kaivopuiston rantaan. Kahvila sai heti helsinkiläisten jakamattoman suosion. Ursula Oy avasi myös toisen liikeyrityksen, nimittäin vuonna 1955 kukkakauppa Ursulan Hakaniemeen Paasivuorenkatu 8:aan ja 1960-luvun alussa vielä hotelli Ursulan. Idea liikeyritysten perustamisesta oli Tyyne Leivo-Larssonin. Osakeyhtiö Ursula toimii taustayhteisöineen edelleen. Kuva: Työväen Arkisto.

matta ns. ottopoikahallitukseen marraskuussa 1957. Malkamäki sai sosiaaliministerin salkun. Sosialidemokraattinen eduskuntaryhmä erotti hallitukseen menneet jäsenyydestään. Skogilainen ryhmä puolestaan ilmoitti, etteivät kyseiset ministerit olleet hallituksessa yksityisinä henkilöinä, vaan heidän edustamansa ryhmä 94:n edustajina. ${ }^{41}$

Kun hallitukselle esitettiin lokakuussa 1957 epäluottamuslausetta, ehdotti Martta Salmela-Järvinen luottamuslauseen anta-

41 Kertomus sosialidemokraattisen eduskuntaryhmän toiminnasta 1957. TA. 
mista. Hallitus kuitenkin kaatui. Salmela-Järvinen oli valinnut linjansa jo aiemmin. Huhtikuun 1957 puoluekokouksessakin hän oli kuulunut ulosmarssijoiden joukkoon, vaikka olikin kokouksessa mukana vain puolueen kunniajäsenenä. Tannerilaisuus rapistui 1940-50-luvun kiistoissa ja Salmela-Järvisestä tuli julki-skogilainen, samoin kuin hänen taisteluparistaan Tyyne Leivo-Larssonista. Salmela-Järvinen muodosti Impi Lukkarisen kanssa vuosina 196266 keväällä 1959 perustetun Työväen ja Pienviljelijäin Sosialidemokraattisen Liiton (TPSL:n) kahden naisen eduskuntaryhmän. Vuonna 1966 Martta Salmela-Järvinen päätti 27 vuotta kestäneen kansanedustajauransa. Samalla hän oli kypsynyt eheyttämään puolueen. Martta Salmela-Järvinen kirjasi marraskuussa 1966 sovittelevasti päiväkirjaansa: "Leskisläinen minäkin jo lienen. Hän kun on muuttunut. Saisi ne vanhat sotakirveet jo haudata". ${ }^{42}$ TPSL:n toiminta päättyi vuonna 1973.

\section{Avantouimari Leivo-Larssonin nousu pinnalle}

Emil Skog luonnehti Tyyne Leivo-Larssonia naiseksi, joka jo nuorena ollessaan Suomen Ammattijärjestön toimistonhoitaja erottui nopeasti terävien ja älykkäiden puheenvuorojensa vuoksi. Hänen luonteenpiirteissään olivat ylpeys ja itsetietoisuus hallitsevia. Skog piti häntä "aikamme huomattavimpana naispoliitikkona".

Leivo-Larsson oli ennen kaikkea sosiaalipoliitikko, mutta tunsi kiinnostusta ulkopolitiikkaan ja "ihme kyllä, myös puolustuslaitosta kohtaan". Skog ehdotti häntä kerran valtioneuvoston iltakoulussa toiseksi "varapuolustusministeriksi". Ministerit katselivat kummastuneina toisiaan, mutta hyväksyivät kuitenkin Skogin esityksen. Presidentti J. K. Paasikivi ei ollut niin hienotunteinen: hän hylkäsi armotta esityksen. Skogin mukaan se oli valitettavaa - varuskuntien sotilaskodit kun olisivat saaneet loistavan puolestapuhujan Leivo-Larssonista. ${ }^{43}$

Skogin arvio Leivo-Larssonista osui oikeaan: 1940-60-luvut olivat Tyyne Leivo-Larssonin nousun ja uran huipennuksen aikaa. Leivo-Larsson syntyi vuonna 1902 työläisperheeseen Uudellakirkolla. Taustastaan huolimatta hän pääsi kuitenkin keskikouluun ja Suomen Ammattijärjestössä vuosina 1926-29 toimiessaan hän opis-

42 Martta Salmela-Järvisen päivăkirja 10.11.1966. TA.

43 Skog 1974, s. 132. 
keli ruotsin lisäksi englantia ja saksaa. Ammattijärjestön hajaantuessa Tyyne siirtyi Helsingin kaupungin rahatoimistoon ja alkoi 1930-luvulla toimia aktiivisesti sosialidemokraattisessa naisliitossa ja Helsingin kaupungin Lastensuojeluvirastossa. Jo ennen sotaa hän toimi myös yli puoluerajojen naisten järjestöissä, kuten Kalevalaisten naisten johdossa.

Tämä yhteistyö tiivistyi talvisodan aikana, jolloin Leivo-Larsson toimi Suomen Huollossa, ja kuten aikaisemmin on todettu, Naisten Työvalmiusliitossa. Tyyne Leivo-Larssonista tuli vuonna 1947 sosialidemokraattisen naisliiton puheenjohtaja.

Leivo-Larsson valittiin vuonna 1948 kansanedustajaksi ja vaalien jälkeen muodostetun Fagerholmin vähemmistöhallituksen toiseksi sosiaaliministeriksi, paikkaan jonka Martta Salmela-Järvinen oli katsonut kuuluvan itselleen. Kaiken kaikkiaan Leivo-Larsson oli seuraavan kymmenen vuoden aikana viisi vuotta ministerinä (1948-50, 1954-58). Ministeriura teki hänestä uskottavan politiikon. Hänen ministerikausillaan toteutettiin työväestölle tärkeä Arava-järjestelmä, kansaneläkeuudistus ja uudistettiin työeläke- ja merimieseläkelakeja. ${ }^{44}$

Tyyne Leivo-Larssonin uran huipennus lienee se, että presidentti Kekkonen nimitti hänet ensimmäiseksi naispuoliseksi suurlähettilääksi Osloon. Nimitystä on luonnehdittu palkinnoksi skogilaisten, joihin Leivo-Larsson kuului, ja Kekkosen välisestä yhteisymmärryksestä. Pilapiirtäjä Kari kuvasi Leivo-Larssonin valintaa näin: "Ei naisten nimittäminen suurlähettilääksi ole vielä mikään todistus heidän tasa-arvoisuudestaan. Nimittihän Caligulakin senaattoriksi hevosen". Joka tapauksessa Tyyne menestyi toimessaan hyvin. Hän oli Oslossa seuraavat seitsemän vuotta ja toimi vuodesta 1959 suurlähettiläänä myös Islannissa. Kaudet päättyivät vuonna 1965 ja Leivo-Larsson palasi kotimaan poliittisiin kuvioihin.

Leivo-Larsson valittiin vuonna 1966 TPSL:n naisjärjestön eli vanhan sosialidemokraattisen naisliiton puheenjohtajaksi ja kansanedustajaksi, missä hän toimi vuoteen 1970. Hän oli tuolloin 68vuotias. Naisasia oli Leivo-Larssonin sydäntä lähellä ja hän seurusteli poikkeuksellisen laajasti eri yhteiskuntaryhmiä edustavien naisaktiivien kanssa. Muistelmakirjassaan "Elämässä tapaa ja tapahtuu" (1970) Leivo-Larsson kuvaa muun muassa "sota-Martta"

44 Ks. Soikkanen 1994, s. 68-71. 


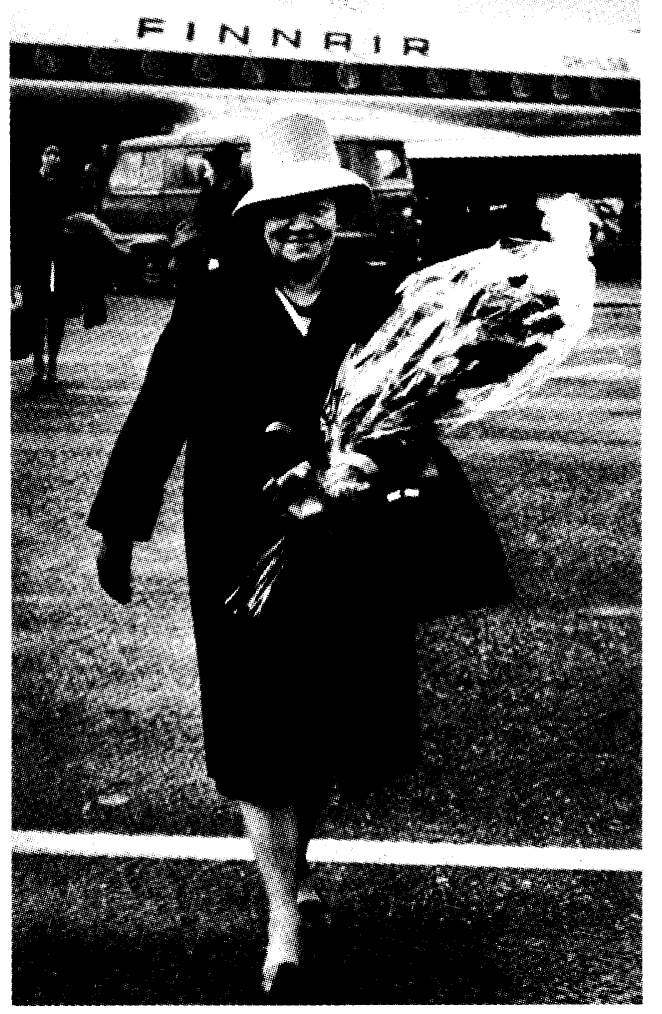

Hattujen ystävä Tyyne Leivo-Larsson (1902-1977) oli sosiaalidemokraattien kestoministeri vuosina 1948 58. Kuva: Työväen Arkisto.

Fanni Luukkosta. Tämä toimelias, kookas ja kenttäharmaa opettaja oli tullut Lotta Svärdin puheenjohtajaksi vuonna 1929 ja näki järjestönsä ennen kaikkea maanpuolustusjärjestönä. Leivo-Larsson tosin arvelee, että kyseisen liiton piirissä oli myös toisenlaisia painotuksia.

Leivo-Larssonin arvio Luukkosesta oli myönteinen. Tämä oli hänen mielestään älykäs ja kyvykäs johtaja, joka pyrki lähentämään lottia ja työväen naisjärjestöjä toisiinsa etenkin "suuren Hallelujan eli kaikkien erimielisyyksien hautaamisen aikana". Ennen naisliiton ja Lotta Svärdin yhteistoimintasopimusta sodan ajalta, nimenomaan Luukkonen otti ensin yhteyttä Leivo-Larssoniin, jonka kanssa hänellä oli ollut paljon yhteistyötä talvisodan aikana ja Suomen Huollon töissä. Lopullisen myönteisen kannan ottivat kuitenkin tuolloinen naisliiton puheenjohtaja Sylvi-Kyllikki Kilpi ja puolue. Vaikka Luukkonen sai "natsi-Saksan" korkean kunniamerkin, ei se Leivo-Larssonin mukaan tehnyt hänestä fasistia. Luukkonen nyt oli sellaisessa asemassa, ettei hän voinut kieltäytyä. Olihan Suomen virallinen politiikka Saksa-myönteinen. 
Samanlaisen ymmärtävän ja ihailevan myönteisen kuvan LeivoLarsson antaa myös muun muassa rouva Alli Paasikivestä, jonka kanssa hän oli yhteistyössä 1930-luvulla Kalevalaisten naisten toiminnassa, Suomen Punaisessa Ristin huoltotyössä tapaamastaan Henrik Ramsayn vaimosta Karinista sekä Ester Ståhlbergista. Jälkimmäisen Leivo-Larsson tapasi tämän perustaessa hyväntekeväisyyttä Helsingissä harjoittavan Tuki- ja Työ -yhdistyksen. Hella Wuolijokea Leivo-Larsson puolestaan luonnehtii komeaksi ihmiseksi, joka harrasti komeita pukuja ja hattuja. Koska Leivo-Larsson itse oli omien sanojensa mukaan "hattuhassu", hän ihaili tämän korkealle kivunneen liikenaisen ja kirjailijan hattukokoelmaa!

Työväenliikkeessä aktiivisesti toimivista naisista Leivo-Larssonin tuttaviin kuului poikkeuksellisen laajalti väkeä. Hän oli mukana Helsingissä 1930-40 -luvulla toimineissa naisten keskustelupiireissä. Toiseen ryhmään kuului viisi naista: professori Santeri Ivalon puoliso Ellinor, maaherra Bruno Sarlinin vaimo Signe, Helsingin Sanomien toimittajan Valto Tuomiojan vaimo ja poliitikko Sakari Tuomiojan äiti Laina, ministeri Heikki Ritavuoren leski Katri Ritavuori ja professori Väinö Voionmaan puoliso Ilma Voionmaa. Tyynehän itse oli insinöörin rouva. Hän oli avioitunut Brorinsa kanssa vuonna 1937. Leivo-Larsson oli omien sanojensa mukaan keskustelupiirin ulkojäsen. Ryhmän pääjoukko muodostui nimittäin samanikäisistä, yhteiskunnallisia asioita harrastaneista naisista, jotka nuorina olivat aktiivisesti olleet mukana tsaarinvastaisessa toiminnassa naiskagaalissa. Vanhat kagaalinaiset katsoivat, että heillä oli ikään kuin "tekijänoikeus" Suomen itsenäisyyteen ja sen kansanvaltaiseen hallitusmuotoon. Ryhmästä ainoastaan Voionmaa ja Leivo-Larsson eivät kuuluneet edistyspuolueeseen.

Toiseen piiriin kuului kuusi naista, jotka kannattivat eri puolueita ja olivat eri ikäisiä. Myös tähän ryhmään kuuluivat Ivalo ja Sarlin. Heidän lisäkseen siihen osallistuivat toimittaja ja kansanedustaja Lassi Hiekkalan puoliso Elna, Helsingin ylipormestarin puoliso Sylvi Rydman ja ylipoliisitarkastaja Walto Halmeen vaimo Helvi. Ja tietysti Leivo-Larsson. Naiset keskustelivat päivän politiikasta ja huhuista, joita varsinkin sodan aikana liikkui. He arvostelivat eduskuntaa, hallitusta ja poliitikkoja. Rouvat muistelivat toisilleen, mitä mieltä heidän tärkeissä asemissa olevat miehensä olivat kustakin asiasta. Yhteiskunnallisten väittelyiden lisäksi tapaamisissa, joita naiset järjestivät vuorollaan kodeissaan, puhuttiin myös henkilökohtaisista kuulumisista. 
Leivo-Larssonin naisverkosto oli ystävien verkosto, jonka merkitys oli erityisen suuri sotien aikana. Muun muassa ennen työpalveluun liittyvää Saksan matkaansa toukokuussa 1941, LeivoLarsson sai molemmilta keskustelupiireiltä ankarat ohjeet pitää silmät ja korvat auki. Tyyne ei saanut antaa hämätä itseään vieraanvaraisuudella, "sillä aivan tarpeeksi oli luettu lehdistä ja kuultu kertomuksia siitä, miten kaikki oli Saksassa mitä parhaimmassa kunnossa". Lisäksi Tyyne lupasi, että heti palattuaan matkalta kertoo kuulumiset muille naisille. Näin tapahtuikin. Hän todisti naisten epäilyjen olleen oikeita: muun muassa näyteikkunat olivat "valetavaroita" täynnänsä, mutta varsinaisia tavaroita ei ollut kaupassa lainkaan. ${ }^{45}$

Leivo-Larssonia voidaan verrata Miina Sillanpäähän nimenomaan yhteistyöstään muiden naisjärjestöaktiivien kanssa. Tuntien Leivo-Larssonin taustan ja yhteydet, olisi voinut kuvitella, että hän edustaisi sodan jälkeen oikeistolaisempaa leskisläistä politiikkaa. Näin ei kuitenkaan tapahtunut. Hänellä oli nuoreen puoluejohtoon vielä kireämmät välit kuin Salmela-Järvisellä. Leivo-Larsson kirjoitti topakasti vuonna 1951, että "Nykyinen naispolvi on täysin hyväksynyt sen näkemyksen, että nainen ja mies ovat erilaisia ihmisiä, mutta tämä erilaisuus ei merkitse eriarvoisuutta". ${ }^{46}$ Leskisen nuiva suhtautuminen naisliiton toimintaan ja halu siirtää naiset sivuun puoluetoimikunnan jäsenyydestä sai Martta SalmelaJärvisen ja Tyyne Leivo-Larssonin vanhoina naisasianaisina vetämään yhteistä köyttä. Kuten aiemmin todettiin, päätyivät he puoluehajaannuksessa rinta rinnan Emil Skogin riveihin.

\section{Lomatoiminta, vanhustyö ja kotitalousneuvonta eriytyvät}

Sosialidemokraattisen naisliiton sosiaalisesta työkentästä erotettiin vuonna 1945 erilliseksi valtakunnalliseksi organisaatiokseen Ensi Koti-toiminta. 1950-luvun alussa tuli lomatoiminnan, vanhustyön ja kotitalousneuvonnan vuoro.

45 Leivo-Larsson 1970, s. 130-136.

46 Naisten panos yhteiskuntaelämän tervehdyttämisessä, kirj. Tyyne Leivo-Larsson. Teoksessa Viitoitettu tie 1951, s. 38. 


\section{*Naisedustajat Suomen eduskunnassa 1907-2000}

Vaali-

Lkm yht. \% nais- Lkm sdp- Lkm \% naisia Sdp-

vuosi naisia edustajia naisia sdp-edust. edustajista

1907

$$
19
$$

25

1908

1909

1910

1911

1913

1916

1917

1919

1922

1924

1927

1929

1930

1933

1936

1939

1945

1948

1951

1954

1958

1962

1966

1970

1972

1976

1979

1983

1987

1991

1995

1999

21

17

14

21

24

18

17

20

17

17

16

11

14

16

16

17

24

29

30

28

27

33

$\begin{array}{rr}10 & \\ 13 & 13 \\ 11 & 12 \\ 9 & 10\end{array}$

9

$\begin{array}{rr}80 & 11 \\ 83 & 16 \\ 84 & 14 \\ 86 & 12 \\ 86 & 10 \\ 90 & 14 \\ 103 & 17 \\ 92 & 11\end{array}$

$10 \quad 92$

11

$\begin{array}{rrrr}11 & 13 & 90 & 14 \\ 12 & 17 & 103 & 17 \\ 9 & 10 & 92 & 11\end{array}$

13

12

10

$\begin{array}{rrrr}9 & 10 & 80 & 13 \\ 10 & 11 & 53 & 21\end{array}$

$\begin{array}{llll}9 & 12 & 60 & 20\end{array}$

9

960

$\begin{array}{lll}8 & 59 & 13 \\ 7 & 66 & 11\end{array}$

$\begin{array}{lll}8 & 78 & 10\end{array}$

$\begin{array}{lll}8 & 83 & 10\end{array}$

$\begin{array}{lll}10 & 85 & 12\end{array}$

$\begin{array}{lll}7 & 50 & 14\end{array}$

$\begin{array}{lll}9 & 54 & 17\end{array}$

$\begin{array}{lll}9 & 53 & 17\end{array}$

$12 \quad 54 \quad 20$

$\begin{array}{lll}9 & 48 & 19\end{array}$

$\begin{array}{lll}6 & 38 & 16\end{array}$

$9 \quad 55 \quad 16$

$\begin{array}{lllll}43 & 22 & 13 & 52 & 25\end{array}$

$\begin{array}{lllll}43 & 22 & 15 & 55 & 27\end{array}$

$\begin{array}{lllll}46 & 23 & 13 & 54 & 24\end{array}$

$\begin{array}{lllll}52 & 26 & 16 & 52 & 31\end{array}$

$\begin{array}{lllll}62 & 31 & 18 & 57 & 32\end{array}$

$\begin{array}{lllll}63 & 32 & 18 & 56 & 32\end{array}$

$\begin{array}{lllll}77 & 39 & 22 & 48 & 46\end{array}$

$\begin{array}{lllll}67 & 34 & 23 & 63 & 37\end{array}$

$\begin{array}{lllll}74 & 37 & 22 & 51 & 43\end{array}$

Tilastossa on nähtävissä vuoden 1970 vaalien tuottama taitekohta. Tuolloinhan naisten osuuden kasvu ylitti kaikkien naisten osalta $20 \%$ :n ja sosiaalidemokraattisten naisten osalta $25 \%$ :n rajan. Lähde: Eduskunnan tiedotusyksikön tilastot. http://www.eduskunta.fi; Sosialidemokraattiset Naiset. Matrikkeli 1996, s. 174 . 
Jo 1800-1900 -luvun vaihteessa äitien ja lasten virkistystoiminta olivat naisliiton tärkeitä toiminta-alueita, kuten aiemmin on esitetty. Kun sodan jälkeen lomatoimintaan alettiin yleisemminkin kiinnittää enemmän huomiota, katsottiin sosialidemokraattisessa naisliitossa tarpeelliseksi eriyttää se kokonaan omaksi liitokseen. Näin syntyi vuonna 1951 Äitien Lomahuolto ry, joka sittemmin sai nimekseen Lomakotien Liitto, jolla nimellä se toimii edelleen.

Vanhusten huollossa oli ennen sotia suuria puutteita. Vaikka kansaneläkelaki saatiin aikaiseksi vuonna 1937, sen vaikutukset ja lain uudistaminen siirtyivät sodanjälkeiseen kauteen. Erityisesti vanhusten asunto-olot olivat heikot. Kun Martta Salmela-Järvinen vieraili Oulunkylän kunnalliskodissa, oli hoidokit sijoitettu suuriin saleihin vieri viereen. Sosiaalidemokraattiset naiset alkoivat haaveilla omasta vanhainkodista. Helsingin sosialidemokraattinen naisyhdistys ryhtyikin sanoista tekoihin ja perusti vanhainkodin kannatusyhdistyksen vuonna 1938. Puheenjohtajaksi valittiin Anni Huotari ja varapuheenjohtajaksi Martta Salmela-Järvinen.

Vanhustyön valtakunnallista järjestämistä varten perustettiin vuonna 1953 Koteja Vanhuksille ry, joka vuonna 1981 sai nimekseen Vanhus- ja lähimmäispalvelun liitto. Myös tässä järjestössä Salmela-Järvinen oli puheenjohtajana vuoteen 1975 asti. Ensimmäinen sosiaalidemokraattisten naisten väliaikaiseksi tarkoitettu vanhainkoti avattiin Helsingissä Unioninkatu 45:ssä. Sota-aika siirsi kuitenkin naisliiton rakennushankkeita ja ensimmäinen varsinainen vanhainkoti, Käpyrinne Helsingissä, avattiin vuonna 1952. Helsingin kaupunki lahjoitti tontin.

Avajaisiin saapui suuri joukko tunnettuja suomalaisia, muun muassa juuri valittu miss Universium Armi Kuusela. Ensimmäiset asukkaat Käpyrinteessä eivät tosin olleet vanhuksia, vaan vuoden 1952 Helsingin olympialaisten urheilijoita. Käpyrinne oli mitä suurimmassa määrin Ida Aalle-Teljon ja Martta Salmela-Järvisen ponnistelujen tulos. Valmistuttuaan se herätti laajaa mielenkiintoa ja siihen käytiin tutustumassa kauempaakin. ${ }^{47}$ Vanhainkotien perustaminen oli Ida Aalle-Teljon viimeinen suuri hanke. Hän kuoli vuonna 1955. On kuvaavaa, että hän testamenttasi varsin mittavan omaisuutensa puoleksi Sosialidemokraattisen naisliiton opintorahastolle ja toisen puolikkaan Käpyrinteen ja Kotkaan nousseen

47 Vanhus - lăhimmäinen 1982, s. 23-27. 


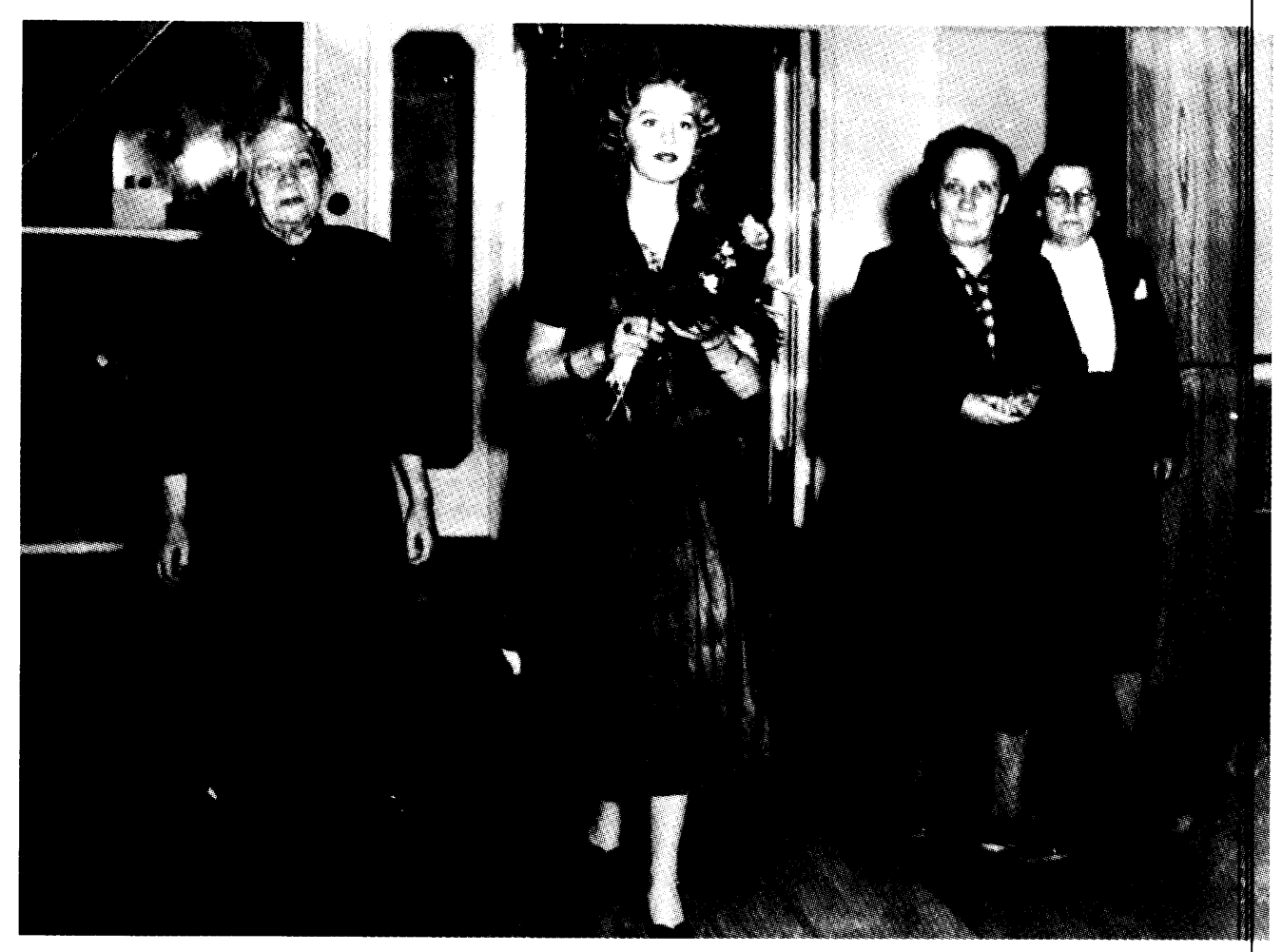

Miss Universum Armi Kuusela vieraili Sosialidemokraattisen naisliiton perustaman Käpyrinteen vanhainkodin avajaisissa Helsingin Käpylässä keväällä 1952. Missin seurassa vasemmalla Ida Aalle-Teljo ja oikealla Martta Salmela-Järvinen ja Aino Malkamäki. Kuva: Työväen Arkisto.

sosiaalidemokraattisten naisten Kalliorinteen vanhainkodin kannatusyhdistyksille. ${ }^{48}$

\section{Kotineuvontaliitto}

Edustajakokouksessaan vuonna 1956 Sosialidemokraattinen naisliitto teki päätöksen myös kotitalousvalistustoiminnan eriyttämisestä. Seuraavana vuonna perustettiinkin Kotineuvontaliitto. Liiton puheenjohtajaksi valittiin naisliittolaisaktiivi Elli Nurminen. Liiton tehtäväksi tuli jatkaa sitä työtä, jota naisliiton piirissä oli 1920-luvulta lähtien harjoitettu, kuten erilaisten kodinhoitoon liit- 
tyvien kurssien, talvipäivien ja kodinhoitopäivien järjestämistä ja perhelisäperheiden neuvontatyötä.

Toiminnan eriyttämistä perusteltiin sillä, että kotiin ja sen hoitoon liittyviin asioihin oli kiinnitettävä enemmän huomiota ja ohjaus- ja neuvontatoiminta oli saatava tehokkaammaksi. Erityisesti oli kiinnitettävä huomiota kotityön ammatillistumiseen, teknistymiseen ja kaupallistumiseen. Kun naisliitosta erotettiin tämänlaatuinen käytännöllinen työ, nousisi liiton toiminnan pääosaan jälleen aatteellinen työ. Tämä seikka oli aina vähän väliä hiertänyt naisliittolaisten välejä.

Tärkeä tekijä eriyttämiselle oli myös raha: poliittisen naisjärjestön oli nyt vaikeampi saada valtionapua tällaiselle työlle kuin aikaisemmin. Naisliiton tavoitteena oli kuitenkin se, että koko kotitalousvalistustyö saataisiin ennemmin tai myöhemmin valtion ja kuntien tukemaksi ja kuntiin perustettaisiin kotitalouslautakuntia asian eteenpäin viemiseksi. ${ }^{49}$ Näin sittemmin tapahtuikin. Kotineuvontaliiton nimi muutettiin vuonna 1979 Kuluttajaneuvontaliitoksi ja vuonna 1987 Suomen Kuluttajaliitoksi. ${ }^{50}$

\section{Naisliiton toinen hajaannus}

Sosialidemokraattinen naisliitto oli kiinteä osa linjariidoissa hajaantuvaa puoluetta. Myös naisliitossa ilmapiiri oli alkanut kiristyä vuoden 1953 edustajakokouksessa. Syitä jännitteisiin oli monia, kuten aiemmin olemme nähneet Martta Salmela-Järvisen synkästä yksinpuhelusta. Syyn avoimeen riitelyyn antoi puolueelta vuonna 1950 naisliiton 50-vuotisjuhlan kunniaksi saatu raha viiden naisjärjestäjän palkkaamista varten. Loppujen lopuksi toimitsijoita saatiin lähetettyä kaksi. Kentältä alkoi kuitenkin kuulua uutisia, että valitut puhujat arvostelivat ankarasti oman liittonsa johtoa: “..koko naisliiton johto on mätä ja Tyyne Leivo-Larsson pitäisi heittää laidan yli..." Edustajakokouksessa (1953) nuorempi polvi esittikin uuden puheenjohtajan valintaa ja ehdottivat Meeri Kalavaista. Tämä ei kuitenkaan vielä tuolloin saanut kannatusta.

49 Sos.dem. Naisliiton XXI edustajakokouksen pöytäkirja 22.23.4.1956 liitteineen, s. 46, 8386.

50 Kotitalouslautakunnista ks. Heinonen 1998

51 Martta Salmela-Järvisen haastattelu. TMTTK:n kokoelmat, sidos 256, s. 37. 


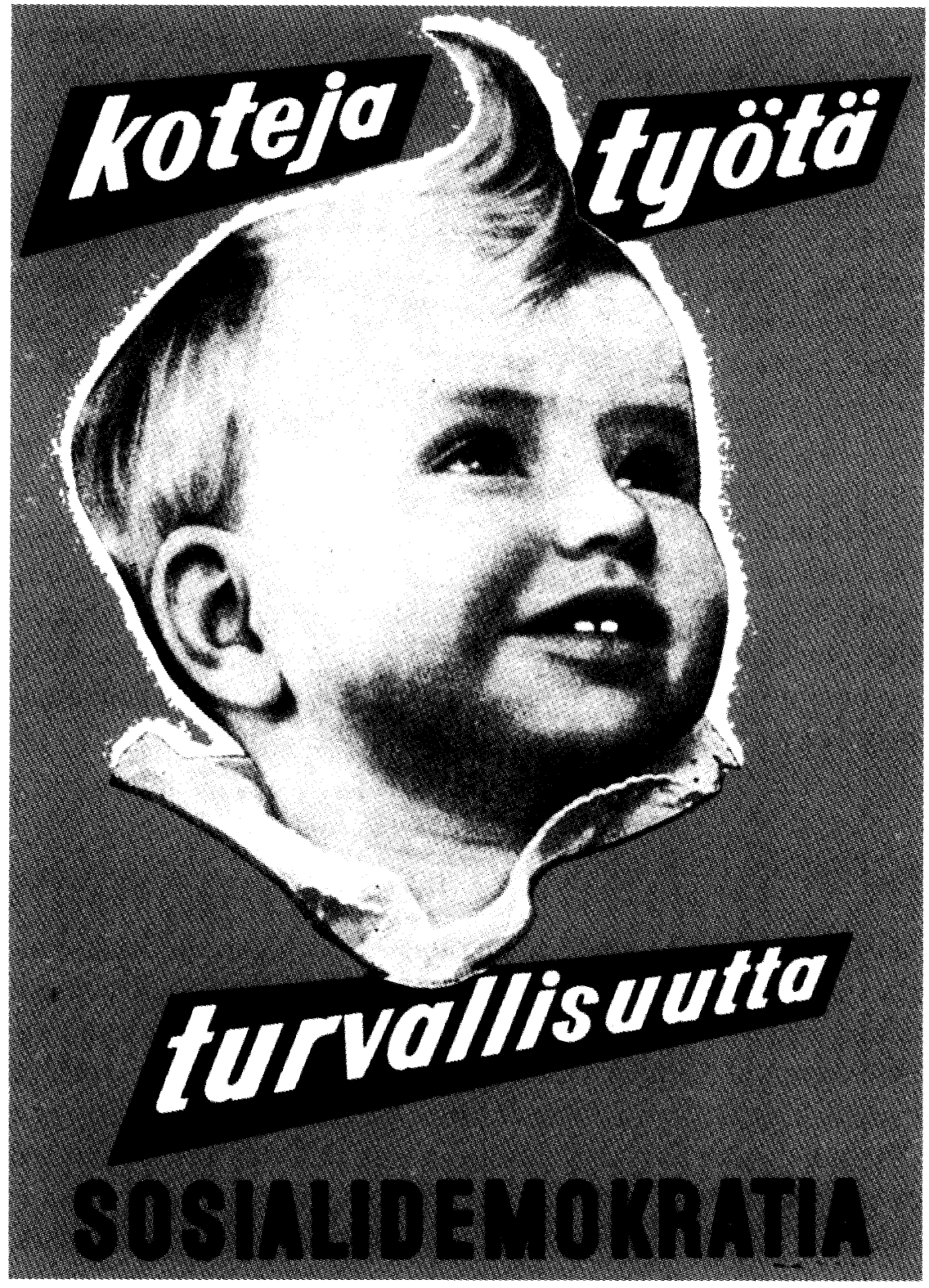

Sosialidemokraattisen puolueen vaalijuliste kunnallisvaaleissa 1950. Kuva: Työväen Arkisto. 


\section{*Vaatepaketteja rajaseutujen lapsille}

Sosialidemokraattinen naisliitto keräsi jäsenyhdistyksineen 1950-luvun alussa varoja ja vaatteita Kuusamon ja Lapin lapsille. Vaikka eteläisemmässä taajamien Suomessa alkoi elintaso jo nousta, ei siitä ollut vielä merkkejä monilapsisissa perheissä maan itäisillä ja pohjoisilla alueilla. Elämä saattoi olla sekä henkisesti että aineellisesti köyhää, kuten seuraavista naisliitolle osoitettujen kirjeiden otteista nähdään:

\section{-K:ssa 4.4.1958 Sosialisdemograatiset Naiset}

Kunnioitaen X.X. Kirjoitaa ja Valitaa köyhyytään ja sairauttaan kun meille on lapsia 8 alikstä ja isä sairastaa keukotautia ja äitikin on samassa taudissa ollut jo 2 vutta meille ei ole varja eikä omaa kotia eikä karjaa ole. Olemme Sosiali huneesa on pieni 1 hune missä asume nyt kysyn tässä jos voistte autaa sairasta köyhää perhettä jos on vartossa käytetyjä vaateta jos kenelle joutaa tälla perheelle antaa...Hauskaa Jumalan siunaamaa Pääsiäistä..

Kuten edellisesti otteesta näkyy, tavallisen rahvaan kirjoitustaito ei 1950luvulla ollut välttämättä kovin kehittynyt. Toisinaan lapset kirjoittivatkin anomuksia sosialidemokraattiseen naisliittoon vanhempiensa puolesta:

\section{-Hyvät ystävät!}

Rupesin kirjoittamaan teille kun sain eräältä tuttavaltanne osoitteenne ja hän kehotti minua kirjoittamaan teille sellaista asiaa, jotta etteköhän te voisi lähettää meille vaatetta ja rahaa. Kerron tässä nyt perheestämme se käsittää 5 henkeä. Minä olen yksi, ikää minulla on 13 v. sitten minulla on pituutta $155 \mathrm{sm}$ sitten minulla on $15 \mathrm{v}$. sisko hänellä on pituutta $160 \mathrm{sm}$ ja toinen sisko jolla on ikää $28 v$. hänellä on sitten $4 v$ vanha orpo poika sitten meillä on $60 v$ v vanha äiti isää meillä ei ole kellään sillä hän kuoli jo 5 v. sitten. Ei ole minkäänlaista hankemiestä kun ainoa hankemiehemme on sotapalveluksessa Kuopiossa ollu jo lokakuusta lähtien. Sisareni siis vanhimman täytyy olla kotona kun äiti on sairaloinen ja kun on jo niin vanha. Meillä ei ole tuloja mistään ei maataloudesta kun ei ole maata yhtään yksi huone. Saamme me kyllä pojasta 3000 mk kuukaudessa sotilasavustusta vaan ei se riitä vaatteeseen ainakaan kun sillä ei saa kun korttiannokset. Minullakaan Erkki pojalla ei ole päällyshousuja kun repaleet samettihousut samoin ei ole puseroa ei alusvaatteita eikä kenkiä. Kun lähetätte niin lähettäkää kunnollisia sillä köyhällä kun on entiset huonoja...os. Koululainen Erkki X.

Lähde: Kuusamon ja Lapin avustaminen 1953-56, k. Hb 17. Sos.dem. Naisliiton arkisto. TA. 
Martta Salmela-Järvisen mukaan naisliitossa oli jo tuolloin kolmen naisen porukka, jotka junttasivat Leskisen linjaa liittoon. ${ }^{52}$

\section{Kaksi naisliittoa}

Naisliiton edustajakokous kokoontui huhtikuussa 1956 rauhattomissa sisäpoliittisissa tunnelmissa. Lukuisat hallitusvaihdokset, juuri päättynyt yleislakko ja Tuntematon sotilas -elokuva herättelivät kansaa yhteiskuntakriittisten kysymysten ääreen. Niin myös naisia. Kokouksen alku oli ulkoisilta puitteiltaan hieno. Helsingin Työväentalon salin seinämille oli ripustettu kymmenen suurta punaista sydäntä. Jokaisen sydämen keskellä oli valokuvasuurennos kuvaamassa liiton keskeisimpiä toimintakenttiä: Ensikodit, vanhainkodit, Tulevaisuus-lehti, lomakodit, Cafe Ursula, Työväen Kukkasrahasto, liittojuhlat, puhujakurssit, kansainvälinen toiminta ja kotitalouskurssit. Touhukkaan näköiset naiset hakivat paikkojaan pienet uudenuutukaiset punaiset muovisalkut käsissään. Muovi oli päivän muoti-ilmiö. Näyttämön yläpuolella oli suuri naisliiton merkki ja parvekkeen reunaa koristi kokouspäivien tunnus "Sosialidemokratia-yhteistyön maailma". Varsinaisen kokouksen alkaessa 280 naisedustajan yhteistyö joutui kuitenkin koetuksille.

Yksimielisyys alkoi rakoilla heti alkuunsa, kun liitolle valittiin puheenjohtajaa. Toiset esittivät Tyyne Leivo-Larssonin valitsemista uudelleen, nuoremman polven edustajat esittivät johtoon Meeri Kalavaista. Suoritetussa äänestyksessä Leivo-Larsson voitti Kalavaisen selvästi 230 äänellä 45 ääntä vastaan.

Seuraavaksi kiisteltiin liittotoimikunnan jäsenvalinnoista. Salmela-Järvisen ja Leivo-Larssonin ympärille kertynyt joukko teki esityksen, jota Ulla Tiilikainen ihmetteli isoon ääneen: siinä ei ollut ketään "toisen linjan" naista: "Koko työväenliike on nykyisin pelkkä junttaliike”. Tiilikainen uhkasi, ettei hän lähde naisliitosta kuin kulumalla ja ettei hänelle kelpaa varasijat. Leivo-Larsson moitti Tiilikaisen puheenvuoroa täysin sopimattomaksi ja perättömäksi. Taimi Rinne-Virolainen tuki Tiilikaista: "Emme halua aina vain sanattomina todeta, mitä päätetään, vaan haluamme, että jär-

52 Sos.dem. naisliiton edustajakokouksen pöytäkirja 19.-20.4.1953, s. 31; Martta Salmela-Järvisen haastattelu. TMTTK:n kokoelmat, sidos 256, s. 37. 
jestödemokratiaa noudatetaan”. Hän ehdotti listaan liitettäväksi "oppositiossa" olevia Ulla Tiilikaista, Lempi Lehtoa ja Meeri Kalavaista. Vanha kaarti syytti asianajaja Tiilikaista junttaajaksi, joka liikkui maakunnissa TUL:n asioilla ja oli tuonut sen riidan naisliitonkin kokoukseen.

Kiihkeä keskustelu päättyi vaaliin, jossa vanhasta kaartista Martta Salmela-Järvinen menestyi parhaiten, hän sai yksistään 229 ääntä. Valituksi tulivat myös Aino Malkamäki ja Elli Nurminen. Uutta linjaa edustaneet saivat kuitenkin puolet paikoista: Ulla Tiilikainen, Lempi Lehto ja Meeri Kalavainen tulivat valituiksi. Uusi liittotoimikunta alkoi työnsä 50-50 -tilanteesta. Nuori polvi oli tullut naisliittoon jäädäkseen. He halusivat äänekkäästi, että myös heille tarjottaisiin luottamuspaikkoja. ${ }^{53}$

Kolmen seuraavan vuoden aikana naisliiton toimihenkilöt sekaantuivat yhä kiihkeämmin puolueriidan ja sisäpolitiikan syövereihin. Syyskuussa 1957 muodostettiin maalaisliittolaisen J.V. Sukselaisen niin sanottu ottopoikahallitus, jossa oli mukana sosiaalidemokraattista oppositiota edustaneet Aino Malkamäki, Aarne Simonen, Olli Uoti, Valdemar Liljeström ja Matti Lepistö. Puolueneuvosto ehdotti heidän erottamistaan puolueesta. Sukselaisen hallitus kaatui kuitenkin ottopojat - ja ottotyttö - mukanaan jo marraskuussa 1957. Sen jälkeen perustettiin uusi Otto von Fieandtin hallitus, joka myös oli lyhytikäinen. Huhtikuussa 1958 nimettiin jälleen uusi, maalaisliitosta ja sosialidemokraattisesta oppositiosta koostunut Reino Kuuskosken hallitus. Tässä hallituksessa istui naisliiton vanhan kaartin edustaja ja puheenjohtaja Tyyne LeivoLarsson sekä Toivo Antikainen, Matti Lepistö ja Valdemar Liljeström.

Kesällä 1958 pidetyt eduskuntavaalit olivat dramaattiset ja jännitteiset. Vaalien jälkeen muodostettiin Fagerholmin kolmas hallitus, jossa sosialidemokraattinen oppositio oli jälleen mukana, mutta sekin hallitus kaatui saman vuoden lopulla. Sosialidemokraattisen puolueen hajaannus aiheutti levottomuutta poliittisessa kentässä ja hallituskuvioissa.

Naisliitossa ristiriidat johtivat siihen, että keväällä 1959 kokoontuneet piirikokouksissa käytiin jo täyttä taistelua. Pienen liittotoimikunnassa olevan enemmistönsä turvin Salmela-Järvisen ja Leivo-

53 Sos.dem. naisliiton XXI edustajakokouksen pöytäkirja 22.-23.4.1956 liitteineen, s. 5-8, 32, $37-45$. 
Larssonin johtama Sosialidemokraattinen naisliitto päätti, että naisliiton jäsenyys ei enää edellyttänyt Sdp:n jäsenyyttä. Nuori polvi paheksui tapahtunutta syvästi, nimitteli vanhaa naisliittoa "pelkäksi" naisliikkeeksi ja tuomitsi sen irtautumisen Sdp:stä. Vähemmistöön jääneillä ei ollut muuta mahdollisuutta kun perustaa kesäkuussa 1959 sosialidemokraattisen puolueen yhteyteen epäitsenäinen naissihteeristö, joka sai nimekseen Sosialidemokraattisten Naisten Keskusliitto: "Itsenäisestä naisliikkeestä haluttiin päästä laajaan yhteistyöhön muun puolueväen kanssa". ${ }^{54}$

Naisliiton aktiivit jakautuivat seuraavasti eri leireihin:

"Skogilaiset"/TPSL

Martta Salmela-Järvinen

Tyyne Leivo-Larsson

Aino Malkamäki

Helvi Raatikainen

Elli Nurminen

Selma Hiisivaara-Mörk

Kaisa Hiilelä

Aune Seme

Anu Karvinen

Irja Salmela

Impi Lukkarinen
"Leskisläiset"/Sdp

Sylvi Siltanen

Meeri Kalavainen

Ulla Tiilikainen

Sinikka Luja (-Penttilä)

Anni Flinck

Lempi Lehto

Helvi Saarinen

Alli Lahtinen

Tyyne Paasivuori

Taimi Rinne-Virolainen

Edit Terästö

Yksi tärkeimmistä naisia jakavista tekijöistä oli suhtautuminen naisten erillistoimintaan eli naisliiton linjariidassa oli toinen painotus kuin puolueriidassa. Martan ja Tyynen vanha kaarti oli linnottautunut itsenäisen naisliiton muurien sisäpuolelle, nuorempi polvi halusi "uida" puolueen sisään ja vaikuttaa sieltä käsin enemmän yleispoliittisiin kysymyksiin. Tämä tulee hyvin esille molempien ryhmittymien hajaannuksen jälkeisissä arvioissa. Keskusliiton Alli Lahtisen mukaan "...perinteistä rikas Sosialidemokraattinen naisliitto liukui viimeisten toimintavuosiensa aikana tilanteeseen, jossa naisasia kulki sosialidemokratian edellä...".55

Keskusliitollekaan asia ei kuitenkaan ollut aivan helppo. Vuoden 1963 kokouksessa esitettiin kiihkeitä puheenvuoroja Keskus- 
liiton rekisteröimisestä itsenäiseksi organisaatioksi. Ellei kentältä olisi tullut rekisteröimisvaatimuksia, ei johdolla olisi ollut tarvetta lyödä niin äänekkäästi rekisteröintihaluja turhiksi.

Naisliiton johto oli kuitenkin tiukasti rekisteröimättömyyden takana ja leimasi vanhan naisliiton politiikan aikansa eläneeksi: "rekisteröimättömyys korostaa Keskusliiton kiinteää yhteyttä puolueeseen ja osoittaa myös irtautumista vanhentuneesta sukupuolirooliajattelusta. "56 Liiton tilannetta kuvaa hyvin se, että Keskusliittoon ei saanut kuulua sellaisia henkilöitä lainkaan, jotka eivät kuuluneet puolueeseen. ${ }^{57}$ Vanhan kaartin naisliittohan oli rekisteröity itsenäiseksi järjestöksi ja sen jäsenet saattoivat kuulua erikseen tai yhdessä naisliittoon ja puolueeseen.

Vanhaan naisliittoon jääneet takertuivat vanhan työväenliikkeen perinteeseen ja pyrkivät ammentamaan sieltä olemassolon oikeutuksensa hajaannuksen jälkeen. Sosialidemokraattisen naisliiton edustajakokouksessa toukokuussa 1962 astui katederille vanha perinteenkantaja, naisliittolaisaktiivi Anni Rinne suurten suosionosoitusten saattelemana. Hän kuvasi oivallisesti naisten tuntoja:58

Olen erittäin kiitollinen siitä, että suuri osa meistä vanhoista on ajatellut juuri samalla tavoin kuin minäkin. He ovat pitäneet kiinni vanhasta sosialidemokratian periaatteesta. Aina kun olen ajatellut menneitä vuosia, niin on tullut mieleen, että kyllä me oikeassa olemme ja vaikka toisin ajattelevat herjaavatkin, ei se enää meihin pysty. Meihin nähden on turha tehdä agitatsionia, me muistelemme kyllä taistelun vuosia, mutta olemme varmat siitä, että naisliitto on vakaana seisonut kaikkien taistelujen läpi työläisnaisten hyväksi, hänen taloudellisen ja henkisen elämänsä kohottamiseksi ja tulee olemaan tästä eteenkinpäin.

Naisliiton itsenäisyyskysymyksen lisäksi kiinnittyminen ammattiyhdistysliikkeeseen ja ideologinen valinta oikeisto- ja vasemmistososialidemokratian välillä vaikuttivat naisten valintoihin. Myös iällä ja koulutustasolla näyttää olleen vaikutusta ratkaisuihin. Keskusliiton naiset olivat koulutetumpia ja nuorempia - ja aatteessaan hieman enemmän oikealla kuin vanha kaarti, jolle yhteistyö kansandemokraattien ja maalaisliiton kanssa ei ollut niin vaikeaa kuin

56 Sosialidemokraattisten Naisten Keskusliitto 10 vuotta, 1969, s. 52.

57 Pöytäkirja Sos.dem. Naisten Keskusliiton II edustajakokouksesta 20-21.4.1963, s. 36

58 Sos.dem. naisliiton XXIII edustajakokouksen pöytäkirja Helsingissä 27.-28.5.1962, s. 10 
leskisläisille, jotka olivat selvemmin suuntautuneet kokoomuksen suuntaan.

\section{Luokkapuolueesta yleispuolueeksi}

Kaiken kaikkiaan Sosialidemokraattisen puolueen linjariitojen taustalla oli kuitenkin kysymys kahden eri järjestökulttuurin yhteentörmäyksestä. Sodan jälkeen oli tosiasiallisesti olemassa kaksi tapaa hahmottaa sosialidemokratia. Keskeisimmät näkemyserot koskivat sosialidemokraattisen puolueen suhdetta yhtäältä kasvavaan keskiluokkaan, toisaalta vahvistuvaan ammattiyhdistysliikkeeseen. Puolueen oli vastattava ajan haasteisiin ja modernisoiduttuva, mutta mikä olisi oikea tie.

Skogilainen siipi voidaan tässä asetelmassa nähdä perinteisiin pitäytyvämpänä luokkapuolueen kannattajana, kun taas leskisläisen sosialidemokratian idean keskiössä oli moderni teollinen yhteiskunta, jossa sosiaalidemokraatit muodostaisivat yleispuolueen. Leskisläiset halusivat keskiluokan kannattajikseen ja varoivat ammattiyhdistysliikettä. Tähän luokkapuolue vai yleispuolue -problematiikkaan liittyi puolueohjelman uudistustyö 1950-luvun alussa. Vuodelta 1903 voimassa oleva puolueohjelmahan oli selkeästi luokkapuolueen ohjelma, jota leskisläinen siipi pyrki uudistamaan. ${ }^{59}$ Naisliitossa leskisläisten modernisointiohjelma alkoi saada aikaisempaa enemmän kannatusta 1950-luvun puolivälissä ja syntyneet ristiriidat johtivat sittemmin hajaannukseen.

59 Ks. tarkemmin Ranto 1987, s.79-84; Soikkanen 1991, s. 457-515. 


\section{*Puhujakurssi vuodelta 1959}

Sosiaalidemokraattiset naiset järjestivät innokkaasti kurssi- ja leiritoimintaa 1950-luvulla. Kun naisliitosta eriytettiin kotitalouskurssitoiminta, saivat puhujakurssit enemmän tilaa ja suosiota. Lomakodeissa maaseudun rauhassa pidetyillä kursseilla tehtiin muistoksi käsintehtyjä lehtiä, jotka saivat sellaisia nimiä kuin Pisara, Pirinä, Synteesi, Kurssiviesti tai Tyynelän tarinat. Tottilan Peili -niminen lehti syntyi elokuussa 1959 Tottijärvellä olevassa tamperelaisten sosiaalidemokraattisten naisten lomakoti Ruskeapäässä pidetyillä naisliiton puhekursseilla. Nykyään noita kursseja sanottaisiin esiintymistaidon tai televisio-esiintymisen kursseiksi. Jo 1950-luvun demarinaisille oli tärkeää oppia esiintymään luontevasti ja puhumaan oikeaoppisesti. Järjestyksessä elokuun kurssit olivat Ruskeapään kymmenennet. Minkälaisia mietteitä naiset sitten kirjoittivat puoluehajaannuksen kuumina vuosina?

Tottijärven kurssien kurssilehden, Tottilan peilin, pääkirjoituksessa arvioitiin heti alkuunsa, että "rikas ja antoisa kurssi oli taas elävä todistus siitä, kuinka liittomme kasvatustyö jatkuvasti rullaa ajallemme ominaisesta rikkinäisyydestä ja viimeaikaisesta hajoitustyöstä huolimatta".

Tarkkailija kuuli kymmenen päivän aikana ihmeellisiä ääniä kaksikerroksisen talon uumenista: aa-aa-ää-ää-piip-piip. Välillä kuului laulua, naurua tai muuta mekastusta. Joskus taas vaikutti siltä, että paikalla olisi nudistileiri. Mekoista päätellen taas näytti siltä, että Suomen väkiluku pian lisääntyisi. Naisten päiväharjoituksiin kuului tärkeänä osana hengittäminen: "Näin siksi, että pysyy hengissä: pitää osata aukoa suutaan ja kaiuttaa kitalakea". Naisia opetettiin myös julkiseen esiintymiseen: ennen suurta tilaisuutta piti paikalle mennä ajoissa ja asettua lattialle selälleen. Siinä asenossa piti tyhjentää aivot vanhoista ajatuksista, että se aiottu puhe mahtui sinne oikeassa järjestyksessä. Huumoria ei tulevien sananselittäjien opetustuokioista puuttunut!

Pyöreän pöydän keskusteluissa naiset käsittelivät sellaisia aiheita kuin "Tämän hetken nuoriso", joka sai osakseen suurta huomiota, sekä "Juhlakulttuuri" ja "Nainen kodissa ja yhteiskunnassa". Kukaan ei tuominnut nuorison "lättähattuisuutta". Tuon ajan nuoriso alkoi ulkoiselta olemukseltaan muistuttaa pieniä james deaneja. Vanhempien nähtiin arvostelevan liikaa nuoriaan, jotka olivat syntyneet tekniikan ja koneiden maailmaan.

Tietojen ja taitojen puute oli saanut naiset kurssille, eikä naisjoukko ollut pieni. Luennoitsijat käsittelivät puhetaidon lisäksi naisliiton historiaa ja sen sosiaalista työtä, kunnallispolitiikan kiemuroita, järjestötyötä, propagandaa ja mainontaa.

Lähde: Tottilan Peili 19.8.1959. Sos.dem. naisliiton arkisto. TA. 


\section{Taistelu tasa-arvosta}

\section{Kohti uutta maailmankuvaa}

Suomalaisten naisjärjestöjen kattojärjestö, Suomen Naisjärjestöjen Keskusliitto, julkaisi vuonna 1961 historiikin 50-vuotisen taipaleensa kunniaksi. Järjestön puheenjohtaja Margit Borg-Sundman arvioi vuosikymmenen vaihdetta näin: "Tämä maailma on nopeasti kasvavien komeiden kaupunkien maailma, joka on vaarallisesti vieraannuttamassa kotikeskeisyydestä ja naapuriavusta. Tämä maailma on aineellisen hyvinvoinnin ja korkean elintason maailma, jolta ovat unohtumassa henkiset arvot ja korkean eetillisen elämänlaadun välttämättömyys". Mielenkiintoista tässä "uuden ajan" kynnyksellä tehdyssä arviossa on se, että siinä menneisyys edusti korkeita henkisiä arvoja ja "eetillistä elämänlaatua", kotikeskeisyyttä ja naapuriapua. Kaiken parempaa tulevaisuutta korostaneen valistuksensa jälkeen naiset yllättäen näkivät epädemokraattisen menneisyyden ihanana aikana. Alunperin seitsemästä porvarillisesta naisjärjestöstä koostettu järjestö oli juhlavuotenaan 50 naisjärjestön yhteistyöelin ja sen piiriin kuului yli 400000 jäsentä. Sosialidemokraattinen naisliitto oli liittynyt järjestöön vuonna 1941. Järjestön ääni ei siis ollut mikään yksinäisen ääni erämaassa. Naisten huoli perinteisten arvojen säilymisestä olikin vakava ja aiheellinen, siksi rajulla tempolla rakennemuutos alkoi ravistella yhteiskunnallisia suhteita.

Samaa uuden tilanteen luomaa jännitettä on nähtävissä myös yksittäisten naisjärjestöjen toiminnassa oikealta vasemmalle. Naisten asemaa määrittävä lainsäädäntö ja käytännöt oli mietittävä uudelleen. Sosialidemokraattisten Naisten Keskusliitto otti edustajakokouksessaan 1963 esille naisten tasa-arvokehityksen vahvistamisen. Liitto ehdotti, että myös Suomessa käynnistettäisiin samanlainen tutkimus kuin Ruotsissa. Siellä oli aloitettu sosiaalidemokraattisten naisten toimesta tutkimushanke, jossa selvitettiin naisten muuttuvaa asemaa uusissa oloissa. Ruotsissa oli käyty kiivaita keskusteluja etenkin äitien roolista palkkatyöläisinä, mikä 


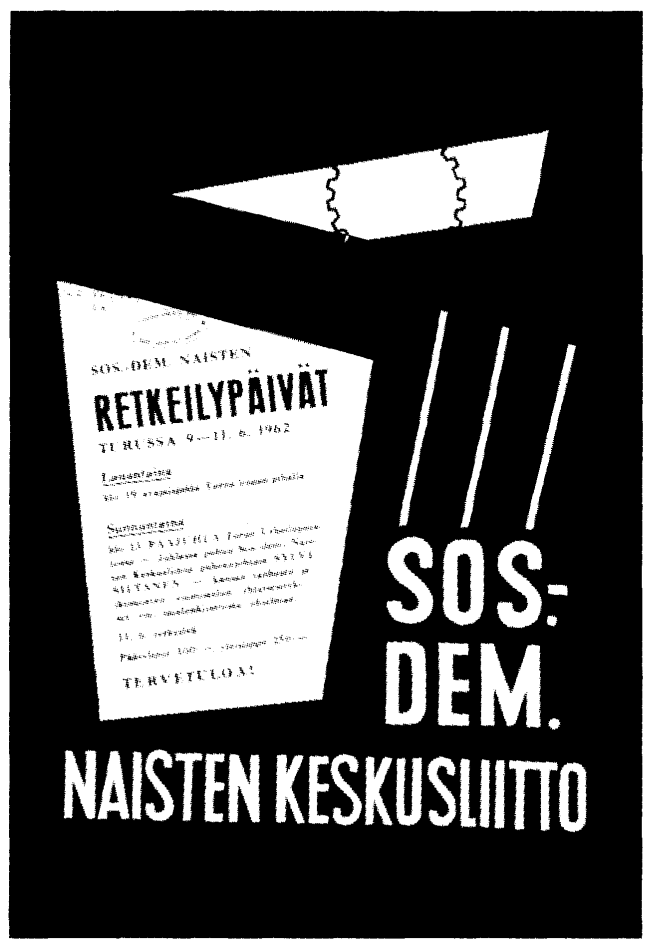

Sosialidemokraattisten Naisten Keskusliiton tunnukseksi valittiin vuonna 1962 kolme viiriä. Kuva: Työväen Arkisto.

heijastui myös suomalaiseen yhteiskuntakeskusteluun. Sittemmin Ruotsissa tehtyä kartoitusta (1964) on arvioitu merkittäväksi periaatteelliseksi virstanpylvääksi syystä, että se oli ensimmäinen sosiaalidemokraattisten naisten aloite ja suunnitelma, joka omaksuttiin koko puolueen periaatteeksi. Raporttia seurasi vielä toinen mietintö samasta aiheesta (1969). Sen työtä johti Alva Myrdal.' Vuoden 1964 selvityksen seuraamukset olivat hyvin kauaskantoisia.

Keskusliiton johtonaisten esitys sai kentän kannatuksen ja liitto kokosi työryhmän valmistelemaan asiaa. Jo elokuussa 1966 Keskusliiton liittotoimikunta meni esittelemään esitystään pääministeri Rafael Paasiolle. Esityksen tultua julkisuuteen se sai myös muiden naisjärjestöjen tuen ja hallitus asetti syyskuussa 1966 asiaa tutkivan komitean. ${ }^{2}$

Eduskunnassa sosiaalidemokraattiset naiset keskittyivät 1960luvulla ajamaan tasa-arvokysymysten lisäksi sosiaalipoliittisia uu-

Sainsbury 1993, s. 280.

2 Sosialidemokraattisten Naisten Keskusliiton edustajakokouspöytäkirjat 20--21.4.1963 ja 2.3.6.1966 liitteineen; Sos.dem. Naisten Keskusliiton liittotoimikunnan pöytäkirja 3.2.1966. TA. 
distuksia, rauhanasiaa ja kansainvälistä solidaarisuustyötä. Samanlaista työtä tekivät myös kansandemokraattiset naiset. ${ }^{3}$

Sinikka Lujan (sittemmin Luja-Penttilä) vuonna 1963 tekemän arvion mukaan oli tultu tilanteeseen, jossa "ei voida vetää rajaa naisten ja miesten asioiden välille...meidän on kiireesti ryhdyttävä tekemään kasvatustyötä naisten keskuudessa muillakin kuin sosiaalipoliittisilla kysymyksillä...me sosialidemokraattiset järjestönaiset olemme vastuussa siitä, että suomalainen nainen osaa asennoitua oikein erilaisissa tilanteissa. "4 Oikea asennoituminen tarkoitti naisten yhä näkyvämpää osallistumista työmarkkinoille ja valtakunnan politiikkaan. Naisten oli oltava siellä missä miehetkin.

Tasa-arvokysymys nousi päivän puheenaiheeksi. Keskusliiton edustajakokous vuodelta 1966 arvioi tilanteen näin: "Maassamme vallitsee eri sukupuolten teoreettinen tasa-arvoisuus". Se, että naiset ja miehet olivat lain edessä yhdenvertaisia, että heillä molemmilla oli yleinen ja yhtäläinen äänioikeus, ei riittänyt. Sillä työmarkkinoilla, perhe-elämässä ja yhteiskunnallisessa toiminnassa naiset kokivat syrjintää. Kokouksessa Ruotsin komitean työtä esitteli Nancy Ericksson Ruotsin sosialidemokraattisesta naisliitosta. ${ }^{5}$

Vuosi 1966 oli monessa suhteessa käänteentekevä vuosi niin sosiaalidemokraattiselle liikkeelle kuin naisliikkeellekin. Sosialidemokraattisen puolueen eheytyminen, vasemmiston vaalivoitto, eduskuntavaaleissa naisten aikaisempaa runsaampi läpimeno ja ennen mainitun tutkimuksen käynnistäminen naisten asemasta suuntasivat katseita toiveikkaasti tulevaisuuteen. Vuonna 1966 perustettiin myös radikaaleja mielipiteitä esittänyt ja vasemmistolaiseksi leimaantunut Yhdistys 9, jonka piirissä toimi myös sosiaalidemokraatteja, kuten kansanedustaja ja sittemmin presidentin puoliso Tellervo Koivisto. Samaan aikaan kasvaneessa feministisessä liikkeessä sosiaalidemokraatteja ei sen sijaan juurikaan ollut.

Sukupuoliroolit, naisen ja perheen aseman uudelleenmäärittäminen ja lasten päivähoitokysymykset ponnahtivat kiihkeinä yleiseen keskusteluun. Uuden naisliikkeen synty kertoo naisten sekä

3 Ks. Katainen 1994, s. 319-358.

4 Pöytäkirja Sos.dem. Naisten Keskusliiton II edustajakokouksesta 20-21.4.1963, s. 60.

5 Pöytäkirja Sos.dem. Naisten Keskusliiton II edustajakokouksesta 20.-21.4.1963, s. 41-52, 59-67. 


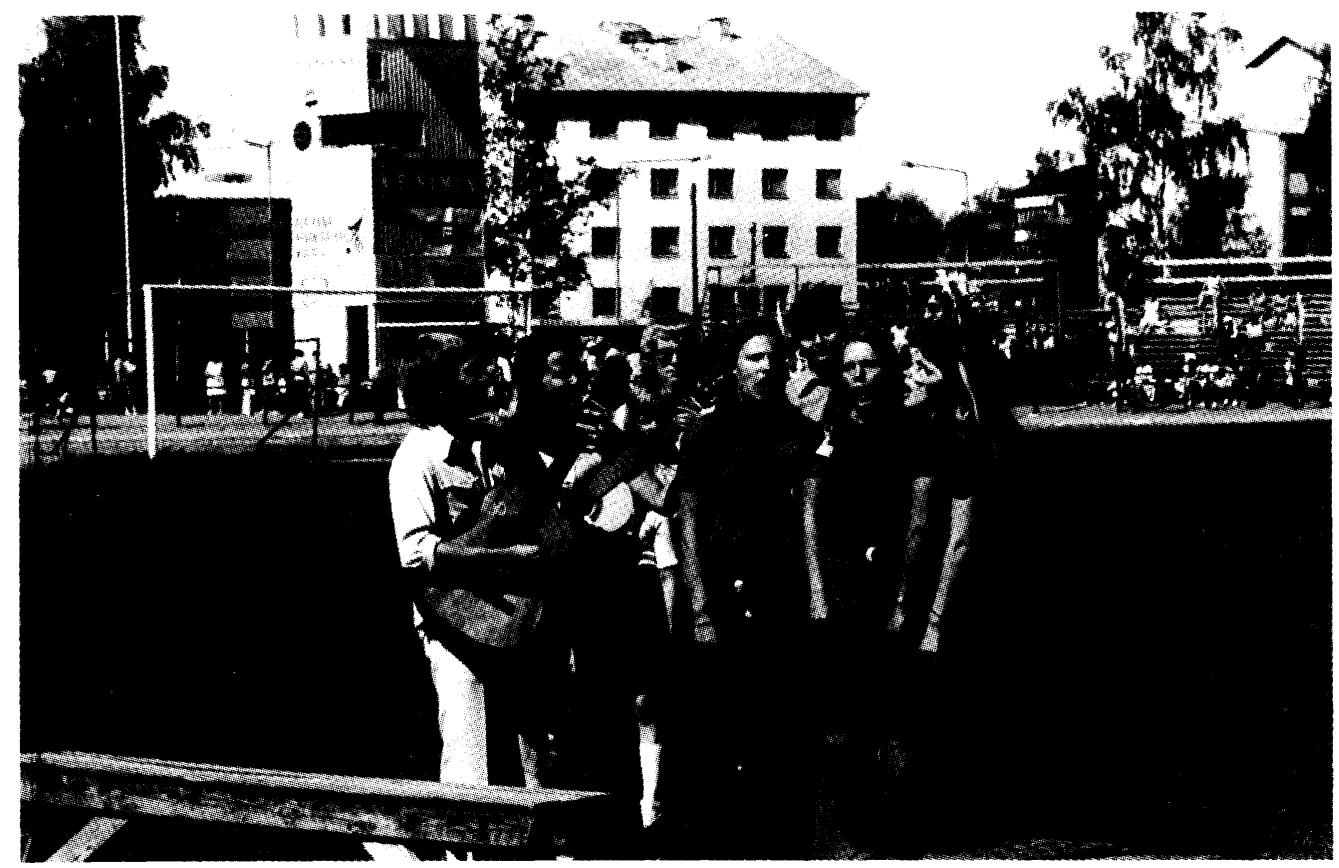

Naisliittolaiset saivat kuulla Vaasan maakuntapäivillä 1970-luvun poliittista nuorisomusiikkia livenä. Kuva: Työväen Arkisto.

sosiaalisten että taloudellisten olojen muutoksesta, mutta myös nuorten naisten vieroksuvasta suhtautumisesta vanhoihin naisjärjestöihin. Ei ihme, että 1960-luvun loppua on sanottu naisasialiikkeen toiseksi taistelukaudeksi. Radikaalin nuoremman naisjoukon nousu barrikaadeille pakotti vanhat naisjärjestöt uusimaan näkemyksiään. Kuten aiemmin on jo tullut esille, kulttuurinen murros oli alkanut jo sodan jälkeen, joten tyhjästä uusi aalto ei noussut.

Suomalaisten naisten järjestöverkosto koostui 1960-70-luvulla puolueiden naisliitoista ja vanhoista naisjärjestöistä, kuten Naisasialiitto Unionista, sekä yli puoluerajojen menevistä radikaaleista ja feministisistä naisasialiikkeistä. ${ }^{6}$ Ryhmittymät erosivat toisistaan paitsi vasemmisto-oikeisto -orientaationsa kautta, myös työskentelytavoiltaan. Toiminta tapahtui uusissa naisyhdistyksissä epämuodollisesti pienryhmissä. Uusi naisliike ei myöskään antanut yleisiä kannanottoja kollektiivina, vaan liikkeen piirissä toi-

6 Ks. Jallinoja 1983, s. 239-247. 
mineet naiset kertoivat yksilöllisiä mielipiteitään. Tässä suhteessa 1960-luvun uusi naisliike muistutti 1970-luvun lopulla noussutta vihreää liikettä.

\section{Täydellisen tasa-arvon vaatimus}

Naisten ja äitien osuus palkkatyössä kasvoi 1960-luvulla. Naisten osuus kokopäiväisesti ammatissa toimivasta väestöstä oli vuonna 1960 Suomessa $39 \%$. Ruotsissa vastaava luku oli $30 \%$, Tanskassa $28 \%$ ja Norjassa $23 \%$. Naiset alkoivat äänekkäästi vaatia naisten palkkatason nostamista, sehän oli noin 60-70 prosenttia miesten palkoista. Samalla vaadittiin palkkatyön seuraamusten, kuten päivähoitojärjestelmän uusimista, osapäivätyön tuottamien ongelmien ratkaisua ja naisten ammattikoulutuksen uudelleenjärjestämistä.

Vuonna 1964 työllisyyslain mukaan järjestettiin miehille 405 ammattikurssia 30 eri ammattinimikkeelle, naisille vastaavasti tarjottiin 174 kurssia 11 ammattinimikkeelle. Naiset kaivoivat vaatimustensa tueksi raa'at tilastotiedot ja vaativat täydellistä tasa-arvoisuutta miesten kanssa. Naisia närkästytti se, ettei Suomen eduskunta ollut vielä tuolloin ratifioinut Kansainvälisen Työjärjestön sopimusta numero 111 syrjinnän poistamiseksi. Suomi ratifioi kyseisen sopimuksen vuonna 1970.

\section{Radikalismin nousu}

1960-luku oli yleisen politisoitumisen ja vasemmistolaistumisen kautta. Suomessa toimineista kansalaisjärjestöistä lähes kolmasosa oli poliittisia yhdistyksiä - 1980-luvulla niitä oli vain $13 \%$. Niiden tilalle olivat tulleet urheilu-, kulttuuri-, opinto- ja harrastusyhdistykset. Poliittinen aktivoituminen ja näkemysten kärjistyminen juuri 1960-luvulla johtui osin taloudellis-sosiaalisesta murroksesta, osin kansainvälisistä vaikutteista ja eri toimijapiirien aktivoitumisesta. Sivistyneistön ja kommunistien liikehdintä voimistui ja vasemmiston todelliset vaikutusmahdollisuudet kasvoivat niille tuloksellisten eduskuntavaalien myötä. ${ }^{7}$

7 Siisiäinen 1990, s. 87. 
Talouselämässä Suomi koki murroskauden teollisuuden ja palvelujen kasvamisen ja maatalouden supistumisen myötä. Kun vielä vuonna 1960 alkutuotannosta sai elantonsa $36 \%$ väestöstä, oli vastaava osuus vuonna 1980 laskenut $13 \%$ :iin. ${ }^{8}$ Väki alkoi siirtyä maaseudulta asutuskeskusten lähiöihin, pohjois- ja itäosista maata muutettiin Etelä-Ruotsin tehtaisiin töihin. Suomi alkoi nopeasti modernisoitua.

Poliittisessa kentässä 1940-luvulta saakka politiikan keskiöstä sivussa olleet kansandemokraatit ja kommunistit nousivat vaikuttavaan asemaan. Vuoden 1966 eduskuntavaaleissa vasemmistopuolueet voittivat ja eduskuntaan tuli vasemmistoenemmistö. Sosialidemokraateista tuli johtava hallituspuolue. Tällä tavalla muodostunut kansanrintama loi mahdollisuuksia protestiliikkeille ja todellisille uudistuspyrkimyksille.

Myös kulttuurinen kenttä avautui 1950-60-luvulla. On sanottu, että 1950-luvun modernismi oli etäisyydenottoa ja vapautumista ahdistavasta kansallisesta yhdenmukaisuudesta. ${ }^{9}$ Taiteessa modernismin tulo, teininuorison ja opiskelijoiden radikalisoituminen, Vanhan Ylioppilastalon valtaus ja Arvo Salon Lapualaisooppera olivat tästä näkyviä esimerkkejä. Suomen kansainvälistäminen oli alkanut jo edellisellä vuosikymmenellä: populaarikulttuurin ja amerikkalaisuuden tulo maahan elokuvien, supertähtien, lehtien ja muodin välityksellä loivat pohjaa 1960-luvun kulttuuri-ilmapiirille.

Uudet poliittiset toimijat olivat sodan kokeneen sukupolven lapsia, vuosina 1945-49 syntyneitä suuria ikäluokkia. Kirjailija Arvo Salo onkin osuvasti sanonut, että hän kutsuu aikakautta mieluummin "sukupolveksi" kuin "kuusikymmenluvuksi". On sanottu, että juuri tämä ikäluokka olisi muodostanut ensimmäisen kerran varsinaisen suuren "autonomisen nuorison" luokan omine kulttuureineen ja arvostuksineen. ${ }^{10}$ Vaikka tämä arvio on hieman ylilyövä eikä tee oikeutta menneisyyden "nuorille", kuvaa se hyvin suuren ikäluokan yhtäaikaista esiinmarssia poliittiselle kentälle. Sosiaalidemokraattinen liike sai osansa tuosta uudesta voimasta ja sen myötä tulleista poliittisen kulttuurin käytännöistä.

8 Siisiäinen 1990, s. 91.

9 Alapuro 1993, s. 5.

10 Tuominen 1991, s. 45; Siisiäinen 1990, s. 108-112. 


\section{*Herraksi tulemisen pelko...}

Monet työväenliikkeessä mukana olleet ovat muistelleet katkerina sitä, ettei heillä ollut mahdollisuutta käydä koulua. Riihimäkeläinen naisliittolaisaktiivi Alma Kaiponen muisteli 1960-luvun alun koulu-uudistuskeskustelujen aikaan kohtaloaan näin:

Olen itse saanut käydä vain kansakoulun ja tuntenut suurta katkeruutta elämää kohtaan siitä, että se on pidellyt niin kovakouraisesti, että opintielle ei ole päässyt...Jotkut epäilevät sitä, kuka tekee raskaat työt, kun kaikki koulutetaan herroiksi. Tieto ei kuitenkaan ole taakaksi ja on varmaa, että nuoret pystyvät paremmin elämänsä järjestämään, jos heillä on mahdollisuus käydä koulua...

Sosiaalidemokraattien ohjelmassa koulukysymys on ollut keskeisellä sijalla toiminnan alkuajoista lähtien. Vaikka kansakouluasetus annettiin jo 1860-luvulla, tuli yleinen oppivelvollisuus voimaan vasta vuonna 1922. Sotienvälisellä kaudella ammattikoulutusjärjestelmän luominen ja vaatimus tyttöjen kouluttamisesta olivat muun muassa eduskunnassa naisliittolaisaktiivien tärkeimpiä vaatimuksia.

Sodan jälkeen sosiaalidemokraatit vaativat kansalaiskoulu- ja ammatillisen koulutuksen laajentamista ja vuonna 1957 kunnallisen oppikoulujärjestelmän voimaantulo oli suuri voitto erityisesti naisliittolaisille. Sosialidemokraattisen naisliiton aktiivi opettajatar Aino Malkamäki oli keskeisellä sijalla tässä uudistuksessa ja laadittua lakia kunnallisista keskikouluista alettiinkin kutsua Lex Malkamäeksi. Olihan hän esittänyt jo vuoden 1945 valtiopäivillä "kansakouluun kuuluvan keskikoulun ja ammatillisen jatkokoulun perustamista". Malkamäki oli naisliiton kouluasiantuntija 1940-50-luvulla. Hän oli jäsenenä sekä valtion kansakoulukomiteassa (1936-45), koulujärjestelmäkomiteassa (194647), opetussuunnitelmakomiteassa (1945-50) että kouluohjelmakomiteassa (1956).

1960-luvulla puhalsivat uudet tuulet koulusuunnitelmissakin. Sosialidemokraattisen naisliiton vuoden 1962 edustajakokous päätyi vaatimaan "...että 9-vuotisen yhtenäiskoulun toteuttamista on kaikin keinoin tuettava ja kiirehdittävä, jotta kaikille kansamme nuorille taataan lahjojensa mukainen koulutus yksityisestä varakkuudesta riippumatta..." Uudistusprosessi oli hidas. Kesti kymmenen vuotta ennen kuin peruskoulu aloitti toimintansa maan pohjoisimmista kunnista vuonna 1972. Kouluissa tapahtui "vallankumous" myös muussa mielessä. Vuonna 1973 


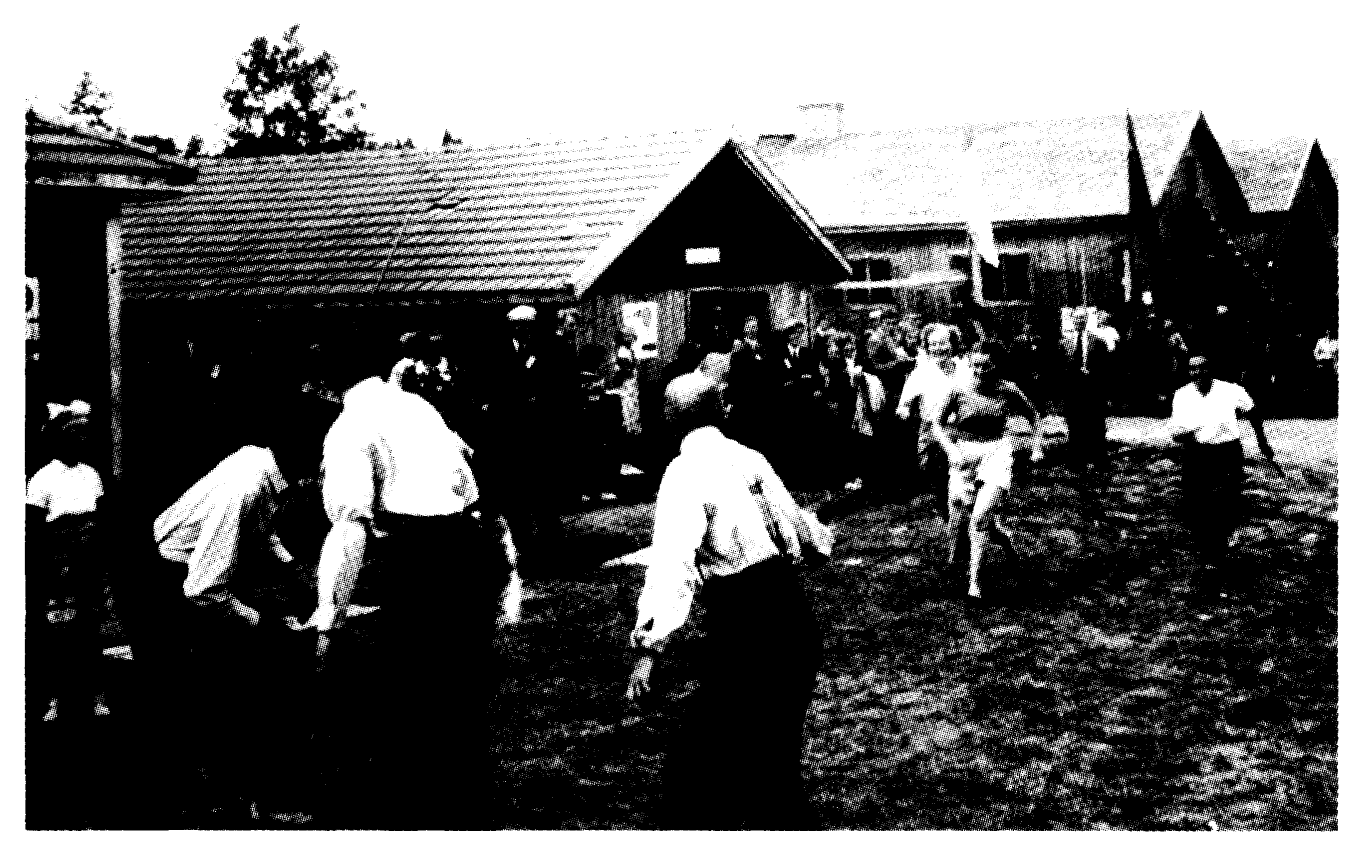

Sylvi Siltanen, Vappu Heinonen ja Kirsti Toivonen kilpailevat Turussa siitä, kuka tavoittaa herrat nopeimmin. Kuva: Työväen Arkisto.

aloittivat toimintansa kouluneuvostot, joissa opettajat ja oppilaat pääsivät ensimmäistä kertaa vaikuttamaan oman koulunsa asioihin. Oppikouluissa koululaiset radikalisoituivat Teiniliiton aktiivisen toiminnan myötä. Teiniliitto oli alun perin perustettu Suomen Toverikuntien Liiton nimellä vuonna 1939 ja sen perustamisajankohtakin kertoo, että sen toiminta oli maanpuolustushenkistä. 1950-luvulla teiniliike oli ns. hippateiniyden kautta. 1960-luku oli teinien yhteiskunnallistumisen kautta. Sosiaalidemokraattiset nuoret olivat näyttävästi esillä uudessa Teiniliitossa. Teiniliiton merkitys oli suuri nuorison radikalisoitumiselle. Oppikouluissa kriittisiksi kasvaneista koululaisista tuli kriittisiä opiskelijoita yliopistoihin.

Lähteet: Sos.dem. naisliiton XXIII ed.kok. pöytäkirja 27.-28.5.1962, s. 55-56, alustuksia s. 49-50; Aino Malkamäen aloitteet. Sos.dem. naisten tekemiä aloitteita 1907-54. Sos.dem. naisliiton arkisto. TA. 


\section{Rauhaa ja solidaarisuutta}

Eräs osoitus uusista tuulista oli rauhankysymyksen paluu työväenliikkeen ajamien asioiden eturiviin. Rauhanaate ja rauhankasvatus ovat kuuluneet sosiaalidemokraattien vaatimuksiin jo 1800-luvun lopulta. Työväenpuolueen ensimmäisessä ohjelmassa (1899) julistettiin, että "rauhanaatetta on kehitettävä ja käytännössä toteutettava sekä sotilastaakkaa suuresti kevennettävä”. Helmikuussa 1899 Työmies-lehti ennätti ottamaan kantaa venäläistämisuhkaan: ${ }^{11}$

Eilinen kävelyretki rauhan aatten hyväksi onnistui paremmin kuin oli voitu odottaakaan. Yleisöä oli kokoontunut Rautatientorille kymmeniätuhansia - väkeä niin paljon, ettei Helsingissä usein ole liikkeessä ollut...Kun suuri valkea lippu, jossa oli sanat Ei sinun pidä tappaman. Eläköön kansain veljeys oli saapunut saattojoukkonsa kanssa Senaatin torille, oli se täynnä odottavaa yleisöä, joka juhlallisin mielin kuunteli kokouksen hyväksyttäväksi valmisteltua lausuntoa...Kun yleisöä nyt, merkiksi siitä, että se hyväksyi luetun lausunnon molemmilla kielillä, kehotettiin yhtymään huutoon: Eläköön kansain veljeys! niin tuhat määrin yleisö yhtyi ja yhtä voimakas oli kansan ääni, kun sitten Eläköön isäinmaa! kohotettiin.

Toinen venäläistämiskausi ja ensimmäisen maailmansodan tyrskyt nostattivat työväenliikkeessä uuden rauhanliikehdinnän. Sosialistit näkivät sodan kansainvälisen työväenliikkeen uhaksi. Katsottiin, että esiin työntyvät nationalistiset pyrkimykset pakottivat työläiset toisiaan vastaan. Toisen Internationaalin ja sen naiskomission ensimmäisen maailmansodan aikaiset militarismin vastaiset julistukset saivat vastakaikua myös Suomessa.

Levottomuuksien lisääntyessä vuoden 1917 lopulla marssivat sosiaalidemokraattiset naiset useilla paikkakunnilla rauhan puolesta. Työväenliikkeen johtoa kiihdytti porvarisehdokkaiden esitys siitä, että Suomeen oli perustettava "sotalaitos". Työväenliike näki sen itseään vastaan kohdistuneena toimena.

Rauhanliikkeen uusi tuleminen 1930-luvulla sai sosiaalidemokraattiset naiset keräämään nimiä aseistariisumisadressiin. Monet työväenliikkeen aktiivit osallistuivat 1920-luvulla perustettujen Suomen Rauhanliiton ja Naisten Vapauden- ja Rauhanliiton toi-

11 Työmies 20.2.1899. 
mintaan. Sosialidemokraattinen puolue hyväksyi vuoden 1930 maanpuolustusohjelmassaan kuitenkin väkivallan käytön erinäisissä tapauksissa, kuten suurissa vallankumouksissa. Asevarustelu kiihtyi vuosikymmenen lopulla kohtalokkain seurauksin. Sosialidemokraattisen puolueen vuoden 1939 puoluekokous tunnusti riittävän puolustuslaitoksen tehostamisen välttämättömyyden, mutta katsoi samalla, että työväestön oli erityisesti vieroksuttava ja vastustettava kaikkia kansalliskiihkoisia pyrkimyksiä.

1960-luvulla rauhanliike aktivoitui jälleen. Vuonna 1963 perustettu Sadankomitea oli omiaan kiihdyttämään keskustelua aiheesta. Kylmän sodan ydinaseuhka, aseistakieltäytymiset ja Vietnamin sota herättivät uinuvan rauhanliikkeen ja kokosivat joukkoihinsa paljon nuorisoa. Sosiaalidemokraattiset naiset osallistuivat vuosina 1965-73 järjestettyihin Vietnam-avun keräyksiin. Kiertokirjeessään lokakuulta 1965 naisliitto kehotti yhdistyksiään kierrättämään listoja varojen hankkimiseksi Vietnamin siviiliväestölle. Varoilla ostettiin lääkkeitä ja ne toimitettiin perille Suomen $\mathrm{Pu}$ naisen Ristin kautta.

Jäsenkunta ei kuitenkaan ollut kovinkaan innokas keräämään apua niin kaukaiseen kohteeseen: "Naisyhdistys ei ole onnistunut saamaan ihmisiä kiinnostumaan...palautan listat tyhjinä...Me keräsimme oman maan puutteenalaisille paketteina ja rahana. Emme katsoneet tätä keräystä niin tärkeäksi...Olen käynyt listojen kanssa työmaalla sekä naapureissa ja tuttavissani, mutta olen saanut vastaukseksi että avun tarvetta on kotimaassakin aivan tarpeeksi..."12 Noissa tunnelmissa keräyksen tuotto jäi vähäiseksi.

Poliittiset naisjärjestöt organisoivat myös yhteisen Vietnam-keräyksen vuonna 1973. Saaduilla varoilla ostettiin maitojauhetta, lääkkeitä ja hoitotarvikkeita Vietnamin lapsille ja äideille. Kampanja aloitettiin jakamalla esitettä Vietnamin historiasta, kulttuurista, taloudesta ja poliittisesta tilanteesta. Listoja kierrätettiin ovelta ovelle listoin ja lippain. Naisten Vietnam-avun toimikuntaan kuuluivat puheenjohtajana Svenska Kvinnoförbundet'in Catherine von Koskull-Hölttä, Sosialidemokraattisen naisliiton Tyyne Leivo-Larsson, Sosialidemokraattisten Naisten Keskusliitosta Helvi Saarinen, keskustapuolueesta Anni-Helena Rämö, kokoomuksesta Eva-Maija Pukkio, liberaaleista Else Stenroos ja Suomen Naisten Demokraat-

12 Sos.dem. Naisliiton kirjeitä 1965-73, Vietnam-apu. Sos.dem. Naisliiton arkisto. TA. 


\section{SUOMEN NAISILLE}

Suomen poliittiset naisjärjestöt ovat päättäneet ryhtyä yhteistoimin keräämään avustusta Vietnamin äideille ja lapsille heidän jouduttua kokemaan elämässään ankaria kärsimyksiä.

VETOAMME KAIKKIIN SUOMEN NAISIIN:

TUKEKAA KERÄYSTÄMME.

AUTTAKAA VIETNAMIN NAISIA JA LAPSIA.

Keräys suoritetaan 1. 3. - 31. 12. 1973 välisellä ajalla. Keräyksen tuotto käytetään maitojauheen, lääkeaineiden ja lastenhoitovälineiden hankkimiseen. Auttakaamme täten vietnamilaisia rauhan ja turvatun tulevaisuuden rakentamisessa.

Helsingissä 31. 1. 1973

Keskustapuolueen Naiset

Kokoomuksen Naisten Liitto

Liberaalisen Kansanpuolueen Naiset

Sos.dem. Naisten Keskusliitto

Sos.dem. Naisliitto

Suomen Naisten Demokraattinen Liitto

Svenska Kvinnoförbundet 
tisesta Liitosta Helvi Laine. Kootut varat toimitettiin perille Kansalaisjärjestöjen Vietnam-avun toimikunnan "Avustusjuna Vietnamiin" lähetysten yhteydessä. ${ }^{13}$

\section{Kansainvälinen solidaarisuussäätiö}

Paitsi sodanvastainen työ ja sotien uhrien avustaminen, on sosiaalidemokraattien sydämiä lähellä ollut jo vanhastaan solidaarisuustyö. Vuoden 1969 puoluekokouksessaan Sosialidemokraattinen puolue päätti perustaa erityisen rahaston kehitysyhteistyötä varten. Mallia otettiin Ruotsista ja rahasto aloitti toimintansa vuonna 1970. Esitellessään asiaa lehdistölle puoluesihteeri Kalevi Sorsa kysyi itsekriittisesti: "Mitä me olemme tehneet maailman väestön enemmistön hyväksi, jonka olosuhteet eivät ole parantuneet lainkaan tai ovat suorastaan huonontuneet?"

Aluksi Kansainvälisen Solidaarisuusrahaston tarkoituksena oli tukea ns. kehitysmaiden vapautusjärjestöjä. Portugalin siirtomaat, Mosambik, Angola ja Guinea-Bissau elivät siirtomaavallan alla, Kreikassa oli sotilashallitus, Espanjassa ja Portugalissa vallitsi oikeistolainen diktatuuri. Vietnamin sota synnytti solidaarisuusliikkeitä ja vähin erin eurooppalaisten kehitysmaatietoisuus heräsi. Suomessa Säätiön tehtävä määriteltiin marraskuussa 1970 näin: tukea kansanvaltaisiin tavoitteisiin pyrkiviä kehitysmaiden edistyksellisiä ja sosialistisia järjestöjä ja vapautusjärjestöjä ja levittää Suomessa tietoja kehitysmaiden oloista sekä herättää mielenkiintoa kansainväliseen toimintaan. Säätiön antama tuki annettiin humanitaarisiin kohteisiin, kasvatus-, ja koulutustoimintaan sekä järjestötoiminnan kehittämiseen.

Sosialidemokraattisen puolueen solidaarisuusrahaston ensimmäiset tukikohteet olivat Afrikassa, Etelä-Vietnamissa ja Kreikassa. Rahaston ensimmäinen toiminnanjohtaja oli Paavo Lipponen. Myös naiset ovat olleet näyttävästi mukana solidaarisuussäätiön toiminnassa, kuten nykyinen presidentti Tarja Halonen. Ensimmäisessä keräyksessään rahasto myi solidaarisuusruusua. Lisäksi piirejä ja perusjärjestöjä kehotettiin toiminnan tehostamiseksi valitsemaan erityisiä kansainvälisten asioiden vastuuhenkilöitä.

13 Suomen poliittisten naisten Vietnam-avun yhteistoimikunnan kokouksen pöytäkirja 31.1.1973. Kokous pidettiin Tyyne Leivo-Larssonin kotona Helsingissä Temppelikatu 15:ssä. Sos.dem. naisliiton arkisto. TA. 
*"Vallankumous leimahti Pariisissa"

Kuten vuosien 1789,1830 ja 1848 vallankumouksissa, nousi Ranska myös vuoden 1968 mellakoissa tapahtumien keskipisteeksi. Eräs silminnäkijä kuvaa Pariisin kaduilla käytyjä "taisteluja" 23.-29.5.1968 näin:

...päästyäni vihdoin ketjun läpi minulta suljetaan tie Odeoniin: vanha teatteri on tänään lasaretti, sinne kuljetetaan parhaillaan haavoittuneita. Useimmat ovat kyynelkaasumyrkytyksen saaneita. Boul'Mich'in suunnalla nousee sankkoja savupilviä, turha yrittääkään suoraa tietä Pantheonille, minne poliisi on keskittänyt suuria voimia. Sitä vastoin pääsen kiertämään Gay-Lussac-kadulle, joka on kuin autojen hautuumaa. Kymmenen päivää sitten siellä raivosi ankara taistelu, eikä poltettujen autojen surkeita jäännöksiä ole vieläkään kuljetettu pois...

Taistelujen meteli kuuluu yhä kovempana lähestyessäni vanhaa kunnianarvoisaa yliopistoa, tilapäisiä sanitaariautoja liikkuu nopeasti edes takaisin, valkopukuisia punaisen ristin tunnuksin varustettuja nuoria seisoo katujen kulmilla hälytysvalmiina. Kun lopulta pääsen yliopiston portista sisään, vastaan tulvahtaa kymmenpäinen ylioppilasjoukko täyttä vauhtia juosten. Hetkeä myöhemmin ymmärrän heidän kiireensä: yliopisto on saarrettu... Ulkona kadulla on kyynelkaasua, se alkaa kirvellä silmissäni vaikka saamani annos mahtaa olla erittäin vähäinen, useilla on oikeat kaasunaamarit. Ulkona lyödään kovaa ja kysymättä...Sana vallankumous on kaikkien huulilla. Mutta onko se todellakaan muuta kuin näytelmä, jonka kulissit ja puvusto, liikehtiminen ja puhetulva ovat peräisin helmikuun vallankumouksen päiviltä 1848, jolloin sama rekvisiitta lainattiin vuodelta 1789...piiritetyssä Sorbonnessa..Maon ja Trotskin kuvat koristivat seiniä ja anarkistiset iskulauseet toitottavat päämääristä, joilla on enemmän tekemistä vallankumouksen romantiikan kuin todellisuuden kanssa...

Solidaarisuusrahaston nimi muutettiin sittemmin Kansainväliseksi solidaarisuussäätiöksi ja sen toimintakenttä laajeni. Samalla se itsenästyi sosialidemokraattisesta puolueesta. Siitä tuli kehitysyhteistyötä tekevä kansalaisjärjestö yli puoluerajojen. 1980-luvulla säätiö organisoi ns. prosenttiliikkeen: lahjoittajat tukivat sääti- 
Myös Suomessa vasemmistolainen opiskelijanuoriso liikehti - tosin paljon maltillisemmissa merkeissä kuin mellakoiden keskuksissa Pariisissa, Kalifornian Bereleyssä tai Berliinin Freie Universitätissa. Miksi sitten opiskeleva nuoriso oli tyytymätön? Toukokuussa 1968 haastatellun 21-vuotiaan valtiotieteen ylioppilaan Ilkka-Christian Björklundin mukaan "nuorison ja opiskelijoiden kohdalla on kysymys sama kuin muillakin vähemmistöryhmillä: yksilöillä ei ole tarpeeksi mahdollisuuksia vaikuttaa päätöksentekoon...nykyinen demokratia ei pelaa, kysymys on näennäisdemokratiasta...". Niin ikään 21-vuotiaitten opiskelijoiden Maija Loikaksen ja Anja Kaiposen mukaan "suomalainen ylioppilas on tottelevainen, kiltti ja saamaton..maailman tapahtumia ei seurata ... Kadun ylioppilaan pimeys on uskomatonta. Kysytään mikä on se Yhdistys 9...". 22-vuotias ylioppilas Erkki Tuomioja puolestaan valotti asiaa tiedustelevalle toimittajalle, että "suomalaiset ylioppilaat eivät ole vielä tiedostaneet asemaansa yhteiskunnassa. Meillä on vallalla passiivinen kasvatusjärjestelmä, jo koulussa opitaan pidättyvyyteen. Nyt on kuitenkin tulossa muutos, sillä koulun ulkopuolelta tulevan informaation määrä on räjähdysmäisesti lisääntynyt...on kysymys nuorison itsenäistymisestä, kypsymisestä, young powerista, sitiä, että nuoriso pääsee tekemään päätöksiä omissa asioissaan."

Sosialidemokraattinen puolue julkaisi vuonna 1965 tiede- ja korkeakoulupoliittisen ohjelmansa. Sen lähtökohtana oli toisen maailmansodan jälkeinen nopea "edistys" tiede-elämässä ja kansainvälisen vuorovaikutuksen lisääntyminen, minkä vuoksi Suomen tuli pysyä kilpailukykyisenä. Koska sosiaalidemokraatit näkivät olevansa "lähivuosina" päävastuussa valtakunnan yleisestä kehityksestä, oli tiede- ja korkeakoulupolitiikkaan kiinnitettävä enemmän huomiota. He vaativat kokonaisvaltaista tiedepoliittista ohjelmaa, omaa tiedeministeriä, kulttuuripolitiikan uudistamista, uusien korkeakoulujen ja virkojen perustamista. Sosiaalidemokraattien mielestä opiskelijoiden määrän lisääntyminen kasvatti yliopistoja, mutta samalla muuttui koko yliopiston status.

Lähteet: Vallankumous leimahti Pariisissa, kirj. Heikki Brotherus. Suomen Kuvalehti nro 23, 8.6.1968, s. 22-27; Miksi ylioppilaat ovat tyytymättömiä. Suomen Kuvalehti nro 20, 18.5.1968, s. 22-25; SDP Tiede- ja korkeakoulupoliittinen ohjelma. Sos.dem. puoluetoimisto 1965.

ön työtä luovuttamalla palkastaan prosentin säätiön kohteiden avustamiseksi. Säätiön jakamat avustussummat nousivat etenkin 1980luvulla ja vuonna 1990 säätiöllä oli lähes 40000 lahjoittajaa. Säätiö kuuluu jäsenenä Kansainväliseen työväenapuun. ${ }^{14}$

14 Kansainvălinen Solidaarisuussăătiö 20 vuotta. 1990. 


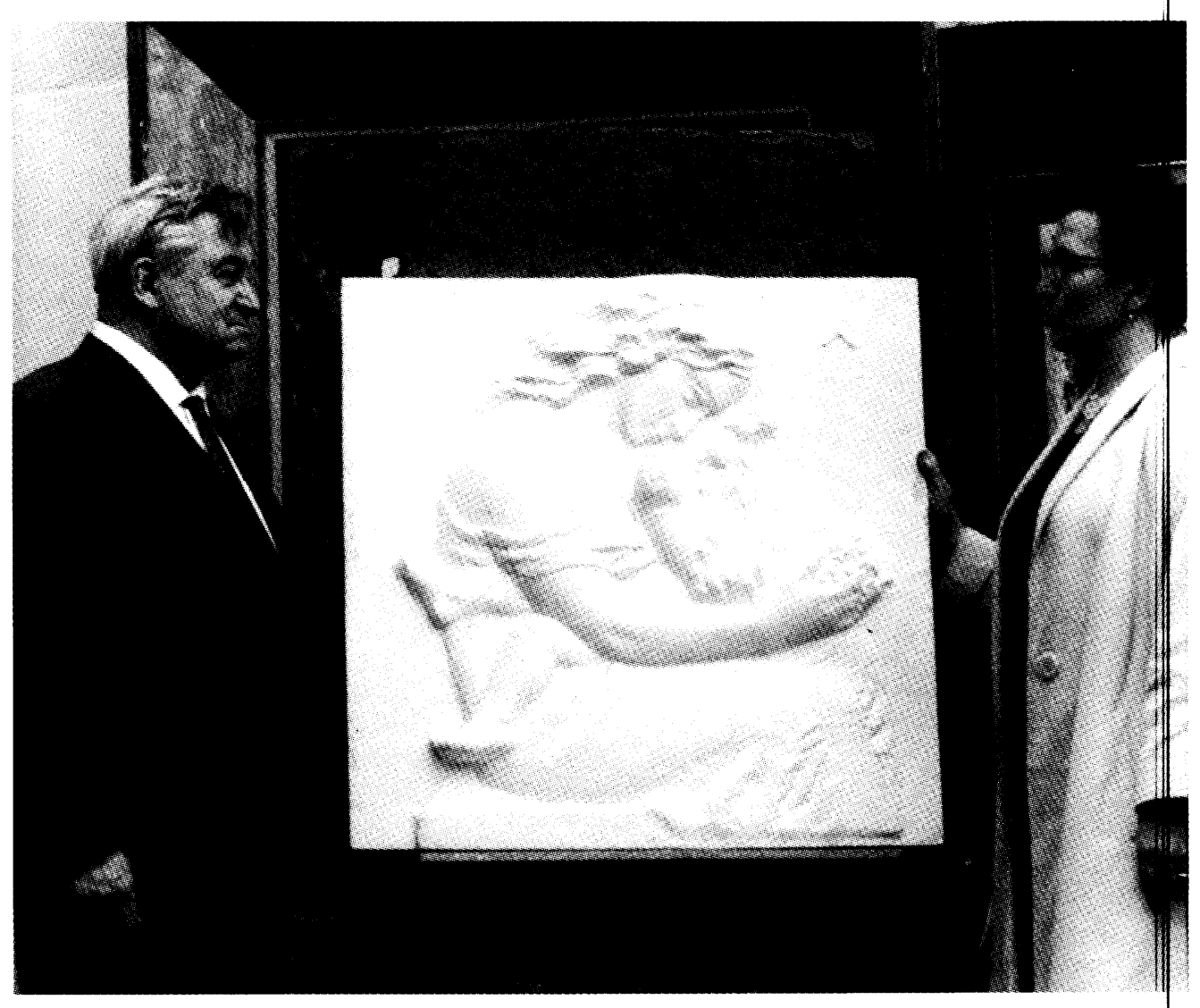

Taiteilija Wäinö Aaltonen lahjoitti Sosialidemokraattisten Naisten Keskusliitołle reliefin "Sydämeni laulu” naisliiton ensimmäisessä edustajakokouksessa vuonna 1960. Kuvassa taiteilija esittelee työtään naisliiton Hilja Tiaiselle. Kuva: Ty öväen Arkisto.

\section{1960-luvun suuri roolitutkimus}

Kuten aiemmin on käynyt ilmi, tekivät sosiaalidemokraattiset naiset Ruotsin malliin vedoten aloitteen naisten aseman tutkimisesta. Valtioneuvosto asettikin syyskuussa 1966 komitean asiaa selvittämään. Sosiaalidemokraattien rooli komitean muodostamisessa ja itse komitean työssä oli keskeinen. Sen puheenjohtajana toimi Sosialidemokraattisten Naisten Keskusliitosta Sylvi Siltanen ja samasta liitosta SAJ:n sihteeri Svea Degerman. "Vanhaa" sosialidemokraattista naisliittoa edustivat Impi Lukkarinen ja Helvi Raatikainen. Muina jäseninä olivat sittemmin sosiaalidemokraatteihin siirtynyt liberaali kansanedustaja Pirkko Aro, professori Inkeri Anttila, kansanedustajat Anna-Liisa Linkola (kokoomus) ja Irma 
Rosnell (SKDL), maisteri Hilkka Pietilä (keskusta) ja toimittaja Jutta Zilliacus (RKP) sekä asiantuntijoina VTK Klaus Mäkelä ja dosentti Paavo Piepponen.

Aikaisemmin Suomessa oli pantu toimeen vastaavanlainen naisten oloja käsittelevä tutkimus heti sodan jälkeen, jolloin tutkimuskohteena olivat naimisissa olevien naisten olot. Myös tuon esityksen aloitteentekijöinä olivat sosiaalidemokraattiset naiset. Vuoden 1966 komitea selvitytti laajasti ja ammattitaitoisesti naisten asemaa määrittävät olot. Ensimmäinen suuri tutkimusalue käsitteli tyttöjen ja poikien kasvatusta, opetusta ja kouluissa vallitsevia sukupuolirooleja, ammattikoulutusta ja uutena ilmiönä television antamaa kuvaa sukupuolirooleista. Toisena tutkimusalueena esiteltiin naisten asemaa työelämässä ja perhesuhteiden vaikutusta naimisissa olevien naisten ammatissa toimivuuteen, työttömyyden hoitoa, työnvälitystä, naisten ammattiasemaa ja ansiotasoa sekä samapalkkaisuutta. Myös äitiys- ja työsuojelukysymykset, osa-aikatyö sekä työajan lyhentäminen nousivat selvityksen kohteiksi.

Komitean kolmas painopistealue oli perhepolitiikka. Siihen kuuluivat naisten aseman arvioiminen avioliitossa ja yksinhuoltajana, syntyvyyden säännöstely, lasten päivähoito, työnjako perheessä ja perheverotuksen haitat. Viimeinen osa-alue komitean johtamassa tutkimustyössä oli naisten yhteiskunnallisen osallistumisen arvioiminen. Siinä todettiin yks'kantaan, että poliittisten puolueiden jäsenistä oli runsas neljännes naisia, mutta heidän osuutensa puolueiden päättävissä elimissä oli selvästi vähäisempi. Tämänhän naisaktiivit tiesivät omasta kokemuksestaankin, nyt se oli kaiken kansan ja miesten luettavissa.

Komitean työ oli tärkeä saavutus sosiaalidemokraateille. Se johti myös merkittäviin tuloksiin. Pitkän, yli kolme vuotta kestäneen työskentelyn jälkeen naisten asemaa tutkinut komitea antoi mietintönsä. ${ }^{15} \mathrm{Se}$ oli perustana vuonna 1972 perustetulle Tasa-arvoasiain neuvottelukunnalle, jonka tehtävänä oli edistää tasa-arvoisuutta suomalaisessa yhteiskunnassa. Komitean työssä mukana ollut Pirkko Aro on luonnehtinut komitean työtä rakentavaksi. Komitean puheenjohtaja Sylvi Siltanen oli Aron mukaan yhteistyökykyinen, mutta samalla tiukan asiallinen ja tuntui noudattavan sosialidemokraattisen puoluetoimiston ohjeita ja linjauksia. ${ }^{16}$

15 Naisten asemaa tutkivan komitean mietintö. Komiteamietintö 1970:A 8

16 Pirkko Aro Maria Lähteenmăelle 20.10.1999. 


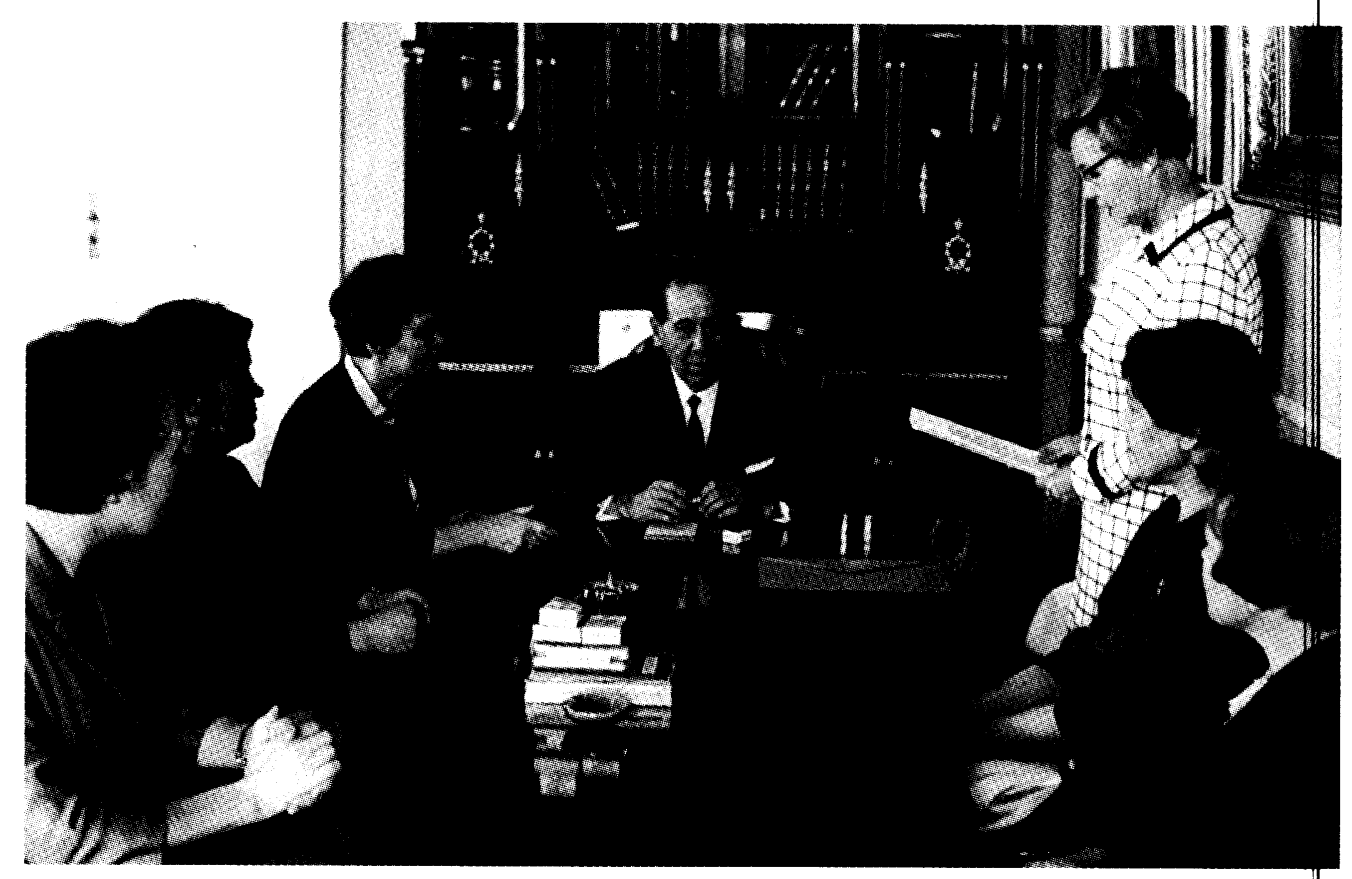

Naisten asemaa tutkinut komitea (1966-70) perustettiin Sosialidemokraattisten Naisten Keskusliiton aloitteesta. Kuvassa naisliiton lähetystö pääministeri Rafael Paasion luona 25.8.1966. Naiset vasemmalta Helvi Saarinen, Taimi RinneVirolainen, Tyyne Paasivuori, Sylvi Siltanen, Anni Vallanti ja Pirkko Merivato. Kuva: Työväen Arkisto.

\section{Perhepolitiikan vuosikymmen}

1970-luku alkoi naisten kannalta näyttävästi: vuoden 1970 vaaleissa naisia valittiin eduskuntaan enemmän kuin koskaan aikaisemmin, ensimmäistä kertaa hallituksessa istui kolme naisministeriä ja ensimmäisen kerran sosiaalidemokraattinen nainen kelpuutettiin myös muuhun kuin sosiaaliministerin paikalle. Margit Eskmanista tuli ensin valtioneuvoston kanslian ministeri (1970) ja sitten toinen valtiovarainministeri (1972). Aatesisar Meeri Kalavaisesta tuli opetusministeri (1970). Lisäksi Sosialidemokraattisen puolueen tärkeimmäksi sosiaalipolitiikan alueeksi määriteltiin 1970-luvulla perhepolitiikka. Puolueen perhepoliittinen ohjelma julkaistiin vuonna 1975.

Se, miksi puolue näki perhepolitiikan kehittämisen tärkeäksi, liittyi perheen aseman ja tehtävien muuttumiseen. Maatalousval- 
taisessa yhteiskunnassa perhe oli tuotantoyksikkö ja tavallisesti usean sukupolven muodostama "suurperhe". Teollistuminen ja 1960-luvun rakennemuutos olivat kuitenkin saaneet aikaan sen, että tuotanto oli siirtynyt kodin ulkopuolelle. Perhe sai elantonsa kodin ulkopuolella tehtävästä ansiotyöstä. Yhä enemmän oli perheitä, joissa molemmat vanhemmat kävivät ansiotyössä. Näin siksi, että tietyn tulotason ylläpitäminen kasvavassa kulutusyhteiskunnassa sitä vaati, toisaalta siksi, että teollisuudessa ja palvelualoilla työvoiman kysyntä kasvoi.

Myös perheen kasvatustehtävä oli muuttumassa perheiden koon pienetessä: yhteiskunta oli ottanut aikaisempaa enemmän hoitaakseen lasten kasvatuksen ja koulutuksen. Nuoriso-ongelmat, perheiden sisäinen väkivalta ja perheiden hajoaminen asettivat uusia haasteita yhteiskunnan harjoittamalle perhepolitiikalle. Myös ikääntyneet, vammaiset ja muut syrjäytyneet eristäytyivät usein omiin hoitolaitoksiinsa: maatalousyhteiskunnassa he olivat olleet kiinteä osa perhettä.

Sosiaalidemokraatit lähtivät rakentamaan ohjelmaansa tästä todellisuudesta käsin. Ensimmäinen lähtökohta oli tasapainoisen väestönkasvun turvaaminen: yhteiskunnan tuli luoda ihmisille taloudelliset ja sosiaaliset mahdollisuudet lasten hankkimiseen ja huoltamiseen. Perheen keskeinen merkitys yksilöille ja yhteiskunnalle oli säilytettävä. Oli korostettava perheen turvallisuutta tuovaa merkitystä, mutta myös sen kulttuurista roolia. Sosiaalidemokraattien mielestä perhe loi perustan kasvatukselle. Sen kautta siirtyivät perinteet, tavat ja taidot sukupolvelta toiselle. Perhe nähtiin myös sosiaalisten suhteiden ja sosiaalisen tietoisuuden lähtökohtana. Yhteiskunnan tuli toimia niin, että se tuki ja edisti yksilöiden oikeutta perhe-elämään. Sosiaalidemokraatit vaativat myös perinteisen avioliiton kautta muodostetun perheen lisäksi avoliittojen tunnustamista.

Sosiaalidemokraattien perhepoliittinen ohjelma nosti vaatimuslistalle myös lasten oikeudet, kuten oikeudet hyvään hoitoon ja läheisiin ihmissuhteisiin. Yhteiskunnan tuli antaa vanhemmille taloudellista, tiedollista ja asenteellista tukea lasten hoidossa ja kasvatuksessa.

Perhepoliittisten tavoitteiden toteuttaminen oli laaja-alainen uudistushanke. Se edellytti sosiaalidemokraattien mielestä puuttumista alue- ja työvoimapolitiikkaan, asuntopolitiikkaan, yhdyskuntasuunnitteluun, oikeus- ja koulutuspolitiikkaan, terveyden- ja so- 
*E-pilleri

Vaikka vanhassa sananlaskussa sanotaan, että "lapsi tuo leivän mukanaan", on syntyvyyden säännöstely kiinnostanut ihmisiä vuosituhansia. Erilaisilla taioilla, loitsuilla ja yrteillä on pyritty pitämään lapsiluku kohtuullisena. 1900-luvulla biologinen ja lääketieteellinen tutkimus toi markkinoille terveydelle vaarattomia ja luotettavia ehkäisyvälineitä, jotka vaikuttivat mullistavasti naisten ja työläisperheiden elintasoon ja -tapaan.

1900-luvun alkupuolella työläispariskunnat käyttivät ehkäisymenetelmänä yleisimmin keskeytettyä yhdyntää. Naiset pyrkivät imettämään lapsiaan pitkään uskoen sen ehkäisevän uuden raskauden. Nuoren äidin kirjassa vuodelta 1932 imetys nähtiin paitsi estävän liian tiheitä raskauksia, myös suojelevan naista ennenaikaiselta "lakastumiselta". 1930luvun lopulla esiteltiin myös ns. varmojen päivien laskemista ehkäisyja hedelmöitymiskeinona. Kondomien ja pessaarien käyttö ja mainonta yleistyivät 1920-30-luvulla. Muun muassa helsinkiläinen kirjakauppa mainosti ehkäisyvälineitä kuvitetulla kirjasella. Myös työväenlehdissä oli ilmoituksia huomaamattomasti lähetettävistä varmuusvälineistä: "Kummisia suojeluesineitä, maaseudulle lähetetään postivapaasti". Välineet olivat kuitenkin tuolloin vielä niin kalliita, ettei työväestö niitä useinkaan hankkinut.

Myös sosiaalidemokraattiset naiset keskustelivat syntyvyyden säännöstelystä ja esittivät sukupuolivalistuksen lisäämistä. Helsinkiin perustettiin vuonna 1934 kunnallinen sukupuolineuvonta-asema Miina Sillanpään ja Kaisu Snellmanin aloitteesta. Aseman avaamista perusteltiin muun muassa sillä, että maailmansodan jälkeen siveellisyys ja yleinen moraali höltyivät pahasti, mikä johti sukupuolitautien leviämiseen.

siaalihuoltoon sekä sosiaalipalveluihin. Perheen tuli olla yksi tärkeimmistä yksiköistä ja perusteluista näissä järjestelmissä, joten perhepoliittinen näkökulma ei ollut mikään pieni tekijä valtion hallinnossa. 1970-luvun sosiaalidemokraattien mielestä se oli toimivan hyvinvointiyhteiskunnan perussolu.

Naisten yhteiskunnallisen aseman kannalta päivähoitojärjestelmän kehittyminen oli yksi tärkeimmistä uudistuksista 1970-luvulla. Sosiaalidemokraatit pitivät sitä vuoden 1975 ohjelmassaan yhtenä keskeisimmistä perhepoliittisista ratkaisuista. He vaativat päivähoitopaikkojen lisäämistä, osa-aikaisia päivähoitomuotoja, päivähoidon sisällön ja hoitohenkilökunnan ammattitaidon kehit- 
Syntyvyyden säännöstely oli myös ajankohtainen vaimojen palkkatyön lisääntyessä: "Äidit eivät enää kestä jatkuvia raskauksia”. Aseman perustamista perusteltiin myös sillä, että laittomat abortit olivat yleistyneet huomattavasti. Tilanteen vakavuudesta kertoo se, että asiaa pantiin tutkimaan erityinen aborttikomitea. Paitsi kansanterveydellinen ja taloudellinen näkökulma, 1930-luvun keskusteluissa oli myös vahva väestöpoliittinen tendenssinsä: Suomen väestön uskottiin hupenevan olemattomiin. 1930-luvun lopulta aina 1950-luvulle perheellistymistä pyrittiin verotuksen, lainojen ja muiden yhteiskunnallisten tukien avulla tukemaan.

1960-luvulla alkoivat puhaltaa uudet tuulet myös syntyvyyden säännöstelyssä. Uusien ehkäisyvälineiden tuleminen, ennen kaikkea hormonien käyttö raskauksien ehkäisyssä mullisti markkinat. Vuonna 1961 ehkäisy- eli e-pillerit hyväksyttiin yleiseen käyttöön. Ne siirsivät ehkäisyn entistä enemmän naisten vastuulle, mutta vapauttivat naisia myös epätoivotuista raskauksista ja peloista, jotka niihin liittyivät. On sanottu, että e-pillerit edesauttoivat seksuaalista vapautumista. Varsinkin alkuvaiheessa e-pillerit olivat kuitenkin monien naisten terveydelle suorastaan vaarallisia. Naisliittolaiset vaativatkin lisää valistusta ja tiedotusta pillereistä. Myös miehiä oli valistettava ehkäisyvälineistä ja yleensä sukupuolielämästä. Heille oli annettava vastuuta perhesuunnittelussa ja ihmissuhteissa. Naisten mukaan puolustusvoimat oli se paikka, jossa tämäntapainen tieto tavoittaisi kaikki ikäluokat.

Lähde: Lähteenmäki 1995, s. 122-126; Palkkatyöläinen 4/1931 ja 14/1930; Toveritar 6/1937; Sos.dem. naisliiton XXIII:n ja XXIV:n edustajakokouksen pöytäkirjat 31.8.-1.9.1968, s. 58-59 ja 5.-6.6.1971, s. 44-45.

tämistä ja vuorotyöntekijöiden lasten hoidon järjestämistä erityisjärjestelyillä. ${ }^{17}$

Sosiaalidemokraatit eivät olleet perhe-painotuksissaan yksin ja 1970-luvulla laadittiinkin huomattava määrä etenkin palkkatyössä käyvien naisten asemaa huojentavia lakeja: Vuonna 1970 tuli voimaan työsopimuslaki, jossa sukupuoleen perustuvasta syrjinnästä säädettiin rangaistus, vuonna 1973 annettiin päivähoitolaki, vuoden 1976 uudistuksilla myös isillä oli mahdollisuus jäädä isyys-

17 SDP:n Perhepoliittinen ohjelma 1975. 


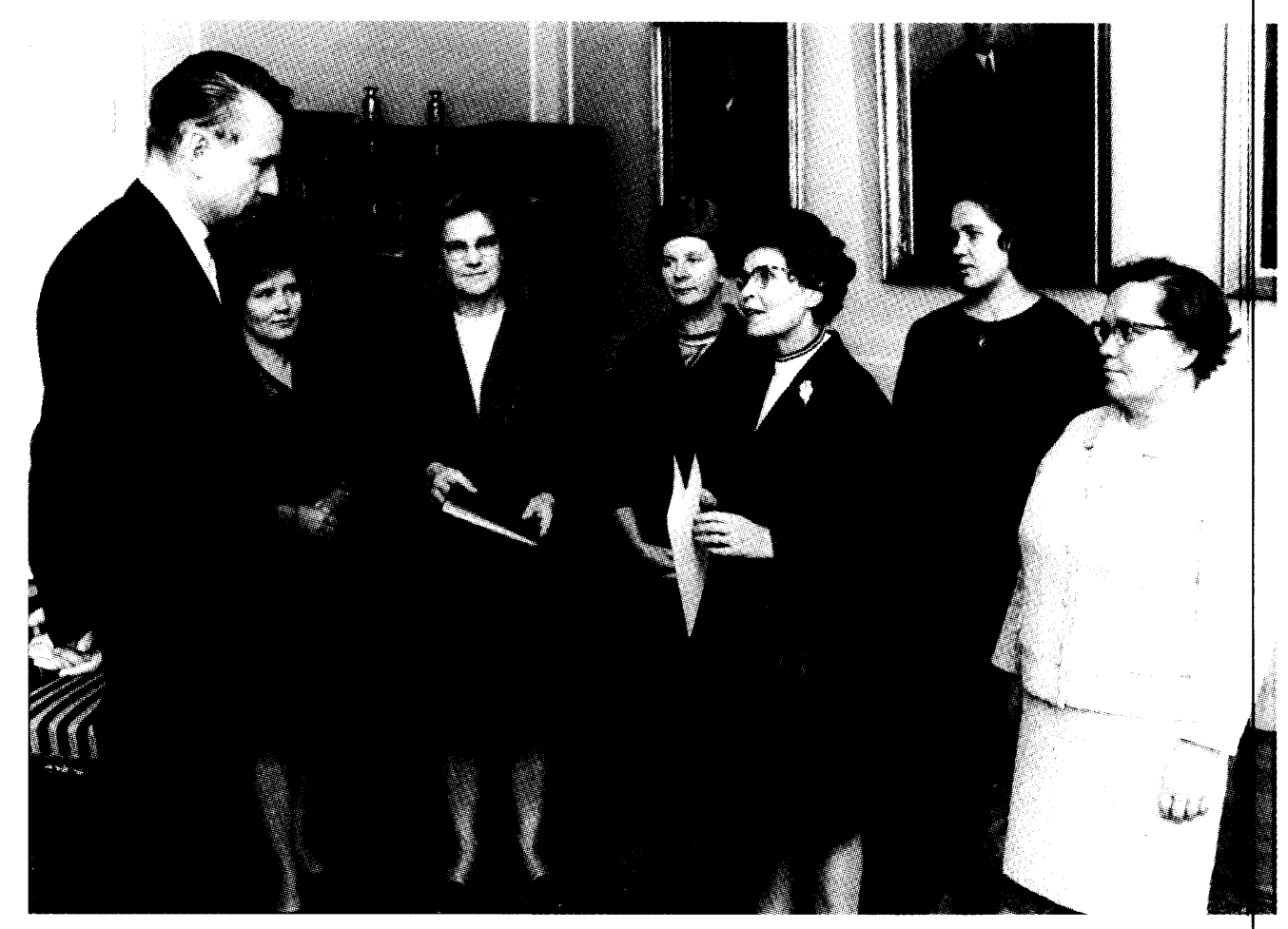

Sosialidemokraattisten Naisten Keskusliitto ja SAJ:n naiset jättivät 8.10.1969 pääministeri Mauno Koivistolle kirjelmän ja adressin äitiyshuollon parantamiseksi. Kuvassa Mauno Koivisto, Pirkko Meriluoto, Svea Degerman, Meeri Kalavainen, Tyyne Paasivuori, Pirkko Tienhaara ja Taimi Rinne-Virolainen. Kuva: Työväen Arkisto.

lomalle ja vuonna 1978 vanhemmilla oli oikeus jakaa keskenään vanhempainloma.

Kaiken kaikkiaan voiman vuosia eläneet sosiaalidemokraatit halusivat palauttaa radikalismin, hippiaatteen ja vapaan rakkauden innostamat nuoret takaisin perinteisten keskiluokkaisten perhearvojen pariin.

\section{Tasa-arvotyö naisjärjestöjen harteilla}

Eräs 1970-luvun merkkivuosista oli eittämättä YK:n kansainvälinen naistenvuosi 1975. Sitä järjestämään valtioneuvosto asetti 23jäsenisen komitean, jonka puheenjohtajana toimi kansanedustaja Pirkko Aro. Järjestelytoimikunnassa olivat edustettuina myös sosialidemokraattiset naisliitot muiden naisjärjestöjen tapaan, puolueet, eri ministeriöt ja työmarkkinajärjestöt. Teemavuoden tavoit- 
Meeri Kalavainen ja Sinikka Luja-Penttilä olivat sosiaalidemokraattisen naisliikkeen aktiiveja 1960-70-luvulla. Kuva on 1970-luvun alusta. Kuva: Työväen Arkisto.

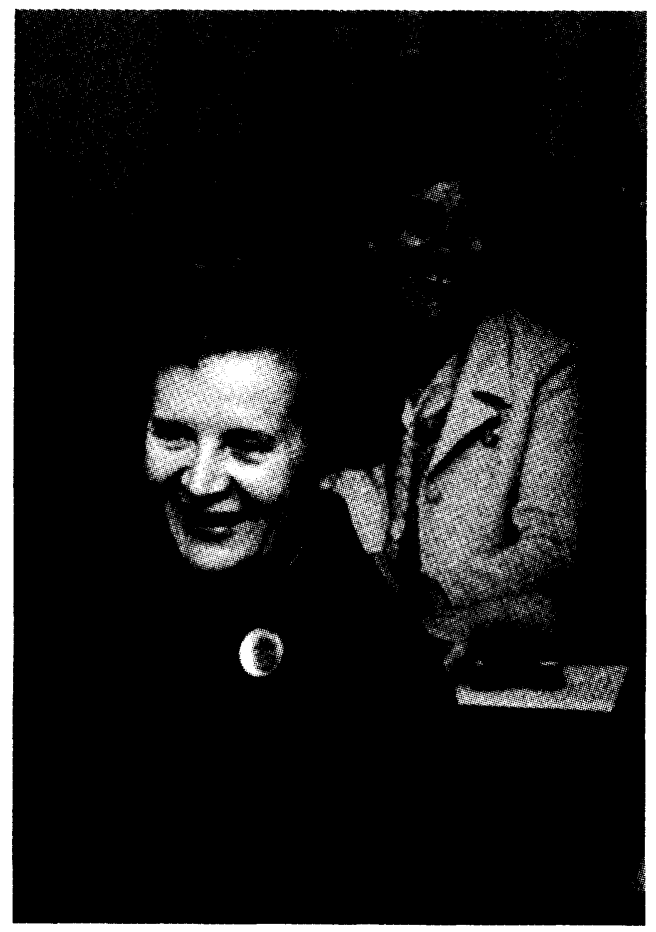

teena oli kiinnittää huomiota miesten ja naisten välillä vallinneeseen eriarvoisuuteen, jonka katsottiin olevan esteenä yhteiskunnalliselle kehitykselle ja rauhanasialle. Kansainvälisen naistenvuoden vietto oli suoraa jatkoa Naisten asemaa tutkineen komitean ja sen työtä jatkaneen Tasa-arvoasiain neuvottelukunnan toiminnalle tasa-arvoisemman yhteiskunnan puolesta.

Puolueiden kanta sukupuolten väliseen tasa-arvotyöhön oli hieman ristiriitainen. Periaatteessa kannatettiin Kansainvälisen naistenvuoden komitean laatimaa tavoiteohjelmaa, mutta käytännössä asia siirrettiin naisjärjestöjen huoleksi: "Yllättävän samansuuntaisesti puolueet katsoivat, että niiden naisjärjestöt huolehtivat asiasta" ${ }^{18}$ Tasa-arvotyö puolueissa oli yksiselitteisesti naisten asia.

18 Kansainvälisen naistenvuoden komitean tavoiteohjelma 1975; Pirkko Aro Maria Lähteenmäelle 20.10.1999. 


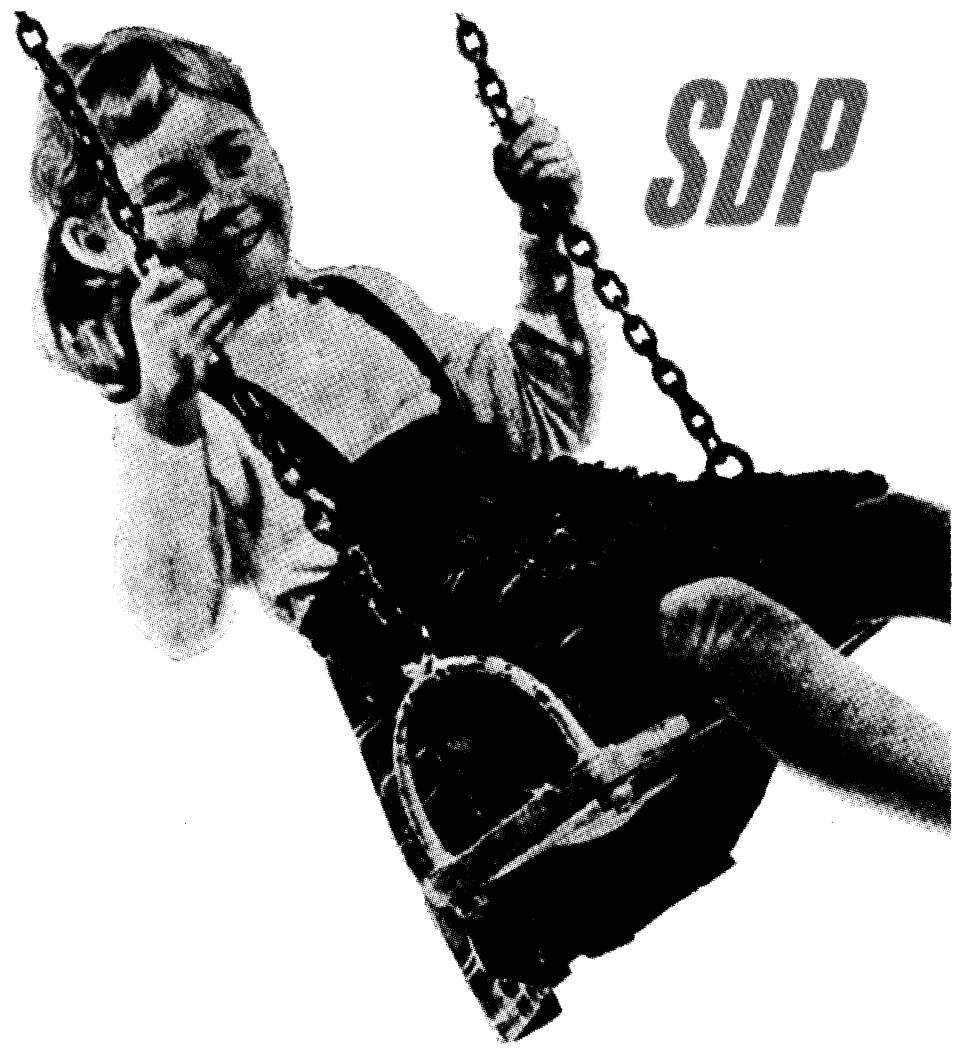

\section{TURVA}

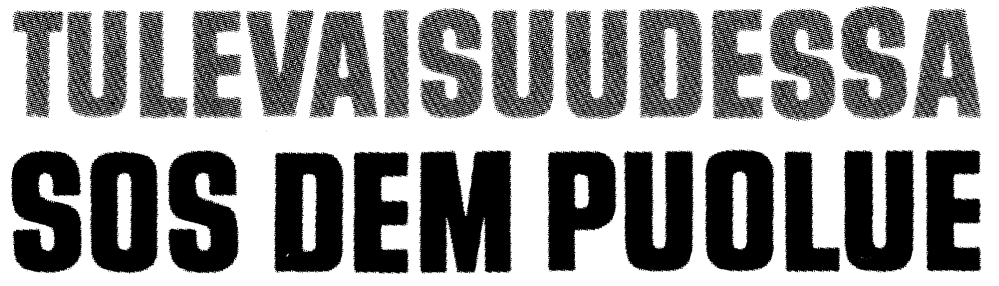

Sosialidemokraattisen puolueen kunnallisvaalijuliste vuodelta 1964. Kuva: Työväen Arkisto. 


\section{*Tane}

Tasa-arvoasiain neuvottelukunta eli Tane perustettiin vuonna 1972 valtioneuvoston kanslian yhteyteen naisten ja miesten yhteiskunnallisen tasa-arvon edistäjäksi ja tasa-arvoa lisäävien uudistusten valmistelijaksi. Sosiaalidemokraateilla oli suuri merkitys neuvottelukunnan synnyssä. Tanen perustaminen liittyi 1960-luvulla nousseeseen tasa-arvokeskusteluun ja vuonna 1966 asetetun Naisten asemaa tutkivan komitean työhön. Mietinnössään vuonna 1970 komitea ehdotti sellaisen elimen perustamista, joka yhteistyössä viranomaisten, valtion ja kuntien laitosten, työmarkkinajärjestöjen ja muiden yhteisöjen kanssa toteuttaisi käytännössä tasa-arvoa lisääviä uudistuksia. Perustetun Tasa-arvoasiain neuvottelukunnan ensimmäiseksi puheenjohtajaksi pyydettiin sosiaalidemokraatti Meeri Kalavainen. Miesten ja naisten tasa-arvoisuudella ymmärrettiin sukupuolten välistä samanarvoisuutta ja tehtävien tasaista jakoa perheessä, työelämässä ja julkisessa elämässä.

Laajamittaisen perustutkimuksen lisäksi Tanen yksi tärkeimmistä saavutuksista on ollut vuonna 1987 voimaan astunut tasa-arvolaki. Sen mukaan samasta työstä on maksettava sama palkka. Rikoslakia uudistettaessa vuonna 1995 syrjintä sukupuolen perusteella säädettiin rangaistavaksi työsyrjintänä. Perhepolitiikassa Tane ajoi äitiysloman pidennystä ja isyysloman sallimista. Myös koulutuspolitiikassa ajettiin tasaarvoa tyttöjen ja poikien kohtelussa. Vaadittiin myös naisten mahdollisuutta kouluttautua perinteisiin miesten ammatteihin. Esimerkiksi naispappeus sallittiin Suomessa vuonna 1988. Kahta vuotta aiemmin naisilla oli oikeus avioiduttuaan pitää oma sukunimensä. Tasa-arvolakiin lisättiin kiintiövaatimus vuonna 1995. Sukupuolikiintiöiden asettaminen valtion ja kuntien eri toimikuntiin ja komiteoihin on ollut kuitenkin hidasta.

Tane siirrettiin vuonna 1986 sosiaali- ja terveysministeriön alaisuuteen ja seuraavana vuonna ministeriöön perustettiin tasa-arvovaltuutetun toimisto. Ensimmäinen tasa-arvovaltuutettu oli Paavo Nikula.

Meeri Kalavaisen (1972-81) lisäksi Tanen puheenjohtajina ovat toimineet sosiaalidemokraatit Liisa Jaakonsaari (1989-92) ja Tuula Haatainen (1995-).

Lähde: Tasa-arvon tiennäyttäjä. Tavoitteita, tuloksia, tuokiokuvia 1972-1997. Tasa-arvoasiain neuvottelukunta. Helsinki 1997. 


\section{Naisyhteisö puolueessa}

\section{Puolueen naiset}

Kahden sosialidemokraattisen naisliiton olemassaolo kulutti naisten voimia. Vaikka ideologisessa mielessä oltiinkin valmiita eheytykseen, olivat monet naiset niin tunteenomaisesti sitoutuneet liittoihinsa, että yhdistyminen oli vaikeaa. Naisliitot olivatkin sosiaalidemokraattisessa järjestökentässä lähes viimeisiä, jotka yhdistyivät. Keskusliittoon kuulunut Sinikka Luja-Penttilä on muistellut kahden sosialidemokraattisen naisliiton suhteita näin: ${ }^{1}$

Se oli aika kiivasta vielä 1960-luvullakin se vastakkainasettelu.... vanha naisliitto oli jo muuttanut sääntöjä sillä tavalla, että se päättää aina ennen vaaleja, mille puolueelle se tukensa antaa. Sehän ei sopinut meidän pirtaan ollenkaan, semmonen tietenkään... sitten oli kyllä yks semmonen neuvottelukin, kai 1960-luvulla, 1966 tai 1967, jossa oli vanhan naisliiton ja keskusliiton ihmisiä saman pöydän vieressä. En muista, mistä se aloite tuli, oliskohan se ollut niin, että puolueet toivo... Mutta ei siitä tullut mitään. Oltiin niin kaukana toisistaan. Minut oli otettu mukaan myös siihen, vaikken mä kuulunut silloin vielä keskusliiton liittotoimikuntaan. Mutta mä olin semmosena kun vähän kentän edustajana mukana. Ja se oli semmonen ihan turha istujainen, siitä ei tullut mitään. Molemmin puolin oli asenteet niin tiukat. - Oli päivän selvää oikeastaan jo silloin, vaikka sitä myöhemminkin yritettiin, että niin kauan kuin Tyyne Leivo-Larsson oli vanhan naisliiton johdossa, niin ei siitä mitään tulekaan. Hän oli niin kuin nahkaansa myöten kiinni...samalla tavalla kuin Aarre Simonen puolueessa, ettei siitä tule sopua.

Tyyne Leivo-Larsson toimi vanhan naisliiton puheenjohtajana vuodet 1965-75, Keskusliitossa puolestaan vaihtui valta vuonna 1972, jolloin Sylvi Siltanen luovutti puheenjohtajan paikkansa Meeri Kalavaiselle ja Sinikka Luja-Penttilästä tuli sihteeri: liitot olivat

1 Sinikka Luja-Penttilän haastattelu 1986. TMTTK 1344/2. 
näiden henkilövaihtojen jälkeen kypsiä keskustelemaan yhdistymisestä vakavasti: "melkein samoilla papereilla sovinto syntyi kuin millä oli aloitettu sitä...puolueella oli tietysti toivomus, että tää asia saatais kuntoon."2

Vanhasta naisliitosta Martta Salmela-Järvinen ajoi tarmokkaasti liittojen yhdistymistä - vanha kitka Leivo-Larssonin ja hänen välillään näytti eläneen vielä näiden jo eläkeiässä olleiden naisten välillä. Kalevi Sorsa pyrki sovittelemaan naisliittolaisten välejä ja kävi neuvotteluja Leivo-Larssonin kanssa tämän kotona. Tyyne ei kuitenkaan antanut periksi: "naisliitto on se oikea, alkuperäinen!" Ainoa mahdollisuus eheytymiseen oli Leivo-Larssonin mukaan se, että Keskusliitto sulautuisi takaisin vanhaan naisliittoon, joka rekisteröitäisiin itsenäiseksi liitoksi. Keskusliiton Siltanen oli vähintään yhtä itsepäinen kuin Leivo-Larssonkin, eikä asia edennyt. ${ }^{3}$

Salmela-Järvinen puolestaan meni Leivo-Larssonin tietämättä tapaamaan eduskuntaan Luja-Penttilää ja Kalavaista. Sovinnonhakijalla oli jo niin huono kuulo, että keskustelu käytiin äänekkäästi. Jotta Leivo-Larsson eli "Leivotar", joksi häntä kutsuttiin, ei olisi saanut tietää neuvottelusta, kokoontuivat naiset puhemiehenä toimineen Veikko Helteen työhuoneessa. Tuosta neuvottelusta lähti yhdistyminen liikkeelle. Naisliittojen yhdistymisestä päätettiin vuonna 1977, mutta käytännön järjestelyjen takia varsinainen yhdistävä kokous pidettiin toukokuussa 1979. Naisliittojen 20-vuotisen erilläänolon päättymistä symboloi Tyyne Leivo-Larssonin kuolema elokuussa 1979.

Uuden liiton, joka sai nimekseen Sosialidemokraattiset Naiset, asema puolueessa määriteltiin seuraavasti: "Naisliitto toimii itsenäisesti Sosialidemokraattisen Puolueen naisjäsenten yhteisönä...Mikäli liittoa ei rekisteröidä, toimii liiton juridisena päättäjänä Suomen Sosialidemokraattinen Puolue r.p:n päätösvaltaelimet".

Jo hajaannuksen alussa kiistelty asia kaihersi yhä eräiden aktiivien mieliä: kokouksessa vaadittiin avoimesti uuden naisliiton rekisteröimistä. Erillisrekisteröintiä vastaan olivat etenkin nuoret naiset, jotka mieluummin liittyivät työväenyhdistyksiin kuin naisyhdistyksiin. He perustelivat valintaa sillä, että katsoivat voivansa näin paremmin vaikuttaa tasa-arvon saavuttamiseksi. Uskottiin, että erilliseksi liitoksi rekisteröiminen irrottaisi naisia liiaksi puolue-

2 Sinikka Luja-Penttilän haastattelu 1986. TMTTK 1344/2.

3 Sorsa 1998 , s. 46-47. 


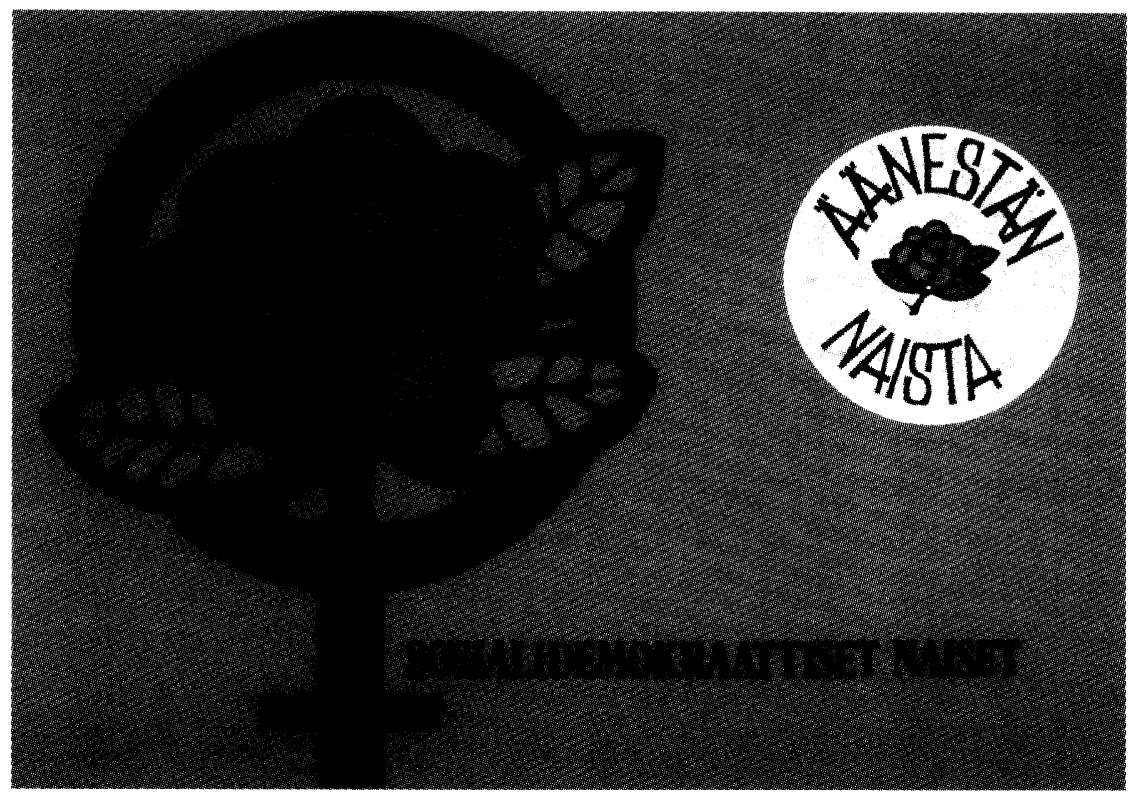

Sosialidemokraattisten Naisten vaalipostikortti 1980-luvulta. Kuva: Työväen Arkisto.

organisaatiosta. Kymen, Keski-Suomen, Kuopion, Vaasan, Oulun ja Lapin piirit kannattivat rekisteröimättömyyttä. Sen sijaan Pohjois-Karjalan ja Uudenmaan piiri sekä Helsinki kannattivat Tuulikki Kanniston esittämää rekisteröimistä. Asiasta äänestettiin ja tulokseksi tuli, ettei naisliittoa rekisteröity erilliseksi liitoksi.

Itsekriittisiä huomioita hajaannuksen vuosilta tuli useampien kokousedustajien terveisinä. Esimerkiksi Uudenmaan piiriläiset näkivät, että hajaannuksen valtataistelu käytiin eräiden henkilöiden kesken kenttäväen tietämättä.

Uusille urille lähdettäessä sosiaalidemokraattiset naiset ottivat ensisijaiseksi tehtäväkseen tasa-arvon lisäämisen. Lähtökohtana vuoden 1979 kokouksessa tuntui olevan ajatus, että "naisena ja äitinä tiedän hyvin, että tämä maailma on miesten maailma. Tämä meidän yhteiskuntamme ei ole tasa-arvon yhteiskunta". Osoituksena epätasa-arvoisuudesta nähtiin se, että erityisiä naistenvuosia (1975) ja lastenvuosia (1979) piti järjestää. Katsottiin, että tasaarvoisuutta sukupuolten välillä oli lisättävä sekä Sosialidemokraattisen puolueen sisällä että yleisemminkin yhteiskunnassa.

Tasa-arvo-ohjelman lisäksi kokous esitti toisen tärkeän suuntapaperin ja se koski kansainvälistä toimintaa. Naisliiton kansainvä- 
linen ohjelma käsitti kolme aihetta: aseistariisunnan, ihmisoikeudet ja uuden kansainvälisen taloudellisen järjestelmän. Naisten aseistariisuntavaatimus nousi Sosialistisen Internationaalin aseriisunnan työryhmän esityksistä. Suomelle työryhmän toiminta oli tuttua erityisesti siksi, että puolueen puheenjohtaja Kalevi Sorsa oli työryhmän puheenjohtaja. Naisten mukaan aseisiin tuhlatut suunnattomat rahamäärät olisi suunnattava kehitysmaihin. Ihmisoikeuksilla naiset tarkoittivat oikeutta ihmisarvoiseen elämään. Naiset pyrkivät lisäämään kansainvälistä solidaarisuustyötä pohjoismaisten sisarjärjestöjen sekä Sosialistisen Internationaalin ja Naisinternationaalin kanssa. ${ }^{4}$

\section{Naiset puolueen periaateohjelmassa}

Miten sitten naiset ovat näkyneet Sosialidemokraattisen puolueen periaateohjelmissa? Puolue on määritellyt ohjelmansa ensin perustamiskokouksessaan vuonna 1899 Turussa, Forssan kokouksessa vuonna 1903, vuonna 1952 ja vuonna 1987 Helsingissä pidetyissä puoluekokouksissa. Seuraavassa palataan ajassa taaksepäin ja tarkastellaan sitä, mitä periaateohjelmat oikein sanovat naisten oikeuksista.

Turun kokouksessa vuonna 1899 Suomen Työväenpuolueen ensimmäiseen ohjelmaan kirjattiin kolme vaatimusta, jotka koskivat naisten aseman kohentamista:

1) Yleinen, yhtäläinen ja välitön vaali- ja äänioikeus kaikille 21-vuotiaille Suomen kansalaisille sukupuoleen katsomatta kaikissa vaaleissa ja äänestyksissä, 2) naisten ja miesten täydellinen yhdenvertaisuus ja 3) naistarkastajia asetettava ja työväensuojelulainsäädäntöä kehitettävä. Uudistusvaatimukset nousivat saksalaisten sosialistien Erfurtin ohjelmasta.

Suomen Sosialidemokraattiseksi puolueeksi nimensä vaihtanut työväenpuolue uusi ohjelmaansa Forssan kokouksessa vuonna 1903. Myös tässä kokouksessa naisten oikeuksien parantaminen otettiin kolmessa eri kohdassa esille. Ääni- ja vaalioikeuden vaatimus oli ensimmäisellä sijalla, toiseksi vaadittiin naisille ilmaista synnytysapua sekä terveydenhoidon valtiollistamista ja kunnallista- 
mista. Kolmas kohta oli sama kuin Turun kokouksessa: "Kaikkien rajoitusten poistaminen, jotka asettavat naisen yleis- ja yksityisoikeudellisessa suhteessa ala-arvoisempaan asemaan kuin miehen". Näiden lisäksi Forssan kokouksessa käsiteltiin työsuojelulainsäädännön uusimista. Naistyöläisten osalta vaadittiin naisten yötyön kieltämistä, raskaana olevan naisen työn keventämistä tai kieltämistä. Lisäksi vaadittiin kiellettäväksi kaikki naista ruumiillisesti vahingoittava työ. Myös vaatimus naisammattientarkastajien määrän lisäämisestä pysyi vaatimuslistalla.

Näiden lisäksi "kansanvakuutuskeskustelu" nostatti vaatimuksia leskien ja orpojen vakuuttamisesta. Koska naisten taloudelliseen asemaan vaikutti myös perheen koko, huollettavien lasten ja vanhusten määrä, olivat Forssan kokouksen vaatimukset tärkeitä naisten aseman näkökulmasta. Puoluejohto oli jo aiemmin kiinnittänyt erityistä huomiota naisten asemaan yhteiskunnassa, kuten puheenjohtajana toiminut Nils R. af Ursin ja Taavi Tainio. Naisista puoluetoimikuntaan kuului Ida Ahlstedt (Aalle-Teljo).

\section{Valtiollisen demokratian lujittaminen}

Sosialidemokraattisen puolueen vuoden 1952 puoluekokous uusi osin vanhentunutta periaateohjelmaansa. Forssan ohjelman kulmakivi oli ollut äänioikeusuudistus, 1950-luvun alussa tärkeimmäksi kysymykseksi nousi valtiollisen demokratian lujittaminen.

Naisten aseman huomioonottaminen näkyi vuoden 1952 periaateohjelmassa selvästi yleisemmällä tasolla kuin Forssan ohjelmassa. Kun Forssan kokouksessa puhuttiin erityisesti "naisen asemasta", vuonna 1952 puhuttiin työväestön asemasta yleensä ja kaikista kansalaisista, tasa-arvosta ja samanarvoisuudesta. Vain yhdessä periaateohjelman kohdassa mainitaan erityisesti naiset: "Suomen Sosialidemokraattinen puolue pyrkii taloudellisten ja sosiaalisten uudistusten sekä talousjärjestelmän muuttamisen avulla yhteiskunnan kaikkien jäsenten samanarvoisuuteen, niin ettei syntyperä tai rikkaus eikä niiden avulla saavutettu valta, vaan henkilökohtainen kyky, taito ja siveellinen kunto ovat niin naisen kuin miehenkin yhteiskunnallisen aseman perustana". Yksilöllisten ominaisuuksien korostaminen astui puolueohjelmaan.

Verrattaessa vuoden 1952 periaateohjelmaa Forssan ohjelmaan voidaan sanoa, että naisten asemaa ei nähty enää niin heikkona, 


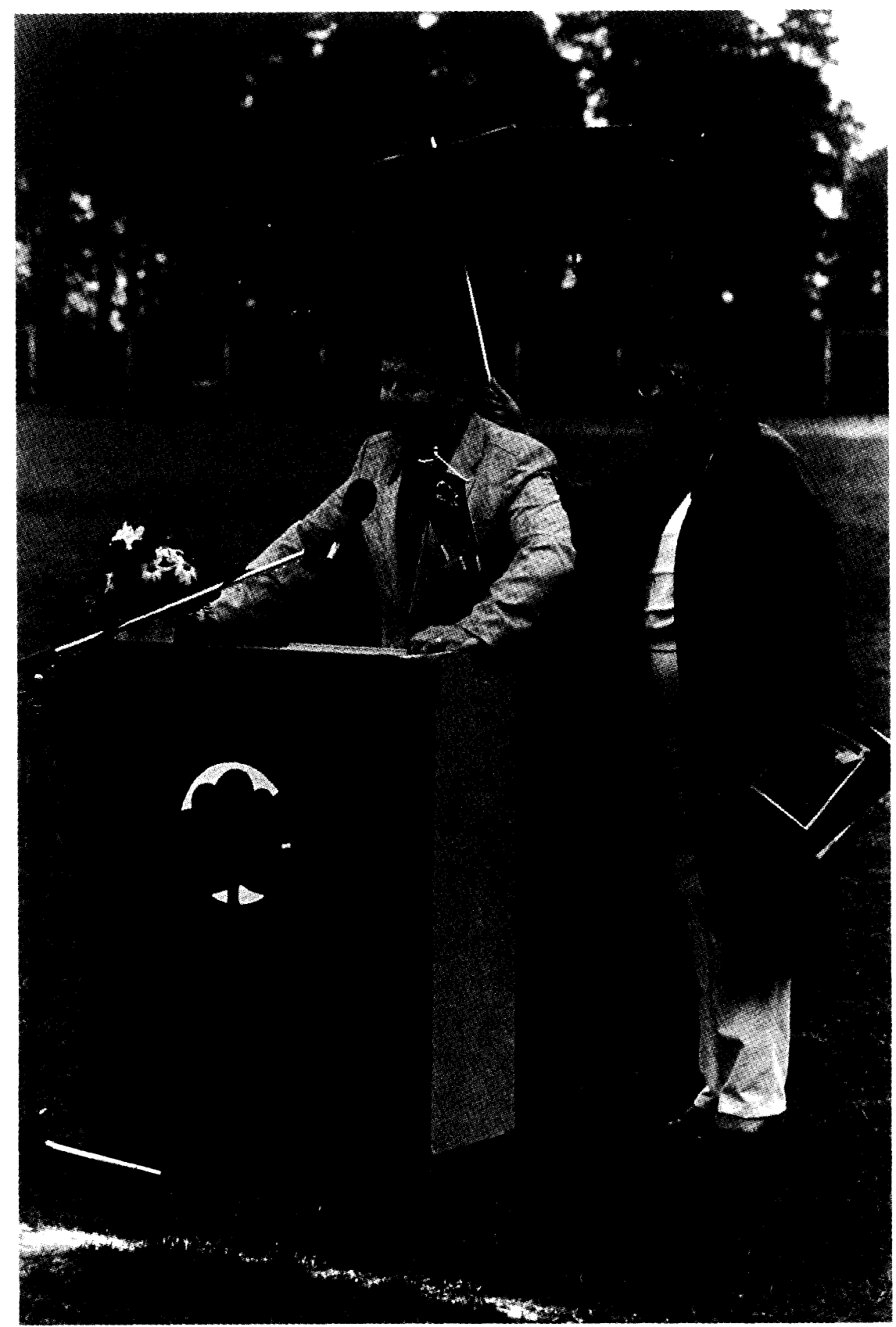

Naiset miestensä tukena. Pertti Paasio puhuu Sosialidemokraattisten Naisten retkeilypäivillä vuonna 1985 ja Pohjois-Hämeen Maija-Liisa Järvi tarjoaa sateensuojaa. Kuva: Sos.dem. Naisten toimisto. 
että se olisi vaatinut erillisiä mainintoja ohjelmaan. Tähän naisten näkymättömyyteen vaikutti se, että vuosisadan alussa naisten työsuojelu, vaimojen vajaavaltaisuus ja äänioikeus olivat keskeisiä vaatimuksia. 1950-luvun alkuun tultaesa pahimmat ongelmat oli korjattu: naiset olivat saaneet äänioikeuden, vaimot olivat lain edessä yhtä tasa-arvoisia kuin miehet ja työsuojelussakin raskaana olevan naisen suojelussa oli saavutettu tuloksia. Lisäksi sosiaalidemokraattien keskeisimmät äitiys- ja lastenneuvoloita ja lastensuojelua koskevat vaatimukset oli saatu ainakin osittain toteutettua. Kansalaisten, siis myös naisten, perusturvan pohja oli rakennettu ja sosiaalidemokraatit lähtivät lujittamaan sosiaaliturvaa ja rakentamaan Suomesta hyvinvointivaltiota.

\section{Keskeneräinen tasa-arvo}

Helsingin vuoden 1987 puoluekokouksen lähtökohtana oli yhdistää vähän vanhaa ja vähän uutta: "Sosialidemokratia on aate, jonka ihanteena ja päämääränä on vapauden, tasa-arvon ja solidaarisuuden yhteiskunta, yhteistyön ja rauhan maailma". Useimpien suomalaisten elämän perusedellytykset olivat muuttuneet sitten 1950-luvun ainakin kahdessa suhteessa. Ensinnäkin, Suomea voitiin 1980-luvulla nimittää hyvinvointivaltioksi: monet taloudelliset ja sivistykselliset tavoitteet, jotka oli kirjattu ensin Forssan ja sitten vuoden 1952 periaateohjelmaan, olivat toteutuneet. Toiseksi ympäröivä maailma oli muuttunut: kansalliset ongelmat kietoutuivat entistä tiiviimmin kansainvälisiin, globaaleihin ongelmiin.

Uudistetussa periaateohjelmassa jatkettiin linjaa, joka näkyi jo vuoden 1952 ohjelmassa. Naiset eivät olleet sukupuolensa perusteella erityisryhmä, eivät liioin "työväkeä", vaan yksilöitä. Sosiaalidemokratian nähtiin yhdistävän yksilölliset tavoitteet yhteiskunnalliselle tasolle. Naisten epätasa-arvoinen asema kuitenkin tunnustettiin: "Tasa-arvon toteutuminen on edelleen kesken. Sukupuolten tasa-arvoisuus on toteutettava työssä, perheessä ja yhteiskunnassa". Perheen sisäisen tasa-arvon vaatimus oli uutta. Perheiden selviytymistä oli tuettava muutenkin. Kotitaustan taloudelliset ja sivistykselliset erot nähtiin vaikuttavan lapsiin jo ennen kouluikää, joten näiden erojen tasaamiseksi oli pyrittävä parantamaan perheiden asemaa ja tukea niitä kasvatustehtävässään. 
Puoluekokousväki muistutti myös itselleen, että puolueen toimintaperiaatteita olivat avoin keskustelu ja tiedonkulku sekä jäsenten tasa-arvoisuus. Myös työelämään kiinnitettiin huomiota: "Työsuhde ei saa olla alistussuhde. Työntekijöiden itsehallinto merkitsee yksilön itsenäisyyttä ja turvallisuutta työssään, työntekijöiden toimintaa yhteisten etujen puolustamiseksi ja oikeutta osallistua työpaikkojaan ja tuotantoa koskevaan päätöksentekoon... Työn käsitettä on laajennettava koskemaan myös erilaisia itsensä toteuttamisen, kanssaihmisten palvelun ja yhteiskunnan rakentamisen muotoja".

Verrattaessa vuoden 1987 periaateohjelmaa edelliseen tai Forssan ohjelmaan, oli 1980-luvun sosiaalidemokraatti korosteisen yksilöllinen. Lähes jokaisessa periaateohjelman tavoitteessa annettiin arvoa yksilön omille valinnoille ja tuettiin yksilöllistä kehitystä sekä kunnioitettiin jäsenten henkilökohtaista vakaumusta. Yksilöllisyyttä korostava 1980-luvun sosiaalidemokraatti erosi selvästi vuosisadan alun kollektiivisesti ajattelevasta aatetoveristaan. Ajattelutavan muutos kieli yhteiskunnan sosio-ekonomisista ja kulttuurisista muutoksista, mutta myös poliittisten painotusten muutoksista. Vuosisadan alun sosiaalidemokraattinen ideologia oli toisenlainen kuin 1920-luvun, 1940-luvun tai 1960-luvun sosialidemokratia. Jotakin kuitenkin pysyi mukana sadan vuoden ajan: tasaarvon vaatimus, heikompien tukeminen ja kansainvälisyys. 1980luvun sosialidemokratia avautui tunnistamaan ja arvioimaan laajemmin kuin aikaisemmin sellaisia yhteiskunnallisia epäkohtia kuin etnisten tai seksuaalisten vähemmistöjen asema, ikärasismi ja luonnonsuojelukysymykset.

Toinen mielenkiintoinen piirre vuoden 1987 periaateohjelmassa oli se, että sukupuolten välinen tasa-arvo kirjattiin huomattavasti selkeämmin esiin kuin vuoden 1952 ohjelmassa. Itse asiassa vuoden 1987 periaateohjelmassa palattiin ensimmäisen puoluekokouksen vaatimukseen: "Naisten ja miesten täydellinen yhdenvertaisuus". Sukupuolten yhdenvertaisuuden vaatimus näyttää olleen yksi vaikeimmin toteutettavista vaatimuksista: muilla rintamilla on menty eteenpäin, mutta tasa-arvokysymys näyttää jäävän periaateohjelmien kestovaatimukseksi. ${ }^{5}$

5 Sosialidemokraattisen puolueen periaateohjelmat $1899,1903,1952$ ja 1987. TA. 


\section{Uudet uljaat naiset}

Sosiaalidemokraattisia naisia värvättiin ministeripaikoille vielä 1970-luvun alkupuolella naisista, joista suurimmalla osalla oli naisjärjestö- ja työläistausta. Heitä olivat muun muassa Alli Lahtinen, Margit Eskman, Meeri Kalavainen ja Sinikka Luja-Penttilä. Sen sijaan vuosikymmenen lopulla ja etenkin 1980-luvulla alettiin sosiaalidemokraattien naisministerit valita yhä useammin muualla kannuksia saaneista naisista. Ei liene sattuma, että samaan aikaan kun politiikka kaupallistui ja "televisioitui", astuivat politiikan näyttämölle hyvännäköiset, yliopistoissa opiskelleet ja itsevarmat naiset. Näin myös poliittisessa vasemmistossa. Sdp:n puheenjohtaja Rafael Paasio lienee tietoisestikin tehnyt tilaa uusille, nuorille voimille.

Selvä päätepiste ja uuden alku tässä perinteessä oli vuonna 1975 eduskuntaan Satakunnan piiristä valittu Pirkko Työläjärvi. Häntä ennen ja hänen jälkeensä ministeriposteja saaneet naispoliitikot edustivat eri tyylejä. 1980-luvun poliitikkotyyppiä edustivat muun muassa Kaarina Suonio ja Vappu Taipale. Nämä uuden aallon poliitikot olivat korkeasti koulutettuja, omassa ammatissaan päteviä eivätkä välttämättä työläis- ja naisjärjestötaustaisia. Esimerkiksi filosofian ja oikeustieteen kandidaatti Suonio ei ollut toiminut naisjärjestöissä ja isäkin oli professori. Taipale puolestaan on lääketieteen ja kirurgian tohtori. Uudet naiset saivat suhteellisen nopeasti ministerinsalkun 1970-80-luvuilla ja siirtyivät aika nopeasti myös politiikan näyttämöltä sivuun korkeisiin virkoihin. Taipale valittiin kolmen ministerivuoden jälkeen sosiaalihallituksen pääjohtajaksi ja sittemmin Stakesin pääjohtajaksi. Suonio puolestaan siirtyi ensin Tampereen kaupunginjohtajaksi ja sitten maaherraksi oltuaan ministerinä viisi vuotta.

Näistä naisista on sanottu, että heidät siirrettiin syrjään juuri silloin, kun heistä alkoi tulla liian vaarallisia kilpailijoita miehiselle puoluejohdolle. Niin tai näin, kukaan näistä naisista ei jäänyt puoluejohtoon. Kauppatieteiden kandidaatin Pirkko Työläjärven "häikäisevän nopea nousu", joksi Kalevi Sorsa on sitä nimittänyt, oli itse asiassa samantyylinen kuin Sorsalla itsellään. Vanhan järjestöväen mielestä nämä uuden ajan poliitikot tulivat tuntemattomuudesta, halusivat kaikki heti ja edustivat ehkä enemmän itse- 


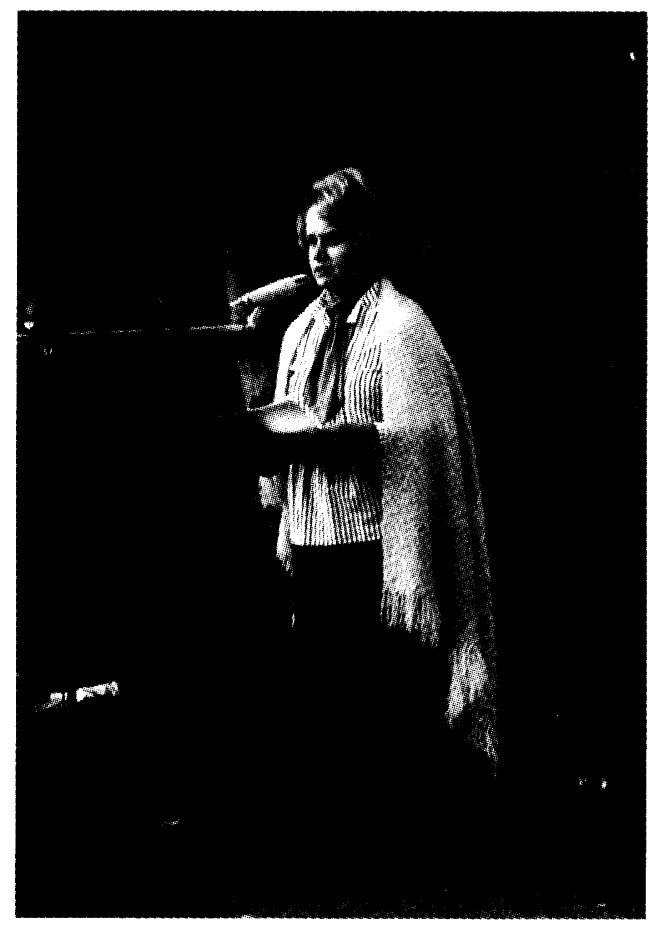

Liian vahva ja itsenäinen? Pirkko Työläjärvi olisi ehkä ollut Suomen ensimmäinen naispuolinen pääministeri, jos hän olisi hyväksynyt presidentti Urho Kekkosen suunnitelmat. Kuva: Työväen Arkisto.

ään kuin vaalipiirejään. ${ }^{6}$ Nämä uudentyyppiset poliitikot eivät olleet ainoastaan naisia, vaan puoluejohtoon alkoi pyrkiä myös nuoria miehiä, kuten Erkki Liikanen ja Matti Ahde.

Kun puolueen johtoon pyrki samalla kertaa suhteellisen samanikäisiä, koulutettuja ja päämäärätietoisia poliitikkoja, aiheutti se ristiriitoja ja suoranaisia valtataisteluja. Tunnetuin niistä lienee puolueen varapuheenjohtajaksi vuonna 1975 nimitetyn Työläjärven ja puoluesihteeri Liikasen keskinäinen antipatia. Toimittaja Lasse Lehtiselle antamassaan haastattelussa Työläjärvi sanoo, että hänestä pyrittiin pääsemään eroon, häntä syytettiin oikeistolaisuudesta, oman edun tavoittelusta ja epätoverillisesta käyttäytymisestä: "Minusta on vapaa puolue se, jossa on turvallista olla puoluesihteerin epäsuosiossa". ${ }^{7}$

Satakunnan piirillä, joka alunperin nosti Työläjärven kansanedustajaksi (1972), oli sittemmin omat ristiriitaiset tunteensa edustajaansa kohtaan. Eikä vähiten sen takia, että piirissä toimi jo yksi vahva nainen, "todellinen" järjestönainen, nimittäin Margit Esk-

6 Ks. mm. Lehtinen 1982, s. 81-82, 88.

7 Lehtinen 1982, s. 96. 
man. Puoluejohto oli nostanut Eskmanin puolueen historian ensimmäiseksi naispuoliseksi varapuheenjohtajaksi Tampereen kokouksessa 1972, mutta seuraavassa puoluekokouksessa se ohjasikin Eskmanin ulos ja antoi hänen paikkansa Työläjärvelle. ${ }^{8}$ Kalevi Sorsan mukaan Eskman otti asian raskaasti. ${ }^{9}$ Tämä johtui osittain siitä, ettei Eskmania eikä liioin Työläjärveä valmisteltu etukäteen puoluejohdon suunnitelmista. ${ }^{10}$

Valinnasta tuli itse asiassa kolmiodraama, sillä myös Alli Lahtinen oli varteenotettava kandidaatti Eskmanin sijalle. Lahtisesta elämänkerran tehnyt Sakari Kiuru kertoo, että puoluejohto ei oikeasti halunnut Työläjärveä varapuheenjohtajaksi. Hänen nostamisensa ehdokkaaksi oli vain hämäysyritys: itse asiassa puoluejohto halusi vaihtaa Eskmanin Alli Lahtiseen. Lahtinen oli ilmeisesti ärsyyntynyt syrjäyttämisestään ja kutsui sittemmin kotiinsa keskustelemaan sekä Työläjärven että Eskmanin. Lasse Lehtisen mukaan Työläjärvi on muistellut tapaamista näin: "Allille oli ominaista suoruus. Kun hän oli kuullut, miten puolueen "junttamiehet" olivat halunneet käyttää minua - siitä mitään minulle puhumatta - Margit Eskmanin sivuuttamiseen ja Allia muka suosiakseen SDP:n varapuheenjohtajan vaalissa, Allin epäluulot väistyivät. Asiat selkiytyivät. Välillemme ei jäänyt mitään kitkaa"."1

Eskmanin ja Työläjärven vahdinvaihdon kipeys kertoo hyvin ja konkreettisesti toisaalta puoluejohdon saneluvallasta, toisaalta järjestökulttuurin muutoksesta. Vanheneva naistoiminnassa "ryvettynyt" järjestöjyrä sai mennä uuden, naisliikkeeseen kriittisemmin suhtautuneen komeetan tieltä. Komeetan, jonka oma poliittinen tie päättyi samantyyppiseen syrjäyttämiseen. Työläjärvi oli todellinen uhka: ennen vuoden 1984 puoluekokousta puhuttiin, että Työläjärvi tulisi haastamaan Sorsan puheenjohtajakisassa ja kaikkien tiedossa oli, että Kekkonen oli tarjonnut Työläjärvelle pääministerin paikkaa toukokuussa 1979 - tosin kehuttuaan tätä sitä ennen älykkääksi ja hyvin naiselliseksi naiseksi. ${ }^{12}$

8 Lehtinen 1982, s. 87.

9 Sorsa 1998, s. 229.

10 Lehtinen 1982 , s. 87.

11 Kiuru 1994, s. 128, 145.

12 Lehtinen 1982, s. 126-127, 11-13. 


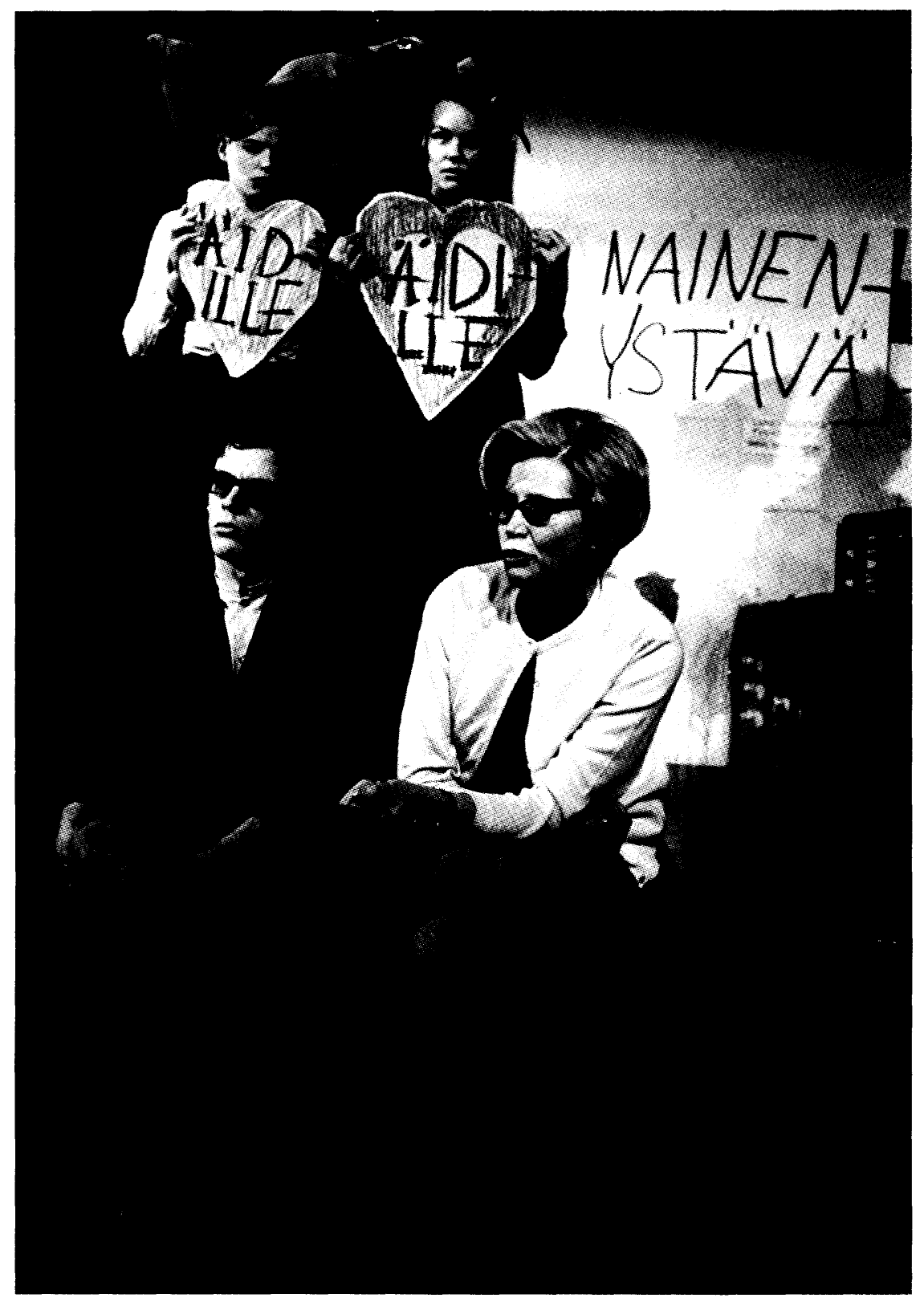

Sosiaalihallituksen pääjohtaja Alli Lahtinen (1926-1976) oli yksi eturivin naispoliitikkoja 1960-70-luvulla. Kuvassa Lahtinen näyttelijä Hannu Kahakorven kanssa television viihdeohjelmassa 1960-70-luvun vaihteessa. Kuva: Työväen Arkisto. 


\section{*Naisinternationaali}

Sosialistinen naisinternationaali on Sosialistisen Internationaalin (SI) rinnakkaisjärjestö, johon kuuluvat SI:n piiriin kuuluvien jäsenpuolueiden naisjärjestöt. Sen päämääränä on ylläpitää yhteyksiä puolueiden naisjärjestöjen kesken, vaihtaa kokemuksia, levittää tietoa ja pyrkiä toimimaan kaikenlaisen syrjinnän poistamiseksi yhteiskunnassa, mukaan lukien sukupuolten välinen epätasa-arvo.

SI:n naisten neuvosto on perustettu vuonna 1907 Stuttgartissa Ensimmäisen Internationaalin toisen kokouksen yhteydessä. Kuten tämän teoksen alussa on esitelty, oli suomalaisten edustajana kyseisessä kokouksessa Hilja Pärssinen ja vuoden 1910 Kööpenhaminan kokouksessa suomalaisia sosiaalidemokraatteja oli viisi. Kolmannessa Bernin kokouksessa 1915 Suomella ei ollut edustajaa. Ensimmäinen maailmansota keskeytti toiminnan ja seuraavat kokoukset pidettiin sosiaalidemokraattisten tunnusten alla vuosina 1923, 1925, 1928 ja 1931, minkä jälkeen maailmanpoliittiset tapahtumat keskeyttivät jälleen järjestön toiminnan.

Toisen maailmansodan jälkeinen ensimmäinen kokous pidettiin vuonna 1948 Wienissä. Siellä valittiin järjestön puheenjohtajaksi tanskalainen Nina Andersen. Sodanjälkeistä kansainvälistä naistoimintaa leimasi sodanvastaisuus: tunnuslauseissa vaadittiin rauhaa, vapautta, humanismia ja kansojen välistä ystävyyttä. Vuoteen 1955 yhteisö käytti nimeä Sosialidemokraattisten Naisten kansainvälinen komitea. Sen jälkeen se kulki Sosialidemokraattisten Naisten kansainvälisen neuvoston (ICSDW) nimellä. Vancouverin kokouksessa vuonna 1978 nimi muutettiin jälleen. Siitä tuli Sosialistinen naisinternationaali eli SI Women. Suomen sosiaalidemokraattisten naisten hajaannuksessa naisinternationaaliin kuului Sosialidemokraattisten Naisten Keskusliitto. Vuoden 1978 kokouksessa Helvi Saarinen valittiin järjestön yhdeksi varapuheenjohtajaksi.

Paitsi kansainvälisen naisinternationaalin toimintaan, suomalaiset sosiaalidemokraattiset naiset osallistuivat aktiivisesti myös pohjoismaiseen yhteistyöhön. Vuosisadan alun vierailujen ja henkilökohtaisten verkostojen ja tuttavuuksien jälkeen siirryttiin vuonna 1935 järjestämään ns. Pohjoismaisia Naisten päiviä. Ensimmäiset pidettiin Tukholmassa, vuonna 1937 Kööpenhaminassa ja vuonna 1938 Helsingissä. 1940-luvulla päiviä pidettiin kaksi kertaa (1946 ja 1948). 1950-luvulla yhteydet tiivistyivät ja yhteistyö on jatkunut näihin päiviin saakka.

Lähde: Sos.dem. naisliiton vuosikertomukset 1907-57. TA; Rauha, Rakkaus, Solidaarisuus. Kv. monistesarja no 1/1978. Sosialidemokraattiset Naiset. TA; Naisliiton osallistumisesta kansainvälisiin ja pohjoismaisiin kokouksiin, ks. liite 5. 


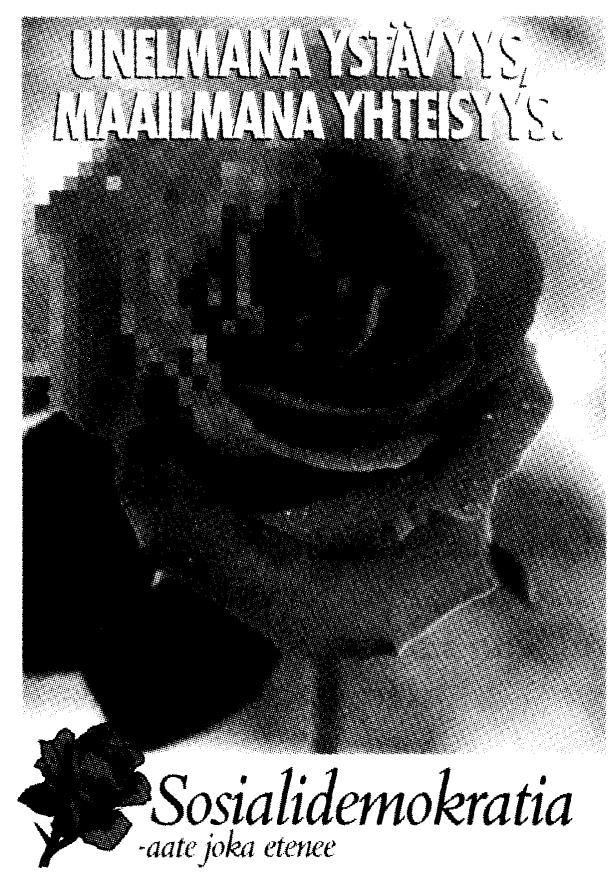

Sosialidemokraattisen puolueen eduskuntavaalijuliste vuodelta 1987. Kuva: Työväen Arkisto.

\section{Mannen liitto}

Marianne Laxénin persoona leimasi sosiaalidemokraattisten naisten toimintaa 1980-luvulla siinä määrin, että on perusteltua kutsua ajanjaksoa Mariannen eli Mannen kaudeksi. Tultuaan valituksi vuonna 1979 naisliiton pääsihteeriksi Laxén määritteli naisliiton tehtäväksi ennen kaikkea koulutus- ja agitaatiotyön. 1960-luvun hengen mukaisesti oli välttämätöntä kehittää edelleen jäsenistön tietoisuutta ei ainoastaan naiskysymyksissä, vaan myös talouspolitiikassa ja yleispolitiikassa. Hänen mukaansa naisten järjestörakennetta oli kehitettävä siten, että se toimisi samojen periaatteiden mukaisesti kentältä liittotoimikuntaan. Näin ei syntyisi kuilua jäsenistön ja johdon välille.

Laxén ei suhtautunut niin mustasukkaisesti naisten omaan liittoon kuin vanhemman polven naiset. Heille naisliitto oli ensisijainen toiminnan kehittämisen kohde. 1980-luvun naisliikkeessä mukana olleet nuoremmat naiset päinvastoin avasivat naisliiton ovet ja olivat tyytyväisiä, jos naisliittoon kuulumattomia naisia toimi sosiaalidemokraattisten tunnusten alla muissa yhteyksissä, kuten ammattiyhdistysliikkeessä: "Nämä uudet naiset ovat toimineet lä- 
hinnä työpaikkatasolla eivätkä siis varsinaisesti sos.dem. naisjärjestöissä. Tämä ei kuitenkaan ole mikään haitta". ${ }^{13}$

\section{Naiset - puolueen perheenemännät}

Naisliittolaisten tasa-arvotyön Laxén määritteli kohdistuvan ensisijaisesti puolueen sisälle: "Mitä paremmin pystymme saamaan omaa väkeämme tasa-arvon kannattajiksi, sitä paremmin voimme saada ulkopuolisia ihmisiä mukaan”. Laxén näki, että puolueen tasa-arvovaatimus ja käytännön toiminta eivät olleet tasapainossa: “...minusta sos. dem. puolueen kannatuksen paikallaan pysyminen 1970-luvulla on yksi osoitus siitä, että sanoma ja käytäntö eivät ole olleet sopusoinnussa keskenään”. Laxén vertasi puolueen ja yhdistysten naisia perheenemänniksi: "Perusosastotasolla voidaan nähdä naisten perinteisesti toimineen juuri tässä roolissa. Tietoista yritystä tasa-arvoon ei ole ollut ja tilanne on hyväksytty molemmin puolin." Laxénin mukaan naiset olivat keittäneet kahvia yhteisissä kokouksissa, tiskanneet ja istuneet ompelukerhoissa tuottaen rahaa yhdistykselle. Kootut rahat oli käytetty sitten miesten vaalikassoihin. Naisten työ oli hukkunut tällaiseen perusjärjestötyöhön, olihan heitä selvästi vähemmän piiritasolla, puoluejohdosta puhumattakaan.

Laxénin periaatteellinen kanta naisten erillistoimintaan oli kielteinen. Hänen mukaansa naisten ei tulisi toimia ulkopuolisena painostusjärjestönä puolueelle, vaan painostuksen tulisi tapahtua kouluttamalla ihmisiä tiedostamaan asioita. Tällöin jokainen alasta ja asemastaan riippumatta veisi "naisasiaa" eteenpäin. Eriytyminen voisi johtaa naisten syrjäytymiseen päätöksenteossa. Keskittyminen "epäpoliittiseen" naisasiaan vahvistaisi Laxénin mukaan sukupuolten eriarvoisuutta politiikassa. ${ }^{14}$

\section{Tasa-arvon vuosikymmen}

Yleisesti ajatellaan, että 1980-luku oli tasa-arvon vuosikymmen. Näin olikin. Se näkyi muun muassa naisten osuuden kasvuna edus- 


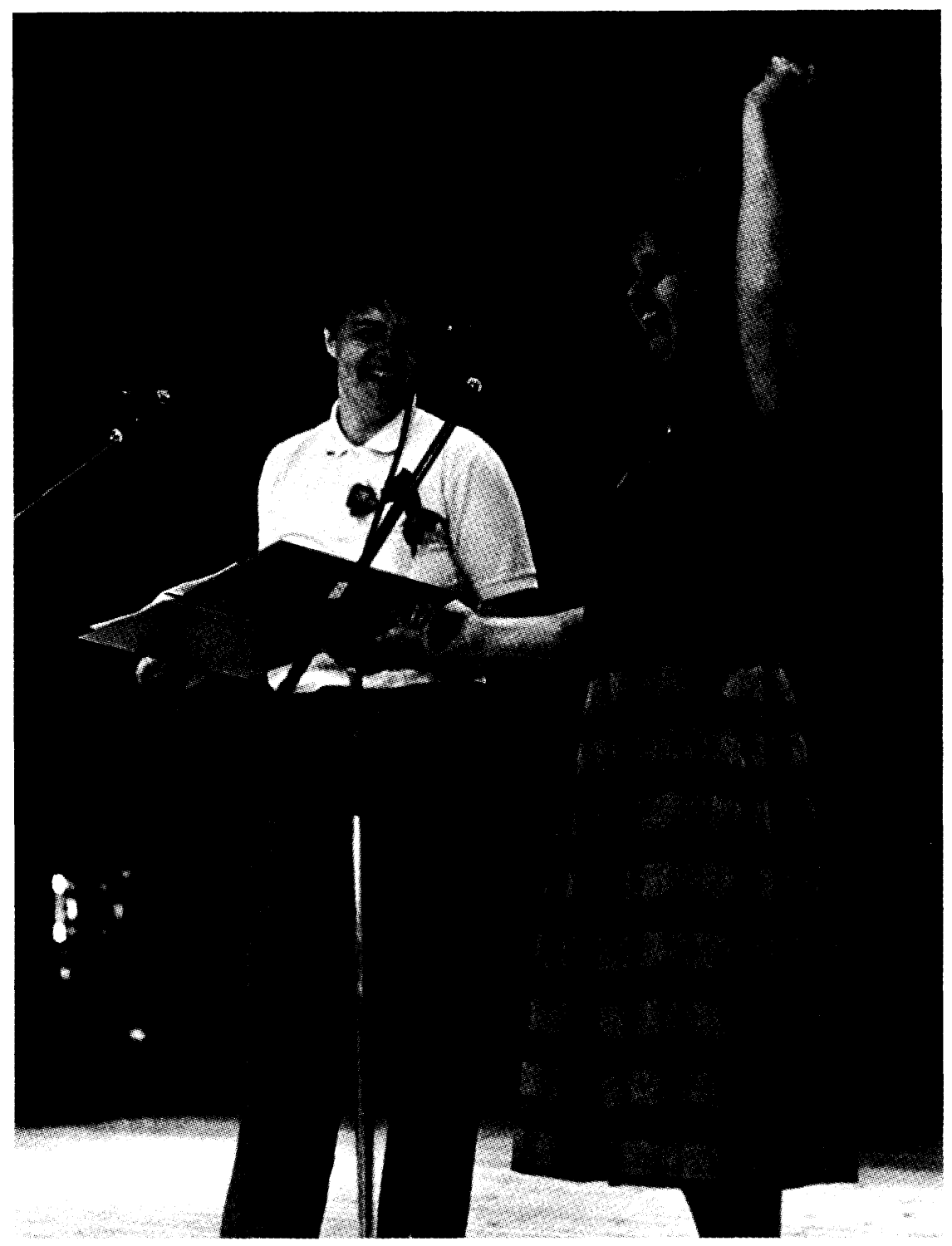

Marianne Laxén (vas.) ja Vappu Taipale vauhdissa Sosialidemokraattisten Naisten retkeilypäivillä vuonna 1985. Kuva: Sos.dem. Naisten toimisto.

kunnassa ja puoluekokouksissa. Taloudellinen nousukausi avasi naisille kasvavia toimintamahdollisuuksia: kaikkien kukkien annettiin kukkia. Puoluejohtoon naisten oli kuitenkin vaikea kivuta. Olivathan Margit Eskman ja Pirkko Työläjärvi toimineet varapuheenjohtajina, mutta puoluesihteerin ja puoluejohtajan paikat olivat vielä naisten saavuttamattomissa. Todellinen kädenvääntö puoluesihteerin paikasta käytiin sosiaalidemokraattien vuoden 1981 
puoluekokouksessa, jossa Marianne Laxén hävisi tiukassa sihteerikilvassa Erkki Liikaselle. Ei siis ihme, että Laxén näki periaatteidensa vastaisesti erillisen naisjärjestön tarpeelliseksi niin kauan kuin puoluekäytäntö ei toiminut tasa-arvoisesti. Laxén arvostelikin tiukasti vallitsevaa puoluekäytäntöä, joka syrji naisia: "Edessä on pitkä taistelu, ennen kuin naisjärjestöt muuttuvat tarpeettomiksi...". ${ }^{15}$

\section{Feminismi ja sosialismi}

Feminismi eli uusi naisliike löi itsensä läpi myös Suomessa 197080-luvulla. Sen juuret olivat 1960-luvun amerikkalaisessa kansalaisoikeus- ja opiskelijaliikkeessä, josta radikaalit naiset pettyneinä toimintamahdollisuuksiinsa irtautuivat. Feministit karttoivat toiminnassaan perinteistä järjestöorganisaatiota ja julistivat toimivansa ryhmissään demokraattisesti. He perustivat tiedostusryhmiä, jotka ottivat tunnuslauseekseen "henkilökohtainen on poliittista". Se perustui ajatukseen, että naiset omien kokemustensa kautta kasvoivat yhteiskunnalliseen tiedostamiseen. Feministit näkivät yhteiskunnassa vallinneen sukupuolten välisen eriarvoisuuden poliittisena ja vaativat siksi yhteiskuntajärjestelmän muutosta. Uudelleen organisoituneet sosialidemokraattiset naiset määrittelivät suhteensa feministiseen liikkeeseen vuonna 1980. Sosiaalidemokraatit arvioivat feminismiä siltä kannalta, olisiko "meillä mahdollisesti jotakin opittavaa feministeiltä ja jos on, niin mitä". ${ }^{16}$

Vaikka sosiaalidemokraattien naisverkostossa oli myös naisia, jotka julistautuivat feministeiksi, kuten vuonna 1982 sosiaali- ja terveysministeriksi nimitetty Vappu Taipale, ${ }^{17}$ oli suhtautuminen uuteen feministiseen liikkeeseen yleensä kriittistä. Naisliitossa feminismiä kritisoi nuoren naissukupolven edustaja Marja Lehto vuonna 1980 näin: "Naiset eivät muodosta yhtenäistä ryhmää. Erilaisessa yhteiskunnallisessa asemassa olevien naisten objektiiviset edut ovat niin erilaiset, että yksiselitteisestä "naisten vaihtoehdosta" tuskin voidaan puhua...Sisaruuden käsitettä voidaan kritisoida samalla tavoin kuin "naisten vaihtoehtoa". Kun se esite-

15 Marianne Laxénin haastattelu. Teoksessa Naisen työ. 1980, s. 103-107.

16 Lehto Marja, Feminismi ja sosialismi. Tietosisko 1/1980.

17 Kuusipalo 1999, s. 67. 
tään itsestään selvänä, voidaan tuskin välttyä pettymyksiltä käytännössä...Sisaruus saattaa toimia politttisena iskulauseena mutta pitkällä tähtäyksellä se ei riitä pitämään koossa liikettä, jolla ei ole teoriaa, ohjelmaa eikä strategiaa...Leimaa-antavaa feministisessä liikkeessä on analyysin ja kritiikin puute...tämä liittyy tiettyyn hahmottomuuteen. "Lehto ei nähnyt edes sosialistifeministien lähestymistapaa mahdolliseksi: miten toteutetaan yhteiskuntamuutos ilman miehiä, hän kysyi. ${ }^{18}$

Se, minkä feministien mallista nähtiin soveltuvan sosiaalidemokraattisille naisille, olivat ajatukset naisten itsetunnon kohentamisesta ja solidaarisuudesta. Naiset oli tehtävä näkyviksi työväenliikkeessä. Naisliittoaktiivi Sinikka Luja-Penttilä kuittasi suhteensa uuteen naisliikkeeseen "...mä kyllä silloin ittekseni sanoin, että näitä samoja asioita on kyllä ajanut tämäkin naisliike. Ihan alusta asti, mutta tietysti ne saatiin paremmin esiin yhden asian liikkeenä..."19

Sosiaalidemokraatit käsittelivät feminismi-kysymystä myös Sosialistisen internationaalin naissihteeristön kokouksessa kesäkuussa 1980. Kokouksessa keskusteltiin aiheesta "Sosialististen puolueiden vastuu tasa-arvosta", jossa juututtiin puhumaan tasa-arvo käsitteen ja myös feminismi-sanan määrittelemisen ongelmista pääsemättä niissä yhteisymmärrykseen. Puheenvuoro "Feministisistä liikkeistä tänä päivänä" nosti esiin sosiaalidemokraatteja huolettaneen kysymyksen naisten eristäytymisestä omiin piireihinsä, ghettoutumisesta. Irtautuminen puolueista johtaisi naiset epäpoliittiseen ja voimattomaan tilaan. Toisaalta korostettiin sitä, että spontaanien liikkeiden synty kieli myös työväenliikkeen sisäisistä ongelmista: osalla naisista oli tarve irrota viiteryhmästä, joka ei keskittynyt ajamaan heidän asiaansa. Marianne Laxénin esityksestä feminismin integroiminen sosialismiin sai seuraavanlaisen sisällön naissihteeristön kokouksessa: "Taistelu naisten alistamista ja eriarvoisuutta vastaan kaikilla alueilla (mukaan lukien taloudellinen, poliittinen, henkinen ja seksuaalinen alistaminen) on osa sosialistista työtämme ja tavoitteitamme,${ }^{20}$

18 Lehto 1980, s. 6-7.

19 Sinikka Luja-Penttilän haastattelu 1986. TMTTK 1344/2.

20 Feminismi ja sosialidemokratia. Tietosisko 5/1980. 
Naiset ottivat 1980-luvulla aikaisempaa järjestelmällisemmin ja ponnekkaammin naisnäkökulman esille myös puoluekokouksissa. Sosialidemokraattisen puolueen Porin puoluekokouksessa kesäkuussa 1981 naiset esittivät peräti 17 aloitetta naisten osuuden lisäämisestä puolueen päätöksenteko- ja valmisteluelimissä. Puoluekokouksessa oli äänioikeutettuja naisia mukana 93 yhteensä 367:sta edustajasta eli $25 \%$ kokousedustajista.

Puoluekokous katsoi, että tulisi asettaa tasa-arvopoliittinen työryhmä, jonka tehtävänä oli laatia tasa-arvopoliittinen ohjelma sekä seurata tasa-arvon edistymistä yleensä. Sisäpoliittisessa julkilausumassaan puoluekokous totesi, että "Suomi on tasa-arvolainsäädännön osalta jäämässä jälkeen muista Euroopan maista. YK:n yleiskokouksen hyväksymän naisten syrjinnän kieltävän sopimuksen hyväksyminen Suomessa edellyttää monia lainmuutoksia. SDP vaatii, että syrjintäsopimuksen hyväksymisen yhteydesä säädettäisiin yleinen tasa-arvolaki. Tässä laissa on erityisesti kiinnitettävä huomiota naisten syrjinnän estämiseen ja tasa-arvon edistämiseen työmarkkinoilla". ${ }^{21}$

Käytännössä Porin puoluekokous pääsi soveltamaan tasa-arvokysymystä puoluesihteerin vaalin yhteydessä. Vahvimpia ehdokkaita olivat naisliiton pääsihteeri Marianne Laxén ja 31-vuotias valtiotieteen maisteri Erkki Liikanen. Menettelytapavaliokunnan puheenjohtaja Antero Anttila totesi puolueen henkilövaintojen alussa, että valiokunnassa käytiin "rakentava, asiallinen ja perusteellinen keskustelu, jossa ehkä sosialidemokraattisen puolueen aikaisempaan maineeseen verraten on kyetty olemaan henkilöistä rakentavasti eri mieltä..." Puoluekokouksessa paljon keskustelua herättänyt ja kentältä tulleen painostuksen vuoksi "naistovereiden aseman nostaminen" näkyi menettelytapavaliokunnan esityksessä siten, että seitsemästä paikasta luvattiin kaksi naiselle.

Puolueen puheenjohtajaksi valittiin yksimielisesti Kalevi Sorsa, ensimmäiseksi varapuheenjohtajaksi Veikko Helle ja toiseksi varapuheenjohtajaksi Pirkko Työläjärvi. Sen jälken puolueväen yksimielisyys loppui. Puoluesihteerikilvan loppusuoralle yltäneiden Laxénin ja Liikasen kokemus, koulutus ja yleistausta arvioitiin

21 Pöytäkirja SDP:n XXXII puoluekokous Pori 3.-7.6.1981, s. 581. 
hyvin samankaltaisiksi. Äänin 9-6 menettelytapavaliokunta esitti kuitenkin Liikasen valitsemista puoluesihteeriksi. Enemmistö perusteli päätöstään sillä, että Liikasella oli valtiollisista ja kansainvälisistä asioista laajaa kokemusta ja korkeatasoista näyttöä. Liikasta kehuttiin valiokunnassa myös hänen "suuren kontaktien luomiskyvyn", järjestelmällisyyden, johdonmukaisuuden ja nopeuden vuoksi.

Puoluekokous ei kuitenkaan asettunut tukemaan menettelytapavaliokunnan esitystä, vaan naiset vaativat äänestystä. Se toimitettiin umpilipuin piireittäin. Sen tulos oli 226-139 Liikasen eduksi. Tuloksen tultua julki Laxén lauloi Liikaselle laulun: "Moni teistä varmasti tietää, että osaan yhden laulun ja se laulu on myös ruusuista. Kun Erkki tyhjensi tämän maljan, niin ei ole enää ruusuja hänelle annettavaksi, mutta voisin laulaa tämän laulun jonka osaan Erkille... se on laulu jonka Nils Ferlin on kirjoittanut ja joka kertoo miehestä tai naisesta joka haluaa antaa rakastetulleen ruusuja. Hän antaa yhden valkoisen ja yhden punaisen, mutta kolmas niistä ruusuista on semmoinen, joka kukkii vasta sitten kun antaja on kuollut. Ja itse olen tulkinnut sen sillä tavalla, että aika paljon siinä on mukana juuri se aate, jonka puolesta me toimimme, ei ole kysymys siitä, jäämmekö me eloon, vaan kysymys on siitä jääkö aate eloon. Ja tämän puolesta kaikki kamppailemme... "22

Vaikka puoluesihteerivaali oli naisliittolaisille katkera tappio, nielivät he sen päät pystyssä.

Kuusi vuotta myöhemmin (1987) sosiaalidemokraatit olivat kypsyneet valitsemaan itselleen naispuolisen puoluesihteerin. Hän oli Kalevi Sorsan nostama Ulpu Iivari, joka tuli naisjärjestöjen ulkopuolelta.

Martta Salmela-Järvinen seurasi sivusta naisten kamppailua puolueen johtopaikoista. Ehkäpä hän muisteli kaikkia niitä sodanjälkeisiä yhteenottoja, joita hän oli joutunut käymään Leivo-Larssonin kanssa puoluesihteeri Leskistä vastaan. Eräässä haastattelussa hän arvioi Laxénia näin: "Mariannella oli semmosta energisyyttä, joka halus pulputa. Ja luonnetyyppinä semmonen kova, vaikka saattoi olla ailahtelevainen. Mutta hän teki töitä. Ja mä sanon, en mä tiedä onk se ihan oikein arvioitu, mutta hänen aikanaan naisliitto näkyi aika paljon ja hyvin...Se oli sitä 80-luvun ulosajoa, että tasa- 
arvo pitää toteuttaa. Ja hän oli semmonen taistelijatyyppi. Mutta ei ilmeisesti sitten aina noiden miesten kanssa oikein osannu taistella kun hän jäi alakynteen. "23

\section{Kikkelikortti tasa-arvohenkilölle}

Naisten taistelu todellisesta tasa-arvosta ei ollut leikkisotaa. Eräiden yhteiskunnallisesti johtavassa asemassa olevien miesten huumorintajusta kertoo Marianne Laxénille 2.1.1990 lähetetty Vive les hommes -kortti. Siinä alaston nainen leijuu taivaalta rintaliivien varassa jäykistyneiden siittimien päälle. Kortin lähettäjät, työmarkkinamiehet Jorma Reini, Mauri Moren, Tenho Olin, Jarmo Pellikka, Stig-Erik Leiponen ja Jarmo Tammenmaa eli ns. Tupolevin veljekset olivat olleet juhlimassa Kalastajatorpalla ja päättäneet ilahduttaa myös tasa-arvohenkilö Manne Laxénia "c/o Ilkka Kanerva Valtioneuvosto". Miesten viesti oli selkeä: "Palkkaerot poistettava, keskitytään olennaiseen”.

Asiasta nousi valtava kohu. Osin syystä, että kortti oli niin härski, mutta pääasiassa sen takia, että kuukautta myöhemmin Reini aloitti työnsä valtakunnansovittelijana. Radiossa vaadittiin muun muassa Reinin eroa. Reini pyysi julkisesti anteeksi: hän ei tiennyt korttia allekirjoittaessaan, että hänestä tulisi valtakunnansovittelija. Samaan aikaan oli meneillään pankkitoimihenkilöiden lakko, mikä sai Reinin mukaan naiset kuohuksiin: "Naisasialiike huomasi, että nyt on tilaisuus nostaa omaa profiliaan".

Reinin oli mentävä televisiokeskusteluun Laxénin kanssa. Hänellä ei ollut vaihtoehtoja, "koska Lenita (Airisto) uhkasi, että jos en tule, olisi valtakunnansovittelijan toimiston ikkunoiden alla oleva Vanha kirkkopuisto, kansanomaisesti Ruttopuisto, täynnä naisasialiikkeen naisia, jotka huutaisivat, että Reini ulos sieltä. Minä rupesin sieluni silmin näkemään, kuinka Ruttopuistossa on hirveä määrä kiljuvia ihmisiä - ja mihin se vie tämän talon arvovallan. Oli parempi mennä ja puhua, vaikkei asia sinänsä sen arvoinen ollutkaan". ${ }^{24}$

23 Martta Salmela-Järvisen haastattelu, nauha 870 II. TMTTK:n kokoelmat.

24 Reini 1996, s. 191-195; Mm. Suomen Kuvalehti 2.3.1990, s. 13, 32-37. 


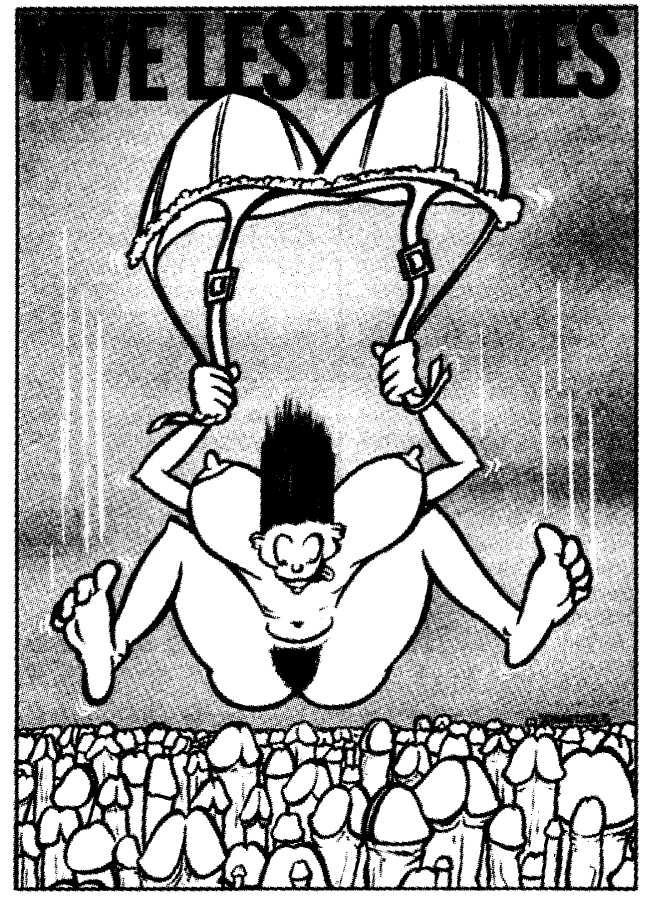

Eläköön miehet. Tupolevin veljesten korttitervehdys Marianne Laxénille vuonna 1990. Kuva: Työväen Arkisto.

Piiritoimintaa 1984

Paitsi puoluekokousagitaatiota naiset ehtivät toimia myös muilla rintamilla. Naiset uurastivat ajankohtaisten asioiden parissa niin piiri- kuin perusjärjestöissäkin vuodet ympäriinsä. Seuraavassa kurkistetaan, mitä piirijärjestöissä tehtiin 1980-luvun alkupuolella. Esimerkiksi Helsingin sosialidemokraattinen naispiiri, johon kuului 50 jäsenjärjestöä, teki vuoden 1984 aikana valmisteluja naisliiton edustajakokoukseen, kevään piirikokouseen, kansainvälisen naistenpäivän viettoon ja syksyn kunnallisvaaleihin. Lisäksi piiri pyrki tekemään yhteistyötä muun muassa ammattiyhdistysnaisten kanssa ja tuki piirin alaista nuorten naisten piiriä.

Vuoden aikana ohjelmatarjonta oli laajaa: Kevätpiirikokoukseen naiset olivat pyytäneet Vappu Taipaleen esitelmöimään puolueen periaateohjelmasta ja Pirkko Heikuran "Työtä ihmiseltä ihmiselle" -aineistosta. Helmikuussa piirillä oli avoin opintotilaisuus, jossa Anna-Liisa Sirjamo alusti lasten päivähoitokysymyksistä. Kansainvälisen naistenpäivän juhlaan (8.3.) naispiiriläiset olivat tehneet hauskoja nukkeja tunnetuista työväenliikkeen naisista (Rosa Luxemburg, Ida Aalle-Teljo, Hilja Pärssinen, Miina Sillanpää ja Tyyne Leivo-Larsson). Yleisö otti nukkeparaatin innoissaan vastaan. 
Päivän päätteeksi naispiiri oli järjestänyt filmiesityksen "Tuote nainen" sekä keskustelun, jossa alustivat Tarja Halonen ja Merja Hurri. Tilaisuudessa oli yli sata henkeä ja keskustelu oli "värikästä ja innostunutta". Huhtikuussa piirillä oli jälleen opintotilaisuus, jossa Kaija-Leena Sinkko esitelmöi naisten eläkkeistä.

Naispiirin syksy alkoi kunnallisvaalitilaisuuksilla. Vaalityöseminaarissa esiintyivät Eeva-Liisa Tuominen, Marja-Liisa Kunnas ja Anna-Liisa Sirjamo. Syyskuussa opintotilaisuuden aiheena oli naisten asuminen. Marraskuun tilaisuudessa esitelmöitsijänä oli ruotsalainen tutkija Rita Liljeström, joka puhui "Eroottisesta sodasta". Joulukuussa piiri järjesti joulumyyjäisiin 26 pöytää 15:n järjestön voimin.

Paitsi omiin tilaisuuksiin, naispiiriläiset osallistuivat aktiivisesti naisliiton järjestämiin seminaareihin. Helmikuussa naiset riensivät "SDP ei tule toimeen ilman naisia" -seminaariin ja Tampereen sosialidemokraattisten tyttöjen järjestämään "Tyttöjen aatteet" seminaariin. Maaliskuussa oli vuorossa naisten EY-kokous ja "Kuntani ei tule toimeen ilman naisia" -seminaari. Piiristä oli edustus myös Tukholman sisarjärjestön kevätkokouksessa ja Strassbourgin naisseminaarissa.

Syksyllä naispiiriläiset matkasivat Seinäjoelle naisliiton kunnallispäiville, Islantiin Pohjoismaiselle opintoviikolle, Voionmaanopistolle "Mitä opimme puoluekokouksesta" -seminaariin ja TUL:n naisseminaariin.

Naispiiri osallistui myös Nicaragua-keräykseen ja Näkövammaisten Keskusliiton Annansilmä-talkoisiin. Naiset olivat mukana Helsingin rauhankulkuetoimikunnassa, Työväen Sivistysliiton opintojärjestössä ja Helsingin sosialidemokraattisessa piiritoimikunnassa sekä sen kansainvälisessä ja ammattiyhdistysjaostoissa. ${ }^{25}$

Naispiirien ja perusjärjestöjen 1980-luvun toimintakertomuksista välittyy aito harrastuneisuus naisten järjestötoimintaan. Sillä, oliko naisliitto erikseen rekisteröity vai ei, ei näyttänyt olevan merkitystä perusjärjestötasolla.

25 Helsingin sosialidemokraattisen naispiirin tiedotuslehti $2 / 1985$. Sos.dem. naisliiton arkisto. TA. 


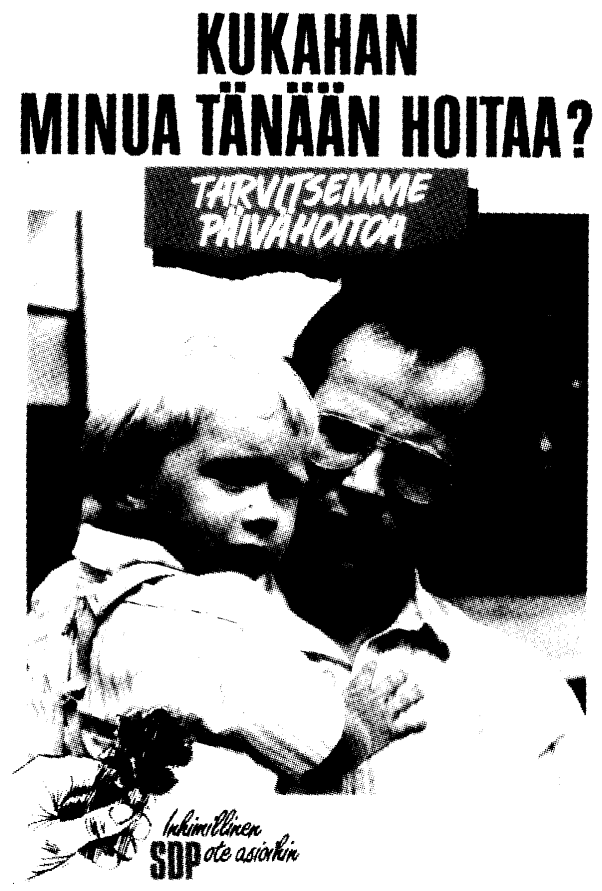

Sosialidemokraattisen puolueen kunnallisvaalijuliste vuodelta 1988. Kuva: Työväen Arkisto.

\section{Naisten Eurooppa}

Suomalaiset sosiaalidemokraattiset naiset ovat olleet aktiivisesti mukana eurooppalaisten aatesisartensa naisverkostossa aina Stuttgartin vuoden 1907 kokouksesta saakka.

1990-luvulle tultaessa Euroopan sosiaalidemokraattiset naiset täsmensivät toimintatavoitteitaan. Kolme keskeistä tavoitetta oli täystyöllisyys, kunnolliset työolosuhteet ja tasokas päivähoito. Oikeus työhön oli naisten näkökulmasta ensisijainen tavoite: vanhemmuus ja palkkatyö tulisi voida sovittaa yhteen myös naisten osalta. Naisille oli myös mahdollistettava osallistuminen kaikilla tasoilla yhteiskunnalliseen työhön.

Jotta naiset voisivat hallita omaa elämäänsä - kouluttautua, osallistua yhteiskunnalliseen toimintaan ja työelämään - heille olisi tarjottava taloudellinen itsenäisyys: niin kauan kuin naiset olivat miesten palkasta riippuvaisia, heillä oli heikommat mahdollisuudet tasa-arvoiseen kohteluun. Eurooppalaisten yhteiskuntien olisi siten panostettava äitiys- ja vanhempainlomaan, päivähoitopalveluihin, vanhusten palveluihin sekä vammaisten ja sairaiden hoivan järjestämiseen. Eli siihen samaan työhön, johon pohjois- 


\section{*Köyhyys hyvinvointivaltiossa}

Usein ajatellaan, että köyhyys kuuluu 1900-luvun alkupuolen ilmiöihin. Yleisessä mielessä näin onkin: vuosina 1966-85 suomalaisten tuloerot kapenivat tulonsiirtojen ja veroratkaisujen seurauksena eli yhä useammilla suomalaisilla meni taloudellisesti vähintäänkin kohtalaisesti. 1980luvulla alkoi kuitenkin viritä keskustelu köyhyyden uusista ilmenemismuodoista suomalaisessa yhteiskunnassa. Yhtäältä kiinnitettiin huomiota sosiaaliturvajärjestelmän kattavuuteen ja tehokkuuteen, toisaalta syrjäytymiseen eli kansalaisten sosiaaliseen ja kulttuuriseen eriarvoistumiseen ja kolmanneksi pienituloisuuteen.

Köyhyys on suhteellinen ilmiö. Tutkijat puhuvat suhteellisesta köyhyydestä, hiljaisesta köyhyydestä, väliinputoajista ja kasautuneesta huono-osaisuudesta sen mukaan, kuinka näkyvästä ilmiöstä on kysymys. Hyvinvointivaltion köyhyys tarkoittaa paitsi suoranaista aineellista puutetta, myös henkistä avuttomuutta, vaikeutta selvitä yhä monimutkaistuvassa yhteiskunnassa. Nykyajan köyhyydessä on kyse elämän hallinnan puutteesta: rahan, tavaran, ystävien, sosiaalisten kontaktien, tukiverkoston ja tieto-taidon vajauksesta.

Pääkaupungin valtalehti uutisoi joulukuussa 1999 ruokajonoista, köyhyydestä, asunnottomuudesta ja työttömyydestä, jotka olivat arkipäivää monille kaupunkilaisille. "Ilmainen leipäkassi on elintärkeä apu, kun rahat vaan eivät tahdo riittää. Asumisen, veden, sähkön ja puhelimen laskut eivät jätä käteen yhtään ylimääräistä... Menot on laskettava tarkkaan. Päivän voi pärjätä viidelläkympillä, yli satasta ei saisi missään nimessä mennä", kertoi 42-vuotias viisi vuotta työttömänä ollut ja viisi vuotta leipäjonoissa käynyt nainen. Vuonna 1999 Helsingissä jakoi 15 seurakuntaa ruokakasseja viikoittain. Vuoden alusta lokakuun loppuun ruokakasseja haettiin 4600 kappaletta. Joulun alla kasseihin pakattiin hieman juhlavampaa pöytään laitettavaksi, muutoin kassi sisälsi pääasiassa leipää. Helsinkiläisistä sai vuonna 1998 toimeentulotukea 76600 henkeä keskimäärin puolen vuoden ajan. Suurin syy tuen hakemiseen oli työttömyyden aiheuttama tilanne. Asunnottomia vuonna 1998 Helsingissä oli noin 4200 henkeä.- Kaikilla ei mene hyvin edes hyvinvointivaltiossa.

Lähde: Heikkilä Matti, Köyhyys ja huono-osaisuus hyvinvointivaltiossa. Tutkimus köyhyydestä ja hyvinvoinnin puutteiden kasaantumisesta Suomessa. Sosiaalihallituksen julk. 8/1990. Helsinki 1990; Kaikilla ei mene yhtä hyvin, kirj. Marko Jokela. Helsingin Sanomat 20.12.1999. 
maiden naisjärjestöt olivat keskittäneet toimintansa jo 1930-luvulta lähtien. Hoiva- ja turvaverkostoajattelun alueeseen kuuluvat sosiaalidemokraattisten naisten mielestä myös työpaikoilla ilmenneen seksuaalisen häirinnän poistaminen ja eri teollisuudenalojen sekä eri alueiden kehittämistä tukevien rakennerahastojen avulla tehtävä tasa-arvotyö. Euroopan jäsenvaltioissa naisten asema on vielä kovin vaihteleva. ${ }^{26}$

\section{Kaksoistaakan alla}

Eurooppalaisen työelämävertailun perusteella voidaan sanoa, että suomalaiset naiset erottuvat muista euronaisista sekä hyvässä että pahassa. Suomalaiset naiset pitävät työtään kehittävämpänä, he saavat osallistua enemmän työnantajien järjestämään koulutukseen ja työnsä suunnitteluun kuin muiden maiden naiset. Sen sijaan kaikki kiiremittarit näyttävät punaista Suomen osalta, suomalaiset naiset paiskivat muiden pohjoismaalaisten tavoin töitä paineiden ja stressin alaisina, ${ }^{27}$ mikä vaikuttaa työssä viihtymiseen, naisten terveyteen sekä palkkatyön jälkeiseen kotityöhön ja perhe-elämään.

Kun tarkastellaan suomalaisten ja muiden eurooppalaisten naisten asemaa politiikassa, parlamenteissa ja hallituksissa, ovat pohjoismaiden naiset kärjessä. Yleisesti voidaan sanoa, että sodan jälkeen (1945) naisten osuus parlamenttien jäsenistöstä on yleisesti ottaen ollut kasvussa. Kuitenkin vielä 1960-luvulla se oli alle 10 prosenttia. Vain Ruotsissa ja Suomessa päästiin jonkin verran tämän yli. Selvä naisosuuden nousu on tapahtunut 1970-80-luvulla. Tasa-arvoisin tilanne on pohjoismaissa. Vuonna 1999 eniten naisparlamentaarikkoja oli Ruotsissa (43\%), sitten Tanskassa (37 \%) ja Suomessa (37\%). Suomen toistaiseksi suurin naisparlamentaarikkojen osuus (39\%) on saavutettu vuoden 1991 vaaleissa. Laman jälkeisissä vaaleissa (1995) naisosuus putosi selvästi (34 \%:iin). Maaliskuun 1999 vaaleissa naisten osuus kohosi jälleen $37 \%$ :iin.

Pohjoismaiden tasoa lähentelee myös Alankomaat (36\%). Eri Euroopan maissa tilanne on kuitenkin kovin erilainen: Kreikassa

26 Sosialidemokraattisten naisten tavoitteet Euroopassa. Sosialidemokraattiset Naiset 1994, s. $1-6$.

27 Lehto 1999, s. 114-119. 


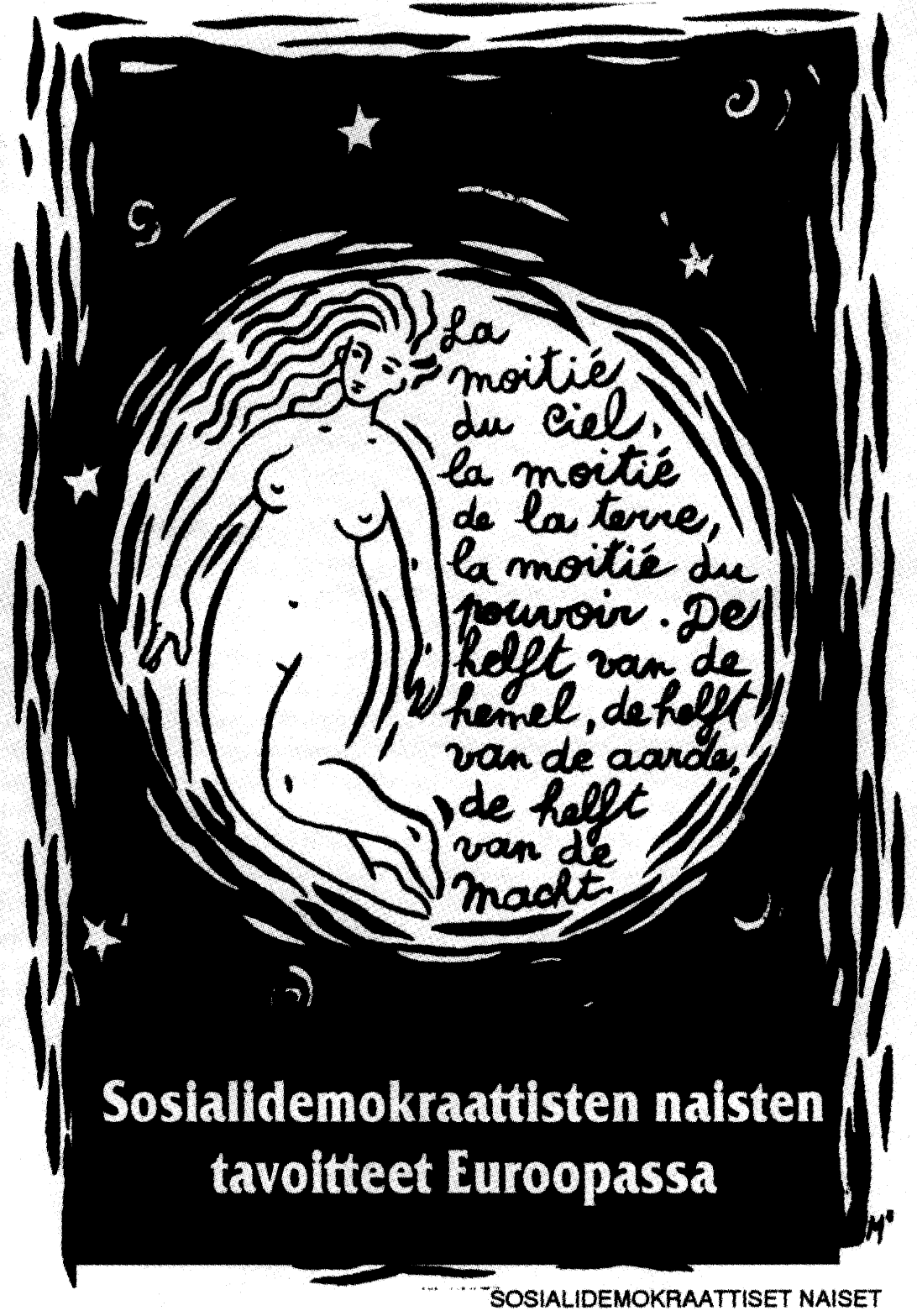

Euroopan sosiaalidemokraattiset naiset julkaisivat yhteiset tavoitteet 1990-luvun alussa. Kuva: Työväen Arkisto.

naisparlamentaarikkoja on vain $6 \%$ edustajista. Myös Ranskassa, Portugalissa, Belgiassa ja Irlannissa naiskansanedustajien osuus on edelleen alhainen, $10-13 \%$. 
Naisministeriys on yleistynyt Euroopassa vasta 1980 -luvulla. ${ }^{28}$ Kuten aiemmin on todettu, Suomessa ensimmäiset naisministerit olivat punaisten hallituksessa vuonna 1918 ja vuoden 1926-27 hallituksessa. Eurooppalaisittain katsottuna myös naisministereitä on pohjoismaissa eniten. Ruotsi on tässä edelläkävijämaa: 1990-luvulla puolet ministerinsalkuista on ollut naisilla. Toisena on Norja (1999: 48 \%) ja Suomi (1999: 44 \%). Ranskassa, Saksassa, Alankomaissa, Espanjassa ja Luxemburgissa 1/3 ministeripaikoista on 1990-luvun lopussa naisilla. Vähiten naisministereitä on ollut Kreikassa (5\%), Portugalissa (12\%) ja Irlannissa (13\%). Pääsääntöisesti naisministerit hoitavat opetus-, terveys-, sosiaali-, perhe- ja työvoima-asioita. ${ }^{29}$

\section{Naisten etenemisen esteet}

Eurooppalaisen politiikan tasa-arvoistumista estävät monet poliittiset, sosio-ekonomiset sekä ideologiset ja psykologiset tekijät. Naisten integroitumista poliittiseen järjestelmään hidastaa muun muassa se, että politiikan toimintatavat rakentuvat miehisille arvoille ja normeille. Tätä väitettä voi tosin arvostella sen takia, että ainakin sosiaalidemokraattisen naisliikkeen historian kautta avautuva kuva osoittaa, että naiset ovat aktiivisesti olleet vaikuttamassa kulloisenkin ajan arvoihin ja normeihin. Toisaalta on korostettu, että naisilla ei ole sellaista hyvä veli -verkostoa kuin miehillä, puolueet kampanjoivat enemmän miesehdokkaiden kuin naisten puolesta, joukkotiedotusvälineet suhtautuvat eri tavalla mies- ja naisehdokkaisiin eivätkä naiset saa samalla tavalla varoja vaalikampanjoihinsa kuin miehet.

Myös kulloinenkin vaalitapa ja naisehdokkaiden lukumäärä vaikuttavat siihen, missä määrin naisia tulee valituksi edustustehtäviin. Sosio-ekonomisista tekijöistä lamakausilla ja muilla kriisiajoilla on nähty olevan naisten osuutta vähentävä vaikutus. Tämä näkyy muun muassa Suomessa 1930-luvun alun laman aikana: eduskuntaan valittiin ennätysvähän naisia, vain kuusi prosenttia. Naiset ovat lisäksi enemmän sidottuja perhe-elämään, kodinhoitotöihin ja lastenhoitoon kuin miehet. Naisten kaksoistaakka eli kotityön ja

28 Suomalaisista eri puolueiden naisministereistä ks. Kuusipalo 1989, liite 4.

29 Sukupuolet EU:n työmarkkinoilla 1999, s. 53-56. 
palkkatyön yhdistäminen näkyy naisten osallistumisessa julkiseen elämään. Ideologisista ja psykologisista esteistä mainittakoon naisten itseluottamuksen puute, kulttuuriset mallit naisten paikasta ja politiikan käsittäminen "likaiseksi peliksi". ${ }^{30}$

Arviot eurooppalaisten naisten keskimääräisestä asemasta perustuvat tilastollisiin tietoihin. Naisten työhönosallistumista arvioineiden nykytutkijoiden mukaan naiseus yhtenä diskurssina ei kuitenkaan kerro koko totuutta. Naiset ovat keskenään erilaisia ja erilaisissa asemissa. Hekin osaavat käyttää valtaa, myös suhteessa toisiin naisiin. Naiserityisyyden määrittelemisen sijasta on alettu purkaa naissubjektin ja sukupuolen käsitteitä. Kiinnostus on kohdistunut ei niinkään enää pelkkään sukupuoleen, vaan siihen miten sukupuoli esitetään tai miten sitä tuotetaan erilaisissa paikoissa, ajoissa ja diskursseissa. ${ }^{31}$

Myös tasa-arvon käsite on sinällään nähty monimerkitykselliseksi. Klassisen näkemyksen mukaan se tarkoittaa "yhdenvertaisia mahdollisuuksia". Naistutkijat ovat kuitenkin viime vuosina tuoneet painokkaasti esiin vaatimuksen "tulosten tasa-arvoisuudesta". Heidän mukaansa esimerkiksi muodollisen äänioikeuden antaminen naisille on ollut riittämätön ehto sukupuolten välisessä tasaarvotyössä. Lainmuutos sinänsä ei poista sosio-ekonomisia tai ideologisia näkymättömiä esteitä naisten yhdenvertaistumisen tieltä. Siksi katseet tulisi suunnata enemmän lainmuutosten todellisiin vaikutuksiin ja sitä kautta tulisi purkaa syvällä yhteiskunnallisissa rakenteissa piilevää eriarvoisuutta. ${ }^{32}$

\section{Käännöskohdat 1900-luvun naisten historiassa}

Viime aikoina tutkittaessa naisten tasa-arvoistumista on korostettu, että numerot eivät kerro kuin vain osatotuuden. Arvioimalla parlamenttien, hallitusten ja muiden edustusjärjestelmien naisosuuksien muutoksia havaitaan, että niiden taustalla on näkymättömiä suuria muutosprosesseja. 1900-luvun osalta voidaan nimetä suomalaisten naisten historiassa kolme keskeisintä käännöskohtaa, jotka ovat merkittävästi vaikuttaneet naisten yhteiskunnalliseen

30 Shvedova 1998, s. 19-40; Sukupuolet EU:n työmarkkinoilla 1999, s. 56-57.

31 Ks. Lehto 1999, 102-103.

32 Dahlerup 1998, s. 95. 


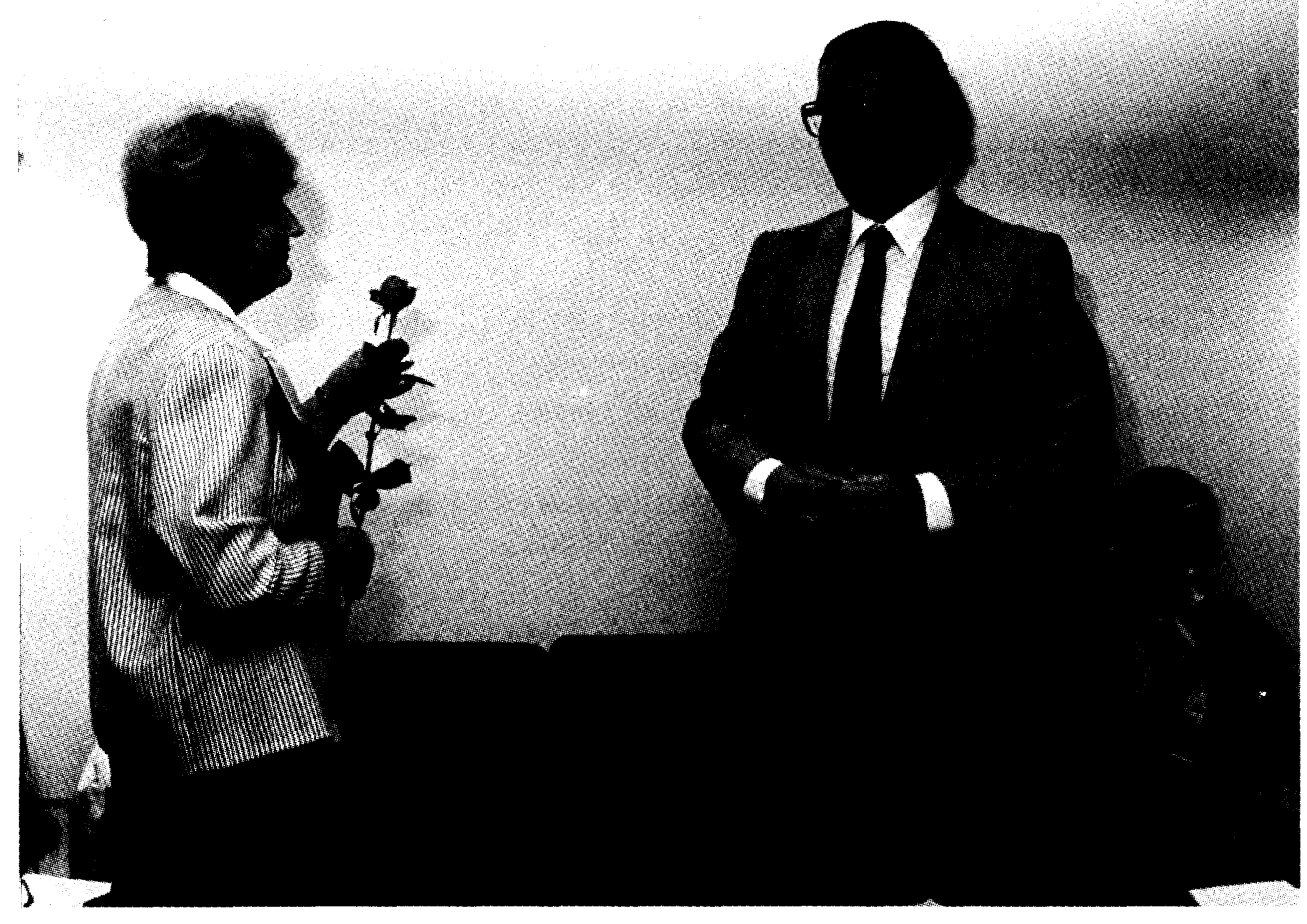

"Toivon, että piikit pistävät kauan, mutta että ruusu hehkuu vielä kauemmin..." Näillä sanoilla Sosialidemokraattisten Naisten 30-henkinen huivivaltuuskunta tervehti puolueen puheenjohtajaa ja pääministeri Kalevi Sorsaa elokuussa 1985. Naiset vaativat kriittiseen sävyyn naisliiton aseman täsmentämistä puolueessa. Ruusun ojentaa Sorsalle Airi Viitanen Kymen piiristä. Kuva: Sos.dem. Naisten toimisto.

tasa-arvoistumiseen: 1) Naimisissa olevien naisten siirtyminen kodin ulkopuoliseen palkkatyöhön 1910-luvulta lähtien. Suomi on tässä muutoksessa ollut muiden pohjoismaiden tapaan edelläkävijä. Naimattomat naisethan vapautettiin palkkatyöhön jo vuonna 1864. 2) Poliittisten oikeuksien saavuttaminen, missä Suomi oli niin ikään mallimaa Euroopassa vuoden 1906 ääni- ja vaaliuudistuksineen. 3) Naisten koulutustason korkeus ja laaja-alaisuus lähtien ensimmäisen yhteiskoulun perustamisesta 1880-luvulta.

Nämä muutokset ovat pohjoismaisten naisten suhteellisen hyvän yhteiskunnallisen aseman kolme peruspilaria. Niiden eteen ja niiden päälle sosiaalidemokraattiset naiset yhteistyökumppaneineen ovat rakentaneet hyvinvointivaltion mallia. 


\section{*Eurooppalaista tasa-arvoa}

* Naisten osuus Euroopan Unionin (EU) jäsenmaiden kansanedustuslaitoksien jäsenistä vaihtelee 5-40 prosentin välillä. Pohjoismaat ovat naisten näkökulmasta hyvässä asemassa eli kärkisijoilla.

* Naisten osuus parlamentin vasemmistoryhmissä on suurempi kuin konservatiivi- tai oikeistoryhmissä. Europarlamentin jäsenistä on $25 \%$ (1998) naisia. Osuus on kasvanut koko ajan, mutta hitaasti.

* Euroopan sosialidemokraattisten puolueiden ryhmään EU:ssa kuuluu 179 jäsentä, joista naisia on 66 eli $37 \%$ (1999).

* Naisten ansiotaso on kaikissa Euroopan Unionin jäsenmaissa alhaisempi kuin miesten. Naisten palkat ovat alasta riippuen 15-33 prosenttia pienemmät kuin miesten.

* Keskimäärin 60 prosenttia jäsenmaiden matalapalkkaisista on naisia.

* Naisten keskimääräinen työttömyysprosentti Euroopan Unionin maissa on 13 prosenttia, miesten vastaava luku on yhdeksän.

Lähde: Pikkusisko 4/1998, s. 7. 


\section{Minne menet sosiaali- demokraattinen naisliike?}

Suomen Kuvalehti kirjoitti Sosialidemokraattisen puolueen 100vuotisjuhlien aikaan toukokuussa 1999, että Sdp toteutti sadassa vuodessa kaikki perustajiensa suuret tavoitteet ja teki kaikista suomalaisista melkein sosiaalidemokraatteja. Sosiaalidemokraateille voitokkaat tammikuun 2000 presidentinvaalit tuntuivat kruunaavan vastustajien mielestä jo omahyväisen pulskan puolueen voittokulun.

Sosialidemokraateilla onkin Suomen eduskunnassa suurin ryhmä, valittu presidentti Tarja Halonen oli jo kolmas puolueen ehdokas Mauno Koiviston ja Martti Ahtisaaren jälkeen. Vuoden 2000 alussa puolueen entinen sihteeri Erkki Liikanen on eurokomissaari ja puheenjohtaja Paavo Lipponen pääministeri. Istuvassa hallituksessa on viisi demaria: ulkoministerinä istuu Erkki Tuomioja, kauppa- ja teollisuusministerinä Sinikka Mönkäre, oikeusministerinä Johannes Koskinen, opetusministerinä Maija Rask ja työministerinä Sosialidemokraattisten Naisten puheenjohtaja Tarja Filatov. Naisten osuus on näyttävästi kasvanut hallituksessa, eduskunnassakin naisia on kaikkiaan 74 (37\%), näistä 22 sosiaalidemokraattia.

Kuvalehden mukaan Sdp on tehnyt Suomesta erehdyttävästi itsensä näköisen: vähän harmaan ja jähmeän, mutta samalla vakaan ja turvallisen tuntuisen maan, jossa kansalaiset törmäävät sosiaalidemokraattisiin saavutuksiin jo lastenneuvoloissa ja päiväkodeissa, käyvät sosiaalidemokraattien luomaa peruskoulua, paiskivat töitä sosiaalidemokraattien kehittelemillä työehdoilla ja siirtyvät lopulta eläkkeelle sosiaalidemokraattien myötävaikutuksella rakennetuilla eläke-ehdoilla. ${ }^{1}$

Mihin siis puoluetta ja sen naisjärjestöä vielä tarvitaan? Tässä luvussa saavat puheenvuoron eräät sosiaalidemokraattisessa naisliikkeessä aktiivisesti mukana olleet naiset. Minne sosiaalidemokraattinen naisliike on menossa, mitkä ovat sen tulevan toiminnan suunnat, uhat ja toiveet?

1 Valmista tuli, kirj. Tuomo Lappalainen. Suomen Kuvalehti 28.5.1999. 


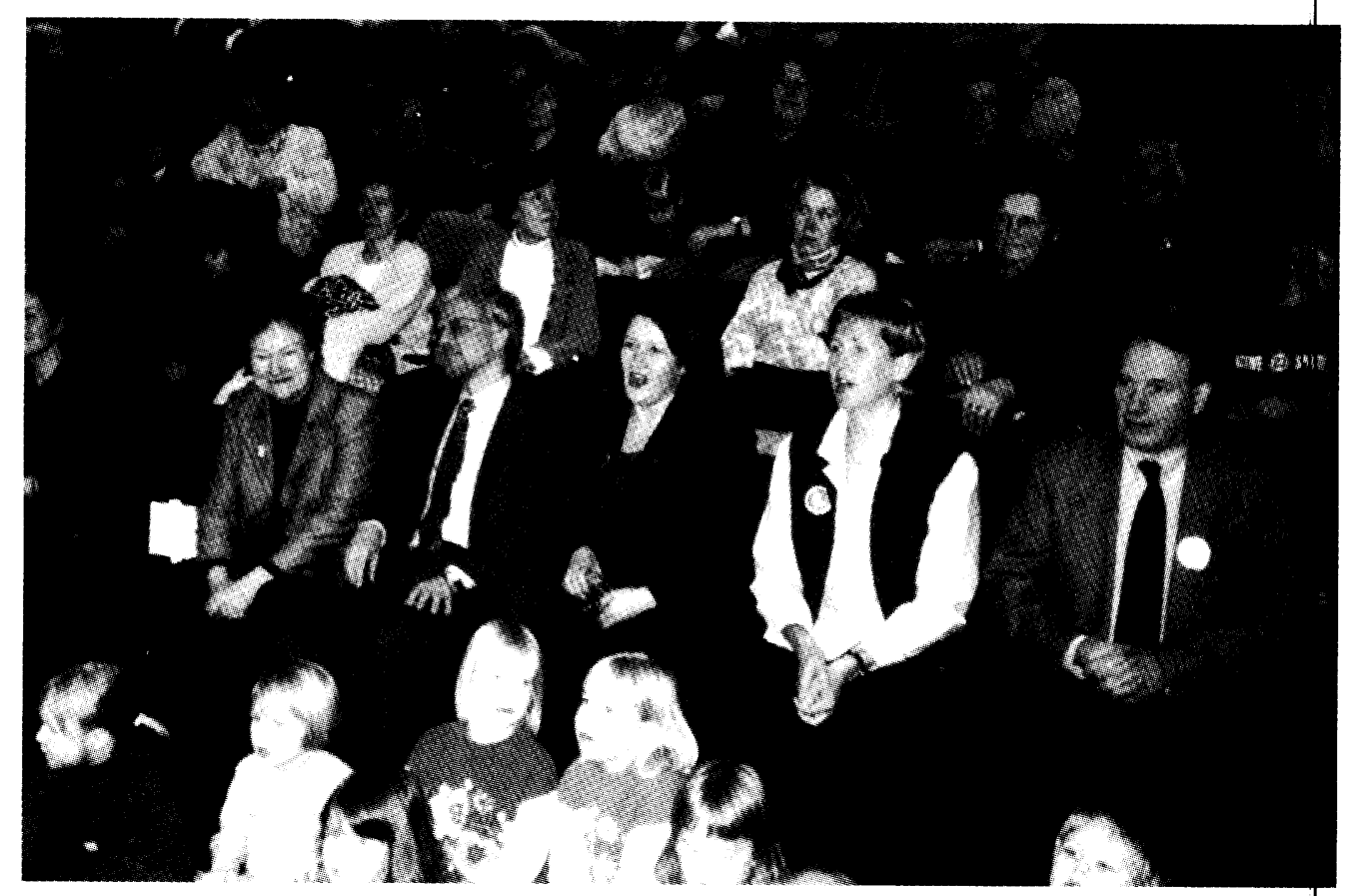

Presidenttiehdokas Tarja Halonen, valiokuntaneuvos Pentti Arajärvi, Sosialidłmokraattisten Naisten pääsihteeri Marja-Liisa Kiljunen, kansanedustaja Tuula Haatainen ja europarlamentaarikko Reino Paasilinna "Koko perheen kekkereissä" Helsingin Stoassa 15.1.2000. Kuva: Sos.dem. Naisten toimisto.

\section{Elitistyvän naisliiton uhka}

Sosialidemokraattisessa työväenliikkeessä ja naisliikkeessä ikänsä toiminut Irja Salmela arvioi uuden vuosituhannen kynnyksellä veteraanin näkökulmasta tulevan naisliikkeen tehtäviä näin: "Ongelmana on edelleen se, miten naisten toiminta saadaan näkyville, miten sitä pystytään tekemään tunnetuksi ja miten pystytään herättämään naisten keskuudessa aktiivisuutta ja toiminnanhalua. Sos.dem. Naisliikkeestä ei saa tulla hyvinkoulutettujen naisten keskustelukerho, vaan sen täytyy löytää keinot niiden suurten naisjoukkojen mukaansaamiseen, jotka työelämässä ja kodeissa suorittavat jokapäiväistä aherrustaan..."

2 Irja Salmelan kirje Maria Lähteenmäelle 22.11.1999; Irja Salmela on Martta Salmela-Järvisen tytär ja oli keskeisellä paikalla 1950-60-luvun sos.dem. naisliikkeessä. 
Salmelan pelko naisliiton elitistymisestä pohjaa siihen työväenliikkeessä sodan jälkeen nousseeseen ristiriitaan, missä koulutettu ja hyvin toimeentuleva keskiluokka pyrki valtaan sekä poliittisessa että ammatillisessa liikkeessä. Sosialidemokraattisen puolueen keskiluokkajaosto julkaisi vuonna 1955 Janne Hakulisen kirjasen "Keskiluokkaan lukeutuvien ryhmien asema ja tehtävät yhteiskunnassa". Puolueen intresseissä oli saada tämä laajeneva kansanosa omiksi tukijoikseen. Keskiluokka tarkoitti lähinnä virkamiehiä, ns. henkisen työn tekijöitä, toimihenkilöitä ja liiketyöntekijöitä. Heidät puolue tahtoi saattaa yhteiseen rintamaan muiden palkansaajien kanssa. Ellei tässä onnistuttaisi, "aiheutuu siitä vaara suomalaisen yhteiskunnan rauhalliselle rakennustyölle". ${ }^{3}$ Vuoden 2000 perspektiivistä sosialidemokraattinen puolue näyttää onnistuneen saamaan keskiluokan puolelleen.

\section{Yhteiskunnallisen eriarvoisuuden uhka}

"Nuorena, pää täynnä ihanteita, me ikäiseni innokkaat toimijat ajattelimme, että sosialidemokraattisen työväenliikkeen valistustyö sai aikaan sen, että pyrkimys tasa-arvoisuuteen ja oikeudenmukaisuuteen tulee vähitellen melkeinpä "ihmisluonnoksi". Niin ei ole käynyt. "Näin luonnehti lyhyesti sosiaalidemokraattisen naisliikkeen 1960-70-luvun eräs keskeisimmistä johtonaisista, kansanedustaja ja ministeri Sinikka Luja-Penttilä. Tulevaisuuden suuntaa hän arvioi näin: "Tulevan toiminnan painopisteet löytyvät muuttuneesta ja muuttuvasta työelämästä. Kansainvälistyminen, työn tekemisen muuttuneet muodot (pätkätyöt ja epämääräiset työajat) sekä kiristyneet työelämän vaatimukset vaikuttavat monella tavoin ihmisten keskeisiin suhteisiinkin. Näin erityisesti perhe-elämässä ja sen yhdistämisessä työelämään. Perhemuodotkin ovat kokeneet muutoksia entisiin perinteisiin perhemalleihin nähden. Miten se kaikki vaikuttaa naisen asemaan? Nainen on perinteisesti ollut perhettä koossa pitävä voima...".

Yhteiskunnan mekanisoituminen ja tietotekniikan kehitys on Luja-Penttilän mukaan johtanut uudenlaiseen eriarvoisuuden syn-

3 Sos.dem. puolueen keskiluokkavaltuuskunta perustettiin 14.11.1954. Hakulinen oli sen yhteyteen perustetun jaoston puheenjohtaja. Vuonna 1955 julkaistu periaatejulkaisu kăsiteltiin sos.dem. puolueen puoluekokouksessa kesăkuussa 1955. Hakulinen 1955, s. 5-11, 4751 . 
tyyn: "Ollessamme nyt aivan uuden ajan kynnyksellä, uusien tietolähteiden äärellä sosialidemokraattisella liikkeellä on vaativa tehtävä olla estämässä pelättävissä olevaa ihmisten jakautumista niihin, joilla on käytettävissä kaikki tietokonemaailman luomat mahdollisuudet ja niihin, jotka syystä tai toisesta jäävät kaikesta paitsi. Aina on niitäkin lähimmäisiä, jotka eivät ylitä matalimmallekaan asetettua vaatimusten rimaa. Jokaisen ihmisen elämän pitäisi kuitenkin olla elämisen arvoista. "4 Huoli heikoimmista ja vähäosaisista tulisi olla Luja-Penttilän mukaan sosiaalidemokraattisen liikkeen yksi kantava teema yhä edelleen.

Sosialidemokraattisten Naisten pääsihteerinäkin toiminut kansanedustaja Tuula Haatainen nostaa yhdeksi tärkeäksi tulevan toiminnan tehtäväkentäksi työelämään liittyvät tasa-arvokysymykset: "Yhteys ammattiyhdistysliikkeen sosialidemokraattisiin aktivisteihin on ollut keskeinen taustatuki ongelmien kartoittamisessa ja uusien asioiden esille ottamisessa. Tasa-arvon näkökulmasta keskeiset tulevaisuuden kysymykset liittyvät mielestäni työelämän rakennemuutokseen, työ- ja perhe-elämän yhteensovittamiseen, työaikakysymyksiin sekä koulutukseen. Tätä kokonaisuutta pitää tarkastella pidemmällä tähtäimellä. Toimenpiteitä tarvitaan esikouluikäisistä ikääntyneisiin työntekijöihin saakka. Koulutuksen puute on yhä voimakkaammin yhteydessä työttömyyteen ja syrjäytymiskehitykseen sekä epävarmoihin työsuhteisiin. Siksi koulutuksen merkitys eriarvoisuuden ehkäisijänä korostuu". ${ }^{5}$

\section{Puolueen omatunto}

"Niin asiat kuin ihmisetkin ovat riidelleet...Ajoittain esiintyneet ehkä joskus vaikeatkin erimielisyydet puoluejohdon ja naisliton johdon välillä lievenevät varmasti sen kehityksen myötä, että puoluejohtoon valitaan jo nykyisin enenevässä määrin naisia. Sitä kautta tulee ns. naisnäkökulma asioita ratkaistaessa otetuksi entistä paremmin huomioon puoluejohdossa". Näin kuvaa lyhyesti naisliiton suhdetta puolueeseen Sinikka Luja-Penttilä. ${ }^{6}$

4 Sinikka Luja-Penttilän kirje Maria Lähteenmäelle 17.11.1999.

5 Tuula Haataisen kirje Maria Lähteenmäelle 9.12.1999.

6 Sinikka Luja-Penttilän kirje 17.11.1999 Maria Lähteenmäelle. 


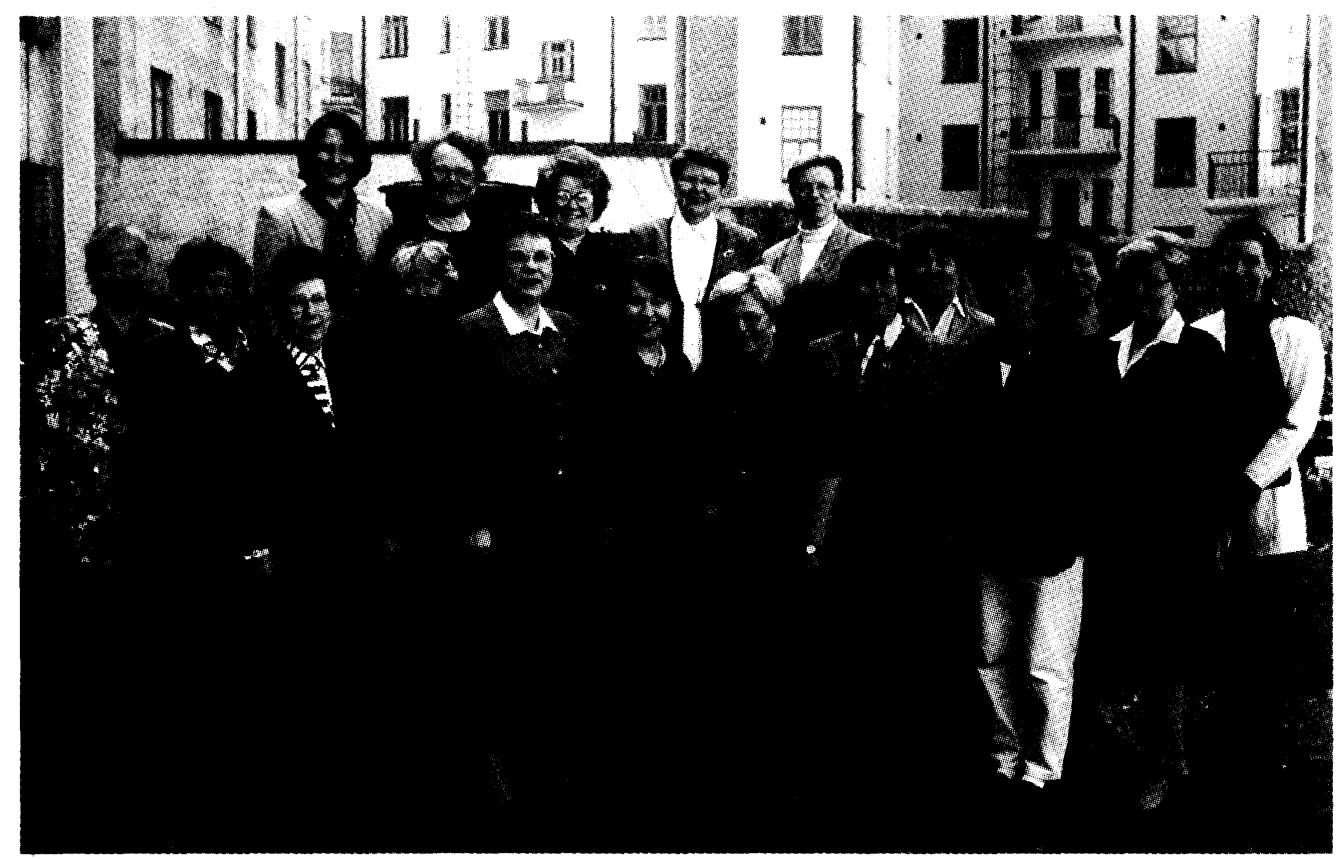

Sosiaalidemokraattisten Naisten liittovaltuusto vuonna 2000. Alarivissä vasemmalta Tuulikki Petäkoski-Hult, Kyllikki Lahtinen, Ruth Hasan, Pirjo Andrejeff, Anja Savolainen, naisliiton puheenjohtaja Tarja Filatov, Anja Oksa, Riitta Nokkala, välissä Tytti Pyöttiälä, Mervi Luhtanen, välissä Virpi Aho, Irja Wiss ja Terttu Mäkinen. Ylärivissä vasemmalta Marja-Liisa Kiljunen, Eeva Puusjärvi, Ritva Holopainen, Kaija Karvinen ja Arja Puoskari. Kuva: Sos.dem. Naisten toimisto.

Sosialidemokraattisten Naisten tiedotussihteeri Merja-Hannele Vuohelainen näkee naisliiton toiminnan perusehdoiksi toisaalta selkeän sitoutumisen sosiaalidemokraattiseen ideologiaan ja toisaalta innostuneen ja osallistuvan jäsenistön olemassaolon. Naisten harjoittama käytännön politiikka tulisi olla oivaltavaa sosialidemokraattista tasa-arvotyötä, jossa taloudellinen järki ja sosiaalinen omatunto ovat läsnä poliittisessa päätöksenteossa. Keskeisiä toiminta-alueita Vuohelaisen mukaan ovat hyvinvointiyhteiskunnan kehittäminen tasa-arvon ja kestävän kehityksen ehdoilla ja tätä tukeva työllisyyspolitiikka, rauhankasvatus ja maailmankansalaisuuden edistäminen.

Naisliiton tulisi hänen mukaansa ottaa tulevaisuudessa huomioon julkisuuden merkityksen muuttaminen: mielikuvat ja tuotekuvat hallitsevat yhä enemmän ihmisten ajattelua. Tämä ei saa Vuohelaisen mielestä merkitä populismia, vaan kykyä koota yhteen yhä 
pirstoutuneemmasta informaatioyhteiskunnasta syrjäytyneiden asemaa parantava toimintastrategia.

2000-luvulle siirtynyt sosiaalidemokraattinen liike on naisistunut ja pikkuhiljaa myös nuortunut. Sdp:n naisista yli 80 prosenttia on myös naisliiton toiminnassa mukana, mutta automaattinen naisliiton jäsenyys puoluejäsenyyden myötä ei ole tavoitteena, koska liitto Vuohelaisen mukaan "haluaa edelleen olla valveutunut ja tiedostava puolueen omatunto”. Yhteistyö naisliiton työntekijöiden ja puoluetoimiston henkilökunnan kesken on tiivistä, mistä molemmat osapuolet hyötyvät.

Vuohelaisen mukaan "erillistä naistoimintaa tarvitaan vahvistamaan naisten valmiuksia poliittiseen osallistumiseen ja feministisen tietoisuuden syventämiseen. Toimintamuotoina panostetaan projekteihin ja kampanjoihin, jotka ovat joko valtakunnallisia tai paikallisia". Myös taloudelliset resurssit pyritään suuntaamaan Vuohelaisen mukaan siten, että palkallisia organisaattoreita on projektialueilla. Uuden tietotekniikan myötä sähköiset verkostot mahdollistavat reaaliajassa käytävän poliittisen keskustelun.

Naisten kansainvälinen yhteistyö on tiedostussihteerin mukaan vahvistunut. Kansainvälisten ja eurooppalaisten sisarjärjestöjen lisäksi Baltian alueella toimii sosiaalidemokraattisten naisten verkosto. Sosialidemokraattisten Naisten toimitsijoiden ammattitaitoa edistetään muun muassa ammattiyhdistysliikkeen, sosiaalidemokraattisen lehdistön ja kansainvälisten yhteistyöjärjestöjen kesken. ${ }^{?}$

\section{Pehmeiden arvojen puolesta}

Helsingin sosialidemokraattisen naisyhdistyksen puheenjohtaja Pirkko Miikkulainen puolestaan arvioi tulevaisuutta näin: "Ihminen on aina unelmoinut hyvästä elämästä. 1980-luvulla mittarit olivat taloudellisia, mutta talouden romahdettua vuosikymmenen lopussa on etsitty uusia arvoja. Eräitä keinoja selviytyä on elämän syvimpien totuuksien oivaltaminen. Kuten, että ihminen voi pyrkiä myös hyvinvoinnin jakamiseen ilman, että hänen täytyy odottaa muiden tekevän samoin. Kunkin on vain ensin tehtävä tarpeel-

7 Merja-Hannele Vuohelaisen (ent. Oksanen) kirje Maria Lähteenmäelle 30.11.1999. 


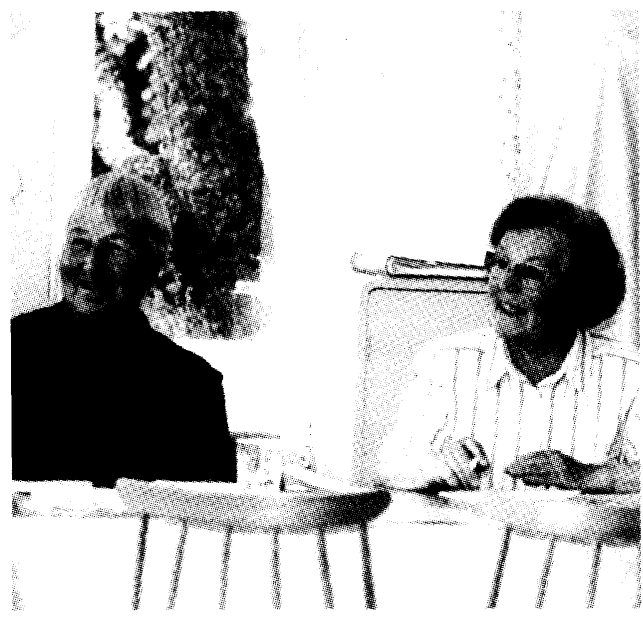

Tietoisuus työläisnaisten perinteestä vahvistaa identiteettiä. Sosialidemokraattiset Naiset alkoivat koota 1990luvulla veteraanien muistitietoa talteen. Kuvassa iloiset ja innokkaat kerääjät Helvi Saarinen (vas.) ja Pirkko Aro haastattelumatkalla Porissa vuonna 1993. Kuva: Yksityiskokoelma.

liset muutokset omassa elämässään. Sosiaalidemokraattisten naisten tavoitteena on taistella tasa-arvoisen ja sosiaalisesti oikeudenmukaisen yhteiskunnan puolesta".

Kun Helsingin sosialidemokraattisen naisyhdistyksen johtokunta pohti naisten toiminnan suuntaviivoja, nousivat esille ensimmäisinä tasa-arvotyö ja rauhantyö. Myös toiminta syrjäytymisen estämiseksi, sosiaalisen vapaaehtoistyön tukeminen ja kansainvälisyyskoulutus koettiin tärkeiksi toiminta-alueiksi. Yhdistys näki edelleenkin erillisen naistoiminnan olevan tärkeä ja tarpeellinen työmuoto. ${ }^{8}$

Tuula Haatainen korostaa tulevassa työssä hoivan järjestämistä. "Hyvinvointiyhteiskunnan keskeinen ratkaistava kysymys liittyy hoivan järjestämiseen väestön ikääntymisen myötä. Työssä käyvät ikäluokat pienenevät ja vanhenevan väestön hoivan tarve kasvaa. Väestön vanhetessa myös terveydenhuollon palvelujen tarve kasvaa. Nyt korostetaan voimakkaasti avohoitoa ja laitoshoitoa on nopeaan tahtiin purettu. Jäävätkö vanhukset naisten vastuulle? Muuttuuko työn ja perheen yhteensovittamisen ongelmat pikkulapsivaiheesta ikääntyvien vanhusten hoiva-ongelmaksi?"

Sosialidemokraattisten Naisten puheenjohtajana vuosina 198390 toiminut Vappu Taipale puolestaan nimeää vanhushuollon yhdeksi tärkeäksi toiminta-alueeksi."On ratkaistava, miten yhteiskunnallinen ja yksityinen vastuu jaetaan. Vastaus ei voi olla vain lisää vanhusten hoitolaitoksia, vaan asia on poliittisesti ja yksityi-

8 Pirkko Miikkulainen ja Pirkko Aro Maria Lăhteenmăelle 2.12.1999.

9 Tuula Haataisen kirje 9.12.1999 Maria Lähteenmăelle. 
sesti monisyisempi. Kuinka paljon minulle kuuluu vastuuta oman perheeni vanhuksista? Miten miehen vastuu omista vanhemmistaan tehdään hänelle luontevaksi? Miten kustannukset jaetaan?"

Taipaleen mukaan toinen tärkeä teema olisi otettava vakavaan keskusteluun, nimittäin köyhyys. "Sillä on 2000-luvulla aineellinen ulottuvuutensa, mutta ennen kaikkea henkinen, "tietämättömyyden loka". Muodollinen koulutus ei hänen mukaansa yksin riitä tuomaan ymmärtämystä ja valmiutta arvovalintojen tekoon. "Ns. tiedon tulva peittää oikeat asiat alleen, turruttaa ja viihdyttää. Ehkä tulee entistä korostuneemmin aika paikalliseen toimintaan, ihmiseltä ihmiselle-viestintään, pintajulkisuuden alla tapahtuvaan toimintaan." 10

Sosialidemokraattisten Naisten pääsihteerin Marja-Liisa Kiljusen mukaan "Naisliikkeen tavoitteena on inhimillisempi yhteiskunta, yhteiskunta jossa jokainen mies ja nainen voi kehittää ja kouluttaa itseään, hankkia toimeentulonsa työllä ja oman elämäntilanteensa mukaan yhdistää työn ja perhe-elämän. Miehille on myös annettava mahdollisuus kantaa vastuuta lapsistaan ja perheistään. Vanhemmuudesta aiheutuvia kustannuksia on jaettava tasapuolisesti mies- ja naisvaltaisten alojen kesken ja asenteita on muokattava myönteiseksi isyydelle. Työelämästä on kehitettävä perheystävällisempi. ${ }^{11}$

\section{Nuoret mukaan}

Parikymppisenä eduskuntaan ja saman tien puoluehallitukseen valittu Säde Tahvanainen kuuluttaa nuorten vetämistä mukaan puoluetoimintaan: "Puolue on nähnyt, että nuoret on pakko ottaa mukaan jotta liike jatkuu. Nuoret taas ovat oppineet, että on pakko tehdä yhteistyötä jotta saa asioita eteenpäin”. Kun 1960-70-luvun nuoret halusivat olla piikkinä puoluesetien ja -tätien lihassa, 1980-90-luvun nuoret olivat tässä suhteessa maltillisempia. Niin naisjärjestöillä kuin puolueellakin ikääntymisen uhka on kuitenkin todellinen. ${ }^{12}$ Sosiaalidemokraattisten naisten toiminta näyttääkin kokoavan keski-ikäisiä ja sitä iäkkäämpiä naisia riveihinsä. Ilmiö on tuttu sekä Euroopan sosialistipuolueissa että muissa puolueissa. Esimerkiksi Ranskassa sosialistipoliitikkojen keski-ikä on

10 Vappu Taipaleen kirje Maria Lähteenmäelle 5.1.2000. 
55 vuotta, kommunistien 47 vuotta ja nuorina pidettyjen vihreiden 47 vuotta. $^{13}$ Suomessa kansanedustajien keski-ikä on 47 vuotta (1999), naiskansanedustajat ovat hieman nuorempia kuin miehet, heidän keski-ikänsä on 42 vuotta. Ensimmäisissä vaaleissa 1907 valittujen naisten keski-ikä oli 38 vuotta. ${ }^{14}$ Kaiken kaikkiaan näyttää siltä, että politiikka on 40-50-vuotiaiden suosima laji.

Naisliiton pääsihteeri myöntää jäsenrakenteen vinouman. Marja-Liisa Kiljusen mukaan koko naisliikkeelle on haaste saada nuoret naiset tasa-arvotaisteluun. Nuoret ovat Kiljusen mukaan "tasaarvoharhan vallassa". Vasta perustettuaan perheen ja siirryttyään työelämään monet naiset omakohtaisesti kokevat tasa-arvon puutteellisuuden. Naisten keskinäisen solidaarisuuden vahvistaminen onkin suuri haaste naisjärjestöille. ${ }^{15}$

\section{Globalisaation naisnäkökulma}

Tuula Haatainen ja Marja-Liisa Kiljunen nostavat molemmat vakavaksi tulevaisuudenhaasteeksi talouden globalisoitumisen. Kiljunen kirjoittaa:

Suuria haasteita naisliikkeellemme on tiivistyvä ja vauhdilla etenevä globalisoituminen. Talouden ja markkinavoimien ehdoilla tapahtuvan globalisaation säätelemiseksi ja pelisääntöjen luomiseksi tarvitaan tiivistyvää poliittisen ja ammatillisen liikkeen kansainvälistä yhteistyötä myös naisten aseman parantamiseksi maailmanlaajuisesti. Suuri haaste on myös työelämässä globalisation ja kaiken kattavan kilpailun ja markkinoitumisen seurauksena naisten työmarkkina-aseman kehitys. Jo nyt on nähtävissä naisvaltaisten alojen suhteellinen heikkous, pätkätöiden yleistyminen ja palkkojen jälkeenjääneisyys. Suomessa uhkana on tulevaisuudessakin jo nyt syvään juurtunut sukupuolittain jakautuneet opiskelu-ja työmarkkinat. Naisten pääsy teknologisen kehityksen ytimeen on tärkeää, ettei yhteiskunnallinen kehitys yksipuolisesti tapahtuisi miesten ehdoilla ja malleilla. ${ }^{16}$

11 Marja-Liisa Kiljusen kirje Maria Lähteenmäelle 9.12.1999.

12 Säde Tahvanainen Suomen Kuvalehdessä 28.5.1999.

13 Ranskalaisnuorten kiinnostus politiikkaan on sammumassa, kirj. Markku Saksa. Helsingin Sanomat 7.3.2000.

14 Naiset Suomen eduskunnassa. http://www.eduskunta.fi

15 Marja-Liisa Kiljusen kirje Maria Lähteenmäelle 9.12.1999.

16 Marja-Liisa Kiljusen kirje Maria Lăhteenmäelle 9.12.1999. 
Naisliikkeellä on vielä pitkä sarka kynnettävänään. Vappu Taipaleen mukaan naisliike ei kyennyt estämään Suomessa seksin kaupallistumista 1990-luvun taitteessa, ei prostituution leviämistä eikä naiskaupan lisääntymistä. Hänen mukaansa naisliikkeelle on suuri haaste selvittää se, miksi siinä ei onnistuttu? "Naisliiton ikivanhat peruskysymykset "oma ruumis, oma raha" ovat siis tulleet jälleen ajankohtaisiksi ja tarvitsevat puolustajansa ja analysoijansa". ${ }^{17}$

Toinen naisliiton aktiiveja huolettanut kysymys oli naisiin kohdistuneen väkivallan lisääntyminen niin Suomessa kuin maailmanlaajuisestikin. "Seksuaalistunut väkivalta on yleisesti käytetty ase sodissa. Naiskauppa, prostituutio ja lasten seksuaalinen hyväksikäyttö on yleistynyt kansainvälisesti". ${ }^{18}$

\section{Kiintiöt käyttöön}

Kaikki naisliiton tulevaisuutta pohtineet naisaktiivit olivat sitä mieltä, että sosiaalidemokraattista naisliikettä tarvitaan edelleenkin. Heidän mukaansa tasa-arvoa ei ole saavutettu sosiaalidemokraattisissa järjestöissä, ei yhteiskunnassa eikä liioin perheessä. Myönteisenä ilmiönä nähtiin, että naisten suhteellinen osuus on asteittain kasvanut koko ajan: vuonna 1999 naisten osuus sosialidemokraattisen puolueen jäsenistä oli $41 \%$. Naisten osuus puolueen päättävissä elimissä sen sijaan oli naisten mielestä saatava vastaamaan vähintään heidän osuuttaan puolueen jäsenistöstä. MarjaLiisa Kiljusen mukaan kaikki järjestöhierarkian tasot olisi saatava kiintiösäännön piiriin naisten osuuden lisäämiseksi. Kiintiöperiaatteen tuli hänen mukaansa koskea myös ehdolle asettelua vaaleissa. "Naisia ei valita ellei heitä ole ehdolla". Vuoden 1999 eduskuntavaaleissa naisia valittiin sekä sosiaalidemokraattien joukosta että eduskuntaan ylipäätään samassa suhteessa kuin heitä oli ehdolla. ${ }^{19}$

Kiljusen mukaan demokratiassa on vaje, jos naiset eivät ole edustettuina päättävissä elimissä osuuttaan vastaavassa suhteessa. "Puo-

17 Vappu Taipaleen kirje Maria Lähteenmäelle 5.1.2000.

18 Marja-Liisa Kiljusen kirje Maria Lähteenmäelle 9.12.1999.

19 Marja-Liisa Kiljusen kirje Maria Lähteenmäelle 9.12.1999. 


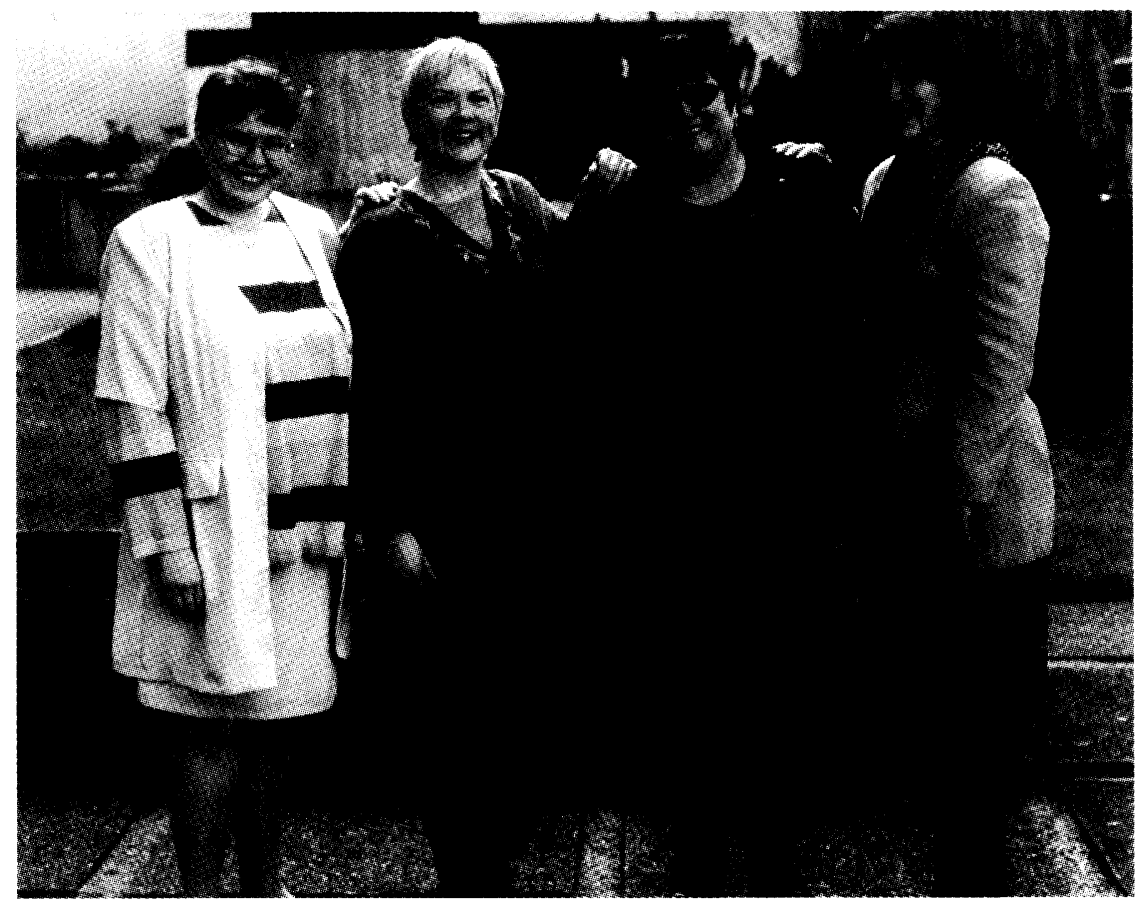

Sosialidemokraattisten Naisten toimiston henkilökunta vuonna 2000. Vasemmalta Ulla Laakso, Merja-Hannele Vuohelainen, Irma Tuomisto ja Marja-Liisa Kiljunen. 1920-luvun tilanteeseen verrattuna henkilömäärä on lisääntynyt peräti yhdellä. Kuva: Sos.dem. Naisten toimisto.

lueilla on tässä tasa-arvon edistämisessä erityinen vastuu valtiovallan ohella. Asenteet ja toimintakulttuuri muuttuvat kuitenkin valitettavan hitaasti, siksi tarvitaan mm. kiintiöiden kaltaisia erityistoimia tasa-arvon edistämiseksi samoin asenteisiin vaikuttavaa valistusta ja tasa-arvokoulutusta eri tahoilla. Naisten ja miesten eriarvoinen yhteiskunnallinen asema on tehtävä näkyväksi mm. sukupuolten mukaan julkaistavin tilastoin". ${ }^{20}$

Sosialidemokraattisen naisliikkeen naiset eivät salaa hienoista pettymystään puolueen käytännön tasa-arvopolitiikassa. Naisliiton pääsihteeri Kiljusen mukaan "on valitettavan totta erään miespuo-

20 Marja-Liisa Kiljusen kirje Maria Lăhteenmäelle 9.12.1999. 
lisen puolueen jäsenen toteamus, että naisten rooli puolueessa on ollut keittää kahvia, kun miehet ovat hoitaneet politiikkaa. Sosialidemokraattinen puolue ei valitettavasti ole enää se sukupuolten tasa-arvon esitaistelija, joka se vuosisadan alussa oli. Asian tila on käännettävä. Sosialidemokraattisen puolueen tavoitteet vastaavat parhaiten naisten yhteiskunnallista asemaa ja tarpeita. Olisi näin ollen puolueen kannalta erittäin positivista, jos se todella aidosti profiloituisi sukupuolten tasa-arvon ajajana sekä puolueessa että yhteiskunnassa. "21

Keskustelu sukupuolikiintiöistä nousi laajempaan keskusteluun kansainvälisessä sosiaalidemokraattisessa liikkeessä 1980-luvun lopulla ja Sosialistisen Internationaalin kokous hyväksyi kiintiöperiaatteen toimintatavoitteeksi vuonna 1989. Suomessa Sosialidemokraattisen puolue otti sen ohjelmaansa vuonna 1996.

Kiintiöperiaate on lisännyt naisten edustusta komiteoissa ja kunnallisissa elimissä. Myös hallitustasolla kiintiöajatusta on sovellettu: sosiaalidemokraatti Paavo Lipposen I hallituksen (1995-99) ministereistä oli naisia lähes vaadittu kiintiö eli $39 \%$.

\section{Yksityinen on poliittista!}

Stakesin pääjohtaja Vappu Taipale päättää puheenvuorot ennakoimalla ihmissuhdeteemojen nousua politiikkaan. "Naisliikkeen olisi eriteltävä pohjia myöten, mitä on tapahtunut seksuaalisuuden ja lisääntymisen alueilla". Naisten rooli on muuttunut rajusti sadassa vuodessa. Taipaleen mukaan ehkäisyvälineet houkuttivat naiset toimimaan kuin miehet, ehkä vastoin omia tarpeitaankin. Uusi teknologia on ratkaissut ihmiskunnan ikuisia kysymyksiä: raskaaksi tuloa voidaan pitkälle hallita. Toisaalta avioerot ovat lisääntyneet. "Naisliitto voisi nostaa esille naisen uudenlaisen "itsensä toteuttamisen" (myös) lasten ja ihmissuhteiden kautta, rohkaista pitkäjänteisyyteen ohi nopean ihmissuhdeonnen etsinnän", ${ }^{22}$

Kaiken kaikkiaan naisaktiivien puheenvuoroista nousee yksi aihe ylitse muiden: naistoiminnan pyrkimyksenä on vahvistaa kansalaisten kokonaisvaltaista elämänhallintaa.

21 Marja-Liisa Kiljusen kirje Maria Lähteenmäelle 9.12.1999.

22 Vappu Taipaleen kirje Maria Lähteenmäelle 5.1.2000. 
*Tasa-arvon, kansanvallan ja yhteisvastuun puolesta

Sosialidemokraattisen puolueen kotisivuilla selostetaan kysymyksen "Miksi olen demari?" avulla sitä, mitä ovat 2000-luvun alun Sosialidemokraattisen puolueen peruslinjaukset. Seuraavassa siitä otteita:

*Sosialidemokratia syntyi 1800-luvun lopulla teollistuvien maiden työväestön yhteiskuntanäkemyksenä. Luokkapuolueesta, työasemaan perustuvasta samaistumisesta on kuitenkin asteittain siirrytty yhteiset arvot omaavien ihmisten liikkeeksi.

*Sosialidemokratian aateperusta koko sen satavuotisen historian aikana on ollut: 1) Tasa-arvossa, 2) yhteisvastuussa ja 3) kansanvallassa. $\mathrm{Ne}$ ovat kestäviä arvoja, joiden varassa myös tulevaisuutta on voitava rakentaa.

*1) Sosialidemokratian tavoitteena on ollut tasata ihmisten elämän edellytyksiä ja mahdollisuuksia. Sosialidemokratia korostaa, että ilman tasa-arvoa vapaus on harvojen etuoikeus. Toisaalta ilman vapautta eli yksilön oikeuksien ja vastuun tunnistamista tasa-arvokin jää merkityksettömäksi.

*2) Sosiaalidemokraatit painottavat ihmisen yksilöllisyyttä ja yhteisvastuuta. Kansakunnan voimaa osoittaa sen heikoimman lenkin vahvuus. Yhteisvastuu ei voi tuntea rajoja. Siksi sosialidemokratia on kansainvälinen liike.

*3) Sosialidemokratia luottaa ihmisiin. Siksi kansanvaltainen päätöksenteko on kaiken uudistuspolitiikan ennakkoehto. Tarkoitus ei pyhitä keinoja. Päämäärän hyväksyttävyys riippuu siitä, millä keinoilla se on 


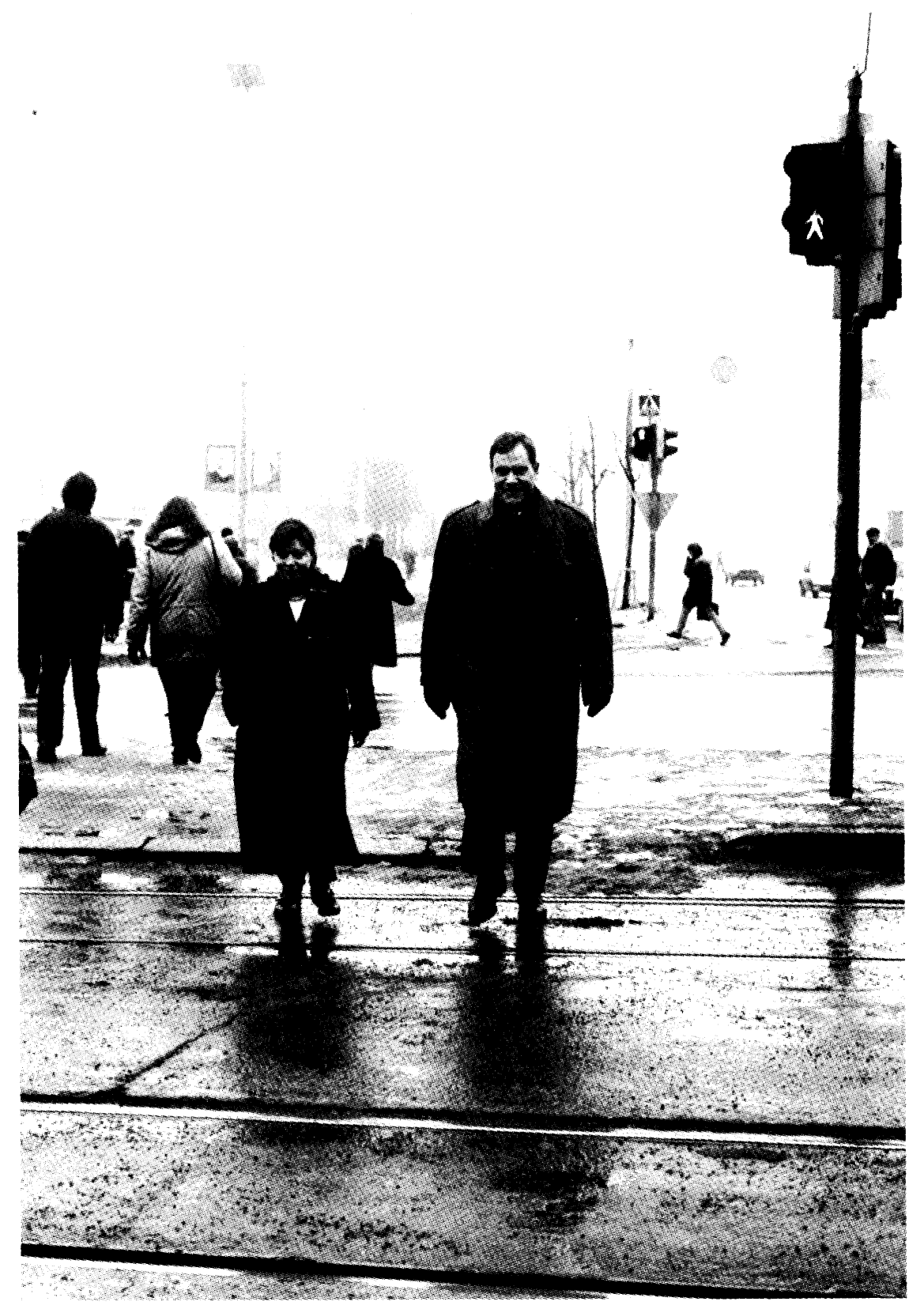

Sosialidemokraattisen puolueen puheenjohtaja ja pääministeri Paavo Lipponen on kasvattanut hallitustensa naiskiintiötä lähes 40 prosenttiin. Lipposen seurassa Helsingin Hakaniemessä kansanedustaja ja ministeri Arja Alho vuonna 1995. Sittemmin Alho joutui luopumaan salkustaan. Kuva: Työväen Arkisto. 
saavutettavissa. Politiikan keinoja arvioidaan ei vain niiden tarkoituksen, vaan myös seurausten perusteella.

* Ideologinen vasemmisto-oikeisto -jako läpikäy koko yhteiskuntapolitiikan. Sosialidemokratia pyrkii ohjaamaan markkinoiden toimintaa ihmisten tarpeista lähtien. Demareille talous on väline inhimillisten tarpeiden tyydyttämisessä.

* Demarit korostavat, että hyvinvointivaltio on luotu elämän riskien kantamiseksi yhdessä. Vahvat ja onnekkaat selviävät yksinkin.

* Yhteisvastuuta tarvitaan heikompien ja haavoittuneiden tukemisessa. Tällöin saadaan kaikki inhimilliset voimavarat elämisen luovaan prosessiin mukaan. Hyvinvointivaltio vahvistaa yksilön riippumattomuutta ja itsetoteutuksen mahdollisuuksia. Rakennamme mahdollisuuksien tasa-arvoa.

* Sosialidemokratian kivijalkana on kansainvälisyys. Sosiaalidemokraatit vastustavat nurkkakuntaista, suvaitsematonta eristäytymistä. Lähtökohtana on kansainvälisesti kehittää poliittista ohjausta, joka säätelee markkinoiden toimintaa ja johtaa voimavarojen tasaisempaan jakoon ja kestävään kehitykseen maailmanlaajuisesti.

Lähde: http://sdp.fi/eduskunta/ryhma-aate.html 


\section{Yhteenveto:}

\section{Hiljaisen vallankumouksen tie}

Suomen vanhimman poliittisen naisliiton, sosialidemokraattisen naisliiton, 1900-luvun historia avautuu moninaisten asiakirjojen, lehtien, muistelmien ja valokuvien kautta valtavan rikkaana, monivärisenä ja työntäyteisenä naisten poliittisen kulttuurin kuvana.

Tutkija ei voi olla hämmästelemättä sitä väkevää voimaa ja peräänantamatonta tarmoa, mikä noihin sataan vuoteen sisältyy. Jos naisten työtaakka olikin valtava, ei ollut vähäinen tavoitekaan: se oli oikeudenmukaisuuteen perustuva yhteiskunta. Eri naissukupolvet tekivät aatteellista työtään välillä pienin askelin, välillä perääntyen, välillä väistäen, välillä vaieten, yhteistyössä muiden naisjärjestöjen ja kansalaisjärjestöjen kanssa, siirtäen tehtävän sukupolvelta toiselle, mutta koko ajan hiljaisessa liikkeessä ollen.

Etenkin kriisien ja murrosten hetkillä naiset ammensivat voimansa vanhan työväenliikkeen myyttiseksi muodostuneesta kultakaudesta. Välillä jopa takertuen menneisyyden riitteihin, rituaaleihin ja symboleihin: mitä tiukemmin tartuttiin työväenliikkeen alkuajan muistoihin, sitä vaikeampi irrottautuminen ja siirtyminen uuteen aikakauteen oli. Sosiaalidemokraattisen liikkeen suuri murros ei liittynytkään puolueen kriisiin kansalaissodan jälkeen tai 1950-luvun lopun hajaannukseen eikä liioin 1960-luvun poliittisiin käänteisiin.

Suureksi murrokseksi osoittautui sodan jälkeinen aika aina 1950luvun puoleenväliin. Järjestökulttuurin uusi suunta ja jäsenrakenteen muutos tulivat ikään kuin varkain, ilman suuria eleitä sisältä päin - ja hajoittivat puolueen rivit. Työläisidentiteetti alkoi rapistua elintason nousun myötä. 1950-luvun jälkeen sosiaalidemokraattisten naisten toimintaa ei voidakaan kutsua enää "työläisnaisliikkeeksi", vaan pikemminkin keskiluokka-liikkeeksi. On kuvaavaa, että kun Sosialidemokraattisten Naisten Keskusliitto nimesi liittotoimikuntansa vuonna 1960 tuli siihen 11 naista, joista yksi oli 
asianajaja, neljä kansanedustajaa, kaksi maisteria, kaksi rouvaa, yksi opintoneuvoja ja yksi ammattitoimitsija.

Tästä sosiaalisesta noususta huolimatta nykyisillä demarinaisilla ja naisliiton perustajanaisilla on vielä paljon yhteistä: itse asiassa kaikki se, mikä oikeudenmukaisuustaistossa jää jäljelle, kun laajalle levinnyt köyhyys ja kansalaisoikeuksien puute eivät enää ole päällimmäisiä epäkohtia. Sosiaaliset epäkohdat eivät ole hävinneet. $\mathrm{Ne}$ ovat nyky-yhteiskunnassa muuttaneet vain muotoaan.

Uusissa oloissa vanhan työväenliikkeen perintöä ei siis ole hylätty, vaikka nykynaisilla ei olekaan sellaista selkeää kansanvalistusmissiota, tapakulttuurin opetusta ja kansanterveydellistä viestiä kuin aatesiskoilla sata vuotta sitten. Liikkeitä yhdistää yhteinen aatteellinen identiteetti, tietoisesti rakennettu ja uusinnettu, mutta edelleenkin elävä. Nuorehkojen naisten modernia sosialidemokratiaa edustavat Sosialidemokraattiset Naiset jatkavat edelleen rituaalien tiellä. Miina Sillanpäälle pystytettiin 1960-luvulla patsas ja toukokuussa 2000 naisliittolaiset veivät edelleen kukkia Liekkipatsaalle Miinan nimipäivänä.

Kokoukset aloitetaan työväenlauluilla ja punaiset liput liehuvat. Liikkeen symbolit ovatkin tärkeitä siksi, että ne kantavat mukanaan menneiden sukupolvien kollektiivista kokemusta, yhdistävät menneisyyden, nykyisyyden ja tulevaisuuden. Ne luovat turvallisuuden ja vahvan yhteenkuulumisen tunteen. Uuden ajan demarinaisten identiteetti on kuitenkin ainakin yhdessä kohden toinen kuin vanhan työväenliikkeen. Vanhan naisliiton minäkuva rakentui poissulkemisen kautta eli ikään kuin negaationa suhteessa muihin identiteetteihin. Tämän päivän demarinaisten minäkuva ei sen sijaan ole niin suljettu, kiinteäksi rakennettu yksi kuin menneisyyden aatesiskoilla. Nykynaisten minäkuvat rakentuvat refleksiivisemmin. Globalisaation myötä muuttuvia identiteettejä tutkijat kutsuvat sirpaloituneiksi, ne muuttuvat ja reflektoivat alituisesti ympäristön muutoksiin.

Sata vuotta naisjärjestötyötä sisältää niin monenmoista toimintaa, ettei läheskään kaikki ole mahtunut tähän kirjaan. Piiri- ja paikallistason toiminta sekä naisten työ tärkeässä kunnallispolitiikassa odottavat vielä perustutkimuksia. Jotkut tuokiokuvat ovat jääneet elämään voimakkaammin, kuten vällyihin kietoutuneen naisagitaat- 


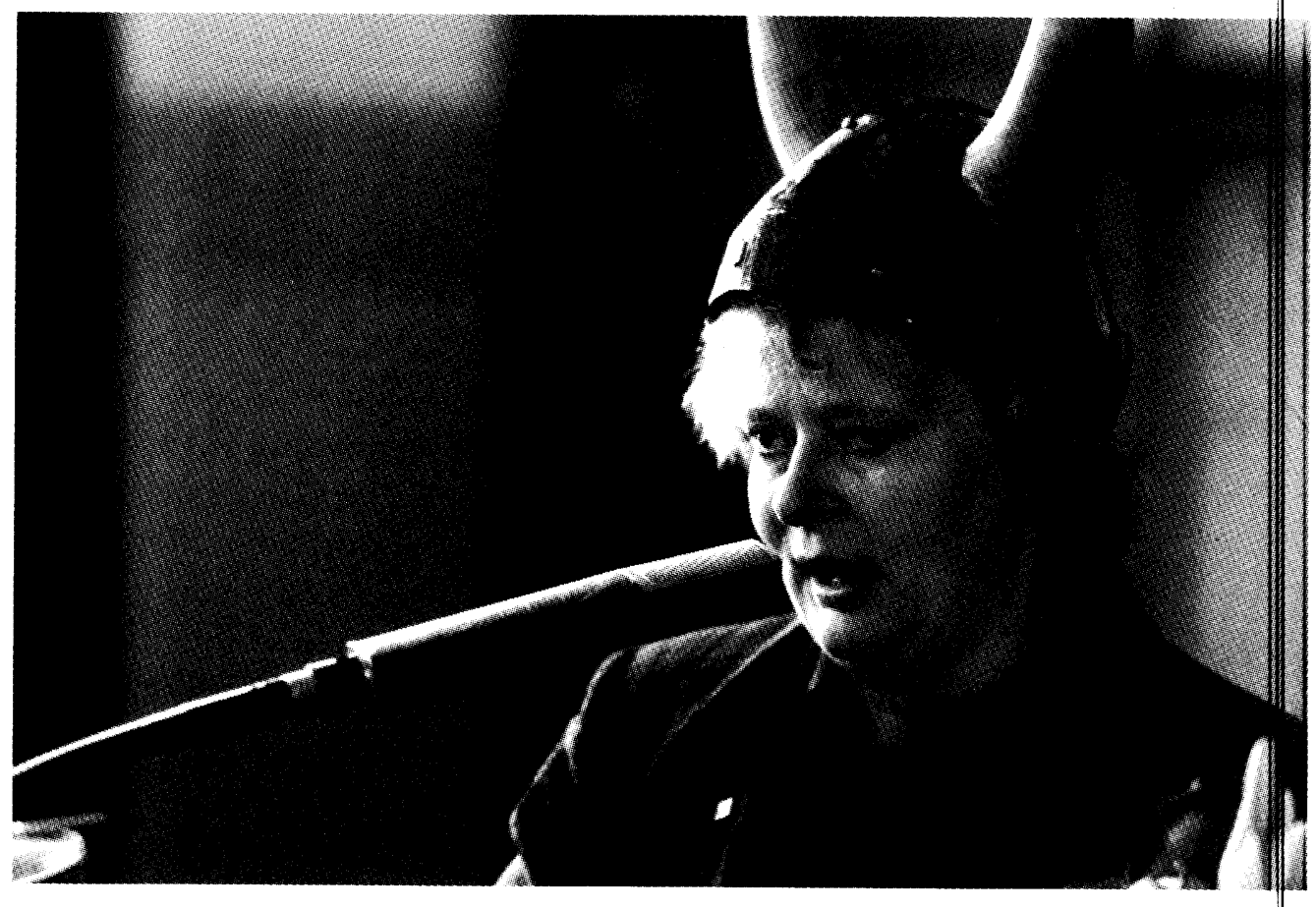

Härkää sarvista. Se luonnistuu hyvin Sosialidemokraattisten Naisten puheenjohtajalta (1990-98) ja työministeriltä Liisa Jaakonsaarelta. Kuva on 1990-luvulta. Kuva: Sos.dem. Naisten toimisto.

torin matka huonoilla teillä heiluvilla hevosrattailla, sorrosta saarnaava napakka naispuhuja vetoisessa työväentalossa, maitotonkkaan piilotetut maanalaiset julistukset, montun reunalla kyyristelevät tytöt teloituskomppanian edessä, rasvankäryiset hellahuoneet, samaa palkkaa vaativat naiset mielenosoituskulkueissa, taikinaa veivaavat äidit ruoanlaittokursseilla, tuntemattomille sotilaille sukkaa kutovat neitokaiset, kansainvälisissä kokouksissa puheenvuoroja pitävät jämäkät edustajat... ja ilta illan jälkeen kokouksissa, ompeluseuroissa, toimikunnissa, jaostoissa, sosiaalilautakunnissa ja eduskunnassa puurtavat naiset...

Joskus naisten työtä ja toimia seuratessa jäi miettimään sitä, olikohan tuokaan työ mitenkään poliittista, niin kuin esimerkiksi pulaajan ruokaohjeiden antaminen tai vanhasta uutta-kurssit. Asiakirjat antavat kyytiä epäilyille: kurssitoimintakin oli toiminnassa mukana olleiden naisten mielestä poliittista mitä suurimmassa määrin. 
Tasa-arvo on yksi kolmesta demokratian pääperiaatteista. Ranskan suuren vallankumouksen lanseeraama iskulause omaksuttiin 1800-luvulla perustettujen työväenpuolueiden ohjelmiin. Suomenkin Työväenpuolue kuulutti näkyvästi “täydellistä yhdenvertaisuutta miesten ja naisten välille”. Mutta miten sosiaalidemokraattinen liike on kyennyt toteuttamaan viimeisen sadan vuoden aikana uudistusvaatimustaan?

Poliittisessa elämässä vallitsevaa tasa-arvon tasoa voidaan mitata hyvin erilaisin mittarein. Naisten osuus puolueen edustusjärjestelmissä on niistä yleisin. Eduskuntapaikkojen suhteen sosiaalidemokraattisten naisten lukumäärä on kasvanut vuosien 19071999 aikana 9:stä 22:een. Työväenliikkeen hajaannuksen huomioon ottaen prosentuaalisesti naiset ovat voittaneet selvästi: maaliskuussa 1907 pidetyissä eduskuntavaaleissa naisten osuus Sosialidemokraattisen puolueen edustajista oli $11 \%$, vuoden 1999 vaaleissa naisten osuus oli jo $43 \%$ demariedustajista. Eduskuntapaikkojen demokratisoituminen alkoi kiihtyä 1970-luvulla, kuitenkin vasta vuoden 1991 vaaleissa naisten määrä ylitti 20 edustajan rajan. Eduskuntapaikkojen tasa-arvoistuminen on siten suhteellisen tuore, 1990-luvun ilmiö.

Hallituspaikkojen suhteen tilanne oli samansuuntainen. Sosiaalidemokraattiset naiset ovat olleet 1900-luvulla naisministereiden kärkijoukkoa. Punaisten hallituksessa 1918 oli kaksi naispuolista ministeriä (Hilja Pärssinen ja Hanna Karhinen), vuoden 1926 hallituksessa oli yksi naisministeri, Miina Sillanpää. Vuonna 1954 valittiin hallitukseen ensimmäisen kerran kaksi naispuolista ministeriä. Toinen heistä oli sosiaalidemokraatti Tyyne Leivo-Larsson. 1970-luvulla sosiaalidemokraattiset naiset saivat ensimmäisen kerran muitakin ministerisalkkuja kuin sosiaaliministerin. Muun muassa Margit Eskman toimi vuonna 1972 toisena valtiovarainministerinä. 1990-luvulla ensimmäiseksi naispuoliseksi oikeusministeriksi ja sittemmin ensimmäiseksi naispuoliseksi ulkoasiainministeriksi valittiin Tarja Halonen ja ensimmäiseksi naispuoliseksi työministeriksi Liisa Jaakonsaari. Vuonna 2000 Paavo Lipposen toisessa hallituksessa naisten osuus täyttää jo kiintiömitan eli se on noin $40 \%$. Sosiaalidemokraateista naisia on vuonna 2000 istuvassa hallituksessa kolme. 
Myös muilla aloilla sosiaalidemokraattisia naisia on nostettu huipulle. Vuonna 1956 Tyyne Leivo-Larssonista tuli ensimmäinen naispuolinen suurlähettiläs, vuonna 1972 Sylvi Siltasesta ensimmäinen naispuolinen maaherra ja vuonna 2000 Tarja Halosesta ensimmäinen naispuolinen presidentti.

Näistä yksittäisistä esimerkeistä voidaan nähdä, että sosiaalidemokraattisessa liikkeessä on tehty sukupuolten välistä tasa-arvotyötä, mutta sitä se ei kerro, kuinka laajaa tasa-arvotyö on ollut. Liikkeessähän oli pitkälle 1960-luvulle saakka käytössä niin sanottu "yhden naisen kiintiö" -periaate. Yhden mallinaisen nostaminen ei kerro edustusjärjestelmän tasa-arvoisuudesta.

Kuka sitten tasa-arvotyötä on tehnyt? Sadan vuoden perspektiivistä näyttää siltä, että naisten tasa-arvoistaminen on ollut pääosin naisten itsensä tekemää työtä. Juuri naiset ovat tehneet esityksiä ja aloitteita eduskunnassa ja puoluekokouksissa. Kuvaava esimerkki naisten aktiivisuudesta olivat vuonna 1948 julkaistu komiteamietintö "Naimisissa olevien naisten ansiotyöstä" ja etenkin vuosina 1966-70 toimineen "Naisten asemaa tutkivan komitean" asettaminen ja sen toiminta. Sosiaalidemokraattiset naiset esittivät ko. tutkimuksen toimeenpanoa Ruotsin malliin vedoten pääministerinä toimineelle puolueensa puheenjohtajalle Rafael Paasiolle, joka käynnisti hankkeen. Ensimmäisen kerran sitten 1800-1900-luvun vaihteen äänioikeuskamppailun Sosialidemokraattinen puolue otti toimintansa yhdeksi keskeiseksi tavoitteeksi naisten esittämän aloitteen ja toimintastrategian.

Jos sosiaalidemokraattiset naiset ovat edenneet eduskunnassa ja hallituksissa, näyttää - ristiriitaista kyllä - heidän etenemisensä olleen paljon työläämpää oman puolueen johtoon. Puolueen ensimmäinen naispuolinen varapuheenjohtaja valittiin vasta vuonna 1972. Hän oli Margit Eskman. Ensimmäinen ja toistaiseksi viimeinen naispuolinen puoluesihteeri oli vuosina 1987-91 sihteerinä toiminut Ulpu Iivari.

Myös puoluekokousedustajista naisten osuus kasvoi vasta 1980luvulla. Naisten osuus 1900-luvun alussa oli sama kuin 1960-luvulla eli noin $10 \%$. Vuosina 1981-1999 pidetyissä puoluekokouksissa naisten keskimääräinen edustusosuus kasvoi 28 prosenttiin.

Tasa-arvosta puhuminen puolueen sisällä on ollut koko sadan vuoden aikana hieman arka asia. Siitä ei ole keskusteltu avoimesti. Näin osittain siksi, että verrattuna muiden puolueiden naisten edustusosuuteen sosiaalidemokraattiset naiset etenivät parhaiten. 
Toisaalta ei ole haluttu päästää riidanalaisia asioita julkisuuteen puoluetta mahdollisesti vahingoittavien seuraamusten takia. Ongelmat on haluttu hoitaa omassa piirissä. Naiset ovat esittäneet historian kulussa useinkin kriittisiä huomautuksia esimerkiksi naisten sijoittumisesta äänestyslistoille, yhden naisen kiintiöstä puoluetoimikunnassa, naispuhujien palkkaamisesta, puolueen antamista avustuksista naisliitolle ja puolueen johtomiesten sanelupolitiikasta. Pinnan alla kytevä tyytymättömyys on purkautunut esille viime vuosina varovaisena kiintiövaatimuksena, joka tulisi ulottaa myös puoluetta johtavaan puoluehallitukseen. Vuonna 2000 puoluehallitukseen kuuluu puolueen puheenjohtajan ja sihteerin lisäksi yksi varapuheenjohtaja, joka on nainen. Heidän lisäkseen hallitukseen kuuluu 13 jäsentä, joista neljä on naista. Naisten osuus puolueen johdossa on siis tällä hetkellä $31 \%$. Naisten osuus puolueen jäsenistä on samanaikaisesti noin $40 \%$.

\section{Naisasia vai puolue?}

Sosialidemokraattisten naisten satavuotinen historia voidaan hahmottaa neljään jaksoon sen mukaan, miten kiinteä naisten kytkentä on ollut yhtäältä puolueen yleispoliittiseen suuntaukseen ja toisaalta naisliikkeen ajamiin kysymyksiin.

1) Vanhan työväenliikkeen kautena (1899-1918) sosialidemokraattisen naisliiton naiset olivat leimallisemmin yleispoliitikkoja kuin naisasian ajajia. Tähän vaikutti ennen muuta työläisnaisten aktiivinen ja näyttävä rooli äänioikeustaistelussa ja tsaarinvastaisessa kamppailussa.

2) Kansalaissodan jälkeen maltillisen reformistinen sosiaalidemokraattinen naisliike hakeutui enemmän porvarillisen naisliikkeen omaksumalle kotitaloutta ja perhettä korostavalle ohjelmalinjalle. Sama ohjelmapoliittinen painotus oli vallitseva myös muiden Euroopan maiden naisliikkeissä. Sosialidemokraattinen naisliitto itsenäistyi puolueesta, sen taloudellinen pohja laajeni valtionavun turvin ja liiton toiminta oli aikaisempaa leimallisemmin naisasian ajamista. Tätä vaihetta naisliiton historiassa kesti aina sosialidemokraattisen puolueen toiseen hajaannukseen 1950-luvun lopulle. Valitun linjan seurauksena oli se, että puolueen edustuselimissä naisten osuus laski selvästi 1920-50-luvulla. 
3) 1950-luvulla naisliiton rooli yhtäältä itsenäisenä naisjärjestönä ja toisaalta puoluejohdosta sivussa olevana naisorganisaationa nostatti ankaria ristiriitoja naisliittolaisten keskuudessa. Itsenäistä naisliittoa tukeneet jatkoivat Sosialidemokraattinen naisliitto -nimisenä ja uusi, puolueeseen tiukemmin sitoutunut naisryhmä perusti Sosialidemokraattisen puolueen yhteyteen Sosialidemokraattisten Naisten Keskusliiton vuonna 1959. Naisliiton hajaannus kesti 20 vuotta eli melkein yhtä pitkään kuin Työväen urheiluliiton, joka yhdistyi myös vuonna 1979. Hajaannuksen aikana vanha Sosialidemokraattinen naisliitto jatkoi naiskysymys-painotteista itsenäistä linjaa, kun taas nuoremman polven Sosialidemokraattisten Naisten Keskusliitto vieroksui naisasiaan leimautumista.

4) Naisliiton yhdistymiskokous vuonna 1979 ratkaisi naisliiton suhteen naiskysymykseen ja puolueen yleispolitiikkaan ainakin organisatorisella tasolla. Uutta liittoa, Sosialidemokraattiset Naiset, ei enää rekisteröity itsenäiseksi liitoksi, vaan siitä tuli vapaamuotoisempi naisten yhteisö puolueen sisälle. Naiset siis "sukelsivat" puolueen sisään.

Se, että naisten osuus eduskunnassa, hallituksissa ja puoluekokouksissa ja -hallituksessa on kohonnut juuri 1980-1990-luvulla kertoo sen, että ehkäpä naisten edustajuuden kasvun näkökulmasta "sukeltaminen" puolueen sisälle on ollut tuloksellinen. Tosin se ei yksin selitä naisten osuuksien kasvua. Integroitumisen hinta oli taloudellisen itsenäisyyden menettäminen. Naisille jäi "oma huone", mutta ei omaa kassaa.

\section{Hiljainen vallankumous}

Sosiaalidemokraattien suosio perustuu puolueen kannatuksen lisääntymisen kannalta onnistuneeseen identiteetin uudelleen muotoiluun. Muutosprosessi alkoi toisen maailmansodan jälkeen. Monien kipeiden sisäisten taistelujen jälkeen puolue irroitti luokkapuolueen leiman itsestään ja alkoi profiloitua hiljakseen yleispuolueeksi. Toinen suosion takaaja on ollut liikkeen naisten satavuotinen työ jäsenkunnan arkielämän kohentamiseksi. Naisten työ on ollut olennainen osa ja yksi keskeisimmistä tukipylväistä, kun hyvinvointivaltiota on luotu. Suomen Työväenpuolueen ensimmäiset miehet Taavi Tainio ja kumppanit olivat oikeassa perustelles- 
saan aikanaan erillisen naisliiton perustamista sillä, että näin saataisiin laajat naisjoukot mukaan liikkeeseen tai ainakin antamaan äänensä vaaleissa. Naisten mukana tulivat lapset, perheet, isovanhemmat, kodit ja työläiskodin arki.

Naisten yhteiskunnallisen toiminnan vahvuus onkin noussut naisten politiikan kosketuksesta arkielämään. Naisten työ on ollut hyvin konkreettista arkipäivän asioihin liittyvää, aate on tarttunut kuulijoihin ja tekijöihin siinä sivussa, jos on ollut tarttuakseen. Naisliiton arkistosta löytyvät kentän kirjeet kertovat työläisjohdon ja kannattajakunnan tiiviistä vuorovaikutussuhteesta.

Vastaavasti voisi ajatella, että uuden vuosituhannen kynnyksellä arki on liukumassa pois liikkeestä ja ylipäätään poliittisista puolueista ja tämä näkyy politiikasta vieraantumisena. Politiikka muuttuu retoriikaksi, jolla ei ole välttämättä kosketuskohtia tavallisen äänestäjän arkitodellisuuteen. Poliitikot ovat yhä useammin ammattipoliitikkoja, jotka "tekevät vain työtään" kuin virkamiehet konsaan.

Kun tarkastellaan kokonaista vuosisataa ja naisten aseman muuttumisen vaikutuksia suomalaiseen yhteiskuntaan voisi sanoa Ulrich Beckiä lainaten, että nykyään "kaikki poliittiset puolueet kannattavat naisten osuuden lisäämistä työelämässä...tällainen johtaa kuitenkin toteutettuna perinteisen järjestyksen vähittäiseen kumoutumiseen...". Beckin mukaan tällaiset vähäiset, mutta laajoihin seurannaisvaikutuksiin johtavat toimenpiteet eivät toteudu vallankumouslippujen liehuessa, vaan modernisaatio etenee hiljaa. ${ }^{1}$ Hiljainen vallankumous näyttää olleen myös sosiaalidemokraattisen naisliikkeen tie.

Lopuksi voisi todeta, että matka sosiaalidemokraattisen naisliikkeen satavuotiseen historiaan osoitti ainakin yhden asian. Nimittäin sen, että Simone de Beauvoir oli väärässä - naisten toiminta ei ole ollut vertauskuvallista liikehdintää. Päinvastoin. Perustellusti voidaan väittää, että sosiaalidemokraattinen naisliike on ollut merkittävä yhteiskunnallinen vaikuttaja tasa-arvon ja hyvinvointivaltion lujittamisessa 1900-luvun Suomessa. 


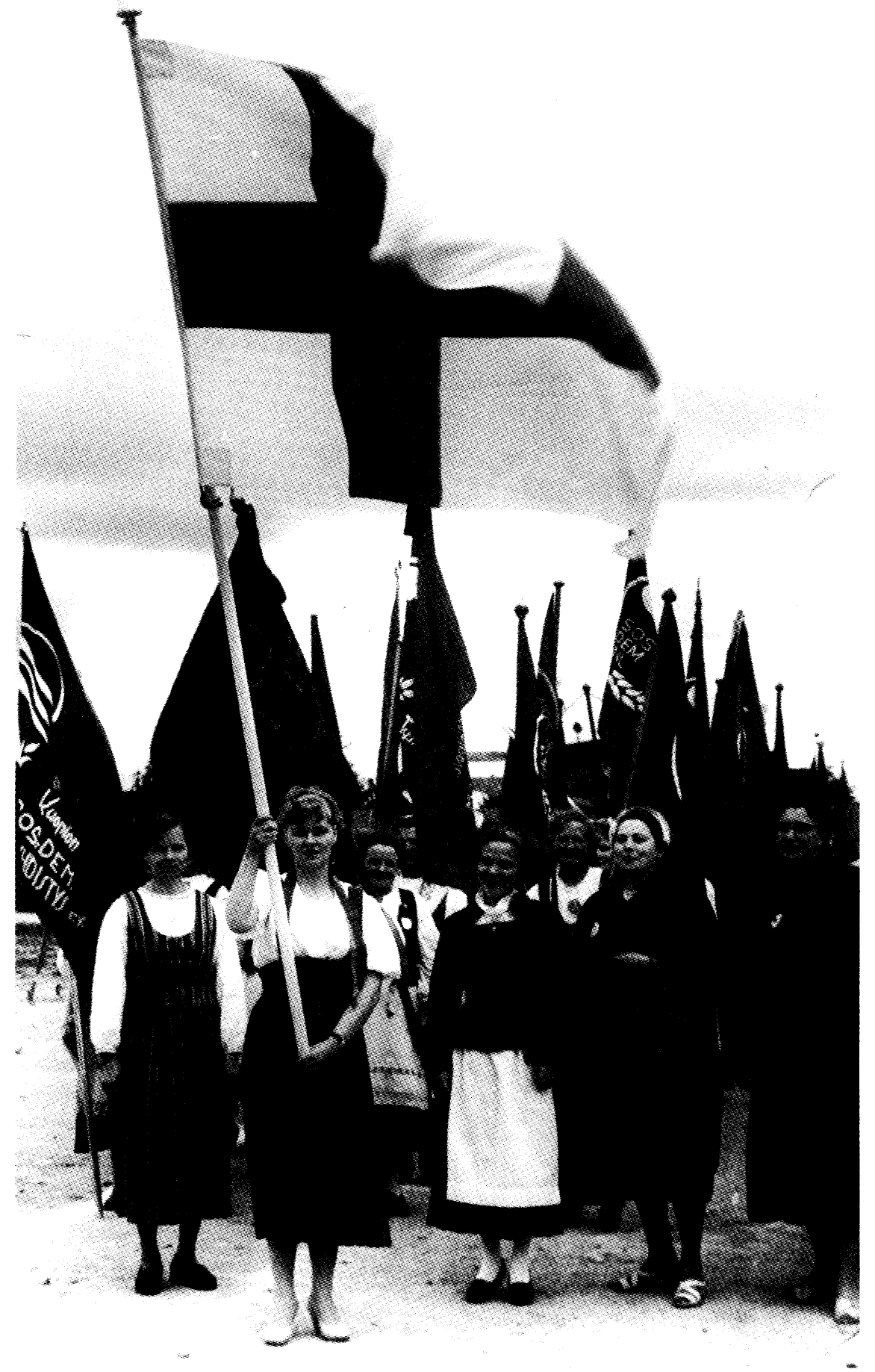

Naiset marssivat paremman Suomen puolesta. Kuva on vuodelta 1956. Kuva: Työväen Arkisto. 


\title{
Lähteet
}

\author{
Arkistolähteet
}

\section{Työväen Arkisto (TA), Helsinki}

-Helsingin työväenyhdistyksen leipuri- ja kondiittori-ammattioaston pöytäkirjat 1897

-Helsingin työväenyhdistyksen naisosaston pöytäkirjoja ja kertomuksia 1899-1904

-Hilja Pärssisen arkisto

-Martta Salmela-Järvisen arkisto

-Miina Sillanpään arkisto

-Hilda Seppälän arkisto

-SSTP:n (Suomen Sosialistisen Työväenpuolueen) arkisto: pöytäkirjat 1920-23

-Sosialidemokraattisen puolueen puoluetoimikunnan pöytäkirjoja, puoluetilastoja, puoluekokousaineisto 1999

-Toveritar-lehden arkisto: avustajaluettelo 1921-22

-Turun eteläisen sos.dem. piirin naisjaoston pöytäkirjat 1944-45

-Työläisnaisten liiton/Sosialidemokraattisen Naisliiton/

Suomen Sosialidemokraattisen Työläisnaisten Liiton/Sosialidemokraattisen Naisliiton/Sosialidemokraattisten Naisten Keskusliiton/ Sosialidemokraattiset Naiset arkistot 1900-2000: pöytäkirjat, kertomuksia, kirjeenvaihtoa, jäsenluettelot, lehtileikkeitä, tilikirjoja, Sos.dem. naisten tekemiä eduskunta-aloitteita 1907-54, sotakummikortisto, sota-ajan huoltoa käsittelevät asiakirjat

-Vaasan työväenyhdistyksen naisosaston pöytäkirjat 1900, 1913

-Vuoden 1918 kokoelma

\section{Kansallisarkisto (KA), Helsinki}

-Jaakko Paavolaisen kokoelma vuoden 1918 teloitetuista

-Etsivän Keskuspoliisin/Valtiollisen poliisin arkisto

-Naisten Työvalmiusliiton arkisto

-Valtiorikossyyttäjistön arkisto: valtiorikosoikeuksien pöytäkirjoja liitteineen 1918-19 


\section{Helsingin kaupunginarkisto:}

-Helsingin Maitopisarayhdistyksen johtokunnan vuosikertomukset 190540

\section{Sosiaaliministeriön arkisto, Helsinki}

-Valtion lahja Suomen äideille-kirjanen. Helsinki 1948.

\section{Painetut lähteet:}

E-liikkeen uranuurtajia. Kulutusosuuskuntien Keskusliitto. Helsinki 1967.

Ensimmäisen Yleisen Työläisnaisten edustajain kokous Helsingissä Heinäkuun 4, 5 ja 6 p:nä 1900. Helsinki 1900.

Hakulinen Janne, Keskiluokkaan lukeutuvien ryhmien asema ja tehtävät yhteiskunnassa. Sos.dem. puolueen keskiluokkajaosto. Lappeenranta 1955.

Helsingin työväenyhdistyksen vuosikertomukset 1899-1905. Helsinki 1899-1905.

Kertomus Helsingin työväen-yhdistyksen toiminnasta vuonna 1890. Suomalaisen Kirjallisuuden Seuran kirjapaino 1891.

Kertomus Helsingin kaupungin kunnallishallinnosta 1938. Helsinki 1939. Liinamaa-Pärssinen Hilja, Vallankumouskuvia Työväenjuhlaan Helsingissä 26.8.1917. Työväen Kirjapaino 1917.

Luokkasodan muisto. Helsinki 1947.

Punaset I. Sosialidemokratisten edustajien kuvat ja elämäkerrat 19071909. Työväen kirjapaino. Helsinki.

Pärssinen Hilja, Kysymyksiä sosialidemokratian alalta. Hancock. Michigan 1907.

Pärssinen Hilja, Porvarit työläisten avioliiton ja perheen vihollisina. Sosialidemokraattisia vaalijulkisuja n:o 13. Helsinki 1908.

Pöytäkirja Sos.dem. Naisten Keskusliiton edustajakokouksesta. Edustajakokous pidettiin Helsingissä maaliskuun 27-28 päivinä 1960. Turku 1961.

Pöytäkirja Sos.dem. Naisten Keskusliiton II edustajakokous. Helsingissä huhtikuun 20-21 päivinä 1963. Helsinki 1963.

Pöytäkirja Sos.dem. Naisten Keskusliiton edustajakokouksesta Helsingissä huhtikuun 2-3- päivinä 1966. Helsinki 1966.

Pöytäkirja Sos.dem. Naisten Keskusliiton edustajakokous. Edustajakokous pidettiin Helsingissä maaliskuun 29-30 päivinä 1969. Helsinki 1969.

Pöytäkirja Sos.dem. Naisten Keskusliiton V edustajakokous Helsingissä huhtikuun 15.-16. päivänä 1972. Helsinki 1973. 
Pöytäkirja Sos.dem. Naisten Keskusliiton VI edustajakokous Helsingissä huhtikuun 19-20 päivänä 1975. Joensuu 1976.

Pöytäkirja Sosialidemokratisen Naisliiton edustajakokouksesta Lahdessa 5, 6 ja 7 päivinä 1909. Sos.dem. Naisliitto. Mikkeli 1909.

Pöytäkirja Sosialidemokratisen Naisliiton VIsta edustajakokouksesta Helsingissä 1-3.p. syyskuuta 1911. Sos.dem. naisliitto. Mikkeli 1911. Sananen työväenasiasta. Lentokirjasia työväestölle II. Myydään Suomen työläisnaisten liittohallinnon hyväksi. Helsinki 1903.

SDP. Sosialidemokraattisen puolueen perhepoliittinen ohjelma. Helsinki 1975.

SDP. Tiede- ja korkeakoulupoliittinen ohjelma. Helsinki 1965.

Sos.dem. naisliiton IX edustajakokouksen pöytäkirja. Kokous pidetty Helsingissä 5, 6 ja 7 p:nä joulukuuta 1919. Kotka 1920.

Sos.dem. naisliiton XX edustajakokouksen pöytäkirja. Kokous pidettiin Helsingissä huhtikuun 19. ja 20. p:nä 1953. Hämeenlinna 1953.

Sos.dem. naisliiton XXI edustajakokouksen pöytäkirja. Kokous pidettiin Helsingissä huhtikuun 22. ja 23. p:nä 1956. Hämeenlinna 1956.

Sos.dem. naisliiton XII edustajakokouksen pöytäkirja. Kokous pidettiin Helsingissä lokakuun 25. ja 26. päivänä 1959. Hämeenlinna 1959.

Sos.dem. naisliiton XXIII edustajakokouksen pöytäkirja. Kokous pidettiin Helsingissä toukokuun 27 ja 28 päivinä 1962. Hämeenlinna 1962.

Sos.dem. naisliiton XXIV edustajakokouksen pöytäkirja. Kokous pidettiin Helsingissä lokakuun 30 ja 31 päivinä 1965. Helsinki 1966.

Sos.dem. naisliiton XXV edustajakokouksen pöytäkirja. Kokous pidettiin Mikkelissä elokuun 31. ja syyskuun 1 p:nä 1968. Helsinki 1968.

Sosialidemokraattisen puolueen periaateohjelma. Helsinki 1987.

Sosialidemokraattisen Työläisnaisliiton XIX edustajakokouksen pöytäkirja. Kokous pidettiin Helsingissä marraskuun 4. ja 5. p:nä 1950. Hämeenlinna 1950.

Sosialidemokraattiset Naiset Suomen hallituksessa ja eduskunnassa 1907-1996. Matrikkeli. Sosialidemokraattiset Naiset. Työväen Arkisto. Helsinki 1996.

Sosialidemokraattisten Naisten I liittokokous Helsingissä 27. toukokuuta 1979. Joensuu 1981.

Sosialidemokraattisten naisten tavoitteet Euroopassa. Sosialidemokraattiset Naiset. Helsinki 1994.

Sosialidemokratian perusta. Periaateohjelma perusteluineen 1952. Sosialidemokraattinen puoluetoimikunta. Helsinki 1953.

Suomen kansanedustajat 1907-1982. Valtion painatuskeskus. Helsinki 1982.

Suomen sos.dem. työläisnaisliiton avustus- ja kurssitoiminta v. 193940. Hämeenlinna 1941. 
Suomen Sosiaalidemokraattisen Työläisnaisliiton XVII edustajakokouksen pöytäkirja. Kokous pidettiin Helsingissä kesäkuun 11 ja 12 p:nä 1944. Hämeenlinna 1944.

Suomen Sosialidemokraattisen Työläisnaisliiton X ja XI edustajakokouksen pöytäkirjat 20.-22.5.1921 ja 29.-31.1.1926. Hämeenlinna 1927.

Suomen Sosialidemokraattisen Työläisnaisliiton XII edustajakokouksen pöytäkirja. Kokous pidettiin Helsingissä 28.-31. toukokuuta 1929. Hämeenlinna 1932.

Suomen Sosialidemokraattisen Työläisnaisliiton XIII edustajakokouksen pöytäkirja. Kokous pidettiin Helsingissä 28.-31. lokakuuta 1932. Hämeenlinna 1934.

Suomen Sosialidemokraattisen Työläisnaisliiton XIV edustajakokouksen pöytäkirja. Kokous pidettiin Helsingissä 27.-29 p:nä lokakuuta 1935. Hämeenlinna 1936.

Suomen Sosialidemokraattisen Työläisnaisliiton X ja XI edustajakokouksen pöytäkirjat 20.-22.5.1921 ja 29.-31.1.1926. Hämeenlinna 1927.

Suomen Sosialidemokraattisen Työläisnaisliiton edustajakokouksen pöytäkirja 16.-17.5.1947.

Suomen Sosialidemokraattisen Työläisnaisliiton XV edustajakokouksen pöytäkirja. Kokous pidettiin Helsingissä lokakuun 22.-24 p:nä 1938. Hämeenlinna 1939.

Suomen Sosialidemokratisen Naisliiton kahdeksannen edustajakokouksen pöytäkirja. Kokous pidetty Helsingissä lokak. 4-6 p. 1917. Suomen sos.dem. naisliitto. Mikkeli 1917.

Suomen Sosialidemokratisen Naisliiton seitsemännen edustajakokouksen pöytäkirja. Kokous pidetty Tampereella lokak. 23.-25. p. 1913. Suomen Sosialidemokratinen Naisliitto. Porvoo 1914.

Suomen Työväenpuolueen ohjelma 1899. Turku 1899.

Suomen Työväenpuolueen ohjelma 1903. Forssa 1903.

Suomen Virallinen Tilasto (SVT) XXIII. Oikeustilasto 32. Tilastollinen tutkimus 1918. Helsinki 1923.

Tiuppa Otto, Helsingin työväenyhdistyksen 25-vuotisvaiheita. Helsinki 1910.

Toisen yleisen Suomen Työläisnaisten edustajain kokouksen Pöytäkirja.

Kokous pidetty Turussa heinäkuun 17-19 p:nä 1902. Turku 1902.

Työläisnaisten kolmannen edustajakokouksen pöytäkirja Tampereella 17, 18 ja 19 p. heinäkuuuta 1905. Tampere 1905.

Työläisnaisten ylimääräisen edustajakokouksen pöytäkirja Viipurissa 8, 9 ja 10 p. lokakuuta 1906. Viipuri 1906.

Työväen tietokirja. Työläisille välttämättömiä tietoja valtiollisista ja yhteiskunnallisista asioista. Työväen sanomalehti O.Y. Helsinki 1922. Ulapalla. Sosialidemokratisen naisliiton kymmenvuotismuisto 1900 1910. Sos.dem. naisliitto. Helsinki 1910. 
Valtiopäivät 1907. Pöytäkirjat II. Helsinki 1907.

Zetkin Clara, Nainen ja hänen taloudellinen asemansa. Viipuri 1907.

Vuosikirjat:

Eteenpäin. Kalenteri Kansalle. Tampere 1913.

Koti - Vuosikirja perheenemännille. Kulutusosuuskuntien Keskusliitto. Helsinki 1930-1935.

Suomen Eduskunnan kalenterit 1907-17. Helsinki 1907-17.

Työväen Kalenteri. Helsinki 1934.

\section{Komiteamietinnöt:}

Naimisissa olevien naisten asemaa tutkineen komitean mietintö 1948:1

Naisten asemaa tutkineen komitean mietintö 1970:A 8

Perhepalkkakomitean mietintö nro 1. Mon. 1947:8

Väestökomitean mietintö 1945:4.

\section{Lehdet:}

Helsingin Sanomat 1999, 2000

Historiallinen Aikakauskirja 1993

Kansan nainen 1906

Kevätesikoinen 1904

Me 1986

Palkkatyöläinen 1930, 1931, 1938

Palvelijatar 1905-06

Pikkusisko

Punahilkka

Suomen Kuvalehti 1968, 1990, 1999

Suomen Sosialidemokraatti

Suomen Työmies 1921

Tietosisko

Toveritar

Tulevaisuus

Turvattomien päivä 1921

Työläisnainen

Työläisnaisen Joululehti 1919

Työmies 1899, 1918 


\section{Opinnäytteet:}

-Hentilä Marjaliisa, Työläisnaisen emansipaatio ja sosialismi. Teorian kehitys August Bebelistä Clara Zetkiniin. Talous- ja sosiaalihistorian lisensiaattityö. Helsingin yliopisto 1989 (b).

-Koskinen Aineli, Wrigtiläiset työväenyhdistykset työväen kasvattajina ja kehittäjinä. Suomen historian pro gradu-tutkielma. Helsingin yliopisto 1952.

-Kuusi Hanna, Keuhkotauti kansallisvaarana: tuberkuloosin vastaiset strategiat Suomessa vuoteen 1939 asti. Talous- ja sosiaalihistorian pro gradu-tutkimus. Helsingin yliopisto 1995.

-Laitinen Hannele, Espanjan lasten hyväksi. Suomalaisten työväen- ja rauhanjärjestöjen humanitäärinen apu Espanjan sisällissodan aikana. Suomen historian pro gradu-tutkielma. Helsingin yliopisto 1998.

-Lähteenmäki Maria, Naisia liikkeessä. Työläisnaisliike poliittisena ja yhteiskunnallisena liikkeenä. Suomen historian lisensiaattityö. Helsingin yliopisto 1990 .

-Piiroinen-Honkanen Marja, Punakaartin aseelliset naiskomppaniat Suomen sisällissodassa 1918. Poliittisen historian pro-gradu-tutkielma. Helsingin yliopisto 1995 .

-Ranto Marja, Luokka- vai yleispuolue: Suomen Sosialidemokraattisen Puolueen järjestö- ja aatteellispoliittisia ongelmia vuosina 1948-52. Poliittisen historian pro gradu-tutkielma. Helsingin yliopisto 1987.

-Saraste Erja, Työvoimahallinto ja -politiikka Suomessa 2. maailmansodan aikana. Poliittisen historian lisensiaattityö. Helsingin yliopisto 1983.

-Toivanen Hannes, Lastenhoitotyö ja varhaisopetuksen kehitys ja kehittäjät Marian turvakodissa ja Semigradskyn pientenlastenkoulussa 1840-1910. Suomen historian proseminaari-esitelmä. Helsingin yliopisto 1996.

\section{Haastattelut/muistitieto/tiedonannot:}

Aalle-Teljo Ida (1875-1955), haastattelu 1941, Y.K. Laineen kok. Työväen Arkisto

Aro Pirkko (s. 1923), haastattelu 20.10.1999, kirje 2.12.1999

Haatainen Tuula, kirje 9.12.1999

Kiljunen Marja-Liisa, kirje 9.12.1999

Lehtimäki Riitta, toimittaja, tiedonanto 17.11.1999

Litonpalo Elvi, Työväen Muistitietotoimikunnan kokoelmat $256 / 1221 / 4$

Luja-Penttilä Sinikka (s. 1924), haastattelu 1986, Työväen Muistitietotoimikunnan kokoelmat 1322/2; kirje 17.11.1999 
Mikola Esteri (s. 1909), SATA 11680-11738. Suomalaisen Kirjallisuuden Seura

Nironen Mandi. Vuoden 1918 kokoelma. Kansan Arkisto (Ka)

Nokka Marjatta (s. 1924), Työväen Muistitietotoimikunnan kokoelmat $1346 / 2$

Salmela Irja (s. 1912), kirje 22.11.1999

Salmela-Järvinen Martta (1892-1987), Työväen Muistitetotoimikunnan kokoelmat sidoa 256 ja nauha 870 II.

Taipale Vappu (s. 1940), kirje 5.1.2000

Vuohelainen (ent. Oksanen) Merja-Hannele, kirje 30.11.1999

Internet-kotisivut:

http://www.eduskunta.fi

http://www.sdp.fi

\section{Kirjallisuus:}

Aatteet ja vaatteet. Suomen työväen henkinen perinne. Toim. Matti Hako, Heimo Huhtanen ja Matti Nieminen. Tammi. Helsinki 1964.

Ahti Martti, Salaliiton ääriviivat. Oikeistoradikalismi ja hyökkäävä idänpolitiikka 1918-1919. Weilin\&Göös. Helsinki 1987.

Ahtisaari Eeva, Hilda Käkikoski: opettaja, puhuja ja poliitikko naisen asialla. Teoksessa yksi kamari - kaksi sukupuolta. Suomen eduskunnan ensimmäiset naiset. Eduskunnan kirjaston tutkimuksia ja selvityksiä 4. Helsinki 1997, s. 213-241.

Ala-Kapee Pirjo-Valkonen Marjaana, Yhdessä elämä turvalliseksi. SAK:laisen ammattiyhdistysliikkeen kehitys vuoteen 1930. SAK ry. Helsinki 1982.

Alapuro Risto, Valta ja valtio - miksi vallasta tuli ongelma 1900-luvun vaihteessa. Teoksessa Talous, valta ja valtio. Tutkimuksia 1800 -luvun Suomesta. Toim. Pertti Haapala. Vastapaino. Tampere 1990, s. $237-$ 254.

Alapuro Risto, 50-luvun vapautuminen ja 60-luvun välttämättömyydet. Seminaariaineistot 20.3.93 ja 17.4 .93 pidetyistä seminaareista Kirjan talolla Helsingissä. Kansan Arkisto ja Työväen Keskusmuseo 1993, s. 2-7.

Alapuro Risto, Liikanen Ilkka, Kerstin Smeds (toim.), Kansa liikkeessä. Kirjayhtymä. Helsinki 1987.

Alfthan von Märta, Seitsemän vuosikymmentä Naisasialiitto Unionin historiaa. Joensuu 1966. 
Aurola Eelis, Suomen tehtaankoulut 1636-1881. Suomen Historiallinen Seura. Helsinki 1961.

Backman Wold.-Savonen Severi, Keuhkotaudin kulku Suomessa vuosina 1771-1929. Suomen tuberkuloosin vastustamisyhdistys. Helsinki 1934.

Bebel August, Naisten asema porvarillisessa ja sosialistisessa yhteiskunnassa. Osuuskunta Kehityksen r.l. Pori 1908.

Bebel August, Nainen ja yhteiskunnallinen kysymys. Kotka 1904.

Beck Ulrich, Politiikan uudelleen keksiminen: kohti refleksiivisen modernisaation teoriaa. Teoksessa Beck Ulrich, Giddens Anthony ja Lash Scott, Nykyajan jäljillä. Vastapaino. Tampere 1996, s. 11-82.

de Beauvoir Simone, Toinen sukupuoli. Ilmestynyt ranskankielisenä 1949. Kirjayhtymä. Helsinki 1981.

Blom Ida, Nation-Class-Gender. Scandinavia at the Turn of the Century. Scandinavian Journal of History, vol. 21, no 1. 1996, s. 1-16.

Bock Gisela, Antinatalism, maternity and paternity in National Socialist racism. Teoksessa Maternity\&Gender Policies, Women and the Rise of the European Welfare States 1880-1950. Ed. Gisela Bock and Pat Thane. London 1991.

Bock Gisela-Thane Pat, Maternity and paternity in National Socialist racism. London 1991.

Carlsson Christina, Kvinnosyn och kvinnopolitik. En studie av svensk socialdemokrati 1880-1910. Arkiv avhandlingsserie 25. Lund 1986.

Dahlerup Drude, Using Quotas to Increase Women's Political Representation. Teoksessa Women in Parlament: Beyond Numbers. International Institute for Demogracy and Electoral Assistance. Handbook Serie 2. Stockholm 1998, s. 91-105.

Degler Carl N., At Odds. Women and the Family in America from the Revolution to the Present. New York 1980.

Edwards Steward, The Paris Commune 1871. Eyre and Spottiswoode. London 1971.

Eerola Jari-Eerola Jouni, Henkilötappiot Suomen sisällissodassa 1918. Turenki 1998.

Ensi Kotien Liitto ry. 25 vuotta. Helsinki 1970.

Evans Richard J., Bourgeois Feminists and Women socialists in Germany 1894-1914. Lost Opportunity or Inevitable Conflict? Women's Studies Int. Quart. vol 3, 1980, p. 358-370.

Flood Hulda, Den socialdemokratiska kvinnorörelsen i Sverige. Tidens förlag. Stockholm 1939.

Giddens Anthony, Elämää jälkitraditionaalisessa yhteiskunnassa. Teoksessa Beck Ulrich, Giddens Anthony ja Lash Scott, Nykyajan jäljillä. Vastapaino. Tampere 1995, s. 83-152. 
Haapala Pertti, Tehtaan valossa. Teollistuminen ja työväestön muodostuminen Tampereella 1820-1920. Historiallisia tutkimuksia 133. Suomen Historiallinen Seura. Helsinki 1986.

Haaveista totta. Sosialidemokraattisten naisten saavutuksia 50-vuotisen toiminnan vaiheilta. Ensi Kotien Liitto ry., Koteja Vanhuksille ry. ja Äitien Lomahuolto ry. Turku 1955.

Haikala Sisko, Naiskysymys valistuksen vuosisadalla. Teoksessa Nainen historiassa. Toim. Auvo Kostiainen. Historian perintö 10. Turun yliopiston historian laitos. Turku 1985, s. 113-124.

Hall Stuart, Identiteetti. Vastapaino. Tampere 1999.

Hartmann Heidi, The Unhappy Marriage of Marxism and Feminism. Towards a More Progressive Union. Teoksessa Women and Revolution. Ed. Sargent Lydia. London 1981, p. 1-41.

Heinonen Visa, Talonpoikainen etiikka ja kulutuksen henki: kotitalousneuvonnasta kuluttajapolitiikkaan 1900-luvun Suomessa. Bibliotheca Historica 33. Suomen Historiallinen Seura. Helsinki 1998.

Heikinheimo Anna-Liisa, Työpalvelu toiveena ja todellisuutena. Teoksessa Me uskomme. Akateemisten Naisten Karjalaseuran 20-vuotisjulkaisu. Helsinki 1942.

Heikkilä Matti, Köyhyys ja huono-osaisuus hyvinvointivaltiossa. Tutkimus köyhyydestä ja hyvinvoinnin puutteiden kasaantumisesta Suomessa. Sosiaalihallituksen julk. 8/1990. Helsinki 1990.

Heinänen Aira, Lapsen tasa-arvoa tavoittelemassa. Ensi- ja turvakotien liiton historiikki 1945-1990. Ensi Kotien liiton julk. 13. Helsinki 1992.

Helsingin Ensi Koti 20 vuotta. Helsinki 1962.

Hentilä Marjaliisa, Keikkavaaka ja kousikka: kaupan työ ja tekijät 1800luvulta itsepalveluaikaan. Liikealan ammattiliitto. Edita. Helsinki 1999. Hentilä Marjaliisa, Maa jossa piiatkin saivat äänestää. Suomen työläisnaisliikkeen kuva kansainvälisessä lehdistössä 1906-1914. Teoksessa Tuntematon työläisnainen. Vastapaino. Tampere 1989 (a), s. 162-185. Hentilä Marjaliisa ja Lähteenmäki Maria, Kansainvälinen naistenpäivä 1910-1990. Työväen Arkiston julkaisuja 2. Helsinki 1990.

Hentilä Seppo, Suomen työläisurheilun historia 1. Työväen Urheiluliitto 1919-1944. Karisto. Hämeenlinna 1982.

Hentilä Seppo, Suomen työläisurheilun historia 2. Työväen Urheiluliitto 1944-1959. Karisto. Hämeenlinna 1984.

Hinkkanen Merja-Liisa ja Lintunen Maija, Aleksandra Gripenberg - taistelija ja kansainvälinen naisasianainen. Teoksessa Yksi kamari - kaksi sukupuolta. Eduskunnan kirjaston tutkimuksia ja selvityksiä 4. Helsinki 1997, s. 193-212.

Hirdman Yvonne, Genussystemet - reflexioner kring kvinnors sociala underordning. Kvinnovetenskaplig Tidskrift 3/1988, s. 49-63. 
Hobsbawm Eric, Nationalismi. Sivilisaatiohistoria-sarja. Vastapaino. Tampere 1994.

Hobsbawm Eric, Äärimmäisyyksien aika. 1900-luvun lyhyt historia. Otava. Helsinki 1999.

Hufton O., Women in Revolution 1789-1796. Past and Present 53/1971. Jallinoja Riitta, Suomalaisen naisasialiikkeen taistelukaudet. Naisasialiike naisten elämäntilanteen muutoksen ja yhteiskunnallis-aatteellisen murroksen heijastajana. WSOY. Helsinki 1983.

Joulumerkkikodit 1936-1973. Suomen Tuberkuloosin Vastustamisyhdistys ry. Helsinki 1982.

Jousimaa Kaarina, Jokainen lapsi on pelastettava elämälle. Ensi kotien liiton julk. 3. Helsinki 1983.

Kaarninen Mervi, Hedvig Gebhard: Pellervossa, parlamentissa ja puutarhassa. Teoksessa Yksi kamari - kaksi sukupuolta. Eduskunnan kirjaston tutkimuksia ja selvityksiä 4. Helsinki 1997, s. 177-192.

Kalemaa Kalevi, Sylvi-Kyllikki Kilpi. Sörnäisten tyttö. WSOY. Helsinki 1992.

Kansainvälinen Solidaarisuussäätiö 20 vuotta. Kehitysapua ihmiseltä ihmiselle. Toim. Jukka Pakkala. Helsinki 1990.

Katainen Elina, Akkain aherrusta aatteen hyväksi. Suomen Naisten Demokraattinen Liitto 1944-1990. Tampere 1994.

Katainen Elina - Oittinen Riitta, Naulaniskuja porvarin ruumiskirstuun: Mimmi Kanervo ja Sandra Lehtinen. Teoksessa Yksi kamari - kaksi sukupuolta. Eduskunnan tutkimuksia ja selvityksiä 4. Helsinki 1997, 81- 105 .

Kaukamaa L.I., Porin työväen järjestäytymispyrkimyksiä 1800-luvulla ennen elinkeinovapautta. Historiallinen Arkisto XLV. Helsinki 1939.

Keskinen Tuomas, Aika sotia - aika sopia. Väinö Leskinen 1917-1972. Tammi. Helsinki 1978.

Kettunen Pauli, Poliittinen liike ja sosiaalinen kollektiivisuus. Tutkimus sosialidemokratiasta ja ammattiyhdistysliikkeestä Suomessa 1918-1930. Historiallisia tutkimuksia 138. Suomen Historiallinen Seura. Helsinki 1986.

Kilpi Sylvi-Kyllikki, Espanjan lasten auttaminen sisällissodan aikana. teoksessa Huomenen tiellä. Suomen työläisnaisliikkeen 60-vuotisjuhlakirja. Suomen Naisten Demokraattinen Liitto. Helsinki 1960, s. 132143.

Kilpi Sylvi-Kyllikki, Suomen työläisnaisliikkeen historia. Kansankulttuuri oy. Pori 1953.

Kilpi Sylvi-Kyllikki, Sörnäisten tytön vaellusvuodet. Helsinki 1965.

Kilpi Sylvi-Kyllikki, Hilja Pärssinen. Teoksessa Tiennäyttäjät 1. Suomen työväenliikkeen merkkimiehiä Ursinista Tanneriin. Tammi. Helsinki 1967. s. 121-162. 
Kilpi Sylvi-Kyllikki-Sinervo Aira, Sosialidemokraattisten naisten valtiollinen toiminta. Helsinki 1937.

Kiuru Sakari, Taakan tasaaja. Alli Lahtinen pohtijana ja päättäjänä 19261976. Painatuskeskus. Helsinki 1994.

Klemettilä Aimo, Tampereen punakaarti ja sen jäsenistö. Acta Universitatis Tamperensis. Ser. A:72. Tampere 1976.

Klinge Matti, Kaksi Suomea. Otava. Helsinki 1982.

Koivisto Juha, Mäki Markku ja Uusitupa Timo, Mitä on valistus? Vastapaino. Tampere 1995.

Koonz Claudia, Mothers in the Fatherhood. Women, the Family and Nazi Politics. New York 1986.

Koskinen Pirkko K., Äänioikeuden lainsäädäntöhistoriaa. Teoksessa Yksi kamari - kaksi sukupuolta. Eduskunnan kirjaston tutkimuksia ja selvityksiä 4. Helsinki 1997, s. 26-41.

Koskinen Seppo-Martelin Tuija, Kuolleisuus. Teoksessa Suomen väestö. Gaudeamus. Helsinki 1994, s. 150-225.

Kujala Antti, Venäjän hallitus ja Suomen työväenliike 1899-1905. Historiallisia tutkimuksia 194. Suomen Historiallinen Seura. Helsinki 1995.

Kuusinen Hertta, Kuolemaan tuomitut - Sofia Hjulgren ja Martta Koskinen. Teoksessa Huomenen tiellä. Suomen työläisnaisliikkeen 60vuotisjuhlakirja. Suomen Naisten Demokraattinen Liitto. Helsinki 1960, s. 149-157.

Kuusipalo Jaana, Naisena politiikan huippupaikoille: naisedustus Suomen hallituksissa ja naisministerien poliittinen ura vuosina 1926-1986. Tampereen yliopiston sosiologian ja sosiaalipsykologian laitoksen tutkimuksia. Sarja A. Tampere 1989.

Kuusipalo Jaana, Suomalaiset naiset politiikassa. Teoksessa Suomalainen nainen. Otava. Helsinki 1999, s. 55-78.

Lehtinen Lasse, Työläjärvi, tasavallan tahtonainen. Naispoliitikon muotokuva. WSOY. Helsinki 1982.

Lehto Anna-Maija, Naiset Suomen työelämässä. Teoksessa Suomalainen nainen. Otava. Helsinki 1999, s. 101-128.

Lehto Anna-Maija-Sutela Hanna, Gender Equality in Working Life. Labour Market 1999:22. Statistics Finland. Helsinki 1999.

Lehto Marja, Feminismi ja sosialismi. Tietosisko 1/1980.

Leivo-Larsson Tyyne, Elämässä tapaa ja tapahtuu. Weilin \& Göös. Helsinki 1970.

Lerner Gerda, The Lady and the Mill Girl: Changes in the Status of Women in the Age of Jackson. Miscontinent American Studies Journal $10 / 1969$.

Liikanen Ilkka, Fennomania ja kansa. Joukkojärjestäytymisen läpimurto ja Suomalaisen puolueen synty. Historiallisia tutkimuksia 191. Suomen Historiallinen Seura. Helsinki 1995. 
Liljeström Marianne, Emanciperade till underordning: det sovjetiska könssystemets uppkomst och diskursiva reproduktion. Åbo Akademis förlag. Åbo 1995.

Lovenduski Joni-Norris Pippa (ed.), Gender and Party Politics. SAGE Publications. London 1993.

Lumme Terhi, Naiskysymyksestä Marxin ja Engelsin ajattelussa. Teoksessa Nainen, järki ja ihmisarvo. Helsinki 1986, s. 295-349.

Lähteenmäki Maria, Jänkäjääkäreitä ja parakkipiikoja. Lappilaisten sotakokemuksia 1939-45. Historiallisia tutkimuksia 203. Suomen Historiallinen Seura. Helsinki 1999.

Lähteenmäki Maria, Mahdollisuuksien aika. Työläisnaiset ja yhteiskunnallinen muutos 1910-30-luvun Suomessa. Bibliotheca Historica 2. Suomen Historiallinen Seura. Helsinki 1995.

Lähteenmäki Maria, Maria Paaso Laine - peloton peräpohjalainen. Teoksessa Yksi kamari - kaksi sukupuolta. Eduskunnan tutkimuksia ja selvityksiä 4. Helsinki 1997, s. 106-121.

Lähteenmäki Maria, "Pohjoinen mallimaa", Suomen työläisnaisliikkeen kansainvälistyminen. Teoksessa Tuntematon työläisnainen. Vastapaino. Tampere 1989, s. 140-161.

Lähteenmäki Maria, Poliittinen kotitalous. Työläisnaisliikkeen kotitalouspoliittisen ohjelman muotoutuminen 1920-luvun Suomessa. Teoksessa Jännittävä työväenhistoria. Prof. Hannu Soikkasen 60vuotisjuhlakirja. Työväen Arkiston julkaisuja 3. Helsinki 1990.

Lähteenmäki Maria, Taudin merkitsemä pohjoinen perhe. Tuberkuloosin ehkäisy rahvaan elämäntapojen muokkaajana. Teoksessa Keulakuvia ja peränpitäjiä: Vanhan ja uuden yhteiskunnan rajalla. Professori Yrjö Kaukiaisen 60-vuotisjuhlakirja. Suomen Historiallinen Seura. Helsinki 2000, s. 147-162.

Lähteenmäki Maria, Yrittäjä ja työväenjohtaja Ida Aalle-Teljo. Teoksessa Yksi kamari - kaksi sukupuolta. Eduskunnan kirjaston tutkimuksia ja selvityksiä 4. Helsinki 1997, s. 63-80.

Markkola Pirjo, Anni Huotari työläisäitien edustajana. Teoksessa Yksi kamari - kaksi sukupuolta. Eduskunnan kirjaston tutkimuksia ja selvityksiä 4. Helsinki 1997, s. 145-162.

McDermid Jane, Midwifes of the revolution: female Bolsheviks and women workers in 1917. UCL Press. London 1999.

Mäkikossa Oma, Yhteiskunnalle omistettu elämä. Miina Sillanpään elämä ja työn vaiheita. Helsinki 1947.

Nainen sodassa, kotona ja rintamalla 1939-1945 Suomen vapauden puolesta. Valitut Palat. Helsinki 1995.

Naisen työ. Sosialidemokraattisen naisliikkeen 80 -vuotisjuhlakirja. Sosialidemokraattiset Naiset. Helsinki 1980.

Naiset ja Sosialidemokratia Suomessa. 25-vuotismuisto. Helsinki 1925. 
Nenola Aili, Parantolaelämää: Tuberkuloosipotilaat muistelevat. Keuhkovammaliitto ry. Helsinki 1986.

Niggemann Heintz, Emanzipation zwischen Sozialismus und Feminismus. Die Sozialdemokratische Frauenbewegung im Keiserreich. Wuppertal Hammer 1981.

Ollila Anne, Suomen kotien päivä valkenee...Marttajärjestö suomalaisessa yhteiskunnassa vuoteen 1939. Historiallisia tutkimuksia 173. Suomen Historiallinen Seura. Helsinki 1993.

Paaso Maria, Lastenkasvatustyö työväenliikkeessä. Kirjassa Naiset ja Sosialidemokratia. 25-vuotismuisto. Helsinki 1925, s. 71-103.

Paavolainen Jaakko, Poliittiset väkivaltaisuudet Suomessa 1918: valkoinen terrori. Helsinki 1967.

Palmunen Ritva, Aitan polulta yhteiskunnalliseksi vaikuttajaksi. Keskustalaisen naisliikkeen toimintaa 1906-1985. Suomen Keskustanaiset ry. Helsinki 1992.

Perheellisyyden vaikutus naisten työsuhteeseen. Sosiaalinen Aikakauskirja 1946, s. 376-386.

Piilonen Juhani, Women's Contribution to Red Finland 1918. Scandinavian Journal of History 13/1988, s. 39-48.

Pohls Maritta, Suvuista virkoihin. Postilaitoksen virkakunta 1864-1899. Hallintohistoriakomitea. Painatuskeskus. Helsinki 1994.

Porter Cathy, Women in revolutionary Russia. Cambridge University Press. Cambridge 1988.

Pulma Panu, Kerjuuluvasta perhekuntoutukseen. Teoksessa Pulma Panu ja Turpeinen Oiva, Suomen lastensuojelun historia. Lastensuojelun Keskusliitto. Helsinki 1987, s. 7-266.

Pylkkänen Anu, Puoli vuodetta, lukot ja avaimet: nainen ja maatalous oikeuskäytännön valossa 1660-1710. Lakimiesliiton kustannus. Helsinki 1990.

Rajainen Maija, Naisliike ja sukupuolimoraali. Keskustelua ja toimintaa 1800-luvulla ja nykyisin vuosisadan alkupuolella noin vuoteen 1918 saakka. Suomen Kirkkohistoriallisen Seuran toimituksia 91. Suomen Kirkkohistoriallinene Seura. Helsinki 1973.

Ramsay Alexandra, Huvudstadens hjärta. Filantropi och social förändring i Helsingfors - twå fruntimmersföreningar 1848-1865. Bidrag till kännedom av Finlands natur och folk 144. Finska VetenskapsSocieteten. Helsingfors 1993.

Reini Jorma, Pispalasta Bulevardille. Toim. Jukka-Pekka Pietiäinen. Edita. Helsinki 1996.

Räisänen Arja-Liisa, Onnellisen avioliiton ehdot. Sukupuolijärjestelmän muodostumisprosessi suomalaisissa avioliitto- ja seksuaalivalistusoppaissa 1865-1920. Bibliotheca Historica 6. Suomen Historiallinen Seura. Helsinki 1995. 
Saarela Tauno, Suomalaisen kommunismin synty 1918-1923. Kansan Sivistystyön Liitto. Helsinki 1996.

Sainsbury Diane, The Politics of Increased Women's Representation: the Swedish Case. Teoksessa Gender and Party Politics. Ed. Joni Lovenduski\&Pippa Norris. SAGE Publications. London 1993, s. $263-$ 290.

Salkola Marja-Leena, Työväenkaartien synty ja kehitys punakaartiksi 1917-18 ennen kansalaissotaa I. Punaisen Suomen historia. Helsinki 1985.

Salmela Martta, Muistelmia Ihanneliitosta. Kirjassa Naiset ja Sosialidemokratia Suomessa. 25-vuotismuisto. Helsinki 1925, s. 101-103.

Salmela-Järvinen Martta, Alas lyötiin vanha maailma. Muistikuvia ja näkymiä vuosilta 1906-1918. WSOY. Helsinki 1966.

Salmela-Järvinen Martta, Kaikissa meissä vikaa on. Muistikuvia ja näkymiä vuosilta 1939-1959. WSOY. Helsinki 1968.

Salmela-Järvinen Martta, Miina Sillanpää - legenda jo eläessään. WSOY. Helsinki 1973.

Saraste Erja, Työvoimapolitiikka sodan ja rauhan kriisissä. Teoksessa Suomi 1944. Toim. Jukka Nevakivi. Helsinki 1984.

Schulz H., Äiti kasvattajana. Käytännöllisiä kasvatusneuvoja köyhälistön äideille. Helsinki 1908.

Scott Joan-Tilly Louise, Women, Work, Family. New York 1978.

Shorter Edward, Women's Work - What Difference Did Capitalism Make? Theory and Society 3/1975, p. 513-527.

Shvedova Nadezhda, Obstacles to Women's Participation in Parlament. Teoksessa Women in Parlament: Beyond Numbers. International Institute for Demogracy and Electoral Assistance. Handbook Serie 2. Stockholm 1998, s. 19-40.

Siisiäinen Martti, Suomalainen protesti ja yhdistykset. Tutkijaliitto. Helsinki 1990.

Sirén Kirsi, Suuresta suvusta pieneen perheeseen. Itäsuomalainen perhe 1700-luvulla. Bibliotheca Historica 38. Suomen Historiallinen Seura. Helsinki 1999.

Skog Emil, Veljet vastakkain. WSOY. Helsinki 1974.

Soikkanen Hannu, Kansalaissota dokumentteina 2. Valkoista ja punaista sanankäyttöä 1917-18. Helsinki 1969.

Soikkanen Hannu, Kohti kansanvaltaa 1. SDP 1889-1937. Suomen Sosialidemokraattinen puolue. Vaasa 1975.

Soikkanen Hannu, Kohti kansanvaltaa 2. SDP 1937-1944. Suomen Sosialidemokraattinen Puolue. Helsinki 1987.

Soikkanen Hannu, Kohti kansanvaltaa 3. SDP 1944-1952. Suomen Sosialidemokraattinen Puolue. Helsinki 1991. 
Soikkanen Hannu, Leivo-Larsson Tyyne Lilja (1902-1979). Suomen Kansallisbiografia. Näytevihko. Suomen Historiallinen Seura. Helsinki 1994, s. 68-71.

Soikkanen Hannu, Sosialismin tulo Suomeen: ensimmäisiin yksikamarisen eduskunnan vaaleihin asto. WSOY. Helsinki 1961.

Sorsa Kalevi, Muistikuvia, mielikuvia. Otava. Helsinki 1995.

Sorsa Kalevi, Sisäänajo. Politiikan kuvioita 1969-72. Otava. Helsinki 1998.

Sosialidemokraattisten Naisten Keskusliitto 10 vuotta. Hämeenlinna 1969.

Sota sotaa vastaan! Suomen Sadankomiteanliitto ry. Hämeenlinna 1973.

Stites Richard, The Russian Revolution and Women. Teoksessa Connecting Spheres. Ed. Boxer M. and Quantaert J. New York 1987, s. 246255.

Sukupuolet EU:n työmarkkinoilla. Sosiaali- ja terveysministeriö. Tasaarvojulkaisuja 1999:2. Helsinki 1999.

Sulkunen Irma, Naisen kutsumus. Miina Sillanpää ja sukupuolten maailmojen erkaantuminen. Hanki ja Jää. Helsinki 1989.

Sulkunen Irma, Naisten järjestäytyminen ja kaksijakoinen kansalaisuus. Teoksessa Kansa liikkeessä. Toim. Risto Alapuro, Ilkka Liikanen, Kerstin Smeds ja Henrik Stenius. Kirjayhtymä. Helsinki 1987, s. 157-172.

Sundberg J., Women in Scandinavian party organizations. Teoksessa Women in Nordic Politics. Ed. L. Karvonen, and P. Selle. Dortmouth 1995.

Suomen työväenliikkeen historia. Toim. Lauri Haataja, Seppo Hentilä, Jorma Kalela ja Jussi Turtola. Työväen Sivistysliitto. Helsinki 1978.

Suonoja Kyösti, Kuluttajat rakentavat 1. KK:lainen osuuskauppaliike 1916-1939. Helsinki 1966.

Sysiharju Anna-Liisa, Työtytöt. Naisten vapaaehtoinen työpalvelu 194045. Edita. Helsinki 1997.

Tanner Väinö, Kahden maailmansodan välissä. Muistelmia 20-30-luvuilta. Tammi. Helsinki 1966.

Tasa-arvon tiennäyttäjä. Tavoitteita, tuloksia, tuokiokuvia 1972-1997. Tasa-arvoasiain neuvottelukunta. Helsinki 1997.

Thompson E. P., Harvojen valta ja rahvaan kulttuuri. Gaudeamus. Helsinki 1996.

Tiainen Hannes, Kun puolue räjähti. Tammi. Helsinki 1968.

Tikka Marko-Arponen Antti, Koston kevät. Lappeenrannan teloitukset 1918. WSOY. Helsinki 1999.

Tuntematon työläisnainen. Toim. Leena Laine ja Pirjo Markkola. Vastapaino. Tampere 1989.

Tunkelo A., Naimisissa olevat naiset ammatinharjoittajaina. Tilastokatsauksia N:o 10. Helsinki 1933. 
Tuominen Marja, Kaikkihan me olemme sotilaiden lapsia. Otava. Helsinki 1991.

Tuomisto Tero, Tienraivaajan osa. Sata vuotta Helsingin Työväenyhdistyksen historiaa 1884-1984. Helsinki 1984.

Työn naisen juhlavuosi. Sosiaalidemokraattinen Työläisnaisliitto. Helsinki 1950.

Uranuurtajan tie. Otteita Ida Aalle-Teljon elämästä. Sos.dem. Naisliitto. Helsinki 1955.

Valkonen Marjaana-Ala-Kapee Pirjo, Naiset SAK:laisessa ammattiyhdistysliikkeessä. Suomen Ammattiliittojen Keskusjärjestö. Helsinki 1980.

Vanhus - lähimmäinen. Vanhus- ja Lähimmäispalvelun Liiton julk. no 1/1982. Helsinki 1982.

Vattula Kaarina, Palvelustytöstä konttoristiin - naisten työhönosallistuminen 1880-1940. Teoksessa Kun yhteiskunta muuttuu. Historiallinen Arkisto 76. Helsinki 1981.

Viitoitettu tie. Naisten Raittiuskeskus. Helsinki 1951.

Voionmaa Väinö, Kuriiripostia 1941-46. Tammi. Helsinki 1971.

Walby Sylvia, Patriarchy at Work. Patriarchal and Capitalist Relations in Employment. Polity press 1986.

Waris Elina, Yksissä leivissä. Ruokolahtelainen perhelaitos ja yhteisöllinen toiminta. Bibliotheca Historica 48. Suomen Historiallinen Seura. Helsinki 1999.

Wilkama Sisko, Naissivistyksen periaatteiden kehitys Suomessa 1840 1880-luvuilla. Pedagogis-aatehistoriallinen tutkimus. Historiallisia tutkimuksia XXIII. Suomen Historiallinen Seura. Helsinki 1938.

Women and socialism/Socialism and women. Europe between the two worlds wars. Edited by Helmut Gruber \& Pamela Graves. Berghahn Books. New York 1998.

Women, state and revolution : essays on power and gender in Europe since 1789. Ed. by Sian Reynolds, Wheatsheaf. Brighton 1986.

Wood Elizabeth A., The baba and the comrade: gender and politics in revolutionary Russia. Indiana University Press. Bloomington 1997.

Yksi kamari-kaksi sukupuolta. Suomen eduskunnan ensimmäiset naiset. Toim. Maria Lähteenmäki, Pirjo Markkola ja Alexandra Ramsay. Eduskunnan kirjaston tutkimuksia ja selvityksiä 4. Eduskunnan kirjasto. Helsinki 1997.

Äitien lomahuolto 20 vuotta. Helsinki 1971.

50 vuotta Suomen naisten yhteistyötä. Suomen Naisjärjestöjen Keskusliiton ja sen jäsenjärjestöjen toimintaa 1911-1961. Ekenäs 1961. 


\section{Liiteosa}

Liite 1: Sosialidemokraattisen naisliiton puheenjohtajat ja sihteerit

Liite 2: Sosialidemokraattisen naisliiton jäsenmääriä $\quad 304$

Liite 3: Sosiaalidemokraattisten naisten lehdet 308

Liite 4: Sosiaalidemokraattisten naisten järjestöjen eriytyminen

Liite 5: Sosiaalidemokraattisten naisten

kansainvälisiä ja pohjoismaisia kokouksia

Liite 6: Naisten asemaa koskevia lakeja ja asetuksia 314

Liite 7: Tapahtumakalenteri 


\section{Liite 1}

Sosialidemokraattisen naisliiton puheenjohtajat ja sihteerit

Sosialidemokraattisen naisliiton puheenjohtajat ja sihteerit vuosina 1900-1979

$\begin{array}{lr}\text { Puheenjohtaja } & \\ \text { Ida Ahlsted } & 1900-02 \\ \text { Hilja Pärssinen } & 1902-05 \\ \text { Anni Huotari } & 1905-06 \\ \text { Hilja Pärssinen } & 1906-07 \\ \text { Mimmi Puolakka } & 1907-09 \\ \text { Sandra Lehtinen } & 1909-13 \\ \text { Miina Sillanpää } & 1913-16 \\ \text { Ida Aalle-Teljo } & 1916-18 \\ \text { Elin Fagerholm } & 1918-20 \\ \text { Miina Sillanpää } & 1921-32 \\ \text { Anni Huotari } & 1932-41 \\ \text { Sylvi-Kyllikki Kilpi } & 1941-46 \\ \text { Miina Sillanpää } & 1946-47 \\ \text { Tyyne Leivo-Larson } & 1947-59 \\ \text { Martta Salmela-Järvinen } & 1959-65 \\ \text { Tyyne Leivo-Larsson } & 1965-75 \\ \text { Fanni Front } & 1975-79\end{array}$

Sihteeri

$\begin{array}{lr}\text { Maria Laine } & 1900-02 \\ \text { Anni Huotari } & 1902-05 \\ \text { Hilja Pärssinen } & 1905-06 \\ \text { Jenny Kilpiäinen } & 1906-07 \\ \text { Aura Kiiskinen } & 1907-13 \\ \text { Hilda Herrala } & 1913-14 \\ \text { Aino Pesonen } & 1914-16 \\ \text { Sandra Lehtinen } & 1916-18 \\ \text { Lyyli Eronen } & 1918-19 \\ \text { Hilda Seppälä } & 1919-32 \\ \text { Miinä Sillanpää } & 1932-36 \\ \text { Martta Salmelä-Järvinen } & 1936-53 \\ \text { Anu Karvinen } & 1953-59 \\ \text { Aune Seme } & 1959-63 \\ \text { Anu Karvinen } & 1963-68 \\ \text { Leila Lindberg } & 1968-70\end{array}$


Riitta-Anneli Lainio

1970-72

Leila Viitamäki

1972-73

Outi Nurmi

1973-76

Pirjo Ojanen

1976-78

Tuulikki Kannisto

1978-79

Sosialidemokraattisten Naisten Keskusliiton puheenjohtajat ja sihteerit vuosina 1959-1979

Puheenjohtaja

Sylvi Siltanen

1959-72

Meeri Kalavainen

1972-79

Sihteeri

Taimi Rinne-Virolainen 1959-72

Sinikka Luja-Vepsä $\quad$ 1972-78

Marianne Laxén 1978-79

Sosialidemokraattiset Naiset, puheenjohtajat ja sihteerit vuodesta 1979-

Puheenjohtaja

Meeri Kalavainen 1979-84

Vappu Taipale 1984-90

Liisa Jaakonsaari $\quad$ 1990-98

Tarja Filatov 1999-

Pääsihteeri

Marianne Laxén 1979-88

Tuula Haatainen 1988-97

Marja-Liisa Kiljunen 1998- 


\section{Liite 2}

Sosialidemokraattisen naisliiton jäsenmääriä

Sosialidemokraattisen naisliiton jäsenet 1900-1940

\begin{tabular}{lrrrrr} 
Vuosi & \multicolumn{3}{c}{ Naisliitossa } & \multicolumn{3}{c}{ Puolueessa } \\
& $1 \mathrm{~km}$ & os. & $\%$ & 109 & $\%$ \\
1899 & & & & 1009 & 11 \\
1900 & 353 & 21 & 22 & 1607 & 18 \\
1901 & 353 & 21 & 33 & 1063 & 18 \\
1902 & 353 & 29 & 24 & 1496 & 22 \\
1903 & 1398 & 29 & 46 & 3013 & 23 \\
1904 & 834 & 32 & 21 & 3895 & 23 \\
1905 & 2404 & 36 & 25 & 9575 & 21 \\
1906 & 2440 & 39 & 13 & 18986 & 22 \\
1907 & 2724 & 106 & 14 & 18876 & 23 \\
1908 & 2255 & 81 & 13 & 16828 & 24 \\
1909 & 1194 & 53 & 8 & 14694 & 25 \\
1910 & 1081 & 46 & 9 & 12223 & 24 \\
1911 & 1509 & 64 & 13 & 11316 & 23 \\
1912 & 1244 & 61 & 11 & 11649 & 23 \\
1913 & 1556 & 75 & 13 & 12280 & 23 \\
1914 & 1459 & 82 & 14 & 10646 & 21 \\
1915 & 1396 & 72 & 13 & 10857 & 21 \\
1916 & 1537 & 69 & 10 & 14874 & 21 \\
1917 & 3772 & 121 & & & \\
1918 & & & & & \\
1919 & 2548 & 81 & 13 & 19320 & 29 \\
1920 & & & & 14710 & 30 \\
1921 & 1285 & 51 & 13 & 10030 & 27 \\
1922 & 1487 & 49 & 17 & 8747 & 28 \\
1923 & 1496 & 48 & 20 & 7482 & 27 \\
1924 & 1525 & 52 & 22 & 6933 & 28 \\
1925 & 1567 & 57 & 21 & 7401 & 27 \\
1926 & 2037 & 61 & 20 & 10133 & 27 \\
1927 & 2157 & 70 & 24 & 9070 & 26 \\
1928 & 2214 & 79 & 24 & 9350 & 26 \\
1929 & 1848 & 71 & 21 & 8708 & 26 \\
1930 & 1963 & 70 & 27 & 7325 & 26 \\
1931 & 1930 & 72 & 28 & 6825 & 25 \\
1932 & & & & 6558 & 26 \\
1933 & & & & 6338 & 26
\end{tabular}




$\begin{array}{llllll}1934 & & & & 6392 & 25 \\ 1935 & 2609 & 141 & 35 & 7510 & 27 \\ 1936 & 2954 & 152 & 37 & 8002 & 27 \\ 1937 & 3022 & 169 & 34 & 8810 & 27 \\ 1938 & 3987 & 136 & 42 & 9477 & 26 \\ 1939 & 3219 & 116 & 37 & 8669 & 26 \\ 1940 & 2842 & 110 & 44 & 6459 & 26\end{array}$

Lähde: Lähteenmäki Maria, Mahdollisuuksien aika. Työläisnaiset ja yhteiskunnan muutos 1920-30-luvun Suomessa. Bibliotheca Historica 2. Suomen Historiallinen Seura. Helsinki 1995, s. 331; Tilastosta näkyy 1930-luvun alun katkos liiton sihteerin Hilda Seppälän kuolemantapauksen takia.

Sosialidemokraattisen naisliiton jäsen-, yhdistys- ja jaosmäärät vuosina 1941-1959

$\begin{array}{lccc}\text { Vuosi } & \text { Jäsenmäärä } & \text { Yhdistyksiä } & \text { Jaostoa } \\ 1941 & 3171 & 42 & 129 \\ 1942 & 2942 & 43 & 133 \\ 1943 & 3205 & 42 & 134 \\ 1944 & 3507 & 43 & 135 \\ 1945 & 5200 & 43 & 152 \\ 1946 & 7307 & 47 & 183 \\ 1947 & 8761 & 49 & 172 \\ 1948 & 10852 & 52 & 219 \\ 1949 & 11189 & 53 & 230 \\ 1950 & 11669 & 53 & 280 \\ 1951 & 12026 & 53 & 341 \\ 1952 & 12307 & 54 & 368 \\ 1953 & 11498 & 55 & 396\end{array}$


Sosialidemokraattisen naisliiton jäsenmäärä vuosina 1959-1979

Vuosi Jäsenmäärä Yhdistyksiä Järjestöä

$1961 \quad 10500$

1962

1963

$1964 \quad 7800 \quad 76$

1965

1966

$1967 \quad 7300 \quad 72$

1968

1969

$1970 \quad 6100 \quad 60$

1971

1972

1973

$1974 \quad 5700 \quad 57$

1975

1976

1977

$1978 \quad 5800$

47

Sosialidemokraattisten Naisten Keskusliiton jäsenet vuosina 1959-1979

$\begin{array}{lll}1959 & 13500 & 307 \\ 1960 & & 331 \\ 1961 & & \\ 1962 & 23300 & 340 \\ 1963 & & 345 \\ 1964 & & \\ 1965 & 28800 & \\ 1966 & & 364 \\ 1967 & & \\ 1968 & 24100 & \\ 1969 & & 414 \\ 1970 & & 400 \\ 1971 & 27200 & \\ 1972 & & \\ 1973 & & \\ 1974 & 24600 & \\ 1975 & & \\ 1976 & & \\ 1977 & 21700 & \\ 1978 & & \\ 06 & & \end{array}$


*Vuosien 1961-1978 jäsenmäärä on arvioitu edustajakokousten perusteella siten, että liiton kukin järjestö on oikeutettu lähettämään edustajakokoukseen 1:n edustajan/alkavaa 100:n jäsenen määrää kohti, paitsi Sos.Dem.Naisten Keskusliiton vuoden 1959 kokouksen osalta, jolloin yhden edustajan sai lähettää jokaista alkavaa 50 jäsenen määrää kohti. Jäsenmäärä on laskettu edellisen vuoden viimeiseltä neljännekseltä.

LÄHTEET: Sosialidemokraattisen Naisliiton toimintakertomukset 1941-1953, toimintasuunnitelmia, tilannekatsauksia 1941-1953, Liittokokouspöytäkirjat 1959-1979, toimintasuunnitelmia 1979-1984. Työväen Arkisto. 


\section{Liite 3}

Sosiaalidemokraattisten naisten lehdet

- Sosialidemokraattisen naisliiton lehdet

\begin{tabular}{|c|c|c|}
\hline Lehti & \multicolumn{2}{|c|}{$\begin{array}{l}\text { Ilmestymis- Vuosi:Numeroa } \\
\text { vuodet }\end{array}$} \\
\hline Yhteistyöhön & 1902 & näytenumero \\
\hline Kevätesikoinen & 1904 & näytenumero \\
\hline Kansan nainen & 1906 & näytenumero \\
\hline Palvelijatar & $1905-06$ & $1905: 16,1906: 20$ \\
\hline Työläisnainen & $1906-14$ & $1906: 1,1907-13$ : noin 50, 1914:29 \\
\hline & $1920-22$ & 1920-22: n. 10-20 \\
\hline Ihanne & $1908-14$ & $1908-13: 12,1914: 14$ \\
\hline Toveritar & $1922-43$ & $1922-23: 12,1924-43:$ n.24 \\
\hline Tulevaisuus & $1944-73$ & $\begin{array}{l}1944-47: \text { n.24, 1948-64:12, 1965- } \\
67: 4,1968-70: 12,1971-73: 4\end{array}$ \\
\hline Järjestönainen & $1946-1966$ & 1946-66: n.4 \\
\hline
\end{tabular}

- Sosialidemokraattisten Naisten Keskusliiton äänenkannattajat

Naisten Viesti 1960-66, 1960-66:4, 1974: n.2

Aikamme Kuvastin $\quad 1962-66 \quad 1962: 1,1963-66: 12$

Sosialidemokraattisten Naisten äänenkannattajat

$\begin{array}{lll}\text { Tietosisko } & 1980- & 1980-: 4 \\ \text { Pikkusisko } & 1984- & 1984-91: 8 \\ \text { Punahilkka } & 1991- & 1991-: 2\end{array}$




\section{Liite 4}

Sosialidemokraattisten naisten järjestöjen eriytyminen

Sosiaalidemokraattiset naiset aviottomien äitien ja lasten puolesta

1929 Päätettiin turvakotien perustamisesta

1936 Työläisäitien ja Lasten Kotiyhdistys

1942 Helsingin Ensi Koti

1945 Ensi Kotien Liitto

1987 Nimeksi Ensi- ja Turvakotien Liitto

Lisäksi:

1932 Työväen Kukkasrahasto (keräsi varoja toimintaa varten)

Sosiaalidemokraattisten naisten vanhusten huolto-organisaation kehitys

1938 Käpyrinteen Vanhainkodin Kannatusyhdistys ry.

1951 Vanhusten Huolto ry.

1953 Koteja Vanhuksille ry., perustajina Vanhusten Huolto ry. ja maan muut vanhainkotien kannatusyhdistykset

1981 Nimeksi Vanhus- ja lähimmäispalvelun liitto ry.

Lisäksi:

1957 Vanhusten kotiapu ry.

Sosiaalidemokraattisten naisten kotitalousvalistus

1924-1957 Sos.dem. Työläisnaisliiton kodinhoitokurssit ja kotitalousjaosto

1957 Kotineuvontaliitto ry.

1979 Nimeksi Kuluttajaneuvontaliitto

1987 Nimeksi Suomen Kuluttajaliitto 
Sosiaalidemokraattisten naisten äitien ja lasten lomatoiminta

1901 Ensimmäiset lomakotien kannatusyhdistykset perustettiin

1951 Äitien Lomahuolto

1981 Nimeksi Lomakotien Liitto

Muita sosiaalidemokraattisten naisten järjestöjä

1902-1912 Ihanneliitto

1962 Kotien Puolesta Keskusliitto 


\title{
Liite 5
}

Sosiaalidemokraattisten naisten kansainvälisiä ja pohjoismaisia kokouksia
Aika
Paikka

SOSIALISTISEN INTERNATIONAALIN NAISTEN EDUSTAJAKOKOUKSET 1907-1986

\section{SOSIALISTISTEN NAISTEN KANSAINVÄLINEN SIHTEERISTÖ}

\author{
1907 I Edustajakokous Stuttgart \\ 1910 II Edustajakokous Kööpenhamina \\ 1915 III Edustajakokous Bern
}

KANSAINVÄLISET SOSIALISTISTEN NAISTEN EDUSTAJAKOKOUKSET
1923 I Edustajakokous Hampuri
1925 II Edustajakokous Marseille
1928 III Edustajakokous Bryssel
1931 IV Edustajakokous Wien

KANSAINVÄLISET SOSIALISTISTEN NAISTEN EDUSTAJAKOKOUKSET II MAAILMANSODAN JÄLKEEN
1948 I Edustajakokous Wien
1950 II Edustajakokous Kööpenhamina
1951 III Edustajakokous Frankfurt am Main
1952 IV Edustajakokous Milano
1953 V Edustajakokous Tukholma

SOSIAALIDEMOKRAATTISTEN NAISTEN KANSAINVÄLISEN NEUVOSTON EDUSTAJAKOKOUKSET
1955 I Edustajakokous Lontoo
1957 II Edustajakokous Wien
1959 III Edustajakokous Hampuri
1961 IV Edustajakokous Rooma
1963 V Edustajakokous Amsterdam
1966 VI Edustajakokous Tukholma
1969 VII Edustajakokous Eastbourne
1972 VIII EdustajakokousWien
1976 IX Edustajakokous Geneve
1978 X Edustajakokous Vancouver 
1980 XI Edustajakokous Madrid

1983 XII Edustajakokous Albufeira

1986 XIII Edustajakokous Lima

\section{KANSAINVÄLISIÄ KOKOUKSIA}

\begin{tabular}{|c|c|c|}
\hline 1912 & Basel & $\begin{array}{l}\text { Kansainvälisen sosialistikongressin yhteydessä } \\
\text { naiskokous }\end{array}$ \\
\hline 1920 & Washington & Työläisnaisten kansainvälinen kongressi \\
\hline 1926 & Zürich & $\begin{array}{l}\text { Sosialistisen Työläisinternationaalin (STI) } \\
\text { toimeenpaneva valiokunta }\end{array}$ \\
\hline 1926 & Bryssel & STI:n naiskomitea \\
\hline 1927 & Köln & STI:n naiskomitea \\
\hline 1927 & Pariisi & STI:n naiskomitea \\
\hline 1930 & Zürich & STI:n kongressi \\
\hline 1931 & Zürich & STI \\
\hline 1932 & Zürich & STI \\
\hline 1933 & Pariisi & STI:n naissihteeristö \\
\hline 1934 & Bryssel & STI:n \\
\hline 1949 & Amsterdam & Sosialistinen Internationaalin (SI) naissihteeristö \\
\hline 1949 & Baarn & SI \\
\hline 1951 & Lontoo & SI \\
\hline 1953 & Bryssel & SI:n naissihteeristö \\
\hline 1954 & Antwerpen & SI:n toimintaa uudelleen järjestävä kokous \\
\hline 1954 & Wien & SI \\
\hline 1958 & Bryssel & SI \\
\hline 1964 & Bryssel & Sosialististen Naisten kansainvälinen neuvosto \\
\hline 1968 & Tel Aviv & Ihmisoikeuksien 20-vuotiskongressi \\
\hline 1969 & Helsinki & Naisten maailmankongressi \\
\hline 1973 & Helsinki & $\begin{array}{l}\text { Conference of Women's Organisation on European } \\
\text { security }\end{array}$ \\
\hline 1977 & Berliini & SI \\
\hline 1977 & Norja & Naiskongressi \\
\hline 1982 & Hampuri & Sosialistinen Naisinternationaali \\
\hline
\end{tabular}




\section{POHJOISMAISIA KOKOUKSIA}

POHJOISMAIDEN SOSIALIDEMOKRAATTISTEN NAISTEN KONGRESSI

$1930 \quad$ Helsinki

POHJOISMAISET SOSIALIDEMOKRAATTISTEN NAISTEN PÄIVÄT

1935 Tukholma

1937 Kööpenhamina

1938 Helsinki

1946 Oslo

1948 Kööpenhamina

1950 Helsinki

1952 Tukholma

1953 Helsinki

1954 Odense

1955 Tanska

1956 Örenäs

$1958 \quad$ Norja

POHJOISMAINEN TYÖLÄISNAISKONGRESSI

1947 Oslo

SOSIALIDEMOKRAATTISTEN NAISTEN POHJOISMAINEN YHTEISTYÖKOMITEA

$\begin{array}{ll}1947 & \text { Tukholma } \\ 1952 & \text { Tukholma } \\ 1953 & \text { Helsinki } \\ 1956 & \text { Tukholma } \\ 1957 & \text { Helsinki } \\ 1958 & \text { Kööpenhamina } \\ 1963 & \text { Oslo } \\ 1964 & \text { Helsinki } \\ 1965 & \text { Tukholma } \\ 1965 & \text { Göteborg } \\ 1966 & \text { Kööpenhamina } \\ 1967 & \text { Kööpenhamina } \\ 1969 & \text { Helsinki } \\ 1971 & \text { Kööpenhamina }\end{array}$




\section{Liite 6}

Naisten asemaa koskevia lakeja ja asetuksia

1864 Naimattoman naisen täysivaltaisuus ja naisen oikeus hallita omaisuuttaan 25-vuotiaana, 21-vuotias sai itse päättää avioliitostaan

1865,1873 Itseään hallitseville naisille kunnallinen äänioikeus

$1866 \quad$ Kansakouluasetus

1878 Perintökaaren muutos siten, että veli ja sisar perivät yhtä paljon

1883 Irtolaisasetus kumosi "laillisen suojelun" ja palveluspakon.

1889 Naimisissa oleva nainen sai päättää rajoitetusti itse hankkimiensa tulojen käytöstä

1900 Laki miehen ja naisen täysi-ikäisyydestä 21-vuotiaana

1903 Ensimmäiset naispuoliset ammattientarkastajat

1906 Yleinen ja yhtäläinen valtiollinen äänioikeus ja vaalikelpoisuus sukupuoleen ja varallisuuteen katsomatta

1907 Senaatin päätös ohjesääntöisen haureuden lakkauttamisesta

1908 Naisen naimaikä 15 ikävuodesta 18 ikävuoteen

1917 Yleinen ja yhtäläinen kunnallinen äänioikeus ja vaalikelpoisuus

Asetus teollisuustöistä sisälsi mm. 4 viikon äitysloman, raskaudenaikaisen työn rajoituksia ja 8-tuntisen työpäivän

Asetus työväen tapaturmavakuutuksesta ja työttömyys kassoista

1918 Senaatin päätökset avustaa kapinassa turvattomiksi jääneitä lapsia hoitavia turvakoteja

1919 Hallitusmuodon $5 \S$ sääti Suomen kansalaisten yhdenvertaisuudesta lain edessä, naisen asema epäselvä

Naisille mahdollisuus harjoittaa itsenäistä elinkeinotoimintaa

$1921 \quad$ Oppivelvollisuuslaki 
1922 Työsopimuslaki salli naimisissakin olevan naisen tekevän itsenäisesti työsopimuksen

Köyhäinhoitolaki ja laki aviottomista lapsista, jonka mukaan avioliiton ulkopuolella syntyneillä lapsilla tuli olla valvojanaan mies tai naimaton nainen äitinsä lisäksi

\section{Vuosilomalaki}

1924 Työehtosopimuslaki

1925 Laki ottolapsista, lastentarhain valtionavusta ja Huoneenvuokra-laki

1926 Laki naisen kelpoisuudesta valtion virkaan, Salavuoteuden rangaistavuus poistui, Avoliitto mahdollistui

1930 Avioliittolaki, jonka mukaan puolisot olivat keskenään oikeudellisesti yhdenvertaisia

1934 Laki työttömyyskassoista

1936 Lastensuojelulaki ja Irtolaislaki

1937 Äitiysavustus vähävaraisille, Lakimuutos mahdollisti pakkosteriloinnin

1937 Kansaneläkelaki, asteittain voimaan 1942 ja 1949

1939 Ammattitaudit tapaturmalakiin, vuosilomalaki

1941,1945 Äitiysavustuksen ehtoja lievennetään

1942 Perhelisälaki

1943 Lakisääteinen kouluruokailu

1944 Laki kunnallisista kätilöistä ja äityshuollosta Perheneuvontatyö aloitetaan

1944,1945 Kodinperustamislaina-laki

1948 Lapsilisälaki, Huorinteon rangaistavuus poistui

1949 Äitiysavustukset kaikille synnyttäjille, Ensikodit valtionavun piiriin

$1950 \quad$ Laki kunnallisista kodinhoitajista

1957 Kansaneläkelain kokonaisuudistus

1959 Työturvallisuuslaki, työttömyyskorvaukset

1960 Erityislapsilisä

1961 E-pilleri hyväksytään

1963 Suomi ratifioi kansainvälisen työjärjestön (ILO) samapalkkaisuussopimuksen

1964 Asumistuki, Sairasvakuutuslaki, sisälsi mm. äitysrahan

1970 Työsopimuslaki, mm. sukupuoleen perustuvasta syrjinnästä säädettiin rangaistus, Laki raskauden keskeyttämisestä 
1971 Kasvatusneuvolalaki, Homoseksuaalisuus demikriminalisoitiin

1972 Kansanterveyslaki, sääti mm. kunnallisista terveysasemista

1973 Päivähoitolaki

1975 Elatusapulaki, Laki naisen kelpoisuudesta valtion virkaan kumotaan. Osa rajoituksista, $\mathrm{mm}$.

puolustusvoimia, rajavartiolaitosta ja kirkkoa koskevia, jää voimaan

1976 Isyyslaki, sisälsi mm. isyysloman

1977 Elatusturvalaki

1978 Vanhemmilla oikeus jakaa keskenään vanhempainloma

1980 Ottolapsilaki

1981 Sosiaali- ja terveysalan tasa-arvo-ohjelma

1982 Rintamasotilaseläke myös naisille

1983 Kansaneläkeuudistus

1984 Lastensuojelulaki, Laki lapsen huollosta ja tapaamisoikeudesta

1985 Laki lasten kotihoidon tuesta ja hoitovapaasta, Laki lapseksi ottamisesta ja äitysrahan muutos vanhempainrahaksi

1986 Sukunimilaki, Irtolaislaki kumotaan, Suomi ratifioi YK:n naisten syrjinnän poistamista koskevan yleissopimuksen

1987 Tasa-arvolaki, sisälsi mm. tasa-arvovaltuutetun ja tasaarvovaltuuston

1990 Lastensuojelulain uudistus ja Perhe-eläkelain uudistus, sisälsi mm. mies- ja naisleskien tasa-arvon, Avioliittolain muutos siten, että avioero ei edellyttänyt toisen osa puolen syyllisyyden osoittamista

1990 Alle 3-vuotiaille taattu oikeus kunnalliseen hoitopaikkaan

1994 Raiskaus avioliitossa kriminalisoitiin

1995 Tasa-arvolain osittaisuudistus: 40-60 \% kiintiösääntö valtion komiteoihin ja kunnallisiin toimielimiin

1995 Laki naisten vapaaehtoisesta asepalvelusta

1995 Pahoinpitely perheessä yleisen syytteen alaiseksi 


\section{Liite 7}

Tapahtumakalenteri

5.3.1883 Helsingin työväenyhdistys perustettiin

1.9.1890 Naisten ensimmäinen oma ammattiosasto, ompelijoiden alaosasto, perustettiin Helsingin ty: $n$ yhteyteen

1899 Helmikuun manifesti

17-20.7.1899 Suomen Työväenpuolue perustettiin

4-6.7.1900 Työläisnaisten Liitto perustettiin

17-19.7.1902 Suomen palvelijataryhdistysten ensimmäinen kokous

17-20.8.1903 Suomen Työväenpuolueen Forssan puoluekokous. Kokous vaihtoi puolueen nimen Suomen Sosialidemokraattiseksi Puolueeksi ja hyväksyi sosialistisen ohjelman

1905 Perustettiin kansallis- (puna-) ja suojeluskuntakaarteja

30.10.-

\subsubsection{Suurlakko}

15-16.3.1907 Ensimmäiset vapaat ja yhtäläiset parlamenttivaalit

15-17.4.1907 Suomen Ammattijärjestö (SAJ) perustettiin Tampereella

14-19.11.

$1917 \quad$ Yleislakko

15.11.1917 Eduskunta julistautui korkeimman vallan haltijaksi Suomessa

6.12.1917 Suomen itsenäisyysjulistus

28.1.-

6.5.1918 Kansalaissota

29.8.1918 Suomen Kommunistinen Työväenpuolue perustettiin

13-15.6.1920 Suomen Sosialistinen Työväenpuolue perustettiin

21-22.5.1921 Työläisnaisliitto jakaantui, kun Suomen Sosialidemokraattinen Työläisnaisten liitto perus tettiin 
1922-1923 Kommunistien pidätyksiä, Suomen Sosialistinen Työväenpuolue kiellettiin

21-25.5.1923 SAJ perusti ensimmäisen naisjaoston

1926-27 Väinö Tannerin vähemmistöhallitus

6.7.1930 SAJ lakkautettiin viranomaisten toimesta. Vuonna 1933 Korkein oikeus vahvisti päätöksen

19-21.10.

1930 Suomen Ammattiyhdistysten Keskusliitto perustettiin

18.11.1930 Eduskunta hyväksyi ns.'kommunistilait", joilla vasemmiston toimintaa rajoitettiin

1937 Punamultahallitus

16-19.5.1938 Ensimmäinen naisjaosto päätettiin perustaa SAK:hon

30.11.1939-

13.3.1940 Talvisota

16.2.1940 “Tammikuun kihlaus", SAK ja STK tunnustivat 25.6.1941toisensa neuvotteluosapuolina

5.9.1944 Jatkosota

15.9.1944-

25.4.1945 Lapin sota

29.10.1944 Suomen Kansan Demokraattinen Liitto perustettiin

28.4.1944 Ensimmäinen työmarkkinaosapuolten yleissopimus

1944-1947 Liittoutuneiden valvontakomissio Suomessa

21.2.1946 Sotasyyllisoikeudenkäynti langetti tuomiot

1944-1947 Sotien jälkeinen asutustoiminta

6.4.1948 Suomi ja Neuvostoliitto solmivat YYA-sopimuksen

18.9.1952 Viimeinen sotakorvauserä Neuvostoliittoon 1.3.-20.3. $1956 \quad$ Yleislakko

21-24.4.1957 Sosialidemokraattinen oppositio syntyi

6-7.5.1959 SDP:stä eriytyneet perustivat Työväen ja Pienviljelijöiden Sosialidemokraattisen Liiton

24.6.1959 Suomen Sosialidemokraattisten Naisten Keskusliitto perustettiin

5.11.1960 Perustettiin Suomen Ammattijärjestö 
17-18.6.1969 SAJ:n tärkeimmät järjestöt ja SAK sopivat yhdistymisestä Suomen Ammattijärjestöjen Keskusliitoksi

1975 Kansainvälinen naistenvuosi

1979 Kansainvälinen lastenvuosi

27.5.1979 Sos.Dem. Naisten Keskusliitto ja Sos.Dem.

Naisliitto yhdistyivät Sosialidemokraattisiksi Naisiksi

1982-1994 Ensimmäinen sosiaalidemokraattinen tasavallan presidentti, Mauno Koivisto

29.4.1990 SKDL:n ja SKP:n poliittinen toiminta yhdistyivät Vasemmistoliitoksi

1992-1995 Työväenliikettä lähellä olleiden yritysten talouskriisi:

STS-Pankki lakkautettiin, Haka, Kansa, TVK ja SKP ajautuivat konkurssiin, Elanto ja EKA pakkosaneeraukseen

1994-2000 Martti Ahtisaari presidenttinä

1.1.1995 Suomesta Euroopan Unionin jäsenvaltio

1.3.2000- Ensimmäinen naispuolinen presidentti Tarja Halonen aloitti työnsä 



\section{Århundradets kvinnorörelse}

Kvinnorna och socialdemokratin i 1900-talets Finland

Man kan med fog kalla 1900-talet för kvinnorörelsens och socialdemokratins århundrade. Åtminstone om man betraktar historien ur ett nordiskt perspektiv. I Finland grundades det socialdemokratiska partiet sommaren 1899 och i anslutning därtill året därpå en riksomfattande kvinnoorganisation, det socialdemokratiska kvinnoförbundet. Sedan dess har socialdemokraterna strävat efter politisk makt på toppnivå. År 2000 kan vi konstatera att partiet på den punkten lyckats utmärkt. Landets kvinnliga president, Tarja Halonen är socialdemokrat, statsministern är socialdemokrat och vi har en socialdemokratisk EU-kommissarie. Också kvinnornas ställning har förändrats under hundra år: av parlamentsledamöterna är 37 procent kvinnor och i regeringen är cirka 40 procent av medlemmarna kvinnor.

Det socialdemokratiska inflytandet över landets utveckling har varit så betydande att en veckotidning gjorde den bedömningen att finländarna har börjat likna SDP: de är litet stela och grå, men trygga. I det följande presenterar vi den socialdemokratiska arbetarrörelsens verksamhet genom att granska den socialdemokratiska kvinnorörelsens hundraåriga historia. Hur anpassade och tillämpade Finlands äldsta politiska kvinnorörelse sin verksamhet i korstrycket mellan arbetarrörelsen och kvinnorörelsen? En annan intressant fråga gäller hur kvinnoorganisationens identitet växte fram under hundra år. Det är en speciellt aktuell fråga idag, då globaliseringen snabbt förändrar de sociala strukturerna i de moderna samhällena. 


\section{Den internationella arbetarrörelsens nordiska etapp}

Man kan se grundandet av en arbetarkvinnorörelse i Finland som en fortsättning på de bröduppror som leddes av arbetarkvinnorna $\mathrm{i}$ Mellaneuropa på 1700- och 1800-talen. De första kraven som kvinnorna ställde konkretiserades nämligen i slagorden om "Bröd", medan det ideologiska budskapet var tunt. Under ledning av männen fann arbetarkvinnorna emellertid efter några år vägen till socialismens klassiker och därmed politiserades kvinnorörelsen. Godkännandet av ett socialistiskt program satte fart på verksamheten i finskhetsrörelsen och i rösträttskampen. Inflytandet från framförallt arbetarrörelsen i Tyskland och Sverige var stort. De finländska kvinnorna följde aktivt med vad som skrevs i de svenska arbetarkvinnornas tidning Morgonbris, den engelska tidningen The Labour Woman och framförallt den tyska tidningen Die Gleichheit, som kom att bli den internationella socialistiska kvinnorörelsens huvudsakliga språkrör. De finländska kvinnorna läste artiklar av Ellen Key, Clara Zetkin och Lily Braun, August Bebels bok "Kvinnan och socialismen" samt inhemsk och utländsk skönlitteratur. Revolutionsretoriken präglade tal och artiklar. Ungefär år 1903 lösgjorde sig arbetarkvinnorna från den borgerliga kvinnorörelsen och steg ut i offentligheten med krav på ett rättvisare samhälle.

\section{Rösträttsreformen år 1906}

Rösträtts- och valbarhetskampen blev för de finländska arbetarkvinnorna ett språngbräde till samhällelig verksamhet. Att Finland som första land i Europa gav kvinnorna rösträtt överraskade också många finländare. Reformen hade emellertid inte genomförts om det inte hade varit för oroligheterna i moderlandet Ryssland, revolutionen år 1905 och följderna av det rysk-japanska kriget. Tsar Nikolaj II tillät reformen för att förhindra en upptrappning av oroligheterna i Finland.

Arbetarrörelsen hade starkt tagit ställning för ett bibehållande av landets autonomi. Bland annat organiserade man storstrejken i slutet av år 1905. Att två av de ledande kvinnorna i det socialdemokratiska kvinnoförbundet satt med i strejkkommittén säger något om kvinnornas centrala roll $\mathrm{i}$ den här verksamheten. 
Kvinnorna var aktiva också i det illegala arbetet. De spred förbjuden litteratur, härbärgerade folk $\mathrm{i}$ motståndsrörelsen och reste runt $\mathrm{i}$ Finland och talade.

Genom sin aktivitet uppfattades arbetarkvinnorna som trovärdiga och som belöning fick kvinnorna rösträtt. I Finland var de olika samhällskretsarna nämligen långt ifrån eniga om huruvida reformen också skulle omfatta de fattiga kvinnorna, som knappt kunde läsa eller skriva. Den borgerliga kvinnorörelsens konservativa flygel motsatte sig bestämt att de medborgerliga rättigheterna också skulle omfatta tjänstefolket. Det gick emellertid annorlunda. I det första valet våren 1907 invaldes 19 kvinnor i parlamentet, av dem var nio socialdemokrater. Valet var en stor framgång för det socialdemokratiska partiet. Socialdemokraterna fick 80 av 200 platser.

\section{Krisen år 1918}

Den socialdemokratiska rörelsen upplevde sin första djupa kris våren 1918, då landet drevs in i ett inbördeskrig. Det pågick 3,5 månader och slutade med ett bittert nederlag för den röda sidan. Utrensningar genomfördes i landet och tio tusentals aktivister i arbetarrörelsen dog i fånglägren av hunger och sjukdomar. En del av rörelsens ledning flydde till Sovjetryssland. Många mötte där sitt öde under Stalins utrensningar.

Krisen ledde till att arbetarrörelsen splittrades och med den kvinnorörelsen. Den radikala flygeln hade ingen särskild kvinnorörelse, men socialdemokraternas väg var en annan. Differentieringen mellan kvinnoförbundet och partiledningen förstärktes och kvinnoförbundet gick in på samma verksamhetsfält som den borgerliga kvinnorörelsen och satsade på hushållsfostran. Förändringen i inriktning påverkades av statens ekonomiska stöd, av det faktum att förbundets medlemmar hade efterlyst mera hushållsfostran och av att partiets män uppmuntrade den nya linjen. I stort sett berördes den finländska socialdemokratiska kvinnorörelsen av samma fenomen som präglade det övriga Europa på 1920- och 30-talen, nämligen "kvinnans-plats-är-i-hemmet"ideologin som var en följd av högervridningen.

De socialdemokratiska kvinnornas roll som en förespråkare för socialpolitiska reformer har varit betydande under hundra år. Tanken 
om "Folkhemmet" som lånades från Sverige blev också en hörnsten i de finländska demokratisträvandena. På 1930-talet genomfördes några för kvinnorna viktiga lagreformer, som t.ex. barnskyddslagen, lagen om moderskapsersättning och folkpensionslagen. De socialdemokratiska kvinnorna såg de här reformerna som en seger. De hade ju redan i början av seklet tagit fram de här missförhållandena. Också förbättrandet av ogifta mödrars ställning, fritidsverksamheten och äldreomsorgen var centrala frågor i de socialdemokratiska kvinnornas verksamhet.

\section{Kvinnor och krig}

Under andra världskriget intensifierades samarbetet mellan de olika kvinnoorganisationerna. Kriget mot Sovjetunionen enade folket. Samarbetet mellan de olika kvinnorörelserna var så intimt att socialdemokraterna slöt ett skriftligt avtal med skyddskårsorganisationerna, som tidigare hade betraktats som fiender.

Krigstiden innebar en ökad arbetsbörda för kvinnorna. Kvinnor arbetade i rustningsindustrin, i lantbruket och i skogen. En del verkade i det frivilliga landsförsvarsarbetet, en del värvades med åberopande av lagen om arbetsplikt. Arbetarfamiljernas barn sändes till Sverige och Danmark som krigsbarn, speciellt år 1942, då livsmedelsbristen var stor. De socialdemokratiska kvinnorna arbetade aktivt med att anvisa arbete åt kvinnor, samla in guldringar, erbjuda hjälp åt storfamiljernas mödrar och sy kläder åt soldaterna.

Efter kriget förändrades den politiska situationen i Finland. Den tidigare förbjudna folkdemokratiska rörelsen fick nu verka och ökade sitt understöd i slutet av 1940-talet. För de socialdemokratiska kvinnorna innebar fredstiden en kamp på en ny front. De män som övertagit ledningen i partiet godkände inte längre kvinnoförbundets hemcentrerade verksamhetslinje och drog in det ekonomiska stödet till förbundet. Kvinnoförbundet upplevde också en intern brytning då de nya kvinnorna som kommit med i verksamheten krävde en ideologisk debatt igen. 


\section{Brytningen under 1950-talet}

Man kan kalla det socialdemokratiska kvinnoförbundets verksamhet på 1920-1950-talen en guldålder för kursverksamheten, så centrala i förbundets verksamhet var de praktiska matlagnings-, konserverings- och handarbetskurserna. I anslutning till dem gav man visserligen också ideologisk skolning, men endast i andra hand. Kvinnoverksamheten var likadan också i de andra kvinnoorganisationerna.

I slutet av 1950-talet var kvinnoförbundets gamla verksamhetslinje inte längre aktuell. Splittringen av det socialdemokratiska partiet i slutet av årtiondet förseglade också en ny linje för kvinnoförbundet. De gamla veteranerna fick ge vika, kvinnoförbundets ledning föryngrades och man tog i högre grad upp allmänpolitiska frågor. Partiets nya kvinnliga ledare strävade efter att värma upp de något kyliga relationerna till partiledningen och återställa förtroendet mellan organisationerna.

Arbetarrörelsen moderniserades snabbt under 1950-talet. Man kunde inte längre kalla det socialdemokratiska kvinnoförbundet för en "arbetarkvinnorörelse". Den nya verksamhetskulturen leddes nu av utbildade kvinnor i medelklassen, som inte nödvändigtvis hade några tidigare erfarenheter av arbete $\mathrm{i}$ kvinnoorganisationer. Förbundets proletära stämpel fördunklades och försvann. De unga kvinnorna öppnade kvinnoförbundets dörrar för nya kvinno- och studentrörelser och för fackföreningskvinnorna. Denna öppning ledde till att förbundet vid omorganiseringen år 1979 inte längre registrerades som en särskild förening utan i stället blev partiets kvinnosekretariat.

Den kommitté som undersökte kvinnans ställning och fungerade mellan åren 1966-70 säger något om de socialdemokratiska kvinnornas aktivitet. Idén att forska i kvinnans ställning fick man av sin systerorganisation i Sverige, där liknande forskning genomfördes. Kommitténs betydelse var stor. På basen av det arbete som där gjordes grundades jämställdhetsdelegationen i Finland och man gjorde upp en långsiktig och heltäckande jämställdhetsplan. 


\section{Partiet och jämställdheten}

Det socialdemokratiska partiets ledning har länge varit mansdominerad. Kvinnorna hade ända fram till 1950-60-talen en kvot på en plats i partiorganen. Beskrivande för situationen är att en kvinna för första gången blev invald som viceordförande $\mathrm{i}$ den trehövdade partiledningen år 1972. Partiet hade en kvinnlig partisekreterare under åren 1987-91. Antalet kvinnliga delegater på partikongresserna var lågt ända fram till 1960-talet, ungefär 10 procent. Den kvinnliga representationen steg först på 1980- och 1990-talen. På partikongressen år 1999 var 33 procent av delegaterna kvinnor. Då uppgick de kvinnliga medlemmarnas andel till 40 procent.

Av partiets riksdagsledamöter har kvinnornas andel varierat så, att som sämst var representationen 1920-1950, med andra ord under den tid då kvinnoförbundet satsade på hemvårdsfostran. I det första riksdagsvalet (1907) var de socialdemokratiska kvinnliga ledamöternas andel 11 procent av alla partiets ledamöter, den motsvarande andelen i valet 1999 hade stigit till 43 procent.

Det socialdemokratiska partiet har i jämförelse med andra partier varit framstegsvänligt då det gäller tillsättandet av kvinnliga ministrar: redan i upprorsregeringen år 1918 var två av ministrarna kvinnor och i regeringen 1926-27 var en minister kvinna. Efter kriget har de flesta regeringarna haft kvinnliga socialdemokratiska ministrar. För första gången hade en regering två kvinnliga ministrar år 1954. I början innehade kvinnorna nästan undantagslöst socialministerposten, men situationen förändrades under 1970-talet och kvinnorna började få ansvar också för andra ministerier.

De socialdemokratiska kvinnorna har jämfört med situationen $\mathrm{i}$ andra partier en ledande ställning då det gäller representationen på partikongresserna, i riksdagsgruppen och vid tillsättandet av ministrar. Andelen kvinnor har emellertid ökat först på 1980- och 1990-talen och de socialdemokratiska kvinnorna har under senare år krävt att en kvot på 40 procent skall tillämpas också vid tillsättandet av partiledning. Trots att spänningen mellan partiledningen och kvinnoförbundet under de senaste hundra åren tidvis varit stark, har den varit tabu. Man har inte diskuterat detta öppet. Man har velat bilägga tvisterna i "familjekretsen". 


\section{Den stillsamma revolutionära vägen}

Den socialdemokratiska kvinnorörelsens hundraåriga historia påvisar hur central kvinnornas roll har varit i skapandet av den finländska välfärdsstaten och i befästandet av jämställdhetsutvecklingen. Då vi betraktar t.ex. kvinnornas arbete i parlamentet inser vi hur systematiskt kvinnor har initierat socialpolitiska reformer. Om förslagen förkastats har man upprepat dem tills de har godkänts. Om en ledamot tröttnat har en annan tagit vid. Att föra traditionen vidare har varit en central faktor i kvinnornas långsiktiga samhälleliga verksamhet.

De symboler som arbetarrörelsen fortfarande värnar om - flaggorna, bröstknapparna och arbetarsångerna - skapar en känsla av gemenskap speciellt i kristider, och de är också ett tecken på att man värnar om att de gamla traditionerna skall leva vidare i nya generationer. De centrala ledarna i arbetarrörelsen fungerar också som överförare av de kollektiva erfarenheterna, som traditionsbärare. Framförallt under brytningsåren på 1950-talet blev dessa traditionsbärare viktiga som samlande krafter då det gällde att förena det förflutna, det nutida och det framtida.

I en globaliserande värld blir traditionsbärarna allt viktigare. Arbetet i kvinnoorganisationerna har i likhet med medborgarverksamheten blivit mera reflektivt och sker i en snabbare takt. Om vi jämför de socialdemokratiska kvinnornas verksamhet idag med hur den såg ut i början av 1900-talet har kontakten mellan medlemmarnas vardag och de politiska aktörerna försvagats. Politikerna är ofta yrkesmänniskor som skapar sig en karriär och "bara gör sitt jobb". Den politiska kulturen som betonar individualitet har flyttat ut ur Folkets hus och in i kabinetten. Förändringen har varit dramatisk på så sätt, att den socialdemokratiska framgången under århundradet mycket långt har grundat sig på en politik som har bedrivits för att möta vardagslivets behov.

Att bibehålla demokratins funktionsduglighet i en globaliserande värld är en allvarlig utmaning både för socialdemokraterna och för andra politiska organisationer. Den tyske sociologen Ulrich Beck har uppmålat en mycket negativ vision av partiernas framtid. Den nya eran i början av 2000-talet uppstår, enligt Beck, inte genom revolution eller bittra erfarenheter som tidigare, utan kommer lågmält och passerar vid sidan om vår demokratiska självförståelse. 
Det traditionella partisystemet är, enligt honom på väg in på ett sidospår i förändringsprocessen: partierna börjar leva sitt eget organisatoriska liv medan förändringen sker någon annanstans. Vissa tecken tyder på att detta redan håller på att ske. Villkoret för den politiska rörelsens framtid är att ungdomarna kommer med. För närvarande är intresset för politisk verksamhet emellertid klart mindre än tidigare. 


\section{Women's Movement of Century}

Women and social democracy in Finland in the 1900s

The 1900s can with grounds be considered the century of women's movement and social democracy. At least this applies to the Nordic countries. In Finland the Finnish Social Democratic Party was founded in the summer 1899 and the national women's organization, the Social Democratic Women's Union was founded the next year in connection with the party. Since then social democrats have strived for the top of political power. In 2000 we can note that they have succeeded very well in it. The President of the Republic is a social democratic woman, Tarja Halonen, Prime Minister is a social democrat and so is EU Commissioner. Also the status of women has changed during the last century: there are $37 \%$ of women in the parliament and the share of women in the government is c. 40 $\%$.

The influence of social democrats to the development of the country has ben so marked that one journal wrote that social democrats have made all Finns look like themselves: somewhat stiff and grey but safe. In the following activities of the Social Democratic Party is presented through the 100- year history of its women's organization. First point to discuss is in which way Finland's oldest political women's organization adjusted and arranged in the pressure conflict between labour movement and women's movement. Another interesting question is to outline the building of the identity of the organization in a hundred year perspective. This question is of special current interest now that globalization is rapidly changing the social structures of modern societies. 
The beginning of the Finnish working women's movement can be seen as an extension of the bread riots of working women in the 1700 s and 1800s. Women's first demands were concretized in "bread" shouts, while ideological message was thin. However, under men's guidance working women found the classics of socialism in a few years and women's movement became political. Activities in the Finnish movement and fight for suffrage hastened the adoption of a socialist programme. Also the ideological influence of specially Germany and Sweden was great. Finnish women followed with eager i.e. Swedish Morgonbris, British The Labour Women and above all German Die Gleichkeit which became the main organ of the international socialist women's movement. They read writings by Ellen Key, Clara Zetkin and Lily Brown, "Woman and Socialism" by August Bebel as well as Finnish and foreign authors. Speeches and writings caught revolutionary rhetoric. Working women withdrew from bourgeois women's movement around 1903 and entered public life demanding a more just society.

\section{Suffrage reform 1906}

The fight for suffrage and eligibility became the springboard for social activity for Finnish working women. The fact that women got both the suffrage and eligibility first in Europe was a surprise for many Finns, too. The reform would not have materialized without internal disturbances in mother country Russia, the 1905 revolution and the consequences of the Russian-Japanese War. Tsar Nicholas II allowed the realization of the reforms in order to prevent further disturbances in Finland.

The labour movement had taken up a forceful opposition in order to preserve autonomy of the country. It organized, among other things, a general strike in late 1905. The fact that two leading members of Social Democratic Women's Union belonged to the strike committee tells about women's central role in this work. Women were active also in illegal work spreading forbidden literature, housing people in resistance movement and giving speeches all over Finland. 
Working women made themselves credible by their active work and as a reward gained suffrage also to women. Different social circles in Finland were not at all unanimous about extending the reform also to poor women who could hardly read or write. The conservative wing of bourgeois women's movement strongly disapproved of extending human rights also to servants. Otherwise happened. In the first general elections in spring 1907 nineteen women were elected, nine of them social democrats. The elections were a huge success to the social democratic party. It won 80 seats out of 200 .

\section{The crisis in 1918}

The social democratic movement experienced its first deep crisis in spring 1918 when the country drifted into a civil war. It lasted 3,5 months and ended in a bitter defeat of the reds. Purges were executed and tens of thousands of labour movement's actives died of hunger and diseases in prison camps. Part of the leadership fled to Soviet-Russia. Later Stalin's purges were the fate of many.

Along with the crisis labour movement was splintered, including women's movement. The radical wing abolished a separate women's union while the social democratic way was on the contrary. They strengthened the separation of women's union from the party leadership and turned towards the same fields of activity as the bourgeois women's movement, that is household instruction. To the turn of direction effected economic support of the state, members' requests for increased household instruction and the sympathy of men in the party to the selected direction. In a larger context the Finnish social democratic women's movement came into contact with the same phenomenon as elsewhere in Europe in the 1920s and 1930s, that is the growth of "woman's place is at home" ideology with a turn to the right.

The work of social democratic women as advocates of social political reforms has been notable during the last hundred years. The "folkhome" idea, borrowed from Sweden, was adopted as a corner-stone for democratic objectives also in Finland. In 1930s legal reforms noteworthy for women were realized, such as legislation on child welfare, maternity benefit and old-age pension. Social democratic women considered these reforms as their victor- 
ies, they had raised these defects already in the beginning of the century. Also improvement of the situation of unmarried mothers, holidays and old-age care were central in the activities of social democratic women.

\section{Women in war}

During the Second World War the cooperation of different women's organizations was further consolidated. The war against Soviet Union united the people. The cooperation of women's organizations was so close that social democrats made a written agreement with civil guard organizations which they formerly considered enemies.

War time meant increased work burden for women. Women moved to munition industry, farms and forest work. One part worked in voluntary national defence, another part was recruited by obligatory work law (during the war). Children from working families were sent to Sweden and Denmark as "war children" especially during the food shortage in 1942. Social democratic women were working in many tasks of the exceptional time such as performing women's labour exchange, collecting golden rings, helping "war children", helping mothers of big families and making clothes for soldiers.

After the war the political situation in Finland changed. The formerly forbidden people's democratic movement was allowed to function and it increased its support in late 1940s. For social democratic women the changing to peace time was a time for fight also on another front. The new men in the party leadership did not approve any more of the home-centred line of activities and stopped economic aid to women's union. The union also started to break from within as younger members demanded return of ideological discussions to the union.

The cultural turning-point of the 1950s

The activities of the social democratic women's union from 1920s through 1950s can be called the golden age of courses, so central were practical courses in cooking, preservation and handiwork. Along with them also ideological information was given but it was 
on the second place. Women's activities were very much similar also in other women's organizations.

In late 1950s the old line of activities had come to an end. The split of the social democratic party at the end of the decade sealed the new direction for the women's union. Old veterans had to go, the leadership of the women's union became younger and it was more directed to questions of general politics. The new female leaders tried to warm up relations to party leadership and restore trust between the organizations.

Labour movement was quickly modernized in the 1950s. Social democratic women's movement cannot be called "working women's movement" after this. New culture of activity was now led by middle-class, educated women who necessarily did not have any former experience in women's organizations. The proletarian impress of the union dimmed and died away. Young women opened the doors of the old women's union to new women's and students' movements and to trade union women. Opening led to the result that when women's union was reorganized in 1979 it was not registered as a separate organization but became women's secretariat within the party.

The social outcome of social democratic women can be described by "Committee on Women's Situation" in 1966-70. The idea of a study on women's situation came from sisters in Sweden where similar study was carried out. The importance of the study is great. On the basis of its work the Council for Equality between Women and Men was founded and a long-term and integrated plan for equality was drawn up.

\section{The party and equality}

The Social Democratic Party has long been an organization led by men. Women had till 1950s and 1960s a so-called one-woman's quote in different committees. The situation is well described by the fact that a woman was elected vice-chair first time in 1972, General Secretary was a woman once, in1987-1991. The share of women in Party Congress delegates was low until the 1960s, c. 10 $\%$. It was not until 1980-90s that the share of women started to increase. In the 1999 Party Congress the share was $33 \%$. At the same time the share in membership was $40 \%$. 
The share of women in social democratic Members of Parliament has changed so that in 1920-1950 it was smallest that is, during the time when the union was oriented towards household instruction. In the first elections (1907) the share of women was $11 \%$ of all social democratic Members of Parliament and in 1999 elections it had grown to $43 \%$.

The Social Democratic Party has been progressive compared with other parties when ministers have been appointed: already in the revolutionary government (1918) there were two female ministers and in the minority government in 1926-27 one. After the war there were female social democratic ministers in most governments. In 1954 there were two female ministers in the same government. In the beginning women were almost exclusively social ministers but the situation changed in the 1970s and women were appointed also to other ministries.

When comparing the share of social democratic women with those in other parties we can note that social democrats have had top places in Party Congresses, Parliamentary Groups and Ministers. Yet the growth of the share of women has been a phenomenon of only the 1980-90s and in the recent years social democratic women have demanded that a $40 \%$ quota be applied also to the party leadership. Even if there has been tension between party leadership and women's union, sometimes stronger, sometimes weaker during the last hundred years, it has been a tabu. There has not been an open discussion. Social democrats have wanted to solve quarrels "in the family circle".

\section{The road of a silent revolution}

The one-hundred-year history of social democratic women's movement proves well, how important role women have had in building the Finnish welfare society and in strengthening equality. When we follow, for instance, women's work in the Parliament, we can see how systematically women have proposed reforms in social policy. If the proposal did not get through, it was repeated so many times that it did. When one MP was exhausted, another came to continue. The transfer of tradition has played an important role in women's long-term social work. 
The transfer of labour movement's old tradition from one generation to another can be seen in the use of old symbols: flags, badges and songs created a feeling of togetherness especially in crisis times. Central leading persons of the labour movement were transferors of the collective experiences of the movement, transferors of tradition. Especially in the cultural turning-point of the1950s these bearers of tradition became important solders of past, present and future.

In a globalizing world the role of bearers of tradition is even more underlined. The work of women's organizations has, along with other kind of citizens' activities, become more reflective and faster. When comparing the work of social democratic women today with the work in early 1900 s, it can be noted that the connection between daily life of members and political actors has weakened. Politicians are all the more career-making professional politicians "who only do their work". Political culture that stresses individuality has moved from labour halls to cabinets. The change is dramatic in the respect that the one-hundred-year success of social democrats was based expressly on their policy being so near to the needs of everyday life.

The functioning of a democratic system in a globalizing world is a serious challenge both to social democrats in power and to other political organizations. A German sociologist Ulrich Beck has painted a negative vision of the future of parties. According to him the new era of early 2000 s does not break through via revolution or bitter experiences as before but silently, putting aside our democratic self-understanding. He thinks that the traditional party system is drifting to the sidetrack of the process of change: Parties begin to live their own organizational life and the change takes place elsewhere. Signs of this can be seen already. The precondition of the future of political movement is entry of the young. Now political activity interests them clearly less than before. 


\section{Henkilöhakemisto}

A

Aalle-Teljo (Ahlstedt) Ida 36, 43-45, 48-51, 55, 56, 62, 64, 84, 85, 87, 88, 98, $109,117,118,137,176,179,180,185,195,234,251$

Aalto Alvar 129

Aaltonen Alina 94

Ahde Matti 239

Ahlfors Fanny 109

Ahlstedt Mandi 44

Ahlstedt Tilda 51

Aho Juhani 40

Ahonen Arvi 86

Ahtisaari Martti 116, 261

Airisto Lenita 250

Aleksanteri I 15

Aleksanteri II 15, 31

Andersen Nina 184, 242

Antikainen Eero 187

Antikainen Toivo 201

Anttila Antero 248

Anttila Inkeri 220

Aro Pirkko 14, 220, 221, 226

Artukka Aino 88

B

Beauvoir de Simone 9, 283

Bebel August 36, 41-43, 46, 66

Beck Ulrich 11, 283

Björklund Ilkka-Christian 219

Blom Ida 13

Bobrikov Nikolai 50

Borg (-Sundman) Margit 146, 206

Braun Lily 41, 42

Bremer Fredrika 33

C

Canth Minna 38, 46 
Dahlström Kata 62

Degerman Svea 220

Duncker Käthe 70

E

Ehrnrooth Adeleine 32, 40

Eklöf Tekla 94

Engels Friedrich 36, 41

Ericksson Nancy 208

Eskman Margit 187, 222, 238, 239, 240, 245, 279, 280

F

Fagerholm Elin 99, 106, 110, 111

Fagerholm K.A. 178, 180, 182, 187, 190, 201

Ferlin Nils 249

Fieandt von Otto 201

Filatov Tarja 14, 261

Flinck Anni 202

Forstén Aino 84, 98

Friberg Maikki 33, 34

Fröbel Friedrich 31

Franco Francisco 132

G

Gebhard Hedvig 84, 88, 109, 118

Giddens Anthony 11, 69

Gripenberg Alexandra 38, 53, 58

Gylling Edvard 88

$\mathrm{H}$

Haapalainen Eero 84

Haatainen Tuula 14, 229, 264, 267, 269

Hagman Lucina 33, 48, 88, 136

Hakkila Väinö 96

Hakulinen Janne 263

Hall Stuart 11

Halme Helvi 192

Halme Walto 192

Halonen Tarja 115, 217, 252, 261, 279, 280

Heikura Pirkko 251

Helle Veikko 174, 231, 248

Hellsten-Kallia Armi 146, 154 
Helo Johan 116

Hentilä Marjaliisa 14

Herrala Hilda 64, 84

Hiekkala Elna 192

Hiekkala Lassi 192

Hiilelä Kaisa 202

Hiisivaara-Mörk Selma 142, 202

Hitler Adolf 149, 150

Hjulgren Antton 89, 91, 92

Hjulgren Sofia 89-91

Hobsbawm Eric 10

Holboll Einar 134

Huotari Aino 86

Huotari Aili 86

Huotari Anni 55, 56, 79, 84, 98, 109, 141, 195

Huotari Anton 33, 34, 86, 98, 109

Huotari Aune 86

Huotari Tapio 86

Huotari Tauno 86

Huotari Terttu 86

Hurri Merja 252

I

Ibsen Henrik 39, 40

Iivari Ulpu 249, 280

Ivalo Ellinor 192

Ivalo Santeri 192

$\mathrm{J}$

Jaakonsaari Liisa 14, 229, 279

Johansson Anna 62

Joki Anni 78

Jokinen Alma 84, 98

Jokinen Väinö 63, 98

K

Kaiponen Alma 212

Kaiponen Anja 219

Kalavainen Meeri 14, 187, 197, 200, 201, 202, 222, 229, 230, 231, 238

Kallinen Yrjö 155

Kanerva Ilkka 250

Kanervo Mimmi 48, 50, 51, 55, 56, 87, 99, 102, 104, 108-110

Kannisto Tuulikki 232

Kantanen Ida 108, 109

Kallio Lydia 111 
Karhinen Hanna 75, 84, 94, 98, 279,

Karvinen Anu 179, 202

Katainen Elina 14

Kautsky Karl 36

Kekkonen Urho 155, 174, 190, 240

Keto J.V. 156

Key Ellen 37, 38, 39, 62

Kianto Ilmari 92

Kiiskinen Aura 64, 84, 88, 91, 98, 109

Kiljander Elna 130

Kiljunen Marja-Liisa 14, 268-271

Kilpeläinen Yrjö 174

Kilpiäinen Jenny 55, 56, 58

Kilpi Eino 132, 153

Kilpi Kalevi 154

Kilpi Sylvi-Kyllikki 99, 127, 130, 140, 153-157, 173, 174, 191

Kilpi Yrjö 155

Kiuru Sakari 240

Kohonen Hanna 84

Koivisto Mauno 261

Koivisto Tellervo 208

Kollontai Alexandra 66, 68, 69

Koskinen Johannes 261

Koskull-Hölttä von Catherine 215

Kunnas Marja-Liisa 14, 257

Kuusela Armi 195

Kuusinen Otto Wille 98

Kuuskoski Reino 201

Käkikoski Hilda 135, 136

Kärki Anni 99

L

Laakso Ulla 14

Lahtinen Alli 202, 238, 240

Laine Helvi 217

Laine (Paaso) Maria 33, 34, 45, 50, 51, 55, 56, 64, 85

Laitinen S. 147

Larsson Bror 192

Laxén Marianne 243, 244, 246-250

Lehmus Kalle 174

Lehtinen Inkeri 98

Lehtinen Lasse 240

Lehtinen (Reinholdsson) Sandra 50, 51, 55, 56, 58, 98, 109

Lehto Marja 246, 247

Lehto Lempi 201, 202

Lehtokoski Aino 103 
Leinonen Olga 99, 110, 111

Leiponen Stig-Erik 250

Leivo-Larsson Tyyne 114, 127, 141, 146, 149, 151, 152, 154, 157, 173, 176$180,182,183,187,189-193,197,200-202,215,230,231,249,251,279$, 280

Lepistö Matti 187, 201

Leskinen Väinö 150, 174, 176, 178, 182-184, 186, 249

Liikanen Erkki 239, 246, 248, 249, 261

Liljeström Rita 252

Liljeström Valdemar 201

Lindblom Olavi 147, 174

Linkola Anna-Liisa 220

Lipponen Paavo 217, 261, 272, 279

Litonpalo Elvi 158

Loikas Maija 219

Luja-Penttilä Sinikka 14, 202, 208, 230, 231, 238, 247, 263, 264

Lukkarinen Impi 189, 202, 220

Luukkonen Fanni 191

Luxemburg Rosa 251

M

Malkamäki Aino 178, 187, 188, 201, 202, 212

Malm Hanna 84, 98

Manner Olga 84

Mannerheim C.G.E. 78, 83

Marx Karl 36, 37

Miikkulainen Pirkko 266

Mill John Stuart 30, 32, 40

Moren Mauri 250

Myrdal Alva 207

Mäkelin Ellen 102, 104, 107, 109

Mäkelin Emmi 111

Mäkelin Yrjö 52, 103, 109

Mäkelä Klaus 221

Mäkikossa Oma 116, 117

Mönkäre Sinikka 261

$\mathrm{N}$

Nikolai II 50

Nikula Paavo 229

Nissinen Alli 136

Nurminen Elli 141, 178, 196, 201, 202 
Olin Tenho 250

Ostroumoff Maria 68

Ostroumoff Ljuba 68

Ostroumoff Vera 68

P

Paasikivi Alli 192

Paasikivi J.K. 189

Paasio Rafael 207, 238, 280

Paasivuori Tyyne 180, 202

Palancia de Isabel 132

Pellikka Jarmo 250

Peltola Edla 111

Pesonen Lilli 157

Pestalozzi Johan Heinrich 31

Piepponen Paavo 221

Pietikäinen Fiina 99, 104, 109, 110

Pietikäinen Tahvo 109

Pietilä Hilkka 221

Pukkio Eva-Maija 215

Pärssinen Hilja 21, 34, 41, 55, 56, 62, 64-66, 68, 75, 76, 79, 84, 94-98, 105, $118,135-137,242,251,279$

Pärssinen Jaakko 94-96

$\mathrm{R}$

Raatikainen Helvi 202, 220

Railo Jussi 176

Ramsay Henrik 192

Ramsay Karin 192

Rantala Marja 14

Rantanen Saima 94

Rask Maija 261

Raunio Maria 55, 56

Reini Jorma 250

Riipinen Hilja 130

Rinne Anni 203

Rinne-Virolainen Taimi 200

Ritavuori Heikki 192

Ritavuori Katri 192

Roine Aino 49

Romppainen Anni 122

Rosnell Irma 221

Runeberg Frederika 32

Runeberg Johan Ludvig 32 
Rydman Sylvi 192

Ryti Risto 155

Ryynänen Anna 49

Rämö Anni-Helena 215

S

Saari Kaarlo 96

Saari Paula 109

Saarinen Helvi 202, 215, 242

Salin Eetu 44

Salmela Irja 179, 202, 262, 263

Salmela-Järvinen Martta 60, 82, 104, 114, 116, 117, 127, 140-142, 154, 156, $157,162,163,173,175-191,195,197,200,201,202,231,249$

Salmi Hulda 85

Salo Arvo 211

Sarlin Bruno 192

Sarlin Signe 192

Savolainen Anni 84

Savolainen Ida 94

Schulz Heinrich 63

Seme Aune 179, 202

Seppälä Hannes 113

Seppälä Hilda 104-106, 108-110, 112-114, 127, 137

Sillanpää Miina 34, 52, 55, 56, 62, 64, 75, 84, 88, 103, 104, 106, 109, 112$118,122,137,152,182,185,193,224,251,277,279$

Siltanen Sylvi 152, 187, 202, 220, 221, 230, 231, 280

Simonen Aarre 174, 187, 201, 230

Simonen Vieno 179

Sinervo Aira 154

Sinervo Elvi 154

Sinkko Kaija-Leena 252

Sirjamo Anna-Liisa 251, 252

Sirola Yrjö 36, 38

Skog Emil 157, 176, 187, 189, 193

Snellman J.V. 30, 32

Snellman Kaisu 224

Sorsa Kalevi 217, 231, 233, 238, 240, 248, 249

Starck Elisabeth 94

Stenroos Else 215

Ståhlberg Ester 192

Ståhlberg Sanni 94

Sukselainen V.J. 187, 201

Sulkunen Irma 116

Suomalainen Kari 190

Suonio Kaarina 238 
Tahvanainen Säde 268

Tainio (Johansson) Olga 44, 103, 107, 185

Tainio Taavi 29, 44, 103, 108, 234, 282

Taipale Vappu 238, 246, 251, 267, 268, 270, 272

Takki (Eronen) Lyyli 99, 109, 126

Takki Uuno 99

Tammenmaa Jarmo 250

Tanner Linda 115

Tanner Väinö 101, 108, 114-116, 150, 156, 173, 174, 178, 187

Tanskanen Petri 14

Teerijoki Ilkka 14

Teljo Kyösti 85

Tervo Penna 150, 174, 186

Terästö Edit 202

Tiainen Loviisa 103

Tigerstedt Helny 117

Tihlä Hulda 88

Tiilikainen Ulla 200, 201, 202

Toivanen Hannes 14

Toivonen Helmi 141

Topelius Zacharias 30

Tristan Flora 38

Tukiainen Aimo 117

Tuominen Eeva-Liisa 252

Tuominen Jorma 174

Tuominen Matilda 49

Tuomioja Erkki 219, 261

Tuomioja Laina 192

Tuomioja Sakari 192

Tuomioja Valto 192

Tuomisto Irma 14

Turgenev Ivan 40

Työläjärvi Pirkko 187, 238, 239, 240, 245, 248

Tähti Maria 94

V

Vankkoja V.V. 147

Varjonen Unto 174

Vatanen Agda 106

Veikkalainen Isma 142

Vihersalo Elviira 85, 98

Voionmaa Ilma 192

Voionmaa Väinö 173, 192

Vuohelainen Merja-Hannele 14, 265, 266 
Wihuri Ida 109

Wiik K.H. 153, 173

Wirtanen Atos 155

Wollstonecraft Mary 9

Woolf Virginia 9

Wright von Julius 26

Wuolijoki Hella 192

Wuori Eero A. 174

Wälläri Niilo 155

Z

Zetkin Clara 41, 42, 58, 64, 65, 70, 78

Zilliacus Jutta 221

Ö

Öberg Hilda 99, 110

Östenson Ebba 146 